Cynthia Kramer

\title{
Medidas Antidumping: \\ devido processo legal à luz das regras da OMC
}

Tese de Doutorado

Orientador: Prof. Alberto do Amaral Junior

Faculdade de Direito da Universidade de São Paulo

São Paulo/2012 
BANCA EXAMINADORA

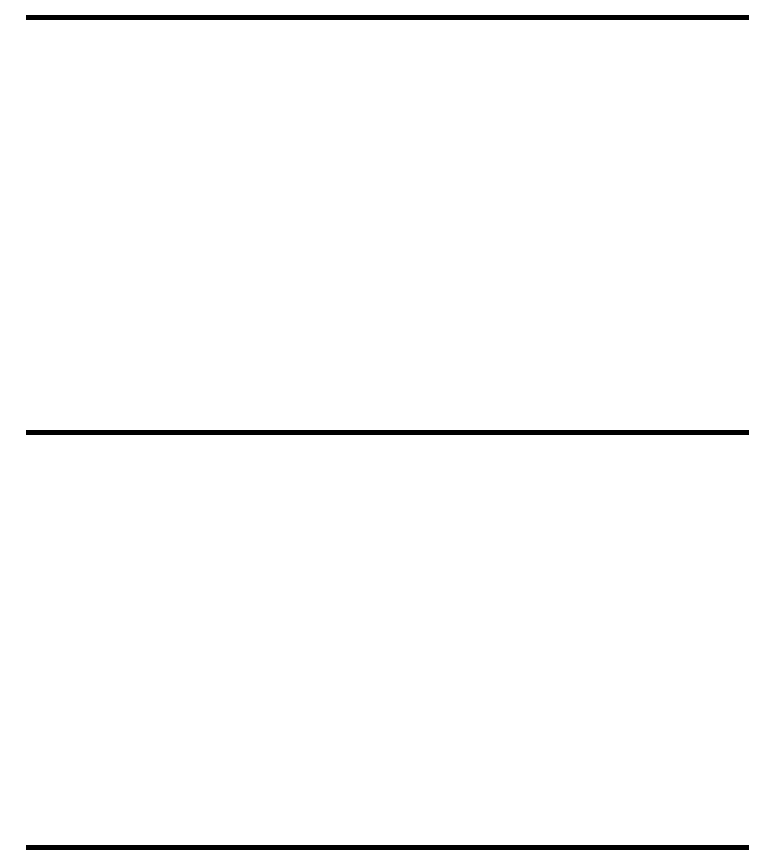


Dedico o presente trabalho ao meu filho Rafael, com o qual deixei de passar momentos importantes para conseguir chegar onde estou. 


\section{AGRADECIMENTOS}

A conclusão do presente trabalho somente tornou-se possível graças a algumas pessoas, às quais sou muito grata:

ao Prof. Alberto do Amaral Júnior, pela orientação e dedicação, desde a época da graduação e do IDCID;

ao Prof. Luiz Olavo Baptista, pelas oportunidades e ensinamentos ao longo desses 12 anos de trabalho conjunto;

à Profa. Vera Thorstensen, pela inspiração e criação do meu fascínio pela OMC, desde o estágio em Genebra em 2003;

aos membros da CGC, pelo aprendizado desde o estágio no Ministério das Relações Exteriores em 2005;

ao Prof. Aluisio de Lima-Campos, pelo incentivo a lidar com o tema antidumping, desde o estágio na Embaixada de Washington em 2007;

aos sócios do LOB-SVMFA, pela compreensão;

à Chris e ao Gustavo, pela colaboração;

aos meus pais e avós, pela educação;

à minha família, em especial ao meu marido, pelo constante apoio;

e por fim, a Hashem, por tudo. 


\section{RESUMO}

Apesar de o fluxo de comércio afetado por medidas antidumping não chegar nem a $1 \%$ do comércio global, aproximadamente $20 \%$ das disputas na OMC são sobre antidumping. A OMC é um órgão intergovernamental e seu sistema de solução de controvérsias tem por objetivo analisar se as medidas adotadas por seus Membros estão em conformidade com os compromissos assumidos nos acordos abrangidos. O Acordo Antidumping da OMC (ADA) estabelece os procedimentos investigatórios a serem seguidos por seus Membros para combater o dumping que comprovadamente causa dano à indústria doméstica. O objetivo é evitar que sejam adotadas medidas em circunstâncias descabidas, com o mero intuito protecionista de criar barreiras ao comércio. O dumping é uma prática do setor privado e não dos governos. Portanto, não é o dumping que é questionado perante a OMC, e sim a obediência pela autoridade investigadora dos procedimentos investigatórios estabelecidos no ADA. Tanto os órgãos da Administração Pública como a OMC exercem uma função fundamental para que o devido processo legal seja observado em matéria antidumping. A função legislativa é criar as normas que regularão o procedimento, a função executiva é aplicar/monitorar o procedimento, e a função judiciária é verificar se o procedimento tem sido aplicado corretamente. À luz dessas considerações, a tese a ser defendida é que: (i) diante das limitações trazidas aos painéis e ao Órgão de Apelação pelo Artigo 17.6 do ADA, a função do sistema de solução de controvérsias da OMC e dos judiciários nacionais, em matéria antidumping, muito se assemelham: ambos buscam controlar a discricionariedade da autoridade investigadora; (ii) mais efetivo para os importadores e/ou exportadores que pretendem questionar uma medida antidumping seria buscar inicialmente uma solução mediante recurso ao judiciário do país importador. $\mathrm{O}$ recurso ao sistema da OMC, além de depender do interesse do governo e ser oneroso, apresenta dificuldades no momento de implementação das recomendações; (iii) entretanto, tendo em vista o despreparo do Judiciário Brasileiro, sugerimos a criação de cortes especializadas; (iv) o recurso ao Judiciário, mesmo perante cortes especializadas, não resolveria os problemas do processo antidumping apontados ao longo da tese. Para sanar, fazemos algumas 
outras sugestões de mudanças estruturais para aplicação: (a) no âmbito da OMC, com vistas a delimitar a atuação do Órgão de Apelação e garantir segurança jurídica aos Membros; e (b) no âmbito brasileiro, com vistas a modificar a dinâmica das investigações antidumping conduzidas pela autoridade administrativa e assegurar o cumprimento de sua real finalidade.

PALAVRAS-CHAVE: OMC, dumping, medidas antidumping, sistema de solução de controvérsias, padrão de revisão. 


\section{SUMMARY}

Despite the fact that the flow of trade affected by anti-dumping measures does not reach $1 \%$ of global trade, approximately $20 \%$ of the disputes at the WTO are about these measures. The WTO is an intergovernmental organization and its dispute settlement system has the objective of analyzing if the measures adopted by its Members are in accordance with the commitments accepted in the covered agreements. The WTO's Anti-Dumping Agreement (ADA) sets forth the investigation proceedings to be followed by its Members in order to deal with dumping proven to have caused damage to domestic industry. The aim is to avoid that measures are taken under inappropriate circumstances, with the mere protectionist purpose of creating trade barriers. Dumping is a private practice, and not a governmental one. Thus, it is not the practice of dumping itself that is questioned before the WTO, but the obedience by the investigating authority of the proceedings established in the ADA. The Public Administration organs and the WTO are equally responsible by a fundamental role of guaranteeing that the due process of law is respected in the matter of anti-dumping measures. The legislative duty is to create rules that will govern the proceedings, the executive duty is to apply/monitor the proceedings and the judiciary duty is to verify if the proceedings have been applied correctly. In light of these aspects, the thesis to be defended is: (i) considering the limitations to panels and the Appellate Body by Article 17.6 of the ADA, the duties of the WTO's dispute settlement system and the national judiciaries, in terms of anti-dumping, are similar: both try to control the discretion of the investigating authority; (ii) it would be more effective to importers and/or exporters who want to challenge an anti-dumping measure to resort initially to the judiciary system of the importer country. The resort to the WTO system, besides depending on the government's political interest and being expensive, has difficulties when it comes to implement the recommendations; (iii) in spite of that, considering the lack of preparation of the Brazilian Judiciary, it is suggested the creation of specialized courts; (iv) the resort to the Judiciary, even before specialized courts, would not solve the problems of the anti-dumping process pointed out throughout this thesis. To tackle these problems, we make some other 
suggestions of structural nature: (a) in what concerns the WTO, aiming at limiting the Appellate Body`s role and guaranteeing legal security to its Members; (b) in what concerns Brazil, aiming at changing the dynamics of the anti-dumping investigations conducted by the administrative authority and securing the fulfillment of its real purpose.

KEY WORDS: WTO, dumping, antidumping investigations, standard of review, dispute settlement system. 


\section{RÉSUMÉ}

Malgré le fait que les flux commerciaux affectés par les mesures antidumping soient inférieurs à $1 \%$ du commerce global, environ $20 \%$ des disputes au sein de l'OMC concernent le dumping. L'OMC est un organisme intergouvernemental et son système de règlement des différends a pour objectif de veiller à ce que les mesures adoptées par ses Membres soient en conformité avec les engagements contenus dans les accords conclus. L'accord antidumping de l'OMC (AAD) établi les procédures d'enquête que les Membres doivent suivre afin de combattre le dumping qui préjudicie l'industrie domestique. L'objectif est d'éviter que ne soient adoptées des mesures en circonstances illegales, avec la intention protectionniste d'élever des barrières au commerce. Le dumping est une pratique du secteur privé et non du gouvernement. Pour autant, ça n'est pas le dumping qui est remis en question devant l'OMC, mais l'obéissance à l'autorité responsable des procédures d'enquête mises en place par l'accord antidumping. Les institutions de l'administration publique comme l'OMC exercent une fonction fondamentale pour que les droits du procès équitable soient respectés en matière de dumping. La fonction législative est de mettre en place des normes régulant les procédures, la fonction exécutive est d'appliquer/surveiller ces procédures, et la fonction judiciaire est de vérifier que les procédures ont été appliquées correctement. La thèse à defendre est: (i) Compte tenu des limites apportées par les Panels et l'Organe d'Appel via l'article 17.6 de l'AAD, le rôle du système de règlement des différends de l'OMC et de les justices nationales, en matière de dumping, sont très proches: les deux ont l’objective de controller la discritionarite de la autorité qui a fait l'ênquete; (ii) ainsi, il est plus efficace pour les importateurs/exportateurs qui souhaitent contester une mesure antidumping de rechercher une solution auprès de la justice nationale dans un premier temps. Le recours auprès de l'OMC, en plus d'être dépendent de l'intérêt du gouvernement et d'être très onéreux, présente des difficultés au stade de l'exécution des recommandations. (iii) Compte tenu du manque de préparation de la justice brésilienne, nous suggérons la création de cours spécialisées. (iv) Il se trouve, pourtant, que le recours au judiciaire, même après la creation de cour spécialisées, ne permettra pas de résoudre les problèmes du processus antidumping soulignés au cours de la thèse. Afin d'y remédier, nous 
faisons quelques suggestions de modifications structurelles, ayant vocation à être appliquées: (a) non seulement au sein de l'OMC (pour limiter l’action del Organ d’Appel et assurer securite aux Membres de l’Organization, mais (b) également au Brésil (pour modifier le processus antidumping et assurer que les mésures remplient ses objectives).

MOTS-CLÉ : OMC, dumping, mésures antidumping, règlements des differends, limites de révision. 


\section{LISTA DE SIGLAS}

\begin{tabular}{|c|c|}
\hline AARU & Acordo Antidumping da Rodada Uruguai \\
\hline $\mathrm{AD}$ & Antidumping \\
\hline $\mathrm{ADA}$ & Acordo Antidumping da OMC \\
\hline $\mathrm{AEE}$ & Área Econômica Europeia \\
\hline ALADI & Associação Latino Americana de Integração \\
\hline ALALC & Associação Latino Americana de Livre Comércio \\
\hline ALCA & Área de Livre Comércio das Américas \\
\hline ANZCERTA & $\begin{array}{l}\text { Acordo Comercial sobre Relações Econômicas entre Austrália } \\
\text { e Nova Zelândia }\end{array}$ \\
\hline ASMC & Acordo sobre Subsídios e Medidas Compensatórias \\
\hline CAMEX & Câmara de Comércio Exterior \\
\hline CAFC & Corte de Apelação do Circuito Federal dos EUA \\
\hline $\mathrm{CE}$ & Comunidades Europeias \\
\hline CEE & Comunidade Econômica Europeia \\
\hline $\mathrm{CF}$ & Constituição Federal Brasileira \\
\hline CIT & Tribunal de Comércio International dos EUA \\
\hline $\mathrm{CPA}$ & Comissão de Política Aduaneira \\
\hline CCM & Câmara de Comércio do Mercosul \\
\hline $\mathrm{CMC}$ & Conselho de Ministros do Mercosul \\
\hline DECEX & Departamento de Comércio Exterior \\
\hline DECOM & Departamento de Defesa Comercial \\
\hline DI & Declaração de Importação \\
\hline DOU & Diário Oficial da União \\
\hline DSB & Órgão de Solução de Controvérsias da OMC \\
\hline ESC & Entendimento sobre Solução de Controvérsias da OMC \\
\hline EUA & Estados Unidos da América \\
\hline FIBGE & Fundação do Instituto Brasileiro de Geografia e Estatística \\
\hline GATT & Acordo Geral sobre o Comércio e Tarifas \\
\hline GATS & Acordo Geral sobre o Comércio e Serviços \\
\hline GECEX & Comitê Executivo de Gestão da Câmara de Comércio Exterior \\
\hline GMC & Grupo Mercado Comum \\
\hline GTDC & Grupo Técnico de Defesa Comercial \\
\hline GTIP & Grupo Técnico para análise do Interesse Público \\
\hline ICM & Imposto sobre Circulação de Mercadoria \\
\hline MEFP & Ministério da Economia, Fazenda e Planejamento \\
\hline MERCOSUL & Mercado Comum do Sul \\
\hline MDIC & Ministério do Desenvolvimento, Indústria e Comércio Exterior \\
\hline MF & Ministério da Fazenda \\
\hline MICT & Ministério da Indústria, Comércio e Turismo \\
\hline NAFTA & Acordo de Livre Comércio da América do Norte \\
\hline $\mathrm{OIC}$ & Organização Internacional de Comércio \\
\hline $\mathrm{OMC}$ & Organização Mundial do Comércio \\
\hline ONU & Organização das Nações Unidas \\
\hline SEAE & Secretaria de Acompanhamento Econômico \\
\hline
\end{tabular}




\begin{tabular}{|c|l|}
\hline SECEX & Secretaria de Comércio Exterior \\
\hline SNE & Secretaria Nacional de Economia \\
\hline STF & Supremo Tribunal Federal \\
\hline STJ & Superior Tribunal de Justiça \\
\hline TRF & Tribunal Regional Federal \\
\hline UE & União Europeia \\
\hline USDOC & Departamento de Comércio dos EUA \\
\hline USITC & Comissão de Comércio Internacional dos EUA \\
\hline
\end{tabular}




\section{SUMÁRIO}

PARTE I - CONSIDERAÇÕES PRELIMINARES ...................................... 16

Capítulo 1 - INTRODUÇÃO ....................................................................... 16

Capítulo 2 - BREVE HISTÓRICO SOBRE ANTIDUMPING ......................... 21

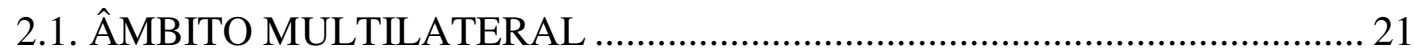

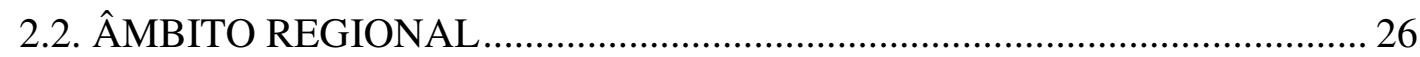

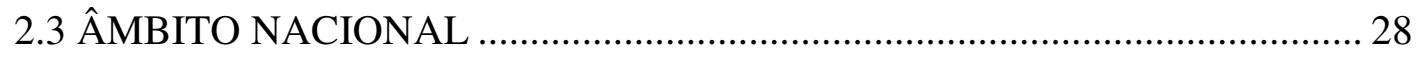

Capítulo 3 - O DEVIDO PROCESSO LEGAL .......................................... 32

PARTE II - FUNÇÕES PARA BUSCA DO DEVIDO PROCESSO LEGAL EM MATÉRIA ANTIDUMPING .............................................. 36

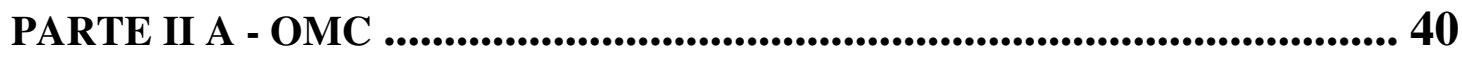

Capítulo 4 - "FUNÇÃO LEGISLATIVA DA OMC" ....................................... 42

Capítulo 5 - "FUNÇÃO EXECUTIVA DA OMC"'............................................ 44

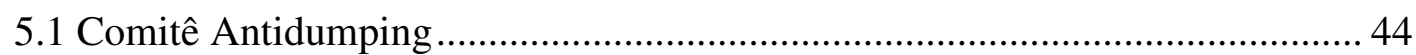

(i) Grupo Ad Hoc sobre Implementação ......................................................... 47

(ii) Grupo Informal sobre Circunvenção ....................................................... 48

CAPÍTULO 6 - "FUNÇÃO JUDICIÁRIA DA OMC" ..................................51

6.1 DSB - Órgão de Solução de Controvérsias ........................................................52

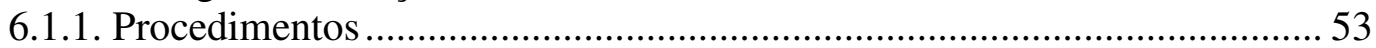

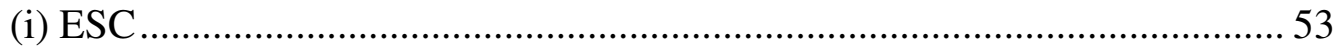

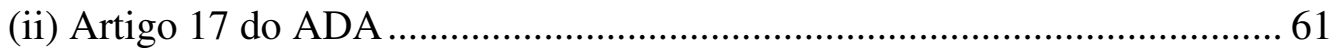

(a) Padrão de Revisão ("Standard of Review").......................................... 62

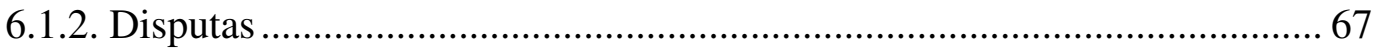

(i) Disputas sobre antidumping na época do GATT ………………………..... 71

(ii) Disputas antidumping perante o DSB .................................................... 75

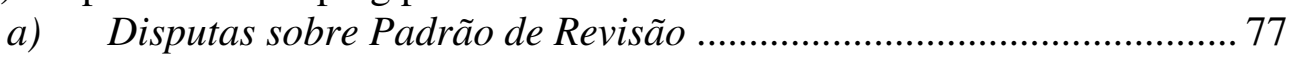

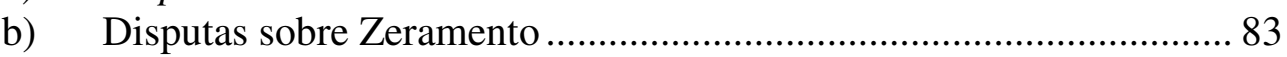

6.2. Conclusão sobre o posicionamento do DSB ............................................ 86

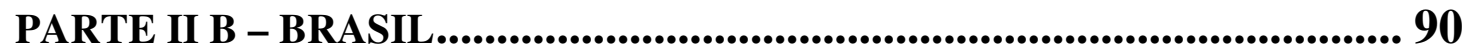

Capítulo 7 - FUNÇÃO LEGISLATIVA BRASILEIRA.................................. 92 
Capítulo 8 - FUNÇÃO EXECUTIVA BRASILEIRA..................................... 96

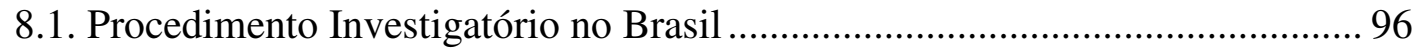

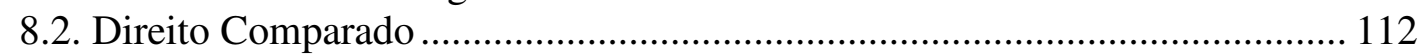

Capítulo 9 - FUNÇÃO JUDICIÁRIA BRASILEIRA.................................... 114

9.1. Breves considerações sobre abuso de poder e discricionariedade ................ 115

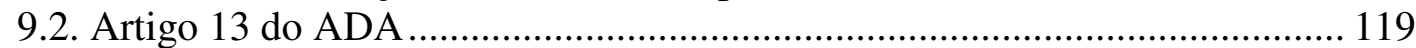

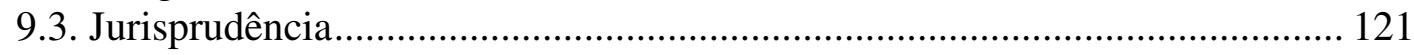

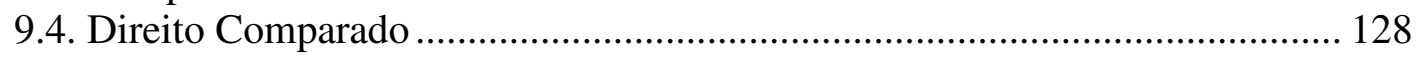

PARTE II C - SIMILARIDADE ............................................................ 140

Capítulo 10 - Similaridade entre as "funções judiciárias" da OMC e do Brasil140

PARTE III - PROBLEMAS IDENTIFICADOS E PROPOSTAS APRESENTADAS .............................................................. 146

Capítulo 11 - PROBLEMAS EM MATÉRIA ANTIDUMPING QUE DIZEM RESPEITO AO DEVIDO PROCESSO LEGAL .................... 146

Capítulo 12 - PROPOSTAS DA RODADA DOHA ........................................... 156

Capítulo 13 - CONSULTA PÚBLICA DO DECRETO 1602/95....................... 164

Capítulo 14 - ANÁlise de PROPOSTAS PARA ALTERAÇÃo do PROCESSO ANTIDUMPING .................................................... 166

14.1. SUGESTÕES A SEREM APLICADAS NO BRASIL................................ 174

(i) Sugestões que dependeriam de renegociação do ADA............................ 175

a. Aumentar os parâmetros para abertura de investigação ........................... 175

b. Aumentar o de minimis da margem de dumping........................................ 176

c. Condução de investigações antidumping por painéis multilaterais............ 177

d. Revisão da medida aplicada por painel binacional como alternativa à

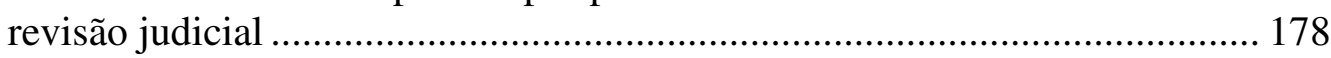

(ii) Sugestões que independeriam de renegociação do ADA ....................... 179

a. Teste do interesse nacional e cortes especializadas................................... 179

14.2. SUGESTÕES A SEREM APLICADAS NA OMC ................................... 180

(i) Padrão de Revisão e Reenvio .................................................................. 180

PARTE IV - CONSIDERAÇÕES FINAIS ............................................... 184

REFERÊNCIAS BIBLIOGRÁFICAS ........................................................... 186 
APÊNDICE 1 - Disputas antidumping encerradas na fase de consultas ........ 210

APÊNDICE 2 - Disputas antidumping em fase de consultas........................ 215

APÊNDICE 3 - Disputas antidumping encerradas ou em fase de painel......... 229

APÊNDICE 4 - Disputas antidumping encerradas ou em fase de apelação..... 245

Anexo I - Propostas Consulta Pública Decreto 1602/95....................................264 


\section{PARTE I - CONSIDERAÇÕES PRELIMINARES}

\section{Capítulo 1 - INTRODUÇÃO}

$\mathrm{O}$ termo dumping tem origem inglesa, tendo sido incorporado a diversos idiomas, inclusive ao português ${ }^{1}$. SCHOENBAUM o caracteriza como a "venda abaixo do custo variável médio",2, mas não entendemos ser essa a definição mais apropriada à luz das regras da Organização Mundial do Comércio (OMC). O Black`s Law Dictionary define dumping como a venda em quantidades grandes e a preços muito baixos ou, também, a venda para o exterior a preço inferior ao da venda em mercado doméstico ${ }^{3}$. Entendemos ser essa última a definição técnica mais apropriada, pois relaciona-se com o preço de venda e não com o custo, conforme consta das regras da OMC. Por essa razão, para fins da presente tese, dumping é a venda para exportação a preço inferior ao da venda no mercado doméstico do país exportador.

Dumping é tema do direito do comércio internacional, regulamentado internamente pelo direito público. A prática de dumping pode levar à imposição de medidas antidumping. A imposição de medidas antidumping só é possível por meio de uma investigação levada a cabo pelo governo do país importador. Essa investigação é um procedimento administrativo e, como tal, deve seguir um iter, i.e. um caminho.

\footnotetext{
${ }^{1}$ Conforme Dicionário HOUAISS da Língua Portuguesa (pag. 1089), dumping é a "ação ou expediente de pôr à venda produtos a um preço inferior ao do mercado, esp. no mercado internacional". O dicionário cita como exemplos "para se desfazer de excedente ou para derrotar a concorrência". O Dicionário AURÉLIO (pag. 706) descreve dumping como a "exportação por preço inferior ao vigente no Mercado interno para conquistar mercados ou dar vazão a excesso de oferta".

2 SCHOENBAUM, Thomas. Market Contestability and Reform in the Antidumping Laws, in German Yearbook of International Law, vol. 39, 1996, pags. 82-99.

${ }^{3}$ Black`s Law Dictionary, $5^{\text {th }}$ edition, St. Paul, West Publishing Co, 1979, pag. 451.
} 
Procedimento é formalidade que se desenvolve dentro de um processo. Consideraremos processo como o instrumento para o exercício de funções com vistas a alcançar um objetivo.

Desde a elaboração da norma aplicável até a aplicação e revisão da medida antidumping (o que, para fins dessa tese, denominaremos processo antidumping), diversos órgãos exercem diferentes funções. Nessa tese abordaremos as funções legislativa, executiva e judiciária, no Brasil e na OMC, no que tange às regras antidumping.

A OMC, criada em 1995 como resultado da Rodada Uruguai, finalizada em abril de 1994, é um foro para regulamentar o comércio internacional, negociar novas normas entre seus Membros e solucionar controvérsias decorrentes da aplicação de suas regras. A OMC incorpora o Acordo Geral sobre Tarifas e Comércio (GATT, sigla em inglês para General Agreement on Tariffs and $\left.\operatorname{Trade}^{4}\right)^{5}$. O Acordo sobre a Aplicação do Artigo VI do GATT, conhecido como Acordo Antidumping (ADA), é fruto de negociação entre os Membros da Organização e sua aplicação é assegurada pelo Sistema de Solução de Controvérsias da OMC, que também o interpreta.

Os Membros da OMC, ao negociarem os acordos com vistas à liberalização comercial, vislumbraram a necessidade de admitir algumas barreiras (tarifárias e não tarifárias) que teriam por objetivo assegurar valores que fossem além do livre comércio. Esses valores constam arrolados, por exemplo, no Artigo XX do GATT $^{6}$.

\footnotetext{
${ }^{4}$ Ao longo da presente tese, utilizaremos a sigla em inglês GATT em razão da consolidação do termo na prática do direito do comércio internacional.

${ }^{5}$ Ao longo da presente tese, referências ao GATT, enquanto texto normativo, referem-se ao GATT 1947, tal como incorporado pelo GATT 1994.

${ }^{6}$ Entre eles, moral pública; vida ou saúde humana, vegetal ou animal; cumprimento de outras obrigações compatíveis com a OMC; proteção de tesouros artísticos, históricos ou arqueológicos; e conservação de recursos naturais exauríveis. Para uma visão completa do assunto, vide AMARAL JUNIOR, Alberto do (e outros). O Artigo XX do Gatt: Meio Ambiente e Direitos Humanos. São Paulo, Aduaneiras, 2009.
} 
Barreiras tarifárias seriam aquelas que, por intermédio de tarifas, dificultam o ingresso de determinado produto em um país. Um exemplo seria o imposto de importação. Barreiras não tarifárias seriam todas as demais, em que o produto não é sobretaxado, mas outras exigências dificultam o ingresso em território nacional, como é o caso de barreiras sanitárias ou técnicas.

Notamos que os Membros da OMC têm recorrido cada vez com mais freqüência às barreiras não tarifárias, pois essas são legitimadas se estiverem de acordo com padrões internacionais. As barreiras tarifárias têm perdido importância, pois as rodadas de negociação multilateral visam diretamente ao corte de tarifas.

As medidas de defesa comercial, que compreendem as medidas antidumping, antisubsídios (medidas compensatórias) e as salvaguardas, têm caráter híbrido, pois são identificadas características inerentes às barreiras tarifárias (por exemplo, a forma de aplicação) e às barreiras não tarifárias (por exemplo, os efeitos no comércio) ${ }^{7}$. Os Membros da OMC criaram acordos para regulamentar essas matérias, a exemplo do ADA, como forma de assegurar que a liberalização comercial não prejudicaria a indústria doméstica indevidamente.

Cumpre lembrar que estamos falando do comércio de bens. Conforme salienta JOSÉ ROBERTO RODRIGUES ${ }^{8}$, o Artigo 18.1 do ADA $^{9}$ impede que um Membro adote medidas antidumping para serviços, posição que estaria confirmada pelo Artigo $18.6^{10}$ do mesmo diploma legal, ao prever que as medidas antidumping serão informadas ao Conselho para o Comércio de Bens. Ressaltamos que o fato de

\footnotetext{
${ }^{7}$ Diversos autores analisaram a natureza juridical dos direitos antidumping. Vide, por exemplo, FERRAZ JR., Tércio Sampaio, DA ROSA, José Del Chiaro Ferreira e GRINBERG, Mauro. Direitos Anti-Dumping e Compensatórios: sua natureza jurídica e consequências de tal caracterização. Revista de Direito Mercantil, Industrial, Econômico e Financeiro (RDM) n. 91, julho/setembro 1993, pag. 94.

${ }^{8}$ RODRIGUES, José Roberto Pernomian. O dumping como forma de expressão do abuso do poder econômico: caracterização e conseqüências. Tese de doutorado. Faculdade de Direito da Universidade de São Paulo, 1999, 284 p.

9 "No specific action against dumping of exports from another Member can be taken except in accordance with the provisions of GATT 1994, as interpreted by this Agreement".

10 "The Committee shall review annually the implementation and operation of this Agreement taking into account the objectives thereof. The Committee shall inform annually the Council for Trade in Goods of developments during the period covered by such reviews".
} 
o ADA ser o Acordo para Implementação do Artigo VI do GATT e constar do Anexo 1A ao Acordo Constitutivo da OMC (Acordo de Marraqueche), que congrega os acordos multilaterais para o comércio de bens, já deixa claro que não abrangeria serviços. Quando da criação do Acordo Geral sobre o Comércio de Serviços (GATS - General Agreement on Tariffs and Services na sigla em inglês), e diante da inexistência de disposição específica para antidumping em serviços ${ }^{11}$, podemos afirmar ser essa uma lacuna das regras de comércio internacional.

Visto que o ADA regula antidumping para bens, ele prevê um procedimento a ser seguido (iter) para que as medidas antidumping restrinjam o mínimo possível o comércio global. Qualquer medida aplicada sem que tenha sido observado esse iter, pode ser considerada contrária às regras da OMC, podendo sujeitar o país que conduziu a investigação antidumping a questionamento perante o Sistema de Solução de Controvérsias da OMC.

Nessa tese serão apontados alguns problemas desse iter, e do processo antidumping como um todo, sendo apresentadas algumas propostas para solucionálos. Todavia, em pouco acrescentaria à Ciência Jurídica se a presente tese se restringisse a constatar o caráter protecionista das medidas antidumping, e apresentasse propostas com vistas a garantir o devido processo legal nessa matéria.

$\mathrm{Na}$ tentativa de inovar, e contribuir para o enriquecimento do Direito do Comércio Internacional no Brasil, a tese a ser defendida é que a função do Poder Judiciário e do Sistema de Solução de Controvérsias da OMC em muito se assemelham no que diz respeito às medidas antidumping. Daí a sugestão para que os exportadores e/ou importadores recorram primeiro ao judiciário. Para tanto, sugerimos a criação de cortes especializadas. Estamos cientes, contudo, de que esta medida não resolveria os problemas, tendo em vista que as medidas antidumping representam parcela ínfima do comércio global, embora representem $20 \%$ das

\footnotetext{
${ }^{11}$ Interessante notar que o Artigo XV do GATS trata de subsídios, e afirma que os Membros deverão negociar dispositivos específicos para regulamentar o tema. Não há previsão similar para antidumping.
} 
disputas submetidas à OMC. Serão, portanto, feitas também algumas sugestões que alteram o processo antidumping para que atendam melhor à sua finalidade. 


\section{Capítulo 2 - BREVE HISTÓRICO SOBRE ANTIDUMPING}

\section{1. ÂMBITO MULTILATERAL}

A Revolução Industrial na Inglaterra, em 1760, trouxe alguns conceitos relacionados a mercado consumidor e fornecedor. Trouxe a inovação tecnológica com o advento da máquina a vapor, e contribuiu para o surgimento do trabalho assalariado. Conforme nos lembra VINER ${ }^{12}$, a independência dos Estados Unidos da América (EUA), em 1776, e a Revolução Francesa, em 1789, foram marcos históricos que, entre outros fatores, abriram o comércio e levaram várias indústrias à falência em razão da inexistência de normas para regular a concorrência.

Foi apenas com o Sherman Anti-trust Act, em 1890, introduzido pelos EUA contra preços predatórios praticados por vendedores nacionais, que o assunto começou a ser discutido. O tema estava circunscrito, porém, apenas ao mercado interno estadunidense e, portanto, não regulava o dumping, tema do comércio internacional. Mais tarde, as regras passaram a abranger transações com o mercado externo. No Canadá, essa legislação surgiu em 1904; na Nova Zelândia, em 1905; na Austrália, em 1906; na França, em 1910; no Japão, em 1911; e nos EUA, em 1916. Essas sim podem ser consideradas legislações específicas sobre defesa comercial (antidumping), e não sobre concorrência (antitruste).

JACKSON $^{13}$ também lembra que o Reino Unido criou sua legislação antidumping antes da Primeira Guerra Mundial, como forma de combater as importações alemães.

Em 1946, ocorreram reuniões em Genebra para criação dos estatutos da Organização Internacional de Comércio (OIC) ${ }^{14}$ e de bases para o GATT.

\footnotetext{
${ }^{12}$ VINER, Jacob. Dumping: a problem in International Trade, New York, Augustus M. Kelley Publishers, 1966, pag. 36.

${ }^{13}$ JACKSON, John. Dumping in International Trade: Its meaning and Context, in Antidumping Law and Practice: a comparative study, Chapter 1, Ann Arbor, Michigan University Press, 1989, pag. 2.

14 A OIC chegou a ser criada pela Carta de Havana em 1948, mas por não ter sido ratificada pelos EUA, não chegou a funcionar, restando apenas as obrigações contratuais do GATT.
} 
Antes da criação do GATT em $1947^{15}$, durante as reuniões de Londres do Comitê Preparatório ${ }^{16}$, discutiram-se as formas de dumping como sendo quatro: (i) de preços, (ii) de serviços, (iii) cambial, e (iv) social, mas foi reconhecida a competência do GATT apenas para tratar do primeiro tipo ${ }^{17}$. Notamos que o Fundo Monetário Internacional, àquela época, já havia sido designado para tratar do dumping cambial. O relatório do subcomitê da Carta de Havana ${ }^{18}$ também deixou claro que o Artigo VI do GATT visava unicamente ao dumping de $\operatorname{preços}^{19}$.

A primeira parte do Artigo VI do GATT, até hoje em vigor, explicita que:

"As Partes Contratantes reconhecem que o
dumping, pelo qual produtos de um país são
introduzidos no comércio de outro país a preços
inferiores que o valor normal, deve ser condenado se
causar dano ou ameaçar causar dano a uma
indústria nacional já estabelecida, ou retardar
substancialmente o estabelecimento de uma
indústria doméstica”. 20

${ }^{15}$ Foram 24 os signatários do GATT: Austrália, Bélgica, Brasil, Burma (atual Mianmar), Canadá, Ceilão (atual Sri Lanka), Chile, China, Cuba, Tchecoslováquia, França, Índia, Líbano, Luxemburgo, Países Baixos, Nova Zelândia, Noruega, Paquistão, Rodésia do Sul (atual Zimbabue), Síria, África do Sul, Reino Unido, Irlanda do Norte e EUA.

${ }^{16}$ Reuniões realizadas em outubro de 1946 no contexto da Conferência sobre comércio e emprego das Nações Unidas (ONU), na qual foram estabelecidos os fundamentos constitutivos da OIC.

${ }_{17}$ EPCT/C.II/48, p. 1: "the discussion had shown that there were four types of dumping: price, service, exchange and social. Article 11 permitted measures to counteract the first type. It would obligate members not to impose anti-dumping duties with respect to the other three types. It seemed to be generally agreed that exchange dumping was a question for the Fund to consider. Social dumping was a matter for consideration by the Committee studying industrialization".

${ }^{18}$ Em novembro de 1947 foram iniciadas discussões em Genebra que culminaram com a assinatura, em março de 1948, da Carta de Havana.

${ }^{19}$ Havana Reports, p. 74 , para. 23; vide também E/CONF.2/C.3/C/18, p. 3: "the Article as agreed to by the Sub-Committee condemns injurious 'price dumping' as defined therein and does not relate to other types of dumping".

20 "The contracting parties recognize that dumping, by which products of one country are introduced into the commerce of another country at less than the normal value of the products, is to be condemned if it causes or threatens material injury to an established industry in the territory of a contracting party or materially retards the establishment of a domestic industry. (...)”. 
Cumpre ressaltar que esse artigo consta da Parte II do GATT e, em razão da grandfather clause $^{21}$, não impôs às Partes Contratantes a obrigação de alterar legislações nacionais já existentes. Importante também notar que foi utilizado o termo "condemned", que traz a ideia de uma prática ilícita, o que entendemos não se tratar.

No tocante ao cálculo da medida antidumping a ser imposta, poucos parâmetros constaram do Artigo VI do GATT, mas foram discutidos entre as Partes Contratantes em momento posterior. Entre esses parâmetros, destacamos que o preço de exportação deve ser, idealmente, ex factory, podendo ser FOB (free on board) mediante a realização de determinados ajustes: o importante é que seja comparável ao valor normal. ${ }^{22}$

Conforme observam CARREAU e JUILLARD ${ }^{23}$, o GATT também não trouxe diretivas de como deveriam ser conduzidos os procedimentos nacionais de investigação, deixando as Partes Contratantes livres para organizar os procedimentos internos de determinação do dumping.

\footnotetext{
${ }^{21}$ Artigo 1(b) do Protocolo de Aplicação Provisória: "The Governments of the Commonwealth of Australia, the Kingdom of Belgium (in respect of its metropolitan territory), Canada, the French Republic (in respect of its metropolitan territory), the Grand-Duchy of Luxemburg, the Kingdom of The Netherlands (in respect of its metropolitan territory), the United Kingdom of Great Britain and Northern Ireland (in respect of its metropolitan territory), and the United States of America, undertake, provided that this Protocol shall have been signed on behalf of all the foregoing Governments not later than 15 November 1947, to apply provisionally on and after 1 January 1948: (...) (b) Part II of that Agreement to the fullest extent not inconsistent with existing legislation."

${ }^{22}$ New Zealand - Imports of Electrical Transformers from Finland. L/978, adotado em 13 de maio de 1959, 8S/145, 146, paras. 5-6: "the Group took the view that it was the export price that had to be compared with the normal domestic price and agreed that the export price would ideally be the exfactory price on sales for export; an equally satisfactory price would be the f.o.b. price, port of shipment. In the exceptional case where the actual f.o.b. price on an invoice could not appropriately be used (for example, where the export sale was between associated houses), the export price might be taken to be a notional f.o.b. price calculated by making adjustments such as would normally be made to convert a c.i.f. or other price to f.o.b. The aim should in any event be to arrive at a price which was genuinely comparable with the domestic price in the exporting country".

${ }^{23}$ CARREAU, Dominique e JUILLARD, Patrick. Droit International Economique. $4^{\mathrm{a}}$ Ed. Paris: LGDJ, 1998, p. 2.
} 
HUGO FONSECA ${ }^{24}$ ressalta que, “a falta de regulamentação do dispositivo do Art. VI do GATT suscitou inúmeras críticas, em virtude das possibilidades de utilização das normas antidumping com fins protecionistas, o que levou a negociação do primeiro código antidumping na denominada Rodada Kennedy (1964-1967)”.

Na Rodada Kennedy foi criado o "1967 Agreement on Implementation of Article VI" ("Acordo AD da Rodada Kennedy") 25 com 17 artigos, mas nenhum anexo. Foi estabelecido que a prática do dumping deveria ser a "causa substancial" de dano à indústria nacional. Além disso, foram inseridas diversas exigências procedimentais e critérios para aplicação das medidas antidumping, tais como: exigência de que medidas provisórias somente fossem aplicadas após uma investigação preliminar; restrição da aplicação de medidas retroativas; e preferência pela imposição de um direito menor que a margem de dumping ("lesser duty") 26 . Ocorre que esse Acordo nunca foi implementado, uma vez que o Congresso dos EUA recusou-se a ratificá-lo. Vale lembrar que o Brasil não foi signatário desse Acordo.

Posteriormente, com a Rodada Tóquio (1973-1979), foi alterado o conceito de causalidade, de modo que esta não fosse mais a causa substancial de dano à indústria nacional. Os países desenvolvidos, maiores usuários do antidumping na época, conseguiram na Rodada Tóquio inserir dois elementos chaves que transformaram o estatuto do dumping no mais utilizado dentro dos mecanismos de proteção do comércio: (i) definição do termo "abaixo do valor normal”; e (ii) necessidade de mera demonstração do dano causado à indústria doméstica.

\footnotetext{
${ }^{24}$ FONSECA, Hugo Soares Porto. Tensões nas Relações Comerciais Internacionais: Medidas Antidumping e Protecionismo sob uma perspectiva brasileira. Dissertação de Mestrado. Belo Horizonte, 2007, pag. $60.0 \mathrm{em}$ http://www.biblioteca.pucminas.br/teses/Direito_FonsecaHS_1.pdf. Último acesso em 21/06/2012. ${ }_{25}^{25}$ A íntegra pode ser encontrada em BISD 15S/4-35.

${ }^{26}$ GUEDES, Josefina e PINHEIRO, Silvia. Antidumping, Subsídios e Medidas Compensatórias. $3^{\text {a }}$ ed. São Paulo: Aduaneiras, 2002, p. 35.
} 
No tocante ao primeiro aspecto, PRUSA e $\mathrm{SKEATH}^{27}$ argumentam que a "definição foi ampliada e passou a abarcar não apenas a discriminação internacional de preços (diferença do preço no mercado doméstico e do preço de exportação), mas também as vendas abaixo do custo de produção, codificando uma prática utilizada por alguns membros como os EUA, Austrália e Canadá”.

Quanto ao segundo aspecto, tendo sido excluído o termo "principal", tornou-se mais fácil iniciar uma investigação antidumping. Esse fato flexibilizou a regra para o procedimento de investigação, passando os EUA a aceitá-lo. Conforme demonstrado por STIGLITZ ${ }^{28}$, essa alteração nas regras possibilitou o aumento do número de investigações antidumping.

Assim, ao final da Rodada Tóquio, em 1 de janeiro de 1980, entrou em vigor o "1979 Agreement on Implementation of Article VI" ("Acordo AD da Rodada Tóquio"). Esse Acordo também tinha 17 artigos, mas foi criado um dispositivo específico para solução de controvérsias, e outro prevendo tratamento especial e diferenciado para países em desenvolvimento. Foi também detalhado o procedimento a ser adotado nas investigações, mas não havia os anexos sobre verificação in loco e melhor informação disponível que foram negociados na Rodada Uruguai. Cumpre lembrar que o Acordo AD da Rodada Tóquio ainda era um acordo de adesão facultativa ${ }^{29}$, assim como os demais acordos da época do GATT $^{30}$. O Brasil foi parte signatária do Acordo AD da Rodada Tóquio.

\footnotetext{
${ }^{27}$ PRUSA, Thomas e SKEATH, Susan. The Economic and Strategic Motives for Antidumping Filings. NBER Working Paper No. 8424, Agosto 2001.

${ }^{28}$ STIGLITZ, Joseph E. Dumping on Free Trade: The US Import Trade Law, Southern Economic Journal, 1997: "in the earlier period, 11,9 cases were investigated for every \$100 billion (1987 dollars) of merchandise imports. In the later period, 13,2 cases were investigated for every \$100 billion of merchandise imports. Thus, unfair imports are assumed to be a constant proportion of total merchandise imports, there was still a significant increase in the use of antidumping procedures, even after accounting for the increased incidence of unfair trade" in BARROS, Maria Carolina Mendonça. Antidumping e Antitruste: interface possível no sistema multilateral de comércio. Tese de Doutorado, USP, 2008, pag. 179.

${ }^{29}$ Eram 24 os signatários do Acordo AD da Rodada Tóquio: Austrália, Áustria, Brasil, Canadá, Tchecoslováquia, Egito, UE, Finlândia, Hong Kong, Hungria, Índia, Japão, Coréia, México, Noruega, Paquistão, Polônia, Romênia, Cingapura, Espanha, Suécia, Suíça, EUA e Iugoslávia.

${ }^{30}$ Desse fato deriva a terminologia "GATT à la carte". Para detalhes a respeito, vide HUANG, Zhixiong. Rise and Fall of Trade Multilateralism: A Proposal for 'WTO à la carte' as an Alternative Approach for Trade Negotiation. In Asian International Economic Law Network (AIELN),
} 
Na Rodada Uruguai, o ADA foi negociado e, juntamente a diversos outros acordos multilaterais sobre o comércio de bens, entrou em vigor em 1 de janeiro de 1995.

Após seis anos de vigência, o mandato de Doha, lançado em 2001, determinou que os Membros da OMC deveriam negociar o ADA com vistas a aprimorar e aperfeiçoar o seu texto. Tais negociações estão em curso até a data de finalização dessa tese, como veremos em capítulo específico.

\section{2. ÂMBITO REGIONAL}

Argentina, Brasil, Paraguai e Uruguai firmaram, em 1991, o Tratado de Assunção que criou o Mercado Comum do Sul (MERCOSUL).

Logo no início, com vistas a eliminar as barreiras ao comércio recíproco, o antidumping intrazona foi tratado nas Decisões do Conselho do Mercado Comum (CMC) 07/93 e 21/94, nas Resoluções do Grupo Mercado Comum (GMC) 63/93 e 129/94, e na Diretiva da Câmara de Comércio do Mercosul (CCM) 5/95 - discutida pelo Comitê Técnico $\mathrm{n}^{\circ} 6$ sobre Práticas Desleais e Salvaguardas. Esses normativos não vincularam os Estados Partes, pois não foram internalizados.

Conforme salienta BARRAL ${ }^{31}$, a Decisão CMC 21/94 estipula que a CCM deveria elaborar um estatuto de defesa da concorrência para o MERCOSUL, com o objetivo de substituir as medidas antidumping no comércio intrabloco, o que até o momento não ocorreu. Em 1996, a Decisão CMC 18/96 (Protocolo de Defesa da Concorrência) determinou que, até 2000, deveria prevalecer a legislação nacional de cada um dos Estados Partes.

Conferência Inaugural, 30 junho de 2009 , disponível $\quad \mathrm{em}$ http://aieln1.web.fc2.com/Huang_panel6.pdf. Último acesso em 06/07/12.

${ }^{31}$ BARRAL, Welber. Dumping e Comércio Internacional: a regulamentação antidumping após a Rodada Uruguai, Editora Forense, Rio de Janeiro, 2000, pag. 321. 
Com relação ao antidumping extrazona (contra países que não fazem parte do bloco econômico), a Decisão CMC 11/97 trouxe o marco normativo, mas também não entrou em vigor. Esse Marco Normativo do Regulamento Comum Relativo à Defesa Contra Importações Objeto de Dumping Provenientes de Países Não-Membros do MERCOSUL reflete os termos do ADA e previa, em seu Artigo 3, a criação de um Regulamento Comum Antidumping do MERCOSUL.

Esse Marco estabelece no âmbito do MERCOSUL: (i) uma instância técnica para zelar pelo cumprimento das disposições do Regulamento, conduzir investigação a fim de determinar a existência de dumping, dano e nexo causal entre ambos, proceder à revisão de medidas antidumping e ao acompanhamento dos compromissos de preços; e (ii) uma instância decisória que, com base em parecer da instância técnica, decidiria sobre abertura de investigação e revisão, aplicação de medidas antidumping provisórias, aplicação e modificação de direitos antidumping, restituição de sobretaxas pagas em excesso à margem de dumping, encerramento de investigação sem aplicação de medidas antidumping e homologação de compromissos de preços. Fazendo uma analogia com o sistema interno brasileiro, a instância técnica seria o Departamento de Defesa Comercial (DECOM) e a instância decisória, a Câmara de Comércio Exterior (CAMEX).

No âmbito intrazona, em 2000, foi promulgada a Decisão CMC 28/00, seguida pela Decisão CMC 64/00. O artigo $1^{\circ}$ da Decisão CMC N 28/00 instruiu o GMC a elaborar uma proposta para disciplinar o processo de investigação e aplicação de medidas antidumping e direitos compensatórios no comércio entre os Estados Partes até 30 de novembro de 2000. A Decisão CMC 64, de 14 de dezembro de 2000, trouxe anexo procedimento a ser observado a partir de julho de 2001, revogando a Diretriz CCM N 5/95. O GMC ficou de submeter proposta de disciplinas adicionais até 30/06/2001, o que não ocorreu.

Um ponto interessante a ser enfatizado é que os Estados Partes do MERCOSUL, apesar de estarem em um processo de integração há mais de 20 anos, ainda veem necessidade de aplicar medidas restritivas intrabloco. O 
procedimento trazido pela Decisão CMC 64/00 (intrazona) é muito similar ao trazido pela Decisão 11/97 (extrazona), exceto no que diz respeito à duração máxima da medida antidumping definitiva: três $\operatorname{anos}^{32}$ se a medida é aplicada contra outro Estado Parte (intrazona), enquanto que a prática multilateral/nacional (extrazona) é permitir a duração por cinco anos.

\section{3 ÂMBITO NACIONAL}

Podemos dizer que o Brasil passou a tratar de medidas antidumping apenas como reflexo dos compromissos assumidos internacionalmente. $\mathrm{O}$ primeiro passo foi a incorporação do GATT a seu ordenamento jurídico, por meio da Lei $n^{\circ} 313$, de 30 de julho de 1948. O Artigo VI tratava especificamente de dumping.

Em 1957, a Lei n. ${ }^{\circ} 3.244 / 57$ veio reformar a política alfandegária brasileira e, em seu Artigo $3^{033}$, admitiu o aumento do imposto de importação na medida necessária para neutralizar o dumping. Ou seja, não se tratava, na época, de uma medida antidumping cobrada na forma de uma sobretaxa (natureza própria), mas sim de um aumento no imposto de importação por um determinado período de tempo.

Conforme mencionado no histórico multilateral, o primeiro código antidumping a ser aderido pelo Brasil foi o Acordo AD da Rodada Tóquio, de 1979, aprovado pelo Congresso Nacional pelo Decreto Legislativo $\mathrm{n}^{\circ} 20$, em 5 de dezembro de 1986, promulgado pelos Decretos $\mathrm{n}^{\circ}$ 93.941, de 19 de janeiro $1987 \mathrm{e}$ n 93.962, de 23 de janeiro de 1987 e publicados no Diário Oficial da União (DOU) de 2/2/87.

\footnotetext{
${ }^{32}$ Artigo 5 da Decisão CMC 64/00.

33 "Poderá ser alterada dentro dos limites máximo e mínimo do respectivo capítulo, a alíquota relativa a produto. Parágrafo $1 .^{\circ}$ - Nas hipóteses dos itens ' $a$ ', ' $b$ ' e 'c' a alteração da alíquota, em cada caso, não poderá ultrapassar, para mais ou para menos, a 30\% (trinta por cento) 'ad valorem'. Parágrafo $2^{\circ}$ - Na ocorrência de 'dumping', a alíquota poderá ser elevada até o limite capaz de neutralizá-lo".
} 
Conforme consta da página eletrônica do Ministério da Indústria e Comércio Exterior ${ }^{34}$, “a implementação desses Códigos no Brasil foi retardada devido ao fato de estarem em vigor então, no país, outros mecanismos de proteção comercial, tais como diversos regimes especiais de importação e severos controles administrativos de importação. Com isso, a produção doméstica encontrava-se relativamente imune às práticas desleais de comércio". Todavia, ressaltam que essas práticas violavam os compromissos que o Brasil estava assumindo nos foros internacionais, razão pela qual se mostrou necessário alterá-los.

Na sequência, a Resolução da Comissão de Política Aduaneira (CPA) 1.227/87 dispôs sobre os procedimentos a serem adotados em casos de dumping. Como lembra SILVIA PINHEIRO e JOSEFINA GUEDES ${ }^{35}$, o peticionário preenchia um roteiro de petição recebido do governo e a participação dos importadores era praticamente inexistente. Ainda menor era a participação dos exportadores acusados. Além disso, as autoras ressaltam que pouco espaço havia para as discussões jurídicas e que, somente com o advento da Constituição Federal em 1988 (CF), é que princípios fundamentais, como contraditório e ampla defesa, começaram a ser exigidos. As autoras citam que a primeira investigação antidumping brasileira foi iniciada em 1988 e impôs medidas contra correntes de bicicletas provenientes da China, União Soviética, Tchecoslováquia e Índia. O segundo caso foi contra cimento da Argentina e do Uruguai, o qual resultou em compromisso de preço em 1989.

Em 1990, no governo Collor de Mello, efetuou-se uma ampla reforma da estrutura da Administração Pública Federal. A gestão do comércio exterior foi transferida para o Departamento de Comércio Exterior (DECEX), subordinado à Secretaria Nacional de Economia (SNE) do Ministério da Economia, Fazenda e Planejamento (MEFP), ficando extinta a CPA. Dentro do MEFP, foi criada a Coordenadoria Técnica de Tarifas para condução das investigações antidumping.

\footnotetext{
${ }^{34}$ Disponível em http://www.desenvolvimento.gov.br/sitio/interna/interna.php?area=5\&menu=228. Último acesso em 8/7/12.

${ }^{35}$ PINHEIRO, Silvia e GUEDES, Josefina. A Defesa Comercial no Brasil - Passado, Presente e Futuro. In LIMA CAMPOS, Aluisio. Ensaios em Comércio Internacional. São Paulo, Editora Singular, 2005, pags. 66-70.
} 
Em 1992, no governo Itamar Franco, foi criado o Ministério da Indústria, Comércio e Turismo (MICT), ao qual foi subordinada a Secretaria de Comércio Exterior (SECEX), que assumiu as investigações antidumping.

Com o fim da Rodada Uruguai, o Decreto Legislativo 30, de 15 de dezembro de 1994, aprovou os acordos abrangidos da OMC, entre eles o ADA. O Decreto 1.355, de 30 de dezembro de 1994, o promulgou. Em 30 de março de 1995 foi criada a Lei 9.019 que, em seus 15 artigos, dispõe, sobretudo, sobre a forma de arrecadação das medidas antidumping (e compensatórias) pelo Ministério da Fazenda, e retroatividade da medida. Na sequência, com o intuito de regulamentar o tema, o Decreto 1.602, de 23 de agosto de 1995, tornou a legislação pátria mais detalhada sobre o tema, sendo praticamente uma cópia do ADA.

Ainda em 1995, no governo Fernando Henrique, o DECOM foi criado como órgão especializado para a condução das investigações.

Vale lembrar que foi a Circular SECEX 21, de 02 de abril de 1996, que trouxe os critérios específicos para início da investigação. Em 2001, a competência para imposição das medidas antidumping, que era conjunta do atual Ministério do Desenvolvimento, Indústria e Comércio Exterior (MDIC) e Ministério da Fazenda (MF), foi transferida para a CAMEX, órgão colegiado composto por sete Ministérios.

Em 2002, o Regulamento Aduaneiro veio tratar do dumping. Segundo o Artigo 695 do Decreto $\mathrm{n}^{\circ}$ 4.543/2002, dumping é a “introdução de um bem no mercado doméstico, inclusive sob as modalidades de drawback, a preço de exportação inferior ao preço efetivamente praticado para o produto similar nas operações mercantis normais, que o destinem a consumo interno no país exportador" (redação dada pelo Decreto $n^{\circ}$. 4.765, de 24/6/2003 que condiz com as obrigações assumidas pelo Brasil na OMC). 
Em 10 de junho de 2003, o Decreto 4.732 versou sobre a competência da CAMEX para imposição das medidas antidumping.

Em 2008, a Lei no 11.786 incluiu na Lei 9.019/95 o Artigo 10-A para prever a possibilidade de combate à circunvenção. A Resolução CAMEX N ${ }^{\circ} 63$, de 17.08.10 (alterada pela Resolução CAMEX N 25, de 05.05.11) disciplinou esse assunto e a Portaria SECEX N ${ }^{\circ} 21$, de 18.10.10 (alterada pela Portaria SECEX N 14, de 13.05.11) regulamentou as regras anticircunvenção no Brasil.

No fim de 2011, ocorreu consulta pública para alteração do Decreto 1602/95 (ainda em análise) e foi criado, pela Portaria SECEX n ${ }^{\circ} 46 / 11$, roteiro para a elaboração de petições relativas a investigações antidumping.

Em 01 de março de 2012, por meio da Resolução CAMEX $n^{0}$ 13, foi instituído o Grupo Técnico de Avaliação de Interesse Público (GTIP), no âmbito da Secretaria de Acompanhamento Econômico do Ministério da Fazenda (SEAE/MF). O GTIP será integrado por representantes de diversos ministérios e terá como função a análise da não aplicação, suspensão ou alteração de direitos antidumping e medidas compensatórias, em vigor ou a serem aplicadas, por razões de interesse público.

Passemos a analisar o conceito e as características do devido processo legal. 


\section{Capítulo 3 - O DEVIDO PROCESSO LEGAL}

O devido processo legal é um princípio por meio do qual se estabelece a obrigatoriedade de seguir uma ordem previamente determinada de procedimentos/atos com vistas a prover segurança e previsibilidade para as partes interessadas.

Criado pela Magna Carta em $1215^{36}$ como um mecanismo processual para garantir que ninguém seria privado de sua liberdade e/ou propriedade indevidamente, hoje tem um significado bem mais abrangente.

No Brasil, está previsto na Constituição Federal de $1988^{37}$ e é uma garantia contra a ação da Administração Pública. Outros princípios basilares, como o da ampla defesa e do contraditório ${ }^{38}$, estão intimamente relacionados, uma vez que necessários para que o devido processo legal seja observado.

A ampla defesa seria a possibilidade de valer-nos de todos os instrumentos jurídicos disponíveis para nos defender. O contraditório seria a possibilidade de sempre apresentarmos argumentos contrários aos apresentados contra os nossos interesses. Nesse sentido, o contraditório também seria uma forma de assegurar a ampla defesa. Ambos esses princípios dependem de uma atuação transparente para que possam ser aplicados. Sem transparência também não é possível alcançar o devido processo legal.

Conforme sustenta CRETELLA NETO 39 , "o `due process of Law' desempenha, assim, a função de verdadeiro mega-princípio, pois permeia e coordena toda a complexa função jurisdicional do Estado, fazendo com que os

\footnotetext{
${ }^{36}$ Para o histórico completo do devido processo legal vide CRETELLA NETO, José. Direito Processual na Organização Mundial do Comércio. Rio de Janeiro, Forense, 2003, pags. 192-199.

${ }^{37}$ Artigo 5, LIV da CF: "ninguém será privado da liberdade ou de seus bens sem o devido processo legal'.

${ }^{38}$ Artigo 5, LV da CF: "aos litigantes, em processo judicial ou administrativo, e aos acusados em geral são assegurados o contraditório e ampla defesa, com os meios e recursos a ela inerentes”.

39 CRETElla NETO, José. Direito Processual na Organização Mundial do Comércio. RJ: Forense, 2003, pag. 196.
} 
princípios processuais atendam aos critérios da proporcionalidade e da razoabilidade, harmonizando-os entre si e garantindo a eficácia da Justiça. Permite, pois, que se chegue ao processo justo."

Esse também é o entendimento de JOSÉ AFONSO DA SILVA ${ }^{40}$. Segundo o autor, pela legislação brasileira "garante-se o processo e quando se fala em processo, e não em simples procedimento, alude-se, sem dúvida, a formas instrumentais adequadas, a fim de que a prestação jurisdicional, quando entregue pelo Estado, dê a cada um o que é seu, segundo os imperativos da ordem jurídica." Daí podemos concluir que o conceito de processo é mais abrangente que o de procedimento (conforme temos adotado nessa tese), e que o objetivo do princípio do devido processo legal é assegurar Justiça.

Embora ambos os autores utilizem o termo prestação/função jurisdicional, o que poderia ser interpretado como se o princípio do devido processo legal fosse aplicável unicamente aos processos judiciais, é indiscutível sua aplicação a toda a atividade da Administração Pública, como os próprios autores reconhecem. CRETELLA NETO ${ }^{41}$ menciona que no caso do Poder Legislativo, revela-se como devido processo legal substancial, e não processual, vedando a promulgação de leis em violação aos direitos fundamentais.

Apesar de a Lei 9.784/99, que regula o processo administrativo, não mencionar expressamente o princípio do devido processo legal, ela garante todos os pressupostos para que este possa ser observado, como, por exemplo, a observância da ampla defesa, contraditório, segurança jurídica e observância das formalidades essenciais à garantia dos direitos dos administrados ${ }^{42}$.

\footnotetext{
40 SILVA, José Afonso da. Curso de Direito Constitucional Positivo, 28a. ed, São Paulo: Malheiros, 2007, pag. 411.

${ }^{41}$ CRETELLA NETO, José. Direito Processual na Organização Mundial do Comércio. RJ: Forense, 2003, pag. 196.

${ }^{42}$ Artigo $2^{\circ}$ da Lei 9.784/99: “A Administração Pública obedecerá, dentre outros, aos princípios da legalidade, finalidade, motivação, razoabilidade, proporcionalidade, moralidade, ampla defesa, contraditório, segurança jurídica, interesse público e eficiência.

Parágrafo Único: Nos processos administrativos serão observados, entre outros, os critérios de: I - atuação conforme a lei e o Direito; (...) VIII - observância das formalidades essenciais à garantia dos direitos dos administrados”.
} 
Outro aspecto importante para garantia do devido processo legal é o direito de recorrer. Sem ele não seria possível alterar decisões que tenham sido proferidas com vícios formais ou substanciais, inerentes à atividade humana. O princípio do duplo grau de jurisdição aplica-se tanto para as decisões do judiciário, como para os atos da Administração Pública. Interessante notar que os atos administrativos estão sujeitos a recursos administrativos para análise da legalidade e do mérito, e poderão tramitar por três instâncias administrativas ${ }^{43}$. Esgotados os meios administrativos, ou mesmo antes de esgotá-los, ainda é possível recorrer ao Poder Judiciário.

Há quem sustente ser necessário esgotar a esfera administrativa para depois recorrer ao Judiciário ${ }^{44}$. Não é esse o entendimento que deveria prevalecer à luz do disposto em nossa Constituição Federal, de que ninguém poderá ser privado do acesso à Justiça, conforme sustenta a Ministra ELLEN GRACIE ${ }^{45}$. Prevalece também o entendimento de que o Judiciário não pode adentrar ao mérito do ato administrativo, mas apenas tratar das questões de forma.

Outro aspecto de extrema relevância para a compreensão do devido processo legal para fins dessa tese diz respeito aos prazos. Nenhum procedimento que seja moroso estará obedecendo ao devido processo legal, exceto se a lei permitir que essa morosidade ocorra. Trataremos dos prazos para recursos

\footnotetext{
${ }^{43}$ Artigos 56 e 57 da Lei 9.784/99.

44 Em pesquisa realizada na jurisprudência nacional, o esgotamento encontra fundamento constitucional apenas nas ações desportivas, com base no Artigo 217, parágrafo primeiro da CF: " $\$$ $1^{\circ}$ - O Poder Judiciário só admitirá ações relativas à disciplina e às competições desportivas após esgotarem-se as instâncias da justiça desportiva, reguladas em lei."

45 "Quanto à alegada preclusão, o prévio uso da via administrativa, no caso, não é pressuposto essencial ao exercício do direito de interposição do mandado de segurança. Condicionar a possibilidade do acesso ao Judiciário ao percurso administrativo equivaleria a excluir da apreciação do Judiciário uma possível lesão a direito individual, em ostensivo gravame à garantia do art. 5', XXXV, da CF." (MS 23.789, voto da Rel. Min. ELLEN GRACIE, julgamento em 30-62005, Plenário, DJ de 23-9-2005.). Em relação a causas trabalhistas/previdenciárias: "Não há previsão constitucional de esgotamento da via administrativa como condição da ação que objetiva o reconhecimento de direito previdenciário." ( $\underline{R E \quad 549.238-A g R, ~ R e l . ~ M i n . ~ R I C A R D O ~}$ LEWANDOWSKI, julgamento em 5-5-2009, Primeira Turma, DJE de 5-6-2009.) No mesmo sentido: RE 549.055-AgR, Rel. Min. AYRES BRITTO, julgamento em 5-10-2010, Segunda Turma, DJE de 10-12-2010; AI 742.874-AgR, Rel. Min. JOAQUIM BARBOSA, julgamento em 2-3-2010, Segunda Turma, DJE de 26-3-2010.
} 
administrativos no capítulo sobre a função executiva, e dos prazos para recursos judiciais no capítulo sobre a função judiciária.

LEANDRO ROCHA DE ARAÚJO ${ }^{46}$ analisou as propostas para facilitação do comércio relacionadas ao devido processo legal apresentadas pelos Membros da OMC e chegou à conclusão de que trariam maior previsibilidade apesar de algumas serem de difícil aplicação. Essas propostas foram: mecanismo único de revisão em união aduaneira ${ }^{47}$; abrangência do direito de recorrer, fixação de prazo e recebimento de informações ${ }^{48}$; abrangência da consulta formal, titularidade e $\operatorname{prazos}^{49}$.

No que diz respeito especificamente a antidumping, conforme ressaltam CZAKO, HUMAN e MIRANDA ${ }^{50}$, o Artigo 6.2 do ADA $^{51}$ traz o princípio geral de que deve ser dada ampla oportunidade para que as partes interessadas defendam seus interesses. Mais especificamente, o Artigo 6.1 do ADA $^{52}$ prevê o direito de acesso aos autos e apresentação de argumentos.

Feitas essas considerações sobre o devido processo legal, passemos a analisar de que forma cada uma das funções contribui para que esse princípio seja observado.

\footnotetext{
46 ARAÚJO, Leandro Rocha. Normas sobre Facilitação do Comércio: reflexos para a institucionalização e a previsibilidade do sistema de comércio exterior brasileiro. Tese de Doutorado, USP/2006.

${ }^{47} \mathrm{TN} / \mathrm{TF} / \mathrm{W} / 122$.

48 TN/TF/W/116/Rev. 1.

${ }^{49}$ TN/TF/W/120/Rev. 1 e TN/TF/W/125.

50 CZAKO, Judith, HUMAN, Johann e MIRANDA, Jorge. A Handbook on Anti-Dumping Investigations, Cambridge University Press, 2003, pag. 13.

51 "Throughout the anti-dumping investigation all interested parties shall have a full opportunity for the defence of their interests. To this end, the authorities shall, on request, provide opportunities for all interested parties to meet those parties with adverse interests, so that opposing views may be presented and rebuttal arguments offered. Provision of such opportunities must take account of the need to preserve confidentiality and of the convenience to the parties. There shall be no obligation on any party to attend a meeting, and failure to do so shall not be prejudicial to that party's case. Interested parties shall also have the right, on justification, to present other information orally."

52 "All interested parties in an anti-dumping investigation shall be given notice of the information which the authorities require and ample opportunity to present in writing all evidence which they consider relevant in respect of the investigation in question."
} 


\section{PARTE II - FUNÇÕES PARA BUSCA DO DEVIDO PROCESSO LEGAL EM MATÉRIA ANTIDUMPING}

O dumping é uma prática privada, e a OMC é um foro intergovernamental que soluciona controvérsias apenas entre seus Membros. O ADA não condena a prática do dumping, e nem poderia condená-la, pois essa não é uma prática dos governos, mas prevê um procedimento investigatório a ser conduzido pelas autoridades nacionais do país importador com vistas a impor medidas antidumping que visem a compensar o dano ${ }^{53}$ que a indústria nacional tem sofrido como decorrência da prática de dumping. A não observância desse procedimento previsto no ADA sujeita o Membro da OMC a questionamento perante o Órgão de Solução de Controvérsias ("DSB", sigla em inglês para Dispute Settlement Body ${ }^{54}$ ).

AQUILES VARANDA ${ }^{55}$ também defende que o dumping não é obrigatoriamente passível de repressão, e só pode ser reprimido se causar ou ameaçar causar dano à indústria doméstica. Esse entendimento também é o de NICOLAIDES ${ }^{56}$, que se vale de expressão bastante interessante a respeito: “o GATT condena o dumping sem proibí-lo". De fato, é condenável apenas o dumping que causa dano. Nenhuma disposição das regras de comércio internacional o proíbe.

Conforme análise de RASLAN ${ }^{57}$, as empresas muitas vezes se encontram em situações em que são obrigadas a praticar o dumping. Essas razões seriam, por exemplo, o excesso de produção e a necessidade de alcançar a concorrência.

\footnotetext{
53 Ao longo da presente tese, sempre que nos referirmos a dano estaremos fazendo referência também a ameaça de dano e retardamento da indústria nascente, hipóteses que, se comprovadas aliadas ao dumping, também são condenáveis, conforme nota de rodapé ao Artigo 3 do ADA.

${ }^{54}$ Ao longo da presente tese, utilizaremos a sigla em inglês DSB para nos referirmos ao Órgão de Solução de Controvérsias da OMC. A opção se deu em razão da consolidação do termo na prática do direito do comércio internacional. O DSB é composto por todos os Membros da OMC e, entre suas funções, adota os relatórios do painel e do Órgão de Apelação.

${ }^{55}$ VARANDA, Aquiles Augusto. Disciplina do dumping do acordo geral de tarifas aduaneiras $e$ comércio: tipificação de um delito num tratado internacional. São Paulo, 1988.

${ }^{56}$ NICOLAIDES, Phedon. The Competition Effects of Dumping, in Journal of World Trade, vol. 24, n. 5, 1990.

${ }^{57}$ RASLAN, Reem Anwar Ahmed. Antidumping: a developing country perspective. Global Trade Law Series. Kluwer Law International, The Netherlands, 2009, pags. 8-11.
} 
RASLAN também ressalta que o dumping pode ter um caráter estratégico (para ganhar mercado ou aumentar sua participação em um mercado do qual já participa) ou predatório (visando prejudicar seus concorrentes).

HOEKMAN e KOSTECKI ${ }^{58}$ apontam para os seguintes tipos de dumping e seus objetivos:

(i) Esporádico: desprovido de intenção;

(ii) Com discriminação de preços: com vistas a maximizar lucro;

(iii) Cíclico: com objetivo de cobrir os custos variáveis ou assegurar níveis de emprego em períodos de baixa demanda;

(iv) Defensivo: busca minimizar perdas decorrentes do excesso de capacidade produtiva para coibir ou desestimular a entrada de concorrentes; (v) Em escala: visa a atingir uma economia de escala ou de capacidade total;

(vi) De marketing: para estabelecer uma empresa como líder de mercado em relação a um produto recém lançado;

(vii) Frontal: com objetivo de atacar um líder de mercado;

(viii) Predatório: que visa a estabelecer um monopólio em um mercado estrangeiro.

O dumping que a OMC coíbe é o da mera discriminação de preços. O esporádico pode não chegar a causar dano no país importador e os demais, muito provavelmente causam dano. Assim, podemos afirmar que o dumping pode ser, ao mesmo tempo: (i) necessário a exportadores; (ii) prejudicial à indústria doméstica do país importador; e (iii) convencional a consumidores, que poderão ter acesso a produtos por preços inferiores.

Em estudo realizado pelo Banco Mundial em 1998 sobre os efeitos do dumping ${ }^{59}$, cita-se levantamento da Comissão de Comércio Internacional dos EUA

\footnotetext{
${ }^{58}$ HOEKMAN, Bernard M. e KOSTECKI, Michel. The Political Economy of the World Trade System - From GATT to WTO. Oxford: Oxford University Press, 1996, pag. 175.

${ }^{59}$ KRISHNA, Raj. Antidumping in Law and Practice, World Bank Policy Research Working Paper n. $1823,1998$.
} 
(USITC) $^{60}$ de que a remoção das medidas antidumping e compensatórias vigentes em 1991 levaria a um ganho de USD 1,9 bilhões para a economia estadunidense. O estudo não aponta para o fato de que o governo deixaria de arrecadar esse montante, beneficiando o consumidor. Isso porque a medida antidumping consiste em uma sobretaxa à alíquota de importação, devida no momento do desembaraço (no caso do Brasil, no momento do registro da declaração de importação - DI), com o objetivo de equalizar/compensar o dano que o dumping causa ou causaria no mercado interno.

A despeito das vantagens e desvantagens das medidas antidumping, cada um dos Membros da OMC deve elaborar e aplicar leis e regulamentos que reflitam os compromissos assumidos no ADA.

Há países que adotam a teoria monista, e os tratados firmados em âmbito internacional têm executoriedade imediata em território nacional. Não é o caso do Brasil, que adota a teoria dualista ${ }^{61}$, pela qual o direito internacional e o direito doméstico constituem sistemas jurídicos distintos. Nesse caso, o Brasil precisa observar um trâmite perante o Poder Legislativo para que os atos internacionais firmados pelo Poder Executivo passem a ter validade em território nacional. Além disso, há casos em que a lei precisa ser regulamentada por ato do Poder Executivo (decreto ou instrução normativa, por exemplo). Essas normas e procedimentos internos é que podem violar as regras da OMC, e sujeitariam o Brasil a questionamento "as such" perante o DSB. "As such" significa que a norma em si viola as regras da $\mathrm{OMC}$, em concreto. O Brasil também pode ser questionado na OMC por uma violação "as applied" em casos em que a autoridade brasileira que conduz a investigação aplica a norma de forma que resulta em uma violação das regras da OMC. Essas são denominadas violações em abstrato.

\footnotetext{
${ }^{60}$ USITC. The Economic Effects of Antidumping and Countervailing Duty Orders and Suspension Agreements. June, 1995.

${ }^{61}$ A teoria dualista foi fundada por Triepel (1868-1946) e Anzilotti (1869-1950), seguindo condutas dos EUA e Grã-Bretanha. Conforme explica CASSESE, "para que o direito internacional pudesse obrigar autoridades nacionais e indivíduos, deveria ser 'transformado em lei nacional". CASSESE, Antonio. Modern constitution and international. Recueil des Cours, 1985. v. 192, p. 334-475.
} 
Portanto, uma violação às regras da OMC pode-se dar em abstrato (“as applied") ou em concreto ("as such"). No caso de medidas antidumping, tendo em vista que as legislações nacionais são praticamente cópia do ADA, e o ADA traz termos muito vagos, passíveis de ser interpretados e executados de diversas maneiras, as violações "as applied" são mais comuns. Por outro lado, como veremos em capítulo específico, a metodologia do zeramento foi condenada "as such" como violatória às regras da OMC.

A maioria das críticas feitas aos painéis e ao Órgão de Apelação da OMC refere-se à atuação desses órgãos em disputas antidumping. Inclusive, apesar de as medidas antidumping afetarem menos de $1 \%$ do comércio global ${ }^{62}$, quase $20 \%$ das disputas levadas ao DSB tratam de antidumping ${ }^{63}$. Como a OMC apenas analisa o processo antidumping (e não o dumping em si), podemos constatar que as causas das controvérsias estão, de uma forma ou de outra, relacionadas com o devido processo legal. Assim, começaremos a análise expondo a função da OMC em matéria antidumping.

\footnotetext{
${ }^{62}$ Percentual informado em STEWART, Terence, DWYER, Amy S. e HEIN, Elizabeth M. Trends in the last decade of Trade Remedy decisions: problems and opportunities for the WTO dispute settlement system, Arizona Journal of International and Comparative Law, 2007, pag. 252. Em apresentação de LEANE NAIDIN realizada em 2008 para UNCTAD-CINDES sobre Medidas Antidumping no Brasil foi apresentada tabela (cobertura em valor) da qual consta que as medidas antidumping correspondem a $0,977 \%$ da pauta importadora brasileira. Disponível em http://www.cindesbrasil.org/site2010/index.php?option=com_jdownloads\&Itemid=14\&view=view. download\&cid=256. Último acesso em 18/06/2012.

${ }_{63}^{91}$ disputas de 439, conforme dados obtidos em www.wto.org. Último acesso em 03/07/12.
} 


\section{PARTE II A - OMC}

De acordo com página eletrônica da $\mathrm{OMC}^{64}$, os dez benefícios do sistema multilateral de comércio da OMC são:

(i) promover a paz;

(ii) resolver disputas de forma construtiva;

(iii) propiciar uma vida mais fácil à luz da regulamentação;

(iv) criar um comércio mais liberalizado para redução do custo de vida;

(v) proporcionar uma maior variedade de produtos e qualidade;

(vi)aumentar a renda;

(vii) estimular o crescimento econômico;

(viii) possibilitar uma vida mais eficiente;

(ix) tornar os governos menos vulneráveis ao lobbying; e

(x) encorajar o exercício da função governamental de forma correta.

Esses objetivos são buscados por diferentes órgãos criados na estrutura da Organização. Todos esses órgãos são compostos pelos próprios Membros da OMC, daí a constatação de que a OMC é uma organização dirigida por seus Membros ("Members driven"). A existência de uma regulamentação antidumping (relacionado com o item iii acima) contribui para que os governos ajam de forma harmonizada. Da mesma forma, o fato de uma investigação conduzida de maneira arbitrária poder ser questionada perante o Sistema de Solução de Controvérsias da OMC também encoraja os governos a exercerem sua função de forma correta (item $\mathrm{x})$.

O objetivo principal é a liberalização comercial. Como lembrado por BHAGWATI $^{65}$, “no campo dos exemplos e das ideias, há tanto argumentos a favor do protecionismo como a favor da liberalização do comércio. Todavia, os

\footnotetext{
64 Disponível em http://www.wto.org/english/thewto_e/whatis_e/10ben_e/10b00_e.htm. Último acesso em 31 de maio de 2012.

${ }^{65}$ BHAGWATI, Jagdish. Protectionism. The MIT Press, Cambridge, 1988, pag. 87: "in the realms of both example and ideas, there are both pro-protection and pro-trade arguments. However, the pro-trade proponents seem to have the better of it".
} 
proponentes do livre comércio parecem levar vantagem”. Portanto, faz-se necessária seguir a tendência de liberalização comercial com mais segurança e previsibilidade na imposição de barreiras ao comércio.

Podemos assim constatar que a OMC tem diversas funções, mas em linhas gerais: é o órgão no qual são criadas as normas que regulamentarão o comércio internacional (“função legislativa da OMC”), é o órgão no qual é fiscalizado o cumprimento dessas normas (o que chamaremos de "função executiva da OMC"), e é o órgão que soluciona controvérsias entre seus Membros decorrentes dessas normas ("função judiciária da OMC"). Passemos a analisá-las. 


\section{Capítulo 4 - "FUNÇÃO LEGISLATIVA DA OMC"}

A função legislativa da OMC deriva do fato de ser um foro para negociação, conforme disposto no Artigo III.2 do Acordo de Marraqueche ${ }^{66}$. Em matéria antidumping, essa função foi exercida com a criação do ADA e, atualmente, é desempenhada pelo comitê negociador de regras para fins de cumprimento do mandato de Doha.

O ADA é estruturado em 18 artigos e dois anexos. Ele estabelece as regras para determinação do dumping (cálculo do valor normal, cálculo do preço de exportação, comparação justa entre ambos para fins de apuração da margem de dumping, ajustes necessários e definição de produto similar); determinação do dano (fatores a serem levados em consideração, possibilidade de cumulatividade de importações em volumes pequenos e apuração do nexo de causalidade); definição da indústria doméstica para fins de apresentação da petição; procedimentos investigatórios e provas. O ADA também trata das possibilidades de aplicação de medidas provisórias ou compromissos de preços, admite que os Membros escolham entre um sistema prospectivo ou retrospectivo para fins de cobrança das medidas antidumping, estabelece expressamente as hipóteses em que é admitida a retroatividade e traz dispositivos sobre a duração e revisão das medidas em vigor. Além disso, trata da necessidade de notificação e explicação das determinações, e expressamente impõe aos Membros a necessidade de haver tribunais para proceder à revisão judicial das determinações antidumping.

Por fim, o ADA admite o início de uma ação antidumping a favor de terceiro país, determina que deve haver tratamento especial e diferenciado para países em desenvolvimento, cria o Comitê de Práticas Antidumping, e parâmetros para as consultas e solução de controvérsias. Os anexos do ADA versam sobre os

66 "The WTO shall provide the forum for negotiations amongs its Members concerning their multilateral trade relations in matters dealt with under the agreements in the Annexes to this Agreement. (...)". 
procedimentos para verificação in loco e melhor informação disponível para fins de investigação.

O Comitê negociador de regras, como veremos em capítulo específico, foi criado justamente para esclarecer os procedimentos previstos no ADA que, como também veremos em outro capítulo específico, apresenta diversos problemas em razão, sobretudo, da vagueza de seus termos. 


\section{Capítulo 5 - "FUNÇÃO EXECUTIVA DA OMC"}

A "função executiva da OMC" deriva de seu poder de fiscalizar o cumprimento pelos Membros do disposto em suas regras. Essa tarefa é desempenhada pelos próprios Membros: (i) no Comitê Antidumping, e (ii) na revisão de suas políticas comerciais (“Trade Policy Review”).

\subsection{COMITÊ ANTIDUMPING}

O Comitê Antidumping, desde a época do GATT, tinha a função de monitorar as legislações antidumping dos países. Importante notar que nem todas as Partes Contratantes do GATT participavam do Comitê Antidumping, principalmente porque o Acordo $\mathrm{AD}$ da Rodada Kennedy e o Acordo AD da Rodada Tóquio eram de adesão facultativa. Antes da criação do Comitê Antidumping, havia um Comitê de Comércio para Bens Industriais para o qual as Partes Contratantes notificavam suas legislações antidumping. Os primeiros países a notificar suas legislações a esse Comitê foram Austrália, Índia, Irlanda, Nova Zelândia, Portugal, África do Sul e Turquia ${ }^{67}$. Israel e Paquistão notificaram não possuírem legislação antidumping. Em atenção ao deliberado em reunião do Comitê Antidumping em setembro de 1971, essas legislações foram compiladas e notificadas às Partes Contratantes que compunham o Comitê Antidumping. Todavia, cumpre ressaltar que a obrigação de notificação das legislações surgiu apenas na Rodada Uruguai (Artigo 16.5 do ADA). Portanto, na época do Acordo AD da Rodada Tóquio, por exemplo, não havia essa obrigação.

Conforme previsto no Artigo 16 do ADA, o Comitê Antidumping se reúne periodicamente (no mínimo semestralmente) e é composto por representantes de todos os Membros da OMC. É ao comitê antidumping que as legislações, as investigações e as medidas aplicadas devem ser notificadas. O intuito sempre foi

\footnotetext{
${ }^{67}$ COM.AD/18. RESTRICTED, datado de 29 de fevereiro de 1972.
} 
assegurar transparência nas relações com os demais Membros, possibilitando acesso às legislações em idioma oficial da OMC. VERA THORSTENSEN ${ }^{68}$ constata que, "cerca de 80 países notificaram suas legislações ao Comitê, sendo que 25 declararam que não possuem leis sobre a matéria". O Comitê Antidumping, em reunião realizada em maio de $2012^{69}$, revisou a legislação antidumping da Austrália, Índia, EUA e Equador, bem como as notificações de medidas provisórias e finais submetidas por 18 Membros.

Com base nos relatórios de investigações iniciadas e medidas aplicadas apresentados pelos Membros, conforme determina o Artigo 16.4 do ADA, o Comitê Antidumping prepara estatísticas e divulga as preocupações. Nessa mesma reunião de maio de 2012 o Comitê Antidumping revisou 30 relatórios de ações antidumping tomadas no segundo semestre de 2011. Nesta revisão, foram levantadas algumas preocupações dos Membros. Ao analisá-las, notamos que todas dizem respeito à inobservância do devido processo legal na condução das investigações ${ }^{70}$.

\footnotetext{
${ }^{68}$ THORSTENSEN, Vera. OMC - Organização Mundial do Comércio: as regras do comércio internacional e a Rodada do Milênio. São Paulo, Aduaneiras, 1999, pag. 126.

${ }_{69}$ Disponível em http://www.wto.org/english/news_e/news12_e/anti_23apr12_e.htm. Último acesso em 10/07/12.

${ }^{70}$ Em específico, as preocupações foram as seguintes: (i) Japão e Austrália iniciaram negociações bilaterais sobre direitos antidumping impostos sobre as importações japonesas há mais de 20 anos; (ii) Turquia se mostrou preocupada com a investigação antidumping do Brasil contra fios de viscose. Brasil afirmou estar aberto para conversas; (iii) Os EUA reclamaram da falta de devido processo legal nas investigações antidumping na China, em particular referente à imposição em dezembro de 2011 de medidas contra automóveis. Japão e UE manifestaram preocupação com relação às investigações chinesas contra papel fotográfico e papel cartão, bem como contra tubos de aço de alto desempenho. A China afirmou que tem aprimorado seus procedimentos, e informou que suas investigações e medidas antidumping são compatíveis com a OMC; (iv) Turquia afirmou que por razões de deficiências na investigação antidumping da República Dominicana contra hastes e vigas de aço da Turquia, a medida final deveria ser revogada. Ainda, a Turquia expressou preocupação de que a medida antidumping da Índia contra carbonato de sódio turco seria um protecionismo disfarçado. Por fim, também afirmou que a Ucrânia não cumpriu com os requisitos do ADA na investigação contra vidros flutuantes da Turquia e solicitou a revogação da medida; (v) A China afirmou que a aplicação de antidumping na UE contra bicicletas chinesas por 20 anos caracterizava um caso de protecionismo. A China também expressou preocupação com a investigação contra tábua de passar que visa atingir apenas um produtor chinês, o que seria contrário ao ADA. A UE afirmou que suas medidas são compatíveis com a OMC; (vi) A Noruega manifestou que a medida antidumping da Índia contra soda cáustica da Noruega foi a primeira ação da Índia contra aquele país. A Noruega insiste que não exportou o produto para a Índia no período investigado. A Índia afirmou que suas medidas são compatíveis com a OMC; (vii) A China expressou preocupação em relação às investigações antidumping do México contra eletrodos de grafite e cabos coaxiais. Os EUA, por sua vez, afirmaram que suas empresas expressaram sérias preocupações quanto às margens antidumping calculadas pelo México na investigação contra perna
} 
Com relação à base de dados estatísticos ${ }^{71}, 4.010$ investigações foram abertas no período de 1995 a 2011, sendo que 2.601 medidas foram aplicadas. Vale apontar para o fato de a China ser o país mais investigado (853 investigações iniciadas) e também contra o qual mais medidas foram aplicadas (630). Em seguida, vem a Coréia do Sul, com 284 investigações abertas para averiguar suas exportações, e 170 medidas aplicadas. Na sequência, encontramos os EUA com 234 investigações iniciadas contra suas exportações, e 136 medidas aplicadas. O Brasil tem 82 medidas aplicadas contra seus produtos, tendo sido abertas 114 investigações. Conforme consta de página eletrônica do MDIC, os países que aplicam medidas antidumping contra o Brasil são: África do Sul, Argentina, Canadá, Moldávia, Turquia, Rússia, Paquistão, Indonésia, Filipinas, México, EUA e União Europeia (UE) ${ }^{72}$.

O Artigo 16.2 do ADA admite que o Comitê Antidumping crie órgãos subsidiários para auxiliá-lo no desempenho de suas funções. A minuta Dunkel ${ }^{73} \mathrm{e}$ o Acordo AD da Rodada Tóquio já continham essa mesma disposição. Atualmente, há o Grupo Ad Hoc sobre Implementação e o Grupo Informal sobre Circunvenção, cujos trabalhos também são reportados pelo Presidente do Comitê Antidumping $^{74}$.

e coxa de frango dos EUA. O México afirmou que todas as suas medidas são compatíveis com a OMC; (viii) O Japão apreciou a revogação da medida antidumping nos EUA contra chapa de aço do Japão. No entanto, mostrou-se preocupado com a continuação de quatro medidas antidumping contra produtos japoneses, que já duram mais de 20 anos. Os EUA explicou que a situação se dá devido à falta de participação das empresas japonesas nas revisões. O Japão afirmou que as empresas participam pouco porque acreditam que os EUA não seriam convencidos de seus argumentos.

${ }_{71}$ Disponível em http://www.wto.org/english/tratop_e/adp_e/adp_e.htm. Último acesso em 28/06/12.

${ }^{72}$ Disponível em http://www.desenvolvimento.gov.br/sitio/interna/interna.php?area=5\&menu=228. Último acesso em 09/07/12.

${ }^{73}$ A Minuta Dunkel foi um documento organizado por Arthur Dunkel, então diretor-geral do GATT, em 1991, durante a Rodada Uruguai. As negociações estavam paradas, então ele resolveu coletar e sistematizar o que havia sido produzido até ali, além de aprimorar tecnicamente o documento. Disponível em http://www.wto.org/english/news_e/pres05_e/pr409_e.htm. Último acesso em 29/06/12.

${ }^{74}$ Em maio de 2012 foi eleito o Sr. Shai Moses (Israel) como o novo Presidente do Comitê Antidumping, substituindo o Sr. Subhas Gujadhur (Ilhas Maurícios). 


\section{(i) Grupo Ad Hoc sobre Implementação}

O Grupo Ad Hoc sobre Implementação foi inicialmente criado na época do GATT e retomou suas atividades em 1997. Desde essa época, conforme salienta DURLING e NICELY ${ }^{75}$, alguns assuntos já preocupavam os Membros:

(i) tratamento de informação confidencial;

(ii) período de coleta de informação para fins da investigação de dumping;

(iii) amostragem para que não investigue todos os exportadores;

(iv)conceito de "circunstâncias especiais" constante do Artigo 5.6 do $\mathrm{ADA}^{76}$

(v) notificação ao governo exportador;

(vi)disposições sobre audiência do Artigo 6.2 do $\operatorname{ADA}^{77}$;

(vii) divulgação dos fatos essenciais antes de ser feita a determinação final;

(viii) notificações públicas;

(ix)conteúdo das determinações preliminares; e

(x) forma de cálculo da medida antidumping.

Notamos que os tópicos continuam sendo preocupações dos Membros. Com o advento da Rodada Doha em 2001, passaram a ser objeto de discussão no Comitê Negociador de Regras. Com isso, esvaziou-se parcialmente a função do Comitê Antidumping. Todavia, tendo em vista a paralização dos trabalhos do Comitê Negociador, o Comitê Antidumping tem retomado essa função. Na reunião realizada em maio de 2012, reportou-se a discussão de três trabalhos: dois

\footnotetext{
75 DURLING, James e NICELY, Matthew. Understanding the WTO Antidumping Agreement negotiation history and subsequent interpretation. Cameron May, Londres, 2002.

${ }^{76} \mathrm{O}$ Artigo 5.6 do ADA é aquele que admite o início de uma investigação de ofício pela autoridade nacional: "If, in special circumstances, the authorities concerned decide to initiate an investigation without having received a written application by or on behalf of a domestic industry for the initiation of such investigation, they shall proceed only if they have sufficient evidence of dumping, injury and a causal link, as described in paragraph 2, to justify the initiation of an investigation.". Ele nunca foi invocado no Brasil.

${ }^{77} \mathrm{O}$ Artigo 6.2 do ADA, transcrito anteriormente, é que garante a ampla defesa e não obriga a participação em audiências.
} 
apresentados pela Colômbia (sobre o Artigo 3.5 do ADA $^{78}$ - outras causas de dano, e sobre o Artigo 11.3 do $\mathrm{ADA}^{79}$ - revisões de fim de período) e um pela Nova Zelândia (Artigo 5.3 do $\mathrm{ADA}^{80}$ - teste de precisão e adequação das provas para fins de abertura da investigação).

\section{(ii) Grupo Informal sobre Circunvenção}

Circunvenção $^{81}$ é a possibilidade de burlar as medidas antidumping. A circunvenção decorre da globalização da produção, em que fabricam-se partes do produto final em diferentes lugares do mundo. $\mathrm{O}$ que se deve evitar é que partes dos produtos que estariam sujeitos à medida antidumping passem a ser importados para serem montados em território do país importador que impôs a medida, prejudicando da mesma forma a sua indústria doméstica. Outra prática a ser evitada é que o mesmo produto passe a vir de um terceiro país, ou passe a ser classificado sob uma nomenclatura diversa para "driblar" a medida antidumping aplicada.

\footnotetext{
78 "It must be demonstrated that the dumped imports are, through the effects of dumping, as set forth in paragraphs 2 and 4, causing injury within the meaning of this Agreement. The demonstration of a causal relationship between the dumped imports and the injury to the domestic industry shall be based on an examination of all relevant evidence before the authorities. The authorities shall also examine any known factors other than the dumped imports which at the same time are injuring the domestic industry, and the injuries caused by these other factors must not be attributed to the dumped imports. Factors which may be relevant in this respect include, inter alia, the volume and prices of imports not sold at dumping prices, contraction in demand or changes in the patterns of consumption, trade restrictive practices of and competition between the foreign and domestic producers, developments in technology and the export performance and productivity of the domestic industry".

79 "Notwithstanding the provisions of paragraphs 1 and 2, any definitive anti-dumping duty shall be terminated on a date not later than five years from its imposition (or from the date of the most recent review under paragraph 2 if that review has covered both dumping and injury, or under this paragraph), unless the authorities determine, in a review initiated before that date on their own initiative or upon a duly substantiated request made by or on behalf of the domestic industry within a reasonable period of time prior to that date, that the expiry of the duty would be likely to lead to continuation or recurrence of dumping and injury. The duty may remain in force pending the outcome of such a review”.

80 "The authorities shall examine the accuracy and adequacy of the evidence provided in the application to determine whether there is sufficient evidence to justify the initiation of an investigation".

${ }^{81}$ Alguns autores preferem adotar o termo "evasão", ao invés de "circunvenção". Para detalhes sobre o tema, vide PUPO, Rodrigo Luís. A Evasão de direitos Antidumping e sua disciplina no Comércio Internacional. Dissertação de Mestrado. USP/2006. Tendo em vista a consagração do termo "circunvenção" na legislação brasileira, optamos por usar essa terminologia.
} 
O Grupo sobre Circunvenção iniciou suas atividades em abril de 1996, e desde então se deparou com a difícil tarefa de conciliar os interesses do Japão, que acreditava não ser necessária a criação de regras específicas sobre essa prática, e de outro lado, dos EUA e da $\mathrm{UE}^{82}$, que sempre foram favoráveis à regulamentação ${ }^{83}$.

O Grupo sobre Circunvenção teve seu trabalho focado em definir o termo, analisar casos hipotéticos e reais trazidos pelos Membros, e exprimir opiniões. Em $2000^{84}$, o Grupo analisou o procedimento anticircunvenção dos EUA, que é levado a cabo pelo Departamento de Comércio, na tentativa de ter um modelo de investigação sumária aprovado. Uma solução estaria na devida regulamentação das regras de origem ${ }^{85}$.

Apresentadas as funções dos órgãos subsidiários do Comitê Antidumping, vale lembrar que o Artigo 16.3 do $\mathrm{ADA}^{86}$ admite que busquem informações junto a qualquer Membro e empresas localizadas nesses Membros. O texto desse artigo,

\footnotetext{
${ }^{82}$ A partir de 1o. de dezembro de 2009, quando entrou em vigor o Tratado de Lisboa firmado em 13 de dezembro de 2007, as Comunidades Europeias passaram a ser oficialmente denominadas União Europeia, conforme comunicado à $\quad$ OMC em http://docsonline.wto.org/GEN catalogViewAllBottom.asp?ct=DDFEnglish\%2CDDFFrench\%2CD DFSpanish\&c2=@meta_Serial_Num\&q2=103908\&c3=@meta_Symbol\&q3=\%22WT\%FCLET\%FC679\%22\&c1=@meta_Language\&q1=E. Último acesso em 03/07/12. Ao longo da tese, buscaremos manter a terminologia tal como na época, mas, para fins de harmonização, como regra geral, utilizaremos a denominação União Europeia (UE). A UE é composta por 27 membros, sendo que na OMC ela têm 28 assentos, pois a própria UE também é um Membro da OMC.

83 BARROS, Maria Carolina Mendonça de. O direito antidumping como arma protecionista. Dissertação de Mestrado. USP/2002, pag 153.

${ }^{84} \mathrm{G} / \mathrm{ADP} / \mathrm{IG} / \mathrm{W} / 22$.

${ }^{85}$ THORSTENSEN, Vera. OMC - Organização Mundial do Comércio: as regras do comércio internacional e a Rodada do Milênio. São Paulo, Aduaneiras, 1999, pag. 165: "os seguintes princípios foram relacionados pelo Comitê Técnico junto à Organização Mundial de Aduanas para criação de normas harmônicas sobre regras de origem: (i) devem ser uniformes para todos os instrumentos comerciais (dumping, direitos compensatórios, exigência de marca, entre outros); (ii) o país de origem de um bem deve ser o país onde o bem tenha sido totalmente obtido ou, caso haja mais de um país envolvido na produção do bem, o país onde a última transformação substancial tenha ocorrido; (iii) devem ser objetivas e previsiveis; (iv) não devem ser utilizadas como instrumento para atingir objetivos comerciais ou para criar distorções no comércio; (v) devem ser administradas de forma consistente e razoável; e (vi) devem ser coerentes".

86 "In carrying out their functions, the Committee and any subsidiary bodies may consult with and seek information from any source they deem appropriate. However, before the Committee or a subsidiary body seeks such information from a source within the jurisdiction of a Member, it shall inform the Member involved. It shall obtain the consent of the Member and any firm to be consulted".
} 
conforme reconhecem DURLING e NICELY ${ }^{87}$, é difícil de ser compreendido ao exigir, além da notificação ao Membro que detém a informação, o seu consentimento para busca das mesmas. Apesar de os autores não continuarem a análise, o texto do Artigo 16.3 do ADA é, de fato, estranho, uma vez os Membros da OMC já assumiram o compromisso de cooperação ao firmar o ADA. Além disso, a busca de informações não poderia ficar sujeita ao seu consentimento caso a caso. Essa exigência deveria se aplicar unicamente às empresas, que não têm obrigação de divulgar suas informações ao Comitê Antidumping ou seus órgãos subsidiários. De qualquer maneira, o papel do Comitê Antidumping não tem se mostrado ativo a ponto de buscar informações junto a Membros ou empresas.

Por fim, é importante ressaltar que o Comitê Antidumping é o foro no qual os Membros podem solicitar esclarecimentos sobre qualquer assunto antidumping, funcionando, na prática, como uma etapa prévia ao Sistema de Solução de Controvérsias, sobre o qual trataremos em capítulo específico.

A Revisão da Política Comercial também é uma oportunidade para se questionar qualquer assunto relativo à política comercial de um Membro, inclusive antidumping. O procedimento é regulado pelo Anexo 3 do Acordo de Marraqueche. Os países desenvolvidos passam por revisão de sua política comercial a cada dois anos. Os países em desenvolvimento, como é o caso do Brasil, são submetidos a essa revisão a cada quatro anos, e os países de menor desenvolvimento relativo, a cada oito anos.

${ }^{87}$ DURLING, James e NICELY, Matthew. Understanding the WTO Antidumping Agreement negotiation history and subsequent interpretation. Cameron May, Londres, 2002. 


\section{CAPÍTULO 6 - "FUNÇÃO JUDICIÁRIA DA OMC"}

Podemos dizer que a "função judiciária da OMC" decorre do disposto no Artigo III.4 do Acordo de Marraqueche ${ }^{88}$, que cria a obrigação de administrar o Entendimento relativo às normas e procedimentos sobre Solução de Controvérsias (ESC). O ESC foi criado na Rodada Uruguai e entrou em vigor em $1^{\circ}$ de janeiro de 1995.

O Diretor Geral da OMC à época, RENATO RUGGIERO ${ }^{89}$, reconheceu que o ESC seria o pilar central do sistema de solução de controvérsias e a maior contribuição da OMC para a estabilidade da economia global.

Conforme sustenta VAN DEN BOSSCHE ${ }^{90}$, o ESC contitui-se, muito provavelmente, na maior conquista singular das negociações da Rodada Uruguai. HUDEC $^{91}$ lembra que o sistema GATT era meramente diplomático. ESSERMAN e HOWSE ${ }^{92}$ ressaltam que, com o ESC, o sistema deixou de ser carregado por grandes influências políticas, para dar peso ao "rule of law”. CELSO LAFER 93 utiliza o termo "adensamento de juridicidade" 94 , que retrata uma transição de um sistema "power-oriented" (do GATT), para um sistema "rule-oriented" (do ESC),

88 "The WTO shall administer the Understanding on Rules and Procedures Governing the Settlement of Disputes (...) in Annex 2 to this Agreement."

${ }^{89}$ RUGGIERO, Renato. WTO, Trading in the Future, 2a . ed, 2001, pag. 38.

${ }^{90}$ VAN DEN BOSSCHE, Peter. The Law and Policy of the World Trade Organization. New York: Cambridge University Press, 2006, pag. 52.

${ }^{91}$ HUDEC, Robert E. The GATT Legal System: a Diplomat's jurisprudence. Journal of World Trade Law, Vol. 4, 1970, pag. 615-616.

92 ESSERMAN, Susan e HOWSE, Robert. The WTO on Trial. Foreign Affairs, Vol. 82, janfev/2003, pag. 131.

93 LAFER, Celso. O Sistema de Solução de Controvérsias da Organização de Comércio Internacional. In Guerra Comercial ou Integração Mundial pelo Comércio? A OMC e o Brasil. CASELLA, Paulo Borba e MERCADANTE, Araminta de Azevedo. SP: LTr, 1998, pag.748.

${ }^{94}$ LAFER, Celso. A OMC e a regulamentação do comércio internacional: uma visão brasileira. Porto Alegre: Livraria do Advogado, 1998, pags 31-32: "o ‘adensamento da juridicidade" resultante da aplicação do Entendimento sobre Solução de Controvérsias significa, em resumo, que o sistema de solução de controvérsias da OMC visa muito mais do que ao cumprimento de uma mera 'obrigação de comportamento', a ser seguida de boa-fé, como no caso de transparência. $E$ ' também radicalmente diferente da `obrigação de comportamento`, relativa à solução pacífica de controvérsias do direito internacional público geral que decorre do Artigo 2(3) da Carta da ONU. $O$ ‘adensamento da juridicidade contido no ESC constitui, na realidade, uma obrigação de resultado, previsto nas normas da organização da OMC." 
como defendido por JACKSON ${ }^{95}$. THIÉBAUT $^{96}$ vale-se da terminologia "jurisdictionnalisation".

ELAINI CRISTINA GONZAGA DA $\operatorname{SILVA}^{97}$ ressalta que "de acordo com a teoria sobre juridicização desenvolvida por K.W.Abbott et al (2000), as características do órgão ao qual se delega a autoridade para solucionar as controvérsias que surgem no âmbito do sistema são elemento decisivo para definição do grau de juridicidade. Assim, quanto mais houver acesso ao sistema, independência do órgão e efeito direto das decisões deste emanadas, mais juridicidade terá um determinado sistema."

Entendemos que o sistema da OMC possibilita o acesso inclusive a países de menor desenvolvimento relativo e é independente, mas suas recomendações ${ }^{98}$ não têm efeito direto, sobretudo no que diz respeito a antidumping. Passemos a analisar o DSB, os procedimentos adotados e as disputas analisadas.

\subsection{DSB - ÓRGÃO DE SOLUÇÃO DE CONTROVÉRSIAS}

O DSB foi criado pelos Membros da OMC com vistas a administrar o procedimento para solução de controvérsias na Organização. Como veremos adiante, a competência desse órgão tem uma limitação específica no que diz respeito às disputas antidumping.

\footnotetext{
95 Para uma visão completa do assunto, vide DUNNE III, Matthew S. Redefining Power Orientation: a reassessment of Jackson`s paradigm in light of asymmetries of Power, negotiation, and compliance in the GATT/WTO dispute settlement system. Law \& Policy in International Business. Vol. 34, 2002-2003.

${ }^{96}$ FLORY, Thiébaut. L'Organisation mondiale du commerce: droit institutionnel et substantial. Bruxelles- Bruylant, 1999, pag. 21.

97 SILVA, Elaini Cristina Gonzaga. Juridicização das Relações Internacionais e Solução de Controvérsias: Análise do Sistema Multilateral de Comércio. Dissertação de Mestrado, USP/2007, pag. 48.

${ }_{98}$ A OMC não é um órgão supranacional que emite decisões vinculantes. Os relatórios dos painéis e do Órgão de Apelação têm natureza recomendatória, por isso, em se tratando de OMC, entendemos que a terminologia mais apropriada é "recomendações" e não "decisões".
} 


\subsubsection{Procedimentos}

\section{(i) ESC}

O ESC é o código de processo civil da OMC. Por intermédio do DSB, o ESC administra a resolução das controvérsias surgidas entre os Membros. O DSB tem sua competência estabelecida pelo Artigo 2.1 do $\mathrm{ESC}^{99}$, qual seja: (i) estabelecer painéis, (ii) acatar relatórios dos painéis e do Órgão de Apelação, (iii) supervisionar a aplicação das recomendações, e (iv) autorizar a suspensão de concessões e de outras obrigações determinadas pelos acordos abrangidos ${ }^{100}$.

O ESC traz os princípios a serem observados na solução das controvérsias e os procedimentos a serem seguidos. Os Artigos 3.2 e 19.2 do ESC deixam claro que o sistema de solução de controvérsias da OMC não pode aumentar nem diminuir os direitos e obrigações negociados entre os Membros durante as sucessivas rodadas de negociação comercial. O Artigo 3.2 do ESC traça os objetivos do DSB e assim determina:

"O sistema de solução de controvérsias da OMC é elemento essencial para trazer segurança e previsibilidade ao sistema multilateral de comércio. Os Membros reconhecem que esse sistema é útil para preservar direitos e obrigações dos Membros dentro dos parâmetros dos acordos abrangidos e para esclarecer as disposições vigentes dos referidos acordos em conformidade com as normas correntes de

\footnotetext{
99 "The Dispute Settlement Body is hereby established to administer these rules and procedures and, except as otherwise provided in a covered agreement, the consultation and dispute settlement provisions of the covered agreements. Accordingly, the DSB shall have the authority to establish panels, adopt panel and Appellate Body reports, maintain surveillance of implementation of rulings and recommendations, and authorize suspension of concessions and other obligations under the covered agreements. With respect to disputes arising under a covered agreement which is a Plurilateral Trade Agreement, the term "Member" as used herein shall refer only to those Members that are parties to the relevant Plurilateral Trade Agreement. Where the DSB administers the dispute settlement provisions of a Plurilateral Trade Agreement, only those Members that are parties to that Agreement may participate in decisions or actions taken by the DSB with respect to that dispute".

${ }^{100}$ Acordos abrangidos são todos aqueles anexados ao Acordo Constitutivo da OMC. São apenas esses acordos que podem ser questionados perante o DSB.
} 
interpretação do direito internacional público. As recomendações e determinações do DSB não poderão aumentar ou diminuir os direitos e obrigações definidos nos acordos abrangidos."

Nessa mesma linha, o Artigo 19.2 do ESC também afirma que:

"em conformidade com o parágrafo 2 do Artigo 3, nas suas conclusões e recomendações, o painel e o Órgão de Apelação não poderão aumentar ou diminuir os direitos $e$ obrigações estabelecidos nos acordos abrangidos."

Abaixo segue breve descritivo das diferentes etapas do procedimento trazido pelo ESC:

(i) Consultas: momento em que o procedimento é formalmente iniciado e é atribuído um número ao caso (importante para fins de estatísticas). As consultas são confidenciais e ocorrem em local escolhido pelas partes. Podem ser realizadas diversas rodadas de consultas. Elas tomam a forma de perguntas e respostas com o intuito de compreender a medida, e tentar chegar a um acordo mutuamente satisfatório. Caso esse acordo não seja alcançado no prazo de 60 dias, pode-se solicitar o estabelecimento de um painel. A maioria das disputas na OMC são resolvidas em fase de consultas. Por esse motivo, consideramos o sistema de solução de controvérsias da OMC como sendo diplomático-jurídico, e eficiente. O Apêndice 1 anexo a esta tese descreve todas as disputas sobre antidumping que foram notificadas como encerradas na fase de consultas, totalizando nove casos. O Apêndice 2 anexo a esta tese descreve todas as disputas sobre antidumping que estão em fase de consultas. Isso significa tanto aquelas iniciadas recentemente, como aquelas que, por algum motivo não notificado, não passaram para a fase de painel, totalizando 33 casos. De 
um total de 91 disputas que versam sobre antidumping, quase metade (Apêndice $1+$ Apêndice $2=43$ casos) foi resolvida em fase de consultas.

(ii) Painel: os painéis são formados por três especialistas escolhidos caso a caso para análise da disputa. Caso as partes não cheguem a um consenso com relação a seus nomes, caberá ao Diretor Geral da OMC indicá-los. O Secretariado da OMC possui uma lista de painelistas indicada por cada um dos Membros, mas podem ser escolhidas pessoas que não constam dessa lista. O Membro insatisfeito com o resultado das consultas poderá, em reunião do DSB, solicitar o estabelecimento de um painel. Como a forma de tomada de decisão da OMC é, em regra, por consenso ${ }^{101}$, nessa reunião o Membro demandado obviamente recusará o pedido, e o estabelecimento do painel será postergado para uma próxima reunião do DSB em que prevalecerá o consenso negativo ${ }^{102}$, para que não seja inviabilizado o prosseguimento da disputa. Nessa reunião do DSB, é aberta oportunidade para as terceiras partes interessadas em participar da disputa se manifestarem, ou apresentarem solicitação no prazo de 10 dias. Estabelecido o painel, este deverá ser composto (indicação dos nomes) e serão iniciados os trabalhos, os quais deverão ser concluídos no prazo de seis meses, prorrogáveis por até nove meses ${ }^{103}$, prazo que não tem sido observado na prática, em razão da complexidade das disputas. O Apêndice 3 anexo a esta tese descreve todas as disputas sobre antidumping encerradas ou em fase de painel, totalizando 25 casos.

(iii) Apelação: o Órgão de Apelação é um órgão permanente composto por sete membros com mandatos de quatro anos, renováveis por mais quatro. Três deles são sorteados para análise de cada disputa. Se qualquer uma das partes em disputa se mostrar insatisfeita com o relatório do painel,

\footnotetext{
${ }^{101}$ Artigo IX.1 do Acordo de Marrraqueche: "The WTO shall continue the practice of decisionmaking by consensus followed under GATT 1947."

${ }^{102} \mathrm{O}$ Artigo 6.1 do ESC foi uma inovação em relação aos procedimentos da época do GATT. Apenas se nenhum dos Membros autorizar o estabelecimento do painel é que ele não será estabelecido.

${ }^{103}$ Artigo 12.8 do ESC.
} 
poderá recorrer ao Órgão de Apelação, cuja competência é limitada a questões de direito e interpretação legal ${ }^{104}$. As discussões factuais devem ser resolvidas em âmbito de painel. O Órgão de Apelação tem dois meses para concluir seus trabalhos, prorrogáveis por até três meses ${ }^{105}$, prazo que não tem sido observado na prática, em razão da complexidade das disputas. O Apêndice 4 anexo a esta tese descreve todas as disputas sobre antidumping que chegaram à fase de apelação, totalizando 23 casos.

(iv) Implementação das Recomendações: após adotados os relatórios do painel e do Órgão do Apelação pelo DSB (necessário para dar legitimidade e efeito jurídico aos relatórios), a recomendação deve ser imediatamente cumprida. Se não for possível, deverá ser acordado um período razoável de tempo, ou este deverá ser fixado por um árbitro ${ }^{106}$. Decorrido esse período, se houver controvérsias sobre a implementação, as partes poderão recorrer novamente ao painel para solução da controvérsia $^{107}$. Nesse meio tempo, o Membro sujeito ao cumprimento da recomendação deve apresentar ao DSB relatórios de monitoramento ("status reports"), sinalizando as medidas que tem tomado para implementar a recomendação. Se constatada a não implementação, passarse-á à fase de sanções.

(v) Sanções: o ESC prevê a compensação e a retaliação como formas de sanção ${ }^{108}$. A compensação é pouco utilizada em razão da necessidade de observar o princípio da nação mais favorecida ${ }^{109}$. A retaliação,

\footnotetext{
${ }^{104}$ Artigo 17.6 do ESC.

${ }^{105}$ Artigo 17.5 do ESC.

${ }^{106}$ Artigo 21.3 do ESC.

${ }^{107}$ Artigo 21.5 do ESC.

108 Artigo 22 do ESC.

109 Artigo I do GATT, pelo qual não se pode dar tratamento preferencial a um Membro, em detrimento de outro: "With respect to customs duties and charges of any kind imposed on or in connection with importation or exportation or imposed on the international transfer of payments for imports or exports, and with respect to the method of levying such duties and charges, and with respect to all rules and formalities in connection with importation and exportation, and with respect to all matters referred to in paragraphs 2 and 4 of Article III, any advantage, favour, privilege or immunity granted by any contracting party to any product originating in or destined
} 
denominação corrente para suspensão de direitos e obrigações, restringe o fluxo de comércio entre os países envolvidos para uma lista de bens, serviços ou direitos de propriedade intelectual elaborada com base em um valor de dano e/ou prejuízo (nullification or impairment) que pode ser apurado em arbitragem ${ }^{110}$. A retaliação também encontra dificuldades para ser utilizada, sobretudo por países em desenvolvimento com pauta exportadora restrita.

Apesar de CRETELLA NETO ${ }^{111}$ incluir a arbitragem como uma fase separada, entendemos que as arbitragens previstas no ESC $^{112}$ estão incluídas nas etapas acima descritas. Entendemos mais correto incluir as sanções como uma das etapas do procedimento, uma vez que são uma inovação em relação à época do GATT e constituem fase final a ser cumprida.

O Artigo 11 do ESC $^{113}$ estabelece que a função dos painéis é auxiliar o DSB a cumprir com suas responsabilidades de acordo com o ESC e com os acordos abrangidos. O painel deve fazer uma análise objetiva: (i) do caso, inclusive dos fatos, e (ii) da aplicabilidade e conformidade com os acordos abrangidos, e apresentar conclusões (findings) que contribuirão para que o DSB acate as

for any other country shall be accorded immediately and unconditionally to the like product originating in or destined for the territories of all other contracting parties".

${ }^{110}$ Artigo 22.6 do ESC.

${ }^{111}$ As fases indicadas são: consultas bilaterais, painel, apelação, implementação das recomendações e arbitragem. CRETELLA NETO, José. Direito Processual na Organização Mundial do Comércio. RJ: Forense, 2003, pag. 109-114.

112 As diferentes "arbitragens" previstas no ESC são: (i) Artigo 25 - arbitragem como forma alternativa de solução de conflitos a ser acordada entre as partes; (ii) Artigo 21.3(c) - arbitragem como forma de fixar o período razoável de tempo para que seja implementada uma recomendação (o árbitro é escolhido entre os membros do Órgão de Apelação); (iii) Artigo 21.5 - painel (e não uma arbitragem) para analisar se houve ou não implementação de uma recomendação; e (iv) Artigo 22.6 - arbitragem como forma de fixar o montante de dano e prejuízo (nullification and impairment) sofrido pelo demandante em razão da não implementação da recomendação do DSB (o árbitro também é escolhido entre os membros do Órgão de Apelação).

113 "The function of panels is to assist the DSB in discharging its responsibilities under this Understanding and the covered agreements. Accordingly, a panel should make an objective assessment of the matter before it, including an objective assessment of the facts of the case and the applicability of and conformity with the relevant covered agreements, and make such other findings as will assist the DSB in making the recommendations or in giving the rulings provided for in the covered agreements. Panels should consult regularly with the parties to the dispute and give them adequate opportunity to develop a mutually satisfactory solution." 
recomendações. Os painéis devem consultar as partes e dar oportunidade para que cheguem a uma solução mutuamente satisfatória.

O Artigo 17.6 do ESC $^{114}$ trata do padrão de revisão a ser adotado pelo Órgão de Apelação e determina que deve estar restrito a questões de direito e interpretações legais desenvolvidas pelo painel. Assim, o painel tem por objetivo analisar os fatos, aplicar os acordos da OMC e solucionar a controvérsia. O Órgão de Apelação revisa as questões de direito analisadas inicialmente pelo painel.

GEORGES ABI-SAAB ${ }^{115}$, ex membro do Orgão de Apelação, chama a atenção para o fato de a instituição ser designada como "órgão" e não "tribunal" ou “corte". Segundo ele, a questão se relaciona com a natureza legal ou características do Órgão de Apelação. O Órgão de Apelação não tem autoridade para resolver definitivamente as disputas entre as partes, por isso emite recomendações e não decisões. Mas como lembra SACERDOTI ${ }^{116}$, também ex membro do Órgão de Apelação, a regra do consenso negativo para que o DSB adote as recomendações dos painéis e do Órgão de Apelação deram a este caráter de tribunal.

JULIO LACARTE-MURÓ ${ }^{117}$, também ex membro do Órgão de Apelação, declara que "o Órgão de Apelação é o guardião da legalidade da OMC e não há espaço para levar em conta reações ou vontades políticas, sejam elas quais forem". É exatamente sobre esse aspecto que, em casos antidumping, os painéis e o Órgão de Apelação sofreram pesadas críticas, sob o argumento de que deixaram de observar o padrão de revisão do Artigo 17.6 do ADA.

\footnotetext{
114 "An appeal shall be limited to issues of law covered in the panel report and legal interpretations developed by the panel."

115 ABI-SAAB, Georges. The Appellate Body and Treaty Interpretation. In SACERDOTI, Griogio; YANOVICH, Alan; BOHANES, Jan (cords.) The WTO at Ten: The contribution of the Dispute Settlement System. Cambridge: Cambridge University Press, 2006, pag. 454.

${ }^{116}$ SACERDOTI, Giorgio. The dispute settlement system of the WTO in action: a perspective on the first ten years. In SACERDOTI, Griogio; YANOVICH, Alan; BOHANES, Jan (cords.) The WTO at Ten: The contribution of the Dispute Settlement System. Cambridge: Cambridge University Press, 2006, pag. 49.

${ }^{117}$ MURO, Julio A. Lacarte. Os Primeiros Anos do Órgão de Apelação e do Sistema de Solução de Controvérsias na OMC: uma perspectiva história. In BAPTISTA, Luiz Olavo e CELLI JUNIOR, Umberto e YANOVICH, Alan (orgs.); 10 anos de OMC: uma análise do Sistema de Solução de Controvérsias e Perspectivas. São Paulo: Aduaneiras, 2007, pag. 40.
} 
A esse respeito, BACCHUS ${ }^{118}$, ex membro do Órgão de Apelação, defende que o Órgão de Apelação foi verdadeiro a todos os Acordos da OMC, e agiu de forma compatível com o padrão de revisão acordado entre os Membros. Reitera que, em nenhum momento, o Órgão de Apelação ampliou ou diminuiu os direitos e obrigações acordadas.

LUIZ OLAVO BAPTISTA ${ }^{119}$, também ex membro do Órgão de Apelação, fazendo referência à $\mathrm{OMC}$, mas trazendo um ensinamento que pode ser aplicável em outras esferas do cotidiano, ressalta que "os membros do Órgão de Apelação nem sempre raciocinarão exatamente de acordo com as expectativas de uma parte, nem chegarão, sempre e precisamente, àquele resultado desejado ou imaginado por um dos demandantes. Isso porque seu raciocínio poderá não corresponder ao do autor das expectativas".

CARLA JUNQUEIRA ${ }^{120}$ realizou estudo dos casos da OMC sob a ótica interpretativa do Órgão de Apelação e constatou que, na prática, o Órgão de Apelação tem interpretado o Artigo 17:13 do ESC $^{121}$ para complementar a análise feita pelo painel e resolver a disputa ${ }^{122}$. Isso pois o ESC não admite o reenvio ao

\footnotetext{
${ }^{118}$ BACCHUS, James. Around the Table of the Appellate Body of the WTO. Vanderbilt Journal of Transnacional Law, v.35, 2002, pag. 1034: "some may say also that we may not have been true in some of our ruling to the standard of review that is established in the WTO treaty for the review of national decision-making in WTO dispute settlement. Here, again, I would disagree. And I would invite them to read carefully both the WTO treaty and our interpretations of the WTO treaty relating to the issue of the appropriate standard of review. They will find that we have been true, consistently, to all that the WTO treaty says about the standard of review. What they seem to be seeking is a standard of review different from the one on which all WTO Members have agreed and which all WTO Members have included in the WTO treaty. For, again, as the treaty says, it is not our place, in dispute settlement, either to add to or diminish the rights and obligations provided in the covered agreements".

119 BAPTISTA, Luiz Olavo. A interpretação e aplicação das regras da OMC nos primeiros anos. Revista de Informação Legislativa, v.41, 2004.

${ }^{120}$ JUNQUEIRA, Carla Amaral de Andrade. A técnica interpretativa do Órgão de Apelação da Organização Mundial do Comércio. Tese de Doutorado. USP/2010, Pag. 39.

${ }^{121}$ Artigo que estabelece que o Órgão de Apelação poderá reverter, modificar ou manter as determinações e conclusões do painel.

${ }^{122}$ Segundo a autora os casos em que o Órgão de Apelação completou a análise foram: "United States - Standards for Reformulated and Conventional Gasoline (DS2), Australia - Measures Affecting Importation of Salmon (DS18), Canada - Certain Measures Concerning Periodicals (DS31), Brazil- Export Financing Programme for Aircraft (DS 46), United States - Import Prohibition of Certain Shrimp and Shrimp Products (DS 58), European Communities - Measures
} 
painel e, ao mesmo tempo, exige que seja dada uma solução positiva para a controvérsia $^{123}$. Essa postura do Órgão de Apelação é passível de críticas, pois as conclusões sobre os fatos tomadas pelo painel podem ser revistas no interim report e, como não há um interim report em fase de apelação, as conclusões acabam sendo definitivas. MAVROIDIS ${ }^{124}$ afirma que, apesar de o Órgão de Apelação ter solucionado a disputa, ele privou as partes do duplo grau de jurisdição.

EVANDRO MENEZES DE CARVALHO ${ }^{125}$, ao explicar a forma de análise pelo Órgão de Apelação, descreve alguns casos da OMC e conclui que o Órgão de Apelação recorre basicamente a duas fontes: (i) Artigos 31 e 32 da Convenção de Viena; e (ii) dicionários.

O Artigo 31 da Convenção de Viena tornou-se um marco para os órgãos decisórios da OMC interpretarem as regras comerciais firmadas no âmbito da Organização, com base no sentido ordinário (ou comum) dos termos do tratado e

Affecting the Importation of Certain Poultry Products (DS69), Japan - Measures Affecting Agricultural Products (DS76), United States - Tax Treatment for Foreign Sales Corporation (DS 108) e United States - Definitive Safeguard Measures on Imports of Wheat Gluten from the EC (DS 166)". JUNQUEIRA, Carla Amaral de Andrade. A técnica interpretativa do Órgão de Apelação da Organização Mundial do Comércio. Tese de Doutorado. USP/2010, nota de rodapé 191, pag. 86.

123 Artigo 3.3 do ESC: "The prompt settlement of situations in which a Member considers that any benefits accruing to it directly or indirectly under the covered agreements are being impaired by measures taken by another Member is essential to the effective functioning of the WTO and the maintenance of a proper balance between the rights and obligations of Members") e

Artigo 3.7 do ESC: "Before bringing a case, a Member shall exercise its judgement as to whether action under these procedures would be fruitful. The aim of the dispute settlement mechanism is to secure a positive solution to a dispute. A solution mutually acceptable to the parties to a dispute and consistent with the covered agreements is clearly to be preferred. In the absence of a mutually agreed solution, the first objective of the dispute settlement mechanism is usually to secure the withdrawal of the measures concerned if these are found to be inconsistent with the provisions of any of the covered agreements. The provision of compensation should be resorted to only if the immediate withdrawal of the measure is impracticable and as a temporary measure pending the withdrawal of the measure which is inconsistent with a covered agreement. The last resort which this Understanding provides to the Member invoking the dispute settlement procedures is the possibility of suspending the application of concessions or other obligations under the covered agreements on a discriminatory basis vis-à-vis the other Member, subject to authorization by the DSB of such measures".

${ }^{124}$ MAVROIDIS, Petros C. Crisis? What Crisis? Is the WTO Appellate Body Coming of Age? In JUNQUEIRA, Carla Amaral de Andrade. A técnica interpretativa do Órgão de Apelação da Organização Mundial do Comércio. Tese de Doutorado. USP/2010, pag. 87: "in all cases in which the $A B$ has completed the analysis, it has ipso facto deprived parties of their right to a two-stage adjudication, albeit it has thus facilitated speedy, resolution of the dispute".

${ }^{125}$ CARVALHO, Evandro Menezes de. O Discurso jurídico-decisório da Organização Mundial do Comércio: uma análise semiótica dos relatórios do Órgão de Apelação. Tese de doutorado. USP/2005, pags. 165-255. 
no seu contexto, em consonância com o seu objeto e finalidade. Com relação ao Artigo 32, CARLA JUNQUEIRA 126 esclarece que "outras formas suplementares de interpretação poderão ser adotadas, como os trabalhos preparatórios do tratado e as circunstâncias de sua conclusão, quando a utilização das regras previstas no Artigo 31 deixarem o sentido buscado ambíguo ou obscuro, ou ainda quando for atingido um resultado que é manifestamente absurdo ou desarrazoado".

Vale ressaltar que os procedimentos acima aplicam-se à solução de quaisquer controvérsias levadas ao DSB. No caso de antidumping, o recurso à Convenção de Viena também é amparado pelo Artigo 17.6(ii) do ADA, por ser uma norma de direito internacional público. Vejamos o que dispõe o Artigo 17 do ADA.

\section{(ii) Artigo 17 do ADA}

O Artigo 17.1 do $\mathrm{ADA}^{127}$ determina que o ESC é aplicável à solução de controvérsias sobre antidumping, exceto no que for contrário ao disposto no ADA. Portanto, a aplicação do ESC é subsidiária.

O Artigo 17.2 do $\mathrm{ADA}^{128}$ é meramente diplomático, estabelecendo que os Membros devem dar "sympathetic consideration" para solucionar as controvérsias surgidas. O Artigo 17.3 do $\mathrm{ADA}^{129}$ prevê o pedido formal de consultas, e o Artigo

\footnotetext{
126 JUNQUEIRA, Carla Amaral de Andrade. A técnica interpretativa do Órgão de Apelação da Organização Mundial do Comércio. Tese de Doutorado. USP/2010, pag. 39.

127 "Except as otherwise provided herein, the Dispute Settlement Understanding is applicable to consultations and the settlement of disputes under this Agreement".

128 "Each Member shall afford sympathetic consideration to, and shall afford adequate opportunity for consultation regarding, representations made by another Member with respect to any matter affecting the operation of this Agreement".

129 "If any Member considers that any benefit accruing to it, directly or indirectly, under this Agreement is being nullified or impaired, or that the achievement of any objective is being impeded, by another Member or Members, it may, with a view to reaching a mutually satisfactory resolution of the matter, request in writing consultations with the Member or Members in question. Each Member shall afford sympathetic consideration to any request from another Member for consultation".
} 
$17.4^{130}$ remete o caso ao DSB, se a controvérsia não tiver sido resolvida durante as consultas. O Artigo 17.5 do ADA traz as diretrizes para o estabelecimento do painel e apresentação da petição e o Artigo 17.6 traz as peculiaridades aplicáveis à solução das disputas antidumping pelos painéis (padrão de revisão). Trataremos de ambos em detalhes abaixo.

Por fim, o Artigo 17.7 do ADA $^{131}$ reconhece a existência de informações confidenciais, as quais só poderão ser divulgadas se previamente autorizadas. Caso contrário, um resumo não confidencial deverá ser apresentado.

\section{(a) Padrão de Revisão ("Standard of Review")}

O termo "standard of review" não é encontrado nos acordos da OMC. Trata-se de terminologia amplamente utilizada em países que seguem o direito comum (Common Law) para tratar do montante de deferência que deve ser dado por uma corte ao revisar a decisão de uma outra corte. Portanto, ao fazer menção ao termo "padrão de revisão", pensamos automaticamente na competência conferida a determinado órgão para rever uma recomendação/decisão específica.

A tradução para o português pode sofrer variações: padrão de fiscalização? Critério de revisão? Nível de fiscalização? Como o termo não é encontrado no ADA, não podemos nos basear nas traduções oficiais para o francês ou espanhol para concluir qual seria mais apropriada. Para fins dessa tese, adotaremos o termo "padrão de revisão".

\footnotetext{
130 "If the Member that requested consultations considers that the consultations pursuant to paragraph 3 have failed to achieve a mutually agreed solution, and if final action has been taken by the administering authorities of the importing Member to levy definitive anti-dumping duties or to accept price undertakings, it may refer the matter to the Dispute Settlement Body ("DSB"). When a provisional measure has a significant impact and the Member that requested consultations considers that the measure was taken contrary to the provisions of paragraph 1 of Article 7, that Member may also refer such matter to the DSB".

131 "Confidential information provided to the panel shall not be disclosed without formal authorization from the person, body or authority providing such information. Where such information is requested from the panel but release of such information by the panel is not authorized, a non-confidential summary of the information, authorized by the person, body or authority providing the information, shall be provided".
} 
Nos EUA há três padrões de revisão: (i) de novo, (ii) arbitrário e discrionário, e (iii) erro latente ${ }^{132}$. Como salienta JANE ALLEN ${ }^{133}$, no caso das revisões de novo, a corte de apelação analisa o caso desde o início, como se fosse a primeira corte a analisá-lo, sem considerar o que foi decidido na instância inferior. No caso do padrão arbitrário e discricionário, também conhecido como abuso de discricionariedade, a corte revisa apenas se houve arbitrariedade ou discricionariedade, excedendo os poderes outorgados por lei. Esse é o padrão adotado para revisão das decisões dos órgãos administrativos. O último padrão (erro latente) revisa os vícios sérios, tanto de fato como de direito.

Em se tratando do sistema de solução de controvérsias da OMC, como salientado, podemos encontrar um padrão de revisão fixado aos painéis pelo Artigo 11 do ESC e ao Órgão de Apelação pelo Artigo 17.6 do ESC. Especificamente para as disputas antidumping, também o Artigo 17.6, mas do ADA, deve ser observado.

CRETELLA NETO ${ }^{134}$ lembra que durante a Rodada Uruguai, quando o Artigo 17.6 do ADA estava sendo negociado, os EUA se esforçaram para inserir limitações ao padrão de revisão a ser criado, enquanto que os países em desenvolvimento e de menor desenvolvimento relativo prefeririam que o padrão de revisão permitisse mais ampla atuação dos painéis, de modo a evitar conclusões contraditórias.

\footnotetext{
${ }^{132}$ BERRY IV, Lee Will. Standards of the Standards of Review. Lewis \& Clark Law Review, 2009, p. 233-235: "United States courts apply three standards of review namely, de novo review, arbitrary and capricious standard and clearly erroneous standard". AMANDA PETERS em seu artigo "The meaning, measure and misuse of standards of review" também expõe a mesma estrutura.

133 ALLEN, Jane. Avoiding controversy over the standard of review - Assistant of the Appelant Defendant, Durham North Carolina, 2001.

${ }^{134}$ CRETELla NETO, José. Direito Processual na Organização Mundial do Comércio, Rio de Janeiro: Forense, 2003, pag. 403.
} 
GREENWALD ${ }^{135}$ defende que ao interpretar o Artigo 17.6 do ADA devemos analisar, conjuntamente, a figura do "standard of review" e o da "deference", típica da jurisprudência estadunidense. Deferência é obediência, acato. Seguir um padrão de revisão, com acato ao determinado pelas autoridades nacionais, é imprescindível à previsibilidade e segurança jurídica.

Como informado anteriormente, o padrão de revisão para disputas antidumping é específico, e deve ser realizado à luz do disposto nos Artigos $17.5 \mathrm{e}$ 17.6 do ADA. O Artigo 17.5 do ADA não traz novidades, e reitera etapas previstas no ESC. Ele estabelece que:

“O DSB deverá, mediante solicitação do demandante, estabelecer um painel para examinar a questão com base em:

(i) Uma petição escrita do Membro indicando como um benefício a ele outorgado, direta ou indiretamente, pelo ADA tem sido anulado ou prejudicado, ou como o alcance dos objetivos do Acordo tem sido impedidos; $e$

(ii) Fatos disponibilizados em conformidade com os procedimentos domésticos perante as autoridades do país importador." 136

Já o Artigo 17.6 determina aos painéis que:

\footnotetext{
${ }^{135}$ GREENWALD, John. WTO Dispute Settlement: An exercise in trade law legislation? Journal of International Economic Law, v.6, 2003, pag. 117.

136 "The DSB shall, at the request of the complaining party, establish a panel to examine the matter based upon:

(i) a written statement of the Member making the request indicating how a benefit accruing to it, directly or indirectly, under this Agreement has been nullified or impaired, or that the achieving of the objectives of the Agreement is being impeded, and

(ii) the facts made available in conformity with appropriate domestic procedures to the authorities of the importing Member."
} 
"Quando conduzirem os procedimentos dispostos no parágrafo 5, devem:

(i) ao analisar os fatos, determinar se a autoridade investigadora agiu de forma apropriada e se a avaliação dos fatos foi imparcial e objetiva. Se o estabelecimento dos fatos foi imparcial e objetivo, mesmo que o painel tenha chegado a uma conclusão diferente, a avaliação não deve ser modificada;

(ii) interpretar as disposições do ADA de acordo com as regras costumeiras de interpretação do direito internacional público. Quando o painel considerar que uma disposição específica possa ter mais de uma interpretação possível, o painel deve considerar que a medida antidumping adotada à luz de uma dessas interpretações está em conformidade com o ADA.” 137 (grifos nossos)

Portanto, com relação aos fatos: o painel deve estabelecê-los de forma apropriada e avaliá-los de forma imparcial e objetiva e, com relação à interpretação legal, caso haja mais de uma possível, o painel deve aceitar a interpretação dada pela autoridade nacional.

Esse padrão de revisão surgiu nos últimos momentos da Rodada Uruguai, e não tem precedentes no Acordo $\mathrm{AD}$ da Rodada Tóquio. Veio para defender,

\footnotetext{
137 "In examining the matter referred to in paragraph 5:

(i) in its assessment of the facts of the matter, the panel shall determine whether the authorities' establishment of the facts was proper and whether their evaluation of those facts was unbiased and objective. If the establishment of the facts was proper and the evaluation was unbiased and objective, even though the panel might have reached a different conclusion, the evaluation shall not be overturned;

(ii) the panel shall interpret the relevant provisions of the Agreement in accordance with customary rules of interpretation of public international law. Where the panel finds that a relevant provision of the Agreement admits of more than one permissible interpretation, the panel shall find the authorities' measure to be in conformity with the Agreement if it rests upon one of those permissible interpretations."
} 
sobretudo, interesses dos EUA, conforme salienta JACKSON e CROLEY ${ }^{138}$. Alguns meses antes do término da Rodada Uruguai, o Comitê de Negociações Comerciais adotou decisão que determinava que o padrão de revisão previsto no Artigo 17.6 do ADA deveria ser revisto após três anos, para determinar se poderia ter aplicação genérica ${ }^{139}$.

Ocorre que quase 20 anos se passaram, tendo permanecido o padrão de revisão previsto no ADA aplicável unicamente às disputas antidumping. Como reconhecido nos casos US - Underwear ${ }^{140}, E C-$ Hormones $^{141}$ e Argentina Footwear $^{142}$, nenhum outro acordo abrangido traz disposição similar. O painel em US - Wooven Wool Shirts and Blouses ${ }^{143}$, todavia, chama a atenção para que essa peculiaridade não interfira na função dos órgãos decisórios da OMC.

Para que esse padrão seja observado, LEONOR CORDOVIL ${ }^{144}$ resume afirmando que "a autoridade deve proceder aos seguintes testes: a) verificar a propriedade; b) verificar imparcialidade; c) verificar a objetividade; d) verificar a possibilidade de mais de uma interpretação; e) verificar se a decisão condiz com alguma das interpretações".

\footnotetext{
138 JACKSON, John e CROLEY, Steven P. WTO Dispute Procedures, Standard of Review, and Deference to National Governments. Journal of International Law, v.90, n.2, pags.2-4:"in the waning months of the Uruguay Round, the standard-of-review issue assumed such importance to some negotiatiors that it reached a place on the short list of problems called "deal breackers"problems that could have caused the entire negoatiations to fail. This was particularly odd, given that the issue was one that only a few persons understood, and that was virtually unnoticed by almost all the public or private policy makers concerned with the negotiation. Clearly, certain economic interests were deeply concerned, most notably those in the United States who favored greater restraints on the capacity of the international body to overrule US government determinations on antidumping duties, and who were perceptive and economically endowed enough to carry their views deeply in to the negotiations process".

139 "Decision on Review of Article 17.6 of the Agreement on Implementation of Article VI of the General Agreement on Tariffs and Trade 1994 Adopted by the Trade Negotiations Committee on 15 December 1993". "Ministers decide as follows: The standard of review in paragraph 6 of Article 17 of the Agreement on Implementation of Article VI of GATT 1994 shall be reviewed after a period of three years with a view to considering the question of whether it is capable of general application."

${ }^{140}$ WT/DS24/R, adotado em 25 de fevereiro de 1997, para. 7.8.

${ }^{141}$ WT/DS26/AB/R, adotado em 13 de fevereiro de 1998, paras. 49 e 114.

${ }^{142}$ WT/DS121/AB/R, adotado em 12 de janeiro de 2000.

${ }^{143}$ WT/DS33/R, para. 7.17.

${ }^{144}$ CORDOVIL, Leonor. O interesse público no antidumping. Tese de Doutorado. USP/2009, pag. 288.
} 
Conforme sustenta CARREAU e JUILLARD ${ }^{145}$, “não há revisão do juízo de oportunidade das medidas antidumping decididas com toda objetividade $e$ imparcialidade pelas autoridades nacionais. Existe, portanto, um controle independente dos procedimentos nacionais seguidos, sendo delicado e pouco aceitável discutir, em uma organização não jurisdicional, como o mecanismo de solução de controvérsias da OMC, as decisões de justiça nacional revestidas de autoridade de coisa julgada".

Vejamos de que forma esse assunto tem sido tratado pelo DSB.

\subsubsection{DISPUTAS}

Como já apontado, apesar de as medidas antidumping não abrangerem nem $1 \%$ do comércio global, conforme explicado anteriormente, aproximadamente $20 \%$ das disputas levadas ao DSB, e metade das recomendações adotadas, versam sobre antidumping. Até o momento, foram 91 disputas iniciadas, em um total de 439 desde a entrada em vigor do $\mathrm{ESC}^{146}$.

Tendo em vista essa disparidade entre o número de disputas que dizem respeito a medidas antidumping, e o percentual que essas medidas representam no comércio global, podemos inferir que há algo errado. Considerando que, em disputas antidumping, analisa-se o procedimento investigatório conduzido pelo governo do país importador, podemos concluir que os procedimentos adotados não têm sido coerentes com o acordado pelos Membros no ADA. Conforme apontado por STEWART, DWYER e HEIN ${ }^{147}$, esse fato traz cinco alertas aos Membros:

\footnotetext{
${ }^{145}$ CARREAU, Dominique e JUILLARD, Patrick. Droit International Economique. Paris: Dalloz, 2003, pag. 199.

${ }_{146}$ Dados obtidos em www.wto.org. Último acesso em 01/07/2012.

147 STEWART, Terence. Trends in the last decade of trade remedy decisions: problems and opportunities for the WTO dispute settlement system, Arizona Journal of International and Comparative Law, vol. 24, no. 1, 2007. Sobre esse estudo, importante ressaltar que os autores são dos EUA, demonstrando claramente sua crítica ao posionamento do DSB que condenou os EUA na maioria dos casos em que foi demandado.
} 
(i) Os demandantes conseguem estabelecer uma violação às regras da OMC em $90 \%$ dos casos levados ao DSB, o que leva a entender que o DSB tem uma tendência a favor dos demandantes;

(ii) $\mathrm{O}$ resultado das disputas sobre medidas de defesa comercial é afetado pelo número de Membros participando como partes ou terceiros interessados;

(iii) Os Membros têm buscado, via painel e Órgão de Apelação, alterar os acordos abrangidos, sobre aspectos que não foram aceitos durante as negociações multilaterais;

(iv) A despeito do disposto no Artigo 17.6 do ADA, o DSB nunca considerou a possibilidade de haver mais de uma interpretação permitida para um determinado dispositivo; e

(v) A despeito do disposto no Artigo 17.6 do ADA, o Órgão de Apelação tem se sentido autorizado a preencher lacunas e tem encontrado obrigações implícitas em dispositivos que são omissos a respeito de determinado assunto.

Com relação ao primeiro aspecto apontado pelos autores (alto índice de condenações), constatamos que o devido processo legal tem sido violado nas investigações antidumping e que o fato de haver tantas disputas antidumping não representa falta de critério/seletividade por parte dos Membros em aceitar levar um caso para a OMC. Essa constatação também não nos permite concluir que os governos têm usado o sistema simplesmente para proteção de direitos de suas empresas nacionais.

Quanto ao segundo aspecto (se vários Membros participam, as chances de ver a medida questionada condenada é maior), entendemos não necessariamente ser verdade. Obviamente, se vários Membros consideram que a medida viola as regras da OMC, as chances de que ela realmente viole são maiores do que nos casos em que um único Membro entende haver violação. Além disso, tendo em vista que nas disputas antidumping o que se questiona é o procedimento, o(s) Membro(s) afetado(s) pela medida, em geral, é(são) unicamente o(s) país(es) 
investigado(s). Os demais participantes teriam apenas interesse sistêmico em acompanhar o desenrolar da controvérsia pois, provavelmente, foram ou serão afetados por medida similar.

Quanto ao terceiro aspecto (alteração dos acordos negociados via DSB), trata-se de crítica bastante frequente que não deveria ocorrer, uma vez que o DSB tem competência apenas para interpretar os dispositivos negociados e acordados pelos Membros, não podendo aumentar ou diminuir seus direitos e obrigações. Esse ativismo do Órgão de Apelação foi analisado em detalhes por CARLA JUNQUEIRA $^{148}$, ficando demonstrado que a maioria dos Membros da OMC aprova os trabalhos desenvolvidos pelo Órgão de Apelação, sendo os EUA os únicos que apontam para tal ativismo.

Com relação ao quarto aspecto levantado pelos autores (o DSB nunca entendeu haver mais de uma interpretação possível), a constatação confere. Ocorre que, com o intuito de dar uma solução para a disputa (outro mandamento do ESC), o DSB tem recorrido às regras costumeiras de interpretação para definir a interpretação mais adequada. Concordamos que esse ponto é contrário ao Artigo 17.6(ii) do ADA e, ao final dessa tese, apresentaremos uma alternativa que entendemos conciliar as obrigações de admitir interpretações permissivas e solucionar a disputa.

Com efeito, a aplicação das normas costumeiras de direito internacional, enraizadas na Convenção de Viena (o que é admitido tanto pelo ESC, como pelo Artigo 17.6(ii) do ADA), tem se mostrado uma maneira dos painéis e do Órgão de Apelação chegarem sempre a uma única interpretação possível. Os autores valemse do exemplo de que, pelo simples fato de o painel ou Órgão de Apelação escolherem uma das diversas definições que o dicionário traz para aquele termo, já está violando o Artigo 17.6 do ADA.

\footnotetext{
148 JUNQUEIRA, Carla Amaral de Andrade. A técnica interpretativa do Órgão de Apelação da Organização Mundial do Comércio. Tese de Doutorado. USP/2010.
} 
O quinto aspecto suscitado (preenchimento de lacunas pelo DSB) está relacionado tanto com o item (iii), como com o item (iv), acima. Concordamos que fere o disposto nos Artigos 3.2 e 19.2 do ESC, mas entendemos que também decorre da "pressão" que o Órgão de Apelação sofre para dar uma solução positiva para o caso. Nesse sentido, a alternativa a ser proposta ao final dessa tese terá por objeto sanar também essa falha.

Em análise feita por RENE MEDRADO ${ }^{149}$ em 2004, ele constata que “o pedido acolhido referente à regra da não-atribuição (Artigo 3.5 do $A D A^{150}$ ) é o único caso em que de fato pode-se ponderar ter havido restrição à aplicação da legislação antidumping em decorrência de o Órgão de Apelação não ter aceito uma interpretação permissível adotada pelas autoridades norte-americanas." Em razão dessa constatação, o autor conclui que o Órgão de Apelação respeita a lei e a prática antidumping dos EUA.

Importante notar que o autor fez a análise antes das inúmeras discussões acerca do zeramento no âmbito do Órgão de Apelação da OMC. Passemos a analisar as disputas sobre antidumping no sistema de solução de controvérsias do GATT/OMC. Daremos especial atenção àquelas que citaram o Artigo 17.6 do ADA e aos casos sobre zeramento, pois seus resultados contribuirão para fins dessa tese.

\footnotetext{
${ }^{149}$ MEDRADO, Renê Guilherme S., A "prova dos nove": o Órgão de Apelação da OMC respeita a legislação e a prática antidumping dos Estados Unidos. In LIMA CAMPOS, Alusio. Ensaios em Comércio Internacional, São Paulo, Editora Singular, 2005, pag. 160.

150 "It must be demonstrated that the dumped imports are, through the effects of dumping, as set forth in paragraphs 2 and 4, causing injury within the meaning of this Agreement. The demonstration of a causal relationship between the dumped imports and the injury to the domestic industry shall be based on an examination of all relevant evidence before the authorities. The authorities shall also examine any known factors other than the dumped imports which at the same time are injuring the domestic industry, and the injuries caused by these other factors must not be attributed to the dumped imports. Factors which may be relevant in this respect include, inter alia, the volume and prices of imports not sold at dumping prices, contraction in demand or changes in the patterns of consumption, trade restrictive practices of and competition between the foreign and domestic producers, developments in technology and the export performance and productivity of the domestic industry".
} 


\section{(i) Disputas sobre antidumping na época do GATT}

Entre 1947 e 1994, período em que não havia sido criado o ESC e as disputas eram resolvidas pelas Partes Contratantes sob os Artigos XXII e XXIII do GATT, houve sete casos que trataram de antidumping.

O primeiro caso ${ }^{151}$, no qual a Itália questionou um decreto de 15 de outubro de 1954 sobre medidas antidumping aplicadas pela Suécia a meia calça de nylon, ficou clara a possibilidade de se valer de qualquer um dos três métodos trazidos no Artigo VI.1 do GATT para definir o valor normal (preço do produto similar no mercado do país exportador; preço do produto similar para exportação a qualquer terceiro país; ou custo de produção mais despesas e lucro).

Mas o grupo de especialistas, quatro anos depois, ao analisar o segundo caso antidumping ${ }^{152}$, esclareceu que o segundo e terceiro métodos só poderiam ser aplicados se o primeiro se mostrou inviável ${ }^{153}$. Nesse segundo caso em que foram questionadas medidas antidumping aplicadas pela Nova Zelândia contra transformadores da Finlândia, o painel notou que na ausência de um preço doméstico na Finlândia para transformadores do mesmo tipo, as autoridades neozelandesas basearam sua determinação de valor normal no custo de produção previsto no Artigo VI:1(b)(ii) - terceiro método ${ }^{154}$. Nesse caso também foram definidos alguns parâmetros para configuração do dano, como a falta de pedidos, queda nos lucros, aumento das importações e incerteza quanto a novos pedidos.

\footnotetext{
${ }^{151}$ Swedish anti-dumping duties. L/328, adotado em 26 de fevereiro de 1955, Basic Instruments and Selected Documents (BISD) 3S/81, 89, para. 28.

${ }^{152}$ New Zealand - Imports of Electrical Transformers from Finland, L/978, BISD 8S/145, adotado em 13 de maio de 1959.

153 "The Group agreed that the criteria under paragraph 1(b) of Article VI could only be used where no domestic price existed as defined in paragraph 1(a) or in cases where there were sales to the home market but where it was not possible to determine normal value from these sales, for example because they did not fall within 'the ordinary course of trade' as required in paragraph 1(a)" (para. 10).

${ }^{154}$ L/5814, adotado em 18 de julho de 1985, BISD 32S/55, 66-67, paras. 4.2-4.3: "in the absence of a domestic price in Finland for custom-built transformers of this kind - the New Zealand authorities had based their determination of normal value on the cost-of-production method foreseen in Article VI:1(b)(ii)".
} 
O relatório do grupo de especialistas emitido em 1988 no caso Japan Trade in Semi-Conductors ${ }^{155}$, terceiro caso da época do GATT, deixou clara a impossibilidade de se impor qualquer outra penalidade à prática do dumping que não seja a imposição de uma medida antidumping no momento do ingresso da mercadoria no mercado importador ${ }^{156}$. Trata-se de caso iniciado pela então Comunidade Europeia (CE) contra o Japão, também com base no Artigo VI do GATT.

No caso subsequente ${ }^{157}$, também iniciado pela então CE sobre a definição de indústria doméstica para vinhos e uvas, adotado em 1992, foi questionado o Artigo 6 do Acordo AD da Rodada Tóquio, e ficou estabelecido que os cultivadores de uva e a indústria do vinho deveriam ser consideradas como indústrias distintas para fins da investigação ${ }^{158}$.

Já o relatório do grupo de especialistas emitido em 1993 no caso Korea Anti-dumping Duties on Imports of Polyacetal Resins from the United States ${ }^{159}$, com base no Acordo AD da Rodada Tóquio, examinou a determinação de ameaça de dano pelas autoridades coreanas, e exigiu a comprovação de alteração das

\footnotetext{
${ }^{155}$ BISD 35S/116, L6309, adotado em 4 de maio de 1988.

156 "The Panel proceeded to examine the contention of the EEC that the measures maintained by Japan to prevent dumping were contrary to Article VI because that provision gave the exclusive right of preventing dumping to the importing countries. The Panel noted that Article VI provided importing countries with the right to levy anti-dumping duties subject to certain specific conditions but was silent on actions by exporting countries".

157 United States - Definition of Industry Concerning Wine and Grape Products, BISD 39S/436, adotado em 28 de abril de 1992.

158 "The Panel then addressed the question whether, as a consequence of the close relationship between grape and wine production, the wine-grape growers could be regarded as part of the industry producing wine. It noted in this respect that both delegations had stated before the Panel that in the United States, the structure of the industries was such that wineries did not normally grow their own grapes but bought them from the grape-growers for processing. In view of this situation, the Panel found that, irrespective of ownership, a separate identification of production of wine-grapes from wine in terms of Article 6:6 of the Code was possible and that therefore in fact two separate industries existed in the United States - the growers of wine-grapes on the one hand and the wineries on the other. Bearing in mind its terms of reference, the Panel did not consider it appropriate to examine the structure of the wine industry in other countries or the situation in other product sectors."

${ }^{159}$ BISD 40S/205, adotado em 27 de abril de 1993.
} 
circunstâncias como tendo sido esperada e iminente (tanto para volume como efeitos nos preços) ${ }^{160}$.

Em 1994, o relatório do painel no caso United States - Imposition of AntiDumping Duties on Imports of Fresh and Chilled Atlantic Salmon from Norway tratou dos requisitos para abertura de uma investigação e determinou que, para que a peticionária tenha representatividade, ela deve corresponder à maior parte da produção doméstica do produto a ser investigado ${ }^{161}$.

O próximo caso, único envolvendo o Brasil na época GATT, foi o $E C-$ Imposition of Anti-dumping duties on imports of cotton yarn from Brazil ${ }^{\mathbf{1 6 2}}$. Em 22 de março de 1990, a então CE publicou uma nota em seu Jornal Oficial de que estava iniciando uma investigação antidumping contra as importações de fios de algodão originários do Brasil, Egito, Índia, Tailândia e Turquia. A investigação de dumping abrangeria o período de 01 de janeiro de 1989 a 31 de dezembro de 1989, e a investigação do dano abrangeria os anos de 1986 a 1989. Em 23 de setembro de 1991, a CE impôs medidas antidumping exceto com relação ao Egito (margem de dumping de minimis).

$\mathrm{Na}$ investigação envolvendo o Brasil, nove exportadores responderam aos questionários e os exportadores foram considerados cooperativos. Três exportadores, Nisshinbo, Renda e Kanebo, foram selecionados como em amostragem e um cálculo separado de dumping foi feito para cada um deles. Para os outros seis exportadores que colaboraram foi aplicada a média ponderada das margens apuradas para os três exportadores incluídos na amostragem. O cálculo da

160 “... It followed from the text of Article 3:6 that a proper examination of whether a threat of material injury was caused by dumped imports necessitated a prospective analysis of a present situation with a view to determining whether a 'change in circumstances' was 'clearly foreseen and imminent'. Interpreted in conjunction with Article 3:1, a determination of the existence of a threat of material injury under Article 3:6 required an analysis of relevant future developments with regard to the volume, and price effects of the dumped imports and their consequent impact on the domestic industry."

161 "A 'written request ... on behalf of the industry affected' ... meant a request on behalf of the domestic producers as a whole of the like products or those of them whose collective output of the products constitutes a major proportion of the total domestic production of those products." ADP/87, adotado pelo Comitê de Práticas Antidumping em 27 de abril de 1994, para. 357.

162 ADP 137, de 4 de julho de 1995. 
margem de dumping para os exportadores não cooperativos foi baseada nos fatos disponíveis.

Em 1989 (ano de apuração do dumping para fins da investigação), a taxa de câmbio oficial entre o cruzado e o dólar dos EUA foi temporariamente congelada pelas autoridades brasileiras para janeiro, fevereiro e março. Em abril, maio e junho de 1989, o cruzado foi permitido depreciar gradualmente. Para o resto de 1989, o cruzado depreciou mais livremente em relação ao dólar.

Em seus cálculos, a CE usou as taxas de câmbio entre o cruzado e o dólar publicadas pela Fundação do Instituto Brasileiro de Geografia e Estatística (FIBGE), uma organização pública vinculada ao Ministério Brasileiro de Planejamento. A CE fez o seu cálculo de dumping para os três exportadores incluídos na amostragem, comparando cada operação de exportação com o valor normal médio mensal, expresso em cruzados; para uma empresa (Kanebo), a CE usou retornos reais em cruzado para o cálculo do dumping, e para as outras duas, usou as taxas de câmbio oficiais do final do mês. Para outubro, novembro e dezembro de 1989, a CE calculou os valores normais para Nisshinbo e Kanebo com base em custos de produção, sob a alegação de que as vendas internas nesses meses não tinham sido feitas no decurso de operações comerciais normais. Além disso, os europeus adotavam a prática do zeramento para cálculo da margem de dumping.

Em 11 de novembro de 1991 e 27 de outubro de 1993, Brasil e CE realizaram consultas relativas à medida antidumping provisória aplicada pela $\mathrm{CE}$ sobre fio de algodão do Brasil. As consultas não resultaram em uma solução mutuamente satisfatória para a controvérsia. O Brasil solicitou uma solução ao Comitê de Práticas Antidumping ${ }^{163}$ e uma reunião especial foi realizada para esta finalidade em 20 de dezembro de $1993^{164}$. Não houve uma solução mutuamente satisfatória para a disputa, e em 5 de abril de 1994, o Brasil solicitou o

\footnotetext{
163 ADP/106.

164 ADP/M/43.
} 
estabelecimento de um painel ${ }^{165}$. Este pedido foi analisado pelo Comitê em sua sessão ordinária em 26 de abril de $1994^{166}$.

O Painel ouviu as partes em 12 e 14 de setembro de 1994, e em 9 e 10 de novembro de 1994. O painel apresentou as suas conclusões em 12 de junho de 1995, condenando a CE em alguns dos aspectos, como o zeramento.

Cumpre ressaltar que esses são os casos do GATT cujos relatórios foram adotados pelas Partes Contratantes. Entre os casos não adotados, citamos Antidumping Duties on Gray Portland Cement and Cement Clinker from Mexico que também examinou os requisitos para abertura de investigação e afirmou que não houve a devida representatividade da indústria doméstica estadunidense para que fosse iniciada a investigação ${ }^{167}$. Cumpre lembrar que, nessa época, ainda não havia padrão de revisão diferenciado para antidumping, mas o zeramento já havia sido condenado.

\section{(ii) Disputas antidumping perante o DSB}

De 1995 até a atualidade, ou seja, durante a vigência do ESC, 91 disputas antidumping foram submetidas à apreciação do DSB. Nos Apêndices 1 a 4 a esta tese, as disputas foram caracterizadas pela etapa do procedimento em que se encontram.

Os EUA são, de longe, os grandes demandados. Os EUA alegam que nas disputas em que foi demandado, o painel e o Órgão de Apelação extrapolaram seus poderes. Abaixo uma lista dos casos cujo assunto problemático está relacionado com o objeto dessa tese:

\footnotetext{
$165 \mathrm{ADP} / 121$.

${ }^{166} \mathrm{ADP} / \mathrm{M} / 44$.

167 "The investigation had been initiated on the basis of a petition which alleged that domestic industries in two regions of the United States had been injured or threatened with injury by dumped imports of gray portland cement and cement clinker from Mexico, and asserted that the petitioners accounted for a majority of domestic production of gray portland cement in the markets in those regions".
} 


\begin{tabular}{|l|l|}
\hline \multicolumn{1}{|c|}{ Caso } & \multicolumn{1}{c|}{ Questão Problemática } \\
\hline US - DRAMS & Padrão de Revisão \\
\hline US - Stainless Steel & $\begin{array}{l}\text { Padrão de Revisão } \\
\text { Períodos múltiplos para cálculo da média }\end{array}$ \\
\hline US - Hot rolled Steel & $\begin{array}{l}\text { Padrão de Revisão } \\
\text { Análise de não atribuição (nexo causal) } \\
\text { Fatos disponíveis } \\
\text { Cálculo da taxa para “outros" }\end{array}$ \\
\hline US - Steel Plate & Padrão de Revisão \\
\hline US - Corrosion Resistant Steel Sunset & Zeramento \\
\hline US - Softwood Lumber & $\begin{array}{l}\text { Análise sobre ameaça de dano } \\
\text { Zeramento }\end{array}$ \\
\hline US - Oil Country Tubular Goods & $\begin{array}{l}\text { Revisão de final de período } \\
\text { Efeito das recomendações do Órgão } \\
\text { Apelação sobre os painéis }\end{array}$ \\
\hline
\end{tabular}

Fonte: Elaboração própria com base em dados apresentados por Stewart e outros $(2007)^{168}$.

STEWART, DWYER e HEIN ${ }^{169}$ dão o exemplo de que nada no ADA proíbe o governo de gastar os recursos provenientes das sobretaxas antidumping no que bem entender, tal como condenado no caso US - Byrd Amendment ${ }^{170}$. Outro exemplo diz respeito à criação de parâmetros para uso dos fatos disponíveis. Os autores lembram que nada no ADA define que os seis critérios fixados pelo Órgão de Apelação no caso US - Hot Rolled Steel devam ser observados.

Notamos que o padrão de revisão é o tema mais recorrente nas disputas. Após encerramento do estudo pelos autores, podemos afirmar que a prática do zeramento (que não deixa de ser uma questão relacionada ao padrão de revisão) é questionada em praticamente todas as investigações iniciadas contra os EUA. Por isso, trataremos abaixo sobre as disputas relacionadas a esses dois temas.

${ }^{168}$ STEWART, Terence, DWYER, Amy S. e HEIN, Elizabeth M. Trends in the last decade of Trade Remedy decisions: problems and opportunities for the WTO dispute settlement system, Arizona Journal of International and Comparative Law, 2007, pag. 291.

169 Idem, pag. 282.

${ }^{170}$ DS 217 - para detalhes vide Apêndice 4 (Órgão de Apelação). 
a) Disputas sobre Padrão de Revisão ${ }^{171}$

1) Thailand - H-Beams ${ }^{172}$ : Em abril de 1998, a Polônia requereu consultas com a Tailândia devido à imposição de medidas antidumping na importação de ângulos, formas e perfis de ferro e aço não ligado e vigas. A Polônia requereu a divulgação das conclusões da investigação que resultou na aplicação da medida, mas a Tailândia não o fez. O Órgão de Apelação interpretou "estabelecimento correto dos fatos", e disponibilização às partes interessadas, como sendo a demonstração de provas. O Órgão de Apelação analisou se o painel seguiu o padrão de revisão do Artigo 17.6 do ADA (opinou desfavoravelmente à Tailândia, mantendo a recomendação do painel) e declarou que essa é uma questão de procedimento e devido processo, discutida também em outros artigos do ADA, especialmente 6 e 12. Outro aspecto relevante desse caso é a confirmação de que os fatos a serem analisados pelo painel são apenas aqueles disponibilizados à autoridade investigadora (conforme descreve o Artigo 17.5 do ADA) e que eles incluem os dados confidenciais.

2) Mexico $-H_{F C S^{173}}$ : Em maio de 1998, os EUA requereram consultas com o México devido a uma investigação antidumping para xarope de milho de alta frutose. De acordo com os EUA, o requerimento de pedido de investigação continha falhas, e a relação entre prática de dumping e dano também não havia ficado comprovada, tendo havido incompatibilidades com o disposto no ADA. Apesar de o Artigo 17.6 do ADA não ter sido suscitado nem em fase de consultas, nem em fase de painel, o Órgão de Apelação, para que pudesse dar a sua recomendação, analisou se o painel seguiu o disposto nesse artigo e concluiu que sim.

\footnotetext{
${ }^{171}$ Vale notar que a base de dados da OMC cita apenas cinco disputas como envolvendo o Artigo 17.6 do ADA: US - DRAMS (mas não localizamos menção a esse artigo em nenhum documento do caso (relatório do painel do Artigo 21.5 do ESC, relatório do painel e pedido de consultas), Brazil Jute Bags, EU - Fasteners, EU - Footwear e US - Shrimp.

${ }^{172}$ DS122 - para detalhes vide Apêndice 4 (Órgão de Apelação).

${ }^{173}$ DS132 - para detalhes, vide Apêndice 4 (Órgão de Apelação).
} 
3) EC - Bed Linen $^{174}$ : Em agosto de 1998 a Índia requereu consultas com a CE, à época, sobre importação de roupa de cama de algodão da Índia. A CE sustenta que sua prática é uma das interpretações permitidas do Artigo 2.4.2 do ADA (à luz do Artigo 17.6 do ADA) e a Índia sustenta que não. Tendo em vista ter sido a Índia que trouxe a disputa, caberia a ela provar que a prática europeia não é permissiva. Outro ponto interessante discutido neste caso foi a interface entre a obrigação do painel de se ater às informações constantes do processo investigatório (conforme precedentes sobre o Artigo 17.6 do ADA), e o seu direito de buscar informações ("seek information") do Artigo 13 do ESC. Ficou definido que no caso das disputas antidumping, o direito dos painéis está restrito aos documentos constantes da investigação.

4) Guatemala - Cement ${ }^{175}$ : Em janeiro de 1999, o México requereu consultas com a Guatemala devido à imposição de medidas antidumping definitivas na importação de determinados cimentos, questionando o modo de condução da investigação. O painel foi estabelecido em setembro de 1999 e esclareceu que, de acordo com o Artigo 17.6 do ADA, não cabe aos painéis fazer uma revisão de novo da investigação conduzida pela autoridade nacional e que deve se limitar às provas constantes dos autos da investigação.

5) US - Stainless Steel ${ }^{176}$ : Em julho de 1999, Coréia do Sul requereu consultas com os EUA devido a determinações preliminares e finais do Departamento de Comércio Americano (United States Department of Commerce - USDOC na sigla em inglês) para chapas e fitas de aço inoxidável em bobinas. A Coréia do Sul considerou que diversos erros foram cometidos pelos EUA durante a investigação, o que modificou a correta conclusão do caso. Dentre os erros, a Coréia destaca a venda de produtos americanos a uma empresa falida, cálculo de dois períodos de

\footnotetext{
${ }^{174}$ DS141 - para detalhes, vide Apêndice 4 (Órgão de Apelação).

${ }^{175}$ DS156 - para detalhes, vide Apêndice 3 (painel).

${ }^{176}$ DS179 - para detalhes vide Apêndice 3 (painel).
} 
câmbio para exportação, e conversão de moeda em dólares. Os EUA sustentam que a discussão se as vendas foram feitas em dólar ou em won é uma questão de fato e, portanto, à luz do disposto no Artigo 17.6 do ADA, não pode ser reanalisada se a avaliação da autoridade investigadora foi imparcial e objetiva. A Coréia argumentou que não havia controvérsia de fato, bastava analisar as notas fiscais. Em outubro de 1999, a Coréia do Sul requereu estabelecimento de painel. O painel entendeu que o critério de exame depende da natureza da questão em análise. Ficou claro que o painel não deve somente verificar se a autoridade nacional estabeleceu corretamente os fatos, mas verificar o valor/peso dado a estes fatos, para constatar se essa valoração foi feita de forma imparcial e objetiva. Nesse caso, o painel concluiu que não implicava em interpretação do ADA e que a autoridade investigadora havia agido corretamente quanto aos fatos.

6) US - Hot Rolled Steel ${ }^{177}$ : Em novembro de 1999, Japão requereu consultas com os EUA com relação às decisões preliminares e finais do USDOC e da Comissão Americana de Comércio Internacional (United States International Trade Commission - USITC na sigla em inglês), na investigação antidumping de determinados produtos siderúrgicos laminados a quente. O Órgão de Apelação esclareceu que o Artigo 17.6 do ADA está dividido em dois parágrafos e que cada um deles serve a um propósito específico. O primeiro trata do estabelecimento dos fatos pelo painel, e o segundo, da interpretação jurídica a ser dada. Os EUA sustentam que deve ser encontrada uma interpretação meramente permissiva ("permissible") e não necessariamente a correta (“correct”). O Órgão de Apelação entendeu que, para concluir se o estabelecimento dos fatos foi apropriado ("proper"), deve-se verificar se a autoridade investigadora coletou informações relevantes e confiáveis ("relevant and reliable"). Uma segunda etapa seria verificar se todas as evidências foram levadas em consideração. Ficou claro que as obrigações da autoridade investigadora e do painel são diversas, mas

${ }^{177}$ DS184 - para detalhes vide Apêndice 4 (Órgão de Apelação). 
como não tem competência para analisar os fatos, o Órgão de Apelação não finalizou a análise.

7) Argentina - Carton-Boards and Tiles ${ }^{178}$ : Em janeiro de 2000, as CE requereram consultas com a Argentina devido a medidas antidumping definitivas impostas contra pisos de ladrilho feitos de cerâmica provenientes da Itália e cartões rígidos da Alemanha. As CE constataram diversas irregularidades durante a investigação, como a desconsideração pelas autoridades argentinas das informações fornecidas pelos exportadores italianos, deficiências na comparação do produto vendido da Itália e o produzido na Argentina, erro no cálculo de margem de dumping, dentre outras. Em novembro de 2000 as CE requereram o estabelecimento de painel. Com relação ao Artigo 17.6(i) do ADA, mais uma vez o painel entendeu que não poderia levar em consideração fatos e esclarecimentos que foram a ele submetidos, mas que à época da investigação, não foram apresentados à autoridade investigadora.

8) Brazil - Jute Bags ${ }^{179}$ : Em abril de 2001, a Índia requereu consultas com o Brasil, pois este decidiu continuar a impor medidas antidumping contra sacos de juta provenientes da Índia baseando-se em um documento, supostamente, forjado, atribuído a uma companhia falida. A Índia questiona o modo de condução da investigação e a Lei de Dumping do Brasil (Decreto 1602/95). A Índia incluiu o Artigo 17.6(i) do ADA na lista de artigos que entendeu estarem sendo violados, mas como não houve pedido de estabelecimento de painel, argumentos sobre esse artigo não foram desenvolvidos.

9) EU - Fasteners ${ }^{180}$ : Em julho de 2009, a China requereu consultas com a UE devido ao Artigo 9(5) da Council Regulation (EC) No. 384/96 (legislação antidumping europeia) que dispõe sobre diferenças de cálculo

\footnotetext{
${ }^{178}$ DS189 - para detalhes vide Apêndice 3 (painel).

${ }^{179}$ DS 229 - para detalhes vide Apêndice 1 (consultas).

${ }^{180}$ DS 397 - para detalhes vide Apêndice 4 (Órgão de Apelação).
} 
de margem de dumping para economias que não são de mercado. Além disso, a China também questionou a imposição de medidas antidumping definitivas na importação de determinados parafusos de ferro e aço, apontando irregularidades ocorridas durante a investigação. Com relação ao Artigo 17.6(i) do ADA, cumulado com o Artigo 11 do ESC, o painel reconheceu que, se feita uma análise objetiva dos fatos, a decisão da autoridade investigadora deveria ser mantida. O Órgão de Apelação manteve o entendimento do painel.

10) $E U-$ Footwear $^{181}$ : Em fevereiro de 2010, a China requereu consultas com a UE devido a imposição de medidas antidumping na importação de determinados calçados de couro. Em fase de consultas, a China alegou violação ao Artigo 17.6(i) do ADA, pois a UE não teria feito uma análise objetiva dos fatos, inclusive quanto à seleção de país análogo e cálculo de medida antidumping a ser aplicada aos exportadores que não participaram da investigação. As consultas não resolveram o conflito e a China requereu estabelecimento de painel. Em fase de painel, a China fez oito pedidos relacionados ao Artigo 17.6(i) do ADA, os quais foram agrupados em duas modalidades: violação do Artigo 17.6(i) isoladamente ou em decorrência da violação de outros artigos específicos. O painel considerou que o padrão de revisão a ser considerado seria o do Artigo 11 do ESC cumulado com o do Artigo 17.6(i) do ADA. Ficou definido que, sob o Artigo 17.6(i), o painel deve estabelecer e avaliar os fatos ("establishment and evaluation") para que possa ser feita a análise ("assessment"). Essa análise dos fatos seria o objetivo expresso no Artigo 11 do ESC. O painel rejeitou todas as alegações da China com relação ao Artigo 17.6 (i) do ADA isoladamente, pois entendeu que uma autoridade nacional não pode violar esse artigo, uma vez que ele é direcionado à atividade dos painéis, na linha da defesa apresentada pela UE. A UE lembra que o artigo que impõe às autoridades investigadoras a obrigação de fazer uma análise objetiva dos fatos é o Artigo 3.1 do ADA. O Brasil, enquanto terceira parte nessa disputa,

${ }^{181}$ DS 405 - para detalhes vide Apêndice 3 (painel). 
também adotou essa postura. Os EUA apoiaram os europeus e disseram que a China estava tentando ampliar os direitos e obrigações negociados entre os Membros. Em fevereiro de 2012 foi adotado o relatório do painel, mas os europeus ainda não implementaram a recomendação alegando ser necessário um período razoável de tempo.

11) US - Frozen Shrimp (Vietnam) ${ }^{182}$ : Em fevereiro de 2012, Vietnã requereu consultas com os EUA contra medidas antidumping aplicadas a determinados camarões congelados de água doce. Além de duas revisões administrativas, e uma revisão de final de período, o pedido de consultas diz respeito a diversas leis estadunidenses, regulamentos, procedimentos administrativos e práticas, incluindo zeramento. Não está claro porque o Vietnã invoca o Artigo 17.6(i) do ADA. Ele apenas afirma, em um rol de dispositivos legais elencados no pedido de consultas, que acredita ter sido esse artigo violado.

Da análise desses casos, podemos chegar às seguintes conclusões sobre o Artigo 17.6 do ADA:

(i) Ele diz respeito à atuação do painel e não da autoridade investigadora. $\mathrm{O}$ artigo análogo para apreciação da conduta da autoridade investigadora seria o Artigo 3.1 do ADA;

(ii) Sendo endereçado aos painéis, ele não é passível de violação pelos Membros da OMC;

(iii) Mesmo não tendo sido suscitado pelas partes, cabe ao Órgão de Apelação levá-lo em consideração quando da submissão de um relatório do painel para sua revisão;

(iv) Trata-se de um padrão de revisão tanto para os fatos - alínea (i) quanto para a interpretação jurídica - alínea (ii);

(v) Os painéis devem analisar se a autoridade investigadora estabeleceu os fatos de forma apropriada, isto é, se coletou informações relevantes e confiáveis;

${ }^{182}$ DS429 - para detalhes vide Apêndice 1 (consultas). 
(vi) Os painéis devem analisar se a autoridade investigadora avaliou esses fatos de forma imparcial e objetiva, isto é, se levou em consideração todas as informações apresentadas;

(vii) Nesses casos, não cabe aos painéis alterar a decisão da autoridade investigadora;

(viii) Os painéis devem aceitar a decisão da autoridade investigadora se puder ser interpretada como permitida à luz das regras da OMC, mesmo que entenda não ser a interpretação mais correta;

(ix) Não cabe aos painéis buscar outras informações ou analisar o caso novamente.

Passemos a analisar as disputas sobre a prática do zeramento:

\section{b) Disputas sobre Zeramento}

O primeiro caso em que a prática do zeramento foi debatida foi $E C$ Cotton Yarn $^{183}$, trazido pelo Brasil às Partes Contratantes durante a época do GATT e já descrito nessa tese. Nesse caso, foi concluído que a prática europeia violava as regras antidumping.

Já sob a vigência do ESC, foram 17 casos que trataram do assunto. O primeiro foi trazido também contra as CE. Dessa vez pela Índia $(E C-$ Bed Linen). O Órgão de Apelação condenou a prática à luz do Artigo 2.4.2 do $\operatorname{ADA}^{184}$ e manteve sua posição nos casos subsequentes. O Órgão de Apelação declarou que a

\footnotetext{
${ }^{183}$ ADP137, relatório adotado pelo Comitê de Práticas Antidumping em 4 de julho de 1995.

184 "Subject to the provisions governing fair comparison in paragraph 4, the existence of margins of dumping during the investigation phase shall normally be established on the basis of a comparison of a weighted average normal value with a weighted average of prices of all comparable export transactions or by a comparison of normal value and export prices on a transaction-to-transaction basis. A normal value established on a weighted average basis may be compared to prices of individual export transactions if the authorities find a pattern of export prices which differ significantly among different purchasers, regions or time periods, and if an explanation is provided as to why such differences cannot be taken into account appropriately by the use of a weighted average-to-weighted average or transaction-to-transaction comparison".
} 
prática do zeramento também viola o Artigo 9.3 do $\mathrm{ADA}^{185}$, pois a sobretaxa aplicada acaba sendo superior à margem de dumping, em violação expressa a esse artigo.

Vejamos a evolução do tema perante o DSB:

1) EC-Bed Linen ${ }^{186}$ : o painel condenou o zeramento com base no Artigo 2.4.2 do ADA (que exige uma comparação justa entre o valor normal e o preço de exportação) e o Órgão de Apelação manteve a condenação e esclareceu que o Artigo 2.4.2 do ADA se refere à comparação de todas as transações. O fato de a prática de zeramento afastar do cálculo as margens negativas consistiria em uma violação do ADA.

2) US - Stainless Steel ${ }^{187}$ : em ambas investigações (para plates e para sheets) o painel considerou a comparação da média ponderada do valor normal com os preços de exportação incompatíveis com as regras da OMC. Não houve apelação.

3) EC - Pipe Fittings ${ }^{188}$ : o painel condenou o zeramento com base no Artigo 2.4.2 do ADA e não houve apelação sobre esse aspecto. Trata-se de caso iniciado pelo Brasil.

4) US - Softwood Lumber ${ }^{189}$ : o painel (com uma opinião discidente) condenou a prática do zeramento sob a alegação de que os EUA não levaram em consideração todas as exportações para cálculo da margem de dumping. O Órgão de Apelação manteve o posicionamento do painel.

5) US - Zeroing $(E C)^{190}$ : o painel condenou a prática nas 15 investigações antidumping questionadas, reconhecendo que a metodologia do zeramento poderia ser condenada como uma norma ("as such”). Todavia, com relação às revisões, o painel (com uma opinião

\footnotetext{
185 "The amount of the anti-dumping duty shall not exceed the margin of dumping as established under Article 2".

${ }^{186}$ DS141 - para detalhes vide Apêndice 4 (Órgão de Apelação).

${ }^{187}$ DS179 - para detalhes vide Apêndice 3 (painel).

${ }^{188}$ DS219 - para detalhes vide Apêndice 4 (Órgão de Apelação).

${ }^{189}$ DS264 - para detalhes vide Apêndice 4 (Órgão de Apelação).

${ }^{190}$ DS294 - para detalhes vide Apêndice 4 (Órgão de Apelação).
} 
discidente) rejeitou o pedido das CE. O Órgão de Apelação manteve a opinião do painel de que a metodologia é "as such" violatória no caso das investigações originais, e reverteu a decisão do painel quanto às revisões administrativas, condenando a prática do zeramento também nessa fase à luz do Artigo 9.3 do ADA e Artigo VI:2 do GATT.

6) US - Zeroing and Sunset Reviews (Japan) ${ }^{191}$ : o painel condenou a prática "as such", mas entendeu que, quando feita comparação transação por transação nas investigações originais ou revisões, não haveria violação ao Artigo 2.4.2 do ADA. O Órgão de Apelação reverteu esse último ponto, entendendo haver violação tanto em fase de investigação original, quanto em revisões.

7) US - Shrimp (Ecuador) ${ }^{192}$ : o painel condenou a prática sob o Artigo 2.4.2 do ADA. Não houve apelação.

8) US - Shrimp (Thailand) ${ }^{193}$ : o painel condenou a prática sob o Artigo 2.4.2 do ADA e essa questão não foi apelada.

9) US - Stainless Steel ${ }^{194}$ : o painel condenou o zeramento em investigações originais e não condenou em fase de revisão. O Órgão de Apelação reverteu o posicionamento do painel no que diz respeito às cinco revisões para condenar a prática também nessa fase.

10) US - Zeroing II $(E C)^{195}$ : o painel entendeu que houve violações: do Artigo 2.4.2 do ADA em quatro investigações originais, do Artigo 9.3 do ADA em 29 revisões administrativas conduzidas pelos EUA, e do Artigo 11.3 do $\mathrm{ADA}^{196}$ em oito revisões de final de período. O Órgão de Apelação manteve esse entendimento.

\footnotetext{
${ }^{191}$ DS322 - para detalhes vide Apêndice 4 (Órgão de Apelação).

${ }^{192}$ DS335 - para detalhes vide Apêndice 3 (painel).

${ }^{193}$ DS343 - para detalhes vide Apêndice 4 (Órgão de Apelação).

${ }^{194}$ DS344 - para detalhes vide Apêndice 4 (Órgão de Apelação).

${ }^{195}$ DS350 - para detalhes vide Apêndice 4 (Órgão de Apelação).

196 "Notwithstanding the provisions of paragraphs 1 and 2, any definitive anti-dumping duty shall be terminated on a date not later than five years from its imposition (or from the date of the most recent review under paragraph 2 if that review has covered both dumping and injury, or under this paragraph), unless the authorities determine, in a review initiated before that date on their own initiative or upon a duly substantiated request made by or on behalf of the domestic industry within a reasonable period of time prior to that date, that the expiry of the duty would be likely to lead to continuation or recurrence of dumping and injury. The duty may remain in force pending the outcome of such a review".
} 
11) US - Orange Juice ${ }^{197}$ : o painel analisou o zeramento em duas revisões e o zeramento enquanto prática continuada ("as such”). Na linha com o decidido em US - Zeroing II, condenou a prática estadunidense. Não houve apelação.

12) US - PET Bags ${ }^{198}$ : o painel condenou a prática com base no Artigo 2.4.2. do ADA. Não houve apelação.

13) US - Zeroing (Korea) ${ }^{199}$ : o painel condenou a prática com base no Artigo 2.4.2. do ADA. Não houve apelação.

14) US - Shrimp (Vietnam) ${ }^{200}$ : o painel entendeu que a metodologia "as such", bem como sua aplicação a investigações originais e revisões viola as regras da OMC.

15) US - Carbon Steel Flat Products ${ }^{201}$ : caso em que foi pedido o estabelecimento de painel, mas aguarda-se posicionamento.

16) US - Shrimp and Sawblades (China) ${ }^{202}$ : o painel condenou a prática com base no Artigo 2.4.2. do ADA. Não houve apelação.

17) US - Frozen Shrimp (Vietnam) ${ }^{203}$ : Vietnã contesta a prática do zeramento, utilizada inclusive em duas revisões administrativas e uma de final de período. O caso encontra-se em fase de consultas.

Assim, podemos dizer que o posicionamento do DSB é claro ao condenar o zeramento e que os EUA nem mais têm recorrido ao Órgão de Apelação para tentar reverter essa interpretação.

\subsection{Conclusão sobre o posicionamento do DSB}

Apesar de os precedentes ${ }^{204}$ da OMC não terem caráter vinculante, é importante que sejam levados em consideração pelos Membros, pois os painéis

\footnotetext{
${ }^{197}$ DS382 - para detalhes vide Apêndice 3 (painel).

${ }^{198}$ DS383 - para detalhes vide Apêndice 3 (painel).

${ }^{199}$ DS402 - para detalhes vide Apêndice 3 (painel).

${ }^{200}$ DS404 - para detalhes vide Apêndice 3 (painel).

${ }^{201}$ DS420 - para detalhes vide Apêndice 3 (painel).

${ }^{202}$ DS422 - para detalhes vide Apêndice 3 (painel).

${ }^{203}$ DS429 - para detalhes vide Apêndice 1 (consultas).
} 
raramente se afastarão deles. Como salienta ALBERTO DO AMARAL JR. ${ }^{205}$, “os painelistas resistem em se distanciar dos argumentos que prevaleceram em julgamentos passados, pois sabem que, a menos que haja fortes razões em sentido contrário, o relatório será revisto pelo Órgão de Apelação".

Notamos que, na maioria das disputas sobre o Artigo 17.6 do ADA, este não foi analisado pelos painéis. Quando o foi, como no caso EU - Footwear, o painel considerou que o artigo é direcionado aos painéis, e não às autoridades investigadoras. Portanto, não há que se falar em violação do Artigo 17.6 do ADA por um Membro da OMC. Assim, concluímos que esse artigo seria base para justificar o recurso ao Órgão de Apelação. No caso US - Hot Rolled Steel, o Órgão de Apelação simplesmente esclareceu a interpretação que deveria ser dada ao artigo, não extrapolando sua competência. No caso US - Stainless Steel, o painel concordou que a discussão era meramente factual, e que não caberia intromissão no ato da autoridade administrativa estadunidense. Posicionamento similar é encontrado nos demais casos. Portanto, não se verifica, na prática, uma violação por parte do DSB do padrão de revisão estabelecido para as disputas antidumping pelo Artigo 17.6 do ADA.

Com relação às disputas sobre zeramento, notamos que 15 das 17 disputas foram contra os EUA. Nesses casos, os EUA reiteram que adotam prática compatível com as regras da OMC (pois não há nada que a proíba) e que, portanto, à luz do Artigo 17.6(ii) do ADA, os painéis e o Órgão de Apelação não poderiam condená-la. Poder-se-ia aceitar o argumento estadunidense se o objetivo do ADA fosse combater o dumping esporádico/predatório. Isso porque, ao zerar as margens negativas, a autoridade investigadora está evitando que o exportador pratique dumping em períodos de tempo curtos, e na sequência, aumente seus preços de exportação, intercalando-os, e fazendo com que a autoridade investigadora não

\footnotetext{
${ }^{204}$ Ao longo dessa tese optamos por utilizar a terminologia precedentes, e não jurisprudência, pois jurisprudência traz a ideia de vinculação, característica que os precedentes da OMC não têm.

${ }_{205}$ AMARAL JUNIOR, Alberto. A solução de controvérsias na OMC. São Paulo: Atlas, 2008, pag. 151.
} 
consiga apurar a prática do dumping em um período de tempo mais longo, como é o caso das investigações sob o ADA.

BARTELS $^{206}$ sustenta que há disputas que, por sua natureza, são inapropriadas para o sistema da OMC:

(i) Casos que digam respeito a questões políticas sensíveis (por exemplo, segurança nacional);

(ii) Casos em que a lei aplicável é indeterminada;

(iii) Casos que envolvam balanço institucional (por exemplo, compatibilidade de acordos regionais).

Para esses casos, o autor apresenta três alternativas:

(i) O DSB não estabelece o painel;

(ii) $\mathrm{O}$ painel declara que o objeto da disputa é inapropriado para sua análise;

(iii) $\mathrm{O}$ caso é suspenso até que o órgão político resolva a questão pendente.

A primeira opção, à primeira vista, parece a melhor, mas, na prática, seria difícil de ser implementada, pois no momento do estabelecimento do painel não há quem faça um juízo da medida questionada, ficando o DSB desprovido de base para se posicionar quanto ao estabelecimento ou não do painel. A terceira opção poderia ser uma alternativa se houvesse a segurança de que o órgão político daria seu parecer em um futuro próximo. Diante da incerteza, e da necessidade de se dar uma solução positiva para a disputa, entendemos ser temerário adotá-la. A segunda opção parece ser a única factível. Infelizmente o sistema de solução de controvérsias se mobilizaria até essa fase para declarar-se inapropriado, gerando um custo desnecessário. Todavia, não vislumbramos momento anterior em que uma análise, ainda que preliminar do caso, poderia ser feita.

206 BARTELS, Lorand. The Separation of Powers in the WTO: how to avoid judicial activism.International and Comparative Law Quaterly. Cambrige Journal, vol. 53, 2004, pag. 861. 
Ocorre que as disputas antidumping não se enquadram em nenhuma das hipóteses trazidas por BARTELS para afastar a jurisdição do DSB. Apesar de a prática do zeramento ter se tornado uma questão politicamente sensível, entendemos que a discussão decorre da soberania dos EUA, que acredita estar o padrão de revisão do ADA em consonância com suas cortes internas (como veremos ao tratar do sistema judiciário estadunidense), e têm se negado a cumprir com as recomendações do DSB.

Feitas essas considerações sobre o sistema da OMC, passemos a discorrer sobre as funções no Brasil para busca do devido processo legal em matéria antidumping, para depois, comparar as funções judiciárias. 


\section{PARTE II B - BRASIL}

$\mathrm{O}$ Art. $2^{\circ}$ da $\mathrm{CF}$ estabelece que "são Poderes da União, independentes $e$ harmônicos entre si, o Legislativo, o Executivo e o Judiciário". MONTESQUIEU ${ }^{207}$ já nos ensinava que somente com os contrapesos da separação dos poderes há garantia do Estado de Direito.

De acordo com o Artigo 84 da CF, "compete privativamente ao Presidente da República: (...) VIII - celebrar tratados, convenções e atos internacionais, sujeitos a referendo do Congresso Nacional; (...)”. E o Artigo 49 da CF determina que "é da competência exclusiva do Congresso Nacional: I - resolver definitivamente sobre tratados, acordos ou atos internacionais que acarretem encargos ou compromissos gravosos ao patrimônio nacional; (...) V - sustar os atos normativos do Poder Executivo que exorbitem do poder regulamentar ou dos limites de delegação legislativa;".

\footnotetext{
${ }^{207}$ MONTESQUIEU. De l'esprit des lois. Paris, Éditions Garnier Frères, 1973. Tradução de Lólio Lourenço de Oliveira. In WEFFORT, Francisco (org.). Os clássicos da política, vol. 1. Ática, São Paulo, $14^{\mathrm{a}}$ ed., 2008. Cumpre ressaltar que Monstesquieu não afirma explícita e categoricamente essa separação, mas sim faz uma análise da Constituição inglesa, em que ele identifica essa ideia. A passagem mais célebre do Monstesquieu, de onde os filósofos políticos deduzem sua teoria da separação dos poderes, é o Capítulo VI - Da constituição da Inglaterra, do Livro XI - Das leis que formam a liberdade política em sua relação com a constituição, que assim dispõe:

"Há, em cada Estado, três espécies de poderes: o poder legislativo, o poder executivo das coisas que dependem dos direitos das gentes, e o poder executivo das que dependem do direito civil. Pelo primeiro, o príncipe, ou o magistrado, elabora leis para um certo tempo ou para sempre, e corrige ou revoga as existentes. Pelo segundo, faz a paz ou a guerra, envia ou recebe embaixadas, instaura a segurança, impede as invasões. Pelo terceiro, pune os crimes, ou julga as pendências entre particulares. Chamaremos a este último o poder de julgar e ao outro simplesmente o poder executivo do Estado.

A liberdade política num cidadão é aquela tranquilidade de espírito que provém da opinião que cada um tem de sua segurança; e para que se tenha essa liberdade, é preciso que o governo seja tal que um cidadão não possa temer outro cidadão.

Quando se reúne na mesma pessoa, ou no mesmo corpo de magistratura, o poder legislativo e o poder executivo, não existe liberdade; porque pode-se temer que o próprio monarca, ou o próprio senado, faça leis tirânicas para executá-las tiranicamente.

Também não existe liberdade, se o poder de julgar não estiver separado do poder legislativo e do poder executivo. Se estivesse ligado ao poder legislativo, o poder sobre a vida e a liberdade dos cidadãos seria arbitrário: pois o juiz seria legislador. Se estivesse unida ao poder executivo, o juiz poderia ter a força de um opressor.

Tudo estaria perdido se o mesmo homem, ou o mesmo corpo de principais, ou de nobres, ou do povo, exercesse esses três poderes: o de fazer leis, o de executar as resoluções públicas, e o de julgar os crimes ou as pendências entre particulares."
} 
Ou seja, o Executivo firma os acordos da OMC, devendo passar pelo Legislativo (Congresso) para que tenham validade no ordenamento jurídico brasileiro. Além disso, cabe ao Legislativo editar a norma válida em território brasileiro, ou delegar esse poder ao Executivo. Após a criação da norma, esta deverá ser aplicada (o que, no caso antidumping, se dá com a investigação conduzida pelo Executivo) e, caso seja acionado, caberá ao Judiciário verificar se o procedimento atende a legalidade. Vejamos cada uma dessas funções. 


\title{
Capítulo 7 - FUNÇÃO LEGISLATIVA BRASILEIRA EM MATÉRIA ANTIDUMPING
}

\author{
O Artigo 44 da CF estabelece que "o Poder Legislativo é exercido pelo \\ Congresso Nacional, que se compõe da Câmara dos Deputados e do Senado \\ Federal".
}

Em matéria antidumping, o Legislativo editou a Lei 9.019/95 com dispositivos sobre cobrança das medidas antidumping e delegou poderes ao Executivo para criar o decreto regulamentador sobre os procedimentos investigatórios para aplicação das medidas. Podemos dizer que o Decreto 1.602/95 é basicamente uma tradução para o português do ADA, daí a possibilidade de afirmarmos que muito dificilmente o Brasil será questionado na OMC por violações "as such".

Por ser a investigação antidumping um procedimento administrativo no âmbito da Administração Pública Federal, aplica-se também a lei de processo administrativo federal (9.784/99). Ela tem 70 artigos e está dividida em 18 capítulos $^{208}$. Seu Artigo $69^{209}$ determina que, em casos em que haja lei específica, como é o caso do antidumping, a Lei 9.784/99 se aplica subsidiariamente.

$\mathrm{Na}$ prática, um dos artigos mais importantes a serem analisados é o artigo $2^{\text {o210 }}$. Esse artigo estabelece que a Administração Pública deverá obedecer, dentre

\footnotetext{
${ }^{208}$ Os capítulos tratam dos seguintes assuntos: Disposições gerais, direitos dos administrados, deveres dos administrados, do início do processo, dos interessados, da competência, dos impedimentos e da suspeição, da forma, tempo e lugar, da comunicação dos atos, da instrução, do dever de decidir, da motivação, da desistência e extinção, da anulação, revogação e convalidação, do recurso administrativo e revisão, dos prazos, das sanções, disposições finais.

209 "Os processos administrativos específicos continuarão a reger-se por lei própria, aplicando-selhes apenas subsidiariamente os preceitos desta Lei".

210 "A Administração Pública obedecerá, dentre outros, aos princípios da legalidade, finalidade, motivação, razoabilidade, proporcionalidade, moralidade, ampla defesa, contraditório, segurança jurídica, interesse público e eficiência. $d e:$

Parágrafo único. Nos processos administrativos serão observados, entre outros, os critérios

I - atuação conforme a lei e o Direito;

II - atendimento a fins de interesse geral, vedada a renúncia total ou parcial de poderes ou competências, salvo autorização em lei;
} 
outros, aos princípios da legalidade, finalidade, motivação, razoabilidade, proporcionalidade, moralidade, ampla defesa, contraditório, segurança jurídica, interesse público e eficiência. No parágrafo único desse Artigo $2^{\circ}$ são citados diversos critérios. Para fins antidumping, destacamos a "adequação entre meios $e$ fins, vedada a imposição de obrigações, restrições e sanções em medida superior àquelas estritamente necessárias ao atendimento do interesse público".

Nesse critério, alguns aspectos nos chamam a atenção, em especial: (i) o que seria o interesse público?; e (ii) seria a regra do menor direito ("lesser duty"optativa de acordo com o $\mathrm{ADA}$ ) vinculante para a Administração Pública Brasileira em razão desse dispositivo da Lei 9.784/99? Com relação ao primeiro aspecto, interesse público deve ser interpretado como o interesse comum à maioria (administrados e governo $)^{211}$. Quanto ao segundo aspecto, podemos sustentar que o Brasil está sim obrigado a aplicar o antidumping apenas na medida necessária para compensar o dano que a indústria doméstica tem sofrido, o que de fato tem feito como veremos no capítulo sobre a função executiva.

Constatamos que a função do Legislativo no Brasil, em matéria antidumping, se limitou a editar poucos normativos e delegar poderes para o

III - objetividade no atendimento do interesse público, vedada a promoção pessoal de agentes ou autoridades;

IV - atuação segundo padrões éticos de probidade, decoro e boa-fé;

$V$ - divulgação oficial dos atos administrativos, ressalvadas as hipóteses de sigilo previstas na Constituição;

$V I$ - adequação entre meios e fins, vedada a imposição de obrigações, restrições e sanções em medida superior àquelas estritamente necessárias ao atendimento do interesse público;

VII - indicação dos pressupostos de fato e de direito que determinarem a decisão;

VIII - observância das formalidades essenciais à garantia dos direitos dos administrados;

IX - adoção de formas simples, suficientes para propiciar adequado grau de certeza, segurança e respeito aos direitos dos administrados;

$X$ - garantia dos direitos à comunicação, à apresentação de alegações finais, à produção de provas e à interposição de recursos, nos processos de que possam resultar sanções e nas situações de litígio;

XI - proibição de cobrança de despesas processuais, ressalvadas as previstas em lei;

XII - impulsão, de ofício, do processo administrativo, sem prejuízo da atuação dos interessados;

XIII - interpretação da norma administrativa da forma que melhor garanta o atendimento do fim público a que se dirige, vedada aplicação retroativa de nova interpretação".

${ }^{211}$ Para detalhes sobre o tema, vide CORDOVIL, Leonor. As medidas antidumping e o interesse público. Tese de Doutorado ou WELLHAUSEN, Marc. The Community Interest Test in Antidumping Proceedings of the European Union. American University International Law Review, vol 16, 2000-2001, pag. 1027. 
Executivo decretá-los. Importante seria estreitar o relacionamento entre as funções públicas com vistas a incentivar a participação do Legislativo e, consequentemente, garantir que o interesse público seja refletido na aplicação do antidumping.

Conforme aponta MICHELLE RATTON ${ }^{212}$, há um Projeto de Lei em trâmite para esse fim: "aprimorar os mecanismos de interação entre o Executivo e o Legislativo nas negociações comerciais, encontra-se atualmente em pauta o Projeto de Lei no. 189/03, que pretende definir a participação do Brasil nas negociações comerciais. De acordo com o artigo $4^{o}$ desse Projeto, o Congresso Nacional (...) acompanhará de perto o andamento das negociações comerciais e, de acordo com os dispositivos regimentais, avaliará seus resultados parciais e finais (...) A avaliação aqui estipulada far-se-á obrigatoriamente antes da firma de quaisquer acordos, ainda que setoriais, que finalizem negociações”.

Trata-se de projeto iniciado no Senado Federal ${ }^{213}$ que aguarda, desde 2004, retorno da Câmara dos Deputados ${ }^{214}$. A autora ${ }^{215}$ sustenta que, no âmbito da OMC, as repercussões desse controle prévio são ainda maiores devido ao single undertaking $^{216}$. Em entrevistas feitas ao longo de seu trabalho, a autora constatou que "o Poder Legislativo entende que deveria ter uma atuação mais ativa e ser o ponto de definição da política externa, cabendo ao Executivo a negociação no fórum internacional".

Tendo em vista ser o Poder Legislativo o representante dos cidadãos brasileiros, de fato caberia ao Poder Legislativo definir os interesses, e o Poder Executivo simplesmente executá-los. Ocorre que o Poder Legislativo não se mostra

\footnotetext{
${ }^{212}$ SANCHEZ, Michelle Ratton. Demandas por um novo arcabouço sociojurídico na Organização Mundial do Comércio e o caso do Brasil. Tese de Doutorado. USP/2004, pag. 246.

${ }^{213}$ Proposto pelo senador Eduardo Suplicy do Partido Trabalhista.

214 Para detalhes sobre o trâmite deste Projeto de Lei vide www.senado.gov.br/atividade/materia/detalhes.asp?p_cod_mate=57669. Último acesso em 29/06/12.

${ }^{215}$ SANCHEZ, Michelle Ratton. Demandas por um novo arcabouço sociojurídico na Organização Mundial do Comércio e o caso do Brasil. Tese de Doutorado. USP/2004, pag. 231.

${ }^{216}$ Single undertanding é o compromisso de que as negociações somente serão encerradas após todos os temas estiverem acordados.
} 
preparado para compreender as negociações da OMC (que são, de fato, bastante complexas, com especificidades técnicas que exigem conhecimento profundo). Assim, o Executivo continua à frente na definição da política comercial exterior brasileira. Cumpre ressaltar, todavia, que um Legislativo despreparado pode não apenas não ajudar, mas também anular os efeitos de medidas adotadas pelo Poder Executivo. Seria o caso, como lembrado por $\mathrm{CHO}^{217}$, de o Poder Legislativo, sob pressão, contribuir para que medidas antidumping aplicadas sejam burladas (caso de circunvenção) ao promulgar, por exemplo, lei que classifique um produto de maneira diferente, afastando a incidência da sobretaxa antidumping.

Nesse sentido, é de extrema importância que os deputados e senadores também sejam familiarizados com os temas de comércio internacional. Esse fato contribuiria não apenas para que acompanhem as negociações internacionais e auxiliem o Poder Executivo a representar da melhor maneira o interesse público, mas também para que não adotem medidas que possam prejudicar ações do Poder Executivo, anulando efeitos de medidas que poderiam (e deveriam) ser de interesse público.

${ }^{217}$ CHO, Sungjoo. Dual Catastrophe of Protectionism, in Northwestern Journal of International Law \& Business, vol. 25, 2005, pag. 315. 


\title{
Capítulo 8 - FUNÇÃO EXECUTIVA BRASILEIRA EM MATÉRIA ANTIDUMPING
}

\author{
O Artigo 76 da CF explicitou que "o Poder Executivo é exercido pelo \\ Presidente da República, auxiliado pelos Ministros de Estado".
}

Em matéria antidumping, o Ministro das Relações Exteriores auxilia, por exemplo: (i) na negociação dos tratados internacionais (que, em âmbito multilateral, seria o ADA); (ii) na interface diplomática com terceiros países que procuram impor medidas antidumping contra exportações brasileiras, ou países sujeitos a investigações iniciadas pelo Brasil; e (iii) em eventuais disputas perante organismos internacionais como a OMC.

O Ministro do Desenvolvimento, Indústria e Comércio Exterior auxilia na condução de investigações. O Ministro da Fazenda é o responsável pela imposição das medidas antidumping na fronteira, controle e coleta das sobretaxas para os cofres públicos. Os demais Ministros que fazem parte da CAMEX contribuem ao analisar o relatório do DECOM e optar por aplicar ou não a medida antidumping, e passarão a opinar sobre o interesse público após a recente criação do GTIP. Vejamos de que forma o MDIC conduz as investigações.

\subsection{PROCEDIMENTO INVESTIGATÓRIO NO BRASIL}

A investigação no Brasil é um procedimento administrativo que dura entre 12 e 18 meses. Nas etapas pré-investigação, importante identificar as partes, objeto e provas a serem colhidas. Quanto ao primeiro item, há grande discussão acerca da definição de indústria doméstica e formas de organização do setor privado para levar adiante uma investigação. De acordo com a legislação atual, uma investigação pode ser aberta se peticionada por empresa(s) que represente(m) $25 \%$ da produção nacional do produto a ser investigado ou se a petição contar com o apoio de mais de $50 \%$ da indústria doméstica daquele produto. Portanto, notamos 
que a legislação beneficia os monopólios e oligopólios. Os pequenos produtores, que de fato necessitariam de uma medida de proteção comercial, muitas vezes não conseguem legitimidade para pleitear a adoção de uma medida antidumping.

Quanto ao objeto da investigação, o ponto discutível é o conceito de produto investigado (que não consta da legislação em vigor), e as dificuldades inerentes à identificação de produto similar. De acordo com as negociações em curso na OMC, o critério da substitutibilidade não seria suficiente. Uma das idéias seria criar critérios distintos para definir o produto similar para fins de cálculo do valor normal e produto similar para fins de dano. Isso porque o valor normal é calculado para o país exportador, e o dano, para o país importador, podendo haver diferença entre eles.

Por fim, antes da abertura da investigação, é importante fazer a coleta de evidências e atender a eventuais exigências da autoridade investigadora.

Aberta a investigação nos termos do Artigo 21 do Decreto 1602/95, são enviados questionários, é feita verificação in loco se assim o DECOM entender necessário e há a possibilidade de imposição de medida provisória ou assinatura de um compromisso de preço. O DECOM, órgão que conduz a investigação, emite o parecer técnico, e a CAMEX, órgão com competência para a imposição das medidas antidumping, emite a resolução a partir de cuja publicação passa a ser aplicável a sobretaxa.

No que tange à análise específica de dano, o Artigo 14 do Decreto 1602/95 reflete os termos da nota de rodapé ao Artigo 3 do $\mathrm{ADA}^{218}$ e dispõe que:

"Para os efeitos deste Decreto, o termo "dano" será entendido como dano material ou ameaça de dano

\footnotetext{
218 "Under this Agreement the term "injury" shall, unless otherwise specified, be taken to mean material injury to a domestic industry, threat of material injury to a domestic industry or material retardation of the establishment of such an industry and shall be interpreted in accordance with the provisions of this Article".
} 
material à indústria doméstica já estabelecida ou retardamento sensível na implantação de tal indústria”.

Notamos que é utilizado, na definição, o mesmo termo "dano" que se busca definir, o que torna difícil estabelecer parâmetros e compreender o sentido que a ele deve ser atribuído.

GUILLERMO CABANELLAS ${ }^{219}$, em seu livro que descreve o procedimento antidumping na Argentina, ressalta que os maiores inconvenientes nos casos iniciados em seu país foram relativos à comprovação de dumping, e que teria sido o direito estadunidense que trouxe um grande número de precedentes sobre o conceito de dano. O autor ressalta que, em razão do critério restritivo adotado pelos EUA, que geralmente leva em consideração grau de penetração das importações no mercado local, nível de emprego e utilização da capacidade instalada, ficou difícil constatar o dano na Argentina nos momentos de crise. Segundo Cabanellas, uma presunção de que haveria prática de dumping é o preço do produto importado $15 \%$ inferior ao preço do produto similar nacional ${ }^{220}$. Todavia, nada na legislação pátria/international sustenta o posicionamento do autor.

O parágrafo $1^{\circ}$ do Artigo 14 do Decreto 1602/95 (Artigo 3.1 do ADA $^{221}$ ) explicita que a determinação do dano deve estar baseada em evidência positiva e deve envolver um exame objetivo (a) do volume de importações sujeitas a dumping e os efeitos dessas importações nos preços no mercado doméstico de produtos similares, e (b) do consequente impacto dessas importações para os produtores domésticos de tais produtos.

\footnotetext{
${ }^{219}$ CABANELLAS, Guillermo. El dumping: legislacion argentina y derecho comparado. Editorial Heliasta S.R.L., Buenos Aires, 1981, pag. 153.

${ }^{220}$ Idem, pag. 164.

221 "A determination of injury for purposes of Article VI of GATT 1994 shall be based on positive evidence and involve an objective examination of both (a) the volume of the dumped imports and the effect of the dumped imports on prices in the domestic market for like products, and $(b)$ the consequent impact of these imports on domestic producers of such products."
} 
Os efeitos nos preços domésticos podem ser constatados pela magnitude da margem de dumping, redução do fluxo de caixa atual ou potencial, estoques, empregabilidade, salários, crescimento da indústria doméstica, habilidade para atrair capital ou investimentos. Já o impacto para os produtores domésticos é averiguado por, a título exemplificativo, atual ou potencial queda nas vendas, lucros, receita, participação no mercado, produtividade, retorno de investimentos, utilização da capacidade produtiva.

Mas o ADA não enumera esses fatores ${ }^{222}$, deixando a critério da autoridade investigadora levar em consideração os aspectos que entender mais apropriado, caso a caso, conforme constatamos da tabela a seguir sobre investigações brasileiras:

\begin{tabular}{|l|l|l|l|}
\hline \multicolumn{1}{|c|}{$\begin{array}{c}\text { Produto/ } \\
\text { NCM/ } \\
\text { País/Ano }\end{array}$} & Resultado & Dano & \multicolumn{1}{|c|}{$\begin{array}{c}\text { Elementos para análise de dano à indústria } \\
\text { doméstica }\end{array}$} \\
\hline $\begin{array}{l}\text { Caneta } \\
\text { esferográfica/96 } \\
08.10 .00 / \\
\text { China/2004 }\end{array}$ & $\begin{array}{l}\text { Aplicação } \\
\text { de Direito }\end{array}$ & Não & $\begin{array}{l}\text { Divisão de mercado/ Volume da produção/ Utilização } \\
\text { da capacidade instalada/ Volume vendido/ Estoques/ } \\
\text { Emprego de mão-de-obra/ Faturamento/ Geração } \\
\text { bruta de caixa/ Saldo operacional de caixa/ } \\
\text { Capacidade de autofinanciamento }\end{array}$ \\
\hline $\begin{array}{l}\text { Tubo de aço } \\
\text { inoxidável/ } \\
7306.40 .00 / \\
\text { Taipé } \\
\text { Chinês/2005 }\end{array}$ & $\begin{array}{l}\text { Sem } \\
\text { Aplicação }\end{array}$ & Não Direito & $\begin{array}{l}\text { Desempenho nas importações do país e de outras } \\
\text { fontes/ Variação do preço/ Desempenho da Indústria } \\
\text { Doméstica/ Utilização da capacidade instalada/ } \\
\text { Produtividade da Indústria Doméstica/ Participação no } \\
\text { mercado nacional/ Faturamento }\end{array}$ \\
\hline $\begin{array}{l}\text { N-Butanol/ } \\
2905.13 .00 / \\
\text { África do Sul e } \\
\text { EUA/2005 }\end{array}$ & $\begin{array}{l}\text { Aplicação } \\
\text { de Direito }\end{array}$ & Não & $\begin{array}{l}\text { Destinação do produto/ Volume das importações e } \\
\text { representação nas importações/ Participação das } \\
\text { importações no mercado interno/ Variação do preço/ } \\
\text { Participações de terceiros países no mercado/ } \\
\text { Desempenho e planta instalada da indústria nacional/ } \\
\text { oscilação das vendas da indústria doméstica/ } \\
\text { Estoques/ Produtividade/ Lucro/ Preços praticados }\end{array}$ \\
\hline
\end{tabular}

${ }^{222}$ Os precedentes Guatemala - Cement (Painel 2000), EC - Bed Linen (Painel 2000), ThailandH-Beams (Painel 2000 e Órgão de Apelação 2001) exigem a observância de, pelo menos, os 15 fatores elencados no Artigo 3.4 do ADA para fins de determinação de dano. 


\begin{tabular}{|c|c|c|c|}
\hline & & & $\begin{array}{l}\text { pela Indústria doméstica/ Relação de preços com o } \\
\text { produto importado/ Custo da produção e sua relação } \\
\text { com o preço }\end{array}$ \\
\hline $\begin{array}{l}\text { Cimento } \\
\text { Portland } \\
\text { (revisão)/ } \\
2523.29 .10 \quad \text { e } \\
2523.29 .90 / \\
\text { México } \\
\text { Venezuela/ } \\
2005\end{array}$ & $\begin{array}{l}\text { Com } \\
\text { aplicação de } \\
\text { Direito }\end{array}$ & Sim & $\begin{array}{l}\text { Comparação do preço nacional e preço de exportação } \\
\text { /Potencial exportador }\end{array}$ \\
\hline $\begin{array}{l}\text { Filmes de PET/ } \\
3920.62 .19 \quad \mathrm{e} \\
3920.62 .91 \quad \mathrm{e} \\
3920.62 .99 / \\
\text { Índia } \\
\text { Tailândia/ } 2008\end{array}$ & $\begin{array}{l}\text { Com } \\
\text { aplicação de } \\
\text { Direito }\end{array}$ & Sim & $\begin{array}{l}\text { Volume das importaçães/ Participação de mercado do } \\
\text { produto importado/ Evolução dos preços/ Capacidade } \\
\text { instalada da indústria doméstica/ Volume dos } \\
\text { estoques/ Custo da produção/ Emprego de mão-de- } \\
\text { obra/ Margem de lucro/ Retorno do investimento }\end{array}$ \\
\hline $\begin{array}{l}\text { Papel cuchê } \\
\text { leve/ } \\
4810.22 .90 / \\
\text { EUA, Finlândia, } \\
\text { Suécia, Bélgica, } \\
\text { Canadá e } \\
\text { Alemanha/ } 2010\end{array}$ & $\begin{array}{l}\text { Com } \\
\text { aplicação de } \\
\text { Direito }\end{array}$ & Sim & $\begin{array}{l}\text { Volume das importações/ Efeito sobre os preços do } \\
\text { produto similar no Brasil/ Impacto de tais importações } \\
\text { sobre a indústria doméstica: } \\
>\text { Vendas } \\
>\text { Lucros } \\
>\text { Produção } \\
>\text { Participação no mercado } \\
>\text { Produtividade } \\
>\text { Retorno dos investimentos } \\
>\text { Ocupação da capacidade instalada } \\
>\text { Fluxo de caixa } \\
>\text { Estoques } \\
>\text { Emprego } \\
>\text { Salários } \\
>\text { Crescimento } \\
>\text { Capacidade de captar recursos investimentos }\end{array}$ \\
\hline $\begin{array}{l}\text { Magnésio } \\
\text { metálico/ } \\
8104.11 .00 / \\
\text { Rússia } \\
\text { / } 2011\end{array}$ & $\begin{array}{l}\text { Com } \\
\text { aplicação de } \\
\text { Direito }\end{array}$ & $\mathrm{Sim}$ & $\begin{array}{l}\text { Volume das importações/ Efeito sobre os preços do } \\
\text { produto similar no Brasil/ Impacto de tais importações } \\
\text { sobre a indústria doméstica: } \\
>\text { Vendas } \\
>\text { Lucros }\end{array}$ \\
\hline
\end{tabular}




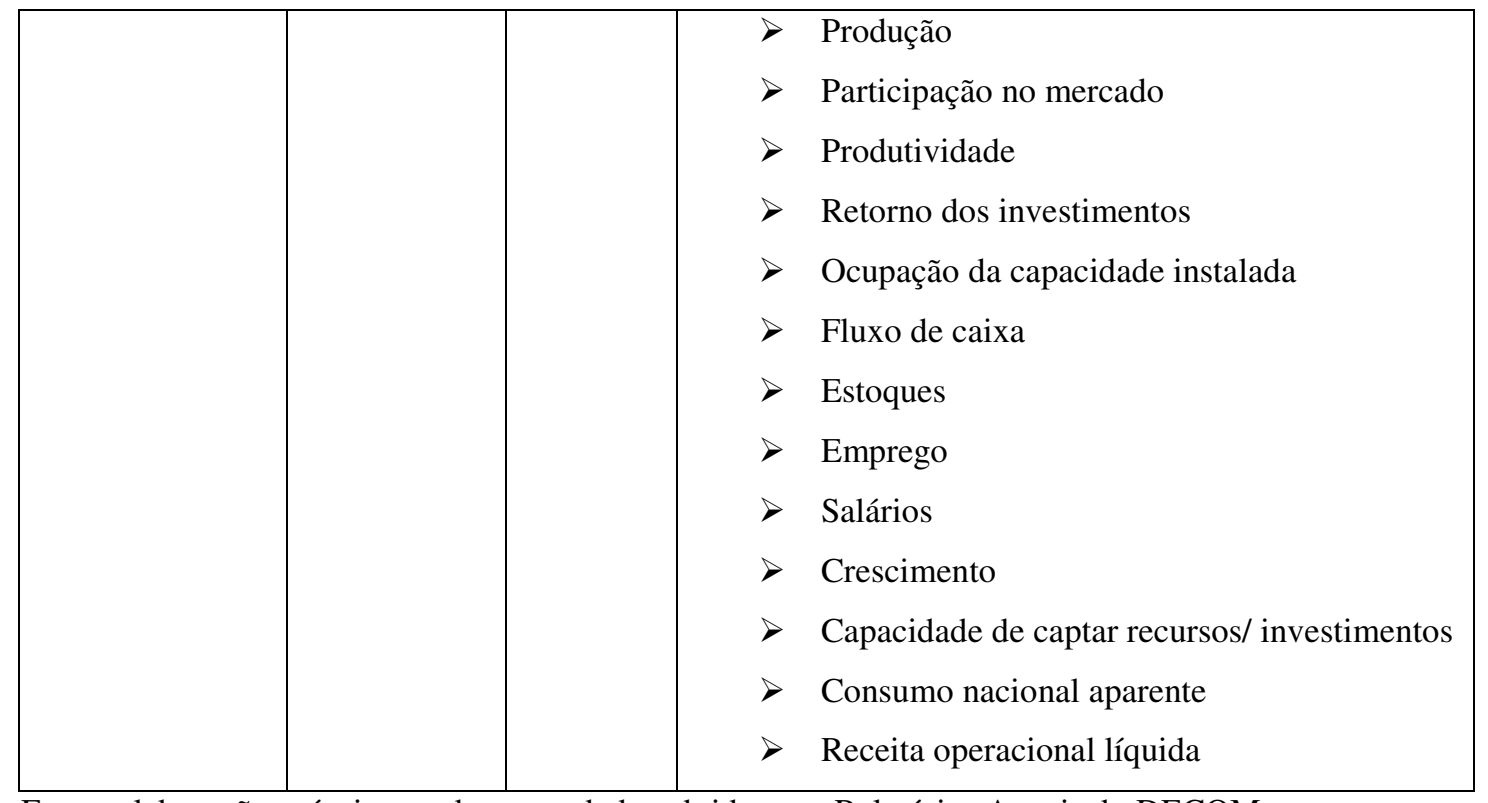

Fonte: elaboração própria com base em dados obtidos nos Relatórios Anuais do DECOM.

O DECOM, recentemente, tem analisado os fatores necessários para constatação de dano. Como vimos ao longo do trabalho, os requisitos para imposição da medida antidumping são dumping, dano e nexo causal. De 1988 até 06 de julho de 2012 foram 375 investigações iniciadas pelo DECOM:

Fonte: elaboração própria com base em Circulares SECEX de abertura de investigação.

\section{Evolução: de 1988 à julho de 2012}

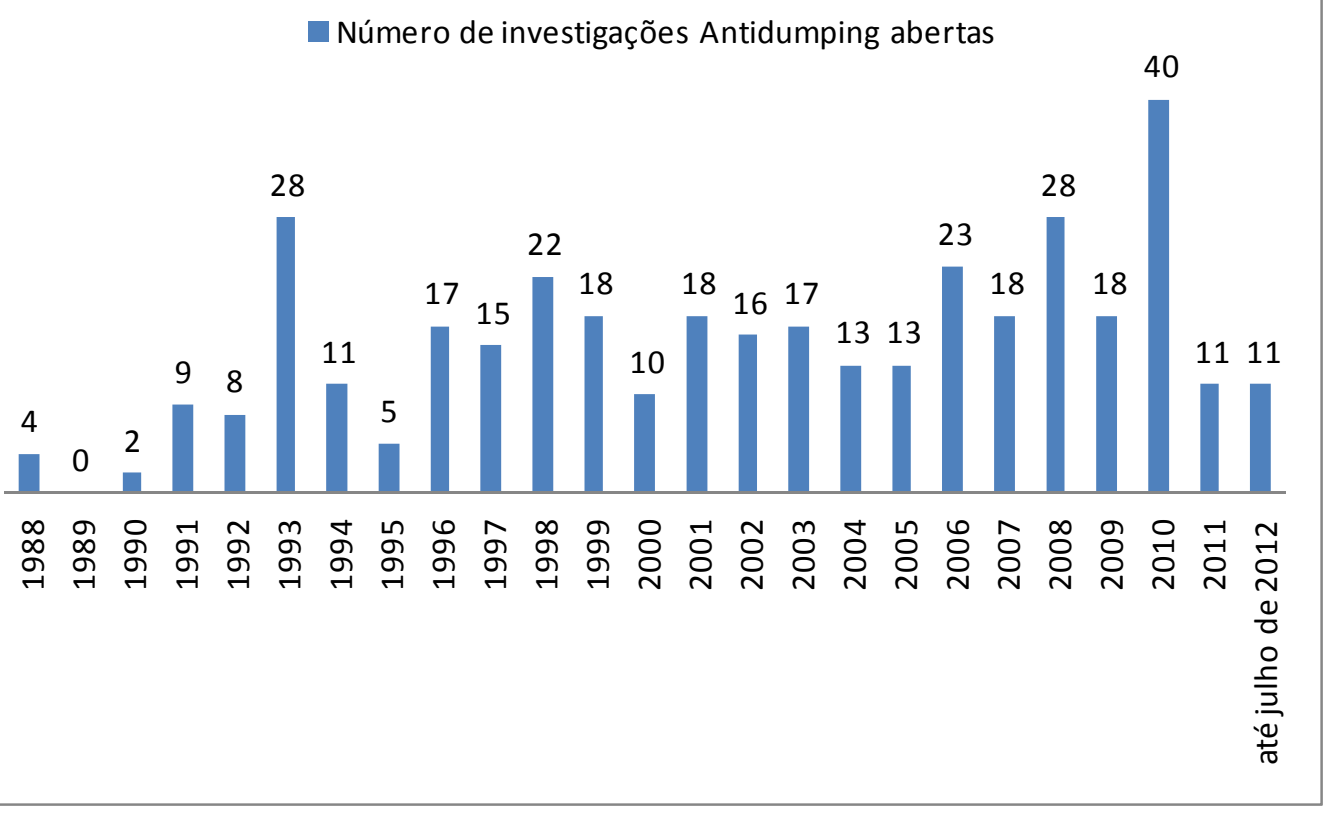


De 1988 a 2010, conforme último relatório anual publicado pelo $\mathrm{DECOM}^{223}$, foram 312 investigações concluídas:

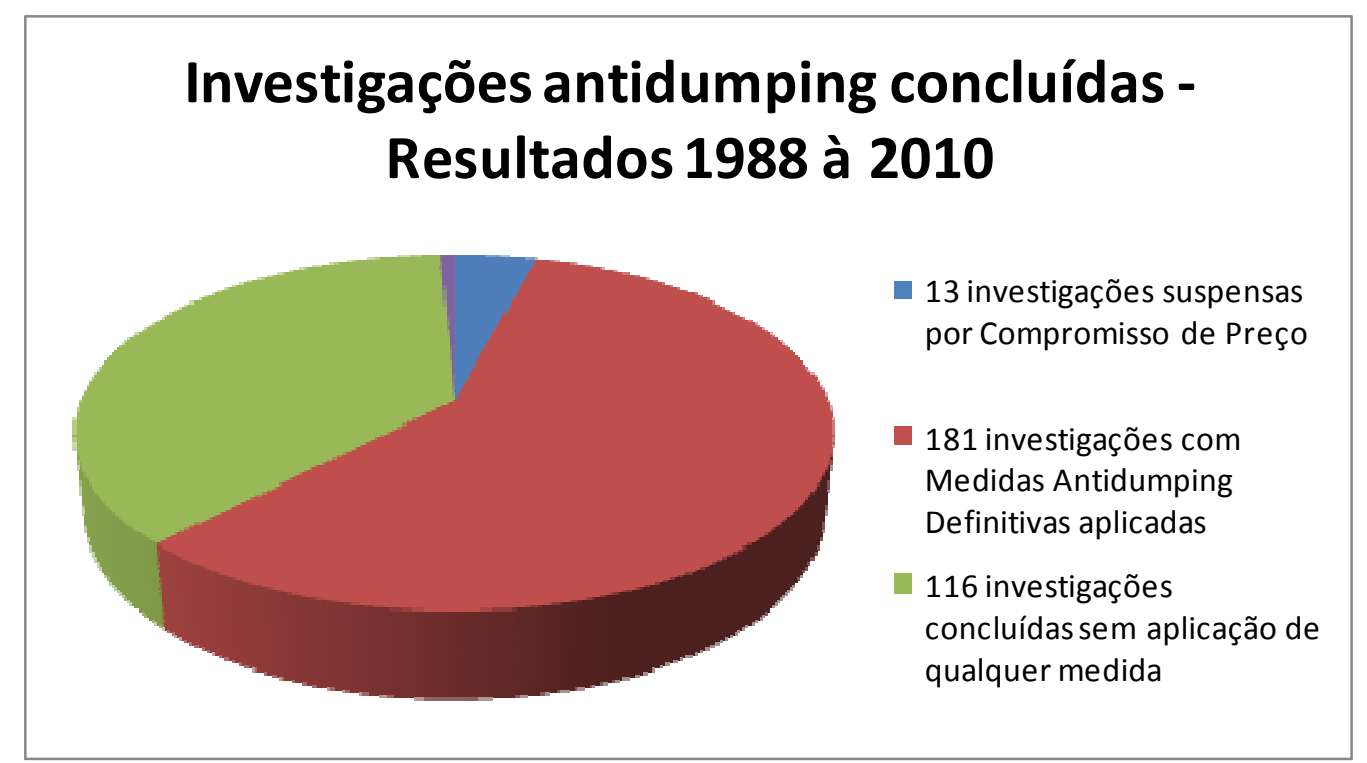

Fonte: elaboração própria com base em dados dos Relatórios Anuais do DECOM.

Dos 181 casos em que houve medidas definitivas aplicadas, 74 tiveram imposição de medidas provisórias durante a investigação. Das 116 investigações concluídas sem aplicação de medida, os motivos foram os seguintes:

(a) a pedido da peticionária ${ }^{224}$;

(b) quantidade importada insignificante ("de minimis" - inferior a 3\% ou, cumulativamente, $7 \%)^{225}$;

\footnotetext{
${ }^{223} \mathrm{http} / / / \mathrm{www} . d e s e n v o l v i m e n t o . g o v . b r / a r q u i v o s / d w n l \_1303755225 . p d f$.

${ }^{224}$ recipientes de aço inoxidável para cocção da China Circular SECEX N ${ }^{\circ} 23$, de 16 de maio de 2012 - DOU de 17/05/2012; vidros planos incolores da China e do México circular secex n 61 , de 28 de novembro de 2011 - DOU de 29/11/2011; laminados planos de baixo carbono e baixa liga provenientes de lingotamento convencional ou contínuo da Rússia, Espanha, Coréia do Sul e Romênia Circular SECEX N 60, de 22 de novembro de 2011 - DOU de 23/11/2011; revisão para glifosato da China Circular SECEX n ${ }^{\circ}$ 43, de 12 de agosto de 2011 - DOU de 15/08/2011; frascos de vidro de até $20 \mathrm{ml}$, para uso farmacêutico e cosmético da Índia Circular SECEX $\mathrm{n}^{\circ} 33$ de 3 de agosto de 2010 - DOU de 5/8/2010; revisão para pneumáticos novos de borracha para bicicletas da China e da Índia Circular SECEX n ${ }^{\circ}$ 50, de 22 de setembro de 2009 - DOU de 23/09/2009; painéis de madeira aglomerada da Argentina Circular SECEX n ${ }^{\circ}$ 03, de 12 de janeiro de 2005 - DOU de $13 / 01 / 2005$
} 
(c) não comprovação de dano, mesmo com existência de dumping ${ }^{226}$;

(d) Não houve comprovação de dumping ${ }^{227}$;

(e) Não comprovação de nexo causal ${ }^{228}$;

(f) Não ter sido possível verificar a correção, por meio de verificação in

loco, das informações apresentadas pela indústria doméstica no curso da investigação ${ }^{229}$.

Para ilustrar a proporção de cada motivo ${ }^{230}$, segue gráfico sobre as investigações de 1999 a $2010^{231}$ :

${ }^{225}$ MDI polimérico (disocianato de difenilmetano) da Bélgica Circular SECEX $\mathrm{n}^{\circ} 21$, de 10 de maio de 2012 - DOU de 11/05/2012; borracha nitrílica da Î́ndia e da Polônia Circular SECEX n ${ }^{\circ}$ 51, de $1^{\circ}$ de novembro de 2011 - DOU de 4/11/2011; recipientes de aço inoxidável para cocção da Índia Circular SECEX N ${ }^{\circ} 38$, de 21 de julho de 2011 - DOU de 22/07/2011; laminados planos de baixo carbono e baixa liga provenientes de lingotamento convencional ou contínuo da Turquia, Coréia do Norte, de Taipe Chinês e do México Circular SECEX nº 23 de 19 de maio de 2011 DOU de 20/5/2011.

${ }^{226}$ borracha nitrílica da Argentina, Coreia do Sul, EUA e França circular secex n ${ }^{\circ} 13$, de 26 de março de 2012 - DOU de 27/03/2012; cobertores de fibra sintética da China circular secex n ${ }^{\circ} 44$, de 03 de julho de 2008 - DOU de 04/07/2008; óculos de sol da China Circular SECEX N ${ }^{\circ} 14$, de 10 de março de 2008 - DOU de 11/03/2008; tubos de aço inoxidável austenítico de Taipé Chinês Circular SECEX n 31, de 17 de abril de 2006 - DOU de 18/04/06; canetas esferográficas da China Circular SECEX $\mathrm{n}^{\circ}$ 77, de 07 de dezembro de 2005 - DOU de 12/12/2005; metacrilato de metila (MMA) dos EUA Circular secex n ${ }^{\circ}$ 61, de 19 de setembro de 2005 - DOU de 22/09/2005; revisão de pêssegos em conserva da Grécia Circular SECEX N ${ }^{\circ} 23$, de 24 de abril de 2008 - DOU de 25/04/2008.

${ }^{227}$ rebitadores manuais da China Circular SECEX n ${ }^{\circ} 46$ de 8 de outubro de 2010 - DOU de 13/10/2010; bolas decorativas para árvores de Natal da China circular secex $\mathrm{n}^{\circ} 55$, de 25 de setembro de 2007 - DOU de 26/09/2007; filme de polipropileno biaxialmente orientado, sem impressão gráfica, com espessura de 10 a 60 micra - filme de BOPP, da Argentina, Chile, China, Equador, EUA e Peru Circular SECEX n ${ }^{\circ} 54$ de 13 de outubro de 2009 - DOU de 14/10/2009.

${ }_{228}$ Filme de polipropileno da Argentina, Chile, China, Equador, EUA e Peru Circular SECEX n ${ }^{\circ} 54$ de 13/10/2009 - DOU de 14/10/2009; acrilonitrila dos EUA Circular SECEX n 7 de 16/02/2004 DOU de 18/02/2004; policloreto de vinila da Coréia do Sul, Coréia do Norte, Japão, Tailândia, Venezuela e Colômbia Circular SECEX no 50 de 18/11/2002 - DOU de 19/11/2002; conexões de ferros fundido maleável da China Circular SECEX no 41 de 08/10/2002 - DOU de 10/10/2002; telas metálicas galvanizadas da China Circular SECEX no 31 de 06/08/2002 - DOU de 07/08/2002.

${ }^{229}$ árvore para decoração de Natal da China Circular SECEX nº 54, de 25 de setembro de 2007 DOU de 26/09/2007.

${ }^{230}$ Para fins de elaboração do gráfico, consideramos o volume insignificante como uma das formas de encerramento da investigação sem ter ficado comprovado o dano, pois o motivo é o mesmo.

${ }^{231}$ Vale notar que esse gráfico considera o produto, e não a origem investigada, ou seja, uma investigação de tubos de aço contra Turquia, EUA, Austrália, é considerada uma investigação, e não três. Os Relatórios do DECOM, para fins de estatísticas, consideram cada origem investigada uma investigação. Não utilizamos os gráficos do DECOM nesta tese, pois a maioria deles congrega as medidas de defesa comercial (antidumping, medidas compensatórias e salvaguardas). 


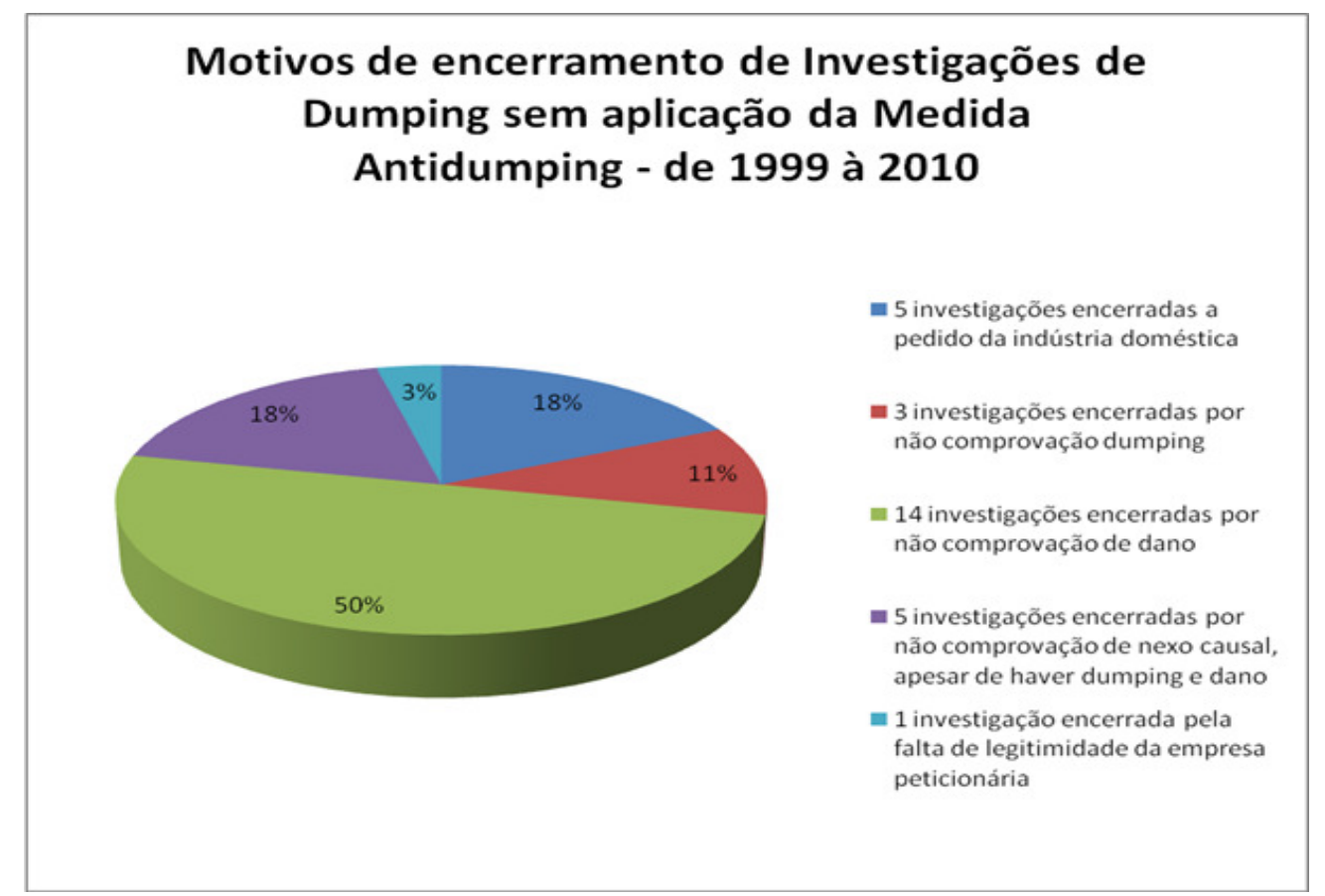

Fonte: elaboração própria com base em Resoluções CAMEX.

Portanto, ao contrário do que imaginávamos, muitas investigações foram encerradas pela ausência de demonstração do dano.

Ainda vale apontar para o fato de que, em 13 casos, nesse mesmo período de 1988 a 2010, foi firmado compromisso de preço $^{232}$. Como se nota, os compromissos de preço são estabelecidos em uma minoria das investigações. Raramente as investigações não foram abertas ${ }^{233}$. No período acima mencionado, apenas a investigação para averiguar circunvenção na importação de lápis de madeira com mina de grafite e com mina de cor da China é que não foi iniciada ${ }^{234}$.

232 Resolução CAMEX n 34, de 30/10/01, cartões semi-rígidos para embalagens do Chile; Resolução CAMEX n ${ }^{\circ}$ 10, de 03 de abril de 2001, leite do Uruguai; Resolução CAMEX n 02, de 23 de fevereiro de 2001, medicamentos contendo insulina dos EUA e da França; Resolução CAMEX $\mathrm{n}^{\circ}$ 01, de 02 de fevereiro de 2001, leite em pó, integral e desnatado da Argentina; Resolução CAMEX no 09, de 04/04/2005, leite em pó integral e desnatado, não fracionado do Uruguai; Resolução CAMEX n ${ }^{\circ}$ 02, de 17/02/2005, leite em pó integral e desnatado , não fracionado da Argentina; Resolução CAMEX n 46, de 10/10/2007, cartões semi-rígidos para embalagens, revestidos, tipos duplex e triplex, de gramatura igual ou superior a $200 \mathrm{~g} / \mathrm{m} 2$, do Chile; Resolução CAMEX n ${ }^{\circ}$ 17, de 07/04/2008, resinas de policarbonato dos EUA e da UE.

${ }^{233}$ Pode ocorrer de a petição ter sido apresentada pela indústria doméstica e não ter sido aceita, antes mesmo de qualquer publicação oficial.

${ }^{234}$ Circular SECEX N ${ }^{\circ} 32$, de 14 de junho de 2011 - DOU de 17/06/2011. 
Quanto ao momento para apuração do dumping e dano, o Artigo 20 do Decreto 1602/95, reflexo do Artigo 5.7 do $\mathrm{ADA}^{235}$, também determina que a prova tanto do dumping como do dano devem ser consideradas simultaneamente (a) no momento da decisão quanto ao início ou não da investigação, e (b) durante o curso da investigação, começando em data não posterior à data mais próxima em que é admitida a aplicação de medidas provisórias. Mas o texto normativo não vai além dessa determinação temporal. Podemos dizer, assim, que há algumas diretivas, mas não está explícito de que forma deve o dano ser apurado para fins de aplicação da medida antidumping.

Além disso, como informado, dano para as regras da OMC inclui a ameaça de dano e o retardamento da indústria nascente. Quanto ao primeiro aspecto, o relatório do Grupo de Especialistas em 1959 no caso New Zealand - Imports of Electrical Transformers from Finland notou que a aplicação das medidas antidumping nesses casos deveria se dar com bastante cautela ${ }^{236}$. No Brasil, o único caso em que foi analisada a ameaça de dano e aplicada a medida, sob o Artigo 16 do Decreto 1602/95, foi para pêssegos em conserva da Grécia ${ }^{237}$.

Quanto ao retardamento da indústria nascente, em Havana ${ }^{238}$, citou-se o exemplo de uma indústria que deixa de produzir lucros por causa do dumping. $\mathrm{O}$ Artigo 3(a) do Acordo AD da Rodada Kennedy estabeleceu, entre outros assuntos, que os planos para uma nova indústria devem estar bastante avançados, com pelo menos uma fábrica construída ou maquinário solicitado ${ }^{239}$. Caso contrário, não se

\footnotetext{
235 "The evidence of both dumping and injury shall be considered simultaneously (a) in the decision whether or not to initiate an investigation, and $(b)$ thereafter, during the course of the investigation, starting on a date not later than the earliest date on which in accordance with the provisions of this Agreement provisional measures may be applied."

236 "with respect to cases where material injury is threatened by dumped imports, the Group stressed that the application of anti-dumping measures had to be studied and decided with particular care". L/978, adotado em 13 de maio de 1959, 8S/145, 150, para. 16.

${ }^{237}$ Circular SECEX N ${ }^{\circ} 42$, de 25 de outubro de 2000 e medida aplicada pela Resolução CAMEX ${ }^{\circ}$ 5 de 25 de abril de 2002.

238 "it was stated that if an industry became economically unprofitable because of dumping, this would be covered by "retard materially". E/CONF.2/C.3/SR.30, p. 5.

239 "in the case of retarding the establishment of a new industry in the country of importation, convincing evidence of the forthcoming establishment of an industry must be shown, for example that the plans for a new industry have reached a fairly advanced stage, a factory is being constructed or machinery has been ordered". BISD 15S/26.
} 
poderá arguir retardamento da indústria nascente ${ }^{240}$. No Brasil não houve nenhuma investigação em que se alegou retardamento da indústria nascente.

Feitas essas considerações sobre o dumping e o dano, passaremos a tratar do nexo causal, terceiro e último requisito para imposição da medida antidumping. Nexo causal é relação. É causa/efeito. Podemos dizer que é a análise mais difícil de ser feita em uma investigação antidumping. É também a defesa que pode ser utilizada pelos exportadores investigados (inexistência de nexo causal), uma vez que de difícil prova por parte do peticionário. Isso porque o dano a uma indústria doméstica pode decorrer de inúmeros outros fatores como a desvalorização cambial, a obsolência da tecnologia aplicada ou da planta industrial e maquinário, ou mesmo políticas comerciais desfavoráveis do próprio país que está conduzindo a investigação, como a alta carga tributária e o excessivo ônus trabalhista/previdenciário.

Concluída a análise técnica pelo DECOM, o assunto passa para a CAMEX. O parágrafo $3^{\circ}$ do Artigo 64 do Decreto 1602/95 determina que o interesse nacional brasileiro seja analisado. Na prática, notamos que a CAMEX considera interesse nacional apenas o da indústria doméstica, razão pela qual muito raramente deixa de aplicar uma medida que o DECOM recomenda.

Apesar de a abertura de uma investigação ser publicada no DOU, e essa ser a forma de dar transparência sobre determinado ato público no Brasil, a publicação no DOU não cumpre com a sua finalidade uma vez que não leva a informação a conhecimento de todos. E mesmo se levasse, o DECOM não admite como parte interessada os consumidores ou entidades de consumidores do produto investigado. O DECOM, como prática, apenas admite como parte interessada exportadores/importadores do produto investigado, proveniente da origem investigada. Não há nenhum documento que seja publicado no DOU após o

\footnotetext{
${ }^{240}$ Para análise completa sobre os critérios para imposição de medidas antidumping em caso de retardamento da indústria nascente, vide NARAYANAN, Prakash. Injury Investigations in "Material Retardation" antidumping cases. Northwestern Journal of International Law \& Business, vol. 25, 2004, pag. 37.
} 
parecer do DECOM concluindo a investigação, e antes da resolução da CAMEX impondo a medida. Portanto, não há oportunidade para as partes se manifestarem sobre o interesse nacional. As partes não são convocadas a participar da reunião da CAMEX, sequer são notificadas da data em que esta ocorrerá. A reunião da CAMEX ocorre a portas fechadas, com a participação exclusiva de representantes dos sete ministérios que a compõe.

Tanto Canadá como UE dispõem de procedimento específico para análise do interesse nacional no curso de uma investigação antidumping ${ }^{241}$. Em Cingapura o interesse público deve ser levado em conta antes de ser iniciada a investigação. $\mathrm{ZENG}^{242}$ ressalta que, em alguns casos, consegue-se a redução da medida aplicada e informa que a China incorporou o conceito de interesse público em sua legislação em 2001.

Atualmente, cabe ao Grupo Técnico de Defesa Comercial (GTDC), no âmbito da CAMEX, examinar as recomendações do DECOM e aconselhar quanto à aplicação de direitos antidumping. O recém criado GTIP, quando demandado por qualquer parte interessada ou órgão da Administração Pública Federal, realizará avaliação paralela no que concerne ao interesse público.

Os pedidos ao GTIP de não aplicação, suspensão ou alteração de medidas antidumping deverão ser instruídos com os elementos de fato e de direito justificativos. Após instaurado o procedimento para análise dos pedidos, o GTIP terá quatro meses para apresentar suas conclusões ao Comitê Executivo de Gestão da Câmara de Comércio Exterior (GECEX) e posteriormente ao Conselho de Ministros da CAMEX. Continuará sendo a CAMEX quem proferirá a decisão final acerca do cabimento e conveniência dos pedidos.

É importante ressaltar que a análise de fatores de interesse público ao longo de investigações antidumping não obstará o fim da investigação. Nessas ocasiões,

\footnotetext{
${ }^{241} \mathrm{Na}$ UE, é um dos requisitos observados para a imposição de medidas antidumping pela Comissão Europeia, segundo o Parágrafo 1o. do Artigo 21 do Regulamento 384/96.

${ }^{242}$ ZENG, Hang. Antidumping and Competition: the case of China, agosto, 2005.
} 
o resultado da análise do GTIP não será submetido ao GECEX ou ao Conselho de Ministros da CAMEX antes de finalizado o procedimento administrativo do DECOM. O GTIP também poderá ser acionado após aplicada uma medida, com vistas à sua suspensão ou revogação.

Acreditamos que a criação do GTIP será benéfica para o sistema de defesa comercial brasileiro. O GTIP abrirá espaço para a discussão dos impactos da aplicação de medidas antidumping não só para o produto sobre o qual a medida será imposta, mas também para produtos de cadeias produtivas a ele relacionadas. Ademais, qualquer fator de ordem econômica que se enquadre como de interesse público poderá ser discutido no âmbito do GTIP. Assim sendo, o impacto concorrencial da medida de defesa comercial para o consumidor, ou para o próprio mercado, também poderá fundamentar um pedido de não aplicação, suspensão ou alteração de medidas antidumping. Isso significa que haverá maior integração entre o direito da concorrência e as medidas de defesa comercial contra a prática de dumping.

Finda a investigação, há a possibilidade de recurso contra a imposição da medida antidumping (recurso administrativo à própria CAMEX no prazo de 10 dias contados da Resolução que impôs a medida ${ }^{243}$ e recurso ao Poder Judiciário na forma de mandado de segurança, por exemplo, no prazo de 120 dias). A Lei 9.784/99 determina que o prazo para proferimento de decisões é de 30 dias, prorrogáveis por mais $30^{244}$. No caso brasileiro, devido à ausência de transparência do âmbito administrativo brasileiro, não é possível constatar em quantos casos foram apresentados recursos administrativos.

Uma vez aplicado, o recolhimento da medida antidumping é feito pelo Ministério da Fazenda. O sistema brasileiro é prospectivo, ou seja, somente são cobradas as sobretaxas antidumping aos produtos que ingressarem no país após a data da publicação no DOU da Resolução da CAMEX que impôs a medida e no

\footnotetext{
${ }^{243}$ Artigo 59 da Lei 9.784/99.

${ }^{244}$ Artigo 49 da Lei 9.784/99.
} 
momento do desembaraço. Vale lembrar, todavia, que pode ser estabelecida a retroatividade por até 90 dias em circunstâncias especiais (fato que não constatamos na prática).

A vigência da medida é por cinco anos e as possibilidades de revisão previstas no sistema são:

(i) revisão de meio de período - unicamente em casos de alteração de circunstâncias permanentes, conforme defendido pelo DECOM;

(ii) novo entrante no mercado, conhecida por revisão sumária ou "new shipper review"; ou

(iii) revisão de final de período, conhecida como "sunset review".

A prática do DECOM não tem sido permissiva com relação a revisões de meio de período. A legislação menciona que bastaria a alteração de circunstâncias, mas o DECOM exige que sejam alterações permanentes, e realizou essa modalidade de revisão apenas nos casos em que os países investigados deixaram de ser economias não de mercado ou em transição.

No Brasil também nunca tivemos nenhuma revisão para novo entrante no mercado, mas os critérios exigidos para que seja aberta uma investigação dessa natureza são: (i) comprovação de que não houve vendas para o Brasil durante o período da investigação; e (ii) comprovação de que a empresa que solicita a revisão não é parte relacionada a nenhum dos exportadores sujeitos à medida antidumping.

Revisões de final de período foram inúmeras, e acabaram por perpetuar algumas medidas antidumping, a exemplo do caso de sacos de juta que usaremos para ilustrar esse fato, sobretudo pois foi a única investigação antidumping brasileira questionada na OMC (apesar de encerrada em fase de consultas, como visto em capítulo específico). 


\begin{tabular}{|c|c|c|}
\hline \multicolumn{3}{|c|}{$\begin{array}{c}\text { MEDIDAS ADMINISTRATIVAS - IMPORTAÇÃO DE SACOS DE JUTA PROVENIENTES } \\
\text { DA ÍNDIA E BANGLADESH }\end{array}$} \\
\hline Normativa & Disposição & Detalhamento \\
\hline $\begin{array}{l}\text { Circular DECEX } \\
\text { n }^{\circ} 412 \text { de } 7 / 11 / 91\end{array}$ & $\begin{array}{l}\text { Início da } \\
\text { investigação }\end{array}$ & $\begin{array}{l}\text { Solicitação feita pelo Instituto de Fomento à Produção de } \\
\text { Fibras Vegetais da Amazônia (IFIBRAM) }\end{array}$ \\
\hline $\begin{array}{lr}\text { Portaria } & \text { MEFP } \\
n^{\circ} \quad 648 & \text { de } \\
30 / 09 / 92 & \end{array}$ & $\begin{array}{l}\text { Encerramento da } \\
\text { investigação com } \\
\text { aplicação } \\
\text { medida } \\
\text { antidumping }\end{array}$ & $\begin{array}{l}\text { Aplicada alíquota ad valorem de } 24,8 \% \\
6305.10 .0100) \text { e } 5,6 \%(6305.10 .9900) \\
\text { (NBM }\end{array}$ \\
\hline $\begin{array}{l}\text { Circular n } \mathbf{n}^{\circ} 39 \text { de } \\
\text { 22/09/97 }\end{array}$ & $1^{a}$ Revisão & $\begin{array}{l}\text { Em } 26 \text { de maio de 1997, o IFIBRAM requereu a prorrogação } \\
\text { do prazo de vigência das medidas antidumping. }\end{array}$ \\
\hline $\begin{array}{l}\text { Portaria } \\
\text { Ministerial } \\
\text { MICT/MF }{ }^{\circ} 16 \\
\text { de } 24 / 09 / 98\end{array}$ & $\begin{array}{l}\text { Encerramento da } \\
\text { revisão com } \\
\text { prorrogação das } \\
\text { medidas } \\
\text { antidumping }\end{array}$ & $\begin{array}{l}\text { Aplicada alíquota ad valorem de } 38,9 \% \text { para Índia e } 64,5 \% \\
\text { para Bangladesh. }\end{array}$ \\
\hline $\begin{array}{l}\text { Circular SECEX } \\
n^{\circ} 28 \text { de 18/07/02 }\end{array}$ & $\begin{array}{l}\text { Revisão de meio } \\
\text { período }\end{array}$ & $\begin{array}{l}\text { Em } 12 \text { de abril de } 2002 \text {, o Consulado Geral da Índia, em } \\
\text { nome do Conselho de Desenvolvimento dos Fabricantes de } \\
\text { Juta - JMDC, com base no disposto no inciso I do art. } 58 \text { do } \\
\text { Decreto no } 1.602 \text {, de } 1995 \text {, solicitou a revisão da medida. }\end{array}$ \\
\hline $\begin{array}{l}\text { Circular SECEX } \\
n^{\circ} 50 \text { de } 08 / 07 / 03\end{array}$ & 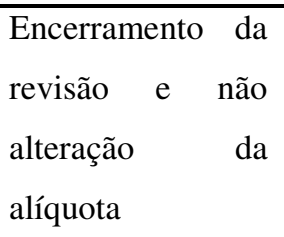 & $\begin{array}{l}\text { Face à insuficiência das informações apresentadas ao longo } \\
\text { do procedimento, a revisão foi encerrada e a medida } \\
\text { antidumping não foi alterada. }\end{array}$ \\
\hline $\begin{array}{l}\text { Circular SECEX } \\
n^{\circ} 69 \text { de } 10 / 09 / 03\end{array}$ & $2^{\mathrm{a}}$ Revisão & $\begin{array}{l}\text { Iniciada nova revisão das medidas antidumping para } \\
\text { prorrogação por mais } 5 \text { anos. }\end{array}$ \\
\hline $\begin{array}{l}\text { Resolução } \\
\text { CAMEX n }{ }^{\circ} 24 \text { de } \\
09 / 09 / 04\end{array}$ & $\begin{array}{l}\text { Encerramento da } \\
\text { revisão com } \\
\text { prorrogação das } \\
\text { medidas } \\
\text { antidumping }\end{array}$ & $\begin{array}{l}\text { Aplicadas alíquotas específicas fixas. As empresas indianas } \\
\text { Gloster Jute Mills Limited, Cheviot Company Limited, } \\
\text { Howrah Mills Company Limited, Birla Corporation Limited } \\
\text { e The Ganges Manufacturing Co. Ltd. foram gravadas com } \\
\text { medida antidumping igual a zero e, para as demais empresas } \\
\text { indianas foi adotada a alíquota específica de US\$ 0,22/kg. } \\
\text { Em relação à totalidade das empresas de Bangladesh, a } \\
\text { medida antidumping específica também correspondeu a US\$ } \\
0,22 / \mathrm{kg} \text {. }\end{array}$ \\
\hline $\begin{array}{l}\text { Circular SECEX } \\
n^{\circ} 49 \text { de 09/09/09 }\end{array}$ & $3^{\mathrm{a}}$ revisão & $\begin{array}{l}\text { Em 16/03/2009 o IFIBRAM manifestou interesse em nova } \\
\text { revisão e prorrogação por mais } 5 \text { anos da medida }\end{array}$ \\
\hline
\end{tabular}




\begin{tabular}{|c|c|c|}
\hline & & $\begin{array}{l}\text { antidumping. Em } 12 \text { de junho de } 2009 \text {, foi protocolizada } \\
\text { petição de abertura da revisão, nos termos do } \S 1 \text { o do art. } 57 \\
\text { do Decreto no } 1.602 \text {, de } 1995 \text {. }\end{array}$ \\
\hline $\begin{array}{l}\text { Resolução } \\
\text { CAMEX n } 66 \text { de } \\
02 / 09 / 10\end{array}$ & $\begin{array}{l}\text { Encerramento da } \\
\text { revisão com } \\
\text { prorrogação das } \\
\text { medidas } \\
\text { antidumping }\end{array}$ & $\begin{array}{l}\text { Aplicadas alíquotas fixas de US\$0,15/kg (Birla Corporation } \\
\text { Limited) e US } \$ 0,45 / \mathrm{kg} \text { (demais empresas) para Índia, e US\$ } \\
0,16 / \mathrm{kg} \text { para Bangladesh. }\end{array}$ \\
\hline
\end{tabular}

Fonte: elaboração própria com base em dados do MDIC.

Ocorre que, mesmo com a medida antidumping em vigor há quase 20 anos, o saco de juta brasileiro tem perdido mercado para Índia. Segundo noticiado ${ }^{245}$, tem havido avanço na importação da Índia e de Bangladesh, com preço $10 \%$ menor, afetando o mercado dos fabricantes da Amazônia, que já iniciaram demissões. Conforme relata empresário que atua no setor há 46 anos, "o produto brasileiro perde na competição com os importados por causa da pesada carga tributária, encargos trabalhistas e deficiências na infraestrutura, entre outros fatores".

Portanto, notamos que a medida antidumping pode não se mostrar como uma medida adequada para proteção da indústria doméstica. Nesse caso dos sacos de juta, o Brasil foi questionado na OMC por não levar em consideração provas, mas não por manter em vigor uma medida antidumping por tanto tempo. Com isso, podemos inferir que, para alguns setores, as dificuldades para enfrentar a concorrência dos produtos importados pode estar relacionada a outros fatores, como a alta carga tributária brasileira ("Custo Brasil”), o que não é resolvido com a imposição das medidas antidumping.

${ }^{245}$ DE CHIARA, Márcia. O Estado de S.Paulo. Saco de Juta perde mercado para a Índia. 14 de março de 2012. 


\subsection{DIREITO COMPARADO}

O procedimento administrativo para imposição de medidas antidumping segue trâmites diversos em cada um dos países ${ }^{246}$. Mas todos eles devem seguir o disposto no ADA. De acordo com o procedimento adotado nos EUA, a análise do dumping é feita por órgão diverso daquele que analisa o dano. O dumping é analisado pelo USDOC enquanto que o dano é analisado pela USITC. Iniciada a investigação, são apresentadas petições perante ambos os órgãos e as análises correm em paralelo. Caso qualquer um dos órgãos chegue a uma determinação negativa, a medida antidumping não poderá ser aplicada. Cabe ao DOC a análise final para atribuição do nexo causal.

Na UE, a estrutura do sistema é similar à brasileira, e a Comissão Europeia analisa tanto dumping como dano. TREBILCOCK ${ }^{247}$ lembra que a primeira investigação antidumping conduzida pela Comissão Europeia foi em 1970. Entre 1977 e 1986 foram iniciadas quase 400 investigações antidumping e, curiosamente, conforme nos conta JACKSON e VERMULST ${ }^{248}$, a maioria delas terminou com a celebração de compromisso de preço. Os autores, ao comparar o sistema dos EUA com o europeu, consideraram o primeiro quase-adjudicatório/compulsório e, o segundo, investigatório. Justificam sua qualificação, sobretudo, no fato de que (i) as informações são disponibilizadas a todos no sistema estadunidense, havendo plena transparência, o que nem sempre ocorre na Europa e, (ii) no sistema europeu,

\footnotetext{
${ }^{246}$ Para análise do sistema da Índia, vide RAJU, K.D. India`s involvement in Anti-dumping cases in the First Decade of WTO, In Global Abuse of a Trade Policy Instrument, New Delhi, Liberty Institute, 2007, pag. 31.

Para análise do sistema da Turquia, vide BAHCEKAPILI, Cenzig e COKGEZEN, Murat. Calculating Normal Value as a Way of Protection: some evidence from Turkish Dumping Investigations, In Global Abuse of a Trade Policy Instrument, New Delhi, Liberty Institute, 2007, pag. 49.

Para análise do sistema da África do Sul, vide THERON, Nicola. Anti-Dumping Procedures: lessons for developing countries with Special emphasis on the South African Experience, In Global Abuse of a Trade Policy Instrument, New Delhi, Liberty Institute, 2007, pag. 67.

Para estatísticas sobre os países asiáticos, vide MCGEE, Robert. Antidumping Laws as Weapons to Protectionism: Asian case studies, Manchester Journal of International Economic Law, vol. 5, issue 1: 36-69, 2008.

${ }^{247}$ TREBILCOCK, Michael J. e HOWSE, Robert, The Regulation of International Trade, 3a ed. Londres e Nova York: Routledge, 2005, pag. 172-173.

248 JACKSON, John e VERMULST, Edwin A. Antidumping Law and Practice: a comparative study. Ann Arbor, The Michigan University Press, 1992, Capítulo 3.
} 
o teste do interesse nacional é aplicado com frequência, o que não ocorre nos EUA, tornando possível que diante da constatação de dumping, dano e nexo causal ao final, a medida antidumping não seja aplicada.

VERA THORSTENSEN ${ }^{249}$ sustenta que "experiências prévias demonstram que a não separação pode afetar a independência das investigações e seus resultados", e por outro lado BARRAL ${ }^{250}$ afirma que "além de criar outras instâncias burocráticas, parece mais importante, na atual conjuntura, uma autoridade administrativa comum que busque a harmonização quanto à interpretação do $A A R U$, ao mesmo tempo que assegure que suas decisões serão compatíveis com a interpretação do DSB quanto à matéria".

Entendemos que a alteração para bipartido não contribuiria muito para o sistema brasileiro e faremos outra proposta, ao final dessa tese, sobre esse tema. Passemos, então, a analisar a função judiciária brasileira.

249 THORSTENSEN, Vera. Commercial Defence Policy and its Instruments, Washington, InterAmerican Development Bank, 1995: "former experiences can demonstrate that the non separation of the groups can affect the independence of the investigations and their results".

${ }^{250}$ BARRAL, Welber. Dumping e Comércio Internacional: a regulamentação antidumping após a Rodada Uruguai, Editora Forense, Rio de Janeiro, 2000, Pag. 326. 


\section{Capítulo 9 - FUNÇÃO JUDICIÁRIA BRASILEIRA EM MATÉRIA ANTIDUMPING}

A função judiciária em matéria antidumping não difere da função judiciária em geral, qual seja, aplicar a lei ao caso concreto. Quando o resultado de uma investigação antidumping não é satisfatório, além dos recursos administrativos, a parte que se sentir prejudicada poderá recorrer ao judiciário. É claro o mandamento constitucional de que ninguém pode ter essa privação ${ }^{251}$.

Conforme determina o Artigo 109 da CF, "aos juízes federais compete processar e julgar: I - as causas em que a União, entidade autárquica ou empresa pública federal forem interessadas na condição de autoras, rés, assistentes ou oponentes, exceto as de falência, as de acidentes de trabalho e as sujeitas à Justiça Eleitoral e à Justiça do Trabalho; (...) III - as causas fundadas em tratado ou contrato da União com Estado estrangeiro ou organismo internacional; (...)”.

Pelo inciso I, as causas sobre antidumping seriam de competência do juiz federal, pois envolvem o DECOM e a CAMEX, órgãos da Administração Pública Federal. O fato de a obrigação decorrer de um tratado internacional, apesar de já internalizado em nosso ordenamento jurídico, também justificaria a competência do juiz federal sob o inciso III do Artigo 109 da CF, acima transcrito.

A limitação da atividade judiciária no Brasil fica a cargo das regras constitucionais sobre a tripartição dos poderes e inafastabilidade do Poder Judiciário, apontadas anteriormente ${ }^{252}$. À luz da tripartição dos poderes, o Judiciário tem competência para revisar os atos da Administração Pública apenas no que diz respeito a sua legalidade. Não cabe ao Judiciário adentrar na conveniência e oportunidade do ato administrativo. Nesse sentido, as hipóteses de

\footnotetext{
251 "Todos são iguais perante a lei, sem distinção de qualquer natureza, garantindo-se aos brasileiros e aos estrangeiros residentes no País a inviolabilidade do direito à vida, à liberdade, à igualdade, à segurança e à propriedade, nos termos seguintes: (...) a lei não excluirá da apreciação do Poder Judiciário lesão ou ameaça a direito".

${ }^{252}$ Artigo $2^{\circ}$ e Artigo $5^{\circ}$, inciso XXXV, da CF.
} 
revisão judicial são limitadas e, na maioria das vezes, está relacionada com o excesso de poder discricionário. Dessa forma, passemos a fazer breves considerações a esse respeito, para que tenhamos melhores condições de analisar o posicionamento do Poder Judiciário Brasileiro.

\subsection{BREVES CONSIDERAÇÕES SOBRE ABUSO DE PODER E DISCRICIONARIEDADE}

Desvio de poder não se confunde com abuso de poder. Cabe aqui uma digressão à diferenciação feita por OSWALDO ARANHA BANDEIRA DE $\mathrm{MELLO}^{253}$ : “o desvio de poder restringe-se aos casos de exercício, por órgão da Administração, da sua competência. Por outro lado, o abuso não atende ao interesse social".

QUEIRÓ $^{254}$ ainda nos esclarece que "o desvio do poder seria um vício próprio do exercício das faculdades discricionárias, consistindo no uso destas fora de seu objeto e fim". Consiste, segundo o autor, no exercício pela administração de um poder discricionário com fim diverso daquele para que a lei o concedeu. $\mathrm{O}$ fim do ato, para que ele esteja amparado juridicamente, deve coincidir com o espírito da lei. Portanto, analisar a discricionariedade administrativa é o ponto focal para compreensão do tema e poder entender as limitações da função judiciária.

JUSTEN FILHO ${ }^{255}$ faz a distinção entre as concepções de discricionariedade trazidas por Hely Lopes Meirelles, Celso Antônio Bandeira de Mello e Maria Sylvia Zanella di Pietro (poder, margem de liberdade e possibilidade de apreciação de acordo com conveniência e oportunidade). $\mathrm{O}$ autor define discricionariedade como a "atribuição do dever-poder de decidir segundo a

\footnotetext{
253 BADEIRA DE MELLO, Oswaldo Aranha. Atos no Exercício do Poder Vinculado e Discricionariedade. In Princípios Gerais de Direito Administrativo, 2a . Edição; Rio de Janeiro, Forense, 1979, pags. 470 a 488.

${ }^{254}$ QUEIRÓ, Afonso Rodrigues. A Teoria do Desvio do Poder em Direito Administrativo. Revista de Direito Administrativo, Volume VII, Janeiro a Março de 1947, Rio de Janeiro, FGV, pags. 52 a 80.

${ }^{255}$ JUSTEN FILHO, Marçal. Atividade Administrativa e Procedimentalização. In Curso de Direito Administrativo, $2^{\mathrm{a}}$. edição, Ed. Saraiva, 2006, pags. 143 a 180.
} 
avaliação da melhor solução para o caso concreto". Não seria, portanto, uma liberdade ou um direito subjetivo. Afirma ainda que a discricionariedade justificase pela impossibilidade de selecionar todas as alternativas disponíveis para resolver um problema.

De fato, a impossibilidade de a lei prever, antecipada e abstratamente, todas as alternativas possíveis, torna a concessão da discricionariedade favorável à Administração Pública, a qual se vê diante da possibilidade de analisar conveniência e oportunidade de agir, bem como sopesar as conseqüências do ato concreto, com o objetivo de melhor atender ao interesse público.

De acordo com CRETELLA JR..$^{256}$, o poder discricionário está desvinculado de qualquer norma que lhe imponha previamente oportunidade e conveniência da conduta. O servidor público não é autônomo, é servo da legalidade. A própria terminologia "servidor" nos deixa claro que seu objetivo principal é servir ao interesse público. Ele edita atos ou os executa selecionando entre as possibilidades que melhor representam a vontade da Administração, visando a um fim.

O autor ainda continua afirmando que o ato discricionário é necessário para ajustar a ação administrativa ao meio. Para tanto, o servidor público vale-se da sensibilidade político-jurídica. É, portanto, um momento pontual. Dessa maneira, falar em discricionariedade é falar de poder: como se maneja o poder estatal. E a forma de manejo do poder estatal (controle) depende de onde provê a discricionariedade. A discricionariedade pode decorrer do interesse público; da necessidade de concretização de comando legal; ou da própria lei (comando expresso ou lacuna de como agir). Podemos dizer, portanto, que há quatro fontes da discricionariedade, e que todas as quatro são encontradas em matéria antidumping:

\footnotetext{
${ }^{256}$ CRETELLA JUNIOR, J. Ato Administrativo - A Tridimensão da Discricionariedade. Revista de Direito Administrativo, Volume 119, jan. a mar. 1975, Rio de Janeiro, FGV, pags. 33 a 39.
} 
1) Lei (aquela que explicitamente deixa a um determinado órgão, a seu critério, determinar como agir em uma situação concreta);

2) Lacunismo (aquela que, por não prever, admite que o administrador leve em consideração a conveniência e oportunidade de agir naquele determinado momento);

3) Opções (lei define comandos dentre um leque de alternativas de agir);

4) Conceitos jurídicos indeterminados (termos que admitem dubiedade semântica).

Segundo BANDEIRA DE MELLO ${ }^{257}$, a discricionariedade pode derivar da hipótese da norma (falta de clareza quanto ao pressuposto do fato), do comando da norma (alternativas quanto a realizá-lo ou não, momento, forma jurídica em que se revestirá) ou da finalidade da norma. Algumas vezes a hipótese da norma se torna clara em razão de sua finalidade. $\mathrm{O}$ autor conclui afirmando que discricionariedade é " a margem de liberdade que remanesce ao administrador para eleger, segundo critérios consistentes de razoabilidade, um dentro de pelo menos dois comportamentos cabíveis, perante cada caso concreto, a fim de cumprir o dever de adotar a solução mais adequada à satisfação da finalidade legal, quando, por força da fluidez das expressões da lei ou da liberdade conferida no mandamento dela não se possa extrair objetivamente, uma solução unívoca para a situação vertente".

De acordo com FLORIANO MARQUES ${ }^{258}$, a regulação transfere discricionariedade para as agências e, ao mesmo tempo, reduz a margem de discricionariedade do servidor público. Ao emitir regulamentos, prescrevendo as condições, critérios, parâmetros que o regulador adotará ao editar atos concretos, fica a eles vinculado. Isso confere estabilidade à regulação, pois autolimita a discricionariedade.

${ }^{257}$ BANDEIRA DE MELLO, Celso Antônio. Discricionariedade e Controle Jurisdicional, São Paulo, Malheiros, 1992, pags. 9 a 48.

${ }^{258}$ MARQUES NETO, Floriano de Azevedo. Discricionariedade e Regulação Setorial - o caso do controle dos atos de concentração por regulador setorial. In $O$ Poder Normativo das Agências Reguladoras, Rio de Janeiro, Forense, 2006, pags. 569 a 604. 
Dessa forma, podemos concluir que quanto maior a discricionariedade, menor o espaço para a legalidade. Antigamente se sustentava que a discricionariedade estava limitada pela legalidade, mas atualmente entendemos estar limitada pelos direitos fundamentais daqueles que são atingidos pelo exercício da autoridade, havendo, portanto, uma ampliação da liberdade, e também do controle.

Por outro lado, vemos a Administração Pública como escrava da legalidade. Como ensina MARIA SYLVIA ZANELLA DE PIETRO ${ }^{259}$ "o poder $d a$ administração é vinculado, porque a lei não deixou opções; ela estabelece que, diante de determinados requisitos, a Administração deve agir de tal ou qual forma".

Aplicando à matéria antidumping, para afastar a classificação do dumping como ato ilícito ${ }^{260}$, TÉRCIO SAMPAIO FERRAZ ${ }^{261}$ lembra que, "a aplicação dos direitos antidumping e compensatórios é discricionária, (...). Ora, se o dumping ou o subsídio forem considerados atos ilícitos, o Estado terá a obrigação - e não apenas a faculdade - de aplicar as penalidades correspondentes", o que não ocorre na prática, pois é permitida a celebração de compromissos de preços e a medida antidumping pode deixar de ser aplicada por razões de interesse público.

Feitas essas considerações, para fins da presente tese, entendemos discricionariedade como margem de liberdade, mas não para eleger um

\footnotetext{
${ }^{259}$ DI PIETRO, Maria Sylvia Zanella. Direito administrativo. 22. ed. São Paulo: Atlas, 2009.

${ }^{260}$ Diversos artigos foram escritos sobre a natureza jurídica dos direitos antidumping, entre eles, LEÃES, Luiz Gastão Paes de Barros. O dumping como forma de abuso do poder econômico. Revista de Direito Mercantil, Industrial, Econômico e Financeiro, n. 91, jul/set 1993. BARRAL (em seu livro Dumping e Comércio Internacional: a regulamentação antidumping após a Rodada Uruguai. Rio de Janeiro: Forense, 2000) defende ter o antidumping natureza jurídica de um direito econômico e intervenção econômica do Estado. O próprio fato de o Artigo 1o. da Lei 9019/95 não incluir o antidumping como tendo natureza tributária afasta a possibilidade de classificá-lo como tributo.

${ }^{261}$ FERRAZ JR., Tércio Sampaio. e DA ROSA, José Del Chiaro Ferreira e GRINBERG, Mauro. Direitos Anti-Dumping e Compensatórios: sua natureza jurídica e consequências de tal caracterização. Revista de Direito Mercantil, Industrial, Econômico e Financeiro (RDM) n. 91, julho/setembro 1993, pag. 94.
} 
comportamento entre alguns cabíveis, e sim para melhor atender ao interesse público, nos limites conferidos pela lei, diante da possibilidade de, no caso concreto, levar em consideração a oportunidade e conveniência de agir.

\subsection{ARTIGO 13 DO ADA}

O Artigo 13 do ADA estabelece que todos os Membros da OMC que têm legislação antidumping devem manter tribunais ou procedimentos judiciais, arbitrais ou administrativos para revisar as medidas antidumping adotadas.

Conforme apontado por DURLING e NICELY ${ }^{262}$, trata-se de uma outra etapa de proteção procedimental, ao exigir uma revisão independente em nível nacional. Conforme salientam, esse dipositivo surgiu na Rodada Uruguai, não tendo precedente na Rodada Tóquio. Não houve oposição quanto a sua inserção durante as negociações e esse artigo, até o momento, não foi objeto de questionamento perante o DSB.

$\mathrm{JAFFE}^{263}$ lembra que "um indivíduo que tem seu interesse afetado por uma ação administrativa tem o direito, em algum ponto, a uma determinação judicial sobre a sua validade”. E STYN ${ }^{264}$ complementa para elencar os objetivos de uma revisão judicial, que são: “( $i$ ) corrigir um eventual exercício arbitrário de poder; (ii) estimular ações oficiais responsáveis com fundamento na possibilidade de análise judicial e anulação; (iii) aumentar a credibilidade do público diante do processo administrativo; (iv) preservar o devido processo legal”.

\footnotetext{
${ }^{262}$ DURLING, James e NICELY, Matthew. Understanding the WTO Antidumping Agreement negotiation history and subsequent interpretation. Cameron May, Londres, 2002.

${ }^{263}$ JAFFE. The right of judicial review, Harvard Law Review, n. 71, 1958, p.408 in CORDOVIL, Leonor, O interesse público no antidumping. Tese de Doutorado, USP/2009, pag. 284.

${ }^{264}$ STYN, Ronald. The Antidumping Act: Problems of Administration and Proposals for Change, Stanford Law Review, v.17, n.4, 1965, pag.748.
} 
EDENS $^{265}$ sustenta que, em razão da discricionariedade exercida pelas autoridades administrativas, muitas vezes de forma abusiva, seria conveniente ter uma revisão judicial mais substantiva e menos formal. Segundo o autor, deve ser delegado ao Poder Judiciário o papel de supervisor à luz de três objetivos: completude, simplicidade e previsibilidade. Como solução e forma de evitar idas e vindas processuais, o que denomina de "efeito io-io" e "never ending game of inter-branch ping pong”, o autor propõe que a revisão judicial possa reverter a decisão da agência administrativa e faça o reenvio (instrumento já existente na legislação dos EUA) com instruções expressas para que se dê uma solução ao caso ("remand with affirmative instructions").

$\mathrm{Na}$ linha com o que defende RESTANI ${ }^{266}$, o simples fato de existir a possibilidade de recorrer ao judiciário já é um limitador do poder executivo.

O Poder Judiciário brasileiro ou de qualquer outro país, no que tangenciam normas da OMC, deve agir para que o Estado cumpra com os compromissos assumidos perante essa Organização.

Conforme afirma LEONOR CORDOVIL" ${ }^{267}$, "impedir que o Poder Judiciário revise uma decisão relativa à vontade nacional pode motivar decisões administrativas extremamente arbitrárias. (...), é muito mais razoável, para a maioria dos interessados, o recurso local, aos seus próprios juízes, do que convencer o país exportador a recorrer ao mecanismo de solução de controvérsias da OMC. Impedir esse acesso é limitar, de forma perversa, a defesa dos interesses destas partes." A autora completa afirmando que "a apreciação pelo Poder Judiciário conferirá credibilidade, tornará as decisões mais elaboradas,

\footnotetext{
${ }^{265}$ EDENS, Bryan A. Substancial Evidence in the law of International Trade: meaningful judicial review of antidumping actions or perpetuation of the yo-yo effect? Cardozo Public Law, Policy \& Ethics Journal, vol. 6, 2007-2008, pag. 431.

${ }^{266} \mathrm{HON}$, Jane A. Restani. A review of recent decisions of the United States Court of Appeals for the Federal Circuit: Introductory Comment: judicial review in International Trade: its role in the balance between delegation by Congress and Limitation of Executive, American University Law Review, 1988, pag. 37.

${ }^{267}$ CORDOVIL, Leonor Augusta Giovine. O interesse público no antidumping. Tese de Doutorado. USP/2009.
} 
preservará o devido processo legal e estimulará ações responsáveis pelas autoridades". Todavia, defende que "a revisão judicial deve se limitar à análise da decisão sobre o interesse público" ${ }^{268}$.

Entendemos que o Artigo 13, apesar de não mandatório, poderia ser aplicado de forma a incentivar o recurso ao Judiciário. Todavia, enquanto não forem criadas cortes especializadas, que compreendam a legislação aplicável, não concordamos que o devido processo legal esteja sendo assegurado. Passemos a analisar a jurisprudência atual para encontrar os motivos.

\subsection{JURISPRUDÊNCIA}

O Judiciário brasileiro vem aplicando as normas do GATT/OMC para resolver conflitos entre particulares e a Administração Pública, sobretudo quanto à incidência de tributos na importação de bens estrangeiros. Há inclusive sete súmulas vinculantes que disciplinam a matéria ${ }^{269}$. Mais recentemente, entende-se que a violação às regras da OMC não fere norma constitucional, razão pela qual não se admite recurso extraordinário ao $\mathrm{STF}^{270}$, mas apenas apreciação pelo STJ.

\footnotetext{
${ }^{268}$ Idem, pag. 285.

${ }^{269}$ Súmula 88 do STF - É válida a majoração da tarifa alfandegária, (...), que modificou o acordo geral sobre tarifas aduaneiras e comércio (GATT), (...).

Súmula 130 do STF - A taxa de despacho aduaneiro continua a ser exigível (...), que aprovou alterações no acordo geral sobre tarifas aduaneiras e comércio (GATT).

Súmula 131 do STF - A taxa de despacho aduaneiro continua a ser exigivel (...), mesmo para as mercadorias incluídas na vigente lista III do acordo geral sobre tarifas aduaneiras e comércio (GATT).

Súmula 575 do STF - À mercadoria importada de país signatário do GATT, ou membro da ALALC, estende-se a isenção do imposto de circulação de mercadorias concedida a similar nacional.

Súmula 20 do STJ - A mercadoria importada de país signatário do GATT é isenta de ICM, quando contemplado com esse favor o similar nacional.

Súmula 71 do STJ - O bacalhau importado de país signatário do GATT é isento de ICM.

Súmula 124 do STJ - A taxa de melhoramento dos portos tem base de cálculo diversa do imposto de importação, sendo legítima a sua cobrança sobre a impotação de mercadorias de países signatários do GATT, da ALALC ou ALADI.

270 AI-AgR 453004/RJ. Relator: Min. Carlos Velloso. Julgamento: 21/09/2004. Órgão julgador: segunda turma.
} 
Em regra ${ }^{271}$, as decisões proferidas no âmbito judiciário brasileiro no que tange a medidas antidumping são de três naturezas, nessa ordem:

i. Mandado de Segurança: cujo prazo para ingresso é 120 dias contados da publicação da medida;

ii. Agravo de instrumento: 10 dias contados da intimação que tenha concedido a segurança;

iii. Apelação: 15 dias contados da publicação da análise de mérito quanto à segurança solicitada.

O mandado de segurança seria a primeira instância da Justiça Federal, pela qual se busca questionar a decisão da autoridade administrativa (em geral a CAMEX, que é o órgão que impõe a medida antidumping). O mandado de segurança deve ser impetrado no foro da residência da autoridade coatora. Da decisão quanto ao pedido de liminar em um mandado de segurança, cabe agravo de instrumento. Da decisão final do mandado de segurança, cabe apelação aos Tribunais Regionais Federais. Recurso especial ao STJ ou Extraordinário ao STF, somente nas hipóteses previstas na CF.

Pesquisamos a jurisprudência dos Tribunais Regionais Federais, STF e STJ. Na jurisprudência pesquisada, localizamos os seguintes números sobre antidumping:

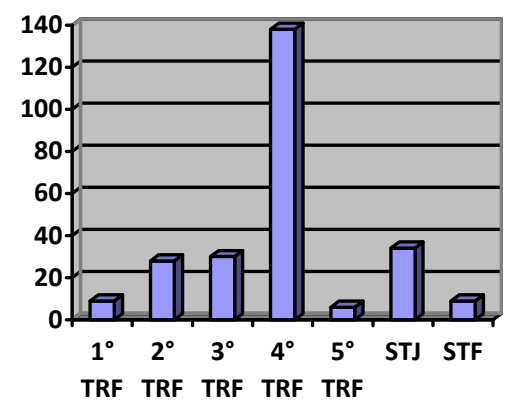

$\square$ Casos Antidumping

271 Poder-se-ia também ingressar com medida cautelar com pedido de liminar, mas diante da existência de direito líquido e certo e prova documental, dá-se preferência ao mandado de segurança. 
Notamos que o $4^{\circ}$ Tribunal Regional Federal, que compreende Rio Grande do Sul, Paraná e Santa Catarina, é o que mais teve casos antidumping (138) ${ }^{272}$ e o período da jurisprudência pesquisada é o menor ${ }^{273}$. A $2^{\text {a }}$ e a $3^{\text {a }}$ região, que compreendem, Rio de Janeiro e Espírito Santo de um lado, e São Paulo e Mato Grosso do Sul do outro, tiveram $28^{274}$ e $30 \operatorname{casos}^{275}$, respectivamente. A $1^{\text {a }}$ região que compreende Acre, Amapá, Amazonas, Bahia, Distrito Federal, Goiás, Maranhão, Mato Grosso, Minas Gerais, Pará, Piauí, Rondônia, Roraima e Tocantins teve nove $\operatorname{casos}^{276}$ e a $5^{\mathrm{a}}$ região, que compreende Alagoas, Ceará, Paraíba, Pernambuco, Rio Grande do Norte e Sergipe, teve apenas seis casos, apesar de o período da jurisprudência ser o maior ${ }^{277}$.

O Superior Tribunal de Justiça (STJ) analisou 34 ações sobre antidumping $^{278}$ e o Supremo Tribunal Federal (STF), nove ${ }^{279}$. As nove ações que chegaram ao STF foram sob a vigência da Lei 3.244/57, antes da criação da OMC, e o entendimento do STF sempre foi no sentido de exigir fundamentação e motivação do ato administrativo, bem como atuação dentro dos limites da lei específica (princípio da legalidade) ${ }^{280}$.

\footnotetext{
${ }^{272}$ A razão talvez seja os incentivos fiscais dados, principalmente, pelo Estado de Santa Catarina, o que incentivou as importações por seus portos, a exemplo de Itajaí e São Francisco do Sul. Outro importante porto na região Sul é o de Paranaguá.

${ }^{273}$ O TRF da $4^{\mathrm{a}}$ região disponibiliza dados a partir de 2007.

${ }^{274}$ O TRF da $2^{\text {a }}$ região disponibiliza dados a partir de 1990.

${ }^{275}$ O TRF da $3^{\text {a }}$ região disponibiliza dados a partir de 2002.

${ }^{276} \mathrm{O}$ TRF da $1^{\text {a }}$ região disponibiliza dados a partir de 2000.

${ }^{277}$ O TRF da $5^{\text {a }}$ região disponibiliza dados a partir de 1996.

${ }^{278}$ O STJ disponibiliza dados a partir de 1996.

${ }^{279}$ O STF disponibiliza dados a partir de 1972.

${ }^{280}$ Nesse sentido: RE 73165, Relator(a): Min. ANTONIO NEDER, PRIMEIRA TURMA, julgado em 17/10/1978, DJ 07-11-1978 PP-08824 EMENT VOL-01114-01 PP-00322) , (RE 76601, Relator(a): Min. ANTONIO NEDER, PRIMEIRA TURMA, julgado em 12/09/1978, DJ 06-101978 PP-) , (RE 73727 embargos, Relator(a): Min. ANTONIO NEDER, TRIBUNAL PLENO, julgado em 29/11/1973, DJ 15-02-1974 PP) , (RE 74448, Relator(a): Min. ANTONIO NEDER, SEGUNDA TURMA, julgado em 23/11/1973, DJ 22-02-1974 PP- RTJ VOL-21193- PP-) , (RE 74027, Relator(a): Min. DJACI FALCAO, PRIMEIRA TURMA, julgado em 03/10/1972, DJ 1011-1972 PP-), (RE 73479, Relator(a): Min. DJACI FALCAO, PRIMEIRA TURMA, julgado em 24/03/1972, DJ 12-05-1972 PP-), (RE 72836, Relator(a): Min. AMARAL SANTOS, PRIMEIRA TURMA, julgado em 22/02/1972, DJ 24-04-1972 PP-), (RE 72042, Relator(a): Min. AMARAL SANTOS, PRIMEIRA TURMA, julgado em 22/02/1972, DJ 28-04-1972 PP-), (RE 69153, Relator(a): Min. DJACI FALCAO, PRIMEIRA TURMA, julgado em 16/06/1970, DJ 04-09-1970 PP-).
} 
Entre os 34 casos que chegaram ao STJ, vale mencionar que o $\mathrm{STJ}^{281}$ pacificou entendimento segundo o qual as autoridades brasileiras, ao apurar a prática de dumping, não estavam obrigadas a adotar, necessariamente, o preço do produto praticado no mercado interno chinês, podendo utilizar, como ocorreu, a metodologia aplicável a países com economia não predominantemente de mercado (art. $7^{\circ}$ do Decreto 1.602/95). Portanto, o STJ concorda com a postura do DECOM de não considerar a China como economia de mercado, o que poderá prevalecer até 2016, prazo final previsto no Protocolo de Acessão da China à OMC.

Mas, o que mais nos chama a atenção dos casos analisados nos Tribunais Regionais Federais é a falta de conhecimento técnico. Abaixo alguns exemplos para ilustrar essa constatação. Nessa tese não nos preocupamos em analisar os casos de primeira instância, mas presumimos que a situação seja bem pior.

$1 \mathrm{TRF}$ - insulina ${ }^{282}$ :

"Não demonstrados de plano os fundamentos que revelam o descabimento da Resolução impugnada, quer quanto à inexistência de prática de dumping, quer quanto à inadequação das sanções aplicadas, não merece ser desprestigiada a conclusão administrativa tomada após procedimento investigatório prévio, que apurou a prática efetiva de preço predatório pela agravada e impôs medidas corretivas, porquanto insuficientes os elementos apresentados para afastar a presunção de legalidade e legitimidade do ato administrativo”.

O Poder Judiciário nos leva a entender que o descabimento da Resolução seria apropriado única e exclusivamente se comprovada a inexistência de prática de dumping ou inadequação das sanções aplicadas. Não se faz menção ao dano ou nexo de causalidade, requisitos exigidos pela legislação para aplicação da medida. Outro aspecto diz respeito à confusão dos termos. A decisão fala em procedimento investigatório prévio que apurou a prática efetiva de preço predatório. Preço predatório não é o que se busca para legitimar a imposição de uma medida

\footnotetext{
${ }^{281}$ Mandado de Segurança 13413, DJ de 6/10/2008, relator ministro Teori Albino Zavascki.

${ }^{282}$ AG 200101000201567 - Relatora: JUÍZA MÔNICA JACQUELINE SIFUENTES (CONV.)TRF1 - DJ DATA:09/01/2002.
} 
antidumping. Daí notamos o despreparo do Poder Judiciário para analisar questões específicas do comércio internacional.

$2 \mathrm{TRF}-$ juta $^{283}$ :

"restou comprovada a existência de indícios positivos de que as importações foram realizadas a preço de dumping, com ameaça de dano à indústria doméstica, justificando, assim, a imposição de medidas compensatórias provisórias”.

Novamente notamos: (i) não ter sido verificado o nexo causal, e (ii) a confusão entre os diferentes mecanismos de defesa comercial. Medidas compensatórias são instrumentos para combate aos subsídios, e não ao dumping.

$2 \mathrm{TRF}-$ alho $^{284}$ :

“Inexiste, in casu, relevância jurídica a amparar a pretensão, eis que a aplicação das salvaguardas antidumping têm como escopo proteger a produção nacional contra a importação desmedida de produtos similares aos que se produzem aqui ou que com eles concorrem diretamente".

Primeiro, salvaguardas e medidas antidumping são ferramentas jurídicas que têm objetivos diversos. Segundo, o papel das medidas antidumping não é proteger a produção nacional contra a importação desmedida, e sim contra preços abaixo do valor normal. As salvaguardas é que se preocupam com surtos de importação (volume).

Notamos que, para suspender os efeitos de uma resolução da CAMEX, o Judiciário busca afastar a presunção de legalidade e legitimidade do ato administrativo, dando direito à Administração Pública de recolher as sobretaxas antidumping. Ocorre que, diante do desconhecimento técnico, não analisam se o

${ }^{283}$ AC - APELAÇÃO CIVEL - 263669 Processo: 2001.02.01.015570-3 UF: RJ Orgão Julgador: SÉTIMA TURMA ESPECIALIZADA Data Decisão: 13/05/2009 Documento: TRF-200214604.

${ }^{284}$ AG 200302010067616 - Relator: Desembargador Federal BENEDITO GONCALVES - TRF2 DJU - Data: 11/11/2004. 
Executivo cumpriu o disposto na lei, e simplesmente motivam a decisão no poder discricionário da Administração Pública.

Esse despreparo dos juízes nos leva a propor, na mesma linha que sugerimos no âmbito legislativo, que haja maior treinamento dos funcionários públicos ou, idealmente, seja criada corte especializada para tratar dos assuntos de comércio internacional $^{285}$.

Aparte dessa constatação, as conclusões encontradas na jurisprudência pátria sempre giram ao redor dos seguintes argumentos:

1) $\underline{O}$ ato administrativo é um ato discricionário

"Nos termos do art. $3^{\circ}$ da Lei n. 9.019, de 30 de março de 2005, "a exigibilidade dos direitos provisórios poderá ficar suspensa, até decisão final do processo, a critério da CAMEX", ou seja, trata-se, de ato discricionário da autoridade coatora, razão pela qual o administrador, diante do caso concreto, deve escolher a providência que melhor satisfaça a finalidade legal. 4. No Estado de Direito, a existência de atos sujeitos ao juízo de conveniência e oportunidade do administrador público se dá em razão da impossibilidade de a lei aferir, antecipadamente, qual o comportamento que melhor atenderia ao interesse público. 5. In casu, além de o ato ser discricionário, a decisão da CAMEX encontra-se motivada (...),286 (grifos nossos).

2) O judiciário não pode interferir na esfera administrativa

\section{"1. Afigura-se incabível ao Poder Judicial arvorar-se em órgão administrativo} competente para, a partir disso, interpretar o fato de o Brasil ser, ou não, autosuficiente e fixar critérios direcionados à suspensão de direito antidumping estabelecido na Resolução $n^{o} 41$, ora impugnada. Tais aspectos deverão ser

\footnotetext{
285 ÁRABE NETO, Abrão M. e BONOMO, Diego Zancan. Tribunal especializado em comércio exterior. Valor Econômico, 03/07/2012.

${ }^{286}$ MS 200901896500 - Relator: HUMBERTO MARTINS - STJ - DJE DATA:18/12/2009.
} 
analisados em processo administrativo competente, no qual se exerce a atuação discricionária técnica, em que, para se aquilatar a necessidade de imposição - ou de suspensão - de direito compensatório antidumping, torna-se imprescindível a prévia aferição de diversas e complexas circunstância fáticas, não se olvidando da política governamental do comércio exterior no contexto da proteção do mercado interno $^{287}$ (grifos nossos).

3) A análise é meramente quanto à legalidade

"Na jurisprudência desta Eg. Corte Regional, a instauração do procedimento, bem como a aplicação de medidas antidumping, revelam-se como ato administrativo de atuação discricionária (Cf. AC n 410662/RJ, 7a TEsp, DJU de DJU de 29-04-2008), de modo que a análise judicial fica circunscrita ao âmbito da legalidade. Na espécie, observa-se que as normas legais de regência foram todas elas respeitadas, não havendo falar-se, portanto, em quaisquer ilegalidade ${ }^{, 288}$ (grifos nossos).

4) A retirada da medida antidumping apresentaria um risco à indústria doméstica

"A concessão de antecipação de tutela, suspendendo a aplicação de medida antidumping em vigor há quase sete anos, configuraria periculum in mora inverso aos produtores nacionais, vez que poderia provocar grave desequilíbrio no mercado"289 (grifos nossos).

Observamos que, em todos os casos citados, e na grande maioria da jurisprudência pesquisada, não foi dada razão à parte sujeita à medida antidumping, restando respeitada, em todos seus aspectos, a decisão do governo

${ }^{287}$ TRF-2 AC - APELAÇÃO CIVEL - 384129 Processo: 2004.51.01.006821-4 UF : RJ Orgão Julgador: SÉTIMA TURMA ESPECIALIZADA Data Decisão: 17/12/2008 Documento: TRF-200202157 DJU - Data::17/02/2009 - Página::111.

288 AC 200451010068214 - Relator: Desembargador Federal THEOPHILO MIGUEL - TRF2 DJU - Data: 17/02/2009.

289 AGTAG 200202010202540 - Relator: Desembargador Federal SERGIO SCHWAITZER TRF2 - DJU - Data: 18/02/2003. 
brasileiro. Notamose que o Judiciário não analisa sequer se a medida antidumping foi imposta de acordo com o processo investigatório estabelecido na legislação brasileira. O fato de não analisar o mérito é justificável, pois o Poder Judiciário deve se restringir às questões formais. Todavia, entendemos cabível ao Poder Judiciário uma análise mais aprofundada, em que seria verificado se o devido processo legal durante as investigações foi observado, de forma a dar efetividade ao princípio dos pesos e contrapesos da separação dos poderes, e assegurar o interesse público.

Ocorre que essa análise mais aprofundada só se mostra possível se feita por juízes especializados, com conhecimento técnico sobre o assunto.

\subsection{DIREITO COMPARADO}

Na Europa, o Tribunal de Primeira Instância, criado em 1988 de acordo com o Artigo 168A do Tratado de Roma, é competente para julgar todas as ações movidas por pessoas físicas ou jurídicas, inclusive medidas antidumping. Conforme lembra DEILTON RIBEIRO BRASIL 290 " por ocasião da elaboração dos estatutos do Tribunal de Primeira Instância das Comunidades Europeias, foi estudada a possibilidade de incluir no campo de sua competência, os recursos relativos ao dumping e aos subsídios, interpostos por pessoas físicas". O Tribunal de Primeira Instância analisa fatos e direito e, quanto aos aspectos legais, cabe recurso ao Tribunal de Justiça.

O recurso ao Tribunal de Justiça pode ocorrer em qualquer etapa da investigação antidumping. Não há cortes especializadas no tema. Conforme nos explica VOGEL ${ }^{291}$, o Tribunal de Justiça pode anular a sentença do Tribunal de

\footnotetext{
${ }^{290}$ BRASIL, Deilton Ribeiro. Tendências da legislação antidumping brasileira, norte-americana e da Comunidade Europeia em face das medidas de defesa comercial, por parte das autoridades comunitárias, do acordo geral sobre as tarifas aduaneiras e o comércio (GATT), Revista da Faculdade de Direito Milton Campos, vol. 7, Belo Horizonte, 2000, pag. 78.

${ }^{291}$ VOGEL, Joliet. Le tribunal de première instance des Communautés européennes. R.M.C. 1989, 423; Lattanzi, "Il procedimento di impugnazione", Leanza, Paone, Saggio (eds.) in KIEHL, Magda de Castro. O Recurso de Apelação para o Órgão de Solução de Controvérsias da Organização
} 
Primeira Instância e ele mesmo decidir, se for tecnicamente possível, ou devolver o caso para que o Tribunal de Primeira Instância resolva. Trata-se, portanto, de um sistema intermediário, que deixa a critério do Tribunal superior optar se decide, ou cassa a decisão, devolvendo o caso para a instância inferior.

No sistema francês $^{292}$, em específico, a contestação de atos administrativos pode ter como fundamento a falta de competência, a violação de uma exigência processual essencial ou a violação de normas legais. Com isso, a competência do tribunal fica limitada à anulação da decisão contestada.

Conforme nos explica BONNAIO ${ }^{293}$, o sistema francês se caracteriza por uma estrutura dupla: jurisdição administrativa e jurisdição judiciária. A administrativa encontra em seu topo o Conselho de Estado e a judiciária tem a Corte de Cassação. Ambas são responsáveis pela uniformidade da interpretação da lei e aplicação do Direito.

O Conselho de Estado é competente para participar do trabalho legislativo e analisar litígios administrativos que envolvam o governo, enquanto que a Corte de Cassação é competente para disputas entre particulares. Em caso de conflito de competência, seja positivo ou negativo ${ }^{294}$, o caso é remetido ao Tribunal de Conflitos. Importante ressaltar que o Conselho de Estado também tem poder para cassar uma decisão das seções e tribunais administrativos (instâncias inferiores), mas poderá ela mesma, resolver a controvérsia sem reenviá-la a outra seção ou tribunal administrativo 295 .

Mundial do Comércio: exame de casos com intervenção de amici curiae. Dissertação de Mestrado. USP/2005, pag. 48.

${ }^{292}$ Os casos antidumping não são submetidos ao sistema francês, pois são de competência comunitária. Todavia, trataremos a seu respeito nessa tese com o intuito de ilustrar o sistema de cassação que, ao final, propomos à OMC.

${ }^{293}$ Premier juge au tribunal de grande instance de Paris. BONNAI, Nicolas. Les institutions judiciaries françaises. Ouvrage sous la direction de Pierre Truche, premier president honoraire de la Cour de cassation. La documentation Française, 2001, pag. 44.

${ }^{294}$ Conflito positivo seria quando ambas as cortes se consideram competentes e conflito negativo ocorre quando nenhuma das duas cortes reconhece sua competência para análise de um caso específico.

295 BONNAI, Nicolas. Les institutions judiciaries françaises. Ouvrage sous la direction de Pierre Truche, premier president honoraire de la Cour de cassation. La documentation Française, 2001, 
A Corte de Cassação foi criada em 1790 e está dividida em seis câmaras, sendo uma comercial, três civis, uma social e uma criminal. Cada caso é analisado por uma turma de três juízes. A Corte de Cassação francesa não figura como um terceiro grau de jurisdição. Ela não reanalisa o caso, mas simplesmente determina se a decisão está em conformidade ou não com a lei. Sua competência, portanto, está limitada a analisar: (i) violação da lei; (ii) ausência de base legal; (iii) falha na motivação; (iv) vícios/rejeições (“dénaturation”); (v) incompetência; (vi) inobservância de exigências formais; (vii) excesso de poder; (viii) contrariedade de julgamentos; (ix) perda de fundamentação jurídica. Conforme salienta MAGNAN $^{296}$, os quatro primeiros são os mais comuns. Os demais são extremamente técnicos e raramente suscitados.

Toda decisão da Corte de Cassação é dividida em duas partes: o motivo e o dispositivo (que é a solução - "casse et annulle" ou "rejette le pourvoi”). Algumas também trazem o dispositivo legal ou princípio de direito que está sendo interpretado ("visa"). Se a Corte rejeita seu poder, a decisão atacada se torna irrevogável e, se a Corte aceita o seu poder, constatando uma violação da lei, geralmente ela reenvia o caso para uma corte da mesma natureza que analisou o caso anteriormente. Essa nova corte reanalisa o caso (tanto os aspectos factuais e de direito), seguindo as diretrizes dadas pela Corte de Cassação ${ }^{297}$. Abaixo da Corte de Cassação estão as Cortes de Apelação, os Tribunais de grande instância e os Tribunais de Instância, como primeira fase das disputas sobre direito civil e

pag. 47: "Par ailleurs, bien plus que la Cour de cassation, le Conseil D`État dispose de la possibilité de régler lui-même l'affaire au fond si l'intérêt d’une bonne administration de la justice le justifie".

${ }^{296}$ MAGNAN, Muriel Fabre. Introduction générale au droit. L’Organisation Jurisdictionenelle. Presses Universitaires de France, 2009, pag. 236.

297 "La Cour ne constitue pas un troisième degré de jurisdiction. En effet, il ne lui appartient pas de rejuger en fait et en droit les affaires don't elle est saisie: le pourvoir en cassation tend seulement à faire censurer par la Cour de cassation la non-conformité du jugement qu'il attaque aux régles de droit. (...)Si la Cour de cassation rejette le pourvoir, la décision attaquée devient irrevocable. Si, au contraire, elle l'accueille, constatant une violation de la loi, elle ne substitute pas sa proper decision à celle qu`elle annule (sauf dans le cas de la cassation sans renvoi, quand la Cour peut appliquer elle-même la règle de droit appropriée). Elle renvoie l`affaire à une autre jurisdiction de même nature que celle qui a rendu la première decision. Cette seconde jurisdiction conserve une totale liberté d’appreciation, en fair bien sûr, mais aussi en droit. (...)” 
comercial. Vale ressaltar que as cortes de apelação analisam tanto os fatos como o direito.

Conforme nos ensina MAGNAN ${ }^{298}$, não há nada que impeça que o mesmo caso volte para a Corte de Cassação. Mas, dessa vez, a Assembléia Plenária da corte analisará o caso. Outro aspecto interessante salientado pelo autor é que o recurso à Corte de Cassação não tem efeito suspensivo, ou seja, a decisão é executada, ao menos que possa ser irreversível (como no caso de divórcio, por exemplo). Esse fato afasta os recursos que teriam por objetivo meramente protelar a execução da sentença. Além disso, uma terceira característica que diferencia esse sistema dos demais é o fato de admitir somente advogados especializados em cortes supremas (Conselho de Estado e Corte de Cassação) para representar os clientes que queiram recorrer a essas cortes. A vantagem dessa exigência é limitar o número de casos (pois apenas aqueles que realmente entendam ter um direito irão recorrer a essa via), e garantir a qualidade das discussões à luz da especialização dos advogados.

Nos EUA, pode-se recorrer à Corte de Comércio Internacional (Court of International Trade - "CIT" na sigla em inglês) e, as decisões da CIT podem ser apeladas para a Corte de Apelação do Circuito Federal (Court of Appeals for the Federal Circuit - "CAFC” na sigla em inglês) ${ }^{299}$.

Conforme salientado por REEDER 300 , "um julgamento final seja da CIT ou da CAFC pode resultar em uma liberação direta para a parte vencedora na forma, por exemplo, de uma revogação ou restabelecimento de uma medida antidumping ou mesmo em redução ou aumento da margem de dumping".

\footnotetext{
${ }^{298}$ MAGNAN, Muriel Fabre. Introduction générale au droit. L’Organisation Jurisdictionenelle. Presses Universitaires de France, 2009, pag. 235.

${ }^{299}$ Para uma visão completa sobre o histórico da legislação antidumping aplicável nos EUA, vide MARKS, Matthew. United States Antidumping Laws - a government overview. Antitrust Law Journal, 580, 1973-1974.

300 REEDER, Caasey. Zeroing in on Charming Betsy: How An Antidumping Controversy Threatens To Sink The Schooner, Stetson Law Review, Vol. 36, 2007, pags. 255-291. "a final judgment from either the CIT or CAFC can result in direct relief for the prevailing party in the form of, for example, the revocation or reinstitution of an antidumping order or the reduction or increase in a dumping margin."
} 
De 1999 até o presente momento, foram apresentados à CIT 1.342 casos antidumping $^{301}$. Desses casos, podemos dizer que praticamente todos (1.226, de acordo com dados da página eletrônica da $\mathrm{CIT}^{302}$ ) questionavam posicionamento do USDOC, portanto, relativo ao cálculo do dumping e/ou nexo causal. Questionando prática da USITC, encontramos 498 casos $^{303}$. Portanto, em quase 400 disputas foram questionados aspectos tanto relativo ao dumping como ao dano. Daí concluimos que a prática do USDOC é mais contestada do que a prática da USITC. Interessante constatar também que, dos 1.226 casos envolvendo o USDOC na CIT, podemos dizer que houve reenvio para a instância inferior em $822^{304}$.

Quanto à CAFC, desde $2004^{305}$ foram $1.065 \operatorname{casos}^{306}$ sobre antidumping. Lembrando que as estatísticas da CIT são desde 1999, podemos concluir que: (i) o número de casos antidumping nos últimos anos aumentou significativamente; e (ii) a maioria dos casos decididos pela CIT são apelados para a CAFC.

\footnotetext{
301 Pesquisa concluída com base em dados disponíveis em http://www.cit.uscourts.gov:8080/query.html?op $0=\% 2 B \& \mathrm{fl} 0=\& \operatorname{ty} 0=w \&$ tx $0=$ antidumping \&op $1=\%$ 2B\&fl1=\&ty $1=$ w\&tx $1=\& o p 2=-$ $\& \mathrm{fl} 2=\& \mathrm{ty} 2=\mathrm{w} \& \mathrm{tx} 2=+\& \mathrm{dt}=\mathrm{an} \&$ inthe $=604800 \& \mathrm{ady}=26 \& \mathrm{amo}=6 \& \mathrm{ayr}=2012 \& \mathrm{bdy}=4 \& \mathrm{bmo}=7 \& \mathrm{byr}=$ 2012\&tp=any\&nh=10\&rf=1\&lk=1\&sc=0\&charset=iso-8859-1\&ql=a\&col=www. Último acesso em $01 / 07 / 12$.

302 Pesquisa concluída com base em dados disponíveis em http://www.cit.uscourts.gov:8080/query.html?op $0=\% 2 B \& \mathrm{fl} 0=\& \operatorname{ty} 0=w \&$ tx $0=$ antidumping \&op $1=\%$ 2B\&fl1=\&ty $1=$ w\&tx $1=+$ Department + of + Commerce\&op2=-

$\& \mathrm{fl} 2=\&$ ty $2=$ w $\& \mathrm{tx} 2=+\& \mathrm{dt}=\mathrm{an} \&$ inthe $=604800 \& \mathrm{ady}=26 \& \mathrm{amo}=6 \& \mathrm{ayr}=2012 \& \mathrm{bdy}=4 \& \mathrm{bmo}=7 \& \mathrm{byr}=$ 2012\&tp=any\&nh=10\&rf=1\&lk=1\&sc=0\&charset=iso-8859-1\&ql=a\&col=www . Último acesso em $01 / 07 / 12$.

303 Pesquisa concluída com base em dados disponíveis em http://www.cit.uscourts.gov:8080/query.html?op0=\%2B\&fl0=\&ty0=w\&tx0=antidumping\&op $1=\%$ 2B\&fl $1=\&$ ty $1=$ w\&tx $1=$ International + Trade + Commission \&op $2=-$

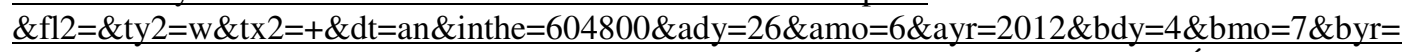
$2012 \& \mathrm{tp}=\mathrm{any} \& \mathrm{nh}=10 \& \mathrm{rf}=1 \& \mathrm{k}=1 \& \mathrm{sc}=0 \& \mathrm{charset}=\mathrm{iso}-8859-1 \& \mathrm{ql}=\mathrm{a} \& \mathrm{col}=\mathrm{www}$. Último acesso em $01 / 07 / 12$.

304 Pesquisa concluída com base em dados disponíveis em http://www.cit.uscourts.gov:8080/query.html?op $0=\% 2 B \& f 10=\& \operatorname{ty} 0=w \& t x 0=$ antidumping \&op $1=\%$ 2B\&fl1=\&ty $1=w \& t x 1=+$ department + of + commerce \&op $2=\% 2 B \& f 12=\& t y 2=w \& t x 2=+$ remand $+\& d t$ $=$ an $\&$ inthe $=604800 \& \mathrm{ady}=27 \& \mathrm{amo}=6 \& \mathrm{ayr}=2012 \& \mathrm{bdy}=5 \& \mathrm{bmo}=7 \& \mathrm{byr}=2012 \& \mathrm{tp}=$ any $\& \mathrm{nh}=10 \& \mathrm{rf}$ $=1 \& \mathrm{k}=1 \& \mathrm{sc}=0 \& \mathrm{charset}=\mathrm{iso}-8859-1 \& \mathrm{ql}=\mathrm{a} \& \mathrm{col}=\mathrm{www}$. Último acesso em 01/07/12.

305 ano do caso mais antigo acusado na pesquisa.

${ }^{306} \mathrm{http}$ ://www.cafc.uscourts.gov/opinions-orders/0/cit/all.html.
} 
Nos EUA, o Judiciário dá grande deferência às medidas tomadas por autoridades administrativas domésticas, sobretudo a partir da década de 80 com o caso da Suprema Corte Chevron USA Inc. v. National Resources Defense Council Inc. ${ }^{307}$. Trata-se de caso paradigmático a partir do qual se instituiu a doutrina Chevron. Por essa doutrina, em caso de ambiguidade da norma, e admissibilidade de duas ou mais interpretações, permite-se que se opte pela que melhor lhe convém, na linha do disposto no Artigo 17.6(ii) do ADA como vimos no capítulo sobre a "função judiciária da OMC".

A doutrina Chevron está baseada na presunção de que, para que o governo possa exercer sua função de forma apropriada, o legislativo deve tomar decisões políticas, seja por meio de mandamentos diretos legais, seja por comandos dos órgãos e agências criadas, e por ele controladas (poder delegado). De acordo com esse padrão, o papel das cortes seria de meramente avaliar a razoabilidade da interpretação dada pelo órgão/agência, exercício que não precisa concluir se a interpretação dada era a única permitida. Não cabe às cortes imporem a sua interpretação, por entenderem ser mais apropriada. Notamos ser exatamente o objetivo por trás do Artigo 17.6 do ADA.

À luz dessa teoria, a CAFC sustentou que deve ser dada ao USDOC discricionariedade na aplicação não apenas dos regulamentos, mas também das metodologias, incluindo o zeramento ${ }^{308}$.

No caso Serampore ${ }^{309}$, julgado em 1987, a Suprema Corte dos EUA entendeu que o zeramento permite combater o "masked dumping" (prática pela

\footnotetext{
307 "Chevron itself dealt with whether a regulation promulgated by the Environmental Protection Agency was based on a reasonable interpretation of a provision of the Clean Air Act Amendments of 1977".

308 "The CAFC has held that the Department of Commerce has broad discretion in executing domestic antidumping law, and that such discretion is subject to Chevron deference. This deference has been described as the deference due to the "masters of the subject." Most importantly, the CAFC has specifically held that courts should afford Chevron deference to the Department of Commerce's determinations in antidumping investigations. The court has also noted that such deference is due even when the agency action at issue is not a formal regulation, but a methodology. United States courts have universally held that the Chevron standard applies to judicial review of the Department of Commerce's use of zeroing in antidumping investigations".
} 
qual um produtor de diversos produtos pratica dumping esporádico em cada um dos produtos, na esperança que, ao final do período, não se consiga apurar margem de dumping positiva). Portanto, a Corte entendeu que o zeramento seria uma prática condizente com o $\mathrm{ADA}^{310}$.

Desde o caso Bowe Passat ${ }^{311}$ em 1996, a CIT também tem reconhecido que, pelo fato de a lei ser omissa quanto à permissividade ou não do zeramento das margens negativas, essa prática do USDOC é permitida.

De outro lado, apesar de menos preponderante, veio também se desenvolvendo a doutrina Charming Betsy, criada em 1804 no caso da Suprema Corte Murray v. Schooner Charming Betsy. Essa doutrina sustenta que nenhuma interpretação pode ser considerada permitida se violar compromissos assumidos internacionalmente pelos $\mathrm{EUA}^{312}$.

Uma relação entre a doutrina Chevron e a Charming Betsy pode ser encontrada em DeBartolo Corp. v. Florida Gulf Coast Building \& Construction Trades Council $^{313}$, caso em que a Suprema Corte dos EUA reconheceu que a doutrina Chevron não é absoluta, e que deve ser aplicada à luz dos princípios constitucionais. A Suprema Corte, nesse caso, fez referência expressa à doutrina Charming Betsy para suportar seu entendimento ${ }^{314}$.

\footnotetext{
${ }^{309}$ Serampore Indus. v. U.S. Dept. of Com., 675 F. Supp. 1354, 1361 (CIT 1987) .

310 "without zeroing, a foreign producer who exports multiple products to the United States would be able to "mask" significant dumping of one product simply by making other sales at fair value in the hope that the respective dumping margins of both products would cancel each other out."

${ }^{311}$ Bowe Passat Reinigungs-Und Waschereitechnik GMBH v. U.S., 926 F. Supp.1138, 1150 (CIT 1996).

312 "The canon of statutory interpretation known as the Charming Betsy doctrine was first advanced in 1804 by the United States Supreme Court in Murray v. Schooner Charming Betsy. The canon states that an act of Congress ought never to be construed to violate the law of nations if any other possible construction remains."

${ }^{313}$ Edward J. Debartolo Corp. V. Florida Gulf Coast Building \& Construction Trades Council Et Al. 485 U.S. 568 (1988). Certiorari to the United States Court Of Appeals for the Eleventh Circuit. No. 86-1461.

314 "in which the United States Supreme Court recognized that Chevron deference is not absolute and may, in certain cases, yield to other constitutional concerns. The Court specifically mentioned the rationale underlying the Charming Betsy doctrine as one such "serious constitutional problem" that might justify the invalidation of an agency action despite the fact that such action would ordinarily be entitled to Chevron deference".
} 
Essa conclusão é similar à que os painéis do NAFTA ${ }^{315}$ (sigla em inglês para North American Free Trade Agreement) têm chegado. Eles constatam que as cortes estadunidenses têm relutado em aplicar a teoria Charming Betsy aos casos de zeramento sob o argumento de que o ADA não proíbe expressamente essa prática e, portanto, essa metodologia não violaria os compromissos assumidos pelos EUA na $\mathrm{OMC}^{316}$. Entretanto, os painéis do NAFTA têm aplicado a teoria Charming Betsy e reenviado o caso para o USDOC, com a expressa ordem para que recalculem a margem de dumping sem zeramento.

Uma vez iniciada uma disputa perante o NAFTA, que até hoje analisou 32 casos antidumping ${ }^{317}$, a CIT não tem mais jurisdição sobre a matéria ${ }^{318}$. Tanto a CIT como um painel do NAFTA aplicam a legislação dos EUA ${ }^{319}$. Nos casos envolvendo medida antidumping mexicana, o painel do NAFTA aplica as regras mexicanas, e nos casos envolvendo medida canadense, aplica as normas do Canadá.

O painel do NAFTA deve observar estritamente o padrão de revisão estabelecido por cada um desses países, quais sejam, conforme devidamente alterados:

(a) no caso do Canadá, a subseção 18.1(4) do Federal Court Act ${ }^{320}$;

\footnotetext{
315 Acordo de Livre Comércio da América do Norte. Para fins dessa tese, em razão da consolidação do termo na prática internacional, utilizaremos a sigla em inglês.

316 "United States courts have been extremely reluctant to apply the Charming Betsy doctrine in zeroing cases. The courts generally justify their refusal to apply the canon by holding that zeroing is not in direct conflict with an international obligation because the Antidumping Agreement does not explicitly prohibit zeroing".

${ }^{317}$ Conforme pesquisa feita em www.nafta-sec-alena.org. Último acesso em 30/06/2012.

${ }^{318}$ WALDERS, Lawrence R. e PRATT, Neil C., Trade Remedy Litigation-Choice of Forum and Choice of Law, 18 St. John's J. Leg. Comment, 2002, pags, 51-53.

${ }^{319}$ Artigo 1904.3 do NAFTA.

320 "The Federal Court may grant relief under subsection (3) if it is satisfied that the federal board, commission or other tribunal

(a) acted without jurisdiction, acted beyond its jurisdiction or refused to exercise its jurisdiction;

(b) failed to observe a principle of natural justice, procedural fairness or other procedure that it was required by law to observe;

(c) erred in law in making a decision or an order, whether or not the error appears on the face of the record;

(d) based its decision or order on an erroneous finding of fact that it made in a perverse or capricious manner or without regard for the material before it;
} 
(b) no caso dos EUA:

(i) a seção 516A(b)(1)(B) do Tariff Act of 1930; e

(ii) em caso de negativa quanto ao início de uma revisão nos termos da seção 751(b) do Tariff Act of 1930, o padrão de revisão estabelecido na seção 516A(b)(1)(A) do Tariff Act of 1930;

c) no caso do México, o Artigo 238 do Código Fiscal de la Federación ${ }^{321}$.

Cumpre ressaltar que o NAFTA dispõe de três mecanismos diversos para solução de controvérsias:

(i) Capítulo 11 - disputas sobre investimentos;

(ii) Capítulo 19 - disputas sobre antidumping e medidas compensatórias; e

(iii) Capítulo 20 - disputas entre partes em geral.

Os procedimentos do Capítulo 19 admitem que seja estabelecido um painel bilateral para revisar decisões antidumping ou medidas compensatórias dos órgãos administrativos nacionais dos seus Estados membros, como um substituto para a revisão judicial nacional. A única exigência é que o painel do NAFTA observe o mesmo padrão de revisão dos tribunais do país cuja decisão está sendo contestada, conforme descrito acima.

Geralmente o painel é composto por cinco membros e o prazo para solução das controvérsias é de 315 dias, mas esse prazo não tem sido observado. O painel poderá confirmar a decisão, ou devolver o processo ao órgão administrativo nacional, para que decida seguindo o entendimento do painel. Como sustenta WALDERS $^{322}$, esse sistema pode resultar em múltiplos reenvios, mas força a adequação da medida.

(e) acted, or failed to act, by reason of fraud or perjured evidence; or $(f)$ acted in any other way that was contrary to law".

321 "Las autoridades de la Administración Pública Federal, tendrán acción para controvertir una resolución administrativa favorable a un particular cuando estime que es contraria a la ley."

${ }^{322}$ WALDERS, Lawrence R. e PRATT, Neil C., Trade Remedy Litigation-Choice of Forum and Choice of Law, 18 St. John's J. Leg. Comment, 2002, pag. 56:"This system often results in multiple remands although, in theory, the agency will eventually be forced to come into compliance with the panel decision". 
A decisão do painel do NAFTA é vinculante e não pode ser contestada nos tribunais nacionais ${ }^{323}$. Todavia, de acordo com o Artigo 1904.13 do NAFTA, as decisões poderão se sujeitar à apreciação do Comitê de Contestação Extraordinário, unicamente nas seguintes hipóteses:

“(i) Um membro do painel é culpado de má conduta intencional, preconceito, ou sério conflito de interesse, ou de outra forma violou substancialmente as normas de conduta;

(ii) O painel se desviou de uma regra processual fundamental; ou

(iii) O painel manifestamente excedeu seus poderes, autoridade ou jurisdição, estabelecidos neste Artigo, por exemplo, ao deixar de aplicar o padrão adequado de revisão".

KIEHL $^{324}$, citando HORLICK e DEBUSK, resume que esse procedimento de revisão de natureza extraordinária "se limita a examinar questões tais como o excesso de poder e a má conduta de membro do Grupo Especial". REEDER ${ }^{325}$ salienta que essas hipóteses são muito limitadoras, tendo apenas três casos sido analisados por esse comitêt $\hat{e}^{326}$. Um dos casos foi o Softwood Lumber, em que se discutiu o zeramento, posteriormente também no âmbito da OMC.

Além disso, para que seja possível o recurso ao Comitê de Contestação Extraordinário deve ser demonstrado o nexo de causalidade, ou seja, que as condutas acima afetaram a decisão. O Comitê de Contestação Extraordinário será composto ad hoc por um juiz ou ex-juiz federal de cada um dos países do NAFTA.

\footnotetext{
${ }^{323}$ Artigo 1904.11 do NAFTA.

${ }^{324}$ HORLICK e DEBUSK. Dispute Resolution under NAFTA. 27 J. World Trade, 2lff (1993), para. 8(f)(II), pag. 39.

${ }^{325}$ REEDER, Caasey. Zeroing in on Charming Betsy: How An Antidumping Controversy Threatens To Sink The Schooner, Stetson Law Review, Vol. 36, 2007.

326 Gray Portland Cement \& Clinker from Mexico, ECC-2000-1904-01USA (30 de outubro de 2003); Pure Magnesium from Canada, ECC-2003-1904-01USA (7 de outubro de 2004); Certain Softwood Lumber Products from Canada, ECC-2004-1904-01USA (10 de agosto de 2005).
} 
O Comitê não analisa nenhuma questão de mérito e, apenas determina a anulação ou não da decisão do painel bilateral, devolvendo-a para nova determinação, na linha do sistema de cassação.

Para recurso a mecanismos plurilaterais em geral, pode ser exigido que tenha se esgotado os remédios administrativos e/ou judiciários locais. KIEHL ressalta que "a única exceção a este padrão bem estabelecido pode ser o mecanismo especial estabelecido pelo NAFTA em matérias relacionadas a antidumping e medidas compensatórias. Os painéis arbitrais estabelecidos em tais casos são chamados para rever as decisões finais de autoridades administrativas nacionais nesta área e substituir as jurisdições nacionais neste particular".

No caso do MERCOSUL, o Protocolo de Olivos de 2002 criou o Tribunal Permanente de Revisão do Mercosul que tem poderes mais amplos que o Órgão de Apelação da OMC, uma vez que pode ser acionado como primeira e única instância devendo apreciar, além das questões legais, também os fatos ${ }^{327}$. Sob esse Protocolo, ainda não tivemos disputas antidumping. O único caso antidumping no âmbito do MERCOSUL foi relativo a medidas argentinas contra o frango brasileiro $^{328}$. As conclusões principais foram:

(i) Há jurisdição para conhecer e resolver sobre o objeto da controvérsia apresentada;

\footnotetext{
${ }^{327}$ Artigo 23 - "Acesso direto ao Tribunal Permanente de Revisão : "1. As partes na controvérsia, culminado o procedimento estabelecido nos artigos 4 e 5 deste Protocolo, poderão acordar expressamente submeter-se diretamente e em única instância ao Tribunal Permanente de Revisão, caso em que este terá as mesmas competências que um Tribunal Arbitral Ad Hoc, aplicando-se, no que corresponda, os Artigos 9, 12, 13, 14, 15 e 16 do presente Protocolo. 2. Nessas condiçães, os laudos do Tribunal Permanente de Revisão serão obrigatórios para os Estados Partes na controvérsia a partir do recebimento da respectiva notificação, não estarão sujeitos a recursos de revisão e terão, com relação às partes, força de coisa julgada."

${ }_{328}$ Laudo 04, de 21.05.2001 - Tribunal Permanente de Revisão. Laudo do Tribunal Arbitral Ad Hoc do MERCOSUL constituído para decidir sobre a controvérsia entre a República Federativa do Brasil e a República Argentina sobre a aplicação de medidas antidumping contra a exportação de frangos inteiros, provenientes do Brasil, (RES. 574/2000) do Ministério de Economia da República Argentina. Disponível em http://www.tprmercosur.org/pt/docum/laudos/bras/Laudo_br_04_es_Aclarac_pollos.pdf, último acesso em 3/07/12.
} 
(ii) Não há razão à parte reclamante, que solicita que se declare o descumprimento pela parte reclamada das normas do Marco Normativo e que ordene a revogação da Resolução impugnada;

(iii) Não há razão à parte reclamada, que solicita que se ratifique que a norma nacional argentina é a única e exclusivamente aplicável no caso dos autos.

Apesar de não estarem vigentes as regras antidumping elaboradas no MERCOSUL, conforme descrito no capítulo sobre histórico no âmbito regional, o tribunal arbitral considerou que poderia analisar o pleito com base nas regras sobre livre circulação de bens. Todavia, quanto à alegação de que houve abuso de poder na condução da investigação argentina, não poderia opinar. O Brasil, então, levou o caso para análise do DSB, que condenou a medida argentina à luz do $\mathrm{ADA}^{329}$.

${ }^{329}$ Argentina - Poultry. DS 241 - para detalhes vide Apêndice 3 (painel). 


\title{
PARTE II C - SIMILARIDADE
}

\section{Capítulo 10 - SIMILARIDADE ENTRE AS "FUNÇÕES JUDICIÁRIAS” DA OMC E DO BRASIL}

Conforme sustenta LEONOR CORDOVIL ${ }^{330}$, "a OMC é um sistema basicamente contratual e intergovernamental (...). O papel dos julgadores na OMC é contratual, diferentemente do papel atribuído a um juiz nacional pela constituição, consistindo em um exame mecânico sobre a concordância da ação do Membro com as obrigações que ele assumiu. Considerações de separação e balanço de poderes, que seriam critérios de revisão nacionais, não têm espaço na OMC. A interpretação das regras à luz de princípios constitucionais encontrados em sistemas domésticos é limitada. Assim, a soberania nacional não limita, de plano, uma análise da medida adotada pelo Membro."

Esse entendimento está pautado em citação de MATTHIAS OESCH ${ }^{331}$ sobre o caso Japan - Alcoholic Beverages (DS 8), que assim dispõe:

\begin{abstract}
"O Acordo da OMC é um tratado internacionalmente equivalente a um contrato. No exercício de sua soberania e na busca de seus interesses nacionais, os Membros da OMC fizeram uma barganha. Em troca dos benefícios que esperam como Membros da OMC, eles acordaram em exercer sua soberania de acordo com os compromissos que assumiram no Acordo da OMC."
\end{abstract}

\footnotetext{
${ }^{330}$ CORDOVIL, Leonor. O interesse público no antidumping. Tese de Doutorado. USP/2009.

331 OESCH, Matthias. Standards of Review in WTO Dispute Resolution. Oxford: Oxford University Press, 2003.
} 
Dessa forma, podemos concluir que o juiz teria legitimidade para analisar o interesse público na aplicação de uma medida antidumping enquanto que o DSB não teria.

CARLA JUNQUEIRA $^{332}$ lembra que se cada Membro da OMC exigisse que a OMC interpretasse os acordos abrangidos da mesma maneira feita pelas suas autoridades domésticas, haveria uma multiplicação de interpretações a respeito da mesma regra, o que acarretaria imprevisibilidade e insegurança, contrárias à finalidade principal do sistema.

ZANDAVALI ${ }^{333}$ critica a possibilidade de se recorrer ao Judiciário por descumprimento das regras da OMC, sem que um Membro tenha levado o caso para o sistema de solução de controvérsias da Organização. A isso chama de efeito direto. A principal razão trazida pelo autor é o fato de o sistema da OMC não ser retroativo e não exigir o cumprimento imediato das recomendações, deixando para a soberania dos Estados definir a melhor forma de implementação. Admitindo o efeito direto, estaríamos retirando essa prerrogativa do Estado e diminuindo os direitos negociados entre os Membros.

O autor, valendo-se do exemplo da compensação e retaliação, salienta que "eventual intervenção do juiz nacional acabaria por impedir o Estado infrator de utilizar-se de tais instrumentos, em evidente descompasso com as disposições do ESC". Cita que um juiz pode determinar indenização por danos sofridos, ou mesmo a devolução de um tributo cobrado em violação ao princípio do tratamento nacional, enquanto que a OMC não poderia. Portanto, o Judiciário imporia ao Executivo uma obrigação além das assumidas perante a OMC.

Todavia, compartilhamos do mesmo entendimento apenas se para defender interesses da União em descumprir compromissos assumidos. Do ponto

\footnotetext{
332 JUNQUEIRA, Carla Amaral de Andrade. A técnica interpretativa do Órgão de Apelação da Organização Mundial do Comércio. Tese de Doutorado. USP/2010, pag. 73.

333 ZANDAVALI. Marcelo Freiberger. O juiz brasileiro e as normas da OMC: o caso da importação de automóveis usados. Dissertação de Mestrado, USP/2008, pag 89.
} 
de vista do setor privado, é imprescindível que se recorra ao Judiciário para exigir o cumprimento das regras da OMC. As regras da OMC são leis brasileiras, uma vez que foram devidamente internalizadas em nosso ordenamento jurídico. Cabe ao juiz aplicá-las. O juiz, diante de um caso concreto, analisará qual a lei aplicável e poderá aplicar as regras da OMC, conforme internalizadas no Brasil. Portanto, um juiz poderia analisar, por exemplo, um pleito da indústria doméstica para que um subsídio proibido fosse revogado pelo governo, ou que uma medida sanitária fosse imposta conforme os padrões internacionais. Nesses casos, a lei a ser aplicada pelo juiz é o ASMC e o Acordo sobre Medidas Sanitárias e Fitosanitárias, conforme aprovados pelo Decreto Legislativo no 30, de 15 de dezembro de 1994 e promulgados pelo Decreto 1355/94. Essa possibilidade de recurso ao Judiciário não estaria tolhendo nenhum direito negociado no âmbito da OMC e estaria em conformidade com o princípio constitucional da inafastabilidade do Poder Judiciário. Essa possibilidade estaria, ainda, por meio da máquina administrativa interna, contribuindo para que os objetivos multilaterais do comércio fossem alcançados.

Entendemos que, conforme preocupação de ZANDAVALI, a grande diferença estaria no caráter do mandamus. A OMC não é uma organização supranacional, e não tem como interferir na soberania de seus Membros. Ao passo que a OMC emite meras recomendações, que apesar de peso diplomático, não conferem força vinculante, o Poder Judiciário decide, e suas decisões têm força executória. Portanto, se um juiz aplica uma norma da OMC, e decide que a União está violando suas obrigações, o juiz tem ferramentas para fazer com que a União, imediatamente, cesse a prática ilegal (por exemplo, com uma liminar para liberação de mercadoria apreendida irregularmente no porto no momento do desembaraço aduaneiro).

Entretanto, no que tange a antidumping, o autor reconhece que a lógica seria um pouco diversa. Nessas circunstâncias, "vê-se restringido o poder judicial de interpretação nos casos em que (...) a regra ordinária é vazada em linguagem vaga, imprecisa, situação em que avulta a alta carga de discricionariedade 
conferida ao destinatário da regra" ${ }^{, 334}$.O autor continua com afirmação que é de extrema relevância para a presente tese, qual seja: "Nesta última situação, em que a amplitude da linguagem empregada pelo legislador revela a liberdade de interpretação conferida ao destinatário da norma, a interferência judicial somente poderia se dar em casos excepcionais, quando a opção escolhida pelo aplicador da regra implicasse afronta à razoabilidade ou à proporcionalidade, desviando-se do 'substantive due process of Law..”

O destinatário da norma da OMC é o Estado, e não os particulares. O Brasil, enquanto destinatário das regras estabelecidas no ADA, tem ampla margem de discricionariedade para aplicá-la.

Conforme já mencionado, em razão do padrão de revisão diferenciado para os casos antidumping, o painel da OMC deve analisar simplesmente se a autoridade investigadora nacional estabeleceu os fatos de maneira apropriada, e fez uma análise imparcial e objetiva. O painel não analisa o dumping, nem tampouco deve buscar outras informações para prover uma solução que entenda mais correta para o caso. Trata-se de um controle da discricionariedade. Assim, ao final de uma disputa antidumping na OMC, o DSB recomenda apenas que a autoridade investigadora coloque a sua medida em conformidade com os compromissos assumidos, o que se dará com a revogação ou reforma dos atos administrativos.

Quando um particular recorre ao Judiciário para exigir, por exemplo, que a Administração Pública revogue uma medida antidumping, ou reduza a sobretaxa aplicada, o juiz tampouco está autorizado a analisar o dumping (que é prática de estrangeiro, fora de sua jurisdição) ou buscar informações para prover uma solução que entenda mais correta para o caso (pois adentraria ao mérito, tirando do executivo o juízo de conveniência e oportunidade). Cabe ao juiz simplesmente analisar se a autoridade administrativa agiu dentro da legalidade, de forma

334 ZANDAVALI, Marcelo Freiberger. O juiz brasileiro e as normas da OMC: o caso da importação de automóveis usados. Dissertação de Mestrado. USP/2008, pag. 67 
imparcial e objetiva. Trata-se, também, de um controle da discricionariedade. Assim, ao final de uma ação judicial, o juiz decide apenas se a autoridade investigadora agiu ou não dentro dos parâmetros da lei. Caso não tenha agido, determina que a medida seja revogada ou reformada.

Portanto, sobretudo, em razão da limitação de competência e objetivo, a “função judiciária da OMC" e do Brasil, em matéria antidumping, são muito semelhantes.

Isso posto, e considerando o caráter decisório e vinculante do Judiciário nacional, seria mais efetivo que os particulares afetados por uma medida antidumping, sejam eles nacionais ou estrangeiros, recorram ao Judiciário nacional. Para tanto, não seria necessário nenhuma alteração no sistema atualmente vigente. Um único aspecto a ser considerado ${ }^{335}$, à luz da falta de conhecimento técnico dos juízes, conforme apontado anteriormente, seria a criação de cortes especializadas em comércio internacional ${ }^{\mathbf{3 3 6}}$. Essas cortes teriam que prezar pela imparcialidade, pois se passassem a adotar posturas nacionalistas, tal como identificamos no caso dos EUA, não restaria ao setor privado afetado outra solução, se não convencer o seu governo a ingressar com uma disputa na OMC.

\footnotetext{
${ }^{335}$ Importante observar que o estrangeiro, se acionar o Poder Judiciário Brasileiro, deverá prover caução conforme exigido pelo Artigo 835 do Código de Processo Civil.

${ }^{336}$ A criação de uma corte especializada pode se dar por meio de um Projeto de Lei ou mesmo uma Resolução do Tribunal competente. Assim, pode-se dizer que o Tribunal Regional Federal da $4^{a}$ região poderia criá-las, em razão do número elevado de disputas sobre comércio internacional, e o Tribunal Federal Regional da $1^{\mathrm{a}}$ região, não.

Há uma discussão se a iniciativa é exclusiva do Tribunal. Há leis que dispõem que os tribunais deverão/poderão criar varas especializadas (crianças e adolescentes, por exemplo), mas a discussão também passa pela questão orçamentária. Se houver impacto no orçamento, seria preciso lei complementar. Vide jurisprudência: "Ao aplicar o precedente firmado no julgamento do HC 88660/CE (j. em 15.5.2008), no sentido de que o Poder Judiciário tem competência para dispor sobre especialização de varas, porque é matéria que se insere no âmbito da organização judiciária dos tribunais, cujo tema não se encontra restrito ao campo de incidência exclusiva da lei, já que depende da integração dos critérios estabelecidos na Constituição, nas leis e nos regimentos internos dos tribunais, (...) que a leitura interpretativa do artigo 96, I, a e d, e II, $d$, da CF, admite que haja alteração da competência dos órgãos do Poder Judiciário por deliberação do tribunal de justiça, desde que sem impacto orçamentário, eis que houve simples alteração promovida administrativamente, constitucionalmente admitida, visando a uma melhor prestação da tutela jurisdicional, de natureza especializada". HC 91024/RN, rel. Min. Ellen Gracie, 5.8.2008. (HC91024). Outros precedentes citados: HC 84056/DF (DJU de 4.2.2005); HC 84103/DF (DJU de 6.8.2004).
} 
Notamos que esse é o motivo pelo qual o DSB tem sido sobrecarregado com diversas disputas sobre o mesmo assunto, como é o caso do zeramento. Mesmo que o Congresso dos EUA continuasse se negando a alterar a legislação para deixar clara a proibição dessa prática, se a CIT e a CAFC passassem a levar menos em consideração a doutrina Chevron e dessem mais peso para a doutrina Charming Betsy ${ }^{337}$, os particulares afetados por uma medida antidumping poderiam se valer do judiciário estadunidense para anulá-los ou reformá-los sem ser necessário que seus países recorram à OMC.

Ocorre que a criação de cortes especializadas, e o recurso ao Judiciário, não resolveriam os problemas relacionados ao devido processo legal em matéria antidumping. Passemos a analisá-los para, na sequência, apresentarmos sugestões.

\footnotetext{
${ }^{337}$ Para detalhes sobre essas doutrinas, vide capítulo sobre Direito Comparado na Parte IIB Função Judiciária no Brasil.
} 


\section{PARTE III - PROBLEMAS IDENTIFICADOS E PROPOSTAS APRESENTADAS}

\section{Capítulo 11 - PROBLEMAS IDENTIFICADOS EM MATÉRIA ANTIDUMPING QUE DIZEM RESPEITO AO DEVIDO PROCESSO LEGAL}

Alguns doutrinadores, entre eles MICHAEL FINGER ${ }^{338}$, consideram que o antidumping tornou-se uma ferramenta de proteção à indústria doméstica.

Conforme defende MARIA CAROLINA MENDONÇA DE BARROS ${ }^{339}$, essa proteção seria a contrapartida ao processo de liberalização de tarifas ocorridas no âmbito do GATT e, posteriormente, da OMC: "sem esse instrumento não teria sido possível atingir o nível de liberalização tarifária que existe atualmente no mundo”. Para defender seu posicionamento, a autora cita trabalho de JOSÉ DE ARAÚJO JR. ${ }^{340}$ que traz comunicação dos EUA à OMC em que se afirma que o antidumping é um mecanismo comercial acordado pelos Membros como necessário para manter o sistema multilateral de comércio ${ }^{341}$.

BARFIELD $^{342}$, em seu livro sobre protecionismo em indústrias de alta tecnologia, demonstra o dano que investigações antidumping causam à concorrência no mercado, e a futilidade de serem utilizadas para salvar indústrias e setores não competitivos. $\mathrm{O}$ autor alega que as indústrias mais prejudicadas são as de alta tecnologia, que têm ciclos de produção curtos e produzem partes e peças no

\footnotetext{
${ }^{338}$ FINGER, Michael J (Editor). Antidumping: How it Works and Who Gets Hurt. The University of Michigan Press, 1998.

339 BARROS, Maria Carolina Mendonça. Antidumping e Antitruste: Interface Possível no Sistema Multilateral de Comércio. Tese de Doutorado. USP/2008, pag. 173.

340 TAVARES, José de Araújo J. Legal and Economic Interfaces between Antidumping and Competition Policy, dezembro 2001, disponível em http://www.seae.fazenda.gov.br/document_center/papers-and-articles/2001-1/1legalandeconomic/?searchterm=legal\%20and\%20economic\%20. Último acesso em 16/07/2012.

${ }^{341}$ WT/WGTCP/W/88, Working Group on the Interaction between Trade and Competition Policy, WTO, Communication from the United States, 28 de agosto de 1998.

342 BARFIELD, Claude. High-Tech Protectionism: The Irrationality of Antidumping Laws. Jackson (Tennessee): AEI Press, 2003, pag. 57.
} 
mundo inteiro. O autor também ressalta a "faca de dois gumes" que as medidas antidumping se tornaram ${ }^{343}$ : antes da década de 90 os maiores beneficiários eram os países desenvolvidos, enquanto hoje os países em desenvolvimento são os que mais se valem dessa medida de defesa comercial.

JALLAB e $\mathrm{KOBAK}^{344}$ detectaram que, entre 1998 e 2001, 68,2\% das investigações antidumping na Europa não tinham uma base econômica sólida, não havendo justificativas para terem sido iniciadas. Esse percentual no caso dos EUA foi de $76 \%$, chegando à conclusão que não foram iniciadas para combater o dumping, mas sim para evitar a concorrência.

BARRAL $^{345}$ aponta para a proliferação das medidas antidumping e as define como a "arma química da guerra comercial". Segundo o autor, a preferência pelas medidas antidumping pode ser explicada pela facilidade de sua aplicação, sobretudo quanto aos aspectos políticos. Esse também é o entendimento de $\mathrm{CORR}^{346}$ que denomina as medidas antidumping como "the weapon of choice for protection".

Esse aumento das investigações antidumping custa caro para o sistema, pois representa uma poderosa proteção à indústria doméstica. Graças à facilidade na sua utilização, as medidas antidumping acabam sendo aplicadas em mais oportunidades que, de direito, possíveis, causando um retrocesso ao livre comércio. Em razão da amplitude dos termos e ambiguidade da lei antidumping, é fácil constatar a existência de dumping. Dessa forma, o antidumping tornou-se uma ferramenta protecionista para manter posição no mercado, às custas do

\footnotetext{
${ }^{343}$ BARFIELD, Claude. High-Tech Protectionism: The Irrationality of Antidumping Laws. Jackson (Tennessee): AEI Press, 2003, pag. 57.

${ }^{344}$ JALLAB Mustapha Sadni e KOBAK, James B., Jr., Antidumping as Anticompetitive Practice Evidence from the United States and the European Union, J. Indus., Competition \& Trade, vol. 6, 2006, pags. 253-275.

345 BARRAL, Welber. Negociações Multilaterais, Antidumping e a Trade Policy Authority: alternativas para o Brasil. In LIMA CAMPOS, Alusio. Ensaios em Comércio Internacional. São Paulo, Editora Singular, 2005, pag. 45.

346 CORR, Christopher. Trade Protection in the New Millenium: the ascendancy of antidumping measures. Northwestern Journal of International Law \& Business, vol. 18, 1997, pag. 49.
} 
consumidor, o que justifica o fato de, entre 1990 e 2003, o comércio mundial ter crescido $80 \%$, e as medidas antidumping, o dobro ${ }^{347}$.

TAVARES e MIRANDA ${ }^{348}$ também criticam o processo antidumping. Segundo eles, "o roteiro de uma investigação antidumping sempre oferece aos exportadores a possibilidade de firmar compromissos de preços, que beneficiam unicamente exportadores e importadores, em detrimento dos consumidores. Assim, por razões pragmáticas, as normas AD tornaram-se o instrumento preferido pelos governos para conferir, em economias abertas, proteção seletiva e temporária àquelas indústrias que, por algum motivo, perderam competitividade internacional".

Concordamos com a conclusão dos autores, mas não com a premissa utilizada. As normas antidumping tornaram-se o instituto preferido pelos governos, pois atende-se aos anseios de indústrias politicamente importantes e a sobretaxa aplicada é direcionada aos cofres públicos. $\mathrm{O}$ fato de o procedimento permitir o compromisso de preços não é ruim, e não beneficia diretamente o governo (exceto quanto à suspensão da investigação, poupando atividade da Administração Pública). Entendemos que o compromisso de preços é uma ferramenta efetiva que deveria ser mais utilizada pelos exportadores para conciliar os interesses dos produtores nacionais, importadores e consumidores.

Outro problema encontrado no processo antidumping diz respeito à ausência de transparência. LEANE NAIDIN ${ }^{349}$ salienta, todavia, que, além da aplicação do menor direito ("lesser duty"), um dos aspectos positivos do

\footnotetext{
${ }^{347}$ FINGER, Michael J. e ZLATE, Andrei. Anti-dumping: Prospects for Discipline from the Doha Negotiations, November 17, 2005 in BARROS, Maria Carolina Mendonça. Antidumping $e$ Antitruste: interface possível no sistema multilateral de comércio. Tese de doutorado, USP, 2008,

pag. 180.
${ }^{448}$ ARAUJO Jr., Jose Tavares de e MIRANDA, Pedro. Antidumping e Antitruste: peculiaridades do caso brasileiro, disponível em http://www.cindesbrasil.org/site2010/index.php?option=com_jdownloads\&Itemid=14\&view=view. download\&cid=10, fevereiro de 2008, pag. 3. Último acesso em 18/06/2012.

$349 \quad$ Disponível em http://www.cindesbrasil.org/site2010/index.php?option=com_jdownloads\&Itemid=14\&view=view. download\&cid=256. Último acesso em 27/6/12.
} 
procedimento brasileiro é a transparência para abertura de investigação e determinação final. Ocorre que não há transparência nas demais etapas do procedimento.

PRUSA $^{350}$ lembra que as ferramentas modernas de proteção da indústria doméstica são menos transparentes que as tarifas, sendo questionável sua compatibilidade com as regras do GATT, uma vez que permitem um alto grau de discricionariedade.

Longo prazo para encerramento das investigações e confidencialidade das informações são outros aspectos que prejudicam o bom resultado e/ou efetividade das medidas antidumping.

MARIA CAROLINA MENDONÇA DE BARROS ${ }^{351}$, em sua obra o Direito Antidumping como arma protecionista, identifica que "o grande problema da legislação é que essa foi elaborada com vistas a proteger os concorrentes do mercado e não a concorrência em si. Desta forma, a tendência protecionista da lei é praticamente inevitável".

A autora aponta para os seguintes aspectos polêmicos do ADA:

(i) Métodos de comparação entre valor normal e preço de exportação: average to average e transaction to transaction;

(ii) Exclusão do cálculo do valor normal das vendas fora de condições normais (e consideração de todas as vendas para exportação);

(iii) Desprezo quanto às flutuações cambiais;

(iv) Cumulatividade;

(v) Provas relevantes (que deveriam visar ao benefício do usuário industrial ou consumidor final);

\footnotetext{
${ }^{350}$ PRUSA, Thomas J., The trade effect of US Antidumping Actions, working paper 5440, janeiro 1996, disponível em www.nber.org/papers/w5440, p.1. Último acesso em 18/06/12.

351 BARROS, Maria Carolina Mendonça de. $O$ direito antidumping como arma protecionista. Dissertação de Mestrado. USP/2002.
} 
(vi) Tratamento especial e diferenciado para países em desenvolvimento (cuja aplicação é nula).

Para explicar como a comparação entre a média ponderada do valor normal e o preço individual de cada exportação ("average to transaction") resulta em uma margem de dumping majorada, a autora cita o seguinte exemplo de PALMETER 352 : “no mesmo dia um exportador vendeu exatamente as mesmas quantidades de mercadorias para um mercado estrangeiro e para seu mercado doméstico, cobrando $\$ 100$ a unidade. Algumas semanas depois, esse mesmo exportador vendeu a mesma quantidade de produtos nos dois mercados a $\$ 200$ a unidade. A média ponderada do valor normal no mercado doméstico é \$150. No momento em que comparamos cada venda de exportação, a primeira venda ocorrida a $\$ 100$ seria considerada como venda com dumping, pois está abaixo da média ponderada \$150, ainda que a segunda venda tenha ocorrido a um preço acima da média ponderada, ou seja, \$200." Caso houvesse sido utilizada a comparação entre as médias dos valores normais e dos preços de exportação, ou se fosse comparada transação por transação, esse problema não ocorreria.

PALMETER ainda aponta para o fato de que o Artigo 2.4.2 do ADA descreve os métodos para cálculo das margens de dumping apenas durante a investigação e que, portanto, em caso de revisão da medida antidumping, a autoridade estaria livre para adotar a metodologia de cálculo que melhor lhe conviesse.

Essa é uma das discussões mais recorrentes nos casos sobre zeramento ${ }^{353}$, tanto que essa prática inicialmente foi admitida em revisões, mas não em investigações originais. Zeramento é a prática pela qual a autoridade investigadora zera as margens de dumping negativas resultando em um direito final inflado. Ao adotar o método transação por transação, a autoridade investigadora compara cada

352 PALMETER, David. A Commentary on the WTO Anti-Dumping Code. Journal of World Trade, v.30, n.4, Kluwer Law International, 1996, pags. 47-48.

${ }^{353}$ Para uma visão do posicionamento do DSB sobre o tema, vide ELLIS, Neil. Introductory Note to WTO Appellate Body Report: United States - Measures relating to zeroing and sunset reviews. International Law Materials, vol. 46, 2007, pag. 94. 
um dos preços de exportação em um determinado período com os valores normais de cada uma das vendas nesse mesmo período. Nas vendas em que o preço de exportação é inferior ao valor normal, apura-se uma margem de dumping positiva. Nas vendas em que o preço de exportação é superior ao valor normal, não há dumping, pois a margem apurada é negativa. Ao invés de a autoridade investigadora somar as margens negativas com as margens positivas de forma a compensar umas com as outras, a autoridade investigadora zera as margens negativas levando a uma conclusão inflada e inverídica da margem de dumping. Em algumas ocasiões, as margens negativas chegam inclusive a superar as margens positivas, o que poderia resultar na inexistência de dumping se não fosse a prática do zeramento.

ALFORD $^{354}$ sustenta que o Órgão de Apelação burlou o padrão de revisão nos casos em que analisou o zeramento. Também criticando a postura do Órgão de Apelação, SPAULDING ${ }^{355}$ defende que o zeramento não é uma prática proibida à luz das regras da OMC. Mas como constatamos nessa tese, o padrão de revisão não foi violado.

Com relação à cumulatividade apontada como outro problema do processo antidumping, conforme admitido pelo ADA, as autoridades investigadoras podem agregar as importações de diversos países e verificar o impacto que o conjunto dessas importações geram para a indústria doméstica peticionária. Esse fato leva a uma probabilidade muito maior de que se chegue a uma determinação positiva de dano. Conforme sustenta PABLO BENTES ${ }^{356}$ em artigo específico sobre o tema no direito dos EUA, "mais de $50 \%$ dos casos em que a ITC decidiu afirmativamente teriam tido resultado negativo para dano caso as importações não tivessem sido cumuladas". A situação no Brasil não é diferente.

\footnotetext{
${ }^{354}$ ALFORD, Roger P., Reflection on US - Zeroing: A Study in Judicial Overreaching by the WTO Appellate Body. Columbia Journal of Transnational Law, vol. 45, 2006-2007, pag. 196.

355 SPAULDING, Jeffrey. Do International Fences really make good neighbors? The zeroing conflict between antidumping law and international obligations. New England Law Review, vol. 41, 2006-2007, pag. 379.

356 BENTES, Pablo. A Cumulatividade na determinação de dano à industria doméstica norteamericana. In LIMA CAMPOS, Aluisio. Ensaios de Comércio Internacional, Editoria Singular, São Paulo, 2005, pag 110.
} 
Alguns outros problemas da legislação em vigor, que interferem diretamente no cálculo da medida antidumping a ser aplicada, e consequentemente no devido processo legal pois desconsideram o interesse público, seriam as possibilidades de amostragem, construção do valor normal e utilização da melhor informação disponível. Essas hipóteses levam, em regra, a resultados inflados de margem de dumping que não correspondem à realidade e contrariam, portanto, os interesses em jogo no comércio internacional.

No que diz respeito à amostragem, o fato de ser aplicada às empresas não selecionadas uma medida antidumping em valor que corresponde à média ponderada das empresas selecionadas, pode levar a resultados injustos. Isso porque retira-se de exportadores que não praticam dumping a oportunidade de provarem que suas exportações não deveriam ser oneradas, aplicando a eles uma penalidade indevida.

A utilização dos fatos disponíveis, em regra apresentados pela indústria doméstica peticionária, teria como finalidade punir aqueles que não cooperaram com a autoridade investigadora. Aplicar fatos disponíveis a empresa que esteja cooperando, mas que não queira divulgar determinada informação por considerá-la confidencial, seria aplicar a lei de forma abusiva.

Apesar de a regra geral trazida pelo Artigo 13 do Decreto 1.602/95 determinar que deva ser aplicada uma margem de dumping individual para cada exportador, na prática há algumas causas que levam a autoridade investigadora a afastar a incidência desse dispositivo. $\mathrm{O}$ cálculo individualizado admite que haja dumping praticado e identificado em relação a um exportador, e não em relação a outros. Ou, que o direito aplicável a um seja menor que o direito aplicável a outro. Portanto, a medida antidumping seria aplicada apenas àqueles exportadores do país investigado que, efetivamente, pratiquem dumping, e na medida necessária para compensar o dano. 
Podemos dizer que cada exportador, contanto que tenha colaborado com a investigação, mediante o fornecimento de resposta completa ao questionário, tem a prerrogativa de ter uma medida antidumping específica aplicada, levando em consideração os seus preços de exportação e o seu valor normal. Ocorre que, em se tratando de países que não são considerados economias de mercado, essa prática se mostra mais difícil. Isso porque, conforme aponta estudo desenvolvido pela $\mathrm{UNCTAD}^{357}$, o ADA não baseia suas determinações em uma abordagem por empresa exportadora e permite que a medida seja aplicada contra o país exportador. Esse fato também dificulta a imposição de medidas em consonância com o interesse público.

Quanto ao cálculo do valor normal, deveria haver inversão da regra geral para que as vendas abaixo do preço de custo não sejam automaticamente excluídas do cálculo do valor normal. Entende-se que as vendas abaixo do custo não são vendas no curso normal do comércio, o que não é necessariamente uma verdade. Para que as margens de dumping não sejam infladas, somente vendas de produtos danificados, devolvidos ou entre partes relacionadas é que deveriam ser excluídas.

Um outro aspecto que vale ser mencionado é que não há nada na legislação brasileira que impeça que um caso seja trazido novamente para análise do DECOM caso tenha sido concluído de maneira insatisfatória para a indústria doméstica.

Por fim, em trabalho desenvolvido por ALUISIO DE LIMA$\mathrm{CAMPOS}^{358}$, ficou provado que a simples solicitação para abertura de investigação causa efeitos nevastos para as exportações do produto investigado. Conforme veremos no gráfico abaixo, mesmo em casos em que é encerrada a investigação sem imposição de medidas, as importações são retomadas apenas um ano depois:

\footnotetext{
357 Anti-Dumping and Countervailing Procedures - use or abuse? Implications for developing countries. United Nations, 2001, pag. 17.

${ }^{358}$ LIMA-CAMPOS, Aluisio de. VITO, Adriana. Abuse and Discretion: the impact of antidumping and countervailing duty proceedings on Brazilian exports to the United States. Journal of World Trade, vol. 38, n. 1, 2004, pag. 37-68.
} 


\section{Determinaçăo final de dano negativa}

\section{Impacto sobre as importações}

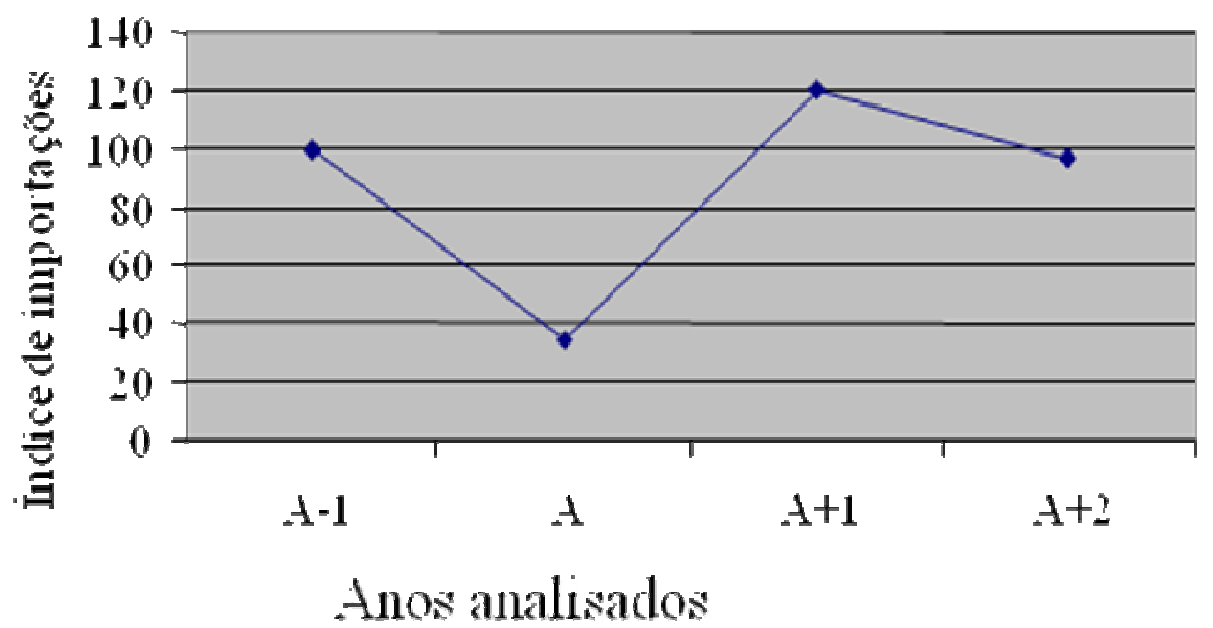

Fonte: LIMA-CAMPOS e VITO (2004)

Em casos em que a medida é aplicada, o estudo demonstra que as importações do produto sujeito à medida antidumping caem drasticamente, passando a ser praticamente inexistentes nos anos subsequentes, conforme gráfico abaixo:

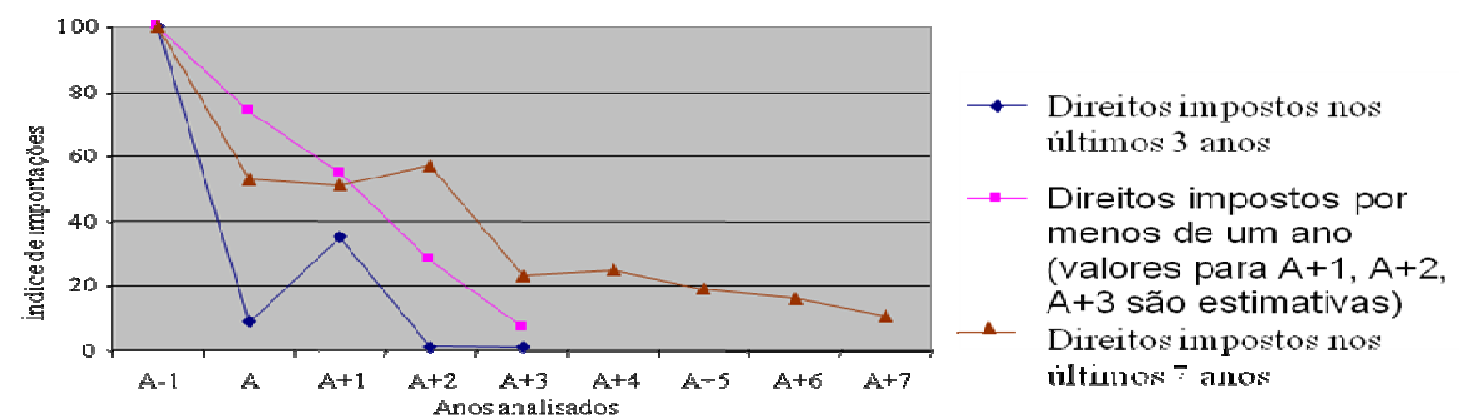

Fonte: LIMA-CAMPOS e VITO (2004)

No Brasil, como analisado anteriormente, nem sempre verificamos uma redução significativa no volume importado. Conforme apontado, provavelmente a medida antidumping não era a ferramenta adequada para o setor que buscou a sua imposição, e uma análise não tão criteriosa do nexo causal entre dumping e dano permitiu a imposição da medida. Em razão dessas, e de outras falhas no sistema, 
em 2001 foi lançado o mandato negociador de Doha para revisão do ADA e, em 2011 foi aberta no Brasil consulta pública para alteração do Decreto 1602/95. Passaremos a analisar as propostas apresentadas. 


\section{Capítulo 12 - PROPOSTAS DA RODADA DOHA}

As negociações multilaterais sobre as regras antidumping foram lançadas em 2001 no âmbito da Rodada Doha ${ }^{359}$. O mandato conferido pelos ministros determina que:

“À luz da experiência e da aplicação crescente desses instrumentos pelos Membros, concordamos em negociar com o objetivo de esclarecer e melhorar as disciplinas do Acordo Antidumping e do Acordo sobre Subsídios e Medidas Compensatórias, preservando os conceitos, princípios e efetividade básicos desses acordos e seus instrumentos $e$ objetivos, levando em consideração as necessidades dos países em desenvolvimento e de menor desenvolvimento relativo" 360 .

O primeiro ponto a se observar é que as negociações para alteração do ADA e do ASMC são realizadas conjuntamente. Esse fato dificulta ainda mais a chegada a um consenso, pois os problemas enfrentados pela aplicação do antidumping nem sempre coincidem com os problemas identificados na aplicação de medidas compensatórias, além de que os interesses dos países são diversos nessas disciplinas.

Outro ponto que chama a atenção é o fato de que as negociações têm escopo limitado. Como conferido pelo mandato acima transcrito, deve-se

\footnotetext{
${ }^{359}$ Para uma abordagem sobre as negociações durante a Rodada Uruguai, vide HORLICK, Gary. Proposals for Reform of the GATT Antidumping Code. Brooklyn Journal of International Law vol XVIII:1, 1992, pag. 181.

${ }^{360}$ Tradução livre de "In light of experience and of the increasing application of these instruments by Members, we agree to negotiations aimed at clarifying and improving disciplines under [the Agreements on Anti-Dumping and on Subsidies and Countervailing Measures], while preserving the basic concepts, principles and effectiveness of these Agreements and their instruments and objectives, and taking into account the needs of developing and least-developed participants".
} 
simplesmente esclarecer e aprimorar os Acordos, mantendo os conceitos básicos, os princípios e efetividade dos mesmos, bem como seus instrumentos e objetivos. Portanto, no âmbito da Rodada Doha, não seriam cabíveis mudanças estruturais. Ocorre que, em razão da vagueza dos termos do mandato, notamos a propositura de alterações sobre os mais diversos temas, que vão muito além do simples esclarecimento e aprimoramento dos termos do ADA.

O terceiro e último aspecto que nos chama a atenção no texto do mandato de Doha seria a negociação das propostas tendo sempre em vista os interesses dos países em desenvolvimento e de menor desenvolvimento relativo. Considerando que esses interesses não coincidem com os interesses dos países desenvolvidos, torna-se mais uma vez difícil alcançar o consenso necessário para conclusão das negociações.

Inicialmente, foram apresentadas 141 propostas $^{361}$. Elas versam sobre os mais diversos temas, cujos principais trataremos a seguir. Na metade de 2004, como uma forma de agilizar o processo negociador, solicitou-se que as propostas fossem submetidas diretamente em forma de alterações textuais aos Acordos atualmente em vigor. Muitas propostas foram apresentadas pelos Friends of Antidumping ${ }^{362}$ que buscam restringir as discricionariedades do texto do ADA no que diz respeito a procedimentos, métodos para cálculo da medida antidumping e formas de determinação do dano.

Com a proximidade da Reunião Ministerial de Hong Kong ${ }^{363}$ e tendo em vista que as negociações sobre os textos dos artigos a serem modificados se mostrou pouco efetiva, os representantes seniores dos Friends of Antidumping, sugeriram que fosse elaborada uma lista ampla dos objetivos para as negociações ${ }^{364}$.

\footnotetext{
${ }^{361}$ Documento TN/RL/W/143, datado de 22 de agosto de 2003.

${ }^{362}$ Esses países são: Brasil, Chile, Cingapura, Colômbia, Coréia do Sul, Costa Rica, Hong Kong, Israel, Japão, México, Noruega, Suíça, Tailândia e Turquia.

${ }^{363}$ Ocorrida entre 13 e 18 de dezembro de 2005.

${ }^{364}$ Documento TN/RL/W/171, datado de 15 de fevereiro de 2005.
} 
Em dezembro de 2007 o então Presidente das negociações de regras emitiu a primeira compilação das propostas ${ }^{365}$ ("Proposta de ADA"). Seis meses mais tarde, em maio de 2008, o Presidente emitiu um Documento de Trabalho refletindo os textos compilados e um resumo das opiniões dos participantes sobre cada uma das propostas de texto ${ }^{366}$.

$\mathrm{Na}$ área de antidumping, o Presidente das negociações identificou 11 questões sobre as quais não havia convergência de opiniões entre os Membros. Essas questões eram: zeramento, causa do dano, retardamento da indústria nascente, exclusão dos produtores relacionados, definição de produto investigado, solicitações de informação para partes afiliadas, interesse público e menor direito, anti-circunvenção, revisões de final de período, dumping de terceiros países e tratamento especial e diferenciado/assistência técnica.

Por outro lado, o Presidente apontou para diversos outros assuntos sobre os quais os participantes haviam chegado a um acordo, por exemplo: notificação aos governos exportadores antes do início da investigação, identificação de exportadores e produtores domésticos, confidencialidade, revisões para novos entrantes ("new shipper reviews"), procedimentos para apuração da medida antidumping, revisões de meio de período, verificações in loco e revisão das práticas e políticas antidumping dos Membros" ${ }^{\text {,367. }}$

Muitas das propostas refletem assuntos que foram objeto de discussão em casos levados ao DSB. Abaixo segue tabela na qual identificamos o assunto, o caso levado ao DSB em que o assunto foi debatido, o Membro que fez a proposta para alteração do ADA a esse respeito, e o número da proposta apresentada ao Secretariado da OMC:

\begin{tabular}{c|c|c|}
\hline Assunto & Caso & Membro propost \\
\hline${ }^{365}$ Documento TN/RL/W/213, datado de 30 de novembro de 2007. \\
${ }^{366}$ Documento TN/RL/W/232, datado de 28 de maio de 2008. \\
${ }^{367}$ Documento TN/RL/W/246, datado de 27 de novembro de 2009.
\end{tabular}




\begin{tabular}{|c|c|c|c|}
\hline Testes "de minimis" & $U S-D R A M S$ & Coréia e outros & $\begin{array}{l}\text { TN/RL/W/6 } \\
\text { TN/RL/W/83 }\end{array}$ \\
\hline $\begin{array}{ll}\text { Período } & \text { da } \\
\text { investigação } & \end{array}$ & US - Hot Rolled Steel & Japão e outros & TN/RL/W/29 \\
\hline Indústria doméstica & US - Hot Rolled Steel & Japão e outros & $\mathrm{TN} / \mathrm{RL} / \mathrm{W} / 10$ \\
\hline Fatos disponíveis & US - Hot Rolled Steel & EUA & TN/RL/W/153 \\
\hline $\begin{array}{l}\text { Taxa para outros ("all } \\
\text { others rate") }\end{array}$ & US - Hot Rolled Steel & EUA & $\mathrm{TN} / \mathrm{RL} / \mathrm{W} / 72$ \\
\hline Vendas a afiliadas & US - Hot Rolled Steel & EUA & TN/RL/W/130 \\
\hline Nexo de causalidade & US - Hot Rolled Steel & EUA & $\begin{array}{l}\text { TN/RL/W/98 } \\
\text { TN/RL/W/130 }\end{array}$ \\
\hline Fatos disponíveis & US - Steel Plates & EUA & TN/RL/W/153 \\
\hline Menor direito & US - Steel Plates & India & TN/RL/W/26 \\
\hline $\begin{array}{l}\text { Compromissos de } \\
\text { preços }\end{array}$ & US - Steel Plates & India & TN/RL/W/26 \\
\hline Fatos disponíveis & US - Steel Plates & India & TN/RL/W/26 \\
\hline $\begin{array}{l}\text { Início da revisão de } \\
\text { final de período }\end{array}$ & US-Carbon Steel & $\mathrm{EU}$ & TN/RL/W/30 \\
\hline Nexo de causalidade & Egypt-Steel Rebar & Turquia e outros & TN/RL/W/28/Rev 1 \\
\hline $\begin{array}{l}\text { Compromissos de } \\
\text { preço }\end{array}$ & $U S-O f f s e t$ Act & Brasil e outros & TN/RL/GEN/2 \\
\hline $\begin{array}{l}\text { Compromissos de } \\
\text { preço }\end{array}$ & EC-Pipe Fittings & Brasil e outros & TN/RL/GEN/2 \\
\hline Cumulatividade & EC-Pipe Fittings & Brasil e outros & TN/RL/GEN/51 \\
\hline Indústria doméstica & Argentina-Poultry & Brasil e outros & TN/RL/GEN/27 \\
\hline $\begin{array}{l}\text { Zeramento em } \\
\text { revisões }\end{array}$ & $\begin{array}{l}U S-\text { Corrosion } \\
\text { Resistant }\end{array}$ & Japão e outros & TN/RL/W/83 \\
\hline
\end{tabular}

Fonte: elaboração própria com base em tabela apresentada por Stewart e outros (2007)

A Proposta de ADA trata de alguns desses assuntos, como veremos adiante. Expressamente condena a prática do zeramento em comparações de médias ponderadas (average to average), mas admite em comparações de transações (transaction to transaction) ou de transação com média ponderada do valor normal (average to transaction). A Proposta de ADA também admite o zeramento em caso de revisão das medidas antidumping aplicáveis (Artigos 9 e 11 do ADA). Isso porque o $\mathrm{ADA}$ não determina o procedimento a ser seguido em fase de revisão e, 
como a medida antidumping já está em vigor, o dumping já deveria ter cessado, sendo o zeramento uma forma de penalizar o exportador que ainda pratica o dumping. Vale lembrar que a Proposta de ADA foi elaborada antes do posicionamento do DSB que condenou o zeramento também em revisões.

No que diz respeito a nexo de causalidade/não atribuição, no caso US Salmon $^{368}$, trazido pela Noruega ainda na época do GATT, o painel determinou que todos os fatores dos Artigos 3.2 e 3.3 do ADA devem ser levados em consideração para fins de determinação do dano, mas que não seria necessário demonstrar em que medida as importações dumpeadas foram responsáveis pelo dano. Ocorre que, o Órgão de Apelação no caso US - Hot Rolled Steel, trazido pelo Japão, estabeleceu que as autoridades investigadoras devem ir um passo além, e verificar se os efeitos danosos decorrentes dos outros fatores não são atribuídos às importações dumpeadas. A Proposta de ADA cosubstancia o posicionamento do Órgão de Apelação para deixar claro que a análise de não atribuição deve ser qualitativa e não quantitativa ${ }^{369}$. O texto proposto exemplifica como critérios de análise: natureza, extensão, concentração geográfica e análise temporal dos efeitos danosos.

Quanto ao menor direito, o Artigo 9.1 do ADA determina que os Membros da OMC devem buscar impor ("it is desirable") medidas antidumping somente na medida necessária para remover/conter o dano à indústria doméstica. Na prática brasileira, essa obrigação de aplicar o menor direito é implementada por meio da margem de subcotação. Essa margem pode também ser chamada de margem de dano. O DECOM, ao final da investigação, calcula não apenas a margem de dumping (que é a comparação do valor normal com o preço de exportação), mas também a margem de subcotação (diferença do preço CIF internado com o preço que tem sido praticado para o produto em território nacional). A Proposta de ADA contempla proposta do Brasil, CE, Índia e Friends

\footnotetext{
${ }^{368}$ ADP/87, adotado em 27 de abril de 2004.

369 “(...) While the authorities should seek to separate and distinguish the injurious effects of such other factors from the injurious effects dumped imports, they need not quantify the injurious effects attributable to dumped imports and to other factors, nor weigh the injurious effects of dumped imports against those of other factors".
} 
of Antidumping nas negociações sobre regras da OMC para tornar obrigatória, e não apenas desejável, a imposição do menor direito (na medida necessária para combater o dano). Essa também é uma das sugestões trazidas por ALUISIO DE LIMA-CAMPOS ${ }^{370}$ em texto que enumera algumas propostas para evitar abuso na aplicação das medidas antidumping. A Índia apresentou proposta para que o ADA traga metodologia detalhada de como deve ser calculado esse menor direito.

No tocante a duração e revisão das medidas antidumping, no caso US - DRAMS, a Coréia argumentou que as medidas antidumping deveriam terminar assim que a prática de dumping deixasse de existir, e poderiam voltar a ser aplicadas se na revisão de final de período fosse constatado que o exportador voltou a praticar dumping. No caso US - Carbon Steel o Japão argumentou que, para iniciar um processo de revisão, de ofício, deveriam ser observados os mesmos critérios para início de uma investigação original. Mas o Órgão de Apelação entendeu que os critérios são diversos, admitindo maior possibilidade para abertura de revisão, entendimento que manteve no caso $U S$ - OCTG. A Proposta de ADA visa impedir que o governo usufrua desse mecanismo para fins de controle de sua balança comercial e impõe a obrigação de observância dos mesmos critérios.

Outro aspecto discutido nas negociações diz respeito às medidas anticircunvenção. Vale lembrar que a tentativa de trazer por outras origens pode ser combatida pelas regras de origem, que devem ser regulamentadas e fiscalizadas de forma efetiva. No caso EEC - Parts and Components, o Japão questionou regulamento europeu que impôs sobretaxa às partes e componentes de produtos sujeitos a antidumping. Ocorre que, na ocasião, conforme salienta $\mathrm{RAI}^{371}$, os europeus utilizaram como defesa o Artigo XX do GATT e não o Artigo VI do GATT, e acabaram perdendo. A Proposta de ADA vem no sentido de regulamentar as medidas anticircunvenção.

\footnotetext{
${ }^{370}$ LIMA-CAMPOS, Aluisio. Nineteen Proposals to curb abuse in antidumping and countervailing duty proceedings. Journal of World Trade, vol. 39, n.2, 2005.

${ }^{371}$ RAI, Sheela. Analysis of the Draft Anti-Dumping Agreement, Chairperson`s Text 2007 in Light of the Jurisprudential Background. Manchester Journal of International Economic Law. Vol. 5, 2008, pags. 126-145.
} 
O ADA é omisso quanto ao tema conversão cambial. A Proposta de ADA traz alguns dispositivos para regulamentar o assunto, mas sabemos ser um assunto controverso entre os Membros, tanto que, mais recentemente, tem-se discutido na OMC se o FMI seria um foro mais adequado para buscar contrapesos à desvalorização cambial por alguns países, fato que causa um efeito direto no comércio mundial $^{372}$.

Quanto aos critérios para definição de dano e ameaça de dano, o Artigo 3.4 do ADA lista fatores a serem levados em consideração para determinação de dano, e o Artigo 3.7 do ADA lista fatores para fins de determinação de ameaça de dano. No caso Mexico - HFCS, trazido pelos EUA, o painel definiu que, para fins de determinação de ameaça de dano, tanto os fatores do Artigo 3.4 como os do Artigo 3.7 devem ser analisados. Essa conclusão decorre da interpretação do Artigo 3.1 do ADA que exige uma análise objetiva do volume importado e do impacto na indústria doméstica. Considerando que o Artigo 3.7 do ADA permite apenas uma análise do volume e preços, torna-se necessário que o Artigo 3.4 também seja analisado para determinar os efeitos na produção doméstica. A Proposta de ADA vem exatamente para codificar esse entendimento ${ }^{373}$.

\section{Com vistas a restringir os poderes dos painéis e Órgão de Apelação,}

foram apresentadas propostas tanto no âmbito das negociações de regras ${ }^{374}$ como nas negociações para revisão do $\mathrm{ESC}^{375}$. Entre as propostas, em sua maioria apresentadas pelos EUA, ressaltamos a obrigatoriedade de o Órgão de Apelação também apresentar um interim report e submetê-lo à revisão das partes em disputa. Como se sabe, somente o painel emite um interim report e submete às partes em

\footnotetext{
${ }^{372}$ Vide LIMA CAMPOS, Aluisio e GIL, Juan Antonio Gaviria. A Case for Misaligned Currencies as Countervailable Subsidies. Jwt, vol. 5, outubro, 2012, pag. 46.

373 “.... [t] [he authorities shall consider the state of the domestic industry during the period of investigation, including an examination of the impact of dumped imports upon it in accordance with paragraph 4, in order to establish a background for the evaluation of threat of material injury".

${ }^{374}$ Tabela completa com as propostas apresentadas no âmbito das negociações de regras pode ser encontrada em BARROS, Maria Carolina Mendonça. Antidumping e Antitruste: uma interface possível no sistema multilateral de comércio, Tese de doutorado. USP, 2008, pags 187 a 190.

${ }^{375}$ Tabela completa com as propostas apresentadas no âmbito das negociações para revisão do ESC pode ser encontrada em AMARAL JUNIOR, Alberto do. A Reforma do Sistema de Solução de Controvérsias da OMC e os Países em Desenvolvimento. IDCID/Ford Foundation, 2005.
} 
disputa para revisão antes de sua circulação aos demais Membros e submissão para adoção do DSB.

Entre as propostas em negociação, vale destacar, em ordem decrescente de importância: (i) aplicação por igual dos critérios em investigações e revisões, para assegurar uniformidade nas decisões e suprir a lacuna das normas tanto da OMC quanto brasileiras em relação aos procedimentos a serem seguidos em fase de revisão das medidas antidumping; (ii) determinação de "importações negligenciáveis" com base em "participação de mercado" e não um percentual do volume importado; (iii) aplicação mandatória do "lesser duty rule", pelo qual devese aplicar obrigatoriamente a menor margem possível para que o dano seja compensado; (iv) proibição do zeramento, impossibilitando que as margens de dumping sejam infladas ao serem zeradas as margens negativas; (v) expiração de direitos antidumping em cinco anos, impedindo a vigência dos mesmos por prazo indeterminado como ocorre nos EUA; e (vi) introdução de um novo procedimento pré-abertura com vistas a dificultar o pedido de investigações desprovidas de base legal com o intuito único e exclusivo de impactar as exportações do produto.

Importante reforma também seria a proposta pela Índia de criar um período de carência de um ano, por exemplo, para que um mesmo caso que tenha sido encerrado possa ser iniciado novamente. Também interessante é a proposta para que a medida antidumping seja suspensa se for aplicada uma salvaguarda para o mesmo produto. A obrigatoriedade do teste do interesse nacional, defendida pela UE, também traria grandes benefícios para o processo. 


\section{Capítulo 13 - CONSULTA PÚBLICA DO DECRETO 1602/95}

Diversas propostas foram submetidas ao DECOM em atenção à Portaria SECEX 28/11 que abriu para consultas públicas a revisão do Decreto 1602/95. Conforme solicitado pelo próprio Departamento, as propostas em geral foram apresentadas na forma de sugestão de texto. No Anexo I a essa tese elaboramos tabela que traz o texto do Decreto 1602/95 atualmente em vigor, e compila as diversas propostas de redação apresentadas para cada um dos artigos.

As propostas buscam esclarecer e limitar a discricionariedade da autoridade investigadora, dentro do acordado pelos Membros no ADA. E não poderia ser diferente: enquanto a Rodada Doha não finalizar, e alterações ao ADA não forem implementadas, o Brasil não poderá alterar sua legislação de maneira que extrapole o disposto no ADA, sob risco de ser questionado na OMC.

Cumpre ressaltar, todavia, que uma das propostas apresentadas não visava esclarecer ou aprimorar o texto do Decreto 1602/95, mas sim alterar o sistema. Ela sugere a adoção, pelo Brasil, das medidas antidumping móveis ${ }^{376}$. Medidas antidumping móveis seriam aquelas que variariam de acordo com o preço do produto. O DECOM estabeleceria uma espécie de valor mínimo para ingresso do produto no país, que seria suficiente para compensar o dano. A diferença entre o preço do produto importado e esse valor de referência seria a sobretaxa antidumping a ser paga. Esse mecanismo incentiva o aumento dos preços pelos exportadores. Os importadores continuariam a pagar a mesma quantia, só que ao invés de recolher um montante maior ao governo, pagariam mais caro ao exportador.

O Capítulo IV da Lei Antidumping Argentina (Lei 21.838) estabelece direitos antidumping movéis pelos quais o governo fixa um preço de orientação, indicativo ou de intervenção a ser assegurado à indústria doméstica e cobra a

\footnotetext{
${ }^{376}$ Proposta apresentada pela empresa Brinox.
} 
diferença com relação aos produtos a serem importados (que seria o que denominamos margem de subcotação - diferença com o valor CIF - "cost insurance and freight"). Esses direitos só podem ser aplicados em circunstâncias especiais, por meio de decreto do Poder Executivo, se comprovado que um direito ad valorem (em um percentual) não cumpriria com a finalidade. O Artigo 33 da lei justifica a criação de tal instrumento no fato de que a cobrança ad valorem não permite que as medidas antidumping (ou compensatórias) cumpram com suas finalidades. Esse fato não deixa de ser verdade, mas lembramos que os direitos específicos (expressos em um valor fixo por quantidade do produto importado) também trazem dificuldades para o alcance dos objetivos das medidas antidumping, pois onera os produtos mais baratos, geralmente de menor valor agregado (mas classificados sob a mesma nomenclatura). O Artigo 35, alínea a), da lei argentina limita a vigência desses direitos móveis a 18 meses. Caso não seja especificado, a vigência é de três meses.

O DECOM ainda não concluiu a análise das propostas mas, conforme informado, em breve deve entrar em vigor novo Decreto regulando a matéria antidumping no Brasil. 


\section{Capítulo 14 - ANÁLISE DE PROPOSTAS PARA ALTERAÇÃO DO PROCESSO ANTIDUMPING}

Tanto as sugestões dos Membros da OMC para a alteração do ADA, como as propostas apresentadas em consulta pública para alteração do Decreto 1602/95 são propostas de esclarecimento do sistema já vigente. Uma ou outra versaram sobre alteração na estrutura, mas possivelmente não serão contempladas pois extrapolam o propósito do mandato de Doha e da consulta pública. Neste capítulo, buscaremos abordar propostas que buscam alterar a estrutura do processo antidumping com vistas a observar o devido processo legal e alcançar seus reais objetivos.

BARRAL $^{377}$ defende a extinção das medidas antidumping sob a "certeza de que as medidas antidumping constituem um meio imperfeito de defender o mercado nacional". O autor baseia sua conclusão na afirmativa de CALIXTO SALOMÃO FILHO ${ }^{378}$ de que "[o] direito, como ciência, de prescrição de comportamentos, é perfeitamente finalístico. Fins confusos geram meios imperfeitos e meios perfeitos, não utilizados para consecução de seus fins, são perfeitamente inúteis".

CHAKRABORTY também sustenta a conveniência de se abolir o processo antidumping como um todo, mas alega que certamente os Membros não concordariam. Lembra que os efeitos são mais danosos em países em desenvolvimento, pois os grandes afetados têm sido os consumidores ${ }^{379}$. Todavia, essa não nos parece a solução mais adequada.

\footnotetext{
377 BARRAL, Welber. Dumping e Comércio Internacional: a regulamentação antidumping após a Rodada Uruguai, Editora Forense, Rio de Janeiro, 2000, pag. 329.

378 SALOMÃO FILHO, Calixto. Direito Concorrencial - as estruturas. São Paulo, Malheiros, 1998, pag. 266.

${ }^{379}$ CHAKRABORTY, Debashis. Misuse of Anti-Dumping Provisions: What do the WTO Disputes Reveal? In Anti-Duping Global Abuse of a Trade Policy Instrument, Academic Foundation, New Delhi, 2007, pag. 180.
} 


\section{Eliminar a regulamentação antidumping e substituí-la por regras}

antitruste, conforme defendem alguns autores da doutrina especializada ${ }^{380}$, seria submeter a análise de dumping ao mesmo orgão que analisa preço predatório no direito doméstico. A vantagem seria o enxugamento da máquina administrativa/institucional e a facilidade para a indústria, que em geral confunde os conceitos. A desvantagem, como bem aponta BARFIELD, seria que as regras antidumping não poderiam ser julgadas sob os mesmos padrões que as regras concorrenciais, uma vez que os institutos servem para tutelar objetos distintos, além de os objetivos almejados serem diversos.

Como salientado por SYKES ${ }^{381}$, "antitruste e antidumping têm a mesma origem, mas acabaram por se distanciar consideravelmente. Na atualidade, o antitruste se concentrou na busca de eficiência econômica... tratando de problemas associados à concentração de poder de mercado (...). Em contraste, as leis antidumping pretendem criar uma forma popular de monopólio... Elas não combatem o monopólio, mas protegem as indústrias em mercados fracos ou em declínio ${ }^{382}$.

Outro ponto trazido por BARFIELD ${ }^{383}$ como desvantagem para tratar os assuntos conjuntamente é que práticas que seriam consideradas legais perante as leis antitruste, se adotadas por indústria nacional, seriam consideradas injustas/desleais ("unfair") perante as normas antidumping, se adotadas por indústria estrangeira. $\mathrm{O}$ autor menciona apenas a obrigatoriedade de observar o princípio do tratamento nacional. O princípio do tratamento nacional, trazido pelo

\footnotetext{
380 Entre eles, BARFIELD, Claude. High-Tech Protectionism: The Irrationality of Antidumping Laws. Jackson (Tennessee): AEI Press, 2003, pag. 58.

381 SYKES, Alan O. Antidumping and Antitrust: What problems does each address?, In LAWRENCE, Robert Z., Brokings Trade Forum: Washington DC: The Brookings Institution, 1998, pags. 1-2.

382 "Antitrust and antidumping law come from the same family tree, but the two branches have diverged widely. In the modern era, antitrust concentrated on the pursuit of economic efficiency... address[ing] problems associated with concentrated economic power, primarily through a common law process that left to the courts much of the task of delineating the practices that violate antitrust law... By contrast, antidumping law was intended to create a politically popular form of contingent of monopoly... Likewise, the political constituency for antidumping law is not an antimonopoly constituency, but one for the protection of industries facing weak markets or long-term declines".

${ }^{383}$ BARFIELD, Claude. High-Tech Protectionism: The Irrationality of Antidumping Laws. Jackson (Tennessee): AEI Press, 2003, pag. 60.
} 
Artigo III do $\mathrm{GATT}^{384}$, é aquele que determina que as leis domésticas devem conferir o mesmo tratamento a nacionais e estrangeiros. Assim, entendemos que se tratados sob um mesmo prisma, seria ilegal afirmar que uma prática é condenável se praticada por uma indústria estrangeira e perfeitamente legal se praticada por agentes nacionais. Concordamos com a menção feita pelo autor de que, se tratadas conjuntamente, seria necessário não haver discriminação entre o nacional e o estrangeiro, porém discordamos do pressuposto de que seria possível tratar conjuntamente tais medidas. Isso porque as medidas antidumping, pela própria definição de dumping, aplicam-se unica e exclusivamente a produtos importados.

$\mathrm{O}$ assunto sobre a conveniência de fusionar leis antitruste e antidumping foi levado ao Comitê de Comércio e Concorrência da OMC e a posição do governo dos EUA foi no sentido de que se as leis antidumping forem eliminadas a favor das leis antitruste ou mesmo modificadas para se adequar aos princípios da políticas antitruste, os problemas que as regras antidumping buscam remediam ficariam sem solução ${ }^{385}$.

Consideramos que, de fato, os objetos tutelados pelo antidumping e pelo antitruste são distintos. Unificar os tratamentos poderia trazer ainda mais confusão por parte da indústria e autoridades que analisarão as controvérsias.

Conforme argumenta BELLIS ${ }^{386}$, "a eliminação das medidas antidumping com adoção de uma legislação antitruste comum redunda, segundo a experiência empírica da ANZCERTA e da AEE, na não-aplicação de sanções correspondentes (...). Na prática, portanto, a substituição de antidumping por

\footnotetext{
384 "III.4 The Products of the territory of any contracting party imported into the territory of any other contracting party shall be accorded treatment no less favourable than that accorded to like products of national origin in respect of all laws, regulations and requirements affecting their internal sale, offering for sale, pruchase, transportation, distribution or use (...)”.

385 "if the antidumping laws were eliminated in favor of competition laws or modified to be consistent with competition policy principles, the problems which the antidumping rules seek to remedy would go unadressed".

386 BELLIS, Jean François. The EEC Antidumping System. In VERMULST e J. H. JACKSON (eds.) Antidumping Law and Practice. Ann Arbor, MI: University of Michigan Press, 1989.
} 
antitruste, no âmbito de um processo de integração, implica renunciar a este instrumento de proteção comercial”.

Na ANZCERTA, Acordo Comercial sobre Relações Econômicas entre Austrália e Nova Zelândia, criado em 1983, e na AEE, Área Econômica Europeia, de fato, não é admitida a imposição de medidas antidumping entre seus signatários. Tal fato não gera problemas uma vez que a ideia dos países é liberaizar o comércio, restringindo barreiras que possam ser impostas. O que não é o caso de um sistema multilateral. BARRAL ${ }^{387}$ também sustenta a necessidade de um sistema antidumping ser mais legalista que um sistema antitruste.

\section{Como ressalta MARIA CAROLINA MENDONÇA DE BARROS ${ }^{388}$, “ $a$} lei antidumping não se preocupa em defender a concorrência no país. Ao contrário, ela auxilia a conduta anticompetitiva dentro do mercado importador, pois possibilita que a indústria doméstica seja protegida por meio de barreira artificial e não incentiva, nem privilegia a indústria mais competitiva, ainda que esta seja estrangeira”.

Não poderíamos finalizar esse tópico sem citar anedota de MICHAEL FINGER $^{389}$ que ilustra uma diferença significativa entre os dois institutos:

“Um advogado antitruste perguntou para um advogado de comércio internacional que representava uma indústria que buscava proteção antidumping porque não procuravam amparo nas leis antitruste, pois essas dão cobertura para danos atuais e futuros, enquanto que as leis antidumping

\footnotetext{
${ }^{387}$ BARRAL, Welber. Dumping e Comércio Internacional: a regulamentação antidumping após a Rodada Uruguai, Editora Forense, Rio de Janeiro, 2000, pag. 315.

388 BARROS, Maria Carolina Mendonça. Antidumping e Antitruste: interface possível no sistema de solução de controvérsias. Tese de Doutorado, USP/2008.

${ }^{389}$ FINGER, Michael J. Dumping and Anti-Dumping: The Rhetoric and the Reality of Protection in Industrial Countries, The World Bank Research Observer, Vol. 7, no. 2, July 1992. In BARROS, Maria Carolina Mendonça. Antidumping e Antitruste: interface possível no sistema de solução de controvérsias. Tese de Doutorado, USP/2008, pag. 182.
} 
apenas remedeiam danos futuros. O advogado de comércio internacional respondeu que, para usar as leis antitruste, ele teria que provar”.

No âmbito regional, NIELS ${ }^{390}$ e GABRIELLE MARCEAU ${ }^{391}$ defendem a importância dos acordos regionais para a interação entre o antitruste e o antidumping, com vistas à eliminação regional do uso do antidumping. Entendemos que, realmente, deva haver apenas regulamentação antitruste intrazona, e antidumping, extra-zona.

Outra proposta que decorre da intenção de aproximar o antidumping do antitruste diz respeito à aplicação de medidas antidumping apenas a casos em que se prove a natureza predatória do dumping.

Os preços predatórios são proibidos pela lei concorrencial, mas não pela lei antidumping. Constatamos uma proliferação das medidas antidumping que, muitas vezes, resultam em uma proteção descabida a indústrias que não têm condições de continuar competindo em um mercado globalizado como o atual. Conforme sustenta alguns autores da doutrina especializada ${ }^{392}$, restringir a aplicação de medidas antidumping a casos em que se prove a natureza predatória do dumping reduziria em muito o número de medidas aplicadas.

FINGER $^{393}$ cita estudo realizado por PALMETER em 1988, pelo qual se demonstra que em nenhuma das 767 determinações positivas de dumping entre

\footnotetext{
${ }^{390}$ NIELS, Gunnar e KATE, Adriaan ten. Trusting Antitrust to Dump Antidumping: Abolishing Antidumping in Free Trade Agreements without Replacing it with Competition Law, Journal of World Trade, vol. 31, number 6, December 1997.

391 MARCEAU, Gabrielle. Anti-dumping and Anti-trust Issues in Free Trade Areas, Clarendon Press. Oxford, 1994.

${ }^{392}$ Entre eles, BARFIELD, Claude. High-Tech Protectionism: The Irrationality of Antidumping Laws. Jackson (Tennessee): AEI Press, 2003, pag. 60. Hindley e Messerlin também defendem a proposta de condenar apenas o dumping predatório, e aplicar a legislação antitruste também a estrangeiros para combater o dumping. HINDLEY, Brian e MESSERLIN, Patrick A. Antidumping Industrial Policy - Legalizes Protectionism in the WTO and What to do about it, The AEI Press, Washington DC, 1996, pags. 70-76.

${ }^{393}$ FINGER, Michael J. Dumping and Anti-Dumping: The Rhetoric and the Reality of Protection in Industrial Countries, The World Bank Research Observer, Vol. 7, no. 2, julho/1992.
} 
1980 e 1986, por EUA, Comunidade Econômica Europeia (CEE), Áustria e Canadá, constatou-se a prática predatória.

JOSÉ DE ARAÚJO TAVARES ${ }^{394}$ também propõe que o caráter predatório seja analisado, mas mediante o envolvimento do órgão de defesa da concorrência nas investigações antidumping para, logo no início, informar a participação no mercado das indústrias envolvidas na investigação.

Além disso, há casos em que as características do mercado interno, tal como alto poder aquisitivo da população ou inexistência de concorrentes, permitem que o exportador venda internamente a preços muito altos e tenha que vender para exportação a preços mais baixos. FINGER e ZLATE ${ }^{395}$ chamam esse fenômeno de "sanctuary markets". Conforme definição de IKESON e LINDSEY 396 , “a sanctuary market is supposed to be an island of artificially high prices and profits”. Essa situação configuraria dumping, mas, logicamente, não deveria ser punida.

Conforme sustenta BARRAL ${ }^{397}$, o dumping nessa categoria seria uma "estratégica mercadológica para eliminar os concorrentes nacionais. Uma vez consolidada a conquista do mercado importador, o produtor estrangeiro majoraria os preços, recuperando os prejuízos suportados e percebendo lucros monopolistas".

\footnotetext{
394 TAVARES, José de Araújo Jr. As Normas Antidumping da ALCA e a Agenda Multilateral, novembro de 2002, disponível em www.sice.oas.org. Último acesso em 16/07/12.

${ }^{395}$ BARFIELD, Claude. High-Tech Protectionism: The Irrationality of Antidumping Laws. Jackson (Tennessee): AEI Press, 2003, pag. 61.

${ }^{396}$ LINDSEY, Brink e IKENSON, Daniel. The Rhetoric and Reality of US Anti-Dumping Law. In Anti-Dumping Global Abuse of a Trade Policy Instrument. Academic Foundation, New Delhi, 2007, pag. 113, também em Anti-Dumping Exposed: the devilish details of unfair trade Law, Cato Institute, Washington DC, 2003, pag. 15.

${ }^{397}$ BARRAL, Welber. Dumping e Comércio Internacional: a regulamentação antidumping após a Rodada Uruguai, Editora Forense, Rio de Janeiro, 2000, pag. 18.
} 
Para que se busque o caráter predatório do dumping, $\operatorname{SHIN}^{398}$ e WILLIG ${ }^{399}$, em seminário realizado em Washington DC, sugerem que as seguintes perguntas sejam respondidas ao longo do processo investigatório:

(i) O dumping alegado reduzirá o número de concorrentes no mercado importador?

(ii) Qual participação no mercado o exportador que alegadamente pratica dumping terá se o peticionário sair do mercado?

(iii) A participação no mercado do exportador que pratica o alegado dumping está crescendo rapidamente?

(iv) Os exportadores que alegamente praticam dumping podem estar agindo de forma coordenada?

(v) Há barreiras à entrada no mercado ou a entrada requer altos investimentos $?^{400}$

Notamos que são perguntas que um especialista em direito antitruste faria, mas que não necessariamente conseguem identificar aumento dos preços na sequência, característica necessária para configuração do preço predatório. Além disso, a comprovação do caráter predatório do dumping é muito difícil. Segundo BOVARD ${ }^{401}$, ao longo da história, "jamais um estrangeiro que praticou dumping em suas exportações para os EUA conseguiu eliminar a concorrência interna e subido os preços na sequência”.

\footnotetext{
${ }^{398}$ SHIN, Hyun Ja. Possible instances of predatory pricing in recent US Antidumping Cases in LAWRENCE, Robert Z., ed. Brookings Trade Forum: Washington DC: The Brookings Institution, 1998.

${ }^{399}$ WILLIG, Robert D. Economic Effects of Antidumping Policy in LAWRENCE, Robert Z., ed. Brookings Trade Forum: 1998, Washington DC: The Brookings Institution.

${ }^{400}$ Tradução livre de: "( $i$ ) is the alleged dumping likely to reduce the number of rivals (both domestic and foreign) in the importing country's market?; (ii) what share of the market would the dumpers have if the complainants left the market?; (iii) is the market share of the dumpers growing rapidly?; (iv) if there are two or more alleged dumpers, could they plausibly be colluding?; (v) are there significant entry and reentry barriers, and concomitantly, does entry require significant capital requirements and sunk costs?".

${ }^{401}$ BOVARD, James. The fair trade fraude. New York: St. Martin`s Press, 1991. In BARRAL, Welber. Dumping e Comércio Internacional: a regulamentação antidumping após a Rodada Uruguai. Editora Forense, Rio de Janeiro, 2000, nota de rodapé, pag. 19.
} 
Assim, podemos dizer que a proposta de que, além do dumping, dano e nexo causal, fique configurado o caráter predatório da medida antidumping, apesar de ter um objetivo louvável que seria a redução das medidas aplicadas em prol de indústrias não competitivas, vale-se de um meio de difícil implementação, pois levaria a um cenário oposto em que não se conseguiria impor nenhuma medida. Exigir que seja comprovado o caráter predatório do dumping imporia um ônus de prova excessivo à indústria doméstica que busca a imposição da medida, podendo resultar em um favorecimento, também indevido, dos exportadores/importadores.

Dessa forma, caso se entenda que a comprovação do caráter predatório é necessário, uma alternativa intermediária seria inverter o ônus da prova com relação a esse quesito e exigir que o exportador/importador prove que o dumping, se constatado, não tem caráter predatório. Caso o exportador/importador não consiga convencer a autoridade investigadora do caráter não predatório da medida, seria cabível a imposição de medidas antidumping. Todavia, exigir a comprovação do caráter predatório da medida não parece a solução mais adequada à luz do disposto no ADA. Seria como, em um processo penal, ter que provar o dolo, o que não é uma tarefa fácil. Pode acontecer de o exportador não ter a intenção de causar o dano (caráter predatório), mas na prática, causar.

O intuito dos Membros da OMC não foi condenar o dumping doloso, mas sim admitir a imposição de contramedidas para o dumping que causar dano à indústria doméstica. Portanto, o que importa é o efeito do dumping. Se praticado de forma culposa e causar dano, também deve estar sujeito às medidas antidumping. Daí a conclusão de que a análise de dano deva ser mais criteriosa, a fim de que sejam aplicadas apenas as medidas que efetivamente causam esse dano. Exigir a comprovação do caráter predatório como um requisito a mais para imposição das medidas antidumping, ou substituir a análise de dano pela comprovação do caráter predatório, não estaria em consonância com o intuito dos Membros da OMC. 
O Instituto Cato, sediado em Washington DC, realizou importante estudo $^{402}$ pelo qual recomenda 21 alterações no processo antidumping. Para fins dessa tese, concluímos que a "função judiciária da OMC" e do Poder Judiciário brasileiro muito se assemelham e que, para benefício do setor privado, em razão da força vinculante das decisões do Judiciário, e desnecessidade de amparo governamental para levar o caso à $\mathrm{OMC}$, seria conveniente recorrer ao Judiciário. Nesse sentido, propomos a criação de cortes especializadas em comércio internacional para que o despreparo técnico identificado não prejudique a solução das controvérsias.

Ocorre que os problemas do processo antidumping, tal como apontamos em capítulo específico, não se verão resolvidos com essa sugestão. Com vistas a sanar os problemas estruturais (e não meramente o esclarecimento dos dispositivos em vigor), e assegurar o devido processo legal em matéria antidumping, agrupamos as propostas para serem aplicadas no Brasil (ou qualquer outro Membro da OMC, pois afetam a forma de aplicação da medida antidumping em geral) e para a OMC, sobre as quais passaremos a discorrer adiante.

\subsection{SUGESTÕES A SEREM APLICADAS NO BRASIL}

Conforme vimos pelos gráficos elaborados por ALUISIO DE LIMA CAMPOS, a simples abertura de uma investigação causa efeitos negativos para as importações do produto investigado. Aplicar uma multa aos peticionários poderia conter aqueles que querem simplesmente auferir os benefícios até que seja negado prosseguimento à investigação. Seria uma atitude que não dependeria de nenhum outro país, e não seria incompatível com as regras da OMC. Cumpre ressaltar que no caso US - Byrd Amendment ${ }^{403}$ o DSB condenou a destinação dos recursos antidumping aos peticionários, pois incentivava a solicitação de investigações,

\footnotetext{
${ }^{402}$ LINDSEY, Brink e IKENSON, Daniel. Anti-Dumping Exposed: the devilish details of unfair trade Law. Washington DC: Cato Institute, 2003.

${ }^{403}$ DS 217 e DS 234 - para detalhes vide Apêndice 4 (Órgão de Apelação).
} 
enquanto que essa proposta visa a restringir o número de investigações, em linha com o objetivo de liberalização comercial da OMC.

BHAGWATI ${ }^{404}$ é a favor dessa proposta e sustenta que, "para minimizar o efeito protecionista das medidas antidumping e compensatórias seria útil que houvesse procedimentos institucionais mais imparciais, sendo analisados por um painel multilateral, aplicando penalidades aos peticionários que ativaram a máquina administrativa somente para assediar o sistema, com intuito frívolo". A proposta de ter procedimentos institucionais mais imparciais e a análise por painel multilateral será comentada abaixo.

Ocorre que, tendo em vista as estatísticas do DECOM trazidas nessa tese, notamos que o sistema brasileiro peca, por exemplo, por não analisar corretamente o nexo causal entre o dumping e o dano. Portanto, cobrar uma multa não adiantaria muito. Faremos algumas outras sugestões que dependeriam de negociação prévia do ADA (para que o Brasil não seja acusado de violar compromissos assumidos perante a OMC), e outras que poderiam ser implementadas mesmo sem a conclusão da Rodada Doha.

\section{(i) Sugestões que dependeriam de renegociação do ADA}

\section{a. Aumentar os parâmetros para abertura de investigação}

De acordo com a legislação atualmente em vigor, exige-se que as importações da origem investigada representem mais de 3\% das importações totais do produto investigado para que não sejam consideradas insignificantes (volume de minimis) ou que, em conjunto com outros importadores, representem mais de $7 \%$ das importações totais. Se importações representam menos que esse percentual,

\footnotetext{
404 BHAGWATI, Jagdish. Protectionism. The MIT Press, Cambridge, 1988, pag. 116: “work toward more impartial institutional procedures by having bilateral or (preferably) multilateral panels investigate the complaints, by permitting the imposition of penalties on petitioners whose complaints are adjudicated to have been frivolours and to have intended only for harassment, (...)".
} 
é muito difícil que causem dano. A ameaça de dano, por sua vez, é mais provável se o percentual se mostra crescente ao longo dos anos.

Tendo em vista que esse valor é muito baixo, sugerimos que seja majorado. Essa é também uma proposta dos Friends of Antidumping, mas eles não especificam o nível de majoração. Com o intuito de refletir as distinções entre dano e ameaça de dano, poderiam ser criados parâmetros distintos. Entretanto, ao fixar um percentual menos elevado para alegação de dano, e mais elevado para ameaça de dano (abaixo dos quais investigações não seriam abertas), poder-se-ia incentivar as alegações de ameaça de dano. Com isso, não se reduziria a possilibidade de abertura de investigação e sim, aumentaria essa possibilidade.

Portanto, sugerimos manter um percentual igualitário para dano e ameaça de dano, mas que seja, por exemplo, $10 \%$ isoladamente (para cada origem) e $25 \%$, por exemplo, conjuntamente. Somente com percentuais mais elevados em relação ao montante total importado, é que se pode reduzir a imposição indevida de medidas antidumping.

TARA $^{405}$ também sustenta que deve ser elevado o requisito para abertura das investigações para combate ao uso protecionista das medidas antidumping. Recomenda que os Membros da OMC consolidem no ADA um parâmatro no que tange à apresentação de provas claras, para evitar que as autoridades nacionais adotem critérios diferentes para abrir ou não uma investigação.

\section{b. Aumentar o de minimis da margem de dumping com vistas a poupar a Administração Pública}

A legislação em vigor determina que a margem de dumping seja superior a $2 \%$ para que a medida possa ser aplicada. Essa também é uma proposta do

\footnotetext{
${ }^{405}$ GINGERICH, Tara. Why the WTO should require the application of the evidentiary threshold requirement in antidumping investigations. American University Law Review, vol. 48, 1998-1999, pag.135.
} 
Canadá em conjunto com os Friends of Antidumping no âmbito da Rodada Doha, mas eles não especificam o montante da majoração. Dois por cento é um percentual muito baixo, que não chega a cobrir os custos administrativos que o governo importador terá para administrar a imposição da medida antidumping, tal como emissão de licenças de importação e eventual investigação decorrente de pedido de revisão.

Além disso, diante da discricionariedade que a autoridade investigadora tem para realização dos cálculos, é possível que a apuração da margem de dumping não reflita exatamente o dumping praticado. Tendo em vista que o princípio geral do direito preza pelo beneficiamento do acusado ("in dubio, pro reu”), sugerimos que esse percentual seja majorado para, no mínimo, 5\%. Admitindo a imposição de sobretaxas somente se a margem de dumping for superior a 5\%, estaríamos poupando a máquina estatal de ativismo que lhe traria mais prejuízos que benefícios. Além disso, teríamos mais certeza de que o acusado de dumping, mesmo se os cálculos da autoridade não estiverem $100 \%$ corretos, deveria mesmo ser punido pela sua prática.

\section{c. Condução de investigações antidumping por painéis multilaterais}

As investigações envolveriam autoridades investigadoras de todos os países envolvidos. A indústria doméstica peticionária ingressaria com uma petição perante o órgão competente de seu país. Após análise preliminar pelo país importador dos volumes importados para se certificar de que não constitui de minimis para abertura da investigação, as autoridades investigadoras dos países exportadores ficariam responsáveis pela análise do dumping, e a autoridade investigadora nacional ficaria responsável pela análise do dano. Findas as análises de dumping e a análise de dano, caberia à autoridade nacional analisar o nexo causal e o interesse público para então, aplicar ou não a medida antidumping. Essa proposta atenderia aos anseios daqueles que procuram instituições com maior indepêndencia, incentivaria a participação dos exportadores em prol do contraditório e ampla defesa, e pouparia a máquina administrativa de se deslocar 
até o país investigado para fazer verificações in loco. Para que essa proposta seja efetiva, os países teriam que confiar na imparcialidade e qualidade do trabalho a ser conduzido pelos países para apurar se, de fato, suas empresas estão praticando dumping.

A implantação de painéis multilaterais também poderia, em um segundo momento, possibilitar que a medida antidumping fosse aplicada apenas às empresas que praticam o dumping, e não a todas as empresas do país investigado. Seria o ideal, uma vez que o dumping é uma prática privada (e não caberia punir o país inteiro por isso). Entretanto, dificuldades práticas, como o grande risco de circunvenção, o número elevado de exportadores e as falhas do sistema de amostragem, tornam essa possibilidade remota.

\section{d. Revisão da medida aplicada por painel binacional como alternativa à revisão judicial}

Após concluída a investigação, se qualquer das Partes se sentir prejudicada, poderia pleitear a instituição de um painel ad hoc para resolver a controvérsia. Esse painel substituiria a revisão judicial que poderia ser conduzida perante o Poder Judiciário do país que aplicou a medida. Cumpre lembrar que a proposta sugerida nessa tese, e que independeria de qualquer alteração no ADA ou negociações com terceiros países, seria a instituição de cortes especializadas em comércio internacional para conduzir as investigações.

Conforme ressalta ANGELA ESTRELLA ${ }^{406}$, admitir que se recorra a um painel binacional ao invés de recorrer ao judiciário "foi a chave para superar conflito de interesses nas negociações entre EUA e Canadá. (...) o principal objetivo do Canadá era restringir as ações norte-americanas em matéria AD, enquanto os EUA, (...) resistiam a efetuar alterações na sua legislação AD".

\footnotetext{
406 ESTRELLA, Angela T. Gobbi. Uma proposta para a ALCA em antidumping, medidas compensatórias e salvaguardas: revisão por painel binacional em alternativa à revisão judicial. In LIMA CAMPOS, Aluisio. Ensaios em Comércio Internacional, Editora Singular, São Paulo, 2005, pag. 169 .
} 
Conforme defende a autora, esse sistema não violaria o princípio da inafastabilidade do judiciário (Artigo $5^{\circ}, \mathrm{XXXV}$ da $\mathrm{CF}$ ) se fosse garantido um prazo para recurso ao Judiciário, e após, aberto prazo para recurso ao painel binacional.

Cumpre ressaltar que essa proposta foi apresentada para aplicação na Área de Livre Comércio das Américas (ALCA), que nunca veio a ser implementada, mas que não vemos empecilhos para que seja implementada no âmbito do MERCOSUL, de acordos bilaterais ou mesmo entre dois países que não tenham firmado nenhum acordo específico. Isso seria possível pois o painel bilateral aplicaria as normas da OMC.

MILLER $^{407}$ ressalta que a maioria dos acordos regionais contém previsões sobre antidumping, mas que o Chile tem optado por celebrar acordos bilaterais pelos quais ambos os países excluem a possibilidade de aplicação de medidas antidumping um contra o outro. Com isso, o comércio se torna ainda mais liberalizado. No caso da negociação com os EUA, grandes defensores do uso das medidas antidumping, o Chile não obteve sucesso em excluir esse tema das negociações bilaterais.

(ii) Sugestões que independeriam de renegociação do ADA

\section{a. Aplicação mandatória do teste do interesse nacional durante as investigações, cujo cumprimento poderá ser averiguado pelas cortes especializadas em comércio internacional}

A CAMEX deveria levar em consideração outros interesses nacionais além dos interesses da indústria doméstica, para definir sobre a conveniência na aplicação de medida antidumping, tal como o interesse do mercado consumidor.

\footnotetext{
407 MILLER, Andrea. The United States Antidumping Statutes: can a trade agreement be both "free"and "fair"? A case study of Chile. Catholic University Law Review, vol. 54, 627, 2004-2005, pag. 640.
} 
Em 2012, foi criado no Brasil o GTIP, órgão interministerial no âmbito do Ministério da Fazenda que tem por objetivo analisar o interesse nacional. Esse órgão ainda não foi acionado e não sabemos os procedimentos e posicionamento a serem adotados, mas esperamos que essa situação seja revertida.

Uma das formas de analisar o interesse público, conforme sustenta BARCELÓ $^{408}$, seria levar em consideração o dano à concorrência, e não o dano aos concorrentes (indústria doméstica). Para tanto, uma análise da cadeia produtiva seria essencial.

Uma vez encerrada a investigação, se acionado, o Judiciário também deveria ser um foro apropriado para analisar o atendimento do interesse público pela medida antidumping.

\subsection{SUGESTÕES A SEREM APLICADAS NA OMC}

(i) Ampliação do Padrão de Revisão dos painéis e criação de um Padrão de Revisão diferenciado para o Órgão de Apelação em casos antidumping (posssibilidade de reenvio)

Como visto anteriormente, o Artigo 17.6 do ADA estabelece um parâmetro de análise pelos painéis para os casos antidumping levados ao DSB. Esse parâmetro é bem mais restritivo que aquele aplicável aos demais acordos abrangidos. Como explicamos, o Artigo 17.6 do ADA determina que um painel da OMC não poderá reverter uma decisão de uma autoridade investigadora nacional se houve o devido estabelecimento dos fatos e a avaliação foi imparcial e objetiva. Trata-se de um limitador quanto à análise do mérito que coloca a autoridade investigadora do país importador em patamar superior às regras da OMC.

408 BARCELÓ, John. Antidumping Laws as Barriers to Trade - the United States and the International Antidumping Code. Cornell Law Review, vol. 57, n. 4, 1972. 
Conforme salientamos, esse artigo foi inserido pelos EUA ao final da negociação da Rodada Uruguai, sem que os demais países tivessem se atentado para os seus reais efeitos. Há quem defenda ser necessário, em uma revisão do ADA, que caia esse padrão diferenciado para que a OMC possa efetivamente solucionar as controvérsias sobre antidumping.

Não parece razoável que a inexistência do padrão de revisão contribua para a solução adequada dos casos. Pelo contrário, se não houver esse padrão, os painéis poderiam incorrer em erro ao analisar o dumping, prática que não é governamental, extrapolando assim sua competência. HAMILTON ${ }^{409}$ sustenta que, para assegurar a soberania de cada um dos Membros da OMC, o padrão de revisão deveria ser ampliado, para permitir maior deferência às interpretações permissíveis. Entendemos, por outro lado, que a ampliação do padrão deva vir para permitir aos painéis também analisar: (i) houve falha no procedimento?; (ii) o interesse nacional foi analisado?; (iii) a medida adotada é proporcional? Notamos que não caberia ao painel analisar se o interesse nacional foi atendido, mas meramente se foi analisado.

Quem analisa se o painel observou o padrão de revisão é o Órgão de Apelação. Como vimos nessa tese, o Órgão de Apelação tem sofrido severas críticas por considerarem que tem extrapolado seus poderes, sobretudo no que diz respeito às disputas antidumping. Apesar de o Artigo 17.6 do ESC já limitar a competência do Órgão de Apelação a questões meramente legais e interpretação jurídica, sugerimos que seja criado no ADA um padrão de revisão específico para o Órgão de Apelação em casos antidumping.

Para que não sejam completadas análises e para evitar que fira a deferência a ser dada às autoridades nacionais, esse padrão deveria se assemelhar à competência de um tribunal de cassação. Em analogia ao sistema francês descrito nessa tese, o Órgão de Apelação deverá simplesmente cassar/anular ou manter a

\footnotetext{
${ }^{409}$ HAMILTON, Lee D. US Antidumping Decisions and the WTO Standard of Review: Deference or Disregard? Chicago Journal of International Law, vol. 4, 2003, pag. 265.
} 
recomendação de um painel em disputas antidumping. Se cassada/anulada a recomendação, novo painel deverá ser instaurado para apreciar o caso (reenvio). Se mantida a recomendação, e a autoridade nacional tiver que adequar sua medida, esta deverá fazê-lo, sob pena de sofrer as sanções previstas pela OMC. Dessa forma, sem afetar os objetivos da OMC, poupamos o Órgão de Apelação de desenvolver relatórios extensos, que trazem fundamentação jurídica complexa.

Não haveria, portanto, a obrigação de o DSB dar uma solução positiva para a controvérsia. Os painéis também deveriam poder reenviar o caso para a autoridade investigadora, e o Órgão de Apelação deveria poder reenviar o caso para o painel.

Fazendo uma analogia com a arbitragem, os recursos são cabíveis para anulação da sentença unicamente, e em hipóteses limitadas ${ }^{410}$. Um novo tribunal arbitral é constituído para reanálise do caso. Esse fato demonstra a tendência, já estampada no sistema francês de cassação descrito nessa tese, de não intervenção e alteração de decisões, mas anulação por completo.

Como vimos nesta tese, o reenvio é procedimento comum em países que seguem a Common Law. PAUWELYN ${ }^{411}$ sustenta que sem ele muitas das disputas poderiam ficar sem solução. $\mathrm{O}$ autor chama a atenção para o caráter híbrido do sistema de solução de controvérsias da OMC que, ao dar competência apenas legal para o Órgão de Apelação assemelha-se ao sistema da Common Law, e ao não permitir o reenvio traz características do direito civil. A proposta dessa tese não seria para admitir o reenvio em todas e quaisquer disputas levadas ao DSB, mas

\footnotetext{
${ }^{410}$ O Artigo V da Convenção de Nova Iorque de 1958 lista alguns motivos para a anulação da sentença arbitral, entre eles: incapacidade das partes; invalidade do acordo arbitral; inobservância do devido processo legal; nomeação dos árbitros; notificação inadequada dos procedimentos; extrapolação dos poderes.

${ }^{411}$ PAUWELYN, Joost. Appeal without Remand: A Design Flaw in the World Trade Organization Dispute Settlement and How to Fix it. Geneva: ICTSD, 2007, pag. 3: "given the original restriction of common law writs of errors to legal questions only, and the continuing focus of appeals on the law (rather than the facts), in most common law system appeals, the procedure of remand was maintained. (...). As much as remand in appeals in most civil law systems is of no use and unnecessary (the appellate court re-hears the full case anyhow), remand in appeals in most common law systems is crucial as without it the dispute could, in certain cases, not be resolved (the appellate court focuses on issues of law, not fact)".
} 
apenas nos casos antidumping. Com isso, manteríamos as características do direito civil e da common law inerentes ao sistema de solução de controvérsias da OMC. 


\section{PARTE IV - CONSIDERAÇÕES FINAIS}

Podemos dizer que as medidas antidumping têm sido utilizadas de forma abusiva, como mecanismo protecionista além dos objetivos para os quais foram criadas. No Brasil, para alguns setores específicos que conseguiram a aplicação de uma medida antidumping sem que o devido processo legal tivesse sido observado (por exemplo, sem uma análise correta do nexo causal entre dano e dumping), a medida antidumping se mostra inócua, mesmo vigente por anos.

Tendo em vista que ficou comprovado nessa tese a similaridade entre a "função judiciária da OMC" e do Poder Judiciário Brasileiro, o setor privado que entende ser uma medida antidumping contrária ao devido processo legal deveria primeiro recorrer ao Judiciário para busca de seus interesses. Para que o Judiciário possa dar uma solução adequada, é imprescindível que sejam criadas no Brasil cortes especializadas em comércio internacional.

Portanto, o primeiro passo para assegurar o devido processo legal em matéria antidumping seria admitir um efetivo controle da atuação do Poder Executivo por meio de cortes especializadas em comércio internacional, que analisariam, por exemplo, se o interesse público está sendo atendido (efeito direto na função judiciária). Essa atitude independe de qualquer negociação internacional e pode ser adotada imediatamente.

O segundo passo para assegurar o devido processo legal em matéria antidumping seria alterar as regras em vigor, tanto no âmbito multilateral, como internamente (efeito direto na função legislativa), o que se tem procurado na OMC com a Rodada Doha e, no Brasil, com a consulta pública para alteração do Decreto 1602/95. Esse fato levaria ao esclarecimento dos dispositivos já em vigor, mas não contemplariam mudanças estruturais.

O terceiro passo seria alterar a forma de aplicação das medidas antidumping (efeito direto na função executiva), mediante a adoção das propostas 
estruturais trazidas por essa tese, tanto em âmbito interno brasileiro, como perante a OMC.

Importante ressaltar que a partir do momento que as medidas antidumping passarem a ser aplicadas em estrita observância a seu intuito e ao devido processo legal, é possível que a maioria das indústrias brasileiras não consigam mais a imposição desse tipo de medida, pois a baixa competitividade da indústria nacional frente às importações deve-se, sobretudo, à alta carga tributária e excessivo ônus trabalhista e previdenciário. Portanto, o combate efetivo não se daria com medidas antidumping, mas sim com ações que visem a equalizar as condições de competitividade da indústria nacional e o câmbio. 


\section{REFERÊNCIAS BIBLIOGRÁFICAS}

\section{$\underline{\text { Livros }}$}

ABI-SAAB, Georges. The Appellate Body and Treaty Interpretation. In: SACERDOTI, Giorgio; YANOVICH, Alan; BOHANES, Jan (coords.). The WTO at Ten: The contribution of the Dispute Settlement System. Cambridge: Cambridge University Press, 2006.

AMARAL JUNIOR, Alberto do. A solução de controvérsias na OMC. São Paulo: Atlas, 2008.

(Org.). A reforma do sistema de solução de controvérsia da OMC e os países em desenvolvimento. São Paulo: Aduaneiras, 2006.

et al.. O Artigo XX do Gatt: Meio Ambiente e Direitos Humanos. São Paulo: Aduaneiras, 2009.

BAGWELL, Kyle; STAIGER, Robert W. The Economics of the World Trading System. Cambridge (MA): The MIT Press, 2002.

BAHCEKAPILI, Cenzig e COKGEZEN, Murat. Calculating Normal Value as a Way of Protection: some evidence from Turkish Dumping Investigations. In: CHAKRABORTY, Debashis; DEBROY, Bibek. Anti-dumping: Global abuse of a trade policy instrument. Nova Délhi: Academic Foundation, 2007, p. 49.

BANDEIRA DE MELLO, Celso Antônio. Discricionariedade e Controle Jurisdicional. São Paulo: Malheiros, 1992.

BANDEIRA DE MELLO, Oswaldo Aranha. Atos no Exercício do Poder Vinculado $e$ Discricionariedade, In: Princípios Gerais de Direito Administrativo, 2.ed. Rio de Janeiro: Forense, 1979.

BARFIELD, Claude. High-Tech Protectionism: The Irrationality of Antidumping Laws. Jackson (Tennessee): AEI Press, 2003.

BARRAL, Welber. Dumping e Comércio Internacional: a regulamentação antidumping após a Rodada Uruguai. Rio de Janeiro: Forense, 2000. 
. Negociações Multilaterais, Antidumping e a Trade Policy Authority: alternativas para

o Brasil. In: LIMA-CAMPOS, Aluísio (Org). Ensaios em Comércio Internacional: antidumping, disputas comerciais e negociações multilaterais. São Paulo: Editora Singular, 2005.

BELLIS, Jean-François. The EEC Antidumping System, In Antidumping Law and Practice, editado por E. Vermulst e J. H. Jackson. Ann Arbor, MI: University of Michigan Press, 1989.

BENTES, Pablo. A Cumulatividade na determinação de dano à indústria doméstica norteamericana. In: LIMA-CAMPOS, Aluísio (Org). Ensaios em Comércio Internacional: antidumping, disputas comerciais e negociações multilaterais. São Paulo: Editora Singular, 2005, p.110.

BHAGWATI, Jagdish. Protectionism. Cambridge (MA): The MIT Press, 1988.

The World Trading System at Risk. Princeton and New Jersey: Princeton University Press, 1991.

BLACK, Henry C. Black`s Law Dictionary. $5^{\text {th }}$ edition. St. Paul: West Publishing Co, 1979.

BODDEZ, Thomas M.; TREBILCOCK, Michael J. Unfinished business: reforming trade remedy laws in North America. Toronto: C.D. Howe Institute, 1993.

BOGDANDY, Armin von; MAVROIDIS. Petros C. (eds.). European Integration and International Co-ordination: Studies in Transnational Economic Law in Honour of Claus-Dieter Ehlermann. The Hague, London and New York: Kluwer Law International, 2002.

BOLTUCK, Richard; Litan, Robert E. (eds.), Down in the dumps : administration of the unfair trade laws (Washington, D.C. : Brookings Institution, c1991).

BONNAI, Nicolas. Les institutions judiciaries françaises. Ouvrage sous la direction de Pierre Truche, premier president honoraire de la Cour de cassation. Paris: La documentation Française, 2001.

BOVARD, James. The fair trade fraude. New York: St. Martin`s Press, 1991.

BROWNLIE, Ian. Public International Law, $6^{\text {th }}$ ed. Oxford: Oxford University Press, 2003.

CANAL-FORGUES, Éric. Le Règlement des Différends à l'OMC, $2^{\text {nd }}$ ed. Bruxelas: Bruylant, 2004. 
CABANELLAS, Guillermo. El dumping: legislación argentina y derecho comparado. Buenos Aires: Editorial Heliasta, 1981.

CARREAU, Dominique; JUILLARD, Patrick. Droit International Economique. Paris: Dalloz, 2003.

CASELlA, Paulo Borba; MERCADANTE, Araminta de Azevedo (Coord.). Guerra Comercial ou Integração Mundial pelo Comércio?: A OMC e o Brasil. São Paulo: Ltr, 1998.

CASSESE, Antonio. Modern constitution and international. In: Recueil des Cours, v. 192, 1985.

CHAKRABORTY, Debashis. Misuse of Anti-Dumping Provisions: What do the WTO Disputes Reveal?. In: ; DEBROY, Bibek. Anti-dumping: Global abuse of a trade policy instrument. Nova Délhi: Academic Foundation, 2007, p. 155.

CHAYES, Abram; CHAYES, Antonia Handler. The New Sovereignty. Cambridge (MA): Harvard University Press, 1995.

COOTER, Robert; ULEN, Thomas. Law and Economics, $4^{\mathrm{a}}$ ed. Boston, São Francisco, Nova York: Pearson, Addison-Wesley, 2004.

COTTIER, Thomas; MAVROIDIS, Petros C. (eds.). The Role of the Judge in International Trade Regulation. Ann Arbor: The University of Michigan Press, 2003.

CRETElLA JUNIOR, José. Ato Administrativo - A Tridimensão da Discricionariedade. Revista de Direito Administrativo, Rio de Janeiro, FGV, v.119, jan. a mar. 1975, pp. 33 a 39.

CRETElla NETO, José. Direito Processual na Organização Mundial do Comércio. Rio de Janeiro: Forense, 2003.

CZAKO, Judith; HUMAN, Johann; MIRANDA, Jorge. A Handbook on Anti-Dumping Investigations. Cambridge: Cambridge University Press, 2003.

DAILLIER, Patrick; PELLET, Alain; QUOC DINH, Nguyen. Droit International Public, $7^{\mathrm{a}}$ ed. Paris: L.G.D.J., 2002.

DENIS, Alland. Justice Privée et Ordre Juridique International: Etude Théorique des ContreMesures en Droit International Public. Paris: Éditions A. Pedone, 1994. 
DUPUY, Pierre-Marie. Droit International Public, 5ª ed. Paris: Dalloz, 2000.

DURLING, James; NICELY, Matthew. Understanding the WTO Antidumping Agreement negotiation history and subsequent interpretation. Londres: Cameron May, 2002.

ESTRELLA, Angela T. G. Uma proposta para a ALCA em antidumping, medidas compensatórias e salvaguardas: revisão por painel binacional em alternativa à revisão judicial. In: LIMACAMPOS, Aluísio (Org). Ensaios em Comércio Internacional: antidumping, disputas comerciais e negociações multilaterais. São Paulo: Editora Singular, 2005, p. 169.

FARRER, Lord. Free Trade versus Fair Trade, atualizada por C.H. Chomley. London: The Free Trade Union, 1904.

FINGER, Michael J (Editor). Antidumping: How it Works and Who Gets Hurt. Ann Arbor: The University of Michigan Press, 1998.

FLORY, Thiébaut. L'Organisation mondiale du commerce: droit institutionnel et substantial. Bruxelles: Bruylant, 1999.

GALLAGHER, Peter. Guide to Dispute Settlement. London, The Hague, Boston: Kluwer Law International, 2002.

GILLIGAN, Michael J. Empowering Exporters: Reciprocity, Delegation, and Collective Action in American Trade Policy. Ann Arbor: The University of Michigan Press, 1997.

GUEDES, Josefina; PINHEIRO, Silvia. Antidumping, Subsídios e Medidas Compensatórias. $3^{\mathrm{a}}$ ed. São Paulo: Aduaneiras, 2002.

HINDLEY, Brian; MESSERLIN, Patrick A. Antidumping Industrial Policy - Legalizes Protectionism in the WTO and What to do about it. Washington DC: AEI Press, 1996.

HILF, Meinhard; Ernst-Ulrich Petersmann (org.). National Constitutions and International Economic Law. Deventer and Boston: Kluwer Law and Taxation Publishers, 1993.

HOEKMAN, Bernard M.; KOSTECKI, Michel. The Political Economy of the World Trade System - From GATT to WTO. Oxford: Oxford University Press, 1996.

HORLICK, Gary. WTO and NAFTA Rules and Dispute Resolution: Selected Essays on Antidumping, Subsidies and other Measures. London: Cameron May, 2003. 
HUDEC, Robert E. Enforcing International Trade Law: The evolution of the Modern GATT Legal System. Salem, (N.H): Butterworth Legal Publishers, 1993.

The GATT Legal System and World Trade Diplomacy. New York: Praeger Publishers, 1975.

IBAÑEZ MARSILLA, Santiago. La valorization de las importaciones. Régimen tributário y experiência internacional. Madrid: Mc Graw-Hill, 2002.

JACKSON, John. Dumping in International Trade: Its meaning and Context, in Antidumping Law and Practice: a comparative study. Ann Arbor: Michigan University Press, 1989.

The World Trading System: Law and Policy of International Economic Relations, $2^{\text {nd }}$ ed. Cambridge (MA), London England: The MIT Press, 1977.

World Trade and The Law of GATT. Indianapolis, Kansas City and New York: The Bobbs-Merril Company, 1969.

; SYKES, Alan O. (org.). Implementing the Uruguay Round. Oxford and New York: Oxford University Press, 1997.

; VERMULST, Edwin A. Antidumping Law and Practice: a comparative study. Ann Arbor, The Michigan University Press, 1992, Chapter 3.

JOHANNPETER, Guilherme Chagas Gerdau. Antidumping - Prática desleal no comércio internacional. Porto Alegre: Editora do Advogado, 1996.

JUSTEN FILHO, Marçal. Atividade Administrativa e Procedimentalização, In: Curso de Direito Administrativo. 2.ed. São Paulo: Saraiva, 2006, pp. 143 a 180.

KRUGMAN, Paul R., OBSTFELD, Maurice. International Economics: Theory and Policy, $5^{\mathrm{a}}$ ed. Boston: Addison-Wesley, 2000.

LAFER, Celso. A OMC e a regulamentação do comércio internacional: uma visão brasileira. Porto Alegre: Livraria do Advogado, 1998. 
O Sistema de Solução de Controvérsias da Organização de Comércio Internacional.

In: Guerra Comercial ou Integração Mundial pelo Comércio? A OMC e o Brasil. CASELLA, Paulo Borba; MERCADANTE, Araminta de Azevedo. São Paulo: LTr, 1998.

LIMA-CAMPOS, Aluisio de (org.). Ensaios em Comércio Internacional: antidumping, disputas comerciais e negociações multilaterais. São Paulo: Editora Singular, 2005.

LOWENFELD, Andreas F. International Economic Law. Oxford and New York: Oxford University Press, 2003.

LUFF, David. Le Droit de l'Organisation Mondiale du Commerce : Analyse Critique. Bruxelles, Paris: Bruylant and L.G.D.J, 2004.

MAGNAN, Muriel Fabre. Introduction générale au droit. L'Organisation Jurisdictionenelle. Paris: Presses Universitaires de France, 2009, pag. 235.

MARQUES NETO, Floriano de Azevedo. Discricionariedade e Regulação Setorial - o caso do controle dos atos de concentração por regulador setorial. In: ARAGÃO, Alexandre Santos (coord.). O Poder Normativo das Agências Reguladoras, Rio de Janeiro, Forense, 2006, pp. 569 a 604.

MARCEAU, Gabrielle. Anti-dumping and Anti-trust Issues in Free Trade Areas. Oxford: Clarendon Press, 1994.

MARTINS, Flavio Alves. A boa-fé objetiva e sua formalização no direito das obrigações brasileiro. Rio de Janeiro: Lumen Juris, 2000.

MATSUSHITA, Mitsuo et al. The World Trade Organization: Law, Practice and Policy. Oxford and New York: Oxford University Press, 2003.

MAVROIDIS, Petros C.; SYKES, Alan O. The WTO and International Trade Law/Dispute Settlement. Cheltenham: Edward Elgar Publishing, 2005.

MESSERLIN, Patrick A.; WAUTERS, Jasper M. The law and economics of contingent protection in the WTO. Cheltenham: Edward Elgar Publishing, 2008.

MEDRADO, Renê Guilherme S. A "prova dos nove”: o Órgão de Apelação da OMC respeita a legislação e a prática antidumping dos Estados Unidos. In: LIMA-CAMPOS, Aluísio (Org). 
Ensaios em Comércio Internacional: antidumping, disputas comerciais e negociações multilaterais. São Paulo: Editora Singular, 2005.

MONSTESQUIEU. De l'esprit des lois. Paris, Éditions Garnier Frères, 1973. Tradução de Lólio Lourenço de Oliveira. In: WEFFORT, Francisco (org.). Os clássicos da política, v.1. 14.ed. São Paulo: Ática, 2008.

MURO, Julio A. L. Os Primeiros Anos do Órgão de Apelação e do Sistema de Solução de Controvérsias na OMC: uma perspectiva história. In: BAPTISTA, Luiz Olavo; CELLI JUNIOR, Umberto; YANOVICH, Alan (orgs.). 10 anos de OMC: uma análise do Sistema de Solução de Controvérsias e Perspectivas. São Paulo: Aduaneiras, 2007.

NYE JR., Joseph S. Soft Power: The Means to Success in World Politics. New York: Public Affairs, 2004.

OESCH, Matthias. Standards of Review in WTO Dispute Resolution. Oxford: Oxford University Press, 2003.

ORTINO, Federico; PETERSMANN, Ernst-Ulrich (eds.). The WTO Dispute Settlement System 1995-2003. The Hague, London, New York: Kluwer Law International, 2004.

PALMETER, David. The WTO as a Legal System: Essays on International Trade Law and Policy. London: Cameron May, 2003.

; MAVROIDIS, Petros C.. Dispute Settlement in the World Trade Organization: Practice and Procedure, $2^{\text {nd }}$ ed. Cambridge: Cambridge University Press, 2004.

PETERSMANN, Ernest-Ulrich. The GATT/WTO Dispute Settlement System: International Law, International Organizations and Dispute Settlement. London, The Hague and Boston: Kluwer Law International, 1997.

PINHEIRO, Silvia; GUEDES, Josefina. A Defesa Comercial no Brasil - Passado, Presente e Futuro. In: LIMA-CAMPOS, Aluísio (Org). Ensaios em Comércio Internacional: antidumping, disputas comerciais e negociações multilaterais. São Paulo: Editora Singular, 2005.

PIRES, Adilson Rodrigues. Práticas abusivas no comércio internacional. Rio de Janeiro: Forense, 2001. 
POLINSKY, Mitchell. An Introduction to Law and Economics, $3^{\mathrm{a}}$ ed. New York: Aspens Publishers, 2003.

POSNER, Richard. Economic Analysis of Law, 6ª ed. New York: Aspen Publishers, 2003.

PRUSA, Thomas; SKEATH, Susan. The Economic and Strategic Motives for Antidumping Filings. Working Papers, Wellesley College, Department of Economics, n.05, 2001.

RAJU, K.D. India's involvement in Anti-umping cases in the First Decade of WTO. In: CHAKRABORTY, Debashis; DEBROY, Bibek. Anti-dumping: Global abuse of a trade policy instrument. Nova Délhi: Academic Foundation, 2007.

RODRIK, Dani. Has Globalization Gone Too Far? Washington, DC: Institute for International Economics, 1997.

ROSS, Alf. On Law and Justice. University of California Press, 1974.

ROUSSEAU, Charles. Droit International Public, Tome V. Paris: Sirey, 1983.

SACERDOTI, Giorgio. The dispute settlement system of the WTO in action: a perspective on the first ten years. In: SACERDOTI, Giorgio; YANOVICH, Alan; BOHANES, Jan (coords.). The WTO at Ten: The contribution of the Dispute Settlement System. Cambridge: Cambridge University Press, 2006.

SEN, Amartya. Development as Freedom, New York: Anchor Books, 1999.

SERLOOTEN, Patrick. Droit fiscal des affaires, $3^{\text {a }}$ ed. Paris: Dalloz, 2003.

SILVA, José Afonso da. Curso de Direito Constitucional Positivo. 28. ed. São Paulo: Malheiros, 2007.

SILVEIRA, Paulo Antônio C. V. da. Defesa da concorrência no Mercosul. São Paulo: LTr, 1998.

SLAUGHTER, Anne-Marie. A New World Order. Princeton and Oxford: Princeton University Press, 2004.

SMITH, Adam. An Inquiry into the Nature and Causes of the Wealth of the Nation, v. II, livro IV, Capítulo II. Dublin: 1776. 
SMOUTS, Marie-Claude (ed.). Les Nouvelles Relations Internationales: Pratiques et Théories. Paris: Presses de Sciences Po, 1998.

TREBILCOCK, Michael J.; HOWSE, Robert. The Regulation of International Trade, $3^{\mathrm{a}}$ ed. Londres e Nova York: Routledge, 2005.

STIGLITZ, Joseph E. Dumping on Free Trade: The US Import Trade Law. Chattanooga: Southern Economic Journal, 1997. Apud BARROS, Maria Carolina M. Antidumping e Antitruste: interface possível no sistema multilateral de comércio. São Paulo, 2008. Tese (Doutorado em Direito) Faculdade de Direito da Universidade de São Paulo, p. 179.

THORSTENSEN, Vera. OMC - Organização Mundial do Comércio: as regras do comércio internacional e a Rodada do Milênio. São Paulo: Aduaneiras, 1999.

UCKMAR, Victor; TAVEIRA TORRES, Heleno (coord.). Impuestos sobre el comercio internacional. Buenos Aires: Editorial Ábaco, 2003.

VAN DEN BOSSCHE, Peter. The Law and Policy of the World Trade Organization. Nova York: Cambridge University Press, 2006.

VERMULST, Edwin A. The WTO anti-dumping agreement : a commentary. Oxford; Nova York: Oxford University Press, 2005.

VINER, Jacob. Dumping: a problem in International Trade. New York: Augustus M. Kelley Publishers, 1966.

ZOLLER, Elisabeth. Peacetime Unilateral Remedies: An Analysis of Countermeasures. Dobbs Ferry, Nova York: Transnational Publishers, 1984.

\section{$\underline{\text { Artigos e Periódicos }}$}

ALEMANNO, Alberto. Judicial enforcement of the WTO Hormones Ruling Within the European Community: Toward EC Liability for the Non-Implementation of WTO Dispute Settlement Decisions. Harvard International Law Journal, Cambridge (MA) v.45, p.547, 2004.

ALFORD, Roger P. Reflection on US - Zeroing: A Study in Judicial Overreaching by the WTO Appellate Body. Columbia Journal of Transnational Law, vol. 45, p. 196, 2006-2007. 
ALLEN, Jane. Avoiding controversy over the standard of review - Assistant of the Appelant Defendant. Durham North Carolina. Disponível em: < http://www.ncids.org/Defender\%20Training/Nuts\%20and\%20Bolts\%20of\%20Appellate\%20Proce dure/Standard\%20of\%20Review.pdf>. Acesso em 11 jul. 2012.

ÁRABE NETO, Abrão M.; Bonomo, Diego Z. Tribunal especializado em comércio exterior. Valor Econômico, sessão Brasil, São Paulo, 03 jul. 2012. Disponível em : < http://www.valor.com.br/brasil/2737276/tribunal-especializado-em-comercio-exterior>. Acesso em 9 jul. 2012.

ARAUJO JUNIOR., Jose Tavares de; MIRANDA, Pedro. Antidumping e Antitruste: peculiaridades do caso brasileiro. Centro de Estudos de Integração e Desenvolvimento, Breves CINDES, n.8, ago. 2008. Disponível

em:

$<$ http://www.cindesbrasil.org/site2010/index.php?option=com_jdownloads\&Itemid=14\&view=finis h\&cid=10\&catid=4>. Acesso em 18 jun. 2012.

ARAÚJO JUNIOR, José Tavares. As Normas Antidumping da ALCA e a Agenda Multilateral. OAS Trade Section, nov. 2002. Disponível em: <www.sice.oas.org>. Acesso em 10 jul. 2012.

AZIZ, Mirian, Sovereignty Lost, Sovereignty Regained? Some Reflections on the Bundesverfassungsgericht's Bananas Judgment. Columbia Journal of European Law, Nova York, v.9, p.109, 2002.

BACCHUS, James. Around the Table of the Appellate Body of the WTO. Vanderbilt Journal of Transnational Law, Nashville, v.35, 2002.

Groping Toward Grotius: The WTO and the International Rule of Law. Harvard International Law Journal, v.44, p.533, 2003.

BAPTISTA, Luiz Olavo. A interpretação e aplicação das regras da OMC nos primeiros anos. Revista de Informação Legislativa, Brasília, v.41, 2004.

BARCELÓ, John. Antidumping Laws as Barriers to Trade - the United States and the International Antidumping Code. Cornell Law Review, Ithaca, v.57, n. 4, 1972.

BARTELS, Lorand. The Separation of Powers in the WTO: how to avoid judicial activism. International and Comparative Law Quaterly - Cambrige Journal, Cambridge, v.53, 2004.

BHALA, Raj, The Bananas war. McGeorge Law Review, v.31, p.839, 2000. 
BOGDANDY, Armin von. Legal Effects of World Trade Organization Decisions Within European Union Law: A Contribution to the Theory of the Legal Acts of International Organizations and the Action for Damages Under Article 288(2) E. Journal of World Trade, v.39, p.45, 2005.

BRASIL, Deilton R. Tendências da legislação antidumping brasileira, norte-americana e da Comunidade Europeia em face das medidas de defesa comercial, por parte das autoridades comunitárias, do acordo geral sobre as tarifas aduaneiras e o comércio (GATT). Revista da Faculdade de Direito Milton Campos, Belo Horizonte, v.7, 2000, p.78.

BRONCKERS, Marco; NABOTH van der Broek. Financial Compensation In The WTO: Improving The Remedies Of WTO Dispute Settlement. Journal of International Economic Law, v.8, 2005, p.101.

BÜTLER, Monika; HAUSER, Heinz. The WTO Dispute Settlement System: A First Assessment from an Economic Perspective. Journal of Law, Economics, and Organization, v.16, p.503, 2000. In: MAVROIDIS, Petros C.; SYKES, Alan O. The WTO and International Trade Law/Dispute Settlement. Cheltenham: Edward Elgar Publishing, 2005.

CHARNOVITZ, Steve. Rethinking WTO Trade Sanctions. The American Journal of International Law, v.95, p.792, 2001.

CHO, Sungjoo. Dual Catastrophe of Protectionism. Northwestern Journal of International Law \& Business, Chicago, 25:315, 2005.

CORR, Christopher. Trade Protection in the New Millenium: the ascendancy of antidumping measures. Northwestern Journal of International Law \& Business, v.18, p.49, 1997.

COTTIER, Thomas. A Theory of Direct Effect in Global Law, 2002. In: Armin von Bogdandy and Petros C. Mavroidis (eds.), European Integration and International Co-ordination: Studies in Transnational Economic Law in Honour of Claus-Dieter Ehlermann. The Hague, London and New York: Kluwer Law International, 2002.

The WTO Permanent Panel Body: A Bridge Too Far? Journal of International Economic Law, v.6, p.187.

DAVEY, William J. Proposals for Improving the Working Procedures of WTO Dispute Settlement Panels, 2004. In ORTINO, Federico; PETERSMAN, Ernst-Ulrich (eds.). The WTO Dispute Settlement System 1995-2003. The Hague, London, New York: Kluwer Law International, 2004. 
Has the WTO Dispute Settlement System Exceeded Its Authority? A Consideration of Deference Shown by the System to Member Government Decisions and Its Use of Issue-Avoidance Techniques, 2003. In: COTTIER, Thomas; MAVROIDIS, Petros C. (eds.). The Role of the Judge in International Trade Regulation. Ann Arbor: The University of Michigan Press, 2003.

The WTO Dispute Settlement System: The First Ten Years. Journal of International Economic Law, v.8, p.17, 2005.

DE CHIARA, Marcia. Saco de juta perde mercado para a Índia. O Estado de São Paulo, São Paulo, 14 de mar. de 2012. Disponível em: <http://www.estadao.com.br/noticias/impresso,saco-de-jutaperde-mercado-para-india-,848099,0.htm>. Acessado em 09 jul. 2012.

DUNNE III, Matthew S. Redefining Power Orientation: a reassessment of Jackson`s paradigm in light of asymmetries of Power, negotiation, and compliance in the GATT/WTO dispute settlement system. Law \& Policy in International Business, Washington, v. 34, 2002-2003.

EECKHOUT, Piet. Judicial Enforcement of WTO Law in the European Union - Some Further Reflections, 2002. Journal of International Economic Law, v.5, p.91.

EDENS, Bryan A. Substancial Evidence in the law of International Trade: meaningful judicial review of antidumping actions or perpetuation of the yo-yo effect? Cardozo Public Law, Policy \& Ethics Journal, Nova York, vol. 6, 2007-2008, pag. 431.

ELLIS, Neil. Introductory Note to WTO Appellate Body Report: United States - Measures relating to zeroing and sunset reviews. In: International Law Materials, v.46, p.94, 2007.

ESSERMAN, Susan; HOWSE, Robert. The WTO on Trial. Foreign Affairs, Washington, v. 82, jan-fev/2003.

FERRAZ JR., Tércio S.; DA ROSA, José Del Chiaro F.; GRINBERG, Mauro. Direitos AntiDumping e Compensatórios: sua natureza jurídica e consequências de tal caracterização. Revista de Direito Mercantil, Industrial, Econômico e Financeiro (RDM), São Paulo, n. 91, julho/setembro 1993.

FINGER, Michael J.; ZLATE, Andrei. Anti-dumping: Prospects for Discipline from the Doha Negotiations. Boston College Working Papers in Economics, n.632, 17 nov. 2005. In: BARROS, Maria Carolina M. Antidumping e Antitruste: Interface Possível no Sistema Multilateral de 
Comércio. São Paulo, 2008. Tese (Doutorado em Direito). Faculdade de Direito da Universidade de São Paulo.

FINGER, Michael J. Dumping and Anti-Dumping: The Rhetoric and the Reality of Protection in Industrial Countries, The World Bank Research Observer, v.7, n.2, jul. 1992.

FUKUGANA, Yuka. Securing Compliance Through the WTO Dispute Settlement System: Implementation of DSB Recommendations, 2006. Journal of International Economic Law, v.9, p.383.

GINGERICH, Tara. Why the WTO should require the application of the evidentiary threshold requirement in antidumping investigations. American University Law Review, Washington, v.48, 1998-1999.

GREENWALD, John. WTO Dispute Settlement: An exercise in trade law legislation? Journal of International Economic Law, v.6, 2003.

GOETZ, Charles J.; SCOTT, Robert E. Liquidated Damages, Penalties, and the Just Compensation Principle: Notes on an Enforcement Model and a Theory of Efficient Breach. Columbia Law Journal, Nova York, v.77, 1977, p.554.

HALLWORTH, Taro; PIRACHA, Matloob. Macroeconomic Fluctuations and Anti-dumping Filings: Evidence from a New Generation of Protectionist Countries. Journal of World Trade, v.40, 2006 p.407.

HAMILTON, Lee D. US Antidumping Decisions and the WTO Standard of Review: Deference or Disregard? Chicago Journal of International Law, Chicago, v.4, 2003.

HORLICK, Gary N. Proposals for Reform of the GATT Antidumping Code. Brooklyn Journal of International Law, vol XVIII, n.1, 1992, p. 181. ; DEBUSK, Amanda. Dispute Resolution under NAFTA: building on the U.S. - Canad FTA, GATT and ICSID. Journal of World Trade, The Hague, London and New York: Kluwer Law International, v.27, 1993, p.21.

HOWSE, Robert. Symposium: The Boundaries of the WTO: From Politics to Technocracy--and Back Again: The Fate of the Multilateral Trading Regime. American Journal of International Law, v.96, 2002, p.94. 
The Most Dangerous Branch? WTO Appellate Body Jurisprudence on the Nature and Limits of the Judicial Power, 2003. In: COTTIER, Thomas; MAVROIDIS, Petros C. (eds.). The Role of the Judge in International Trade Regulation. Ann Arbor: The University of Michigan Press, 2003.

HUANG, Zhixiong. Rise and Fall of Trade Multilateralism: A Proposal for 'WTO à la carte' as an Alternative Approach for Trade Negotiation. ASIAN INTERNATIONAL ECONOMIC LAW NETWORK (AIELN) INAUGURAL CONFERENCE, 30 junho de 2009. Disponível em <http://aieln1.web.fc2.com/Huang_panel6.pdf>, Acesso em 06 jul. 2012.

HUDEC, Robert E. The GATT Legal System: a Diplomat`s jurisprudence. Journal of World Trade Law, The Hague, London and New York: Kluwer Law International, v. 4, 1970.

JACKSON, John H. Editorial Comment: International Law Status of WTO Dispute Settlement Reports: Obligation to Comply or Option to "Buy Out"? American Journal of International Law, v.98, 2004, p.109.

Editorial Comment: The WTO Dispute Settlement Understanding: Misunderstandings on the Nature of Legal Obligations. American Journal of International Law, v.91, 1997, p.60.

; CROLEY, Steven P. WTO Dispute Procedures, Standard of Review, and Deference to National Governments. American Journal of International Law, v.90, n.2, abr. 1993, p.193.

JAFFE, Louis L. The right of judicial review, Harvard Law Review, Cambridge/Massachussetts, $\mathrm{n}$. 71, 1958, p.408. Apud CORDOVIL, Leonor. O interesse público no antidumping. São Paulo, 2009. Tese (Doutorado em Direito) - Faculdade de Direito da Universidade de São Paulo, p. 284.

JALLAB, Mustapha Sadni; KOBAK, James B. Antidumping as Anticompetitive Practice Evidence from the United States and the European Union. Journal of Industry, Competition \& Trade, Berlim, v.6, n. 3-4, p.253-275, 2006.

KRISHNA, Raj. Antidumping in Law and Practice. World Bank Policy Research Working Paper, Washington, n. 1823, 1998.

WALDERS, Lawrence R.; PRATT, Neil C. Trade Remedy Litigation-Choice of Forum and Choice of Law. Journal of Civil Rights and Economic Development, New York, v.18, n.1, 2003, article 3 . 
LEÃES, Luiz Gastão P. de B. O "dumping" como forma de abuso do poder econômico. Revista de Direito Mercantil, Industrial, Econômico e Financeiro, São Paulo: Revista dos Tribunais, n. 91, p. 05-15, jul./set. 1993.

LIMA-CAMPOS, Aluisio de. Nineteen Proposals to curb abuse in antidumping and countervailing duty proceedings. Journal of World Trade, The Hague, London and New York: Kluwer Law International, v.39, n.2, 2005.

; VITO, Adriana. Abuse and Discretion: the impact of antidumping and countervailing duty proceedings on Brazilian exports to the United States. Journal of World Trade, The Hague, London and New York: Kluwer Law International, vol. 38, n. 1, 2004, p-37-68.

; GIL, Juan Antonio G. A Case for Misaligned Currencies as Countervailable Subsidies. Journal of World Trade, The Hague, London and New York: Kluwer Law International, v.46, n.5, a ser publicado em out. 2012.

LINDSEY, Brink; IKENSON, Daniel. The Rhetoric and Reality of US Anti-Dumping Law. AntiDumping Global Abuse of a Trade Policy Instrument, Nova Délhi, Academic Foundation, 2007, p. 113.

Anti-Dumping Exposed: the devilish details of unfair trade Law. Washington DC:

Cato Institute, 2003.

MAVROIDIS, Petros C. Remedies in the WTO Legal System: Between a Rock and a Hard Place. European Journal of International Law, v.11, 2000, p.763.

MARKS, Matthew. United States Antidumping Laws - a government overview. Antitrust Law Journal, Nova York, 580, 1973-1974.

MCGEE, Robert. Antidumping Laws as Weapons to Protectionism: Asian case studies. Manchester Journal of International Economic Law, Manchester, v.5, n.1, 2008, pp.36-69.

MEZIAT, Armando. A defesa comercial no Brasil. Revista Brasileira de Comércio Exterior, n. 58, jan./mar.1999, p. 54-56.

MILLER, Andrea. The United States Antidumping Statutes: can a trade agreement be both “free"and "fair"? A case study of Chile. Catholic University Law Review, Washington DC, v.54, rev.627, 2004-2005. 
NAIDIN, Leane Cornet. Nove anos de aplicação da política "antidumping" no Brasil. Revista Brasileira de Comércio Exterior, n. 58, jan/mar. 1999, p. 57-63.

NARAYANAN, Prakash. Injury Investigations in "Material Retardation" antidumping cases. Northwestern Journal of International Law \& Business, 25:37, 2004.

NEUFELD, Inge Nora. Anti-Dumping and Countervailing Procedures - use or abuse? Implications for developing countries. UNCTAD - Policy Issues In International Trade And Commodities Study Series, Nova York e Genebra, n.9, 2001.

NICOLAIDES, Phedon. The Competition Effects of Dumping. Journal of World Trade, The Hague, London and New York: Kluwer Law International, v. 24, n. 5, 1990.

PALMETER, David. A Commentary on the WTO Anti-Dumping Code. Journal of World Trade, The Hague, London and New York: Kluwer Law International, v.30, n.4, 1996, pp. 47-48.

PAUWELYN, Joost. Enforcement And Countermeasures In The WTO: Rules Are Rules - Toward A More Collective Approach. American Journal of International Law, v.94, 2000, p.335.

The Sutherland Report: A Missed Opportunity for Genuine Debate on Trade, Globalization, and Reforming the WTO. Journal of International Economic Law, v.8, n.2, 2005, p.329.

The Transformation of World Trade. Michigan Law Review, v.104, 2005, p.1.

NIELS, Gunnar; KATE, Adriaan Ten. Trusting Antitrust to Dump Antidumping: Abolishing Antidumping in Free Trade Agreements Without Replacing it with Competition La. Journal of World Trade, v.31, n.6, dez. 1997.

PAUWELYN, Joost. Appeal without Remand: A Design Flaw in the World Trade Organization Dispute Settlement and How to Fix it. Geneva: International Centre for Trade and Sustainable Development, 2007. Disponível em: <http://ictsd.org/i/publications/11655/>. Acesso em 10 jul. 2012.

PETERS, Amanda. The meaning, measure and misuse of standards of review. Lewis \& Clark Law Review, Portland, 233, 234, 235 (2009), In: BERRY IV, Lee Will. Standards of the Standards of Review. Veterans Law Review, v.3, 2011, p. 263. 
PRUSA, Thomas J. The trade effect of US Antidumping Actions. National Bureau of Economic Research, working paper 5440, jan. 1996. Disponível em www.nber.org/papers/w5440, p.1. Acesso em 18 jun. 2012.

QUEIRÓ, Afonso Rodrigues. A Teoria do Desvio do Poder em Direito Administrativo. Revista de Direito Administrativo, Rio de Janeiro, FGV, v.VII, jan. a mar. de 1947, pp. 52 a 80.

RAI, Sheela. Analysis of the Draft Anti-Dumping Agreement, Chairperson`s Text 2007 in Light of the Jurisprudential Background. Manchester Journal of International Economic Law, v.5, n.126$145,2008$.

RASLAN, Reem Anwar A. Antidumping: a developing country perspective. Global Trade Law Series, The Hague, London and New York: Kluwer Law International, 2009.

REEDER, Caasey. Zeroing in on charming betsy: how an antidumping controversy threatens to sink the schooner. Stetson Law Review, Gulfport, v.36, 2007, pp. 255-291.

RESTANI, Jane A. A review of recent decisions of the United States Court of Appeals for the Federal Circuit: Introductory Comment: judicial review in International Trade: its role in the balance between delegation by Congress and Limitation of Executive. American University Law Review, Washington, v.37, 1988, p.1075.

RUGGIERO, Renato. WTO, Trading in the Future, $2^{\mathrm{a}}$. ed, 2001, pag. 38.

SCHWARTZ, Warren F.; SYKES, Alan O. The economic structure of Renegotiation and Dispute Resolution in the World Trade Organization. Journal of Legal Studies, v.31 2002, p.179. In: MAVROIDIS, Petros C.; SYKES, Alan O. The WTO and International Trade Law/Dispute Settlement. Cheltenham: Edward Elgar Publishing, 2005.

SPAULDING, Jeffrey. Do International Fences really make good neighbors? The zeroing conflict between antidumping law and international obligations. New England Law Review, vol. 41, pag. 379, 2006-2007.

SCHOENBAUM, Thomas. Market Contestability and Reform in the Antidumping Laws. German Yearbook of International Law, Kiel, v. 39, 1996.

SHIN, Hyun Ja. Possible instances of predatory pricing in recent US Antidumping Cases. In: Robert Z. Lawrence (ed). Brookings Trade Forum: Washington DC: The Brookings Institution, 1998. 
STEWART, Terence P.; DWYER, Amy S.; HEIN, Elizabeth M. Trends in the last decade of trade remedy decisions: problems and opportunities for the WTO dispute settlement system. Arizona Journal of International and Comparative Law, Tucson, v.24, p.251, 2007.

STYN, Ronald. The Antidumping Act: Problems of Administration and Proposals for Change Stanford Law Review, Stanford, v.17, n.4, 1965, p. 748.

SYKES, Alan O. Antidumping and Antitrust: What problems does each address? In: LAWRENCE, Robert Z. (ed.), Brokings Trade Forum. Washington DC: The Brookings Institution. 1998, pp. 1-2.

TAVARES, José de Araújo J. "Legal and Economic Interfaces between Antidumping and Competition Policy”. Secretaria de Acompanhamento Econômico - Ministério da Fazenda, Dez. 2001. Disponível em: <http://www.seae.fazenda.gov.br/document_center/papers-and-articles/20011/1-legalandeconomic/?searchterm=legal\%20and\%20economic\%20interface $>$. Acesso em 10 jul. 2012.

THERON, Nicola. Anti-Dumping Procedures: lessons for developing countries with Special emphasis on the South African Experience. Department of Economics, University of Stellenbosch, p.

em: $<$ http://www.google.com.br/url?sa=t\&rct=j\&q=\&esrc=s\&frm=1\&source=web\&cd=1\&ved=0C EUQFjAA\&url=http\%3A\%2F\%2Fwww.econex.co.za\%2Findex.php\%3Foption\%3Dcom_docman \%26task\%3Ddoc_download\%26gid\%3D12\%26Itemid\%3D60\&ei=ToP9T6_VOur46wGfwMXHB g\&usg=AFQjCNGoU_MVVXadz0k1ZJvDUKLpjjo-og. Acesso em 11 jul. 2012.

VÁZQUEZ, Carlos M.; JACKSON, John H. Some reflections on compliance with WTO Dispute Settlement Decisions. Law and Policy in International Business, v.33, 2002, p.555.

ZANARDI, Maurizio. Antidumping: What are the Numbers to Discuss at Doha? The World Economy, v.27, n.3, pp. 403-433, mar. 2004.

WELlHAUSEN, Marc. The Community Interest Test In Antidumping Proceedings of the European Union. In American University International Law Review, Washington, v.16, 2000-2001.

WILLIG, Robert D. Economic Effects of Antidumping Policy. In: LAWRENCE, Robert Z. (ed.) Brookings Trade Forum. Washington DC: The Brookings Institution, 1998. 


\section{$\underline{\text { Teses e Dissertacões }}$}

ARAÚJO, Leandro Rocha. Normas sobre Facilitação do Comércio: reflexos para a institucionalização e a previsibilidade do sistema de comércio exterior brasileiro. São Paulo, 2006. Tese (Doutorado em Direito) - Faculdade de Direito da Universidade de São Paulo.

BARROS, Maria Carolina M. Antidumping e Antitruste: Interface Possível no Sistema Multilateral de Comércio. São Paulo, 2008. Tese (Doutorado em Direito). Faculdade de Direito da Universidade de São Paulo.

. O direito antidumping como arma protecionista. São Paulo, 2002. Dissertação (Mestrado em Direito) - Faculdade de Direito da Universidade de São Paulo.

CARVALHO, Evandro Menezes de. O Discurso jurídico-decisório da Organização Mundial do Comércio: uma análise semiótica dos relatórios do Órgão de Apelação. São Paulo, 2005. Tese (Doutorado em Direito) - Faculdade de Direito da Universidade de São Paulo.

CORDOVIL, Leonor A. G. O interesse público no antidumping. São Paulo, 2009. Tese (Doutorado em Direito) - Faculdade de Direito da Universidade de São Paulo.

FONSECA, Hugo Soares Porto. Tensões nas Relações Comerciais Internacionais: Medidas Antidumping e Protecionismo sob uma perspectiva brasileira. Belo Horizonte, 2007. Dissertação (Mestrado em Direito). Disponível em $<$ http://www.biblioteca.pucminas.br/teses/Direito_FonsecaHS_1.pdf>. Acesso em 21 jun. 2012.

JUNQUEIRA, Carla Amaral de A. A técnica interpretativa do Órgão de Apelação da Organização Mundial do Comércio. São Paulo, 2010. Tese (Doutorado em Direito) - Faculdade de Direito da Universidade de São Paulo.

PUPO, Rodrigo Luís. A evasão de direitos antidumping e sua disciplina no comércio internacional. São Paulo, 2006. Dissertação (Mestrado em Direito) - Faculdade de Direito da Universidade de São Paulo.

RODRIGUES, José Roberto Pernomian. O dumping como forma de expressão do abuso do poder econômico: caracterização e consequências. São Paulo, 1999. Tese (Doutorado em Direito) Faculdade de Direito da Universidade de São Paulo. 
SANCHEZ, Michelle R. Demandas por um novo arcabouço sócio-jurídico na Organização Mundial do Comércio e o caso do Brasil. São Paulo, 2004. Tese (Doutorado em Direito) Faculdade de Direito da Universidade de São Paulo.

SILVA, Elaini Cristina Gonzaga. Juridicização das Relações Internacionais e Solução de Controvérsias: Análise do Sistema Multilateral de Comércio. São Paulo, 2007. Dissertação (Mestrado em Direito) - Faculdade de Direito da Universidade de São Paulo.

VARANDA, Aquiles Augusto. Disciplina do dumping do acordo geral de tarifas aduaneiras $e$ comércio: tipificação de um delito num tratado internacional. São Paulo, 1988. Tese (Doutorado em Direito) - Faculdade de Direito da Universidade de São Paulo.

USITC. The Economic Effects of Antidumping and Countervailing Duty Orders and Suspension Agreements. Publication 2900, June, 1995.

ZANDAVALI, Marcelo Freiberger. O juiz brasileiro e as normas da OMC: o caso da importação de automóveis usados. São Paulo, 2008. Dissertação (Mestrado em Direito) - Faculdade de Direito da Universidade de São Paulo.

ZENG, Hang. Antidumping and Competition: The case of China. Vancouver, 2005. Dissertação (Mestrado em Direito) - The Faculty of Graduate Studies (Law) of the University of British Columbia - Canada.

\section{Dicionários}

BLACK, Henry C. Blacks Law Dictionary. 5a. ed. St. Paul: West Publishing Co, 1979.

FERREIRA, Aurélio Buarque de Holanda. Novo Dicionário Aurélio da língua portuguesa, 4a. edição, Curitiba, 2009.

HOUAISS, Antônio e VILLAR, Mauro de Salles. Dicionário Houaiss da Língua Portuguesa. Editora Objetiva. Rio de Janeiro: 1a. ed., 2001.

\section{Trabalhos apresentados em eventos}

BAGWELl, Kyle; MAVROIDIS, Petros C.; STAIGER, Robert W. (2003). The Case for Auctioning Countermeasures in the WTO (mimeo). 


\section{Legislacão e Documentos Oficiais}

\section{A. Documentos do Brasil}

BRASIL. Constituição (1988). Constituição da República Federativa do Brasil. Brasília, DF: Senado, 1988.

BRASIL. Lei n. ${ }^{\circ}$ 9.784, de 29 de janeiro de 1999. Regula o processo administrativo no âmbito da Administração Pública Federal. Diário Oficial da União, Brasília, DF, 01 fev. 1999 e retificado no Diário Oficial da União em 11. Mar. 1999.

BRASIL. Decreto n. ${ }^{\circ} 1.602$, de 23 de agosto de 1995. Regulamenta as normas que disciplinam os procedimentos administrativos, relativos à aplicação de mediadas antidumping. Diário Oficial da União, 24 ago.1995.

Decreto Legislativo ${ }^{\circ}$ 20, em 5 de dezembro de 1986.

Decreto $\mathrm{n}^{\circ}$ 93.941, de 19 de janeiro 1987

Decreto ${ }^{\circ}$ 93.962, de 23 de janeiro de 1987 - D.O.U. de 2 de fev. 1987.

Decreto Legislativo 30, de 15 de dezembro de 1994.

Decreto 1.355, de 30 de dezembro de 1994.

Lei 9.019, de 30 de março de 1995.

Decreto 4543/02.

Decreto 4765, de 24 de junho de 2003.

Decreto 4732, de 10 de junho de 2003.

Circular SECEX n 03, de 12 jan. 2005 - D.O.U. de 13 jan. 2005.

Circular SECEX n 13, de 26 mar. 2012 - D.O.U. de 27 mar. 2012.

Circular SECEX n 14, de 10 mar. 2008 - D.O.U. de 11 mar. 2008.

Circular SECEX n 21, de 10 mai. 2012 - D.O.U. de 11 mai. 2012.

Circular SECEX n 23, de 24 abr. 2008 - D.O.U. de 25 abr.2008.

Circular SECEX n 23, de 19 mai. 2011 - D.O.U. de 20 mai. 2011.

Circular SECEX n ${ }^{\circ} 23$, de 16 mai. 2012 - D.O.U. De 17 mai.2012.

Circular SECEX n 31, de 17 abr. 2006 - D.O.U. de 18 abr. 2006.

Circular SECEX n 32, de 14 jun. 2011 - D.O.U. de 17 jun. 2011.

Circular SECEX n 33, de 3 ago. 2010 - D.O.U. de 5 ago. 2010.

Circular SECEX n 38, de 21 jul. 2011 - D.O.U. de 22 jul. 2011.

Circular SECEX n 43, de 12 ago. 2011 - D.O.U. de 15 ago. 2011

Circular SECEX n 44, de 03 jul. 2008 - D.O.U. de 04 jul. 2008.

Circular SECEX n 46, de 8 out. 2010 - D.O.U. de 13 out. 2010.

Circular SECEX n ${ }^{\circ}$ 50, de 22 set. 2009 - D.O.U. de 23 set. 2009.

Circular SECEX n ${ }^{\circ}$ 51, de $1^{\circ}$ nov. 2011 - D.O.U. de 4 nov. 2011.

Circular SECEX n ${ }^{\circ}$ 54, de 25 set. 2007 - D.O.U. de 26 set. 2007.

Circular SECEX n ${ }^{\circ}$ 54, de 13 out. 2009 - D.O.U. de 14 out. 2009.

Circular SECEX n 55, de 25 set. 2007 - D.O.U. de 26 set. 2007. 
Circular SECEX n 60, de 22 nov. 2011 - D.O.U. de 23 nov. 2011.

Circular SECEX n 61, de 19 set. 2005 - D.O.U. de 22 set. 2005.

Circular SECEX n 61, de 28 nov. 2011 - D.O.U. de 29 nov. 2011.

Circular SECEX n ${ }^{\circ}$ 77, de 07 dez. 2005 - D.O.U. de 12 dez. 2005.

Circular SECEX n 42, de 25 out. 2000 - D.O.U de 27 out. 2000.

Resolução CAMEX n 5 de 25 abr. 2002 - D.O.U. de 26 abr. 2002.

Julgados e súmulas disponíveis nos seguintes endereços eletrônicos. Último acesso em 12 jul. 2012:

STF: <http://www.stf.jus.br/portal/jurisprudencia/pesquisarJurisprudencia.asp>

STJ: <http://www.stj.jus.br/SCON/>

TRF $1^{\text {a }}$ Região: <http://www.trf1.jus.br/default.htm>

TRF $2^{\text {a }}$ Região:

$<\mathrm{http}: / /$ www2.trf2.gov.br/NXT/gateway.dll?f=templates\&fn=default.htm\&vid=base_jju:v_juris>

TRF $3^{\mathrm{a}}$

Região:

$<$ http://www.trf3.jus.br/NXT/Gateway.dll?f=templates\&fn=default.htm\&vid=trf3e:trf3ve>

TRF 4 ${ }^{a}$ Região: <http://jurisprudencia.trf4.jus.br/pesquisa/pesquisa.php?tipo=1>

TRF 5 Região: <http://www.trf5.jus.br/Jurisprudencia/>

\section{B. Documentos da ONU}

EPCT/C.II/48 (1946)

E/CONF.2/C.3/C/18

E/CONF.2/C.3/SR.30

\section{Documentos da OMC}

Disponíveis em: < http://docsonline.wto.org/?language=1>. Último acesso em 12 jul. 2012.

Understanding on Rules and Procedures Governing the Settlement of Disputes, 15 April 1994, WTO Agreement, Annex 2, 33 I.L.M. 112 (1994) [ESC].

Relatórios de painéis e Órgão de Apelação

Acordo de Marraqueche

Acordo AD Rodada Tóquio

Acordo AD Rodada Kennedy

Havana Reports

Agreement for Implementation of Article VI of GATT (Anti-Dumping Agreement ) - [ADA]

Documentos do grupo de negociação para facilitação do comércio:

- $\mathrm{TN} / \mathrm{TF} / \mathrm{W} / 122$.

- $\quad$ TN/TF/W/116/Rev. 1.

- $\quad$ TN/TF/W/120/Rev. 1

- $\mathrm{TN} / \mathrm{TF} / \mathrm{W} / 125$.

- $\quad \mathrm{TN} / \mathrm{TF} / \mathrm{W} / 43 / \mathrm{Rev} .3$. 
Documentos do grupo de negociação sobre regras:

- $\mathrm{TN} / \mathrm{RL} / \mathrm{W} / 143$.

- $\mathrm{TN} / \mathrm{RL} / \mathrm{W} / 171$.

- $\mathrm{TN} / \mathrm{RL} / \mathrm{W} / 213$.

- $\mathrm{TN} / \mathrm{RL} / \mathrm{W} / 232$.

- $\mathrm{TN} / \mathrm{RL} / \mathrm{W} / 246$.

Documentos do Comitê Antidumping:

- $\quad \mathrm{ADP} / 87$.

- $\quad$ ADP 137.

- $\mathrm{ADP} / 106$.

- $\mathrm{ADP} / \mathrm{M} / 43$.

- $\mathrm{ADP} / 121$

- $\mathrm{ADP} / \mathrm{M} / 44$.

- $\mathrm{G} / \mathrm{ADP} / \mathrm{IG} / \mathrm{W} / 22$

- COM.AD/18. RESTRICTED

General Agreement on Tariffs and Trade, 30 October 1947, 58 U.N.T.S. 187, Can. T.S. 1947 No. 27 [GATT 1947].

BISD 15S/4-35 - 1964/1967 Trade Conference (Kennedy Round)

BISD 8S/145 L/978 - Report of the GATT Working Group, Anti-Dumping and Countervailing Duties

BISD 3S/81

BISD 15S/26

BISD 32S/55

BISD 35S/116

BISD 39S/436

BISD 40S/205

\section{Documentos do MERCOSUL}

Disponíveis em: < http://www.mercosur.int/>. Último acesso em 12 jul. 2012.

MERCOSUL. Protocolo de Olivos para Solução de Controvérsias no MERCOSUL (2004). Argentina, Olivos, 18 fev. 2002. Promulgado pelo Decreto $n^{\circ}$ 4.982, de 9 fev. 2004, publicado no D.O.U de 10 fev. 2004.

Decisão CMC 11/97

Decisão CMC No $18 / 96$

Decisão CMC 64/00.

Diretiva CCM N $5 / 95$

Resolução GMC N 63/93

Resolução GMC No 129/94 
Laudo 04, de 21.05.2001 - Tribunal Permanente de Revisão.

\section{E. Documentos do NAFTA}

Disponíveis em: < http://www.nafta-sec-alena.org/en/view.aspx>. Último acesso em 12 jul. 2012. Acordo Norte-Americano de Livre Comércio (North American Free Trade Agreement) - Canadá, México e EUA, 1994.

- ECC-2000-1904-01USA (Oct. 30, 2003)

- ECC-2003-1904-01USA (Oct. 7, 2004)

- ECC-2004-1904-01USA (Aug. 10, 2005)

\section{F. Documentos dos EUA}

US Court of International Trade: <http://www.cit.uscourts.gov/>

US Court of Appeals for the Federal Circuit: <http://www.cafc.uscourts.gov/>

Supreme Court of the United States: <http://www.supremecourt.gov/> 


\begin{tabular}{|c|c|c|c|c|}
\hline \multicolumn{5}{|c|}{ APÊNDICE 1 - DISPUTAS ANTIDUMPING ENCERRADAS NA FASE DE CONSULTAS } \\
\hline $\begin{array}{l}\text { Dispute } \\
\text { Settlement } \\
\text { (DS): } \\
\text { Caso }\end{array}$ & $\begin{array}{l}\text { Short Title } \\
\text { "Apelido" }\end{array}$ & Nome Completo & Resumo do caso & Cronológico \\
\hline DS374 & $\begin{array}{c}\text { South } \\
\text { Africa - } \\
\text { Uncoated } \\
\text { Woodfree } \\
\text { Paper }\end{array}$ & $\begin{array}{l}\text { África do Sul - Medidas } \\
\text { antidumping em papel fino } \\
\text { não revestido A4 } \\
\text { proveniente da Indonésia/ } \\
\text { South Africa - Anti- } \\
\text { Dumping Measures on } \\
\text { Uncoated Woodfree Paper }\end{array}$ & $\begin{array}{l}\text { A Indonésia requereu consultas com África do Sul devido à } \\
\text { contínua imposição de medidas antidumping definitivas na } \\
\text { importação de papel fino não revestido A4 proveniente da } \\
\text { Indonésia. Apesar da revisão de final de período ter } \\
\text { concluído que a medida antidumping não teria continuaçãa, } \\
\text { a África do Sul continuou a impor medidas antidumping na } \\
\text { importação do mencionado produto da Indonésia. } \\
\text { No relatório semi-anual sul africano, a revisão de final de } \\
\text { período no caso de papel fino não revestido A4 proveniente } \\
\text { da Indonésia foi listado como uma revisão ainda em } \\
\text { andamento. Desse modo, a Indonésia reclama da extensão } \\
\text { do período de revisão além do permitido pelo ADA (artigo } \\
\text { 11.4), que determina que revisões não podem ter duração } \\
\text { superior a } 12 \text { meses. } \\
\text { Após certo período, a Indonésia informou ao ESC que a } \\
\text { África do Sul promulgou uma reforma normativa que } \\
\text { alterou a dinâmica da alfândega e cobrança fiscal, retirando } \\
\text { as medidas antidumping impostas ao papel fino não } \\
\text { revestido A4 proveniente da Indonésia com efeito } \\
\text { retroativo ao final dos } 5 \text { anos iniciais de imposição de } \\
\text { dumping. } \\
\text { A Indonésia retirou seu pedido de consultas. }\end{array}$ & $\begin{array}{l}\text { Pedido de consulta recebido } \\
\text { em: } 09 \text { de maio de } 2008 \\
\text { Notificação de acordo em: } 20 \\
\text { de novembro de } 2008\end{array}$ \\
\hline
\end{tabular}




\begin{tabular}{|c|c|c|c|c|}
\hline \multicolumn{5}{|c|}{ APÊNDICE 1 - DISPUTAS ANTIDUMPING ENCERRADAS NA FASE DE CONSULTAS } \\
\hline $\begin{array}{l}\text { Dispute } \\
\text { Settlement } \\
\text { (DS): } \\
\text { Caso }\end{array}$ & $\begin{array}{l}\text { Short Title } \\
\text { "Apelido" }\end{array}$ & Nome Completo & Resumo do caso & Cronológico \\
\hline DS313 & $\begin{array}{l}\text { EU-Flat } \\
\text { Rolled Iron } \\
\text { and Steel } \\
\text { Products }\end{array}$ & $\begin{array}{c}\text { Comunidades Europeias - } \\
\text { Deveres Antidumping em } \\
\text { determinados laminados } \\
\text { planos de ferro ou } \\
\text { produtos de aço não } \\
\text { ligado/ } \\
\text { European Communities - } \\
\text { Anti- Dumping Duties on } \\
\text { Certain Flat Rolled Iron } \\
\text { or Non-Alloy Steel } \\
\text { Products from India }\end{array}$ & $\begin{array}{l}\text { A Índia requereu consultas com a CE devido a imposição } \\
\text { de direitos antidumping definitivos na importação de } \\
\text { determinados laminados planos de ferro ou produtos de aço } \\
\text { não ligado provenientes da Índia. } \\
\text { De acordo com o pedido da Índia, a CE violou diversos } \\
\text { artigos do ADA, dentre eles o artigo } 9.2 \text {, devido à } \\
\text { imposição europeia de medidas antidumping para produtos } \\
\text { indianos, mas não para o mesmo produto proveniente do } \\
\text { Egito, Eslováquia e Turquia, mesmo que tivesse sido } \\
\text { constatada a prática de dumping com consequente dano à } \\
\text { indústria da CE. } \\
\text { Após certo período, a Índia e CE notificou o ESC que } \\
\text { ambos tinham chegado a um consenso no que diz respeito à } \\
\text { questão levantada pela Índia no pedido de consultas. De } \\
\text { acordo com a notificação, a CE concordou em extinguir a } \\
\text { barreira comercial questionada. }\end{array}$ & $\begin{array}{l}\text { Pedido de consulta recebido } \\
\text { em: } 05 \text { de julho de } 2004 \\
\text { Pedido de consulta retirado } \\
\text { em: } 22 \text { de outubro de } 2004\end{array}$ \\
\hline DS306 & $\begin{array}{c}\text { India - } \\
\text { Batteries }\end{array}$ & $\begin{array}{l}\text { Índia - Medidas } \\
\text { Antidumping em baterias } \\
\text { provenientes de } \\
\text { Bangladesh// } \\
\text { India - Anti-Dumping } \\
\text { Measure on Batteries from } \\
\text { Bangladesh }\end{array}$ & $\begin{array}{l}\text { Bangladesh requereu consultas com a Índia devido à } \\
\text { medida antidumping imposta pela Índia na importação de } \\
\text { lead acid batteries provenientes de Bangladesh. } \\
\text { Bangladesh questionou diversos aspectos do modo de } \\
\text { condução da investigação de dumping pela autoridade } \\
\text { indiana. } \\
\text { Após certo período, as partes informaram o ESC que uma } \\
\text { solução mutuamente satisfatória para a medida questionada. } \\
\text { A medida foi extinta pela Îndia na notificação aduaneira }\end{array}$ & $\begin{array}{l}\text { Pedido de consulta recebido } \\
\text { em: } 28 \text { de janeiro de } 2004 \\
\text { Pedido de consulta retirado } \\
\text { em: } 20 \text { de fevereiro de } 2006\end{array}$ \\
\hline
\end{tabular}




\begin{tabular}{|c|c|c|c|c|}
\hline \multicolumn{5}{|c|}{ APÊNDICE 1 - DISPUTAS ANTIDUMPING ENCERRADAS NA FASE DE CONSULTAS } \\
\hline $\begin{array}{l}\text { Dispute } \\
\text { Settlement } \\
\text { (DS): } \\
\text { Caso }\end{array}$ & $\begin{array}{l}\text { Short Title } \\
\text { "Apelido" }\end{array}$ & Nome Completo & Resumo do caso & Cronológico \\
\hline & & & No. $01 / 2005$ de 04 de janeiro de 2005. & \\
\hline DS247 & $\begin{array}{c}\text { US- } \\
\text { Softwood } \\
\text { Lumber }\end{array}$ & $\begin{array}{c}\text { EUA - Medidas } \\
\text { Antidumping provisórias } \\
\text { na importação de } \\
\text { determinadas madeiras } \\
\text { macias serradas/ } \\
\text { United States - } \\
\text { Provisional Anti-Dumping } \\
\text { Measure on Imports of } \\
\text { Certain Softwood Lumber } \\
\text { from Canada }\end{array}$ & $\begin{array}{l}\text { Canadá requereu consultas com os EUA devido à } \\
\text { imposição de medidas antidumping na importação de } \\
\text { determinadas madeiras macias serradas provenientes do } \\
\text { Canadá. Em seu pedido, o Canadá questionou a condução } \\
\text { do início da investigação, a inconsistência da determinação } \\
\text { do direito antidumping provisório e a prática do zeramento. } \\
\text { Os EUA, apesar de aceitarem o pedido de consultas, não } \\
\text { aceitaram que este era um caso de urgência. } \\
\text { Após certo período, os EUA e Canadá informaram ao ESC } \\
\text { que ambos haviam atingido o consenso em diversas } \\
\text { disputas, dentre elas o DS } 247 \text {. A solução foi formalizada } \\
\text { em um Acordo entre EUA e Canadá (Softwood Lumber } \\
\text { Agreement) de } 12 \text { de setembro de } 2006 \text {. Em } 23 \text { de fevereiro } \\
\text { de } 2007 \text {, Canadá e EUA comunicaram ao ESC que em } 12 \\
\text { de outubro de } 2006 \text { foi celebrado um novo Acordo que } \\
\text { modificou o Acordo original para facilitar sua entrada em } \\
\text { vigor. }\end{array}$ & $\begin{array}{l}\text { Pedido de consulta recebido } \\
\text { em: } 06 \text { de março de } 2002 \\
\text { Notificação de acordo em: } 12 \\
\text { de outubro de } 2006\end{array}$ \\
\hline DS119 & $\begin{array}{l}\text { Australia- } \\
\text { Coated } \\
\text { Woodfree } \\
\text { Paper } \\
\text { Sheets }\end{array}$ & $\begin{array}{l}\text { Austrália - Medidas } \\
\text { antidumping na } \\
\text { importação de woodfree } \\
\text { papéis finos/ } \\
\text { Australia - Anti- } \\
\text { Dumping Measures on }\end{array}$ & $\begin{array}{l}\text { A Suíça requereu pedido de consultas com Austrália devido } \\
\text { à imposição de medidas antidumping provisórias na } \\
\text { importaçâo de "woodfree" papéis finos provenientes da } \\
\text { Suíça. } \\
\text { A Suíça alega que a investigação não está em conformidade } \\
\text { com as obrigações da Austrália estabelecidas no ADA. }\end{array}$ & $\begin{array}{c}\text { Pedido de consulta recebido } \\
\text { em: } 20 \text { de fevereiro de } 1998 \\
\text { Notificação de acordo em: } 13 \\
\text { de maio de } 1998\end{array}$ \\
\hline
\end{tabular}




\begin{tabular}{|c|c|c|c|c|}
\hline \multicolumn{5}{|c|}{ APÊNDICE 1 - DISPUTAS ANTIDUMPING ENCERRADAS NA FASE DE CONSULTAS } \\
\hline $\begin{array}{l}\text { Dispute } \\
\text { Settlement } \\
\text { (DS): } \\
\text { Caso }\end{array}$ & $\begin{array}{l}\text { Short Title } \\
\text { "Apelido" }\end{array}$ & Nome Completo & Resumo do caso & Cronológico \\
\hline & & $\begin{array}{c}\text { Imports of Coated } \\
\text { Woodfree Paper Sheets }\end{array}$ & $\begin{array}{l}\text { Após certo período, ambas as partes notificaram acordo } \\
\text { com solução. }\end{array}$ & \\
\hline DS89 & $\begin{array}{c}\text { US - } \\
\text { Television } \\
\text { Receivers }\end{array}$ & $\begin{array}{l}\text { Estados Unidos - Deveres } \\
\text { Antidumping na } \\
\text { importação de receptores } \\
\text { de televisões em cores/ } \\
\text { United States-Anti- } \\
\text { Dumping Duties on } \\
\text { Imports of Colour } \\
\text { Television Receivers from } \\
\text { Korea }\end{array}$ & $\begin{array}{l}\text { A Coréia do Sul pediu consultas com os EUA devido à } \\
\text { imposição de medidas antidumping na importação } \\
\text { receptores de televisões em cores (CTVs) provenientes da } \\
\text { Coréia do Sul. A Coréia do Sul alega que os EUA, pelos } \\
\text { últimos } 12 \text { anos, mantiveram direito antidumping para } \\
\text { receptores de TVs em cores da Samsung apesar da ausência } \\
\text { da prática de dumping e cessação de exportação da Coréia } \\
\text { do Sul, sem que houvesse exame da necessidade de } \\
\text { continuação ou não da imposição destes deveres. A Coréia } \\
\text { do Sul alega que os EUA desrespeitaram diversos artigos } \\
\text { do ADA e do GATT } 1994 \text {. } \\
\text { Em 06 de novembro de 1997, a Coréia do Sul requereu o } \\
\text { estabelecimento de Painel. Após certo período, a Coréia do } \\
\text { Sul informou ao ESC que estava retirando seu pedido de } \\
\text { estabelecimento de painel mas mantendo seu direito de } \\
\text { reintroduzir o pedido. }\end{array}$ & $\begin{array}{l}\text { Pedido de consulta recebido } \\
\text { em: } 10 \text { de julho de } 1997 \\
\text { Notificação de acordo em: } 5 \text { de } \\
\text { janeiro de } 1998\end{array}$ \\
\hline DS60 & $\begin{array}{l}\text { Guatemala - } \\
\text { Cement }\end{array}$ & $\begin{array}{l}\text { Guatemala - Investigação } \\
\text { Antidumping em Cimento } \\
\text { Portland provenientes do } \\
\text { México/ } \\
\text { Guatemala - Anti- } \\
\text { Dumping Investigation } \\
\text { Regarding Portland }\end{array}$ & $\begin{array}{l}\text { O México requereu consultas com a Guatemala devido a } \\
\text { uma investigação antidumping iniciada pela Guatemala em } \\
\text { importaçôes de cimento portland proveniente do Mexico. } \\
\text { Mexico alegou que a investigação foi inconsistente com } \\
\text { diversos artigos do ADA e GATT } 1994 \text {. } \\
\text { Em } 04 \text { de fevereiro de 1997, o México requereu } \\
\text { estabelecimento de Painel. Após certo período, o ESC }\end{array}$ & $\begin{array}{l}\text { Pedido de consulta recebido } \\
\text { em: } 15 \text { de outubro de } 1996\end{array}$ \\
\hline
\end{tabular}




\begin{tabular}{|c|c|c|c|c|}
\hline \multicolumn{5}{|c|}{ APÊNDICE 1 - DISPUTAS ANTIDUMPING ENCERRADAS NA FASE DE CONSULTAS } \\
\hline $\begin{array}{l}\text { Dispute } \\
\text { Settlement } \\
\text { (DS): } \\
\text { Caso }\end{array}$ & $\begin{array}{l}\text { Short Title } \\
\text { "Apelido" }\end{array}$ & Nome Completo & Resumo do caso & Cronológico \\
\hline & & Cement from Mexico & postergou o estabelecimento do Painel. & \\
\hline DS49 & $\begin{array}{c}\text { US - } \\
\text { Tomatoes }\end{array}$ & $\begin{array}{l}\text { Estados Unidos - } \\
\text { Investigação Antidumping } \\
\text { de tomates frescos } \\
\text { refrigerados/ } \\
\text { United States - Anti- } \\
\text { Dumping Investigation } \\
\text { Regarding Imports of } \\
\text { Fresh or Chilled Tomatoes } \\
\text { from Mexico }\end{array}$ & $\begin{array}{l}\text { O México decidiu requerer consultas com os EUA devido a } \\
\text { uma investigação antidumping em fresh and chilled } \\
\text { tomatoes importados do México. } \\
\text { O México alegou que a investigação foi inconsistente com } \\
\text { diversos artigos do ADA e GATT 1994, também alegando } \\
\text { ser um pedido com urgência. } \\
\text { O Departamento de Comércio dos EUA indica que as } \\
\text { partes entraram em acordo. }\end{array}$ & $\begin{array}{l}\text { Pedido de consulta recebido } \\
\text { em: } 1 \text { de julho de } 1996\end{array}$ \\
\hline DS23 & $\begin{array}{c}\text { Venezuela - } \\
\text { Tubular } \\
\text { Goods }\end{array}$ & $\begin{array}{l}\text { Venezuela - Investigação } \\
\text { Antidumping na } \\
\text { importação de } \\
\text { determinados materiais } \\
\text { tubulares para petróleo/ } \\
\text { Venezuela - Anti- } \\
\text { Dumping Investigation in } \\
\text { Respect of Imports of } \\
\text { Certain Oil Country } \\
\text { Tubular Goods (OCTG) }\end{array}$ & $\begin{array}{l}\text { O México requereu consultas com a Venezuela devido à } \\
\text { investigação antidumping de determinados materiais } \\
\text { tubulares para petróleo (provenientes do México. O México } \\
\text { alegou que a investigação foi inconsistente com diversos } \\
\text { artigos do ADA e GATT } 1994 \text {. } \\
\text { Após certo período, o México informou ao ESC que as } \\
\text { partes consideraram as consultas desnecessárias, pois as } \\
\text { autoridades competentes da Venezuela acabaram por } \\
\text { decidir em encerrar a investigação questionada. }\end{array}$ & $\begin{array}{c}\text { Pedido de consulta recebido } \\
\text { em: } 05 \text { de dezembro de } 2005 \\
\text { Notificação de acordo em: } 06 \\
\text { de maio de } 1997\end{array}$ \\
\hline
\end{tabular}




\begin{tabular}{|c|c|c|c|c|}
\hline \multicolumn{5}{|c|}{ APÊNDICE 2 - DISPUTAS ANTIDUMPING EM FASE DE CONSULTAS } \\
\hline $\begin{array}{c}\text { Dispute } \\
\text { Settlement (DS): } \\
\text { Caso }\end{array}$ & $\begin{array}{l}\text { Short Title } \\
\text { "Apelido" }\end{array}$ & Nome Completo & Resumo do caso & Cronológico \\
\hline DS429 & $\begin{array}{c}\text { US - Frozen } \\
\text { shrimps }\end{array}$ & $\begin{array}{l}\text { Estados Unidos - Medidas } \\
\text { Antidumping em determinados } \\
\text { camarões congelados de água } \\
\text { doce provenientes do Vietnã/ } \\
\text { United States - Anti-Dumping } \\
\text { Measures on Certain Frozen } \\
\text { Warmwater Shrimp from Viet } \\
\text { Nam }\end{array}$ & $\begin{array}{l}\text { O Vietnã requereu consultas com os EUA devido ao } \\
\text { número de medidas antidumping aplicadas a } \\
\text { determinados camarões congelados de água doce } \\
\text { provenientes do Vietnã. } \\
\text { Além de duas revisões administrativas e revisão de } \\
\text { final de período, o pedido de consulta diz respeito a } \\
\text { diversas leis norte americanas, regulamentos, } \\
\text { procedimentos administrativos e práticas, incluindo } \\
\text { zeramento. }\end{array}$ & $\begin{array}{l}\text { Pedido de consulta } \\
\text { recebido em: } 16 \text { de } \\
\text { fevereiro de } 2012\end{array}$ \\
\hline DS424 & $\begin{array}{l}\text { US - Stainless } \\
\text { Steel Sheet } \\
\text { and Strip }\end{array}$ & $\begin{array}{l}\text { Estados Unidos - Medidas Anti- } \\
\text { Dumping na importação de } \\
\text { Chapas e Fitas de Aço } \\
\text { inoxidável em bobinas } \\
\text { provenientes da Itália)/ } \\
\text { United States - Anti-Dumping } \\
\text { Measures on Imports of Stainless } \\
\text { Steel Sheet and Strip in Coils } \\
\text { from Italy }\end{array}$ & $\begin{array}{l}\text { A União Europeia requereu consulta com os EUA } \\
\text { devido à medidas antidumping impostas na } \\
\text { importação de Chapas e Fitas de Aço inoxidável em } \\
\text { bobinas provenientes da Itália, mais especificamente } \\
\text { questionando a prática do zeramento. } \\
\text { O Japão requereu para se juntar às consultas. }\end{array}$ & $\begin{array}{l}\text { Pedido de consulta } \\
\text { recebido em: } 1 \text { de } \\
\text { abril de } 2011\end{array}$ \\
\hline DS410 & $\begin{array}{l}\text { Argentina - } \\
\text { Fasteners and } \\
\quad \text { Chains }\end{array}$ & $\begin{array}{l}\text { Argentina - Deveres Anti- } \\
\text { Dumping em parafusos } \\
\text { separáveis e não separáveis e } \\
\text { correntes provenientes do Peru/ } \\
\text { Anti-Dumping Duties on }\end{array}$ & $\begin{array}{l}\text { O Peru requereu consulta com a Argentina devido às } \\
\text { medidas antidumping impostas pela Argentina na } \\
\text { importação de parafusos separáveis e não separáveis e } \\
\text { correntes provenientes do Peru e também à } \\
\text { investigação que resultou na aplicação das medidas }\end{array}$ & $\begin{array}{l}\text { Pedido de consulta } \\
\text { recebido em: } 19 \text { de } \\
\text { maio de } 2010\end{array}$ \\
\hline
\end{tabular}




\begin{tabular}{|c|c|c|c|c|}
\hline \multicolumn{5}{|c|}{ APÊNDICE 2 - DISPUTAS ANTIDUMPING EM FASE DE CONSULTAS } \\
\hline $\begin{array}{c}\text { Dispute } \\
\text { Settlement (DS): } \\
\text { Caso }\end{array}$ & $\begin{array}{l}\text { Short Title } \\
\text { "Apelido" }\end{array}$ & Nome Completo & Resumo do caso & Cronológico \\
\hline & & Fasteners and Chains from Peru & $\begin{array}{l}\text { antidumping. } \\
\text { Peru alegou que a Resolução SICPYME 120/08 do } \\
\text { Ministério da Economia e Produção da Argentina, que } \\
\text { iniciou a investigação antidumping, e também diversas } \\
\text { medidas impondo medidas antidumping provisorias e } \\
\text { definitivas, são incompatíveis com diversas previsões } \\
\text { do ADA e o GATT } 1994 \text {. }\end{array}$ & \\
\hline DS407 & $\begin{array}{l}\text { China-Iron } \\
\text { and Steel }\end{array}$ & $\begin{array}{l}\text { China - Deveres Antidumping } \\
\text { provisórios em determinados } \\
\text { parafusos de ferro e aço } \\
\text { provenientes da União Européia/ } \\
\text { China - Provisional } \\
\text { Antidumping Duties on Certain } \\
\text { Iron and Steel Fasteners from } \\
\text { the European Communities }\end{array}$ & $\begin{array}{l}\text { A União Europeia requereu consulta com a China } \\
\text { devido à medidas antidumping provisórias em } \\
\text { determinados parafusos de ferro e aço provenientes da } \\
\text { União Europeia. } \\
\text { A União Européia alega que normativas do Ministério } \\
\text { do Comércio Chinês que impõe as medidas } \\
\text { antidumping provisórias em questão é incompatível } \\
\text { com diversas previsões do ADA e GATT } 94 \text {. } \\
\text { A União Européia também considera que o artigo } 56 \\
\text { do Regulamento Antidumping Chinês é incompatível } \\
\text { com diversas previsões do ADA, Entendimento sobre } \\
\text { solução de controvérsias (ESC) e GATT 1994. De } \\
\text { acordo com este artigo 56, quando um país ou região } \\
\text { impõe discriminatoriamente medidas antidumping nas } \\
\text { exportações provenientes da China, esta pode tomar } \\
\text { medidas correspondentes contra aquele país. }\end{array}$ & $\begin{array}{l}\text { Pedido de consulta } \\
\text { recebido em: } 07 \text { de } \\
\quad \text { maio de } 2010\end{array}$ \\
\hline DS393 & $\begin{array}{l}\text { Chile-Wheat } \\
\text { flour }\end{array}$ & $\begin{array}{l}\text { Chile - Medidas Antidumping } \\
\text { na importação de farinha de trigo }\end{array}$ & $\begin{array}{l}\text { A Argentina requereu consulta com Chile devido à } \\
\text { medidas antidumping impostas pelo Chile em farinha }\end{array}$ & $\begin{array}{l}\text { Pedido de consulta } \\
\text { recebido em: } 14 \mathrm{de}\end{array}$ \\
\hline
\end{tabular}




\begin{tabular}{|c|c|c|c|c|}
\hline \multicolumn{5}{|c|}{ APENDICE 2 - DISPUTAS ANTIDUMPING EM FASE DE CONSULTAS } \\
\hline $\begin{array}{c}\text { Dispute } \\
\text { Settlement (DS): } \\
\text { Caso }\end{array}$ & $\begin{array}{l}\text { Short Title } \\
\text { "Apelido" }\end{array}$ & Nome Completo & Resumo do caso & Cronológico \\
\hline & & $\begin{array}{l}\text { proveniente da Argentina/ } \\
\text { Chile - Anti-Dumping } \\
\text { Measures on Imports of Wheat } \\
\text { Flour from Argentina }\end{array}$ & $\begin{array}{l}\text { de trigo. } \\
\text { A reclamação da Argentina se estende à investigação } \\
\text { conduzida pelas autoridades chilenas com } \\
\text { determinações e medidas dela resultantes. } \\
\text { Em seu pedido, Argentina cita a legislação } \\
\text { antidumping do Chile que, de acordo com a visão } \\
\text { Argentina, é incompatível com as obrigações do Chile } \\
\text { sob os Acordos da OMC. }\end{array}$ & maio de 2009 \\
\hline DS385 & $E C-P E T$ & $\begin{array}{c}\text { Comunidades Europeias - } \\
\text { Revisões expiradas em medidas } \\
\text { antidumping e medidas } \\
\text { compensatórias impostas na } \\
\text { importação de PET provenientes } \\
\text { da Índia/ } \\
\text { European Communities - } \\
\text { Expiry Reviews of Anti-dumping } \\
\text { and Countervailing Duties } \\
\text { Imposed on Imports of PET from } \\
\text { India }\end{array}$ & $\begin{array}{l}\text { A Índia requereu consulta com as Comunidades } \\
\text { Europeias por considerar que diversos artigos de } \\
\text { Regulamentos Europeus Antidumping e de Medidas } \\
\text { Compensatórias lidos conjuntamente com outros } \\
\text { regulamentos são incompatíveis as such com as } \\
\text { obrigações das Comunidades Europeias sob o GATT. } \\
\text { Os regulamentos europeus não dispõem que a extinçãa } \\
\text { de direitos antidumping definitivos ou medidas } \\
\text { compensatórias deve ocorrer não depois de } 5 \text { anos, } \\
\text { contados da data de imposição do dever, permitindo o } \\
\text { início de uma data de extinção após } 5 \text { anos de } \\
\text { imposição da medida de defesa comercial. }\end{array}$ & $\begin{array}{l}\text { Pedido de consulta } \\
\text { recebido em: } 04 \text { de } \\
\text { dezembro de } 2008\end{array}$ \\
\hline DS368 & $\begin{array}{c}\text { US - Sheet } \\
\text { paper }\end{array}$ & $\begin{array}{l}\text { Estados Unidos - Determinações } \\
\text { preliminares de antidumping e } \\
\text { medidas compensatórias em } \\
\text { papéis finos sem revestimento/ }\end{array}$ & $\begin{array}{l}\text { A China requereu consulta com os EUA devido a } \\
\text { medidas preliminares antidumping e medidas } \\
\text { compensatórias impostas pelo Departamento de } \\
\text { Comércio Americano a papéis finos sem revestimento }\end{array}$ & $\begin{array}{l}\text { Pedido de consulta } \\
\text { recebido em: } 14 \text { de } \\
\text { setembro de } 2007\end{array}$ \\
\hline
\end{tabular}




\begin{tabular}{|c|c|c|c|c|}
\hline \multicolumn{5}{|c|}{ APÊNDICE 2 - DISPUTAS ANTIDUMPING EM FASE DE CONSULTAS } \\
\hline $\begin{array}{c}\text { Dispute } \\
\text { Settlement (DS): } \\
\text { Caso }\end{array}$ & $\begin{array}{l}\text { Short Title } \\
\text { "Apelido" }\end{array}$ & Nome Completo & Resumo do caso & Cronológico \\
\hline & & $\begin{array}{c}\text { United States }- \text { Preliminary } \\
\text { Anti-Dumping and } \\
\text { Countervailing Duty } \\
\text { Determinations on Coated Free } \\
\text { Sheet Paper from China }\end{array}$ & $\begin{array}{l}\text { provenientes da China } \\
\text { A China considera a medida incompatível com o } \\
\text { GATT 1994, ADA e ASMC. }\end{array}$ & \\
\hline DS346 & $\begin{array}{l}\text { US - Tubular } \\
\text { goods }\end{array}$ & $\begin{array}{l}\text { Estados Unidos - Revisão } \\
\text { Administrativa em acessórios } \\
\text { para tubos de petróleo } \\
\text { provenientes da Argentina/ } \\
\text { United States - Anti-Dumping } \\
\text { Administrative Review on Oil } \\
\text { Country Tubular Goods from } \\
\text { Argentina }\end{array}$ & $\begin{array}{l}\text { A Argentina requereu consultas com os EUA devido à } \\
\text { revisão administrativa de acessórios para tubos de } \\
\text { petróleo que teria sido incompatível com o ADA e } \\
\text { GATT } 1994 \text {. } \\
\text { O requerimento de consultas também se refere a parts } \\
\text { da Lei dasTarifas de } 1930 \text { dos EUA (US Tariff Act of } \\
\text { 1930). De acordo com a Argentina, tal normativa } \\
\text { permite que os EUA aufiram um montante de lucro } \\
\text { que excede o lucro normalmente auferido por outros } \\
\text { exportadores da mesma categoria de produtos, } \\
\text { violando o ADA e o GATT 1994. }\end{array}$ & $\begin{array}{l}\text { Pedido de consulta } \\
\text { recebido em: } 20 \text { de } \\
\text { junho de } 2006\end{array}$ \\
\hline DS338 & Canada-Corn & $\begin{array}{c}\text { Canadá - Medidas Antidumping } \\
\text { Provisórias e Medidas } \\
\text { compensatórias em grão de } \\
\text { milho proveniente dos Estados } \\
\text { Unidos/ } \\
\text { Canada - Provisional Anti- } \\
\text { Dumping and Countervailing } \\
\text { Duties on Grain Corn from the } \\
\text { United States }\end{array}$ & $\begin{array}{l}\text { Os EUA requereram consultas com o Canadá devido à } \\
\text { imposição de medidas antidumping provisórias e } \\
\text { medidas compensatórias em grãos de milho não } \\
\text { processados provenientes dos EUA. Simultaneamente, } \\
\text { os EUA questionaram certas previsões da Lei de } \\
\text { Medidas de Importações Especiais publicada no } \\
\text { Canadá em dezembro de } 2005 \text {. Os EUA alegam que } \\
\text { tais previsões são incompatíveis com o GATT 1994, } \\
\text { ADA e ASMC. }\end{array}$ & $\begin{array}{l}\text { Pedido de consulta } \\
\text { recebido em: } 17 \text { de } \\
\quad \text { março de } 2006\end{array}$ \\
\hline
\end{tabular}




\begin{tabular}{|c|c|c|c|c|}
\hline $\begin{array}{c}\text { Dispute } \\
\text { Settlement (DS): } \\
\text { Caso }\end{array}$ & $\begin{array}{l}\text { Short Title } \\
\text { "Apelido" }\end{array}$ & Nome Completo & Resumo do caso & Cronológico \\
\hline DS325 & $\begin{array}{c}\text { US - Stainless } \\
\text { Steel }\end{array}$ & $\begin{array}{l}\text { Estados Unidos - Determinações } \\
\text { Antidumping em aço inoxidável } \\
\text { proveniente do México / } \\
\text { United States - Anti-Dumping } \\
\text { Determinations regarding } \\
\text { Stainless Steel from Mexico }\end{array}$ & $\begin{array}{l}\text { O México requereu consultas com os EUA devido à } \\
\text { determinações de medidas antidumping impostas pelo } \\
\text { Departamento de Comércio dos EUA à chapas e fitas } \\
\text { de aço inoxidável em bobinas e também à } \\
\text { determinadas leis antidumping, regulamentos e } \\
\text { práticas administrativas, dentre elas, o zeramento. } \\
\text { Em janeiro de } 2012 \text {, Japão requereu para se juntar às } \\
\text { consultas. Em janeiro de } 2005 \text {, As Comunidades } \\
\text { Europeias requereram para se juntar às consultas. }\end{array}$ & $\begin{array}{l}\text { Pedido de consulta } \\
\text { recebido em: } 05 \text { de } \\
\text { janeiro de } 2005\end{array}$ \\
\hline DS324 & $\begin{array}{c}\text { US - Shrimp } \\
\text { (Thailand) }\end{array}$ & $\begin{array}{l}\text { Estados Unidos - Medidas } \\
\text { Antidumping provisórias em } \\
\text { camarões provenientes da } \\
\text { Tailândial } \\
\text { United States - Provisional } \\
\text { Anti-Dumping Measures on } \\
\text { Shrimp from Thailand }\end{array}$ & $\begin{array}{l}\text { A Tailândia requereu consultas com os EUA devido a } \\
\text { medidas antidumping impostas pelos EUA em } \\
\text { determinados camarões congelados e enlatados } \\
\text { provenientes da Tailândia. Dentre as medidas } \\
\text { questionadas, encontram-se o zeramento, método dos } \\
\text { fatos desfavoráveis disponíveis (adverse facts } \\
\text { available) para determinar o valor normal de } \\
\text { exportação do produto proveniente da Tailândia e para } \\
\text { o fato de os EUA terem falhado em fazer concessões } \\
\text { devidas na determinação preliminar das diferenças que } \\
\text { afetam a comparação de preços entre preços de } \\
\text { exportação e valores normais para os exportadores } \\
\text { tailandeses. } \\
\text { Em } 20 \text { de dezembro de } 2004 \text {, Japão e Brasil pediram } \\
\text { para se juntar às consultas. Em } 22 \text { de dezembro de } \\
2004 \text {, as Comunidades Europeias pediram para se } \\
\text { juntar às consultas. Em } 23 \text { de dezembro de } 2004 \text {, }\end{array}$ & $\begin{array}{l}\text { Pedido de consulta } \\
\text { recebido em: } 09 \text { de } \\
\text { dezembro de } 2004\end{array}$ \\
\hline
\end{tabular}




\section{APÊNDICE 2 - DISPUTAS ANTIDUMPING EM FASE DE CONSULTAS}

\begin{tabular}{|c|c|c|c|c|}
\hline $\begin{array}{c}\text { Dispute } \\
\text { Settlement (DS): } \\
\text { Caso }\end{array}$ & $\begin{array}{l}\text { Short Title } \\
\text { "Apelido" }\end{array}$ & Nome Completo & Resumo do caso & Cronológico \\
\hline & & & $\begin{array}{l}\text { China, Índia e Equador pediram para se juntar às } \\
\text { consultas. }\end{array}$ & \\
\hline DS319 & $\begin{array}{l}\text { US - } 1930 \\
\text { Tariff Act }\end{array}$ & $\begin{array}{l}\text { Estados Unidos - Seção } 776 \text { da } \\
\quad \text { Lei das Tarifas de } 1930 / \\
\text { United States - Section } 776 \text { of } \\
\quad \text { the Tariff Act of } 1930\end{array}$ & $\begin{array}{l}\text { As Comunidades Europeias requereram consultas com } \\
\text { os EUA devido à Seção } 776 \text { (Section 776) da Lei } \\
\text { americana de Tarifas de } 1930 \text { e também devido à } \\
\text { determinações do Departamento de Comércio } \\
\text { Americano que impuseram direitos antidumping em } \\
\text { barras de aço inoxidável provenientes de determinada } \\
\text { empresa do Reino Unido. }\end{array}$ & $\begin{array}{l}\text { Pedido de consulta } \\
\text { recebido em: } 05 \text { de } \\
\text { novembro de } 2004\end{array}$ \\
\hline DS318 & $\begin{array}{l}\text { India - } \\
\text { Certain } \\
\text { products }\end{array}$ & $\begin{array}{c}\text { Índia - Medidas Antidumping } \\
\text { em sete determinados produtos } \\
\text { de Taiwan, Penghu, Kinmen and } \\
\text { Matsu/ } \\
\text { India - Anti-Dumping Measures } \\
\text { on Certain Products from the } \\
\text { Separate Customs Territory of } \\
\text { Taiwan, Penghu, Kinmen and } \\
\text { Matsu }\end{array}$ & $\begin{array}{l}\text { A China Taipé requereu consultas com a Índia devido } \\
\text { à medidas antidumping provisórias e definitivas } \\
\text { impostas pela Índia nos seguintes sete produtos: fibras } \\
\text { acrílicas, "Analgin", permanganato de potássio, } \\
\text { paracetamol, nitrito de sódio, soda cáustica e "Green } \\
\text { veneer tape". }\end{array}$ & $\begin{array}{l}\text { Pedido de consulta } \\
\text { recebido em: } 28 \text { de } \\
\text { outubro de } 2004\end{array}$ \\
\hline DS310 & $\begin{array}{l}\text { US - Hard } \\
\text { Red Spring } \\
\text { Wheat }\end{array}$ & $\begin{array}{l}\text { Estados Unidos - Determinação } \\
\text { da Comissão de Comércio } \\
\text { Internacional de trigo duro } \\
\text { vermelho da primavera } \\
\text { proveniente do Canadál } \\
\text { United States - Determination } \\
\text { of the International Trade }\end{array}$ & $\begin{array}{l}\text { O Canadá requereu consultas com os EUA devido à: } \\
\text { investigação do USITC em trigo duro vermelho da } \\
\text { primavera proveniente do Canadá, determinação final } \\
\text { do USITC de que a indústria americana sofreu dano } \\
\text { devido à importação do produto canadense subsidiado } \\
\text { e vendido nos EUA abaixo do preço justo e também à } \\
\text { imposição de medida antidumping definitiva e }\end{array}$ & $\begin{array}{l}\text { Pedido de consulta } \\
\text { recebido em: } 08 \text { de } \\
\text { abril de } 2004\end{array}$ \\
\hline
\end{tabular}




\begin{tabular}{|c|c|c|c|c|}
\hline $\begin{array}{c}\text { Dispute } \\
\text { Settlement (DS): } \\
\text { Caso }\end{array}$ & $\begin{array}{l}\text { Short Title } \\
\text { "Apelido" }\end{array}$ & Nome Completo & Resumo do caso & Cronológico \\
\hline & & $\begin{array}{c}\text { Commission in Hard Red Spring } \\
\text { Wheat from Canada }\end{array}$ & $\begin{array}{l}\text { medidas compensatórias ao mesmo produto. } \\
\text { O Canadá afirma que houve violação ao GATT, ADA } \\
\text { e ASMC. Em } 10 \text { de junho de } 2004 \text {, o Canadá requereu } \\
\text { estabelecimento de Painel. No encontro de } 22 \text { de } \\
\text { junho de 2004, o ESC postergou o estabelecimento do } \\
\text { Painel. }\end{array}$ & \\
\hline DS304 & $\begin{array}{c}\text { India- } \\
\text { Certain } \\
\text { products from } \\
\text { the EC }\end{array}$ & $\begin{array}{l}\text { Índia - Medidas Antidumping na } \\
\text { importação de determinados } \\
\text { produtos provenientes das } \\
\text { Comunidades Europeias/ } \\
\text { India - Anti-Dumping } \\
\text { Measures on Imports of Certain } \\
\text { Products from the European } \\
\text { Communities }\end{array}$ & $\begin{array}{l}\text { As Comunidades Europeias requereram consultas com } \\
\text { a Índia devido à imposição de medidas antidumping } \\
\text { na importação de } 27 \text { produtos originários das } \\
\text { Comunidades Europeias que violaria diversos artigos } \\
\text { do GATT } 1994 \text { e ADA. } \\
\text { Em } 19 \text { de dezembro de } 2003 \text {, Turquia e Taipé Chinês } \\
\text { requereram para se juntar às consultas. Em } 22 \text { de } \\
\text { janeiro de } 2004 \text {, Índia aceitou ambos pedidos. }\end{array}$ & $\begin{array}{l}\text { Pedido de consulta } \\
\text { recebido em: } 08 \text { de } \\
\text { dezembro de } 2003\end{array}$ \\
\hline DS288 & $\begin{array}{c}\text { South Africa - } \\
\text { Blankets }\end{array}$ & $\begin{array}{l}\text { África do Sul - Medidas } \\
\text { Antidumping definitivas em } \\
\text { cobertores em rolo provenientes } \\
\text { da Turquia } \\
\text { South Africa - Definitive Anti- } \\
\text { Dumping Measures on } \\
\text { Blanketing from Turkey }\end{array}$ & $\begin{array}{l}\text { A Turquia requereu consultas com a África do Sul } \\
\text { devido à imposição de medidas antidumping } \\
\text { definitivas na importação de cobertores em rolo } \\
\text { provenientes da Turquia. Tais medidas foram impostas } \\
\text { adicionalmente a uma investigação de circunvenção } \\
\text { realizada pela África do Sul do mesmo produto } \\
\text { proveniente da Turquia. } \\
\text { A Turquia alega descumprimento de diversos artigos } \\
\text { do GATT } 1994 \text { e ADA devido à condução inadequada } \\
\text { da investigação, o que acabou por interferir no } \\
\text { resultado da mesma. }\end{array}$ & $\begin{array}{l}\text { Pedido de consulta } \\
\text { recebido em: } 10 \text { de } \\
\text { abril de } 2003\end{array}$ \\
\hline
\end{tabular}




\section{APÊNDICE 2 - DISPUTAS ANTIDUMPING EM FASE DE CONSULTAS}

\begin{tabular}{|c|c|c|c|c|}
\hline $\begin{array}{c}\text { Dispute } \\
\text { Settlement (DS): } \\
\text { Caso }\end{array}$ & $\begin{array}{l}\text { Short Title } \\
\text { "Apelido" }\end{array}$ & Nome Completo & Resumo do caso & Cronológico \\
\hline DS272 & $\begin{array}{c}\text { Peru- } \\
\text { Vegetable Oils }\end{array}$ & $\begin{array}{l}\text { Peru - Medidas antidumping } \\
\text { provisórias em óleos vegetais } \\
\text { provenientes da Argentina/ } \\
\text { Peru - Provisional Anti- } \\
\text { Dumping Duties on Vegetable } \\
\text { Oils from Argentina }\end{array}$ & $\begin{array}{l}\text { A Argentina requereu consulta com o Peru devido à } \\
\text { investigação antidumping referente à importação dos } \\
\text { produtos óleo de girassol, óleo de soja e sua mistura, } \\
\text { provenientes da Argentina. A Argentina alega que a } \\
\text { investigação que impôs medidas antidumping } \\
\text { provisórias que considerou a existência de dumping, } \\
\text { dano e nexo causal é incompatível com diversas } \\
\text { obrigações do Peru estabelecidas pelo GATT } 1994 \text { e } \\
\text { ADA. }\end{array}$ & $\begin{array}{l}\text { Pedido de consulta } \\
\text { recebido em: } 21 \text { de } \\
\text { outubro de } 2002\end{array}$ \\
\hline DS262 & US - Steel & $\begin{array}{l}\text { Estados Unidos - Revisão de } \\
\text { final de período em medidas } \\
\text { antidumping e medidas } \\
\text { compensatórias em determinados } \\
\text { produtos de aço provenientes da } \\
\text { França e Alemanha / } \\
\text { United States - Sunset Reviews } \\
\text { of Anti-Dumping and } \\
\text { Countervailing Duties on } \\
\text { Certain Steel Products from } \\
\text { France and Germany }\end{array}$ & $\begin{array}{l}\text { As CE requereram consultas com os EUA devido a } \\
\text { medidas antidumping e medidas compensatórias } \\
\text { impostas pelos EUA, adicionalmente a procedimentos } \\
\text { de revisão de final de periodo, na importação de } \\
\text { determinados produtos de aço. Em seu pedido de } \\
\text { consultas, as CE consideraram que a continuação da } \\
\text { aplicação da medida resultante de determinações do } \\
\text { governo americano são errôneas e baseadas em } \\
\text { normativas deficientes que não estão em conformidade } \\
\text { com as obrigações norte americanas estipuladas em } \\
\text { artigos do GATT 1994, ADA e ASMC. } \\
\text { Em } 07 \text { e } 08 \text { de Agosto de 2002, respectivamente } \\
\text { Canadá e Japão requereram para se juntar às consultas. }\end{array}$ & $\begin{array}{l}\text { Pedido de consulta } \\
\text { recebido em: } 25 \text { de } \\
\text { julho de } 2002\end{array}$ \\
\hline
\end{tabular}




\begin{tabular}{|c|c|c|c|c|}
\hline \multicolumn{5}{|c|}{ APENDICE 2 - DISPUTAS ANTIDUMPING EM FASE DE CONSULTAS } \\
\hline $\begin{array}{c}\text { Dispute } \\
\text { Settlement (DS): } \\
\text { Caso }\end{array}$ & $\begin{array}{l}\text { Short Title } \\
\text { "Apelido" }\end{array}$ & Nome Completo & Resumo do caso & Cronológico \\
\hline DS239 & $\begin{array}{c}\text { US - Silicon } \\
\text { Metal }\end{array}$ & $\begin{array}{l}\text { Estados Unidos - Medidas } \\
\text { Antidumping em Silício } \\
\text { Metálico/ } \\
\text { United States - Anti-Dumping } \\
\text { Duties on Silicon Metal from } \\
\text { Brazil }\end{array}$ & $\begin{array}{l}\text { O Brasil requereu consultas com os EUA. Em } 1^{\circ} \text { de } \\
\text { novembro de } 2001 \text {, o Brasil requereu que o pedido de } \\
\text { consultas original fosse cancelado e substituído por } \\
\text { um novo pedido. Neste novo pedido, Brasil } \\
\text { questionou a prática do zeramento, a Seção } 351.106 \\
\text { (c) do Departamento de Comércio dos EUA que } \\
\text { estabelece uma margem mínima de } 0,5 \% \text { de direito } \\
\text { aplicado para revisões administrativas e também os } \\
\text { direitos antidumping impostos pelos EUA na } \\
\text { importação de silício metálico proveniente do Brasil } \\
\text { desde } 31 \text { de julho de } 1991 \text {. } \\
\text { Em } 28 \text { de setembro de } 2001 \text {, a Tailândia requereu para } \\
\text { se juntar às consultas. Em } 19 \text { de novembro de } 2001 \text {, } \\
\text { As Comunidades Europeias requereram para se juntar } \\
\text { às consultas. }\end{array}$ & $\begin{array}{l}\text { Pedido de consulta } \\
\text { recebido em: } 17 \text { de } \\
\text { setembro de } 2001\end{array}$ \\
\hline DS229 & $\begin{array}{c}\text { Brazil-Jute } \\
\text { Bags }\end{array}$ & $\begin{array}{l}\text { Brasil - Medidas Antidumping } \\
\text { em Sacos de juta provenientes da } \\
\text { Índia/ } \\
\text { Brazil - Anti-Dumping Duties } \\
\text { on jute bags from India }\end{array}$ & $\begin{array}{l}\text { A Índia requereu consultas com o Brasil, pois este } \\
\text { decidiu continuar a impor medidas antidumping em } \\
\text { sacos de juta provenientes da Índia baseando-se em } \\
\text { um documento, supostamente, forjado atribuído a uma } \\
\text { companhia falida. Além disso, a Índia questiona o } \\
\text { modo de condução da investigação e Lei de Dumping } \\
\text { do Brasil (Lei 1602). } \\
\text { De acordo com a Índia, tais determinações são } \\
\text { incompatíveis com o GATT } 1994 \text { e Acordo de } \\
\text { Marraqueche. }\end{array}$ & $\begin{array}{l}\text { Pedido de consulta } \\
\text { recebido em: } 09 \text { de } \\
\text { abril de } 2001\end{array}$ \\
\hline
\end{tabular}




\begin{tabular}{|c|c|c|c|c|}
\hline \multicolumn{5}{|c|}{ APÊNDICE 2 - DISPUTAS ANTIDUMPING EM FASE DE CONSULTAS } \\
\hline $\begin{array}{c}\text { Dispute } \\
\text { Settlement (DS): } \\
\text { Caso }\end{array}$ & $\begin{array}{l}\text { Short Title } \\
\text { "Apelido" }\end{array}$ & Nome Completo & Resumo do caso & Cronológico \\
\hline DS225 & $\begin{array}{c}\text { US - Seamless } \\
\text { Pipe }\end{array}$ & $\begin{array}{l}\text { Estados Unidos - Medidas } \\
\text { antidumping em tubos de } \\
\text { pressão sem costura } \\
\text { provenientes da Itália / } \\
\text { United States - Anti-Dumping } \\
\text { Duties on Seamless Pipe from } \\
\quad \text { Italy }\end{array}$ & $\begin{array}{l}\text { As CE requereram consultas com os EUA devido a } \\
\text { medidas antidumping impostas pelos EUA em tubos } \\
\text { de pressão sem costura provenientes da Itália. } \\
\text { O pedido questiona o resultado final da revisão final } \\
\text { de período conduzida pelo Departamento de Comércio } \\
\text { dos EUA, alegando incompatibilidades com o ADA e } \\
\text { Acordo de Marraqueche. }\end{array}$ & $\begin{array}{l}\text { Pedido de consulta } \\
\text { recebido em: } 5 \text { de } \\
\text { fevereiro de } 2001\end{array}$ \\
\hline DS216 & $\begin{array}{c}\text { Mexico- } \\
\text { Electric } \\
\text { Transformers }\end{array}$ & $\begin{array}{c}\text { México - Medidas Antidumping } \\
\text { provisórias em transformadores } \\
\text { elétricos/ } \\
\text { Mexico - Provisional Anti- } \\
\text { Dumping Measure on Electric } \\
\text { Transformers }\end{array}$ & $\begin{array}{l}\text { O Brasil requereu consultas com o México devido a } \\
\text { medidas antidumping provisórias em transformadores } \\
\text { elétricos com poder de mais de } 10.000 \text { KVA } \\
\text { provenientes do Brasil. Brasil considerou que a } \\
\text { determinação do dever antidumping é incompatível } \\
\text { com as obrigações do México estabelecidas no ADA e } \\
\text { no GATT 1994. }\end{array}$ & $\begin{array}{l}\text { Pedido de consulta } \\
\text { recebido em: } 20 \text { de } \\
\text { dezembro de } 2000\end{array}$ \\
\hline DS215 & $\begin{array}{l}\text { Philippines - } \\
\quad \text { Resins }\end{array}$ & $\begin{array}{c}\text { Filipinas - Medidas } \\
\text { Antidumping em resinas de } \\
\text { polipropileno provenientes da } \\
\text { Coréia do Sul/ } \\
\text { Philippines - Anti-Dumping } \\
\text { Measures Regarding } \\
\text { Polypropylene Resins from } \\
\text { Korea }\end{array}$ & $\begin{array}{l}\text { A Coréia do Sul requereu consultas com as Filipinas } \\
\text { devido a determinações preliminares e finais da } \\
\text { Comissão de Tarifas das Filipinas em resinas de } \\
\text { polipropileno provenientes da Coréia do Sul, datadas } \\
\text { de } 15 \text { de novembro de } 1999 \text { e } 11 \text { de setembro de } 2000 \text {. } \\
\text { A Coréia do Sul afirma que foram cometidos erros na } \\
\text { investigação que resultaram conclusões distorcidas, } \\
\text { alterando informações de produtos similares (like } \\
\text { products), dumping, dano e nexo de causalidade. } \\
\text { Assim, diversos artigos do ADA e GATT } 1994 \text { teriam } \\
\text { sido violados. }\end{array}$ & $\begin{array}{l}\text { Pedido de consulta } \\
\text { recebido em: } 15 \text { de } \\
\text { dezembro de } 2000\end{array}$ \\
\hline
\end{tabular}




\begin{tabular}{|c|c|c|c|c|}
\hline \multicolumn{5}{|c|}{ APÊNDICE 2 - DISPUTAS ANTIDUMPING EM FASE DE CONSULTAS } \\
\hline $\begin{array}{c}\text { Dispute } \\
\text { Settlement (DS): } \\
\text { Caso }\end{array}$ & $\begin{array}{l}\text { Short Title } \\
\text { "Apelido" }\end{array}$ & Nome Completo & Resumo do caso & Cronológico \\
\hline DS208 & $\begin{array}{l}\text { Turkey - Pipe } \\
\text { Fittings }\end{array}$ & $\begin{array}{l}\text { Turquia - Medidas Antidumping } \\
\text { em acessórios para tubos de aço } \\
\text { e de ferro / } \\
\text { Turkey - Anti-Dumping Duty on } \\
\text { Steel and Iron Pipe Fittings }\end{array}$ & $\begin{array}{l}\text { O Brasil requereu consultas com a Turquia devido a } \\
\text { imposição de medidas antidumping em acessórios para } \\
\text { tubos de aço e de ferro provenientes do Brasil. } \\
\text { O Brasil considerou que a Turquia não conduziu a } \\
\text { investigação corretamente desde sua abertura, o que } \\
\text { teria alterado as conclusões no resultado da } \\
\text { investigação, tendo a Turquia não cumprido diversos } \\
\text { artigos do ADA e GATT 1994. }\end{array}$ & $\begin{array}{l}\text { Pedido de consulta } \\
\text { recebido em: } 09 \text { de } \\
\text { outubro de } 2000\end{array}$ \\
\hline DS191 & $\begin{array}{l}\text { Ecuador- } \\
\text { Cement II }\end{array}$ & $\begin{array}{c}\text { Equador - Medidas } \\
\text { Antidumping Definitivas em } \\
\text { cimento proveniente do México/ } \\
\text { Ecuador-Definitive Anti- } \\
\text { Dumping Measure on Cement } \\
\text { from Mexico }\end{array}$ & $\begin{array}{l}\text { O México requereu consultas com o Equador devido a } \\
\text { medidas antidumping definitivas impostas pelo } \\
\text { Equador na importação de cimento proveniente do } \\
\text { México. O México questionou a condução da } \\
\text { investigação desde sua abertura, incluindo a imposição } \\
\text { anterior de medidas antidumping provisórias. De } \\
\text { acordo com o México, o Equador estaria não } \\
\text { cumprindo artigos do ADA e do GATT } 1994 \text {. }\end{array}$ & $\begin{array}{l}\text { Pedido de consulta } \\
\text { recebido em: } 15 \text { de } \\
\text { março de } 2000\end{array}$ \\
\hline DS187 & $\begin{array}{l}\text { Trinidad e } \\
\text { Tobago - } \\
\text { Macaroni }\end{array}$ & $\begin{array}{c}\text { Trinidad e Tobago - Medidas } \\
\text { Antidumping em macarrão e } \\
\text { espaguete provenientes da Costa } \\
\text { Rica/ } \\
\text { Trinidad and Tobago - } \\
\text { Provisional Anti-Dumping } \\
\text { Measure on Macaroni and } \\
\text { Spaghetti from Costa Rica }\end{array}$ & $\begin{array}{l}\text { A Costa Rica requereu consultas com Trinidad and } \\
\text { Tobago devido à imposição de medidas antidumping } \\
\text { provisórios impostos na importação de macarrão e } \\
\text { espaguete proveniente da Costa Rica. Costa Rica alega } \\
\text { incompatibilidades com o ADA e ASMC. }\end{array}$ & $\begin{array}{l}\text { Pedido de consulta } \\
\text { recebido em: } 17 \text { de } \\
\text { janeiro de } 2000\end{array}$ \\
\hline
\end{tabular}




\begin{tabular}{|c|c|c|c|c|}
\hline \multicolumn{5}{|c|}{ APÊNDICE 2 - DISPUTAS ANTIDUMPING EM FASE DE CONSULTAS } \\
\hline $\begin{array}{c}\text { Dispute } \\
\text { Settlement (DS): } \\
\text { Caso }\end{array}$ & $\begin{array}{l}\text { Short Title } \\
\text { "Apelido" }\end{array}$ & Nome Completo & Resumo do caso & Cronológico \\
\hline DS185 & $\begin{array}{l}\text { Trinidad e } \\
\text { Tobago - } \\
\text { Pasta }\end{array}$ & $\begin{array}{l}\text { Trinidad e Tobago - Medidas } \\
\text { Antidumping em macarrão } \\
\text { proveniente da Costa Rica/ } \\
\text { Trinidad and Tobago - Anti- } \\
\text { Dumping Measures on Pasta } \\
\quad \text { from Costa Rica }\end{array}$ & $\begin{array}{l}\text { A Costa Rica requereu consultas com Trinidad e } \\
\text { Tobago devido a procedimentos preliminares à } \\
\text { investigação antidumping e a própria investigação } \\
\text { conduzida por Trinidad and Tobago a pedido da } \\
\text { empresa "Cereal Products Limited" contra a } \\
\text { importação de macarrão proveniente da empresa costa } \\
\text { riquenha "Roma Prince Sociedad Anónima". } \\
\text { Costa Rica alega violações ao ADA e ASMC. }\end{array}$ & $\begin{array}{l}\text { Pedido de consulta } \\
\text { recebido em: } 18 \text { de } \\
\text { novembro de } 1999\end{array}$ \\
\hline DS182 & $\begin{array}{c}\text { Ecuador- } \\
\text { Cement }\end{array}$ & $\begin{array}{l}\text { Equador - Medidas } \\
\text { Antidumping em cimento } \\
\text { proveniente do México/ Ecuador } \\
\text { - Provisional Anti-Dumping } \\
\text { Measure on Cement from } \\
\text { Mexico }\end{array}$ & $\begin{array}{l}\text { O México requereu consultas com o Equador } \\
\text { questionando medidas antidumping provisórias } \\
\text { impostas pelo Equador na importação de cimento bem } \\
\text { como o modo que a investigação foi conduzida. } \\
\text { México considerou que houve violações ao ADA e ao } \\
\text { GATT 1994. }\end{array}$ & $\begin{array}{l}\text { Pedido de consulta } \\
\text { recebido em: } 05 \text { de } \\
\text { outubro de } 1999\end{array}$ \\
\hline DS168 & $\begin{array}{l}\text { South Africa - } \\
\text { Medicines }\end{array}$ & $\begin{array}{l}\text { África do Sul - Deveres } \\
\text { Antidumping em determinados } \\
\text { produtos farmacêuticos } \\
\text { provenientes da Índia/ } \\
\text { South Africa - Anti-Dumping } \\
\text { Duties on Certain } \\
\text { Pharmaceutical Products from } \\
\quad \text { India }\end{array}$ & $\begin{array}{l}\text { A Índia requereu consultas com a África do Sul } \\
\text { devido a recomendação de imposição de medidas } \\
\text { antidumping definitivas pelo Conselho de Tarifas e } \\
\text { Comércio da África do Sul dada em } 03 \text { de outubro de } \\
1997 \text { em determinados produtos farmacêuticos } \\
\text { provenientes da Índia. A Índia alegou que a África do } \\
\text { Sul iniciou o processo antidumping se colocando } \\
\text { contra a importação de ampicilina e amoxicilina em } \\
\text { cápsulas de } 250 \text { mg provenientes da Îndia. Em } 26 \text { de } \\
\text { março de } 1997 \text {, o Conselho de Tarifas e Comércio da } \\
\text { África do Sul fez uma determinação preliminar } \\
\text { afirmando que ampicilina e amoxicilina em 250mg e }\end{array}$ & $\begin{array}{l}\text { Pedido de consulta } \\
\text { recebido em: } 1^{\circ} \text { de } \\
\quad \text { abril de } 1999\end{array}$ \\
\hline
\end{tabular}




\begin{tabular}{|c|c|c|c|c|}
\hline \multicolumn{5}{|c|}{ APÊNDICE 2 - DISPUTAS ANTIDUMPING EM FASE DE CONSULTAS } \\
\hline $\begin{array}{c}\text { Dispute } \\
\text { Settlement (DS): } \\
\text { Caso }\end{array}$ & $\begin{array}{l}\text { Short Title } \\
\text { "Apelido" }\end{array}$ & Nome Completo & Resumo do caso & Cronológico \\
\hline & & & $\begin{array}{l}\text { 500mg em cápsulas, exportados pela "M/S Randaxy } \\
\text { Laboratories Ltd" da Îndia estavam com preço de } \\
\text { dumping. De acordo com o pedido, isso foi seguido } \\
\text { por uma recomendação de imposição de deveres } \\
\text { definitivos nestes produtos, o que foi reportado dia } 10 \\
\text { de setembro de } 1997 \text {. }\end{array}$ & \\
\hline DS157 & $\begin{array}{c}\text { Argentina - } \\
\text { Drill Bits }\end{array}$ & $\begin{array}{l}\text { Argentina - Medidas } \\
\text { antidumping definitivas na } \\
\text { importação de brocas } \\
\text { provenientes da Itália/ } \\
\text { Argentina - Definitive Anti- } \\
\text { Dumping Measures on Imports } \\
\text { of Drill Bits from Italy }\end{array}$ & $\begin{array}{l}\text { As Comunidades Europeias requereram consultas com } \\
\text { a Argentina devido à imposição de medidas } \\
\text { antidumping definitivas alegadamente impostas pela } \\
\text { Argentina na importação de brocas da Itália. A } \\
\text { investigação teria sido iniciada em } 21 \text { de fevereiro de } \\
1997 \text { e encerrada em } 12 \text { de setembro de } 1998 \text {. As } \\
\text { Comunidades Europeias alegaram que o período de } \\
\text { investigação excedeu } 18 \text { meses, o que violava o ADA. }\end{array}$ & $\begin{array}{c}\text { Pedido de consulta } \\
\text { recebido em: Em } 14 \\
\text { de janeiro de } 1998\end{array}$ \\
\hline DS140 & EC-Cotton & $\begin{array}{l}\text { Comunidades Europeias - } \\
\text { Investigações antidumping em } \\
\text { tecido de algodão cru/ } \\
\text { European Communities - Anti- } \\
\text { Dumping Investigations } \\
\text { Regarding Unbleached Cotton } \\
\text { Fabrics from India }\end{array}$ & $\begin{array}{l}\text { A Índia requereu consultas com as Comunidades } \\
\text { Europeias alegando repetidos recursos realizados pelos } \\
\text { europeus durante investigação antidumping de tecido } \\
\text { de algodão cru proveniente da Î́ndia. A Índia } \\
\text { considerou violações ao ADA e GATT } 1994 \text { devido à } \\
\text { inconsistências na seleção de amostras, determinação } \\
\text { de dumping e dano, erro na avaliação dos fatos pelas } \\
\text { Comunidades Europeias, além do fato de não ter sido } \\
\text { levado em consideração o fato da Índia ser um país em } \\
\text { desenvolvimento. }\end{array}$ & $\begin{array}{l}\text { Pedido de consulta } \\
\text { recebido em: } 03 \text { de } \\
\text { Agosto de } 1998\end{array}$ \\
\hline DS101 & Mexico-Corn & $\begin{array}{l}\text { México - Investigação } \\
\text { Antidumping em xaropes de alta }\end{array}$ & $\begin{array}{l}\text { Os EUA requereram consultas com o México devido a } \\
\text { uma investigação antidumping conduzida pelo México }\end{array}$ & $\begin{array}{l}\text { Pedido de consulta } \\
\text { recebido em: } 04 \text { de }\end{array}$ \\
\hline
\end{tabular}




\section{APÊNDICE 2 - DISPUTAS ANTIDUMPING EM FASE DE CONSULTAS}

\begin{tabular}{|c|c|c|c|c|}
\hline $\begin{array}{c}\text { Dispute } \\
\text { Settlement (DS): } \\
\text { Caso }\end{array}$ & $\begin{array}{l}\text { Short Title } \\
\text { "Apelido" }\end{array}$ & Nome Completo & Resumo do caso & Cronológico \\
\hline & Syrup & $\begin{array}{c}\text { frutose de milho/ } \\
\text { Mexico - Anti-Dumping } \\
\text { Investigation of High-Fructose } \\
\text { Corn Syrup }(\text { HFCS }) \text { from the } \\
\text { United States }\end{array}$ & $\begin{array}{l}\text { de xarope de milho de alta frutose proveniente dos } \\
\text { EUA. } \\
\text { Os EUA alegam violações a diversos artigos do ADA. } \\
\text { Em } 08 \text { de maio de 1998, os EUA requereram consultas } \\
\text { devido à mesma investigação antidumping que } \\
\text { resultou, posteriormente, na imposição de direitos } \\
\text { antidumping definitivos. }\end{array}$ & setembro de 1997 \\
\hline DS63 & US - Urea & $\begin{array}{l}\text { Estados Unidos - Medidas } \\
\text { Antidumping na importação de } \\
\text { uréia sólida proveniente da } \\
\text { antiga República Democrática } \\
\text { Germânical } \\
\text { United States - Anti-Dumping } \\
\text { Measures on Imports of Solid } \\
\text { Urea from the Former German } \\
\text { Democratic Republic }\end{array}$ & $\begin{array}{l}\text { As Comunidades Europeias requereram consultas com } \\
\text { os EUA devido a medidas antidumping impostos na } \\
\text { exportação de uréia sólida proveniente da antiga } \\
\text { República Democrática Germânica para os EUA. As } \\
\text { Comunidades Europeias alega violação ao ADA. }\end{array}$ & $\begin{array}{l}\text { Pedido de consulta } \\
\text { recebido em: } 28 \text { de } \\
\text { novembro de } 1996\end{array}$ \\
\hline
\end{tabular}




\begin{tabular}{|c|c|c|c|c|}
\hline \multicolumn{5}{|c|}{ APÊNDICE 3 - DISPUTAS ANTIDUMPING ENCERRADAS OU EM FASE DE PAINEL } \\
\hline $\begin{array}{c}\text { Dispute } \\
\text { Settlement } \\
\text { (DS): } \\
\text { Caso }\end{array}$ & $\begin{array}{l}\text { Short Title } \\
\text { "Apelido" }\end{array}$ & Nome Completo & Resumo do caso & Cronológico \\
\hline DS427 & $\begin{array}{l}\text { China- } \\
\text { Broiler } \\
\text { Products }\end{array}$ & $\begin{array}{c}\text { China - Antidumping e } \\
\text { Medidas Compensatórias em } \\
\text { produtos de grelha } \\
\text { provenientes dos Estados } \\
\text { Unidos / } \\
\text { China - Anti-Dumping and } \\
\text { Countervailing Duty } \\
\text { Measures on Broiler Products } \\
\text { from the United States }\end{array}$ & $\begin{array}{l}\text { Os EUA requereram consultas com a China devido a } \\
\text { imposições de direitos antidumping e Medidas } \\
\text { Compensatórias em produtos de grelha provenientes dos } \\
\text { EUA. } \\
\text { Os EUA alegaram que as medidas são incompatíveis com } \\
\text { várias disposições do ADA, referindo-se ao processo de } \\
\text { investigação, bem como a determinação do direito em questão } \\
\text { (incluindo dumping impróprio e determinação de dano, } \\
\text { desconfiança nos fatos disponíveis, falha no fornecimento de } \\
\text { informaçõe relevantes, explicação insuficiente para as } \\
\text { determinações, a ausência de uma análise adequada dos } \\
\text { efeitos das importações e falta de determinação objetiva da } \\
\text { causalidade). } \\
\text { Os EUA alegaram que as medidas são incompatíveis com as } \\
\text { várias disposições do ASMC devido ao modo que a } \\
\text { investigação de subsídios foi conduzida. A conclusão de } \\
\text { determinação de medidas compensatórias também possui } \\
\text { irregularidades (desconfiança nos fatos disponíveis, } \\
\text { explicação insuficiente que justifique as determinações e } \\
\text { imposição de deveres excessivos face ao subsídio constatado). } \\
\text { Foi estabelecido o Painel. União Européia, Japão, Noruega, } \\
\text { Arábia Saudita e Tailândia reservaram seus direitos como } \\
\text { terceira parte. }\end{array}$ & $\begin{array}{c}\text { Pedido de consulta } \\
\text { recebido em: } 20 \text { de } \\
\text { setembro de } 2011 \\
\text { Estabelecimento do } \\
\text { painel em: } 20 \text { de janeiro } \\
\text { de } 2012\end{array}$ \\
\hline
\end{tabular}




\begin{tabular}{|c|c|c|c|c|}
\hline \multicolumn{5}{|c|}{ APÊNDICE 3 - DISPUTAS ANTIDUMPING ENCERRADAS OU EM FASE DE PAINEL } \\
\hline $\begin{array}{l}\text { Dispute } \\
\text { Settlement } \\
\text { (DS): } \\
\text { Caso }\end{array}$ & $\begin{array}{l}\text { Short Title } \\
\text { "Apelido" }\end{array}$ & Nome Completo & Resumo do caso & Cronológico \\
\hline DS425 & $\begin{array}{c}\text { China - X- } \\
\text { Ray } \\
\text { Equipment }\end{array}$ & $\begin{array}{c}\text { China - Medidas antidumping } \\
\text { definitivas em equipamentos } \\
\text { de segurança de inspeção em } \\
\text { Raio-X/ } \\
\text { China-Definitive Anti- } \\
\text { Dumping Duties on X-Ray } \\
\text { Security Inspection Equipment } \\
\text { from the European Union }\end{array}$ & $\begin{array}{l}\text { A União Europeia requereu consultas com a China devido a } \\
\text { imposição de medidas antidumping definitivos em } \\
\text { equipamentos de inspeção de segurança em Raios-X } \\
\text { provenientes da União Europeia. } \\
\text { A União Europeia alega que a medida é incompatível com } \\
\text { diversas previsões do ADA e GATT 1994, apontando } \\
\text { irregularidades no decorrer da investigação e no acesso às } \\
\text { informações relevantes. Durante a análise de preços, danos e } \\
\text { nexo causal houve falta de exame objetivo. } \\
\text { Em 08 de dezembro a União Europeia requereu } \\
\text { estabelecimento de painel. O painel foi estabelecido. Índia, } \\
\text { Japão, Noruega, Tailândia e EUA reservaram seus direitos } \\
\text { como terceira parte. }\end{array}$ & $\begin{array}{c}\text { Pedido de consulta } \\
\text { recebido em: } 25 \text { de julho } \\
\text { de } 2011 \\
\text { Painel foi estabelecido } \\
\text { em: } 20 \text { de janeiro de } \\
2012\end{array}$ \\
\hline DS422 & $\begin{array}{c}\text { US - } \\
\text { Shrimp and } \\
\text { Sawblades }\end{array}$ & $\begin{array}{l}\text { Estados Unidos - Medidas } \\
\text { antidumping em camarões e } \\
\text { lâminas de diamante } \\
\text { provenientes da China/ }\end{array}$ & $\begin{array}{l}\text { A China requereu consultas com os EUA em virtude da } \\
\text { imposição de medidas antidumping em determinados } \\
\text { camarões congelados provenientes da China. A China alega } \\
\text { que o os EUA utilizaram-se do método do zeramento na } \\
\text { investigação original e em diversas revisões administrativas } \\
\text { para calcular margens de dumping, o que torna sua prática } \\
\text { incompatível com o GATT } 1994 \text { e ADA. } \\
\text { Em } 11 \text { de março de 2011, o Japão requereu para se juntar às } \\
\text { consultas. } \\
\text { Em } 22 \text { de julho de 2011, a China requereu consultas } \\
\text { complementares com os EUA devido à prática do método do }\end{array}$ & $\begin{array}{l}\text { Pedido de consulta } \\
\text { recebido em: } 28 \text { de } \\
\text { fevereiro de } 2011 \\
\text { O relatório do Painel foi } \\
\text { circulado em: } 8 \text { de junho } \\
\text { de } 2012 \text {. }\end{array}$ \\
\hline
\end{tabular}




\begin{tabular}{|c|c|c|c|c|}
\hline \multicolumn{5}{|c|}{ APÊNDICE 3 - DISPUTAS ANTIDUMPING ENCERRADAS OU EM FASE DE PAINEL } \\
\hline $\begin{array}{l}\text { Dispute } \\
\text { Settlement } \\
\text { (DS): } \\
\text { Caso }\end{array}$ & $\begin{array}{l}\text { Short Title } \\
\text { "Apelido" }\end{array}$ & Nome Completo & Resumo do caso & Cronológico \\
\hline & & $\begin{array}{c}\text { United States - Anti- } \\
\text { Dumping Measures on Shrimp } \\
\text { and Diamond Sawblades from } \\
\text { China }\end{array}$ & $\begin{array}{l}\text { zeramento em importações de lâminas de diamantes e suas } \\
\text { partes provenientes da China. } \\
\text { A China alega que o método do zeramento criou margens de } \\
\text { dumping artificiais ou, no mínimo, inflou a margem de } \\
\text { dumping original. A China considera que o método em } \\
\text { questão é incompatível com as obrigações dos EUA } \\
\text { celebradas no GATT } 1994 \text { e ADA. } \\
\text { Em } 13 \text { de outubro de } 2011 \text {, a China requereu estabelecimento } \\
\text { de painel e União Européia, Honduras, Japão, Coréia do Sul, } \\
\text { Tailândia e Vietnã reservaram seus direitos como terceiras } \\
\text { partes. O Painel foi estabelecido em } 25 \text { de outubro de } 2011 . \\
\text { O painel foi estabelecido. União Europeia, Honduras, Japão, } \\
\text { Coreia, Tailândia e Vietnã reservaram seus direitos como } \\
\text { terceira parte. } \\
\text { Após análise, o Painel concluiu que o emprego do método de } \\
\text { zeramento pelos EUA é incompatível com ADA. }\end{array}$ & \\
\hline DS420 & $\begin{array}{l}\text { US - carbon } \\
\text { steel flat } \\
\text { products }\end{array}$ & $\begin{array}{l}\text { Estados Unidos - Medidas } \\
\text { antidumping em chapas de aço } \\
\text { carbono anticorrosiva/ }\end{array}$ & $\begin{array}{l}\text { Coréia requereu consultas com os EUA devido ao número de } \\
\text { medidas antidumping em produtos anticorrosivos de aço plano } \\
\text { provenientes da Coréia do Sul. Mais especificamente, o } \\
\text { pedido alega diversas leis americanas, regulações, } \\
\text { procedimentos e práticas administrativas, dentre elas o } \\
\text { zeramento, que são incompatíveis com as obrigaçôes } \\
\text { americanas sob o GATT 1994, ADA e Acordo de }\end{array}$ & $\begin{array}{l}\text { Pedido de consulta } \\
\text { recebido em: } 31 \text { de } \\
\text { janeiro de } 2011 \\
\text { Painel foi estabelecido } \\
\text { em: } 22 \text { de fevereiro de } \\
\quad 2012\end{array}$ \\
\hline
\end{tabular}




\begin{tabular}{|c|c|c|c|c|}
\hline \multicolumn{5}{|c|}{ APÊNDICE 3 - DISPUTAS ANTIDUMPING ENCERRADAS OU EM FASE DE PAINEL } \\
\hline $\begin{array}{l}\text { Dispute } \\
\text { Settlement } \\
\text { (DS): } \\
\text { Caso }\end{array}$ & $\begin{array}{l}\text { Short Title } \\
\text { "Apelido" }\end{array}$ & Nome Completo & Resumo do caso & Cronológico \\
\hline & & $\begin{array}{l}\text { United States - Anti-dumping } \\
\text { measures on corrosion- } \\
\text { resistant carbon steel flat } \\
\text { products from Korea }\end{array}$ & $\begin{array}{l}\text { Marraqueche. } \\
\text { Em } 10 \text { e } 14 \text { de fevereiro, Japão e México, respectivamente, } \\
\text { requereram para se juntar às consultas. } \\
\text { Em foi estabelecido o Painel. China, União Europeia, Japão, } \\
\text { México e Noruega, Brasil e Tailândia requereram para se } \\
\text { juntar às consultas. }\end{array}$ & \\
\hline DS414 & $\begin{array}{c}\text { China - } \\
\text { GOES }\end{array}$ & $\begin{array}{c}\text { China - Medidas } \\
\text { Compensatórias e medidas } \\
\text { antidumping em grãos } \\
\text { laminados orientados de aço/ } \\
\text { China-Countervailing and } \\
\text { Anti-Dumping Duties on } \\
\text { Grain Oriented Flat-rolled } \\
\text { Electrical Steel from the } \\
\text { United States }\end{array}$ & $\begin{array}{l}\text { Os EUA requereram consultas com a China devido a } \\
\text { imposição de medidas compensatórias e medidas antidumping } \\
\text { em grãos de aço plano laminado orientado provenientes dos } \\
\text { EUA. } \\
\text { A China considerou que o chamado "Buy American" é } \\
\text { subsídio, portanto, taxou a importação com medidas } \\
\text { compensatórias. } \\
\text { Os EUA alegaram que a China agiu incompativelmente com } \\
\text { as suas obrigações celebradas no ASMC, ADA e GATT } 1994 . \\
\text { O Painel foi estabelecido em. União Europeia, Honduras, } \\
\text { Índia, Japão, Coréia do Sul, Vietnã, Argentina e Arábia } \\
\text { Saudita reservaram seus direitos como terceiras partes. }\end{array}$ & $\begin{array}{l}\text { Pedido de consulta } \\
\text { recebido em: } 15 \text { de } \\
\text { setembro de } 2010 \\
\text { Relatório do painel } \\
\text { circulado em: } 15 \text { de } \\
\text { junho de } 2012\end{array}$ \\
\hline DS405 & $\begin{array}{c}E U- \\
\text { Footwear } \\
\text { (China) }\end{array}$ & $\begin{array}{l}\text { União Européia - Medidas } \\
\text { Antidumping em } \\
\text { determinados calçados } \\
\text { provenientes da China/ } \\
\text { European Union - Anti- }\end{array}$ & $\begin{array}{l}\text { A China requereu consultas com a União Européia devido à } \\
\text { três medidas relacionadas com a imposição de medidas } \\
\text { antidumping na importação de determinados calçados de } \\
\text { couro provenientes da China. } \\
\text { A China alega inconsistências com o Regulamento }\end{array}$ & $\begin{array}{l}\text { Pedido de consulta } \\
\text { recebido em: } 04 \text { de } \\
\text { fevereiro de } 2010 \\
\text { Relatório do painel } \\
\text { circulado em: } 28 \mathrm{de}\end{array}$ \\
\hline
\end{tabular}




\begin{tabular}{|c|c|c|c|c|}
\hline \multicolumn{5}{|c|}{ APÊNDICE 3 - DISPUTAS ANTIDUMPING ENCERRADAS OU EM FASE DE PAINEL } \\
\hline $\begin{array}{c}\text { Dispute } \\
\text { Settlement } \\
\text { (DS): }\end{array}$ & $\begin{array}{l}\text { Short Title } \\
\text { "Apelido" }\end{array}$ & Nome Completo & Resumo do caso & Cronológico \\
\hline & & $\begin{array}{c}\text { Dumping Measures on } \\
\text { Certain Footwear from China }\end{array}$ & $\begin{array}{l}\text { Antidumping da União Européia, previsões do Acordo de } \\
\text { Marraqueche, Protocolo de Acessão da China, GATT } 1994 \text { e } \\
\text { ADA. } \\
\text { A China também alega que as regulações de revisão de } \\
\text { dumping e imposição de antidumping definitivo são } \\
\text { incompatíveis com a OMC. } \\
\text { A China e a União Européia estabeleceram consultas em } 31 \text { de } \\
\text { março de } 2010 \text {. As consultas não resolveram o conflito e dia } \\
08 \text { de abril de } 2010 \text { a China requereu estabelecimento de } \\
\text { painel. O painel foi estabelecido e após análise, boa parte dos } \\
\text { questionamentos europeus foram negados. }\end{array}$ & outubro de 2012 \\
\hline DS404 & $\begin{array}{c}U S- \\
\text { Shrimp } \\
\text { (Vietnam) }\end{array}$ & $\begin{array}{l}\text { Estados Unidos - Medidas } \\
\text { Antidumping em } \\
\text { determinados camarões } \\
\text { provenientes do Vietnã/ } \\
\text { United States - Anti-dumping } \\
\text { Measures on Certain Shrimp } \\
\text { from Viet Nam }\end{array}$ & $\begin{array}{l}\text { O Vietnã requereu consultas com os EUA devido a um } \\
\text { número de medidas antidumping em determinados camarões } \\
\text { congelados de água doce. } \\
\text { Além de diversas revisões administrativas, o pedido de } \\
\text { consultas refere-se a leis americanas, regulamentos, práticas e } \\
\text { procedimentos administrativos, incluindo zeramento. O Vietnã } \\
\text { cita inconsistências com o GATT 1994, ADA, Acordo de } \\
\text { Marraqueche e Protocolo de Acessão do Vietnã. } \\
\text { Em } 12 \text { de fevereiro de 2010, a União Européia e o Japão } \\
\text { requereram para se juntar às consultas. Em } 15 \text { de fevereiro de } \\
2010 \text {, a Tailândia requereu para se juntar às consultas. } \\
\text { Em } 07 \text { de abril de 2010, Vietnã requereu estabelecimento de } \\
\text { painel. União Europeia, Japão, Coreia, México e Tailândia }\end{array}$ & $\begin{array}{l}\text { Pedido de consulta } \\
\text { recebido em: } 01 \mathrm{de} \\
\text { fevereiro de } 2010 \\
\text { Relatório do painel } \\
\text { circulado em: } 11 \text { de } \\
\text { julho de } 2011\end{array}$ \\
\hline
\end{tabular}




\begin{tabular}{|c|c|c|c|c|}
\hline \multicolumn{5}{|c|}{ APÊNDICE 3 - DISPUTAS ANTIDUMPING ENCERRADAS OU EM FASE DE PAINEL } \\
\hline $\begin{array}{c}\text { Dispute } \\
\text { Settlement } \\
\text { (DS): } \\
\text { Caso }\end{array}$ & $\begin{array}{l}\text { Short Title } \\
\text { "Apelido" }\end{array}$ & Nome Completo & Resumo do caso & Cronológico \\
\hline & & & $\begin{array}{l}\text { reservaram seus direitos como terceira parte. Após análise, a } \\
\text { utilização do método americano de zeramento foi condenada. }\end{array}$ & \\
\hline DS402 & $\begin{array}{l}\text { US- } \\
\text { Zeroing } \\
\text { (Korea) }\end{array}$ & $\begin{array}{l}\text { Estados Unidos - Uso do } \\
\text { zeramento em medidas } \\
\text { antidumping envolvendo } \\
\text { produtos provenientes da } \\
\text { Coréia/ } \\
\text { United States - Use of Zeroing } \\
\text { in Anti-Dumping Measures } \\
\text { Involving Products from } \\
\text { Korea }\end{array}$ & $\begin{array}{l}\text { A Coréia requereu consultas com os EUA devido ao uso do } \\
\text { zeramento em três casos antidumping envolvendo } \\
\text { determinados produtos provenientes da Coréia do Sul: chapas } \\
\text { de aço inoxidável em bobinas, chapas e fitas de aço inoxidável } \\
\text { em bobinas lâmina de serra de diamante e suas partes. } \\
\text { Coréia do Sul alega que os EUA tiveram o intuito de inflar ou } \\
\text { criar margens artificiais de dumping em casos nos quais sem o } \\
\text { método do zeramento tal preço inflado ou margem não } \\
\text { existiriam. Além disso, a Coréia citou inconsistências com o } \\
\text { GATT } 1994 \text { e ADA. } \\
\text { Em } 03 \text { de dezembro de 2009, Japão requereu para se juntar às } \\
\text { consultas. } \\
\text { Em } 08 \text { de abril de 2010, a Coréia do Sul requereu o } \\
\text { estabelecimento de painel. Após análise, a utilização do } \\
\text { método de zeramento pelos EUA foi condenada. }\end{array}$ & $\begin{array}{l}\text { Pedido de consulta } \\
\text { recebido em: } 24 \text { de } \\
\text { novembro de } 2009 \\
\text { Relatório do painel } \\
\text { circulado em: } 18 \text { de } \\
\text { janeiro de } 2010\end{array}$ \\
\hline DS383 & $\underset{\text { Bags }}{U S-P E T}$ & $\begin{array}{l}\text { Estados Unidos - Medidas } \\
\text { Antidumping em sacos de } \\
\text { polietileno para varejo } \\
\text { provenientes da Tailândia/ } \\
\text { United States - Measures on } \\
\text { Polyethylene Retail Carrier }\end{array}$ & $\begin{array}{l}\text { A Tailândia requereu consultas com os EUA devido à } \\
\text { aplicação pelos EUA do método de zeramento na investigação } \\
\text { de Sacos de Polietileno para Varejo provenientes da Tailândia. } \\
\text { Tailândia alega que os EUA tiveram o intuito de inflar ou criar } \\
\text { margens artificiais de dumping em casos nos quais sem o } \\
\text { método do zeramento tal preço inflado ou margem não }\end{array}$ & $\begin{array}{l}\text { Pedido de consulta } \\
\text { recebido em: } 26 \text { de } \\
\text { novembro de } 2008 \\
\text { Relatório do painel } \\
\text { circulado em: } 22 \text { de } \\
\text { janeiro de } 2010\end{array}$ \\
\hline
\end{tabular}




\begin{tabular}{|c|c|c|c|c|}
\hline \multicolumn{5}{|c|}{ APÊNDICE 3 - DISPUTAS ANTIDUMPING ENCERRADAS OU EM FASE DE PAINEL } \\
\hline $\begin{array}{c}\text { Dispute } \\
\text { Settlement } \\
\text { (DS): } \\
\text { Caso }\end{array}$ & $\begin{array}{l}\text { Short Title } \\
\text { "Apelido" }\end{array}$ & Nome Completo & Resumo do caso & Cronológico \\
\hline & & Bags from Thailand & $\begin{array}{l}\text { existiriam. } \\
\text { A Tailândia considera que a prática do método de zeramento é } \\
\text { incompatível com as obrigações assumidas pelos EUA no } \\
\text { GATT } 1994 \text { e ADA. Em 09 de março de } 2009 \text { a Tailândia } \\
\text { requereu estabelecimento de painel Após análise, os EUA } \\
\text { foram condenados e foi recomendado que ele pusesse suas } \\
\text { medidas em conformidade com o ADA. }\end{array}$ & \\
\hline DS382 & $\begin{array}{c}\text { US- } \\
\text { Orange } \\
\text { Juice }\end{array}$ & $\begin{array}{l}\text { Estados Unidos - Revisões } \\
\text { Administrativas e outras } \\
\text { medidas relacionadas à } \\
\text { importação de determinados } \\
\text { sucos de laranja provenientes } \\
\text { do Brasil/ } \\
\text { United States - Anti-Dumping } \\
\text { Administrative Reviews and } \\
\text { Other Measures Related to } \\
\text { Imports of Certain Orange } \\
\text { Juice from Brazil }\end{array}$ & $\begin{array}{l}\text { O Brasil requereu consultas devido a ações do Departamento } \\
\text { de Comércio dos EUA que impuseram medidas na importação } \\
\text { de determinados sucos de laranja provenientes do Brasil. } \\
\text { O Brasil questionou determinadas leis americanas, } \\
\text { regulamentos, procedimentos administrativos, práticas e } \\
\text { métodos e alega que são as applied e as such incompatíveis } \\
\text { com as obrigações dos EUA perante o Acordo de } \\
\text { Marraqueche e seus anexos (GATT } 1994 \text { e ADA) } \\
\text { Em } 10 \text { de dezembro de } 2008 \text {, Japão requereu para se juntar às } \\
\text { consultas. } \\
\text { Em } 22 \text { de maio de } 2009 \text {, Brasil requereu consultas novamente } \\
\text { relacionadas a questões complementares também } \\
\text { incompatíveis com o GATT 1994, ADA e Acordo de } \\
\text { Marraqueche. } \\
\text { Em } 05 \text { de junho de } 2009 \text {, o Japão requereu para se juntar às } \\
\text { novas consultas. Em } 20 \text { de agosto de 2009, o Brasil requereu } \\
\text { estabelecimento de painel. }\end{array}$ & $\begin{array}{l}\text { Pedido de consulta } \\
\text { recebido em: } 27 \text { de } \\
\text { novembro de } 2008 \\
\text { Relatório do painel } \\
\text { circulado em: } 25 \text { de } \\
\text { março de } 2011\end{array}$ \\
\hline
\end{tabular}




\begin{tabular}{|c|c|c|c|c|}
\hline \multicolumn{5}{|c|}{ APÊNDICE 3 - DISPUTAS ANTIDUMPING ENCERRADAS OU EM FASE DE PAINEL } \\
\hline $\begin{array}{l}\text { Dispute } \\
\text { Settlement } \\
\text { (DS): } \\
\text { Caso }\end{array}$ & $\begin{array}{l}\text { Short Title } \\
\text { "Apelido" }\end{array}$ & Nome Completo & Resumo do caso & Cronológico \\
\hline & & & $\begin{array}{l}\text { O painel foi estabelecido. Argentina, CE, Japão, Coréia do } \\
\text { Sul, Tailândia, México e Taipé Chinês reservaram seus } \\
\text { direitos como terceira parte. Após análise do caso pelo Painel, } \\
\text { a utilização do método de zeramento pelos EUA foi } \\
\text { condenada. }\end{array}$ & \\
\hline DS355 & $\begin{array}{c}\text { Brazil- } \\
\text { Resins }\end{array}$ & $\begin{array}{c}\text { Brasil - Medidas antidumping } \\
\text { na importação de } \\
\text { determinadas resinas } \\
\text { provenientes da Argentina/ } \\
\text { Brazil - Anti-dumping } \\
\text { Measures on Imports of } \\
\text { Certain Resins from Argentina }\end{array}$ & $\begin{array}{l}\text { A Argentina requereu consultas com o Brasil devido a } \\
\text { imposição de medidas antidumping aplicadas pelo Brasil na } \\
\text { importação de determinadas resinas provenientes da } \\
\text { Argentina. A Argentina considera que a condução da } \\
\text { investigação, a determinação dela resultante e os deveres } \\
\text { impostos pelo Brasil são incompatíveis com o GATT 1994, } \\
\text { Acordo de Marraqueche e ADA, questionando também } \\
\text { determinadas normativas brasileiras. } \\
\text { Em } 07 \text { de junho de 2007, a Argentina requereu o } \\
\text { estabelecimento de painel. O painel foi estabelecido. A CE, } \\
\text { Japão, Taipé Chinesa e EUA reservaram seus direitos como } \\
\text { terceiras partes. Após tratativas, o Órgão administrativo } \\
\text { brasileiro responsável suspendeu a medida antidumping, } \\
\text { suspendendo o Painel. }\end{array}$ & $\begin{array}{l}\text { Pedido de consulta } \\
\text { recebido em: } 26 \text { de } \\
\text { dezembro de } 2006 \\
\text { Painel foi estabelecido } \\
\text { em: } 24 \text { de julho de } 2007 \\
\text { Painel foi suspenso em: } \\
4 \text { de fevereiro de } 2008\end{array}$ \\
\hline DS337 & $\begin{array}{c}E C- \\
\text { Salmon } \\
\text { (Norway) }\end{array}$ & $\begin{array}{l}\text { Comunidades Europeias - } \\
\text { Medida Antidumping em } \\
\quad \text { salmões de criação/ } \\
\text { European Communities - Anti- } \\
\text { Dumping Measure on Farmed }\end{array}$ & $\begin{array}{l}\text { A Noruega requereu consultas com a CE devido ao Council } \\
\text { Regulation Regulation }(E C) \text { No. } 85 / 2006 \text { de } 17 \text { de janeiro de } \\
2006 \text { impondo medidas antidumping definitivos na } \\
\text { importação de salmão de criação (salmão de viveiro) } \\
\text { provenientes da Noruega, que considera as ações } \\
\text { incompatíveis com o GATT 1994 e ADA. }\end{array}$ & $\begin{array}{l}\text { Pedido de consulta } \\
\text { recebido em: } 17 \text { de } \\
\text { março de } 2006 \\
\text { Relatório do painel } \\
\text { circulado em: } 16 \text { de }\end{array}$ \\
\hline
\end{tabular}




\begin{tabular}{|c|c|c|c|c|}
\hline \multicolumn{5}{|c|}{ APÊNDICE 3 - DISPUTAS ANTIDUMPING ENCERRADAS OU EM FASE DE PAINEL } \\
\hline $\begin{array}{c}\text { Dispute } \\
\text { Settlement } \\
\text { (DS): }\end{array}$ & $\begin{array}{l}\text { Short Title } \\
\text { "Apelido" }\end{array}$ & Nome Completo & Resumo do caso & Cronológico \\
\hline & & Salmon from Norway & $\begin{array}{l}\text { A Noruega fez pedido de consultas suplementares e em } 29 \text { de } \\
\text { maio de } 2006 \text { requereu estabelecimento de painel. Após } \\
\text { análise, foi concluído que as medidas questionadas violavam } \\
\text { os artigos 2.2.1.1, 2.2.2., 2.2.2 (iii), } 3.1,3.2,3.4,3.5,4.1,5.4 \text {, } \\
6.4,6.8 \text { e parágrafo } 3 \text { do Anexo II do ADA. As demais } \\
\text { medidas questionadas estão em conformidade. }\end{array}$ & novembro de 2007 \\
\hline DS335 & $\begin{array}{c}\text { US - } \\
\text { Shrimp } \\
\text { (Ecuador) }\end{array}$ & $\begin{array}{l}\text { Estados Unidos - Medidas } \\
\text { Antidumping em camarões } \\
\text { provenientes do Equador/ } \\
\text { United States - Anti-Dumping } \\
\text { Measure on Shrimp from } \\
\text { Ecuador }\end{array}$ & $\begin{array}{l}\text { O Equador requereu consultas com os EUA devido a } \\
\text { determinação final de vendas pelo menor que o justo em } \\
\text { camarões de água doce congelados provenientes do Equador, } \\
\text { acompanhada da ordem de dever antidumping. } \\
\text { De acordo com o Equador, os EUA determinaram direitos } \\
\text { antidumping devido ao método do zeramento e considera tal } \\
\text { método é incompatível com as obrigações assumidas pelos } \\
\text { EUA no GATT } 1994 \text { e ADA. } \\
\text { Em } 28 \text { de novembro de } 2005 \text {, a Índia requereu para se juntar } \\
\text { às consultas. Tailândia requereu para se juntar às consultas. O } \\
\text { Equador requereu estabelecimento do painel. Brasil, China, } \\
\text { CE, Índia, Japão, Coréia do Sul e Tailândia reservaram seus } \\
\text { direitos como terceira parte. O painel foi estabelecido. Após } \\
\text { análise, foi concluído que a autoridade americana } \\
\text { administrativa tinha violado alguns artigos do ADA. }\end{array}$ & $\begin{array}{l}\text { Pedido de consulta } \\
\text { recebido em: } 17 \mathrm{de} \\
\text { novembro de } 2005 \\
\text { Relatório do painel } \\
\text { circulado em: } 30 \text { de } \\
\text { janeiro de } 2007\end{array}$ \\
\hline
\end{tabular}




\begin{tabular}{|c|c|c|c|c|}
\hline \multicolumn{5}{|c|}{ APÊNDICE 3 - DISPUTAS ANTIDUMPING ENCERRADAS OU EM FASE DE PAINEL } \\
\hline $\begin{array}{l}\text { Dispute } \\
\text { Settlement } \\
\text { (DS): } \\
\text { Caso }\end{array}$ & $\begin{array}{l}\text { Short Title } \\
\text { "Apelido" }\end{array}$ & Nome Completo & Resumo do caso & Cronológico \\
\hline DS331 & $\begin{array}{l}\text { Mexico-- } \\
\text { Steel Pipes } \\
\text { and Tubes }\end{array}$ & $\begin{array}{l}\text { México - Medidas } \\
\text { Antidumping em tubos de aço } \\
\text { provenientes da Guatemala/ } \\
\text { Mexico - Anti-Dumping Duties } \\
\text { on Steel Pipes and Tubes from } \\
\text { Guatemala }\end{array}$ & $\begin{array}{l}\text { Em } 17 \text { de junho de } 2005 \text {, a Guatemala requereu consultas com } \\
\text { o México devido à imposição de medidas antidumping } \\
\text { impostas pelo México na importação de tubos de aço } \\
\text { provenientes da Guatemala. } \\
\text { De acordo com a Guatemala os medidas antidumping } \\
\text { mencionados são incompatíveis com as obrigações do México } \\
\text { sob o GATT } 1994 \text { e o ADA. } \\
\text { Em } 06 \text { de fevereiro de 2006, a Guatemala requereu } \\
\text { estabelecimento de painel. O painel foi estabelecido. Após } \\
\text { análise, foi concluído que a abertura de investigação, } \\
\text { condução e fechamento da mesma pelo México não foi feito } \\
\text { em conformidade com o ADA. }\end{array}$ & $\begin{array}{l}\text { Pedido de consulta } \\
\text { recebido em: } 17 \mathrm{de} \\
\text { junho de } 2005 \\
\text { Relatório do painel } \\
\text { circulado em: } 8 \text { de junho } \\
\text { de } 2007\end{array}$ \\
\hline DS327 & $\begin{array}{l}\text { Egypt-— } \\
\text { Matches }\end{array}$ & $\begin{array}{l}\text { Egito - Deveres antidumping } \\
\text { em caixas de fósforo } \\
\text { provenientes do Paquistão/ } \\
\text { Egypt - Anti-Dumping Duties } \\
\text { on Matches from Pakistan }\end{array}$ & $\begin{array}{l}\text { O Paquistão requereu consultas com o Egito devido a } \\
\text { medidas antidumping definitivas impostos pelo Egito na } \\
\text { importação de caixas de fósforo provenientes do Paquistão. } \\
\text { De acordo com o Paquistão, a imposição dos deveres é } \\
\text { incompatível com as obrigações do Egito sob o GATT } 1994 \\
\text { e ADA. } \\
\text { O Paquistão requereu o estabelecimento do painel. Em } 20 \\
\text { de julho de } 2005 \text { foi estabelecido o painel. A China, } \\
\text { Comunidade Européia, Japão e EUA. } \\
\text { Após certo período, foi informado ao DSB que as partes } \\
\text { firmaram acordo mutuamente satisfatório. }\end{array}$ & $\begin{array}{l}\text { Pedido de consulta } \\
\text { recebido em: } 21 \text { de } \\
\text { fevereiro de } 2005 \\
\text { Painel estabelecido em: } \\
20 \text { de julho de } 2005 \\
\text { Acordo firmado em: } \\
27 \text { de março de } 2006\end{array}$ \\
\hline
\end{tabular}




\begin{tabular}{|c|c|c|c|c|}
\hline \multicolumn{5}{|c|}{ APÊNDICE 3 - DISPUTAS ANTIDUMPING ENCERRADAS OU EM FASE DE PAINEL } \\
\hline $\begin{array}{l}\text { Dispute } \\
\text { Settlement } \\
\text { (DS): } \\
\text { Caso }\end{array}$ & $\begin{array}{l}\text { Short Title } \\
\text { "Apelido" }\end{array}$ & Nome Completo & Resumo do caso & Cronológico \\
\hline DS312 & $\begin{array}{c}\text { Korea- } \\
\text { Certain } \\
\text { Paper }\end{array}$ & $\begin{array}{l}\text { Coréia do Sul - Deveres } \\
\text { Antidumping na importação } \\
\text { de determinados papéis } \\
\text { provenientes da Indonésia / } \\
\text { Korea - Anti-Dumping Duties } \\
\text { on Imports of Certain Paper } \\
\quad \text { from Indonesia }\end{array}$ & $\begin{array}{l}\text { A Indonésia requereu consultas com a Coréia devido à } \\
\text { imposição de medidas antidumping definitivas pela Coréia do } \\
\text { Sul na importação de papel de informações business e papel } \\
\text { de impressão sem revestimento wood-free provenientes da } \\
\text { Indonésia, questionando determinados aspectos da } \\
\text { investigação que resultou na imposição desses deveres. De } \\
\text { acordo com a Indonésia, houve diversas deficiências no início } \\
\text { e decorrer da investigação (não há suficiente evidências de } \\
\text { dumping, dano e nexo causal), erros no modo pelo qual a } \\
\text { Coréia garantiu tratamento confidencial à determinadas } \\
\text { informações, dentre outras. } \\
\text { A Indonésia considera que as medidas coreanas são } \\
\text { incompatíveis com o GATT 1994 e ADA. } \\
\text { Em } 16 \text { de agosto de 2004, a Indonésia requereu o } \\
\text { estabelecimento do painel. . Após análise, foi concluído que as } \\
\text { medidas coreanas questionadas não violavam artigos } \\
\text { realmente relevantes do ADA. }\end{array}$ & $\begin{array}{l}\text { Pedido de consulta } \\
\text { recebido em: } 04 \text { de } \\
\text { junho de } 2004 \\
\text { Relatório do painel } \\
\text { circulado em: } 28 \text { de } \\
\text { outubro de } 2005\end{array}$ \\
\hline DS281 & $\underset{\text { Cement }}{U S-}$ & $\begin{array}{l}\text { Estados Unidos - Medidas } \\
\text { antidumping em determinados } \\
\text { tipo de cimento provenientes } \\
\text { do México/ } \\
\text { United States - Anti- } \\
\text { Dumping Measures on } \\
\text { Cement from Mexico }\end{array}$ & $\begin{array}{l}\text { O México requereu consultas com os EUA devido a diversas } \\
\text { medidas antidumping impostas na importação de } \\
\text { determinados tipos de cimento, incluindo determinações finais } \\
\text { em revisões administrativas e revisões de final de período. } \\
\text { Além disso, o México questiona o método do zeramento, } \\
\text { regulamentos e leis que seriam incompatíveis com o GATT } \\
\text { 1994, Acordo de Marraqueche e ADA. } \\
\text { Foi estabelecido painel. Em } 16 \text { de janeiro de } 2006 \text { foi sugerido }\end{array}$ & $\begin{array}{l}\text { Pedido de consulta } \\
\text { recebido em: } 31 \text { de } \\
\quad \text { janeiro de } 2003 \\
\text { Painel estabelecido em: } \\
29 \text { de agosto de } 2003 \\
\text { Acordo firmado em: } 16 \\
\quad \text { de janeiro de } 2006\end{array}$ \\
\hline
\end{tabular}




\begin{tabular}{|c|c|c|c|c|}
\hline \multicolumn{5}{|c|}{ APÊNDICE 3 - DISPUTAS ANTIDUMPING ENCERRADAS OU EM FASE DE PAINEL } \\
\hline $\begin{array}{c}\text { Dispute } \\
\text { Settlement } \\
\text { (DS): } \\
\text { Caso }\end{array}$ & $\begin{array}{l}\text { Short Title } \\
\text { "Apelido" }\end{array}$ & Nome Completo & Resumo do caso & Cronológico \\
\hline & & & $\begin{array}{l}\text { às partes que celebrassem um acordo. O painel foi suspenso e } \\
\text { sua autoridade encerrou-se em } 2007 \text {. }\end{array}$ & \\
\hline DS241 & $\begin{array}{l}\text { Argentina } \\
\text { - Poultry }\end{array}$ & $\begin{array}{l}\text { Argentina - Medidas } \\
\text { Antidumping Definitivas em } \\
\text { carne suína proveniente do } \\
\text { Brasil/ } \\
\text { Argentina - Definitive Anti- } \\
\text { Dumping Duties on Poultry } \\
\quad \text { from Brazil }\end{array}$ & $\begin{array}{l}\text { O Brasil requereu consultas com a Argentina devido à } \\
\text { imposição de medidas antidumping definitivas pela Argentina } \\
\text { na importação de carne de suína proveniente do Brasil. } \\
\text { O Brasil alega irregularidades na condução da investigação e } \\
\text { na sua conclusão, afirmando que as medidas adotadas são } \\
\text { incompatíveis com o GATT 1994, ADA e Acordo de } \\
\text { Aduanas. } \\
\text { A CE pediu para se juntar às consultas. } \\
\text { Em } 25 \text { de novembro de 2002, Brasil requereu estabelecimento } \\
\text { de painel. O painel foi estabelecido. Após análise, foi } \\
\text { concluído que as medidas argentinas questionadas violavam } \\
\text { diversos artigos do ADA. }\end{array}$ & $\begin{array}{c}\text { Pedido de consulta } \\
\text { recebido em: } 07 \text { de } \\
\text { novembro de } 2001 \\
\text { Relatório do painel } \\
\text { circulado em: } 22 \text { de abril } \\
\text { de } 2003\end{array}$ \\
\hline DS221 & $\begin{array}{c}\text { US - } \\
\text { Section } \\
\text { 129(c)(1) } \\
\text { URAA }\end{array}$ & $\begin{array}{l}\text { Estados Unidos: Seção 129(c) } \\
\text { (1) do Uruguay Round } \\
\text { Agreements Act/ } \\
\text { United States - Section } \\
\text { 129(c)(1) of the Uruguay } \\
\text { Round Agreements Act }\end{array}$ & $\begin{array}{l}\text { O Canadá requereu consultas com os EUA devido a Seção } \\
129(\text { c)(1) do Uruguay Round Agreements Act (URAA). } \\
\text { Na visão do Canadá, a norma Americana proíbe que os EUA } \\
\text { cumpram inteiramente o que foi estabelecido pelo ESC. } \\
\text { O Canadá considerou que tais medidas são incompatíveis com } \\
\text { as obrigações dos EUA sob o ESC, GATT, Acordo sobre } \\
\text { Subsídios e Medidas Compensatórias, ADA e Acordo de } \\
\text { Marraqueche. . Após análise, foi concluído que o Canadá } \\
\text { falhou em comprovar que a normativa questionada ia de }\end{array}$ & $\begin{array}{l}\text { Pedido de consulta } \\
\text { recebido em: } 17 \text { de } \\
\text { janeiro de } 2001 \\
\text { Relatório do painel } \\
\text { circulado em: } 15 \text { de } \\
\text { julho de } 2002\end{array}$ \\
\hline
\end{tabular}




\begin{tabular}{|c|c|c|c|c|}
\hline \multicolumn{5}{|c|}{ APÊNDICE 3 - DISPUTAS ANTIDUMPING ENCERRADAS OU EM FASE DE PAINEL } \\
\hline $\begin{array}{c}\text { Dispute } \\
\text { Settlement } \\
\text { (DS): } \\
\text { Caso }\end{array}$ & $\begin{array}{l}\text { Short Title } \\
\text { "Apelido" }\end{array}$ & Nome Completo & Resumo do caso & Cronológico \\
\hline & & & encontro com o ADA e GATT 1994. & \\
\hline DS211 & $\begin{array}{c}\text { Egypt-- } \\
\text { Steel Rebar }\end{array}$ & $\begin{array}{l}\text { Egito - Medidas Antidumping } \\
\text { definitivas em vergalhões de } \\
\text { aço provenientes da Turquia/ } \\
\text { Egypt - Definitive Anti- } \\
\text { Dumping Measures on Steel } \\
\text { Rebar from Turkey }\end{array}$ & $\begin{array}{l}\text { A Turquia requereu consultas com o Egito devido a uma } \\
\text { investigação conduzida pelo Ministério Egípcio de Comércio } \\
\text { e Abastecimento referente à importação de vergalhões de aço } \\
\text { provenientes da Turquia. } \\
\text { A Turquia alega que o Egito fez determinações parciais, } \\
\text { pouco objetivas e sem uma própria avaliação dos fatos, agindo } \\
\text { incompativelmente com o ADA, GATT 1994. } \\
\text { A Turquia requereu o estabelecimento de painel. Após análise, } \\
\text { foi concluído que a maioria das medidas egípcias questionadas } \\
\text { não violavam o ADA nem o GATT 1994, com exceção dos } \\
\text { artigos } 3.4 \text { e } 6.8 \text {. }\end{array}$ & $\begin{array}{c}\text { Pedido de consulta } \\
\text { recebido em: } 6 \text { de } \\
\text { novembro de } 2000 \\
\text { Relatório do painel } \\
\text { circulado em: } 8 \text { de } \\
\text { agosto de } 2002\end{array}$ \\
\hline DS206 & $\underset{\text { Plate }}{\text { Steel }}$ & $\begin{array}{l}\text { Estados Unidos - Medidas } \\
\text { Antidumping e Medidas } \\
\text { compensatórias em chapas de } \\
\text { aço carbono provenientes da } \\
\text { Índia/ } \\
\text { United States - Anti-Dumping } \\
\text { and Countervailing Measures } \\
\text { on Steel Plate from India }\end{array}$ & $\begin{array}{l}\text { A Índia requereu consultas com os EUA devido a } \\
\text { determinações finais relacionadas às vendas de determinadas } \\
\text { chapas de aço carbono provenientes da Índia, por um valor } \\
\text { menor do que o dusto. } \\
\text { A Î́ndia considerou que essas determinações eram errôneas e } \\
\text { baseadas em procedimentos deficientes dispostos em diversas } \\
\text { leis americanas de antidumping e medidas compensatórias, } \\
\text { que poderiam desencadear questionamentos sob o } \\
\text { cumprimento do Acordo de Marraqueche, GATT 1994, ADA } \\
\text { e ASMC. Através do pedido da Índia, foi estabelecido painel. } \\
\text { Após análise, foi concluído que as medidas americanas } \\
\text { questionadas estavam em conformidade com os artigos do }\end{array}$ & $\begin{array}{c}\text { Pedido de consulta } \\
\text { recebido em: } 4 \text { de } \\
\text { outubro de } 2000 \\
\text { Relatório do painel } \\
\text { circulado em: } 28 \text { de } \\
\text { junho de } 2002\end{array}$ \\
\hline
\end{tabular}




\begin{tabular}{|c|c|c|c|c|}
\hline \multicolumn{5}{|c|}{ APÊNDICE 3 - DISPUTAS ANTIDUMPING ENCERRADAS OU EM FASE DE PAINEL } \\
\hline $\begin{array}{l}\text { Dispute } \\
\text { Settlement } \\
\text { (DS): } \\
\text { Caso }\end{array}$ & $\begin{array}{l}\text { Short Title } \\
\text { "Apelido" }\end{array}$ & Nome Completo & Resumo do caso & Cronológico \\
\hline & & & ADA. & \\
\hline DS189 & $\begin{array}{c}U S- \\
\text { Stainless } \\
\text { Steel }\end{array}$ & $\begin{array}{c}\text { Argentina - Medidas } \\
\text { antidumping definitivas na } \\
\text { importação de carton board e } \\
\text { medidas antidumping } \\
\text { definitivas na importação de } \\
\text { pisos de ladrilho feito de } \\
\text { cerâmica provenientes da } \\
\text { Itália/ } \\
\text { Argentina - Definitive Anti- } \\
\text { Dumping Measures on } \\
\text { Carton-Board Imports from } \\
\text { Germany and Definitive Anti- } \\
\text { Dumping Measures on } \\
\text { Imports of Ceramic Tiles from } \\
\text { Italy }\end{array}$ & $\begin{array}{l}\text { A CE requereu consultas com a Argentina devido à medidas } \\
\text { antidumping definitivas impostas em pisos de ladrilho feito de } \\
\text { cerâmica provenientes da Itália. A CE constatou diversas } \\
\text { irregularidades durante a investigação, como a } \\
\text { desconsideração pelas autoridades argentinas das informações } \\
\text { fornecidas pelos exportadores italianos, deficiências na } \\
\text { comparação do produto vendido da Itália e do produzido na } \\
\text { Argentina, erro no cálculo de margem de dumping, dentre } \\
\text { outros. A CE concluiu que a Argentina descumpriu diversos } \\
\text { artigos do ADA. } \\
\text { A CE requereu o estabelecimento de painel. O painel foi } \\
\text { estabelecido. Após análise, foi concluído que as medidas } \\
\text { argentinas questionadas violavam artigos do ADA. }\end{array}$ & $\begin{array}{c}\text { Pedido de consulta } \\
\text { recebido em: } 30 \text { de julho } \\
\text { de } 1999 \\
\text { Relatório do painel } \\
\text { circulado em: } 22 \text { de } \\
\text { dezembro de } 2000\end{array}$ \\
\hline DS179 & $\begin{array}{c}\text { US- } \\
\text { Stainless } \\
\text { Steel }\end{array}$ & $\begin{array}{l}\text { Estados Unidos - Medidas } \\
\text { antidumping em chapas e fitas } \\
\text { de aço inoxidável em bobinas } \\
\text { provenientes da Coréia do Sul/ }\end{array}$ & $\begin{array}{l}\text { A Coréia do Sul requereu consultas com os EUA devido a } \\
\text { determinaões preliminares e finais do Departamento de } \\
\text { Comércio Americano em chapas e fitas de aço inoxidável em } \\
\text { bobinas provenientes da Coréia. } \\
\text { Coréia do Sul considerou que diversos erros foram cometidos } \\
\text { pelos EUA durante a investigação, o que modificou a correta } \\
\text { conclusão do caso. Dentre os erros, a Coréia destaca a venda } \\
\text { de produtos americanos a uma empresa falida, cálculo de dois } \\
\text { períodos de câmbio para exportação e conversão de moeda em }\end{array}$ & $\begin{array}{c}\text { Pedido de consulta } \\
\text { recebido em: } 30 \text { de julho } \\
\text { de } 1999 \\
\text { Relatório do painel } \\
\text { circulado em: } 22 \text { de } \\
\text { dezembro de } 2000\end{array}$ \\
\hline
\end{tabular}




\begin{tabular}{|c|c|c|c|c|}
\hline \multicolumn{5}{|c|}{ APÊNDICE 3 - DISPUTAS ANTIDUMPING ENCERRADAS OU EM FASE DE PAINEL } \\
\hline $\begin{array}{c}\text { Dispute } \\
\text { Settlement } \\
\text { (DS): }\end{array}$ & $\begin{array}{l}\text { Short Title } \\
\text { "Apelido" }\end{array}$ & Nome Completo & Resumo do caso & Cronológico \\
\hline & & $\begin{array}{l}\text { United States - Anti-Dumping } \\
\text { measures on Stainless Steel } \\
\text { Plate in Coils and Stainless } \\
\text { Steel Sheet and Strip from } \\
\text { Korea }\end{array}$ & $\begin{array}{l}\text { dólares. } \\
\text { A Coréia do Sul requereu estabelecimento de painel. O painel } \\
\text { foi estabelecido. Após análise, foi concluído que as medidas } \\
\text { questionadas violavam diversos artigos do ADA. }\end{array}$ & \\
\hline DS156 & $\begin{array}{c}\text { Guatemala } \\
- \text { Cement } \\
\text { II }\end{array}$ & $\begin{array}{c}\text { Guatemala - Medidas } \\
\text { antidumping definitivas na } \\
\text { importação de determinados } \\
\text { cimentos provenientes do } \\
\text { México/ } \\
\text { Guatemala - Definitive Anti- } \\
\text { Dumping Measure on Grey } \\
\text { Portland Cement from Mexico }\end{array}$ & $\begin{array}{l}\text { O México requereu consultas com a Guatemala devido a } \\
\text { imposição de direitos antidumping definitivos pelas } \\
\text { autoridades da Guatemala na importação de determinados } \\
\text { cimentos provenientes do México, questionando o modo de } \\
\text { condução da investigação. } \\
\text { O México alegou que a medida antidumping é incompatível } \\
\text { com o ADA e GATT } 1994 \text {. } \\
\text { O México requereu o estabelecimento do painel. } \\
\text { O painel foi estabelecido. Após análise, foi concluído que os } \\
\text { questionamentos do México tinham fundamento. Todas as } \\
\text { medidas questionadas da Guatemala eram incompatíveis com } \\
\text { o ADA e GATT 1994. }\end{array}$ & $\begin{array}{l}\text { Pedido de consulta } \\
\text { recebido em: } 05 \text { de } \\
\text { janeiro de } 1999 \\
\text { Relatório do painel } \\
\text { circulado em: } 24 \text { de } \\
\quad \text { outubro de } 2000\end{array}$ \\
\hline DS 99 & $\begin{array}{l}U S- \\
D R A M S\end{array}$ & $\begin{array}{l}\text { Estados Unidos - Medidas } \\
\text { antidumping em Dynamic } \\
\text { Random Access Memory } \\
\text { Semiconductors (DRAMS) de } \\
\text { um Megabit proveniente da } \\
\text { Coréia do Sul/ } \\
\text { United States - Anti- }\end{array}$ & $\begin{array}{l}\text { A Coréia requereu consultas com os EUA devido a uma } \\
\text { decisão do Departamento de Comércio dos EUA que não } \\
\text { revogou medida antidumping pagas pela Coreia na } \\
\text { importação de dynamic random access memory semi- } \\
\text { conductors (DRAMS) de um megabyte. } \\
\text { A Coréia alegou que tal decisão de não revogação foi tomada } \\
\text { apesar de ter sido constatado que o preço do produto em }\end{array}$ & $\begin{array}{l}\text { Pedido de consulta } \\
\text { recebido em: } 14 \mathrm{de}\end{array}$ \\
\hline
\end{tabular}




\begin{tabular}{|c|c|c|c|c|}
\hline \multicolumn{5}{|c|}{ APENNDICE 3 - DISPUTAS ANTIDUMPING ENCERRADAS OU EM FASE DE PAINEL } \\
\hline $\begin{array}{c}\text { Dispute } \\
\text { Settlement } \\
\text { (DS): }\end{array}$ & $\begin{array}{l}\text { Short Title } \\
\text { "Apelido" }\end{array}$ & Nome Completo & Resumo do caso & Cronológico \\
\hline & & $\begin{array}{l}\text { Dumping Duty on Dynamic } \\
\text { Random Access Memory } \\
\text { Semiconductors (DRAMS) of } \\
\text { One Megabit or Above from } \\
\text { Korea }\end{array}$ & $\begin{array}{l}\text { questão não estava em preço de dumping há mais de } 3 \text { anos } \\
\text { consecutivos, alegando descumprimento pelos EUA do ADA. } \\
\text { A Coréia requereu o estabelecimento do painel. O painel foi } \\
\text { estabelecido somente em } 16 \text { de janeiro de } 1998 \text {. } \\
\text { As partes notificaram que ESC que haviam alcançado uma } \\
\text { solução mutuamente satisfatória, envolvendo a revogação do } \\
\text { dever antidumping como resultado da revisão de final de } \\
\text { período. } \\
\text { O painel foi estabelecido. Após análise, foi concluído que as } \\
\text { medidas questionadas violavam o artigo } 11.2 \text { do ADA. }\end{array}$ & $\begin{array}{c}\text { agosto de } 1997 \\
\text { Relatório do painel } \\
\text { circulado em: } 29 \text { de } \\
\text { janeiro de } 1999\end{array}$ \\
\hline
\end{tabular}




\begin{tabular}{|c|c|c|c|c|}
\hline $\begin{array}{l}\text { Dispute } \\
\text { Settlement } \\
\text { (DS): Caso }\end{array}$ & $\begin{array}{l}\text { Short title } \\
\text { "Apelido" }\end{array}$ & Nome completo & Resumo do caso & Cronológico \\
\hline DS397 & $\begin{array}{c}E U- \\
\text { Fasteners } \\
\text { (China) }\end{array}$ & $\begin{array}{l}\text { União Européia - } \\
\text { Medidas Antidumping } \\
\text { Definitivas contra } \\
\text { determinados } \\
\text { parafusos de ferro e } \\
\text { aço provenientes da } \\
\text { China/ } \\
\text { European Union - } \\
\text { Definitive Anti- } \\
\text { Dumping Measures on } \\
\text { Certain Iron or Steel } \\
\text { Fasteners from China }\end{array}$ & $\begin{array}{l}\text { A China requereu consultas com a União Europeia devido } \\
\text { ao artigo 9(5) do Council Regulation (EC) No. } 384 / 96 \text { (the } \\
\text { EC's Basic Anti-Dumping Regulation) que dispõe sobre } \\
\text { diferenças de cálculo de margem de dumping para } \\
\text { economias que não são de mercado. Além disso, também } \\
\text { questiona uma normativa europeia que impõe direitos } \\
\text { antidumping definitivos na importação de determinados } \\
\text { parafusos de ferro e aço provenientes da China, apontando } \\
\text { irregularidades ocorridas durante a investigação. } \\
\text { De acordo com a China, tais normativas são incompatíveis } \\
\text { com o GATT 1994, ADA e Protocolo de Acessão da } \\
\text { China. } \\
\text { O painel foi estabelecido. Brasil, Canadá, Chile, Colômbia, } \\
\text { Índia, Japão, Noruega, Taipé Chinês, Tailândia, Turquia e } \\
\text { EUA reservaram seus direitos como terceira parte. Após } \\
\text { análise, foi decido que alguns artigos da Basic Regulation } \\
\text { eram incompatíveis com artigos do ADA e GATT 1994, } \\
\text { entretanto, todos os outros questionamentos chineses foram } \\
\text { negados. Após apelação da China, o Órgão de Apelação } \\
\text { decidiu por manter as decisões tomadas pelo Painel. }\end{array}$ & $\begin{array}{c}\text { Pedido de consulta } \\
\text { recebido em: } 31 \text { de julho } \\
\text { de } 2009 \\
\text { Relatório do painel } \\
\text { circulado em: } 03 \text { de } \\
\text { dezembro de } 2010 \\
\text { Relatório do Órgão de } \\
\text { Apelação circulado em: } 15 \\
\text { de julho de } 2011 \\
\text { Adoção pelo DSB em: } 28 \\
\text { de julho de } 2011\end{array}$ \\
\hline DS379 & $\begin{array}{c}U S-A D / C V D \\
(\text { China })\end{array}$ & $\begin{array}{l}\text { Estados Unidos - } \\
\text { Medidas antidumping } \\
\text { definitivas e medidas } \\
\text { compensatórias contra } \\
\text { determinados produtos }\end{array}$ & $\begin{array}{l}\text { A China requereu consultas devido a medidas antidumping } \\
\text { definitivas e medidas compensatórias impostas pelos EUA } \\
\text { em uma série de investigações. } \\
\text { A China considera que as medidas impostas são } \\
\text { incompatíveis com as obrigações dos EUA perante o }\end{array}$ & $\begin{array}{l}\text { Pedido de consulta } \\
\text { recebido em: } 19 \text { de } \\
\text { setembro de } 2008 \\
\text { Relatório do painel } \\
\text { circulado em: } 22 \text { de }\end{array}$ \\
\hline
\end{tabular}




\begin{tabular}{|c|c|c|c|c|}
\hline $\begin{array}{c}\text { Dispute } \\
\text { Settlement } \\
\text { (DS): Caso }\end{array}$ & $\begin{array}{l}\text { Short title } \\
\text { "Apelido" }\end{array}$ & Nome completo & Resumo do caso & Cronológico \\
\hline & & $\begin{array}{l}\text { provenientes da China } \\
\text { / } \\
\text { United States - } \\
\text { Definitiver Anti- } \\
\text { Dumping and } \\
\text { Countervailing Duties } \\
\text { on Certain Products } \\
\text { from China }\end{array}$ & $\begin{array}{l}\text { GATT 1994, ASMC ADA e Protocolo de Acesso da } \\
\text { China. } \\
\text { Argentina, Austrália, Bahrein, Canadá, Kuwait, Arábia } \\
\text { Saudita, Turquia á e CE reservaram seus direitos como } \\
\text { terceira parte. O painel foi estabelecido e após análise, os } \\
\text { questionamentos chineses contra medidas americanas } \\
\text { impostas foram negados. } \\
\text { Após apelação chinesa, o Órgão de Apelação decidiu por } \\
\text { manter as decisões do Painel. }\end{array}$ & $\begin{array}{c}\text { outubro de } 2010 \\
\text { Relatório do Órgão de } \\
\text { Apelação circulado em: } 11 \\
\text { de março de } 2011 \\
\text { Adoção pelo DSB em: } 25 \\
\text { de março de } 2011\end{array}$ \\
\hline DS350 & $\begin{array}{c}\text { US - Zeroing } \\
\text { II }(E C)\end{array}$ & $\begin{array}{l}\text { Estados Unidos - } \\
\text { Existência continuada } \\
\text { e aplicação do método } \\
\text { de zeramento / } \\
\text { United States - } \\
\text { Continued Existence } \\
\text { and Application of } \\
\text { Zeroing Methodology }\end{array}$ & $\begin{array}{l}\text { A CE requereu consultas com os EUA devido ao uso } \\
\text { continuado do método do zeramento. De acordo com a CE, } \\
\text { os EUA estão descumprindo o ADA, GATT } 1994 \text { e } \\
\text { Acordo de Marraqueche. } \\
\text { O Japão, Brasil e Índia requereram para se juntar as } \\
\text { consultas. } \\
\text { O painel foi estabelecido e Taipé Chinês, Índia, Japão, } \\
\text { Brasil, China, Egito, Coreia do Sul, Noruega, Tailândia e } \\
\text { EUA reservaram seus direitos como terceira parte. } \\
\text { Após análise, o Painel decidiu que os EUA agiam de forma } \\
\text { incompatível com diversos artigos e obrigações estipuladas } \\
\text { no GATT } 1994 \text { e ADA. O painel decidiu a favor dos } \\
\text { demandantes em todos os questionamentos. Houve uma } \\
\text { exceção: um dos membros do Painel rejeitou um pedido da } \\
\text { CE relacionado à prática do zeramento simples (simple } \\
\text { zeroing) }\end{array}$ & $\begin{array}{c}\text { Pedido de consulta } \\
\text { recebido em: 02 de outubro } \\
\text { de } 2006 \\
\text { Relatório do painel } \\
\text { circulado em: } 01 \text { de } \\
\text { outubro de } 2008 \\
\text { Relatório do Órgão de } \\
\text { Apelação circulado em: } 04 \\
\text { de fevereiro de } 2009 \\
\text { Adoção pelo DSB em: } 19 \\
\text { de fevereiro de } 2009\end{array}$ \\
\hline
\end{tabular}




\begin{tabular}{|c|c|c|c|c|}
\hline \multirow[t]{2}{*}{$\begin{array}{l}\text { Dispute } \\
\text { Settlement } \\
\text { (DS): Caso }\end{array}$} & $\begin{array}{l}\text { Short title } \\
\text { "Apelido" }\end{array}$ & Nome completo & Resumo do caso & Cronológico \\
\hline & & & $\begin{array}{l}\text { Após apelação europeia, o Órgão de Apelação reverteu } \\
\text { parte da decisão do Painel a favor da CE e declinou de } \\
\text { concluir sobre os questionamentos restantes. }\end{array}$ & \\
\hline DS345 & $\begin{array}{l}\text { US - Customs } \\
\text { Bond } \\
\text { Directive }\end{array}$ & 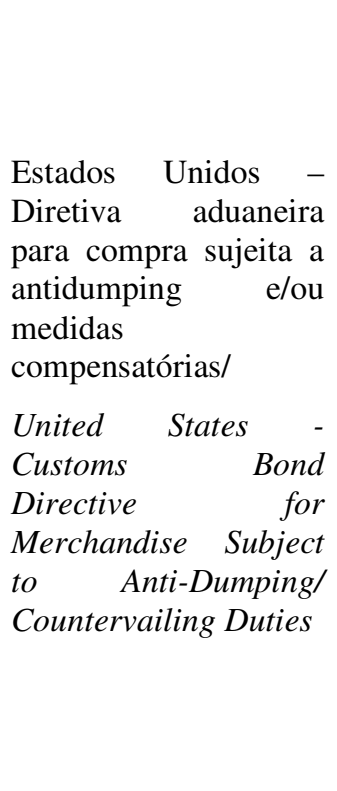 & $\begin{array}{l}\text { A Índia requereu consultas com os EUA devido a medida } \\
\text { imposta pelos americanos ao camarão de água doce } \\
\text { congelado proveniente da Índia. } \\
\text { A Índia considera tal medida (“Amended Bond Directive”) } \\
\text { as such incompatível com o ADA, GATT } 1994 \text { e ASMC. } \\
\text { Brasil, China e Tailândia requereram para se juntar às } \\
\text { consultas. O painel foi estabelecido. Brasil, China, CE, } \\
\text { Japão e Tailândia reservaram seus direitos como terceira } \\
\text { parte. } \\
\text { Após análise, o Painel rejeitou questionamentos indianos } \\
\text { que alegavam que leis, regras e regulamentos americanos } \\
\text { que autorizam a imposição da medida são incompatíveis } \\
\text { com diversos artigos do GATT 1994, ADA e ASMC. } \\
\text { Entretanto, aceitou os questionamentos indianos e decidiu } \\
\text { a seu favor no quesito de inconsistência da aplicação da } \\
\text { medida contra os camarões indianos e artigos do ADA. } \\
\text { Após apelação indiana, o Órgão de Apelação decidiu por } \\
\text { confirmar todas as decisões do Painel. }\end{array}$ & $\begin{array}{c}\text { Pedido de consulta } \\
\text { recebido em: } 06 \text { de junho } \\
\text { de } 2006 \\
\text { Relatório do painel } \\
\text { circulado em: } 29 \text { de } \\
\text { fevereiro de } 2008 \\
\text { Relatório do Órgão de } \\
\text { Apelação circulado em: } 16 \\
\text { de julho de } 2008 \\
\text { Adoção pelo DSB em: } 01 \\
\text { de agosto de } 2008\end{array}$ \\
\hline DS344 & $\begin{array}{l}\text { US - Stainless } \\
\text { Steel (Mexico) }\end{array}$ & 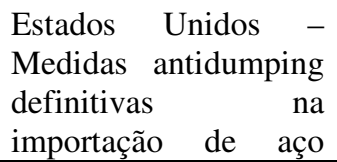 & $\begin{array}{l}\text { O México requereu consultas com os EUA devido a uma } \\
\text { série de medidas antidumping impostas pelo Departamento } \\
\text { de Comércio dos EUA na importação de chapas e fitas de } \\
\text { aço inoxidável em bobinas de janeiro de } 1999 \text { a junho de }\end{array}$ & $\begin{array}{l}\text { Pedido de consulta } \\
\text { recebido em: } 26 \text { de maio } \\
\text { de } 2006\end{array}$ \\
\hline
\end{tabular}




\begin{tabular}{|c|c|c|c|c|}
\hline $\begin{array}{c}\text { Dispute } \\
\text { Settlement } \\
\text { (DS): Caso }\end{array}$ & $\begin{array}{l}\text { Short title } \\
\text { "Apelido" }\end{array}$ & Nome completo & Resumo do caso & Cronológico \\
\hline & & $\begin{array}{l}\text { inoxidável proveniente } \\
\text { do México/ } \\
\text { United States - Final } \\
\text { Anti-dumping } \\
\text { Measures on Stainless } \\
\text { Steel from Mexico }\end{array}$ & $\begin{array}{l}2004 . \\
\text { México alega que há descumprimento ao GATT } 1994 \text { e } \\
\text { ADA, destacando leis americanas, regulamentos, práticas } \\
\text { administrativas, métodos e determinações. } \\
\text { O Japão requereu para se juntar às consultas. O painel foi } \\
\text { estabelecido e Chile, China, CE, Japão e Tailândia } \\
\text { reservaram seus direitos como terceira parte. } \\
\text { Após análise, o Painel concluiu que a aplicação do método } \\
\text { do zeramento em investigações é incompatível com } \\
\text { algumas obrigações do GATT } 1994 \text { e ADA. } \\
\text { Após apelação mexicana contra a interpretação de certos } \\
\text { quesitos (o Painel não considerou que o método do } \\
\text { zeramento é incompatível com todos artigos questionados } \\
\text { pelo México). O Órgão de Apelação decidiu por reverter } \\
\text { alguns quesitos decididos pelo Painel não condenando o } \\
\text { método do zeramento e acabou por decidir em favor do } \\
\text { México. }\end{array}$ & $\begin{array}{c}\text { Relatório do painel } \\
\text { circulado em: } 20 \text { de } \\
\text { dezembro de } 2007 \\
\text { Relatório do Órgão de } \\
\text { Apelação circulado em: } 30 \\
\text { de abril de } 2008 \\
\text { Adoção pelo DSB em: } 20 \\
\text { de maio de } 2008 \\
\text { Relatório de arbitragem } \\
\text { 21.3: } 31 \text { de outubro de } 2008\end{array}$ \\
\hline DS343 & $\begin{array}{c}\text { US - Shrimp } \\
\text { (Thailand) }\end{array}$ & $\begin{array}{l}\text { Estados Unidos - } \\
\text { Medidas relacionadas } \\
\text { à importação de } \\
\text { camarão da Tailândia/ } \\
\text { United States - } \\
\text { Measures Relating to } \\
\text { Shrimp from Thailand }\end{array}$ & $\begin{array}{l}\text { A Tailândia requereu consultas com os EUA devido a } \\
\text { medidas antidumping impostas na importação de camarões } \\
\text { de água doce congelados. } \\
\text { A Tailândia alega que o método do zeramento descumpre } \\
\text { o disposto no GATT } 1994 \text { e ADA e questiona o Enhaced } \\
\text { Bond Requirements (EBR) relacionado à importação de } \\
\text { camarão congelado tailandês. } \\
\text { O Brasil, China e Índia se juntaram às consultas. O painel }\end{array}$ & $\begin{array}{l}\text { Pedido de consulta } \\
\text { recebido em: } 24 \text { de abril de } \\
\qquad 2006 \\
\text { Relatório do painel } \\
\text { circulado em: } 29 \text { de } \\
\text { fevereiro de } 2008 \\
\text { Relatório do Órgão de } \\
\text { Apelação em: } 16 \text { de julho }\end{array}$ \\
\hline
\end{tabular}




\begin{tabular}{|c|c|c|c|c|}
\hline \multicolumn{5}{|c|}{ APÊNDICE 4 - DISPUTAS ANTIDUMPING ENCERRADAS OU EM FASE DE APELACÃO } \\
\hline $\begin{array}{l}\text { Dispute } \\
\text { Settlement } \\
\text { (DS): Caso }\end{array}$ & $\begin{array}{l}\text { Short title } \\
\text { "Apelido" }\end{array}$ & Nome completo & Resumo do caso & Cronológico \\
\hline & & & $\begin{array}{l}\text { foi estabelecido e Brasil, Chile, China, CE, Índia, Japão, } \\
\text { Coreia do Sul, Vietnã e México reservaram seus direitos } \\
\text { como terceira parte. Após análise, o Painel deferiu todos os } \\
\text { pedidos tailandeses que questionavam o zeramento, mas } \\
\text { declinou em concluir sobre o Enhaced Bond Requirements } \\
\text { (EBR) relacionado à importação de camarão congelado } \\
\text { tailandês. } \\
\text { Ambas as partes apelaram. Após análise, o Órgão de } \\
\text { Apelação manteve todas as conclusões do Painel. }\end{array}$ & $\begin{array}{c}\text { de } 2008 \\
\text { Adoção pelo DSB: } 01 \text { de } \\
\text { agosto de } 2008\end{array}$ \\
\hline DS322 & $\begin{array}{c}\text { US - Zeroing } \\
\text { (Japan) }\end{array}$ & $\begin{array}{l}\text { Estados Unidos - } \\
\text { Medidas relacionadas } \\
\text { ao zeramento de } \\
\text { revisões de final de } \\
\text { periodo/ } \\
\text { United States - } \\
\text { Measures Relating to } \\
\text { Zeroing and Sunset } \\
\text { Reviews }\end{array}$ & $\begin{array}{l}\text { O Japão requereu consultas com os EUA devido à prática } \\
\text { do zeramento em investigações antidumping, revisões } \\
\text { administrativas, revisões de final de período e a "presunção } \\
\text { irrefutável" do Departamento de Comércio Americano. } \\
\text { O Japão alega descumprimento do ADA e GATT } 1994 \text {. } \\
\text { Índia, Noruega, Argentina, Taipé Chinês, CE e México } \\
\text { requereram para se juntar às consultas. } \\
\text { O painel foi estabelecido. Argentina, CE, Hong Kong, } \\
\text { China, Índia, Coreia do Sul, Noruega, Tailândia, Nova } \\
\text { Zelândia e México reservaram seus direitos como terceira } \\
\text { parte. Após análise, o Painel decidiu que o método de } \\
\text { zeramento é passível de questionamento na OMC, } \\
\text { concordando com o Japão, mas rejeitou o questionamento } \\
\text { japonês que alegava proibição do emprego do método de } \\
\text { zeramento em determinadas situações. } \\
\text { Após apelação japonesa, o Órgão de Apelação concluiu }\end{array}$ & $\begin{array}{l}\text { Pedido de consulta } \\
\text { recebido em: } 24 \text { de } \\
\text { novembro de } 2004 \\
\text { Relatório do painel } \\
\text { circulado em: } 20 \text { de } \\
\text { setembro de } 2006 \\
\text { Relatório do Órgão de } \\
\text { Apelação circulado em: } 09 \\
\text { de janeiro de } 2007 \\
\text { Relatório Arbitragem } \\
\text { 21.3: } 11 \text { de maio de } 2007 \\
\text { Relatório do painel do } \\
\text { 21.5 circulado em: } 24 \text { de } \\
\text { abril de } 2009 \\
\text { Relatório do Órgão de } \\
\text { Apelação do } 21.5\end{array}$ \\
\hline
\end{tabular}




\begin{tabular}{|c|c|c|c|c|}
\hline \multirow{2}{*}{$\begin{array}{c}\text { Dispute } \\
\text { Settlement } \\
\text { (DS): Caso }\end{array}$} & $\begin{array}{l}\text { Short title } \\
\text { "Anelide" }\end{array}$ & Nome completo & Resumo do caso & \multirow{2}{*}{$\begin{array}{c}\text { Cronológico } \\
\text { circulado em: } 18 \text { de agosto } \\
\text { de } 2009 \\
\begin{array}{c}\text { Adoção pelo DSB em: } 31 \\
\text { de agosto de } 2009\end{array}\end{array}$} \\
\hline & & & $\begin{array}{l}\text { por: (i) manter a decisão do Painel de permitir o } \\
\text { questionamento do método de zeramento na OMC; (ii) } \\
\text { reverteu a decisão do Painel que concluiu que os EUA não } \\
\text { agiram de modo incompatível com diversos artigos do } \\
\text { ADA e GATT 1994. }\end{array}$ & \\
\hline DS295 & $\begin{array}{c}\text { Mexico-Beef } \\
\text { and Rice }\end{array}$ & $\begin{array}{l}\text { México - Medidas } \\
\text { definitivas } \\
\text { antidumping contra } \\
\text { carne e arroz/ } \\
\text { Mexico - Definitive } \\
\text { Anti-Dumping } \\
\text { Measures on Beef and } \\
\text { Rice }\end{array}$ & $\begin{array}{l}\text { Os EUA requereram consultas com o México devido a } \\
\text { imposição de medidas antidumping definitivas a carne e } \\
\text { arroz longo branco. Os EUA também questionam a Lei de } \\
\text { Comércio Internacional Mexicana (Mexico's Foreign } \\
\text { Trade Act) e Código Federal (Federal Code of Civil } \\
\text { Procedure). } \\
\text { Os EUA alegam que tais medidas são incompatíveis com } \\
\text { obrigações do México sob o GATT 1994, ADA e ASMC. } \\
\text { O painel foi estabelecido. China, CE e Turquia reservaram } \\
\text { seus direitos como terceira parte.Após análise, com relação } \\
\text { à lei mexicana de comércio internacional, o Painel decidiu } \\
\text { a favor dos EUA em praticamente todos os quesitos. O } \\
\text { Painel rejeitou o questionamento americano com relação ao } \\
\text { Código de Processo Civil mexicano. } \\
\text { Após apelação mexicana, o Órgão de Apelação manteve a } \\
\text { maioria das conclusões do Painel com exceção da que } \\
\text { afirma que o México agiu de forma incompatível com os } \\
\text { artigos 6.1, } 6.10 \text { e } 12.1 \text { do ADA. }\end{array}$ & $\begin{array}{c}\text { Pedido de consulta } \\
\text { recebido em: } 16 \text { de junho } \\
\text { de } 2003 \\
\text { Relatório do painel } \\
\text { circulado em: } 06 \text { de junho } \\
\text { de } 2005 \\
\text { Relatório do Órgão de } \\
\text { Apelação circulado em: } 29 \\
\text { de novembro de } 2005 \\
\text { Adoção pelo DSB em: } 20 \\
\text { de dezembro de } 2005\end{array}$ \\
\hline DS294 & $\begin{array}{c}\text { US - Zeroing } \\
(E C)\end{array}$ & $\begin{array}{l}\text { Estados Unidos - Leis, } \\
\text { regulamentos }\end{array}$ & $\begin{array}{l}\text { A CE requereu consultas com os EUA com relação à } \\
\text { metodologia utilizada pelos EUA no cálculo das margens }\end{array}$ & $\begin{array}{l}\text { Pedido de consulta } \\
\text { recebido em: } 12 \text { de junho }\end{array}$ \\
\hline
\end{tabular}




\begin{tabular}{|c|c|c|c|c|}
\hline $\begin{array}{c}\text { Dispute } \\
\text { Settlement } \\
\text { (DS): Caso }\end{array}$ & $\begin{array}{l}\text { Short title } \\
\text { "Apelido" }\end{array}$ & Nome completo & Resumo do caso & Cronológico \\
\hline & & $\begin{array}{l}\text { métodos para cálculos } \\
\text { de margem de } \\
\text { dumping e zeramento/ } \\
\text { United States - Laws, } \\
\text { Regulations and } \\
\text { Methodology for } \\
\text { Calculating Dumping } \\
\text { Margins (Zeroing) }\end{array}$ & $\begin{array}{l}\text { de dumping, conhecido como método do zeramento. A } \\
\text { maioria dos produtos neste caso era aço. Alega-se } \\
\text { incompatibilidade das obrigações americanas assumidas no } \\
\text { ADA e GATT 1994. } \\
\text { Índia, Coreia do Sul, Japão e México se juntaram as } \\
\text { consultas.O painel foi estabelecido e Argentina, Brasil, } \\
\text { China, Índia, Japão, Coreia do Sul, México, Noruega, } \\
\text { Turquia, Hong Kong, China e Taipé Chinesa reservaram } \\
\text { seus direitos como terceira parte. } \\
\text { Após análise, foi decidido que o método de zeramento é } \\
\text { passível de questionamento na OMC, entretanto, rejeitou as } \\
\text { alegações europeias de que as previsões normativas em } \\
\text { questão não mencionavam o zeramento e outros } \\
\text { questionamentos sobre revisões de medidas existentes. } \\
\text { Após apelação europeia e americana, o Órgão de Apelação } \\
\text { decidiu por: manter a decisão de que o método de } \\
\text { zeramento é passível de questionamento na OMC; reverter } \\
\text { a decisão que diz respeito a revisões administrativas e } \\
\text { afirma que os EUA não agiram de forma incompatível com } \\
\text { artigos do GATT } 1994 \text { e ADA. O Órgão de Apelação } \\
\text { também rejeitou todos os questionamentos europeus } \\
\text { alegando descumprimento pelo Painel do artigo } 11 \text { do } \\
\text { ESC. }\end{array}$ & $\begin{array}{c}\text { de } 2003 \\
\text { Relatório do painel } \\
\text { circulado em: } 31 \text { de } \\
\text { outubro de } 2005 \\
\text { Relatório do Órgão de } \\
\text { Apelação circulado em: } 18 \\
\text { de abril de } 2006 \\
\text { Relatório do painel do } \\
\text { 21.5 circulado em: } 17 \text { de } \\
\text { dezembro de } 2008 \\
\text { Relatório do Órgão de } \\
\text { Apelação do } 21.5 \\
\text { circulado em: } 14 \text { de maio } \\
\text { de } 2009 \\
\text { Adoção pelo DSB em: } 11 \\
\text { de junho de } 2009\end{array}$ \\
\hline DS282 & US - OCTG & $\begin{array}{lc}\text { Estados } & \text { Unidos - } \\
\text { Medidas antidumping }\end{array}$ & $\begin{array}{l}\text { O México requereu consultas com os EUA com relação a } \\
\text { várias medidas antidumping impostas pelos EUA na }\end{array}$ & $\begin{array}{l}\text { Pedido de consulta } \\
\text { recebido em: } 18 \mathrm{de}\end{array}$ \\
\hline
\end{tabular}




\section{APÊNDICE 4 - DISPUTAS ANTIDUMPING ENCERRADAS OU EM FASE DE APELAÇÃO}

\begin{tabular}{|c|c|c|c|c|}
\hline $\begin{array}{c}\text { Dispute } \\
\text { Settlement } \\
\text { (DS): Caso }\end{array}$ & $\begin{array}{l}\text { Short title } \\
\text { "Apelido" }\end{array}$ & Nome completo & Resumo do caso & Cronológico \\
\hline & & $\begin{array}{l}\text { contra produtos } \\
\text { tubulares / } \\
\text { United States - Anti- } \\
\text { Dumping Measures on } \\
\text { Oil Country Tubular } \\
\text { Goods from Mexico }\end{array}$ & $\begin{array}{l}\text { importação de produtos tubulares para petróleo } \\
\text { provenientes do México, incluindo decisões finais } \\
\text { administrativas e revisão de final de período e as decisões } \\
\text { das autoridades americanas com relação a continuidade das } \\
\text { medidas antidumping. A consulta solicitada pelo México } \\
\text { inclui várias leis, regulamentos e práticas administrativas } \\
\text { (tais como o zeramento). } \\
\text { O painel foi estabelecido. Argentina, China, CE, Japão, } \\
\text { Taipé Chinesa e Venezuela reservaram seus direitos como } \\
\text { terceira parte. } \\
\text { Após análise, o Painel concluiu que o US Statute e o "SAA" } \\
\text { não eram incompatíveis com o artigo } 11.3 \text { do ADA, mas o } \\
\text { Sunset Policy Bulletin era incompatível com o artigo } 11.3 \text {. } \\
\text { Além disso, condenou a determinação de revisão de final } \\
\text { de período. O painel também afirmou que a "USITC" não } \\
\text { agiu de forma incompatível, ao concluir que o } \\
\text { encerramento da medida antidumping acarretaria na } \\
\text { recorrência de dano. } \\
\text { Após apelação mexicana, o Órgão de Apelação confirmou } \\
\text { que a "USITC" não agiu de forma incompatível com suas } \\
\text { obrigações, mas reverteu a decisão referente ao Sunset } \\
\text { Policy Bulletin, afirmando que o Painel falhou em fazer } \\
\text { uma análise objetiva do tópico. }\end{array}$ & $\begin{array}{c}\text { fevereiro de } 2003 \\
\text { Relatório do painel } \\
\text { circulado em: } 20 \text { de junho } \\
\text { de } 2005 \\
\text { Relatório do Órgão de } \\
\text { Apelação circulado em: } 02 \\
\text { de novembro de } 2005 \\
\text { Adoção pelo DSB em: } 28 \\
\text { de novembro de } 2005\end{array}$ \\
\hline
\end{tabular}




\begin{tabular}{|c|c|c|c|c|}
\hline $\begin{array}{c}\text { Dispute } \\
\text { Settlement } \\
\text { (DS): Caso }\end{array}$ & $\begin{array}{l}\text { Short title } \\
\text { "Apelido" }\end{array}$ & Nome completo & Resumo do caso & Cronológico \\
\hline DS277 & $\begin{array}{l}\text { US - Softwood } \\
\text { Lumber VI }\end{array}$ & $\begin{array}{lr}\text { Estados Unidos } & - \\
\text { Investigação } & \text { da } \\
\text { Comissão } & \text { de } \\
\text { Comércio } & \\
\text { Internacional } & \text { sobre } \\
\text { Madeira macia } & \text { serrada } \\
\text { proveniente } & \text { do } \\
\text { Canadá/ } & \\
\text { United States } & - \\
\text { Investigation of the } \\
\text { International Trade } \\
\text { Commission } \\
\text { Softwood Lumberfrom } \\
\text { Canada in }\end{array}$ & $\begin{array}{l}\text { O Canadá requereu consultas com os EUA sobre a } \\
\text { investigação de madeira macia serrada do Canadá. } \\
\text { O Canadá alega que, por meio dessas medidas, os EUA } \\
\text { violaram várias obrigações dispostas no GATT 1994, ADA } \\
\text { e ASMC. } \\
\text { O painel foi estabelecido. CE, Coreia do Sul e Japão } \\
\text { reservaram seus direitos como terceira parte. Após análise, } \\
\text { o Painel decidiu que a medida antidumping imposta pelos } \\
\text { EUA é incompatível com o ADA devido a falta de } \\
\text { comprovação de nexo causal entre aumento de importações } \\
\text { de madeiras canadenses e dano à indústria doméstica } \\
\text { americana. } \\
\text { Os EUA afirmaram que iriam implementar as } \\
\text { recomendações do Órgão de Solução de Controvérsias, } \\
\text { entretanto, após um período razoável de tempo, o Canadá } \\
\text { requereu que o painel original fosse reestabelecido } \\
\text { alegando inconsistências americanas no cumprimento das } \\
\text { recomendações do Órgão de Solução de Controvérsias. O } \\
\text { painel foi reestabelecido e após análise foi decidido que } \\
\text { não havia irregularidades no cumprimento da } \\
\text { recomendação. Após apelação canadense, o Órgão de } \\
\text { Apelação reverteu a decisão do Painel afirmando que } \\
\text { realmente havia inconsistências americanas no } \\
\text { cumprimento da primeira recomendação. }\end{array}$ & $\begin{array}{c}\text { Pedido de consulta } \\
\text { recebido em: } 20 \text { de } \\
\text { dezembro de } 2002 \\
\text { Relatório do painel } \\
\text { circulado em: } 22 \text { de março } \\
\text { de } 2004 \\
\text { Adoção pelo Órgão de } \\
\text { Solução de Controvérsias } \\
\text { em: } 26 \text { de abril de } 2004 \\
\text { Relatório do painel do } \\
\text { 21.5 circulado em: } 15 \text { de } \\
\text { novembro de } 2005 \\
\text { Relatório do Órgão de } \\
\text { Apelação do 21.5 } \\
\text { circulado em: } 13 \text { de abril } \\
\text { de } 2006 \\
\text { Solução mutuamente } \\
\text { acordada notificada em: } \\
12 \text { de outubro de } 2006\end{array}$ \\
\hline DS268 & $\begin{array}{c}\text { US - OCTG } \\
\text { Sunset }\end{array}$ & $\begin{array}{lll}\text { Estados Unidos } & - \\
\text { Revisões de final de }\end{array}$ & $\begin{array}{l}\text { A Argentina requereu consultas com os EUA com relação } \\
\text { à determinação final do Departamento de Comércio }\end{array}$ & $\begin{array}{l}\text { Pedido de consulta } \\
\text { recebido em: } 07 \text { de outubro }\end{array}$ \\
\hline
\end{tabular}




\begin{tabular}{|c|c|c|c|c|}
\hline $\begin{array}{c}\text { Dispute } \\
\text { Settlement } \\
\text { (DS): Caso }\end{array}$ & $\begin{array}{l}\text { Short title } \\
\text { "Apelido" }\end{array}$ & Nome completo & Resumo do caso & Cronológico \\
\hline & Reviews & $\begin{array}{lr}\begin{array}{l}\text { período de } \\
\text { antidumping } \\
\text { produtos }\end{array} & \text { medidas } \\
\text { para } & \text { tubulares } \\
\text { provenientes } & \text { petróleo } \\
\text { Argentina/ } & \text { da } \\
\text { United States } & \text { Sunset } \\
\text { Reviews of } & \text { Anti- } \\
\text { Dumping Measures on } \\
\text { Oil Country Tubular } \\
\text { Goods from Argentina }\end{array}$ & $\begin{array}{l}\text { Americano e da Comissão Americana de Comércio sobre a } \\
\text { Revisão de final de período da medida antidumping para } \\
\text { produtos tubulares para petróleo provenientes da } \\
\text { Argentina. } \\
\text { A Argentina considerou que leis, regulamentos, medidas e } \\
\text { procedimentos relacionados com a revisão de final de } \\
\text { período e aplicação das medidas antidumping eram } \\
\text { incompatíveis de pronto ou quando aplicadas junto com o } \\
\text { ADA ou GATT 1994. } \\
\text { O painel foi estabelecido. CE, Japão, Coreia do Sul, } \\
\text { México e China reservaram seus direitos como terceira } \\
\text { parte. } \\
\text { Após análise, o Painel concluiu que determinadas } \\
\text { previsões normativas americanas relacionadas a } \\
\text { investigações antidumping e o procedimento de revisão } \\
\text { final de período (sunset review) são incompatíveis com } \\
\text { obrigações assumidas no GATT } 1994 \text { e ADA. Entretanto, } \\
\text { o modelo americano de determinação de recorrência de } \\
\text { dano utilizado nas revisões de final de período não é } \\
\text { incompatível com o ADA. } \\
\text { Após apelação de ambas as partes, o Órgão de Apelação } \\
\text { decidiu que o Painel não cumpriu sua obrigação } \\
\text { estabelecida no artigo } 11 \text { do ESC, revertendo a decisão do } \\
\text { Painel sobre inconsistência dos EUA no cumprimento do } \\
\text { artigo } 11.3 \text { do ADA. Além disso, o Órgão de Apelação } \\
\text { declinou em decidir sobre dois questionamentos argentinos } \\
\text { relativos ao modo de condução dos EUA em uma }\end{array}$ & $\begin{array}{c}\text { de } 2002 \\
\text { Relatório do painel } \\
\text { circulado em: } 16 \text { de julho } \\
\text { de } 2004 \\
\text { Relatório do Órgão de } \\
\text { Apelação circulado em: } 29 \\
\text { de novembro de } 2004 \\
\text { Adoção pelo DSB em: } 11 \\
\text { de maio de } 2007 \\
\text { Arbitragem 21.3: } 12 \text { de } \\
\text { abril de } 2007 \\
\text { Relatório do painel do } \\
\text { 21.5 circulado em: } 30 \text { de } \\
\text { novembro de } 2006 \\
\text { Relatório do Órgão de } \\
\text { Apelação do 21.5: } 12 \text { de } \\
\text { abril de } 2007\end{array}$ \\
\hline
\end{tabular}




\begin{tabular}{|c|c|c|c|c|}
\hline \multicolumn{5}{|c|}{ APÊNDICE 4 - DISPUTAS ANTIDUMPING ENCERRADAS OU EM FASE DE APELAÇÃO } \\
\hline $\begin{array}{l}\text { Dispute } \\
\text { Settlement } \\
\text { (DS): Caso }\end{array}$ & $\begin{array}{l}\text { Short title } \\
\text { "Apelido" }\end{array}$ & Nome completo & Resumo do caso & Cronológico \\
\hline & & & investigação antidumping de final de período. & \\
\hline DS264 & $\begin{array}{l}\text { US - Softwood } \\
\text { Lumber V }\end{array}$ & $\begin{array}{lr}\text { Estados Unidos } & - \\
\text { Determinação Final de } \\
\text { dumping em } & \text { Madeira } \\
\text { macia } & \text { serrada } \\
\text { proveniente } & \text { do } \\
\text { Canadár } & \\
\text { United States } & \text { Final } \\
\text { Dumping } \\
\begin{array}{l}\text { Determination } \\
\text { Softwood Lumber from } \\
\text { Canada }\end{array}\end{array}$ & $\begin{array}{l}\text { O Canadá requereu consultas com base no Artigo 4.8. do } \\
\text { ESC (procedimento de urgência) com os EUA com relação } \\
\text { a determinação final de dumping com relação a certos } \\
\text { produtos de Madeira macia cerradas provenientes do } \\
\text { Canadá. O Canadá também questionava a investigação } \\
\text { feita pelos EUA, desde sua abertura., condução até seu } \\
\text { encerramento. } \\
\text { O Painel foi estabelecido. CE, Índia e Japão reservaram } \\
\text { seus direitos como terceira parte. Após análise, foi } \\
\text { concluído que o órgão administrativo americano } \\
\text { responsável falhou em ser consistente com diversos artigos } \\
\text { do ADA devido ao uso do método de zeramento. Todos os } \\
\text { outros questionamentos canadenses foram negados pelo } \\
\text { Painel. } \\
\text { Após apelação dos EUA, o DSB manteve as decisões do } \\
\text { Painel, com exceção de: conclusão do Painel de que os } \\
\text { EUA não agiu de forma incompatível com o ADA no } \\
\text { cálculo das despesas financeiras atribuíveis à madeira } \\
\text { canadense. Os EUA afirmaram que iriam implementar as } \\
\text { recomendações do Orgão de Solução de Controvérsias. }\end{array}$ & $\begin{array}{c}\text { Pedido de consulta } \\
\text { recebido em: } 13 \text { de } \\
\text { setembro de } 2002 \\
\text { Relatório do painel } \\
\text { circulado em: } 13 \text { de abril } \\
\text { de } 2004 \\
\text { Relatório do Órgão de } \\
\text { Apelação circulado em: } 11 \\
\text { de agosto de } 2004 \\
\text { Artigo 21.3 (c)/ Painel de } \\
\text { Arbitragem: } 13 \text { de } \\
\text { dezembro de } 2004 \\
\text { Relatório do Painel do } \\
\text { 21.5 circulado em: } 03 \text { de } \\
\text { abril de } 2006 \\
\text { Relatório do Órgão de } \\
\text { Apelação do 21.5 } \\
\text { circulado em: } 15 \text { de agosto } \\
\text { de } 2006 \\
\text { Adoção pelo DSB em: } 01 \\
\text { de setembro de } 2006 \\
\text { Solução Mutuamente } \\
\text { acordada: } 12 \text { de outubro de }\end{array}$ \\
\hline
\end{tabular}




\begin{tabular}{|c|c|c|c|c|}
\hline $\begin{array}{c}\text { Dispute } \\
\text { Settlement } \\
\text { (DS): Caso }\end{array}$ & $\begin{array}{l}\text { Short title } \\
\text { "Apelido" }\end{array}$ & Nome completo & Resumo do caso & Cronológico \\
\hline & & & & 2006 \\
\hline DS244 & $\begin{array}{c}U S- \\
\text { Corrosion- } \\
\text { Resistant } \\
\text { Steel Sunset } \\
\text { Review }\end{array}$ & $\begin{array}{l}\text { Estados Unidos - } \\
\text { Revisões de final de } \\
\text { período para chapas de } \\
\text { aço carbono } \\
\text { anticorrosivo/ } \\
\text { United States - Sunset } \\
\text { Review of Anti- } \\
\text { Dumping Duties on } \\
\text { Corrosion-Resistant } \\
\text { Carbon Steel Flat } \\
\text { Products from Japan }\end{array}$ & $\begin{array}{l}\text { Japão requereu consultas com os EUA com relação a } \\
\text { determinação final do USDOC e da USITC na revisão de } \\
\text { final de período das obrigações antidumping impostas a } \\
\text { importação de chapas de aço carbono anticorrosivo do } \\
\text { Japão. O Japão alegou que as determinações estavam } \\
\text { erradas e baseadas em decisões, procedimentos e provisões } \\
\text { errôneas com relação a Lei das Tarifas de } 1930 \text { ("Tariff } \\
\text { Act de } 1930 \text { dos EUA"), conforme alterado ("the Act"), e } \\
\text { regulamentações relacionadas. A CE e Índia se juntaram às } \\
\text { consultas. } \\
\text { O painel foi estabelecido e Brasil, Canadá, Chile, CE, } \\
\text { Índia, Coréia do Sul e Noruega reservaram seus direitos } \\
\text { como terceira parte. } \\
\text { O painel rejeitou todas as alegações do Japão que } \\
\text { questionavam diversas leis americanas e regulamentos } \\
\text { sobre a condução das sunset reviews. Além disso, concluiu } \\
\text { que a determinação de dumping pela autoridade } \\
\text { administrativa americana não era incompatível com as } \\
\text { previsões da OMC. } \\
\text { Após apelação japonesa, o Órgão de Apelação concluiu } \\
\text { que os EUA realmente não agiram de modo incompatível } \\
\text { com nenhuma previsão da OMC. }\end{array}$ & $\begin{array}{c}\text { Pedido de consulta } \\
\text { recebido em: } 30 \text { de janeiro } \\
\text { de } 2002 \\
\text { Relatório do painel } \\
\text { circulado em: } 14 \text { de agosto } \\
\text { de } 2003 \\
\text { Relatório do Órgão de } \\
\text { Apelação circulado em: } 15 \\
\text { de dezembro de } 2003 \\
\text { Adoção pelo DSB em: } 09 \\
\text { de janeiro de } 2004\end{array}$ \\
\hline DS234 & $\begin{array}{l}\text { US - Offset } \\
\text { Act - Byrd }\end{array}$ & $\begin{array}{ll}\text { Estados } & \text { Unidos - } \\
\text { Dumping } & \text { e subsídios }\end{array}$ & $\begin{array}{l}\text { Canadá e México requereram consultas com os EUA } \\
\text { devido à implementação do "Tariff Act"de 2000, }\end{array}$ & $\begin{array}{l}\text { Pedido de consulta } \\
\text { recebido em: } 21 \text { de maio }\end{array}$ \\
\hline
\end{tabular}




\begin{tabular}{|c|c|c|c|c|}
\hline $\begin{array}{c}\text { Dispute } \\
\text { Settlement } \\
\text { (DS): Caso }\end{array}$ & $\begin{array}{l}\text { Short title } \\
\text { "Apelido" }\end{array}$ & Nome completo & Resumo do caso & Cronológico \\
\hline & $\begin{array}{c}\text { Amendment } \\
\text { (Canada, } \\
\text { Mexico) }\end{array}$ & $\begin{array}{l}\text { contínuos na Offset } \\
\text { Act } \text { de 2000/ } \\
\text { United States - } \\
\begin{array}{l}\text { Continued Dumping } \\
\text { and Subsidy Offset Act } \\
\text { of } 2000\end{array}\end{array}$ & $\begin{array}{l}\text { usualmente chamado de "Byrd Amendment". De acordo } \\
\text { com os demandantes, o Act é incompativel com as } \\
\text { obrigações dos EUA sob várias provisões do GATT, do } \\
\text { ADA, e do ASMC. } \\
\text { O painel foi estabelecido e Argentina, Canadá, Costa Rica, } \\
\text { Hong Kong, China, Israel, Noruega e México reservaram } \\
\text { seus direitos como terceira parte. } \\
\text { Após análise, o Painel concluiu que a normativa americana } \\
\text { era incompatível com diversos artigos do ADA e ASMC, } \\
\text { entretanto, rejeitou a alegação de que a normativa era } \\
\text { incompatível com os artigos } 8.3 \text { e } 15 \text { do ADA, artigos } \\
4.10,7.9 \text { e } 18.3 \text { do ASMC e artigo X.3 (a) do GATT } 1994 \text {. } \\
\text { Após apelação americana, o Órgão de Apelação confirmou } \\
\text { todas as conclusões do Painel, com exceção de: (i) a } \\
\text { normativa é incompatível com o artigo } 5.4 \text { do ADA e } 11.4 \\
\text { do ASMC; (ii) rejeitou a conclusão do Painel de que os } \\
\text { EUA podem não ter agido em boa fé com relação ao artigo } \\
\text { 5.4 do ADA e artigo } 11.4 \text { do ASMC. }\end{array}$ & $\begin{array}{c}\text { de } 2001 \\
\text { Relatório do painel } \\
\text { circulado em: } 16 \text { de } \\
\text { setembro de } 2002 \\
\text { Relatório do Órgão de } \\
\text { Apelação circulado em: } 16 \\
\text { de janeiro de } 2003 \\
\text { Adoção pelo DSB em: } 27 \\
\text { de janeiro de } 2003 \\
\text { Arbitragem 21.3: } 13 \text { de } \\
\text { junho de } 2003 \\
\text { Recurso ao Artigo 22.6/ } \\
\text { Relatório de arbitragem: } \\
\text { 31 de agosto de } 2004\end{array}$ \\
\hline DS219 & $\begin{array}{l}\text { EC - Tube or } \\
\text { Pipe Fittings }\end{array}$ & $\begin{array}{l}\text { Comunidades } \\
\text { Europeias - Medidas } \\
\text { antidumping contra } \\
\text { tubos maleáveis de } \\
\text { ferro fundido ou } \\
\text { acessórios para tubos/ } \\
\text { European } \\
\text { Communities - Anti- }\end{array}$ & $\begin{array}{l}\text { O Brasil requereu consultas com as Comunidades } \\
\text { Europeias sobre a definição das obrigações antidumping } \\
\text { impostas pela Regulação do Conselho Europeu No. } \\
1784 / 2000 \text { com relação a tubos maleáveis de ferro fundido } \\
\text { ou acessórios para tubos originários do Brasil. } \\
\text { O Brasil considerou que os fatos estabelecidos pela CE não } \\
\text { estavam corretos e que a avaliação dos fatos não foi } \\
\text { independente e objetiva. }\end{array}$ & $\begin{array}{l}\text { Pedido de consulta } \\
\text { recebido em: } 21 \text { de } \\
\text { dezembro de } 2000 \\
\text { Relatório do painel } \\
\text { circulado em: } 07 \text { de março } \\
\text { de } 2003 \\
\text { Relatório do Órgão de } \\
\text { Apelação circulado em: } 22\end{array}$ \\
\hline
\end{tabular}




\begin{tabular}{|c|c|c|c|c|}
\hline \multicolumn{5}{|c|}{ APÊNDICE 4 - DISPUTAS ANTIDUMPING ENCERRADAS OU EM FASE DE APELAÇÃO } \\
\hline $\begin{array}{c}\text { Dispute } \\
\text { Settlement } \\
\text { (DS): Caso }\end{array}$ & $\begin{array}{l}\text { Short title } \\
\text { “Apelido" }\end{array}$ & Nome completo & Resumo do caso & Cronológico \\
\hline & & $\begin{array}{l}\text { Dumping Duties on } \\
\text { Malleable Cast Iron } \\
\text { Tube or Pipe Fittings } \\
\text { from Brazil }\end{array}$ & $\begin{array}{l}\text { O Brasil requereu estabelecimento de painel na reunião de } \\
24 \text { de julho de } 2001 \text {. } \\
\text { O Painel foi estabelecido e Chile, Japão, México e EUA } \\
\text { reservaram seus direitos como terceira parte. } \\
\text { Após análise, o Painel concluiu que a CE agiu de forma } \\
\text { incompatível com relação ao método de zeramento, artigo } \\
2.4 .2 \text { do ADA e artigos } 12.2 \text { e 12.2.2. O painel rejeitou } \\
\text { todos os outros requerimentos brasileiros. Após apelação } \\
\text { brasileira, o Órgão de Apelação confirmou o relatório do } \\
\text { Painel, com exceção de um ponto: reverteu a decisão que } \\
\text { considerou que a CE agiu de modo consistente aos artigos } \\
6.2 \text { e } 6.4 \text {. }\end{array}$ & $\begin{array}{c}\text { de julho de } 2003 \\
\text { Adoção pelo DSB em: } 18 \\
\text { de agosto de } 2003\end{array}$ \\
\hline DS217 & $\begin{array}{c}\text { US - Offset } \\
\text { Act (Byrd } \\
\text { Amendment) }\end{array}$ & $\begin{array}{l}\text { Estados Unidos - } \\
\text { Dumping e subsídios } \\
\text { contínuos na Offset } \\
\text { Act de } 2000 / \\
\text { United States - } \\
\begin{array}{l}\text { Continued Dumping } \\
\text { and Subsidy Offset Act } \\
\text { of } 2000\end{array}\end{array}$ & $\begin{array}{l}\text { Argentina, Brasil, Chile, CE, Índia, Indonésia, Japão, } \\
\text { Coreia do Sul e Tailândia requereram consultas com os } \\
\text { EUA com relação a alteração no Tariff Act of } 1930 \\
\text { assinado em } 28 \text { de outubro de } 2000 \text {, com o título } \\
\text { "Continued Dumping and Subsidy Offset Act of } 2000 \\
\text { (CDSOA"" normalmente conhecido como "the Byrd } \\
\text { Amendment". } \\
\text { O painel foi estabelecido e Argentina, Canadá, Costa Rica, } \\
\text { Hong Kong, China, Israel, Noruega e México reservaram } \\
\text { seus direitos como terceira parte. } \\
\text { Após análise, o Painel concluiu que o "CDSOA" era } \\
\text { incompatível com diversos artigos do ADA. Após apelação } \\
\text { dos EUA, o Órgão de Apelação manteve as conclusões do } \\
\text { Painel, com exceção: (i)"CDSOA é incompatível com o }\end{array}$ & $\begin{array}{l}\text { Pedido de consulta } \\
\text { recebido em: } 21 \text { de } \\
\text { dezembro de } 2000 \\
\text { Relatório do painel } \\
\text { circulado em: } 16 \text { de } \\
\text { setembro de } 2002 \\
\text { Relatório do Órgão de } \\
\text { Apelação circulado em: } 16 \\
\text { de janeiro de } 2003 \\
\text { Adoção pelo DSB em: } 27 \\
\text { de janeiro de } 2003 \\
\text { Arbitragem 21.3: } 13 \text { de }\end{array}$ \\
\hline
\end{tabular}




\section{APÊNDICE 4 - DISPUTAS ANTIDUMPING ENCERRADAS OU EM FASE DE APELAÇÃO}

\begin{tabular}{|c|c|c|c|c|}
\hline $\begin{array}{c}\text { Dispute } \\
\text { Settlement } \\
\text { (DS): Caso }\end{array}$ & $\begin{array}{l}\text { Short title } \\
\text { "Apelido" }\end{array}$ & Nome completo & Resumo do caso & Cronológico \\
\hline & & & $\begin{array}{l}\text { artigo } 5.4 \text { do ADA e } 11.4 \text { do ASMC; (ii) rejeitou a } \\
\text { conclusão do Painel de que os EUA podem não ter agido } \\
\text { em boa fé com relação ao artigo } 5.4 \text { do ADA e artigo } 11.4 \\
\text { do ASMC. }\end{array}$ & $\begin{array}{c}\text { junho de } 2003 \\
\text { Recurso ao Artigo 22.6/ } \\
\text { Relatório de arbitragem: } \\
31 \text { de agosto de } 2004\end{array}$ \\
\hline DS184 & $\begin{array}{c}\text { US - Hot- } \\
\text { Rolled Steel }\end{array}$ & $\begin{array}{l}\text { Estados Unidos - } \\
\text { Medidas antidumping } \\
\text { contra determinados } \\
\text { produtos siderúrgicos } \\
\text { lâminados a quente/ } \\
\text { United States - Anti- } \\
\text { Dumping Measures on } \\
\text { Certain Hot-Rolled } \\
\text { Steel Products from } \\
\text { Japan }\end{array}$ & $\begin{array}{l}\text { Japão requereu consultas com os EUA com relação às } \\
\text { decisões preliminares e finais do USDOC e da USITC, na } \\
\text { investigação antidumping de determinados produtos } \\
\text { siderúrgicos laminados a quente provenientes do Japão, } \\
\text { proferidas em } 25 \text { e } 30 \text { de novembro de } 1998 \text {. } \\
\text { O Painel foi estabelecido e Brasil, Canadá, Chile, CE e } \\
\text { Coréia do Sul reservaram seus direitos como terceira } \\
\text { parte. Após análise, o Painel decidiu que os EUA agiram } \\
\text { incompatívelmente com diversos artigos ao ADA. Após } \\
\text { apelação dos EUA, o Órgão de Apelação decidiu que todas } \\
\text { as conclusões do Painel deveriam ser mantidas, com } \\
\text { exceção da conclusão do Painel relativa a: (i) } \\
\text { inconsistência americana com os artigos } 2.1 \text { do ADA; (ii) } \\
\text { provas suficientes para permitir a reclamação do Japão } \\
\text { sobre o artigo 2.4; (iii) reverteu a conclusão do Painel de } \\
\text { que os EUA não agiram de forma incompatível com o } \\
\text { ADA com relação a normas de "captive production"; (iv) } \\
\text { reverteu a conclusão do painel, afirmando que o "USITC" } \\
\text { não demonstrou nexo causal entre dumping e dano. }\end{array}$ & $\begin{array}{c}\text { Pedido de consulta } \\
\text { recebido em: } 18 \text { de } \\
\text { novembro de } 1999 \\
\text { Relatório do painel } \\
\text { circulado em: } 28 \text { de } \\
\text { fevereiro de } 2001 \\
\text { Relatório do Órgão de } \\
\text { Apelação circulado em: } 24 \\
\text { de julho de } 2001 \\
\text { Arbitragem 21.3: } 19 \text { de } \\
\text { fevereiro de } 2002 \\
\text { Adoção pelo DSB em: } 23 \\
\text { de agosto de } 2001\end{array}$ \\
\hline
\end{tabular}




\begin{tabular}{|c|c|c|c|c|}
\hline \multicolumn{5}{|c|}{ APÊNDICE 4 - DISPUTAS ANTIDUMPING ENCERRADAS OU EM FASE DE APELAÇÃO } \\
\hline $\begin{array}{l}\text { Dispute } \\
\text { Settlement } \\
\text { (DS): Caso }\end{array}$ & $\begin{array}{l}\text { Short title } \\
\text { "Apelido" }\end{array}$ & Nome completo & Resumo do caso & Cronológico \\
\hline DS162 & $\begin{array}{c}\text { US - } 1916 \text { Act } \\
\text { (Japan) }\end{array}$ & $\begin{array}{l}\text { Estados Unidos - Lei } \\
\text { Antidumping de } 1916 \\
/ \\
\text { United States - Anti- } \\
\text { Dumping Act of } 1916\end{array}$ & $\begin{array}{l}\text { O Japão requereu consultas com os EUA a respeito do } \\
\text { "Anti-Dumping Act" de 1916, ("US } 1916 \text { Act"), alegando } \\
\text { incompatibilidades da normativa com o ADA e GATT } \\
1994 . \\
\text { O painel foi estabelecido e a CE e Índia reservaram seus } \\
\text { direitos como terceira parte. Após análise o Painel } \\
\text { considerou que a Lei de Dumping de } 1916 \text { era } \\
\text { incompatível com o ADA. Após apelação de ambas as } \\
\text { partes, o Órgão de Apelação confirmou todas as conclusões } \\
\text { do Painel. }\end{array}$ & $\begin{array}{c}\text { Pedido de consulta } \\
\text { recebido em: } 10 \text { de } \\
\text { fevereiro de } 1999 \\
\text { Relatório do painel } \\
\text { circulado em: } 29 \text { de maio } \\
\text { de } 2000 \\
\text { Relatório do Órgão de } \\
\text { Apelação circulado em: } \\
28 \text { de agosto de } 2000 \\
\text { Arbitragem 21.3: } 28 \text { de } \\
\text { fevereiro de } 2001 \\
\text { Adoção pelo DSB em: } 26 \\
\text { de setembro de } 2000\end{array}$ \\
\hline DS141 & $\begin{array}{c}\text { EC - Bed } \\
\text { Linen }\end{array}$ & $\begin{array}{l}\text { Comunidades } \\
\text { Européias - Medidas } \\
\text { antidumping a } \\
\text { importação de roupa } \\
\text { de cama de algodão/ } \\
\text { EC - Anti-Dumping } \\
\text { Duties on Imports of } \\
\text { Cotton-type Bed Linen } \\
\text { from India }\end{array}$ & $\begin{array}{l}\text { A Índia requereu consultas com a CE com relação a } \\
\text { Regulação do Conselho Europeu No } 2398 / 97 \text { de } 28 \text { de } \\
\text { novembro de } 1997 \text { sobre importação de roupa de cama de } \\
\text { algodão da Índia. } \\
\text { O painel foi estabelecido e Egito, Japão e EUA reservaram } \\
\text { seus direitos como terceira parte. } \\
\text { Após análise, foi decidido que a CE não agiu de forma } \\
\text { incompatível com a maioria das obrigações do GATT } 1994 \\
\text { e ADA, entretanto, agiu de forma incompatível com os } \\
\text { artigos } 2.4 .2 \text { e } 3.4 \text { e } 15 \text { do ADA. } \\
\text { Após apelação da CE, o Órgão de Apelação confirmou que }\end{array}$ & $\begin{array}{l}\text { Pedido de consulta } \\
\text { recebido em: } 3 \text { de agosto } \\
\text { de } 1998 \\
\text { Relatório do painel } \\
\text { circulado em: } 30 \text { de } \\
\text { outubro de } 2000 \\
\text { Relatório do Órgão de } \\
\text { Apelação circulado em: } \\
\text { 01 de março de } 2001 \\
\text { Adoção pelo DSB em: } 12\end{array}$ \\
\hline
\end{tabular}




\begin{tabular}{|c|c|c|c|c|}
\hline \multicolumn{5}{|c|}{ APÊNDICE 4 - DISPUTAS ANTIDUMPING ENCERRADAS OU EM FASE DE APELAÇÃO } \\
\hline $\begin{array}{l}\text { Dispute } \\
\text { Settlement } \\
\text { (DS): Caso }\end{array}$ & $\begin{array}{l}\text { Short title } \\
\text { "Apelido" }\end{array}$ & Nome completo & Resumo do caso & Cronológico \\
\hline & & & $\begin{array}{l}\text { as conclusões do Painel a respeito do zeramento estão } \\
\text { corretas, mas reverteu as decisões que dizem respeito ao } \\
\text { Artigo 2.2.2 do ADA. }\end{array}$ & $\begin{array}{c}\text { de março de } 2001 \\
\text { Artigo 21.5/ Relatório do } \\
\text { Painel circulado em: } 29 \text { de } \\
\text { novembro de } 2002 \\
\text { Artigo 21.5/ Relatório do } \\
\text { Órgão de Apelação } \\
\text { circulado em: } 08 \text { de abril } \\
\text { de } 2003\end{array}$ \\
\hline DS136 & $\begin{array}{c}U S-1916 \text { Act } \\
(E C)\end{array}$ & $\begin{array}{l}\text { Estados Unidos - Lei } \\
\text { antidumping de 1916/ } \\
\text { United States - Anti- } \\
\text { Dumping Act of } 1916\end{array}$ & $\begin{array}{l}\text { A CE requereu consultas com os EUA devido a uma } \\
\text { alegada falha dos EUA em revogar a Lei de Dumping de } \\
1916 \text {. } \\
\text { A CE alegou violações ao GATT } 1994 \text { e ADA. } \\
\text { O painel foi estabelecido e Índia, Japão e México } \\
\text { reservaram seus direitos como terceira parte. Após análise } \\
\text { o Painel decidiu que a Lei de Dumping de } 1916 \text { violava } \\
\text { diversos artigos do GATT 1994. Após apelação dos EUA e } \\
\text { CE, o Órgão de Apelação confirmou todas as conclusões } \\
\text { do Painel. }\end{array}$ & $\begin{array}{c}\text { Pedido de consulta } \\
\text { recebido em: 04 de junho } \\
\text { de } 1998 \\
\text { Relatório do painel } \\
\text { circulado em: } 31 \text { de março } \\
\text { de } 2000 \\
\text { Relatório do Órgão de } \\
\text { Apelação circulado em: } \\
28 \text { de agosto de } 2000 \\
\text { Arbitragem do 21.3: } 28 \text { de } \\
\text { fevereiro de 2001 } \\
\text { Artigo 22.6/ Relatório do } \\
\text { Painel de Arbitragem } \\
\text { circulado em: } 24 \text { de } \\
\text { fevereiro de } 2001 \\
\text { Adoção pelo DSB em: } 26\end{array}$ \\
\hline
\end{tabular}




\begin{tabular}{|c|c|c|c|c|}
\hline $\begin{array}{c}\text { Dispute } \\
\text { Settlement } \\
\text { (DS): Caso }\end{array}$ & $\begin{array}{l}\text { Short title } \\
\text { "Apelido" }\end{array}$ & Nome completo & Resumo do caso & Cronológico \\
\hline & & & & de setembro de 2000 \\
\hline DS132 & $\begin{array}{c}\text { Mexico - } \\
\text { HFCS }\end{array}$ & $\begin{array}{l}\text { México - Investigação } \\
\text { antidumping de xarope } \\
\text { de milho de alta } \\
\text { frutose proveniente } \\
\text { dos Estados Unidos/ } \\
\text { México - Anti- } \\
\text { Dumping Investigation } \\
\text { of High-Fructose Corn } \\
\text { Syrup from the United } \\
\text { States }\end{array}$ & $\begin{array}{l}\text { Os EUA requereram consultas com o México devido à } \\
\text { investigação antidumping conduzida pelo México na } \\
\text { importação de xarope de milho de alta frutose proveniente } \\
\text { dos EUA. } \\
\text { De acordo com os EUA, o requerimento de pedido de } \\
\text { investigação continha falhas e a relação entre prática de } \\
\text { dumping e dano também não havia sido comprovada, } \\
\text { ocorrido incompatibilidades com o disposto no ADA. } \\
\text { O painel foi estabelecido. Jamaica e Ilhas Maurícius } \\
\text { reservaram seus direitos como terceira parte. Foi decidido } \\
\text { que a investigação antidumping conduzida pelo México era } \\
\text { consistente com o ADA, mas que a imposição de medidas } \\
\text { antidumping na importação do produto em questão era } \\
\text { incompatível com diversos artigos do ADA. } \\
\text { O México afirmou que necessitaria de um período de } \\
\text { tempo para implementar as recomendações do Órgão } \\
\text { Solução de Controvérsias e após publicação do resultado } \\
\text { final da investigação antidumping, os EUA recorreram ao } \\
\text { Órgão, requerendo que o Painel original verificasse a } \\
\text { implementação da recomendação. } \\
\text { O painel original foi composto e após análise, foi } \\
\text { verificado que o México falhou em implementar as } \\
\text { recomendações do Órgão de Solução de Controvérsias. O } \\
\text { México apelou contra o Relatório do Painel e após nova }\end{array}$ & $\begin{array}{c}\text { Pedido de consulta } \\
\text { recebido em: } 08 \text { de maio } \\
\text { de1998 } \\
\text { Relatório do painel } \\
\text { circulado em: } 28 \text { de janeiro } \\
\text { de } 2000 \\
\text { Adoção pelo DSB em: } 24 \\
\text { de fevereiro de } 2000 \\
\text { Relatório do painel do } \\
\text { 21.5 circulado em: } 22 \text { de } \\
\text { junho de } 2001 \\
\text { Relatório do Órgão de } \\
\text { Apelação do 21.5 } \\
\text { circulado em: } 22 \text { de } \\
\text { outubro de } 2001\end{array}$ \\
\hline
\end{tabular}




\section{APÊNDICE 4 - DISPUTAS ANTIDUMPING ENCERRADAS OU EM FASE DE APELAÇÃO}

\begin{tabular}{|c|c|c|c|c|}
\hline $\begin{array}{c}\text { Dispute } \\
\text { Settlement } \\
\text { (DS): Caso }\end{array}$ & $\begin{array}{l}\text { Short title } \\
\text { "Apelido" }\end{array}$ & Nome completo & Resumo do caso & Cronológico \\
\hline & & & análise, as conclusões do relatório foram confirmadas. & \\
\hline DS122 & $\begin{array}{c}\text { Thailand - H- } \\
\text { Beams }\end{array}$ & $\begin{array}{l}\text { Tailândia - Medidas } \\
\text { Antidumping em } \\
\text { ângulos, formas e } \\
\text { perfis de ferro e aço } \\
\text { não ligado e vigas da } \\
\text { Polônia/ } \\
\text { Thailand - Anti- } \\
\text { Dumping Duties on } \\
\text { Angles, Shapes and } \\
\text { Sections of Iron or } \\
\text { Non-Alloy Steel and H } \\
\text { Beams from Poland }\end{array}$ & $\begin{array}{l}\text { A Polônia requereu consultas com a Tailândia devido à } \\
\text { imposição de medidas antidumping na importação ângulos, } \\
\text { formas e perfis de ferro e aço não ligado e vigas. } \\
\text { Após imposição de medidas antidumping pela Tailândia, a } \\
\text { Polônia requereu a divulgação das conclusões da } \\
\text { investigação que resultou na aplicação do direito. Após } \\
\text { sucessivas tentativas sem sucesso, alega que a Tailândia } \\
\text { descumpriu o ADA. } \\
\text { O painel foi composto e a CE, Japão e EUA reservaram } \\
\text { seus direitos como terceira parte. O painel conclui que a } \\
\text { Polônia falhou em comprovar que a Tailândia agiu de } \\
\text { forma incompatível com as obrigações estabelecidas no } \\
\text { Artigo } 2^{\circ} \text { do ADA, mas afirmou que a imposição } \\
\text { tailandesa era incompatível com o artigo } 3^{\circ} \text { do ADA, o que } \\
\text { teria prejudicado a Polônia. } \\
\text { A Tailândia recorreu ao Órgão de Apelação e a decisão do } \\
\text { Painel foi mantida. }\end{array}$ & $\begin{array}{c}\text { Pedido de consulta } \\
\text { recebido em: 06 de abril de } \\
1998 \\
\text { Relatório do painel } \\
\text { circulado em: } 28 \text { de } \\
\text { setembro de } 2000 \\
\text { Relatório do Órgão de } \\
\text { Apelação circulado em: } 12 \\
\text { de março de } 2001 \\
\text { Adoção pelo DSB em: } 05 \\
\text { de abril de } 2001\end{array}$ \\
\hline
\end{tabular}




\begin{tabular}{|c|c|}
\hline \multicolumn{2}{|r|}{$\begin{array}{l}\text { ANEXO I - CONSULTA PÚBLICA: DECRETO 1602/95 } \\
\text { PORTARIA SECEX 28 DE 25/08/2011 }\end{array}$} \\
\hline \multicolumn{2}{|r|}{ Artigo $1^{\circ}$} \\
\hline $\begin{array}{l}\text { Redação } \\
\text { original }\end{array}$ & $\begin{array}{l}\text { Art. } 1^{\circ} \text { Poderão ser aplicados direitos antidumping quando a importação de produtos primários e não primários objeto de dumping cause } \\
\text { dano à indústria doméstica. } \\
\S 1^{\circ} \text { Os direitos antidumping serão aplicados de acordo com as investigaç̃̃es abertas e conduzidas segundo o disposto neste Decreto } \\
\S 2^{\circ} \text { Em cumprimento ao disposto no Parágrafo } 5 \text { do Artigo VI do GATT/1994, a importação de um produto não poderá estar sujeita, } \\
\text { simultaneamente, à aplicação de direito antidumping e de direito compensatório, de que trata o Acordo sobre Subsídios e Medidas } \\
\text { Compensatórias do GATT/1994. }\end{array}$ \\
\hline Proposta 01 & $\begin{array}{l}\text { Art. } 1^{\circ} \text { Poderão ser aplicados direitos antidumping quando a importação de produtos objeto de dumping cause dano à indústria } \\
\text { doméstica. } \\
\S 1^{\circ} \text { Os direitos antidumping serão aplicados de acordo com as investigações abertas e conduzidas segundo o disposto neste Decreto } \\
\S 2^{\circ} \text { Em cumprimento ao disposto no Parágrafo } 5 \text { do Artigo VI do GATT/1994, a importação de um produto não poderá estar sujeita, } \\
\text { simultaneamente, à aplicação de direito antidumping e de direito compensatório, de que trata o Acordo sobre Subsídios e Medidas } \\
\text { Compensatórias do GATT/1994, com o fim de compensar uma mesma situação resultante do dumping ou dos subsídios às exportações. }\end{array}$ \\
\hline \multicolumn{2}{|r|}{ Artigo $2^{\circ}$} \\
\hline $\begin{array}{l}\text { Redação } \\
\text { original }\end{array}$ & $\begin{array}{l}\text { Art. } 2^{\circ} \text { Compete aos Ministros de Estado da Indústria, do Comércio e do Turismo e da Fazenda a decisão de aplicar, mediante ato } \\
\text { conjunto, medidas antidumping provisórias ou direitos definitivos e homologar compromissos de preços, com base em parecer da } \\
\text { Secretária de Comércio Exterior - SECEX, do Ministério da Indústria, do Comércio e do Turismo, que comprove a existência de } \\
\text { dumping e de dano dele decorrente. }\end{array}$ \\
\hline Proposta 01 & $\begin{array}{l}\text { Art. } 2^{\circ} \text { - Compete à Câmara de Comércio Exterior (CAMEX) fixar direitos antidumping provisórios ou definitivos e homologar } \\
\text { compromissos de preços. }\end{array}$ \\
\hline Proposta 02 & Art. $2^{\circ}$ - Compete à Câmara de Comércio Exterior (CAMEX), com base em parecer da Secretaria de Comércio Exterior-SECEX, do \\
\hline
\end{tabular}




\begin{tabular}{|c|c|}
\hline & $\begin{array}{l}\text { Tinistério do Desenvolvimento, Indústria e Comércio Exterior, que comprove a existência de dumping e de dano dele decorrente: } \\
\text { I- Aplicar direitos antidumping definitivos } \\
\text { II- Prorrogar a vigência de direitos antidumping } \\
\text { III- Homologar compromissos de preços } \\
\text { IV- Determinar a cobrança retroativa de direitos antidumping definitivos } \\
\text { V- Determinar a extensão da aplicação de direitos antidumping em casos de existência de práticas elisivas que frustrem a } \\
\text { aplicação de tais direitos. } \\
\text { VI- Estabelecer a forma de aplicação de direitos antidumping, bem como sua alteração, caso de faça necessária; e } \\
\text { VII-Suspender a exigibilidade dos direitos provisórios, desde que o importador ofereça garantia equivalente ao valor integral da } \\
\text { obrigação e demais encargos legais, que consistirá em depósito em dinheiro ou fiança bancária. } \\
\text { VIII- Estabelecer regras de origem específicas para o produto investigado } \\
\text { Parágrafo único: Compete à Secretaria de Comércio Exterior- SECEX do Ministério do Desenvolvimento, da Indústria e do } \\
\text { Comércio Exterior-MDIC a decisão de aplicar medidas antidumping provisórias, com base em parecer da própria SECEX que } \\
\text { comprove a existência de dumping de dano dele decorrente. }\end{array}$ \\
\hline Proposta 03 & $\begin{array}{l}\text { Art. } 2^{\circ} \text {. Compete à Câmara de Comércio Exterior - CAMEX a decisão sobre a: } \\
\text { I - aplicação de direitos antidumping provisórios ou definitivos; } \\
\text { II - prorrogação de direitos antidumping; } \\
\text { III - homologação de compromissos de preços; } \\
\text { IV - cobrança de direitos antidumping retroativos; } \\
\text { V - extensão da aplicação de direitos antidumping para combater práticas elisivas que frustrem a aplicação dos direitos antidumping em } \\
\text { vigor; } \\
\text { VI - forma de aplicação de direitos antidumping; } \\
\text { VII - suspensão da exigibilidade dos direitos provisórios, na forma do art. } 3^{\circ} \text { da Lei no }{ }^{\circ} 9.019 \text {, de } 30 \text { de março de } 1995 ; \\
\text { VIII - suspensão da aplicação do direito, não homologação de compromisso de preços ou, respeitado o parágrafo único do art. } 42 \text {, } \\
\text { aplicação de direito em valor diferente do que o recomendado; e }\end{array}$ \\
\hline
\end{tabular}




\begin{tabular}{|c|c|}
\hline & $\begin{array}{l}\text { IX - regulamentação dos procedimentos de trabalho no âmbito do Grupo Técnico de Defesa Comercial - GTDC. } \\
\S 1^{\circ} \text {. As decisões da CAMEX referidas no caput deverão estar fundamentadas em parecer da Secretária de Comércio Exterior - SECEX, } \\
\text { do Ministério do Desenvolvimento, Indústria e Comércio Exterior. } \\
\S 2^{\circ} \text { As decisões referidas no inciso VIII acima apenas poderão ser tomadas em circunstâncias excepcionais, quando, mesmo havendo } \\
\text { comprovação de dumping e de dano dele decorrente, a CAMEX entender existirem razões de interesse nacional que as justifiquem. } \\
\S 3^{\circ} \text { As razões de interesse nacional referidas no } \S 2^{\circ} \text { deverão ser publicadas no ato que contenha a decisão da CAMEX. }\end{array}$ \\
\hline Proposta 04 & $\begin{array}{l}\text { Art. } 2^{\circ} \text { Compete aos Ministros de Estado que compõe a Câmara de Comércio Exterior - CAMEX, criada pelo Decreto } \mathrm{n}^{\circ} 4.732 \text {, de } 10 \\
\text { de junho de } 2003 \text {, a decisão de aplicar, mediante ato conjunto, medidas antidumping provisórias ou direitos definitivos e homologar } \\
\text { compromissos de preços, com base em parecer da Secretária de Comércio Exterior - SECEX, do Ministério do Desenvolvimento, } \\
\text { Indústria e Comércio Exterior, que comprove a existência de dumping e de dano dele decorrente. }\end{array}$ \\
\hline \multicolumn{2}{|r|}{ Artigo $3^{\circ}$} \\
\hline $\begin{array}{l}\text { Redação } \\
\text { original }\end{array}$ & Art. $3^{\circ}$ Compete à SECEX promover o processo administrativo disciplinado por este Decreto. \\
\hline Proposta 01 & $\begin{array}{l}\text { Art. } 3^{\circ} \text {. Compete à SECEX promover o processo administrativo disciplinado por este Decreto e decidir sobre: } \\
\text { I - abertura de investigação antidumping, inclusive de ofício; } \\
\text { II - encerramento da investigação sem aplicação de medidas; } \\
\text { III - prorrogação do prazo de investigação; } \\
\text { IV - arquivamento do processo a pedido do peticionário; e } \\
\text { V - início, inclusive de ofício, de procedimento de revisão do direito definitivo ou de compromisso de preços. }\end{array}$ \\
\hline \multicolumn{2}{|r|}{ Artigo $4^{\circ}$} \\
\hline $\begin{array}{l}\text { Redação } \\
\text { original }\end{array}$ & $\begin{array}{l}\text { Art. } 4^{\circ} \text { Para os efeitos deste Decreto, considera-se prática de dumping a introdução de um bem no mercado doméstico, inclusive sob as } \\
\text { modalidades de drawback, a preço de exportação inferior ao valor normal. }\end{array}$ \\
\hline Proposta 01 & Art. $4^{\circ}$ Para os efeitos deste Decreto, considera-se prática de dumping a introdução de um bem no mercado brasileiro, inclusive sob as \\
\hline
\end{tabular}




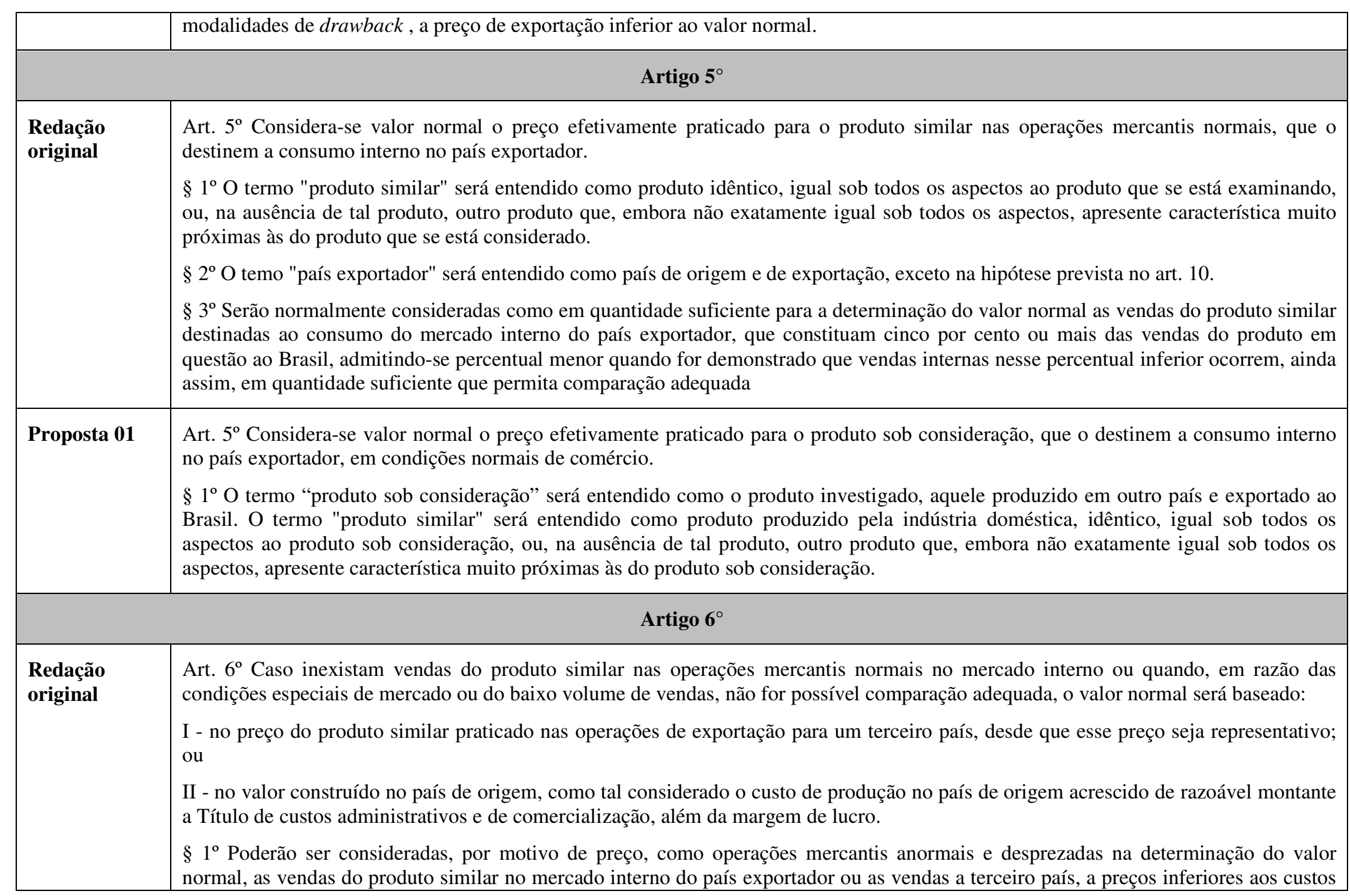




\begin{tabular}{|c|c|}
\hline & $\begin{array}{l}\text { unitários do produto similar, neles computados os custos de produção, fixos e variáveis, mais os administrativos e de comercialização. } \\
\S 2^{\circ} \text { O disposto no parágrafo anterior aplicar-se-á somente quando se apurar que as vendas são realizadas: } \\
\text { a) ao longo de um período dilatado, normalmente de um ano, mais nunca inferior a seis meses; } \\
\text { b) em quantidades substanciais, como tal consideradas as transações levadas em conta para a determinação do valor normal, realizadas } \\
\text { a preço médio ponderado de vendas inferior ao custo unitário médio ponderado, ou um volume de vendas abaixo do custo unitário } \\
\text { correspondente a vinte por cento ou mais do volume vendido nas transações consideradas para a determinação do valor normal; e } \\
\text { c) a preços que não permitam cobrir todos os custos dentro de período razoável. } \\
\text { (...) }\end{array}$ \\
\hline Proposta 01 & $\begin{array}{l}\text { (...) } \S 2^{\circ} \text { - O disposto no parágrafo anterior aplicar-se-á somente quando se apurar que as vendas são realizadas: } \\
\text { a) ao longo de um período dilatado, normalmente de um ano, mais nunca inferior a seis meses; } \\
\text { b) em quantidades substanciais, como tal consideradas as transações levadas em conta para a determinação do valor normal, } \\
\text { realizadas a preço médio ponderado de vendas inferior ao custo unitário médio ponderado em base anual, trimestral, ou mensal, } \\
\text { ou um volume de vendas abaixo do custo unitário em base anual, trimestral, ou mensal correspondente a vinte por cento ou mais } \\
\text { do volume vendido nas transações consideradas para a determinação do valor normal; } \\
\text { c) em havendo vendas de distintos tipos ou categorias do produto similar no mercado interno do país exportador ou nas vendas a } \\
\text { terceiro país, os testes indicados na alínea acima deverão ser realizados por tipo ou categoria de produto, e } \\
\text { d)a preços que não permitam cobrir todos os custos dentro de período razoável. } \\
\text { OBS: modificar no } \S 3^{\circ} \text { a letra "C" pela letra "D" }\end{array}$ \\
\hline Proposta 02 & $\begin{array}{l}\text { rt. } 6^{\circ} \text { Caso inexistam vendas do produto similar nas operações mercantis normais no mercado interno ou quando, em razão das } \\
\text { ondiçôes especiais de mercado ou do baixo volume de vendas, conforme estabelecido no } \$ 3^{\circ} \text { do artigo } 5^{\circ} \text {, não for possível comparação } \\
\text { lequada, o valor normal será baseado: (...) }\end{array}$ \\
\hline Proposta 03 & $\begin{array}{l}\text { Art. } 6^{\circ} \text { Caso inexistam vendas do produto sob consideração, em condições normais de comércio no mercado interno do país exportador } \\
\text { ou quando em razão das condições especiais de mercado ou do baixo volume de vendas no mercado interno do país exportador, não for } \\
\text { posśvel comparação adequada, o valor normal será apurado a partir: } \\
\text { I - do preço do produto sob consideração praticado nas operações de exportação para um terceiro país, desde que esse preço seja } \\
\text { representativo; ou }\end{array}$ \\
\hline
\end{tabular}




\begin{tabular}{|c|c|}
\hline & $\begin{array}{l}\text { II - do valor construído no país de origem, como tal considerado o custo de produção no país de origem, acrescido de razoável montante } \\
\text { a título de custos administrativos, de vendas e custos gerais, além da margem de lucro. } \\
\S 1^{\circ} \text { Poderão ser consideradas, por motivo de preço, como operaçães mercantis anormais e desprezadas na determinação do valor } \\
\text { normal, as vendas do produto sob consideração no mercado interno do país exportador ou as vendas a terceiro país, a preços inferiores } \\
\text { aos custos unitários do produto sob consideração, neles computados os custos de produçã̃o, fixos e variáveis, mais os administrativos e } \\
\text { de comercialização. } \\
\S 2^{\circ} \text { O disposto no parágrafo anterior será aplicado somente quando se apurar que as vendas são realizadas: }\end{array}$ \\
\hline \multicolumn{2}{|r|}{ Artigo $7^{\circ}$} \\
\hline $\begin{array}{l}\text { Redação } \\
\text { original }\end{array}$ & $\begin{array}{l}\text { Art. } 7^{\circ} \text { Encontrando-se dificuldades na determinação do preço comparável no caso de importações originárias de país que não seja } \\
\text { predominantemente de economia de mercado, onde os preços domésticos sejam em sua maioria fixados pelo Estado, o valor normal } \\
\text { poderá ser determinado com base no preço praticado ou no valor construído do produto similar, em um terceiro país de economia de } \\
\text { mercado, ou no preço praticado por este país na exportação para outros países, exclusive o Brasil, ou, sempre que isto não seja possível, } \\
\text { com base em qualquer outro preço razoável, inclusive o preço pago ou a pagar pelo produto similar no mercado brasileiro, devidamente } \\
\text { ajustado, se necessário, a fim de incluir margem de lucro razoável. } \\
\S 1^{\circ} \text { A escolha do terceiro país de economia de mercado adequado levará em conta quaisquer informaçães fiáveis apresentadas no } \\
\text { momento da seleção. } \\
\S 2^{\circ} \text { Serão levados em conta os prazos da investigação e, sempre que adequado, recorrer-se-á a um terceiro país de economia de } \\
\text { mercado que seja objeto da mesma investigação. } \\
\S 3^{\circ} \text { As partes interessadas serão informadas, imediatamente após a abertura da investigação, do terceiro país de economia de mercado } \\
\text { que se pretende utilizar, e poderão se manifestar no prazo fixado para o restituição dos respectivos questionários, de que trata o caput do } \\
\text { art. 27. }\end{array}$ \\
\hline Proposta 01 & $\begin{array}{l}\text { Art. } 7^{\circ} \text { - No caso de importações originárias de país que não seja predominantemente de economia de mercado, onde os preços } \\
\text { domésticos sejam em sua maioria fixados pelo Estado, o valor normal poderá ser determinado com base no preço praticado ou no valor } \\
\text { construído do produto similar, em um terceiro país de economia de mercado, ou no preço praticado por este país na exportação para } \\
\text { outros países, exclusive o Brasil. } \\
\S 1^{\circ} \text { - A escolha do terceiro país de economia de mercado adequado levará em conta quaisquer informações fiáveis apresentadas no } \\
\text { momento da seleção e ao longo do processo de investigação, sendo levados em consideração, dentre outros fatores, a produção (volume, } \\
\text { rota de produção, etc.), o produto, o mercado e os indicadores econômicos, que devem ser comparáveis aos do país que não seja } \\
\text { predominantemente de economia de mercado. }\end{array}$ \\
\hline
\end{tabular}




\begin{tabular}{|c|c|}
\hline & 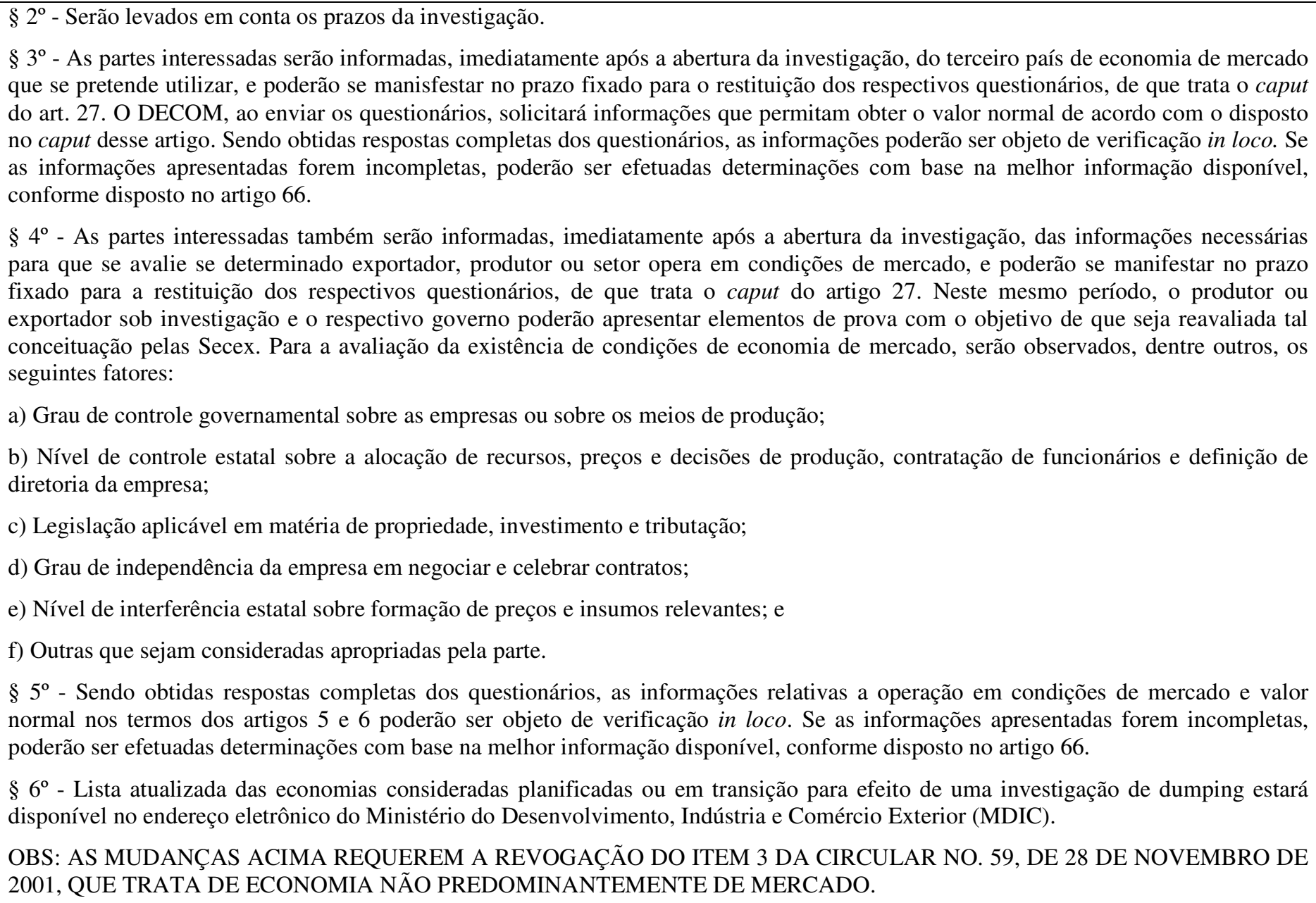 \\
\hline Proposta 02 & $\begin{array}{l}\text { Art. } 7^{\circ} \text { Encontrando-se dificuldades na determinação do preço comparável no caso de importações originárias de país que não seja } \\
\text { predominantemente de economia de mercado, onde os preços domésticos sejam em sua maioria fixados pelo Estado, o valor normal }\end{array}$ \\
\hline
\end{tabular}




\begin{tabular}{|c|c|}
\hline & $\begin{array}{l}\text { poderá ser determinado com base nas seguintes alternativas: } \\
\text { a) no preço praticado do produto sob consideração, em um terceiro país de economia de mercado,; ou } \\
\text { b) no valor construído do produto sob consideração, em um terceiro país de economia de mercado; ou } \\
\text { c) no preço praticado pelo país exportador do produto sob consideração para outros países, exclusive o Brasil, ou, sempre que isto não } \\
\text { seja possível, } \\
\text { d) com base em qualquer outro preço razoável, inclusive o preço pago ou a pagar pelo produto similar no mercado brasileiro, } \\
\text { devidamente ajustado, se necessário, a fim de incluir margem de lucro razoável. (...) } \\
\S 4^{\circ} \text { A decisão final a respeito da definição do terceiro país de economia de mercado a ser utilizado na investigação em questão será } \\
\text { emitida pelo DECOM em até } 90 \text { (noventa dias) da abertura da investigação. }\end{array}$ \\
\hline Proposta 03 & 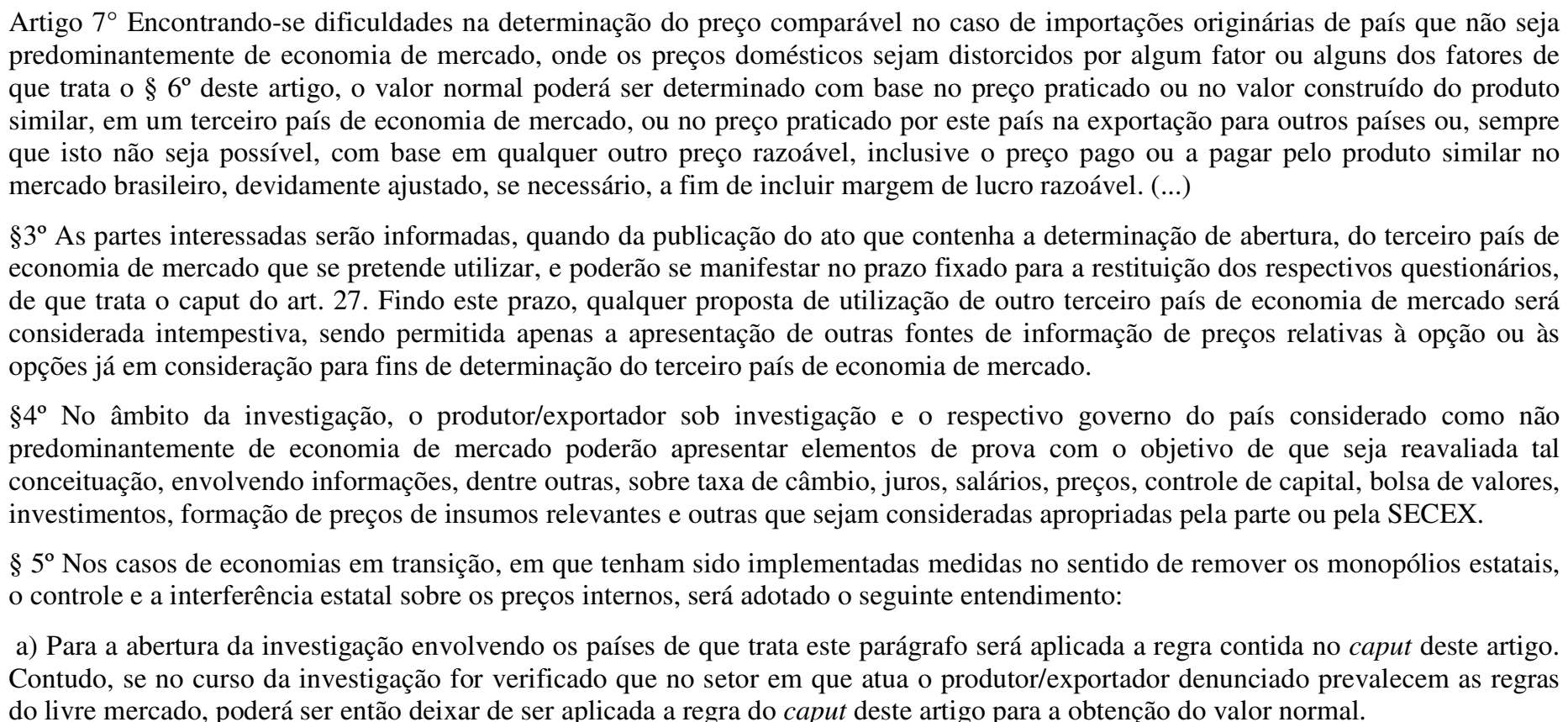 \\
\hline
\end{tabular}




\begin{tabular}{|c|c|}
\hline & $\begin{array}{l}\text { b) O DECOM, ao enviar os questionários, solicitará informações que permitam obter o valor normal e o preço de exportação, de acordo } \\
\text { com o disposto nos artigos } 50 \text { o } 60 \text { deste Decreto. Sendo obtidas respostas completas dos questionários, as informaçães poderão ser } \\
\text { objeto de verificação in loco, consoante o disposto no artigo } 30 \text { deste Decreto. Se as informações apresentadas forem incompletas, } \\
\text { poderão ser efetuadas determinaçães com base na melhor informação disponível, conforme artigo } 66 \text { deste Decreto. } \\
\text { c) Se a qualquer tempo da investigação o Departamento de Defesa Comercial-DECOM concluir que no setor em que o } \\
\text { produtor/exportador sob investigação atua não prevalecem as regras do livre mercado, será então aplicada a regra do caput deste artigo } \\
\text { para a obtenção do valor normal. Neste sentido, poderão ser solicitadas informaç̃̃es sobre o preço praticado ou o valor construído em } \\
\text { um terceiro país de economia de mercado, para a eventualidade de vir a ser utilizada a regra do caput deste artigo. } \\
\S 6^{\circ} \text { Para avaliação da existência de condições de economia de mercado, serão observados, entre outros, os seguintes fatores: } \\
\text { a) grau de controle governamental sobre as empresas ou sobre os meios de produção; } \\
\text { b) nível de controle estatal sobre a alocação de recursos, sobre preços e decisões de produção de empresas; } \\
\text { c) legislação aplicável em matéria de propriedade, investimento, tributação e falência; } \\
\text { d) grau em que os salários são determinados livremente em negociações entre empregadores e empregados; }\end{array}$ \\
\hline Proposta 04 & $\begin{array}{l}\text { (...) acrescentar: } \\
\text { § } 7^{\circ} \text { A lista de quais países se enquadram na categoria de país considerado como não predominantemente de economia de mercado e na } \\
\text { categoria de países em transição será objeto de ato publicado no Diário Oficial da União. Da mesma forma, qualquer caso de alteração } \\
\text { no status dos países de que tratam este parágrafo será publicado no Diário Oficial da União ato que contenha tal determinação, em que } \\
\text { deverão constar as razões para a alteração citada. }\end{array}$ \\
\hline Proposta 05 & $\begin{array}{l}\text { Art. } 7^{\circ} \text {. Encontrando-se dificuldades na determinação do preço comparável no caso de importações originárias de país que não seja } \\
\text { predominantemente de economia de mercado, o valor normal poderá ser determinado com base no preço praticado ou no valor } \\
\text { construído do produto similar, em um terceiro país de economia de mercado, ou no preço praticado por este país na exportação para } \\
\text { outros países, inclusive o Brasil, ou, sempre que isto não seja possível, com base em qualquer outro preço razoável, inclusive o preço } \\
\text { pago ou a pagar pelo produto similar no mercado brasileiro, devidamente ajustado, se necessário, a fim de incluir margem de lucro } \\
\text { razoável. } \\
\S 1^{\circ} \text { Considera-se país que não seja predominantemente de economia de mercado aquele onde, segundo determinação da autoridade } \\
\text { investigadora, não prevaleçam condições de livre mercado e que, portanto, os preços domésticos sejam significativamente fixados pelo } \\
\text { Estado ou não reflitam o real valor do produto. } \\
\S 2^{\circ} \text { A escolha do terceiro país de economia de mercado adequado levará em conta quaisquer informações fiáveis e razoavelmente }\end{array}$ \\
\hline
\end{tabular}




\begin{tabular}{|c|c|}
\hline & $\begin{array}{l}\text { disponíveis às partes, apresentadas no momento da seleção. } \\
\S 3^{\circ} \text { Serão levados em conta os prazos da investigação e, sempre que adequado, recorrer-se-á a um terceiro país de economia de mercado } \\
\text { que seja objeto da mesma investigação. } \\
\S^{\circ} \text { As partes interessadas serão informadas, imediatamente após a abertura da investigação, do terceiro país de economia de mercado } \\
\text { que se pretende utilizar, e poderão se manifestar no prazo de vinte dias. }\end{array}$ \\
\hline & Artigo $8^{\circ}$ \\
\hline $\begin{array}{l}\text { Redação } \\
\text { Original }\end{array}$ & $\begin{array}{l}\text { Art. } 8^{\circ} \text { O preço de exportação será o preço efetivamente pago ou a pagar pelo produto exportado ao Brasil, livre de impostos, descontos } \\
\text { e produções efetivamente concedidos e diretamente relacionados com as vendas de que se trate. } \\
\text { Parágrafo único. Nos casos em que não exista preço de exportação ou que este pareça duvidoso, por motivo de associação ou acordo } \\
\text { compensatório entre o exportador e o importador ou uma terceira parte, o preço de exportação poderá ser construído a partir: } \\
\text { a) do preço pelo qual os produtos importados foram revendidos pela primeira vez a um comprador independente; ou } \\
\text { b) de uma base razoável, no caso de os produtos não serem revendidos a comprador independente, ou não serem revendidos na mesma } \\
\text { condição em que foram importados. }\end{array}$ \\
\hline Proposta 01 & $\begin{array}{l}\text { Art. } 8^{\circ} \text { - O preço de exportação será o preço efetivamente pago ou a pagar pelo produto exportado ao Brasil, livre de impostos, } \\
\text { descontos e produções efetivamente concedidos e diretamente relacionados com as vendas de que se trate. } \\
\S 1^{\circ} \text { Nos casos em que não exista preço de exportação ou que este pareça duvidoso, por motivo de associação ou acordo compensatório } \\
\text { entre o exportador e o importador ou uma terceira parte, o preço de exportação poderá ser construído a partir: } \\
\text { a) do preço pelo qual os produtos importados foram revendidos pela primeira vez a um comprador independente; ou } \\
\text { b) de uma base razoável, no caso de os produtos não serem revendidos a comprador independente, ou não serem revendidos na mesma } \\
\text { condição em que foram importados. } \\
\S 2^{\circ} \text { - No caso de importaçães originárias de país que não seja predominantemente de economia de mercado, tendo o produtor e/ou } \\
\text { exportador participado da investigação e cooperado com a autoridade, o seu preço de exportação ao Brasil será utilizado para fins de } \\
\text { cálculo da margem individual de dumping. Para a utilização dos efetivos preços de exportação ao Brasil, poderão ser solicitadas } \\
\text { informações adicionais ou esclarecimentos sobre o grau de controle governamental, e de independência do produtor ou exportador com } \\
\text { relação a outras empresas controladas pelo governo, no que se refere à determinação de preços de exportação, inexistência de restrições } \\
\text { a exportações, e decisões quanto a receitas de exportação. Referidas informaçôes poderão ser objeto de verificação in loco. Se as } \\
\text { informaçôes apresentadas forem incompletas, poderão ser efetuadas determinações com base na melhor informação disponível, }\end{array}$ \\
\hline
\end{tabular}




\begin{tabular}{|c|c|}
\hline & conforme disposto no artigo 66. \\
\hline Proposta 02 & $\begin{array}{l}\text { Art. } 8^{\circ} \mathrm{O} \text { preço de exportação será o preço efetivamente pago ou a pagar pelo produto sob consideração exportado ao Brasil, livre de } \\
\text { impostos e, descontos e produções efetivamente concedidos e diretamente relacionados com as vendas de que se trate sob investigação. }\end{array}$ \\
\hline \multicolumn{2}{|r|}{ Artigo $9^{\circ}$} \\
\hline $\begin{array}{l}\text { Redação } \\
\text { Original }\end{array}$ & $\begin{array}{l}\text { Art. } 9^{\circ} \text { Será efetuada comparação justa entre o preço de exportação e o valor normal, no mesmo nível de comércio, normalmente o ex } \\
\text { fabrica, considerando as vendas realizadas tão simultaneamente quanto possível. As partes interessadas, como definidas no } \S 3^{\circ} \text { do art. } \\
21 \text {, serão comunicadas do tipo de informação necessária para assegurar comparação justa, não lhes sendo exigido excessivo ônus de } \\
\text { prova. } \\
\S 1^{\circ} \text { Serão examinadas, para fins de ajuste, caso a caso, de acordo com sua especificidade, diferenças que afetem comparação de preços, } \\
\text { entre elas diferenças nas condições e nos termos de venda, tributação, níveis de comércio, quantidades, características físicas e } \\
\text { quaisquer outras que comprovadamente afetem a comparação de preços. Quando alguns desses fatores incidirem, cumulativamente, } \\
\text { evitar-se-á a duplicação de ajustes que já tenham sido efetuados. } \\
\text { (...) }\end{array}$ \\
\hline Proposta 01 & $\begin{array}{l}\S 1^{\circ} \text { - Serão examinadas, para fins de ajuste, caso a caso, de acordo com sua especificidade, diferenças que afetem comparação de } \\
\text { preços, entre elas diferenças nas condições e nos termos de venda, tributação, níveis de comércio, quantidades, características físicas e } \\
\text { quaisquer outras que comprovadamente afetem a comparação de preços durante o período de investigação ou em períodos menores. } \\
\text { Quando alguns desses fatores incidirem, cumulativamente, evitar-se-á a duplicaçãa de ajustes que já tenham sido efetuados. }\end{array}$ \\
\hline Proposta 02 & $\begin{array}{l}\text { Art. } 9^{\circ} \text { Será efetuada comparação justa entre o preço de exportação e o valor normal, no mesmo nível de comércio, normalmente o ex } \\
\text { fabrica considerando as vendas realizadas tão simultaneamente quanto possível. As partes interessadas, como definidas no } \$ 3^{\circ} \text { do art. } \\
21 \text {, serão comunicadas do tipo de informação necessária para assegurar comparação justa, não lhes sendo exigido excessivo ônus de } \\
\text { prova. Tal comunicação deverá preceder a realização da verificação "in loco". } \\
\S 1^{\circ} \text { Serão examinadas, para fins de ajuste, caso a caso, de acordo com sua especificidade, diferenças que afetem comparação de preços, } \\
\text { entre elas diferenças nas condições e nos termos de venda, tributação, níveis de comércio, quantidades, caracterínticas físicas e } \\
\text { quaisquer outras que comprovadamente afetem a comparação de preços. Quando alguns desses fatores incidirem, cumulativamente, } \\
\text { evitar-se-á a duplicação de ajustes que já tenham sido efetuados. O DECOM poderá realizar em separado comparaçôes entre grupos de } \\
\text { vendas em condições semelhantes, apurando-se posteriormente a margem ponderada dumping. }\end{array}$ \\
\hline & Artigo $10^{\circ}$ \\
\hline
\end{tabular}




\begin{tabular}{|c|c|}
\hline $\begin{array}{l}\text { Redação } \\
\text { Original }\end{array}$ & $\begin{array}{l}\text { Art. 10. Na hipótese de um produto não ser importado diretamente de seu país de origem, mas exportado ao Brasil a partir de terceiro } \\
\text { país intermediário, as disposições deste Decreto serão também aplicáveis e o preço pelo qual o produto é vendido a partir do país de } \\
\text { exportação ao Brasil será comparado com o preço comparável praticado no país de exportação. } \\
\text { Parágrafo único. Poder-se-á efetuar a comparação com o preço praticado no país de origem se: } \\
\text { a) ocorrer mero trânsito do produto no país exportador; } \\
\text { b) o produto não for produzido no país exportador; ou } \\
\text { c) não houver preço comparável para o produto no país exportador. }\end{array}$ \\
\hline Proposta 01 & $\begin{array}{l}\text { Art. } 10 \text { - Na hipótese de um produto não ser importado diretamente de seu país de origem, mas exportado ao Brasil a partir de terceiro } \\
\text { país intermediário, as disposiç̃es deste Decreto serão também aplicáveis e o preço pelo qual o produto é vendido a partir do país de } \\
\text { exportação ao Brasil será comparado com o preço comparável praticado no país de exportação. } \\
\S 1^{\circ} \text { Poder-se-á efetuar a comparação com o preço praticado no país de origem se: } \\
\text { a) ocorrer mero trânsito do produto no país exportador; } \\
\text { b) o produto não for produzido no país exportador; ou } \\
\text { c) não houver preço comparável para o produto no país exportador. } \\
\S 2^{\circ} \text { - A determinação de origem basear-se-á nas regaras de origem não preferências em vigor ao tempo da exportação do produto objeto } \\
\text { de investigação no Brasil. }\end{array}$ \\
\hline Proposta 02 & $\begin{array}{l}\text { Art. } 10 \text { - Na hipótese de um produto não ser diretamente de seu país de origem, mas exportado ao Brasil a partir de terceiro país } \\
\text { intermediário, as disposições deste Decreto serão também aplicáveis e o preço pelo qual o produto é vendido a partir do país de } \\
\text { exportação ao Brasil será comparado com o preço comparável praticado no mercado interno do país de exportação (valor normal). } \\
\text { Parágrafo único. Poder-se-á efetuar a comparação com o preço praticado no país de origem se: } \\
\text { a) ocorrer mero trânsito do produto no país exportador; } \\
\text { b) o produto não for produzido no país exportador, observadas as regras de origem aplicáveis; ou } \\
\text { c) não houver preço comparável para o produto no país exportador. }\end{array}$ \\
\hline & \\
\hline
\end{tabular}




\begin{tabular}{|c|c|}
\hline $\begin{array}{l}\text { Redação } \\
\text { Original }\end{array}$ & $\begin{array}{l}\text { Art. 12. A existência de margens de dumping será determinada com base em comparação entre: } \\
\text { I - o valor normal médio ponderado e a média ponderada dos preços de todas as transações comparáveis de exportação; ou } \\
\text { II - o valor normal e os preços de exportação apurados em cada transação. } \\
\S 1^{\circ} \text { Um valor normal, estabelecido por meio de média ponderada, poderá ser comparado com os preços de transações específicas de } \\
\text { exportação, no caso de se encontrar um padrão de preços de exportação que difira significativamente entre diversos compradores, } \\
\text { regiões ou períodos de tempo e se for apresentada explicação sobre a razão de tais diferenças não poderem ser consideradas, } \\
\text { adequadamente, por meio de comparação entre médias ponderadas ou transação a transação. } \\
\S 2^{\circ} \text { Poderão ser aplicadas técnicas de amostragem para estabelecer o valor normal e os preços de exportação, mediante a utilização dos } \\
\text { preços que apareçam com maior freqüência ou que sejam os mais representativos, desde que compreendam volume significativo das } \\
\text { transações sob exame. }\end{array}$ \\
\hline Proposta 01 & $\begin{array}{l}\text { Art. } 12 \text { - A existência de margens de dumping será determinada com base em comparação entre: } \\
\text { I - o valor normal médio ponderado e a média ponderada dos preços de todas as transações comparáveis de exportação; ou } \\
\S 1^{\circ} \text { - A comparação poderá ser feita em base anual, trimestral, ou mensal, levando-se em consideração as variações de preço e em cada } \\
\text { mercado e o momento em que as condições de venda foram estabelecidas. } \\
\text { II - o valor normal e os preços de exportação apurados em cada transação. } \\
\S 1^{\circ} \text { - A comparação poderá ser feita em base anual, trimestral, ou mensal, levando-se em consideração as variações de preço e em cada } \\
\text { mercado e o momento em que as condições de venda foram estabelecidas. } \\
\S 2^{\circ} \text { - Dar-se-á ciência às partes interessadas, previamente à determinação preliminar, sobre a intenção de se utilizar este método de } \\
\text { comparação, sendo as partes comunicadas do tipo de informação necessária para assegurar comparaça justa, não lhes sendo exigido } \\
\text { excessivo ônus de prova, nos termos do artigo } 9^{\circ} \text {. O volume de vendas no mercado interno do país exportador deverá ser equivalente a, } \\
\text { no mínimo, } 5 \% \text { do volume exportado ao Brasil. } \\
\S 3^{\circ} \text { - Um valor normal, estabelecido por meio de média ponderada, poderá ser comparado com os preços de transações específicas de } \\
\text { exportação, no caso de se encontrar um padrão de preços de exportação que difira significativamente entre diversos compradores, } \\
\text { regiões ou períodos de tempo e se for apresentada explicação sobre a razão de tais diferenças não poderem ser consideradas, } \\
\text { adequadamente, por meio de comparação entre médias ponderadas ou transação a transação. } \\
\S 4^{\circ} \text { - Poderão ser aplicadas técnicas de amostragem para estabelecer o valor normal e os preços de exportação, mediante a utilização } \\
\text { dos preços que apareçam com maior frequiência ou que sejam os mais representativos, desde que compreendam volume significativo } \\
\text { das transações sob exame, observado o efeito que o volume ou outros fatores possam ter sobre a comparabilidade entre o valor normal e }\end{array}$ \\
\hline
\end{tabular}




\begin{tabular}{|c|c|}
\hline & o preço de exportação. \\
\hline \multicolumn{2}{|r|}{ Artigo $13^{\circ}$} \\
\hline $\begin{array}{l}\text { Redação } \\
\text { Original }\end{array}$ & $\begin{array}{l}\text { Art. 13. Constituirá regra geral a determinação de margem individual de dumping para cada um dos conhecidos exportadores ou } \\
\text { produtores do produto sob investigação. } \\
\S 1^{\circ} \text { No caso em que o número de exportadores, produtores, importadores conhecidos ou tipos de produtos sob investigação seja de tal } \\
\text { sorte expressivo que torne impraticável a determinação referida no parágrafo anterior, o exame poderá se limitar: } \\
\text { a) a um número razoável de partes interessadas ou produtos, por meio de amostragem estatisticamente válida com base nas informações } \\
\text { disponíveis no momento da seleção; ou } \\
\text { b) ao maior percentual razoavelmente investigável do volume de exportações do país em questão. } \\
\S 2^{\circ} \text { Qualquer seleção de exportadores, produtores, importadores ou tipos de produtos, que se faça conforme o disposto no parágrafo } \\
\text { anterior, será efetuada após terem sido consultados os exportadores, produtores ou importadores e obtida a sua anuência, desde que } \\
\text { tenham fornecido informações necessárias para seleção de amostra representativa. } \\
\S 3^{\circ} \text { Caso uma ou várias das empresas selecionadas não forneçam as informações solicitadas uma outra seleção será feita. Caso não haja } \\
\text { tempo hábil para uma nova seleção ou as novas empresas selecionadas igualmente não forneçam as informações solicitadas, as } \\
\text { determinações ou decisões se basearão na melhor informação disponível, conforme o disposto no art. 66. } \\
\S 4^{\circ} \text { Será, também, determinada a margem individual de dumping para cada exportador ou produtor que não tenha sido incluído na } \\
\text { seleção, mas que venha a apresentar a necessária informaçãa a tempo de que esta seja considerada durante o processo de investigação, } \\
\text { com exceção das situações em que o número de exportadores ou produtores seja de tal sorte expressivo que a análise de casos } \\
\text { individuais resulte em sobrecarga despropositada e impeça a conclusão da investigação dentro dos prazos prescritos. Não serão } \\
\text { desencorajadas as repostas voluntárias. }\end{array}$ \\
\hline Proposta 01 & $\begin{array}{l}\text { Art. } 13 \text { - Constituirá regra geral a determinação de margem individual de dumping para cada um dos conhecidos exportadores ou } \\
\text { produtores do produto sob investigação, inclusive para aqueles de países que sejam de economia não predominantemente de mercado. } \\
\text { (...) } \\
\S 4^{\circ} \text { - Será, também, determinada a margem individual de dumping para cada exportador ou produtor que não tenha sido incluído na } \\
\text { seleção, mas que venha a apresentar a necessária informação a tempo de que esta seja considerada durante o processo de investigação, } \\
\text { com exceção das situações em que o número de exportadores ou produtores seja de tal sorte expressivo que a análise de casos } \\
\text { individuais resulte em sobrecarga despropositada e impeça a conclusão da investigação dentro dos prazos prescritos. Não serão } \\
\text { desencorajadas as respostas voluntárias. A critério da autoridade investigadora, a margem individual de dumping para cada exportador } \\
\text { ou produtor que não tenha sido incluído na seleçãao poderá ser calculada com base na margem reportada pelo próprio exportador ou }\end{array}$ \\
\hline
\end{tabular}




\begin{tabular}{|c|c|}
\hline & produtor, ou na média ponderada das margens dos exportadores selecionados. \\
\hline Proposta 02 & $\begin{array}{l}\text { Art. 13. Constituirá regra geral a determinação de margem individual de dumping para cada um dos conhecidos exportadores ou } \\
\text { produtores do produto sob investigação. } \\
\S 1^{\circ} \text { No caso em que o número de exportadores, produtores, importadores conhecidos ou tipos de produtos sob investigação seja de tal } \\
\text { sorte expressivo que torne impraticável a determinação referida no parágrafo anterior, o exame poderá se limitar: } \\
\text { a) a um número razoável de partes interessadas ou produtos, por meio de amostragem estatisticamente válida com base nas informações } \\
\text { disponíveis no momento da seleção; ou } \\
\text { b) ao maior percentual razoavelmente investigável do volume de exportações do país em questão. } \\
\S 2^{\circ} \text { Qualquer seleção de exportadores, produtores, importadores ou tipos de produtos, que se faça conforme o disposto no parágrafo } \\
\text { anterior, será efetuada após terem sido consultados os exportadores, produtores ou importadores e obtida a sua anuência, desde que } \\
\text { tenham fornecido informações necessárias para seleção de amostra representativa. } \\
\S 3^{\circ} \text { Caso uma ou várias das empresas selecionadas não forneçam as informações solicitadas uma outra seleção será feita. Caso não haja } \\
\text { tempo hábil para uma nova seleção ou as novas empresas selecionadas igualmente não forneçam as informações solicitadas, as } \\
\text { determinações ou decisões se basearão na melhor informação disponível, conforme o disposto no art. 66. } \\
\S 4^{\circ} \text { Será, também, determinada a margem individual de dumping para cada exportador ou produtor que não tenha sido incluído na } \\
\text { seleção, mas que venha a apresentar a necessária informação a tempo de que esta seja considerada durante o processo de investigação, } \\
\text { com exceção das situaç̃̃es em que o número de exportadores ou produtores seja de tal sorte expressivo que a análise de casos } \\
\text { individuais resulte em sobrecarga despropositada e impeça a conclusão da investigação dentro dos prazos prescritos. Não serão } \\
\text { desencorajadas as repostas voluntárias. }\end{array}$ \\
\hline & Artigo 14 \\
\hline $\begin{array}{l}\text { Redação } \\
\text { original }\end{array}$ & $\begin{array}{l}\text { Art. 14. Para os efeitos deste Decreto, o termo "dano" será entendido como dano material ou ameaça de dano material à indústria } \\
\text { doméstica já estabelecida ou retardamento sensível na implantação de tal indústria. } \\
\S 1^{\circ} \text { A determinação de dano será baseada em provas positivas e incluirá exame objetivo } \\
\text { a) volume das importações objeto de dumping; } \\
\text { b) seu efeito sobre os preços do produto similar no Brasil ;e } \\
\text { c) consequente impacto de tais importações sobre a indústria doméstica. } \\
\S 2^{\circ} \text { No tocante ao volume das importações objeto de dumping, levar-se-á em conta se este não é insignificante e se houve aumento }\end{array}$ \\
\hline
\end{tabular}




\begin{tabular}{|c|c|}
\hline & 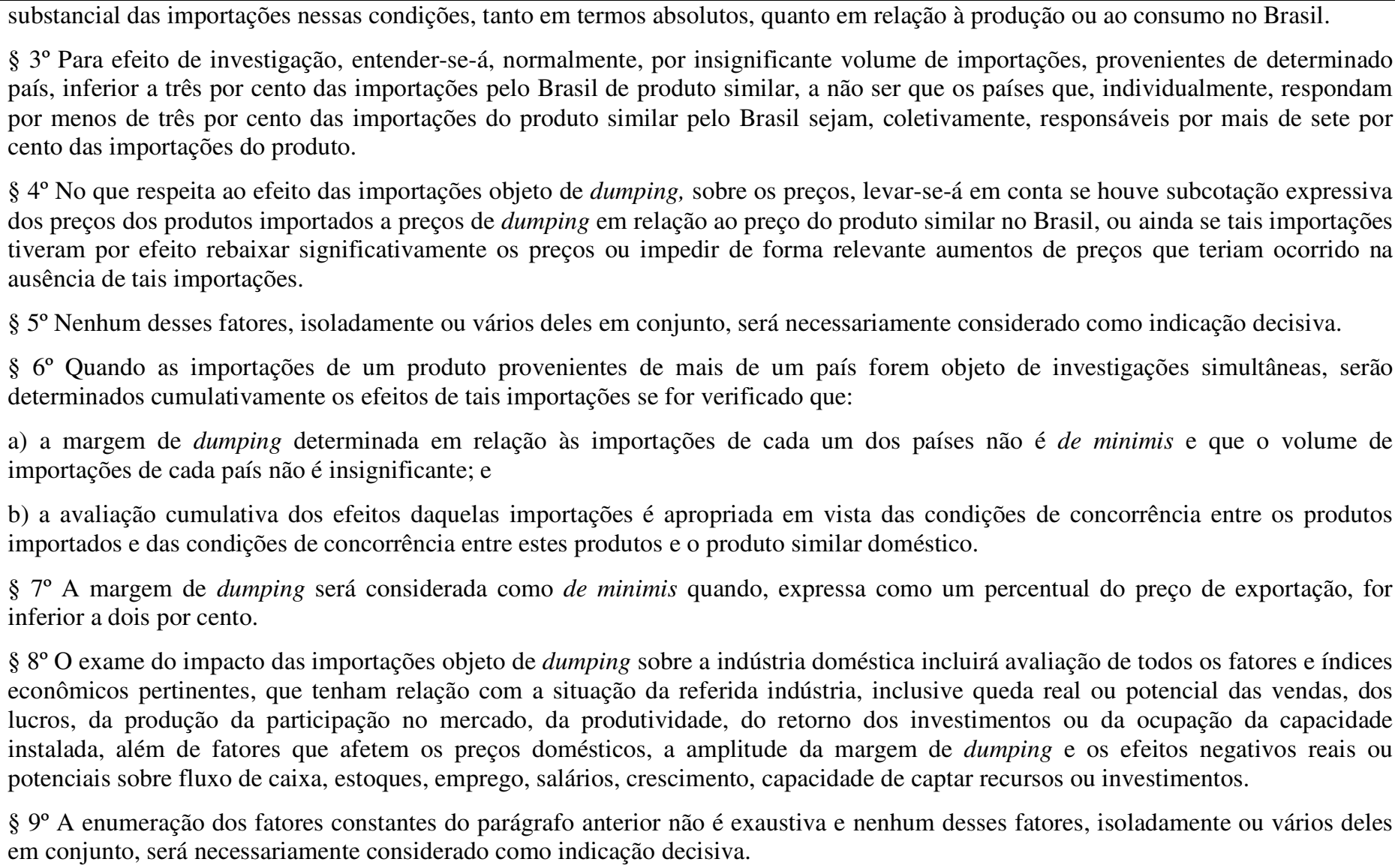 \\
\hline Proposta 01 & $\begin{array}{l}\S 3^{\circ} \text { - Para efeito de investigação, entender-se-á, normalmente, por insignificante volume de importações, provenientes de determinado } \\
\text { país, inferior a três por cento das importações pelo Brasil de produto similar, a não ser que os países que, individualmente, respondam } \\
\text { por menos de três por cento das importações do produto similar pelo Brasil sejam, coletivamente, responsáveis por mais de sete por } \\
\text { cento das importações do produto. O exame de insignificância do volume de importação deverá considerar os dados referentes aos doze } \\
\text { meses que compreendem o período de investigação de dumping. Deverá ser determinado, quando da abertura da investigação, se as }\end{array}$ \\
\hline
\end{tabular}




\begin{tabular}{|c|c|}
\hline & 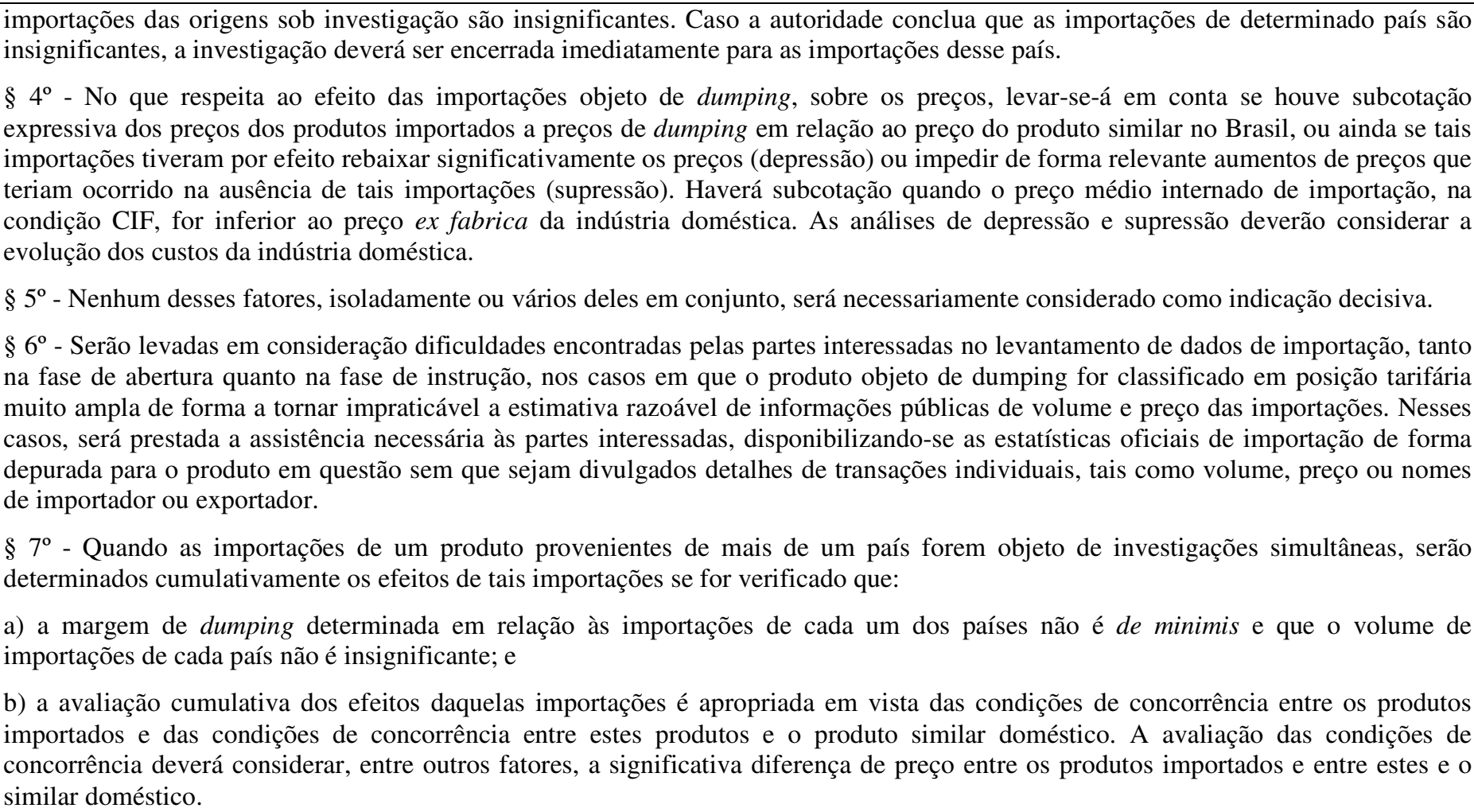 \\
\hline Proposta 2 & $\begin{array}{l}\S 4^{\circ} \text { No que respeita ao efeito das importações objeto de dumping, sobre os preços, levar-se-á em conta se houve subcotação expressiva } \\
\text { dos preços dos produtos importados a preços de dumping em relação ao preço do produto similar no Brasil, ou ainda se tais importações } \\
\text { tiveram por efeito rebaixar significativamente os preços (depressão) ou impedir de forma relevante aumentos de preços que teriam } \\
\text { ocorrido na ausência de tais importações (supressão). }\end{array}$ \\
\hline & Artigo 16 \\
\hline Redação & Art. 16. A determinação de existência de ameaça de dano material basear-se-á em fatos e em motivo convincente. A alteração de \\
\hline
\end{tabular}




\begin{tabular}{|c|c|}
\hline original & $\begin{array}{l}\text { condições vigentes, que possa criar uma situação em que o dumping causaria dano, deve ser claramente previsível e iminente. } \\
\S 1^{\circ} \text { Na determinação de existência de ameaça de dano material, serão considerados, entre outros, os seguintes fatores: } \\
\text { a) significativa taxa de crescimento das importações objeto de dumping, indicativa de provável aumento substancial destas } \\
\text { importações; } \\
\text { b) suficiente capacidade ociosa ou iminente aumento substancial na capacidade produtiva do produtor, que indiquem a probabilidade de } \\
\text { significativo aumento das exportações objeto de dumping para o Brasil, considerando-se a existência de terceiros mercados que possam } \\
\text { absorver o possível aumento das exportações; } \\
\text { c) importações realizadas a preços que terão efeito significativo em reduzir preços domésticos ou impedir o aumento dos mesmos e que, } \\
\text { provavelmente, aumentarão a demanda por novas importações; } \\
\text { d) estoques do produto sob investigação. } \\
\S 2^{\circ} \text { Nenhum dos fatores, constantes do parágrafo anterior, tomados isoladamente fornecerá orientação decisiva, mas a existência da } \\
\text { totalidade desses fatores levará, necessariamente, à conclusão de que mais importações objeto de dumping são iminentes que, se não } \\
\text { forem tomadas medidas de proteção, ocorrerá dano material }\end{array}$ \\
\hline Proposta 01 & $\begin{array}{l}\text { e) existência de medidas de defesa comercial em vigor em terceiros países, ou a existência de investigações de defesa comercial em } \\
\text { curso que estejam acarretando ou venham a acarretar aumento das exportações do produto objeto da investigação ao Brasil. }\end{array}$ \\
\hline Proposta 02 & $\begin{array}{l}\text { Art. 16. A determinação de existência de ameaça de dano material basear-se-á em fatos e não meramente em alegações, conjecturas ou } \\
\text { possibilidades remotas. A alteração de condiços vigentes, que possa criar uma situação em que o dumping causaria dano, deve ser } \\
\text { claramente previsível e iminente, o que inclui a existência de motivo convincente para acreditar que haverá, em futuro próximo, } \\
\text { aumento substancial na importação de produtos a preço de dumping. } \\
\S 2^{\circ} \text { Nenhum dos fatores, constantes do parágrafo anterior, tomados isoladamente, fornecerá, necessariamente, orientação decisiva, mas } \\
\text { a existência da totalidade desses fatores levará à conclusão de que mais importações objeto de dumping são iminentes e de que, se não } \\
\text { forem tomadas medidas de proteção, ocorrerá dano material. }\end{array}$ \\
\hline Proposta 03 & $\begin{array}{l}\text { Art. 16. A determinação de existência de ameaça de dano material basear-se-á em fatos e não meramente em alegações, conjecturas ou } \\
\text { possibilidades remotas. A alteração de condições vigentes, que possa criar uma situação em que o dumping causaria dano, deve ser } \\
\text { claramente previsível e iminente. } \\
\S \text { (a definir). A existência de motivo convincente para acreditar que haverá, em futuro próximo, aumento substancial na importação de } \\
\text { produtos a preço de dumping configura uma das possibilidades da situação prevista no caput deste artigo. }\end{array}$ \\
\hline
\end{tabular}




\begin{tabular}{|c|c|}
\hline \multicolumn{2}{|r|}{ Artigo 17} \\
\hline $\begin{array}{l}\text { Redação } \\
\text { original }\end{array}$ & 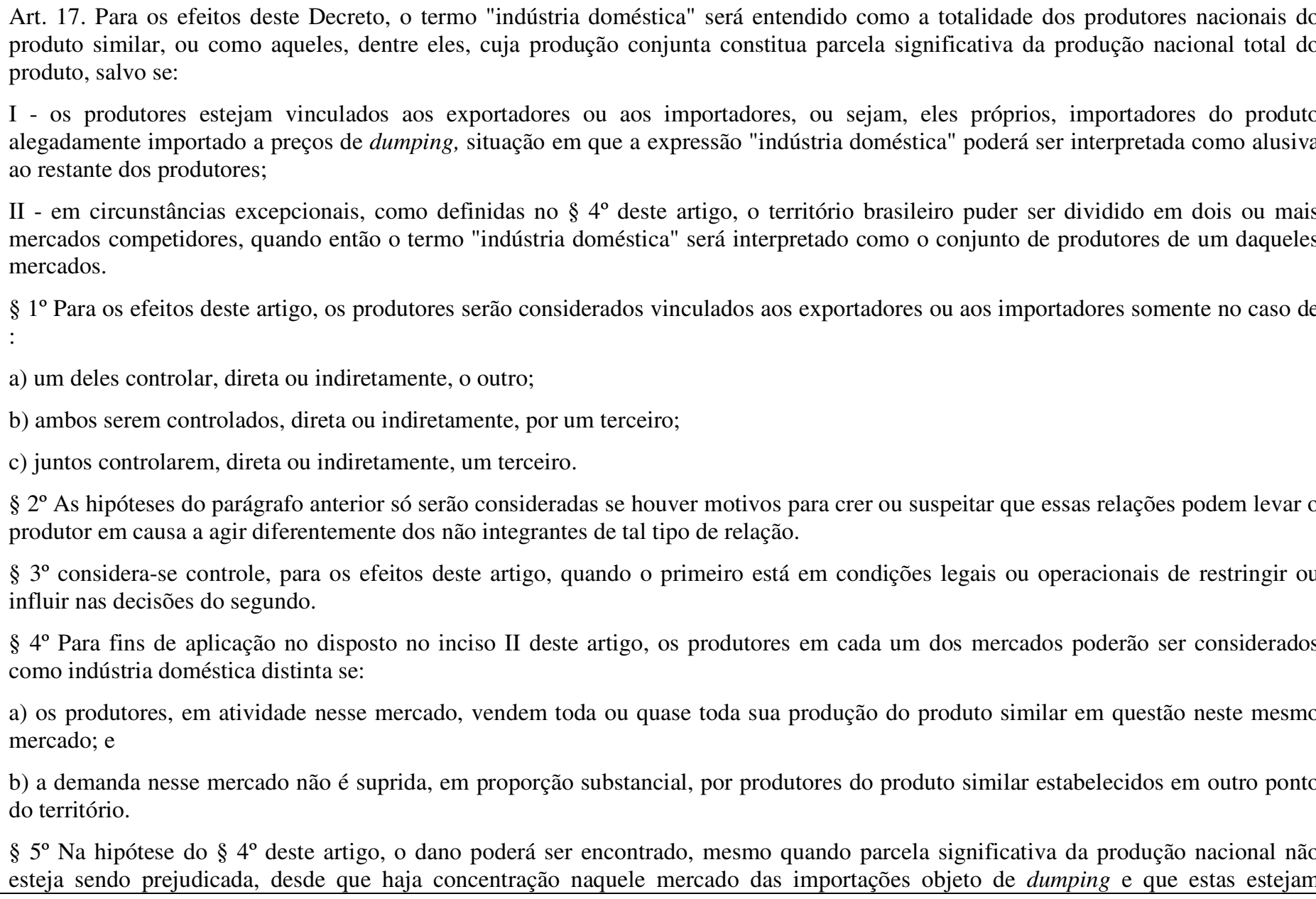 \\
\hline
\end{tabular}




\begin{tabular}{|c|c|}
\hline & usando dano aos produtores de toda e toda produção daquele mercado. \\
\hline Proposta 01 & $\begin{array}{l}\text { III - O dispositivo desse artigo aplica-se também aos casos de pedidos de investigação de práticas elisivas, nos termos do artigo 10-A } \\
\text { da Lei No. } 9.019 \text {, de } 1995 \text {, inclusive na extensão de direitos antidumping em vigor sobre importações de partes, peças e componentes, } \\
\text { assim considerados as matérias-primas, os produtos intermediários e quaisquer outros bens empregados na industrialização do produto } \\
\text { objeto de direitos antidumping em vigor. }\end{array}$ \\
\hline Proposta 02 & $\begin{array}{l}\S 1^{\circ} \mathrm{O} \text { termo "parcela significativa da produção nacional total do produto" deve ser entendido como o conjunto de produtores que } \\
\text { representem ao menos } 25 \% \text { (vinte por cento) da produção nacional, desconsiderando-se os produtores vinculados e/ou importadores, } \\
\text { conforme inciso I, acima. [Nota: percentual está em consonância com o art. 21, "c" e artigo } 5.4 \text { do Acordo Antidumping] }\end{array}$ \\
\hline & Artigo 18 \\
\hline & $\begin{array}{l}\text { Art. 18. Com exceção do disposto no art. } 24 \text {, a investigação, para determinar a existência, o grau e o efeito de qualquer alegação de } \\
\text { dumping, será solicitada pela indústria doméstica ou em seu nome por meio de petição, formulada por escrito, de acordo com roteiro } \\
\text { elaborado pela SECEX. } \\
\S 1^{\circ} \text { A petição, mencionada no caput deste artigo, deverá incluir elementos de prova de dumping, de dano e de nexo causal entre as } \\
\text { importaçães objeto de dumping e o dano alegado e os seguintes dados: } \\
\text { a) qualificação do peticionário, indicação do volume e do valor da produção da indústria doméstica que lhe corresponda. No caso de a } \\
\text { petição ter sido feita em nome da indústria doméstica, o documento deverá indicar a indústria em nome da qual foi feita a petição e o } \\
\text { nome das empresas representadas, bem como o volume e o valor da produção que lhes corresponda; } \\
\text { b) estimativa do volume e do valor da produção nacional do produto similar; } \\
\text { c) lista dos conhecidos produtores domésticos do produto similar que não estejam representados na petição e, na medida do possível, } \\
\text { indicação do volume e do valor da produção doméstica do produto similar correspondente àqueles produtores, bem como sua } \\
\text { manifestação quanto ao apoio à petição; } \\
\text { d) descrição completa do produto alegadamente importado a preços de dumping, nome do respectivo país de origem e de exportação, } \\
\text { identidade de cada exportador ou produtor estrangeiro conhecidos e lista dos conhecidos importadores do produto em questão; } \\
\text { e) descrição completa do produto fabricado pela indústria doméstica; } \\
\text { f) informação sobre preço representativo pelo qual o produto em questão é vendido, quando destinado ao consumo no mercado interno } \\
\text { do país ou países exportadores, ou, nas hipóteses previstas no art. } 6^{\circ} \text {, a informação sobre preço representativo pelo qual o produto é } \\
\text { vendido, pelo país ou países exportadores a um terceiro país ou países, ou sobre o valor construído do produto; }\end{array}$ \\
\hline
\end{tabular}




\begin{tabular}{|c|c|}
\hline & $\begin{array}{l}\text { g) informação sobre preço de exportação representativo ou, nas hipóteses previstas no art. } 8^{\circ} \text {, sobre preço representativo pelo qual o } \\
\text { produto é vendido, pela primeira vez, a um comprador independente situado no território brasileiro; } \\
\text { h) informação sobre a evolução do volume das importações, alegadamente objeto de dumping, os efeitos de tais importações sobre os } \\
\text { preços do produto similar no mercado doméstico e o consequente impacto das importações sobre a indústria doméstica, demonstrado } \\
\text { por fatores e índices pertinentes, que tenham relação com o estado dessa indústria. } \\
\S 2^{\circ} \text { caso a petição contenha informações sigilosas, aplica-se o disposto no art. } 28 \text {. }\end{array}$ \\
\hline Proposta 01 & $\begin{array}{l}\text { d) descrição completa e definição do escopo do produto alegadamente importado a preços de dumping, posição tarifária que serve de } \\
\text { refereneia para descrição e definição do escopo do produto, nome do respectivo país de origem e de exportação, identidade de cada } \\
\text { exportador ou produtor estrangeiro conhecidos e lista dos conhecidos importadores do produto em questão; } \\
\text { e) descrição completa do produto similar fabricado pela indústria doméstica; }\end{array}$ \\
\hline Proposta 02 & $\begin{array}{l}\text { lista dos conhecidos produtores domésticos do produto similar que não estejam representados na petição e, na medida do possível, } \\
\text { dicação do volume e do valor da produção doméstica do produto similar correspondente àqueles produtores, bem como sua } \\
\text { anifestação quanto ao apoio à petiçãao, se possível; }\end{array}$ \\
\hline Proposta 03 & $\begin{array}{l}\text { b) estimativa, na medida do possível, do volume e do valor da produção nacional do produto similar; } \\
\text { d) descrição completa do produto fabricado pela indústria doméstica; produto é vendido pelo país ou países de origem ou de exportação } \\
\text { a um terceiro país ou países, ou sobre o valor construído do produto; } \\
\text { f) informação sobre preço representativo pelo qual o produto em questão é vendido, quando destinado ao consumo no mercado interno } \\
\text { do país ou países de origem ou de exportação, ou, nas hipóteses previstas no art. } 6^{\circ} \text {, a informação sobre preço representativo pelo qual o } \\
\text { produto é vendido, pelo país ou país de origem ou de exportação a um terceiro país ou países, ou sobre o valor construído do produto. }\end{array}$ \\
\hline Proposta 04 & $\begin{array}{l}\text { Art. } 18, \S 1^{\circ} \text { A petição, mencionada no caput deste artigo, deverá incluir elementos de prova de dumping, de dano e de nexo causal } \\
\text { entre as importaçóes objeto de dumping e o dano alegado e, dentro dos limites razoáveis ao alcance do peticionário, deverá conter } \\
\text { informaçôes sobre os seguintes pontos: } \\
\text { a) qualificação do peticionário, indicação do volume e do valor da produçãa da indústria doméstica que lhe corresponda. No caso de a } \\
\text { petição ter sido feita em nome da indústria doméstica, o documento deverá indicar a indústria em nome da qual foi feita a petição e o } \\
\text { nome das empresas representadas, bem como o volume e o valor da produção que lhes corresponda; } \\
\text { b) estimativa do volume e do valor da produção nacional do produto similar; } \\
\text { c) lista dos conhecidos produtores domésticos do produto similar que não estejam representados na petição e, na medida do possível, }\end{array}$ \\
\hline
\end{tabular}




\begin{tabular}{|c|c|}
\hline & $\begin{array}{l}\text { sua manifestação quanto ao apoio à petição; } \\
\text { d) descrição completa do produto alegadamente importado a preços de dumping, nome do respectivo país ou dos países de origem e ou } \\
\text { de exportação, identidade de cada exportador ou produtor estrangeiro conhecidos e lista dos conhecidos importadores do produto em } \\
\text { questão; } \\
\text { e) descrição completa do produto fabricado pela indústria doméstica; } \\
\text { f) informação sobre preço representativo pelo qual o produto em questão é vendido, quando destinado ao consumo no mercado interno } \\
\text { do país ou países de origem ou de exportação, ou, nas hipóteses previstas no art. } 6^{\circ} \text {, a informação sobre preço representativo pelo qual o } \\
\text { produto é vendido, pelo país ou países de origem ou de exportação a um terceiro país ou países, ou sobre o valor construído do produto; } \\
\text { g) informação sobre preço de exportação representativo ou, nas hipóteses previstas no parágrafo único do art. } 8^{\circ} \text {, sobre preço } \\
\text { representativo pelo qual o produto é revendido, pela primeira vez, a um comprador independente situado no território brasileiro ou } \\
\text { sobre uma base razoável, no caso de os produtos não serem revendidos a comprador independente, ou não serem revendidos na mesma } \\
\text { condição em que foram importados; } \\
\text { h) informação sobre a evolução do volume das importações, alegadamente objeto de dumping, os efeitos de tais importações sobre os } \\
\text { preços do produto similar no mercado doméstico e o consequiente impacto das importações sobre a indústria doméstica, demonstrado } \\
\text { por fatores e índices pertinentes, que tenham relação com o estado dessa indústria. }\end{array}$ \\
\hline & Artigo 19 \\
\hline $\begin{array}{l}\text { Redação } \\
\text { original }\end{array}$ & $\begin{array}{l}\text { Art. 19. A petição será preliminarmente examinada com o objetivo de se verificar se está devidamente instruída ou se são necessárias } \\
\text { informações complementares. O peticionário será comunicado do resultado deste exame no prazo de vinte dias contados a partir da data } \\
\text { de entrega da petição. } \\
\S 1^{\circ} \text { Quando forem solicitadas informações complementares, novo exame será realizado a fim de se verificar se são necessárias novas } \\
\text { informações ou se a petição está devidamente instruída. O peticionário será comunicado do resultado deste exame no prazo de vinte } \\
\text { dias contados a partir da data de entrega das informações complementares. } \\
\S 2^{\circ} \text { A partir da data de entrega das novas informações o peticionário será comunicado, no prazo de vinte dias, se a petição estáa } \\
\text { devidamente instruída ou se foi considerada definitivamente inepta. } \\
\S 3^{\circ} \text { O prazo para atendimento as informações complementares ou às novas informações solicitadas será determinado pela SECEX, de } \\
\text { acordo com a sua natureza, e comunicado ao peticionário. } \\
\S 4^{\circ} \text { O peticionário terá o prazo de dez dias contados a partir da data de expedição da comunicação que informar que a petição estáá } \\
\text { devidamente instruída, para apresentar tantas vias do texto completo da petição, inclusive o resumo não-sigiloso da mesma, quando for } \\
\text { o caso, nos termos do } \S 1^{\circ} \text { do art. } 28 \text {, quantos forem os produtores e exportadores conhecidos e os governos de países exportadores }\end{array}$ \\
\hline
\end{tabular}




\begin{tabular}{|c|c|}
\hline & $\begin{array}{l}\text { arrolados. } \\
\S 5^{\circ} \text { No caso do número de produtores e exportadores, referidos no } \S 4^{\circ} \text {, ser especialmente alto, poderão ser fornecidas cópias da petição } \\
\text { apenas para remessa aos governos dos países exportadores arrolados e entidades de classe correspondentes. }\end{array}$ \\
\hline Proposta 01 & $\begin{array}{l}\text { Artigo } 19 \text {. A petição será preliminarmente examinada com o objetivo de se verificar se está devidamente instruída ou se são necessárias } \\
\text { informaços complementares. O peticionário será comunicado do resultado deste exame no prazo de quinze dias contados a partir da } \\
\text { data de entrega da petição } \\
\S 1^{\circ} \text { Quando forem solicitadas informações complementares, novo exame será realizado a fim de se verificar se a petição está } \\
\text { devidamente instruída. } \\
\S 2^{\circ} \text { A partir da data de entrega das informaçães complementares o peticionário será comunicado, no prazo de dez dias, se a petição estáá } \\
\text { devidamente instruída ou se foi considerada definitivamente inepta. } \\
\text { (...) } \\
\S 4^{\circ} \text { O peticionário terá o prazo de dez dias contados a partir da data de expedição da comunicação que informar que a petição está } \\
\text { devidamente instruída, para apresentar tantas vias do texto completo da petição, excluindo-se as informaçôes consideradas sigilosas nos } \\
\text { termos do } \S 1^{\circ} \text { do art. } 28 \text {, quantos forem os produtores e exportadores conhecidos e os governos de países exportadores arrolados, } \\
\text { limitados a um limite máximo de cinco produtores/exportadores. } \\
\S 5^{\circ} \text { No caso do número de produtores e exportadores, referidos no } \S 4^{\circ} \text {, ser superior ao limite máximo indicado em tal parágrafo, } \\
\text { poderão ser fornecidas cópias da petição apenas em arquivos eletrônicos, gravados em mídias ópticas, para remessa aos governos dos } \\
\text { países exportadores arrolados e entidades de classe c. }\end{array}$ \\
\hline Proposta 02 & $\begin{array}{l}\text { Art. 19. A petição será preliminarmente examinada com o objetivo de se verificar se está devidamente instruída ou se são necessárias } \\
\text { informaçôs complementares. O peticionário será comunicado do resultado deste exame no prazo de quinze dias contados a partir da } \\
\text { data de entrega da petição. } \\
\S 1^{\circ} \text { Quando forem solicitadas informações complementares, novo exame será realizado a fim de se verificar se são necessárias novas } \\
\text { informaçôes ou se a petição está devidamente instruída. O peticionário será comunicado do resultado deste exame no prazo de quinze } \\
\text { dias contados a partir da data de entrega das informaçôes complementares. } \\
\S 2^{\circ} \text { A partir da data de entrega das novas informações o peticionário será comunicado, no prazo de vinte quinze dias, se a petição está } \\
\text { devidamente instruída ou se foi considerada definitivamente inepta. }\end{array}$ \\
\hline & \\
\hline
\end{tabular}




\begin{tabular}{|c|c|}
\hline $\begin{array}{l}\text { Redação } \\
\text { original }\end{array}$ & $\begin{array}{l}\text { Art. 20. Os elementos de prova da existência de dumping e de dano por ele causado serão considerados, simultaneamente, na análise } \\
\text { para fins de determinação da abertura da investigação. } \\
\S 1^{\circ} \text { Serão examinadas, com base nas informações de outras fontes prontamente disponíveis, a correção e a adequação dos elementos de } \\
\text { prova oferecidos na petição, com vistas a determinar a existência de motivos suficientes que justifiquem a abertura da investigação. } \\
\S 2^{\circ} \text { A SECEX procederá a exame do grau de apoio ou rejeição à petição, expresso pelos demais produtores nacionais do produto } \\
\text { similar, com objetivo de verificar se a petição foi feita pela indústria doméstica ou em seu nome. No caso de indústria fragmentária, que } \\
\text { envolva um número especialmente alto de produtores, poderá se confirmar apoio ou rejeição mediante a utilização de técnicas de } \\
\text { amostragem estatisticamente válidas } \\
\S 3^{\circ} \text { Considerar-se-á como feita "pela indústria doméstica ou em seu nome" a petição que for apoiada por aqueles produtores cuja } \\
\text { produção conjunta constitua mais de cinqüenta por cento da produção total do produto similar produzido por aquela parcela da indústria } \\
\text { doméstica que tenha expressado apoio ou rejeição à petição. }\end{array}$ \\
\hline Proposta 01 & $\begin{array}{l}\S 3^{\circ} \text { Considerar-se-á como feita "pela indústria doméstica ou em seu nome" a petição que for apoiada por aqueles produtores cuja } \\
\text { produção conjunta constitua mais de cinqüenta por cento da produção total do produto similar produzido por aquela parcela da indústria } \\
\text { doméstica que tenha de alguma forma se manifestado a respeito da expressado apoio ou rejeição à petição. }\end{array}$ \\
\hline & Artigo 21 \\
\hline $\begin{array}{l}\text { Redação } \\
\text { original }\end{array}$ & $\begin{array}{l}\text { Art. } 21 \text {. O peticionário será notificado da determinação, positiva ou negativa, quanto à abertura da investigação, no prazo de trinta dias } \\
\text { contados a partir da data de expedição da comunicação de que a petição está devidamente instruída. } \\
\S 1^{\circ} \text { A petição será indeferida e o processo consequentemente arquivado, quando: } \\
\text { a) não houver elementos de prova suficientes da existência de dumping ou de dano por ele causado, que justifiquem a abertura da } \\
\text { investigação; } \\
\text { b) a petição não tiver sido feita pela indústria doméstica ou em seu nome; ou } \\
\text { c) os produtores domésticos, que expressamente apoiam a petição, reúnam menos de } 25 \% \text { da produção total do produto similar } \\
\text { realizada pela indústria doméstica. } \\
\S 2^{\circ} \text { caso haja determinação positiva, a investigação será aberta e deverá ser publicado ato que contenha tal determinação no Diário } \\
\text { Oficial da União. As partes interessadas conhecidas serão notificadas e será concedido prazo de vinte dias contados a partir da data da } \\
\text { publicação da determinação, para pedido de habilitação de outras partes que se considerem interessadas, com a respectiva indicação de } \\
\text { representantes legais, segundo o disposto na legislação pertinente. }\end{array}$ \\
\hline
\end{tabular}




\begin{tabular}{|c|c|}
\hline & 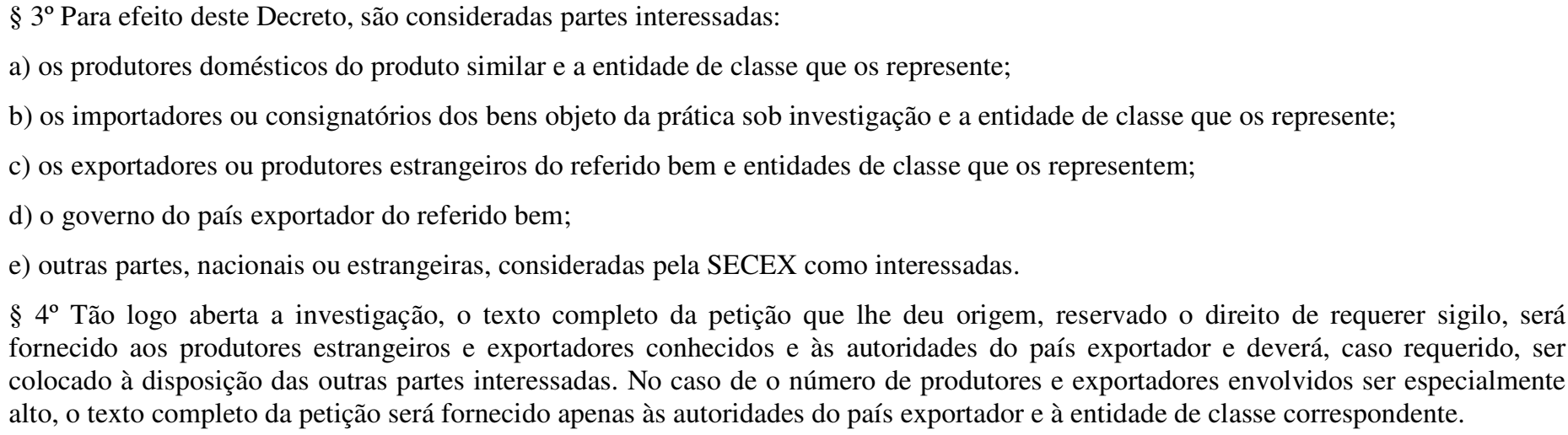 \\
\hline Proposta 01 & $\begin{array}{l}\text { Art. 21. O peticionário será notificado, por meio de ofício, da determinação, positiva ou negativa, quanto à abertura da investigação, no } \\
\text { prazo de dez dias contados a partir da data de expedição da comunicação de que a petição está devidamente instruída. } \\
\text { (...) } \\
\S 2^{\circ} \text { Caso haja determinação positiva, a investigação será aberta e deverá ser publicado, no prazo de dez dias contados a partir da } \\
\text { notificação de determinação positiva de que trata o caput, ato que contenha tal determinação no Diário Oficial da União. As partes } \\
\text { interessadas conhecidas serão notificadas, e será concedido prazo de vinte dias contados a partir da data da publicação da determinaçâ, } \\
\text { para pedido de habilitação de outras partes, à exceção daquelas listadas no } \S 3^{\circ} \text { deste artigo, que se considerem interessadas, com a } \\
\text { respectiva indicação de representantes legais, segundo o disposto na legislação pertinente. }\end{array}$ \\
\hline Proposta 02 & $\begin{array}{l}\text { Art. 21. O peticionário será notificado da determinação, positiva ou negativa, quanto à abertura da investigação, no prazo de vinte dias } \\
\text { contados a partir da data de expedição da comunicação de que a petição está devidamente instruída. }\end{array}$ \\
\hline \multicolumn{2}{|r|}{ Artigo 22} \\
\hline $\begin{array}{l}\text { Redação } \\
\text { original }\end{array}$ & $\begin{array}{l}\text { Art. 22. Aberta a investigação, a SECEX comunicará à Secretaria da Receita Federal, do Ministério da Fazenda, para que adote as } \\
\text { providências cabíveis que possibilitem, se for o caso, a posterior aplicação de direitos antidumping definitivos sobre as importações } \\
\text { objeto de investigação, de que trata o art. } 54 \text {. } \\
\text { Parágrafo único. As providências adotadas pela Secretaria da Receita Federal, na forma deste artigo, não constituirão entrave ao } \\
\text { desembaraço aduaneiro. }\end{array}$ \\
\hline
\end{tabular}




\begin{tabular}{|c|c|}
\hline Proposta 01 & $\begin{array}{l}\text { Art. 22. Aberta a investigação, a SECEX, na data da publicação da respectiva Circular de abertura: } \\
\text { I - Incluirá o produto sob investigação no Regime de Licenciamento Não-Automático; } \\
\text { II - Estabelecerá a exigência de Certificado de Origem, em consonância com o disposto na Resolução CAMEX no } 80 \text {, de } 9 \text { de } \\
\text { novembro de } 2010 \text {, em todas as importaçóes do produto sob investigação, emitido por órgão acreditado pelo Governo Federal. Em caso } \\
\text { de conflito entre as regras determinadas neste inciso e aquelas constantes em Regime de Origem em acordos preferenciais, prevalecerão } \\
\text { as primeiras. } \\
\text { III - comunicará à Secretaria da Receita Federal do Brasil (RFB), do Ministério da Fazenda para que esta: } \\
\text { a) efetue a suspensão da valoração para fins aduaneiros nas importações objeto da investigação; } \\
\text { b) inclua o produto sob investigação seja parametrizado no Canal Cinza de conferência aduaneira; } \\
\text { c) adote as providências cabíveis que possibilitem, se for o caso, a posterior aplicação de direitos antidumping definitivos sobre as } \\
\text { importações objeto de investigação, de que trata o art. } 54 \text {. }\end{array}$ \\
\hline Proposta 02 & $\begin{array}{l}\S 1^{\circ} \text { As providências adotadas pela Secretaria da Receita Federal, na forma deste artigo, não constituirão entrave ao desembaraço } \\
\text { aduaneiro. } \\
\S 2^{\circ} \text { Aberta a investigação, as importações realizadas por meio da classificação fiscal do produto objeto da análise estarão } \\
\text { imediatamente sujeitas a licenciamento não automático. } \\
\S 3^{\circ} \text { A análise e emissão das licenças não automáticas a que se referem o } \S 2^{\circ} \text {. }\end{array}$ \\
\hline \multicolumn{2}{|r|}{ Artigo 23} \\
\hline $\begin{array}{l}\text { Redação } \\
\text { original }\end{array}$ & $\begin{array}{l}\text { Art. 23. Antes da determinação de abertura da investigação, não será divulgada a existência de petição que a solicitou, salvo em relação } \\
\text { ao governo do país exportador interessado, que deverá ser notificado da existência de petição devidamente instruída. }\end{array}$ \\
\hline Proposta 01 & $\begin{array}{l}\text { Art. 23. Antes da determinação de abertura da investigação ou de indeferimento de petição de abertura de investigação, não será } \\
\text { divulgada a existência de petição que a solicitou, salvo em relação ao governo do país exportador interessado, que deverá ser notificado } \\
\text { da existência de petição devidamente instruída. }\end{array}$ \\
\hline Proposta 02 & $\begin{array}{l}\text { Art. 23. Antes da determinação de abertura da investigação, não será divulgada a existência de petição que a solicitou, salvo em relação } \\
\text { ao governo do país exportador interessado, que deverá ser notificado em } 10 \text { (dez) dias antes da publicação do ato que determinar a } \\
\text { abertura da investigação. }\end{array}$ \\
\hline
\end{tabular}




\begin{tabular}{|c|c|}
\hline \multicolumn{2}{|r|}{ Artigo 24} \\
\hline $\begin{array}{l}\text { Redação } \\
\text { original }\end{array}$ & $\begin{array}{l}\text { Art. 24. Em circunstâncias excepcionais, o Governo Federal, ex offício, poderá abrir a investigação, desde que haja elementos de prova } \\
\text { suficientes da existência de dumping, de dano e do nexo causal entre eles, que justifiquem a abertura. O governo do país interessado } \\
\text { será notificado da existência desses elementos de prova, antes da abertura da investigação. }\end{array}$ \\
\hline Proposta 01 & $\begin{array}{l}\text { Art. 24. Em circunstâncias excepcionais, o Governo Federal, ex offício, poderá abrir a investigação, desde que haja elementos de prova } \\
\text { suficientes da existência de dumping, de dano e do nexo causal entre eles, que justifiquem a abertura. }\end{array}$ \\
\hline \multicolumn{2}{|r|}{ Artigo 25} \\
\hline $\begin{array}{l}\text { Redação } \\
\text { original }\end{array}$ & $\begin{array}{l}\text { Art. 25. Durante a investigação os elementos de prova da existência de dumping e de dano por ele causado serão considerados } \\
\text { simultaneamente. } \\
\S 1^{\circ} \text { O período objeto da investigação de existência de dumping deverá compreender os doze meses mais próximos possíveis anteriores } \\
\text { à data da abertura da investigação, podendo, em circunstâncias excepcionais, ser inferior a doze meses, mas nunca inferior a seis meses. } \\
\S 2^{\circ} \text { O período objeto da investigação da existência de dano deverá ser suficientemente representativo a fim de permitir a análise de que } \\
\text { dispõe o Capítulo III, não será inferior a três anos e incluirá, necessariamente, o período de investigação de dumping. }\end{array}$ \\
\hline Proposta 01 & $\begin{array}{l}\text { Art. 25. Durante a investigação os elementos de prova da existência de dumping e de dano por ele causado serão considerados } \\
\text { simultaneamente. } \\
\S 1^{\circ} \text { O período objeto da investigação de existência de dumping deverá compreender os doze meses mais próximos possíveis anteriores à } \\
\text { data da abertura da investigação, podendo, em circunstâncias devidamente justificadas, ser inferior a doze meses, mas nunca inferior a } \\
\text { seis meses. } \\
\S 2^{\circ} \text { O período objeto da investigação da existência de dano deverá ser suficientemente representativo a fim de permitir a análise de que } \\
\text { dispõe o Capítulo III, será preferencialmente de, mas não inferior a, três anos e incluirá, necessariamente, o período de investigação de } \\
\text { dumping. }\end{array}$ \\
\hline \multicolumn{2}{|r|}{ Artigo 26} \\
\hline $\begin{array}{l}\text { Redação } \\
\text { original }\end{array}$ & $\begin{array}{l}\text { Art. 26. As partes interessadas conhecidas em uma investigação de dumping serão comunicadas sobre as informações requeridas e terão } \\
\text { ampla oportunidade de apresentar, por escrito, os elementos de prova que considerem pertinentes com respeito à investigação em } \\
\text { apreço. }\end{array}$ \\
\hline
\end{tabular}




\begin{tabular}{|c|c|}
\hline & $\begin{array}{l}\text { Parágrafo único. Serão levadas na devida conta quaisquer dificuldades encontradas pelas partes interessadas, em especial às } \\
\text { microempresas e empresas de pequeno porte, no fornecimento das informações solicitadas, e lhes será proporcionada a assistência } \\
\text { possível. }\end{array}$ \\
\hline Proposta 01 & $\begin{array}{l}\S 2^{\circ} \text {. Todos os documentos apresentados pelas partes interessadas deverão ser juntados aos autos da investigação. Nenhum documento } \\
\text { apresentado pelas partes interessadas será desentranhado dos autos da investigação, a menos que manifestamente estranho ao processo. } \\
\S 3^{\circ} \text {. O DECOM deverá levar em consideração todos os argumentos e documentos apresentados pelas partes em suas decisões na } \\
\text { investigação. No caso de rejeição de determinados argumentos ou documentos, o DECOM indicará claramente os motivos para tanto. }\end{array}$ \\
\hline \multicolumn{2}{|r|}{ Artigo 27} \\
\hline & $\begin{array}{l}\text { Art. 27. As partes interessadas conhecidas, à exceção dos governos dos países exportadores, receberão questionários destinados à } \\
\text { investigação e disporão de quarenta dias para restituí-los. Este prazo será contado a partir da data de expedição dos referidos } \\
\text { questionários. } \\
\S 1^{\circ} \text { Serão devidamente considerados pedidos de prorrogação do prazo de quarenta dias e, caso demostrada sua necessidade, tal } \\
\text { prorrogação poderá ser autorizada sempre que praticável, por um prazo de até trinta dias, tendo em conta os prazos de investigação. } \\
\S 2^{\circ} \text { Poderão ser solicitadas ou aceitas por escrito, informações adicionais ou complementares, ao longo de uma investigação. O prazo } \\
\text { para o fornecimento das informações solicitadas será estipulado em função da sua natureza e poderá ser prorrogado a partir de } \\
\text { solicitação devidamente justificada. Deverão ser levados em conta dos prazos da investigação, tanto para as informações solicitadas } \\
\text { quanto para consideração daquelas informações adicionais apresentadas. } \\
\S 3^{\circ} \text { Caso qualquer das partes interessadas negue acesso à informação necessária, não a forneça no prazo que lhe for determinado ou, } \\
\text { ainda, crie obstáculos à investigação, o parecer, com vistas às determinaçôes preliminares ou finais, será elaborado com base na melhor } \\
\text { informação disponível, de acordo com o disposto no art. } 66 \text {. }\end{array}$ \\
\hline Proposta 01 & $\begin{array}{l}\S 1^{\circ} \text { Serão devidamente considerados pedidos de prorrogação do prazo de quarenta dias e, caso demonstrada sua necessidade, tal } \\
\text { prorrogação poderá ser autorizada sempre que praticável, por um prazo de até trinta dias, tendo em conta os prazos da investigação. } \\
\text { Somente as respostas aos questionários da investigação apresentadas no prazo original de quarenta dias serão consideradas para fins de } \\
\text { determinação preliminar com vistas à decisão sobre a aplicação de direito provisório, conforme o disposto no art. } 34 \text { deste Decreto. }\end{array}$ \\
\hline Proposta 02 & $\begin{array}{l}\text { Art. 27. As partes interessadas conhecidas, à exceção dos governos dos países exportadores, receberão questionários destinados à } \\
\text { investigação e disporão de trinta dias para restituí-los. Este prazo será contado a partir da data do envio dos referidos questionários. } \\
\S 1^{\circ} \text { Serão devidamente considerados pedidos de prorrogação do prazo de trinta dias e, caso demonstrada sua necessidade, tal } \\
\text { prorrogação poderá ser autorizada, uma única vez, sempre que praticável, por um prazo de até trinta dias, tendo em conta os prazos de }\end{array}$ \\
\hline
\end{tabular}




\begin{tabular}{|c|c|}
\hline & \\
\hline \multicolumn{2}{|r|}{ Artigo 28} \\
\hline $\begin{array}{l}\text { Redação } \\
\text { original }\end{array}$ & $\begin{array}{l}\text { Art. 28. Informação que seja sigilosa por sua própria natureza ou seja fornecida em base sigilosa pelas partes de uma investigação será, } \\
\text { desde que bem fundamentada, tratada como tal e não será revelada sem autorização expressa da parte que a forneceu. As informações } \\
\text { classificadas como sigilosas constituirão processo em separado. } \\
\S 1^{\circ} \text { As partes interessadas, que forneçam informações sigilosas, deverão apresentar resumo não-sigiloso das mesmas, que permita } \\
\text { compreensão razoável da informação fornecida. Nos casos em que não seja possível a apresentação do resumo, as partes justificarão por } \\
\text { escrito tal circunstância. } \\
\S 2^{\circ} \text { Caso se considere que uma informação sigilosa não traz plenamente justificado esse caráter, e se o fornecedor da informação } \\
\text { recusar-se a torná-la pública na totalidade ou sob forma resumida, poderá ser desconsiderada tal informação, salvo se demonstrado, de } \\
\text { forma convincente, e por fonte apropriada, que tal informação é correta. }\end{array}$ \\
\hline Proposta 01 & $\begin{array}{l}\text { Art. } 28 \text { - Informação que seja sigilosa por sua própria natureza ou seja fornecida em base sigilosa pelas partes de uma investigação será, } \\
\text { desde que bem fundamentada, tratada como tal e não será revelada sem autorização expressa da parte que a forneceu. As informações } \\
\text { classificadas como sigilosas constituirão processo em separado. } \\
\S 1^{\circ} \text { - Para efeito deste artigo, será considerada informação sigilosa por sua própria natureza aquela cuja revelação daria substancial } \\
\text { vantagem competitiva a um competidor ou aquela que teria efeito substancialmente negativo sobre a pessoa que a está prestando ou } \\
\text { sobre a pessoa que forneceu a informação àquela que a está prestando, tais como: } \\
\text { a) Nome de clientes; } \\
\text { b) Nome de fornecedores; } \\
\text { c) Volume, valor, preço unitário e termos e condições de transação individual de importação, compra e/ou venda; } \\
\text { d) Descontos e abatimentos; } \\
\text { e) Custo de produção; } \\
\text { f) Descrição detalhada do processo produtivo, inclusive consumo unitário de matéria-prima, insumo e utilidades; } \\
\S 2^{\circ} \text { - As partes interessadas, que forneçam informaçães sigilosas, deverão apresentar resumo não-sigiloso das mesmas, que permita } \\
\text { compreensão razoável da informação fornecida. Nos casos em que não seja possível a apresentação do resumo, as partes justificarão por } \\
\text { escrito tal circunstância. } \\
\S 3^{\circ} \text { - Caso se considere que uma informação sigilosa não traz plenamente justificado esse caráter, e se o fornecedor da informação }\end{array}$ \\
\hline
\end{tabular}




\begin{tabular}{|c|c|}
\hline & $\begin{array}{l}\text { recusar-se a torná-la pública na totalidade ou sob forma resumida, poderá ser desconsiderada tal informação, salvo se demonstrado, de } \\
\text { forma convincente, e por fonte apropriada, que tal informação é correta. } \\
\text { Referida desconsideração será comunicada à parte antes do término da fase de instrução para que lhe seja facultado apresentá-la de } \\
\text { forma pública antes do término da fase de instrução. } \\
\S 4^{\circ} \text { - Caso haja indevida divulgação de informações sigilosas fornecidas em caráter sigiloso, independentemente do fato de se aceitar } \\
\text { que referida informação sigilosa traz plenamente justificado esse caráter, a autoridade responsável pela divulgação será responsabilizada } \\
\text { civil e criminalmente. }\end{array}$ \\
\hline Proposta 02 & $\begin{array}{l}\S 1^{\circ} \text { As partes interessadas, que forneçam informações sigilosas, deverão apresentar resumo não-sigiloso das mesmas, com detalhes } \\
\text { suficientes que permitam compreensão razoável da informação fornecida, sob pena de ser desconsiderada a informação original. Nos } \\
\text { casos em que não seja possível a apresentação do resumo, as partes justificarão por escrito tal circunstância. } \\
\text { a) Em atendimento ao princípio do contraditório e da ampla defesa, as informações anualizadas a respeito de importações do produto } \\
\text { sob consideração, vendas (valor e volume), produção, exportação (valor e volume), estoques e número de empregados, relacionados ao } \\
\text { produto sob consideração e ao produto similar, não se constituem em informações sigilosas, devendo ser apresentadas nos autos } \\
\text { públicos do processo; } \\
\text { b) para as informações sigilosas de caráter numérico, o resumo não-sigiloso deverá ser apresentado em formato de número-índice, } \\
\text { demonstrando-se a evolução periódica de tais informações. Para as informações sigilosas submetidas em forma de texto, deverá ser } \\
\text { apresentado breve resumo. } \\
\S 2^{\circ} \text { Caso se considere que uma informação sigilosa não traz plenamente justificado esse caráter, e se o fornecedor da informação } \\
\text { recusar-se a torná-la pública na totalidade ou sob forma resumida, poderá ser desconsiderada tal informação, salvo se demonstrado, de } \\
\text { forma convincente, e por fonte apropriada, que tal informação é correta. } \\
\S 3^{\circ} \text { O resumo não-sigiloso deverá ser apresentado simultaneamente à versão confidencial das informações originais, sob pena de essas } \\
\text { serem desconsideradas. }\end{array}$ \\
\hline Proposta 03 & $\begin{array}{l}\text { Art. 28. Informação que seja sigilosa por sua própria natureza ou seja fornecida em base sigilosa pelas partes de uma investigação será, } \\
\text { desde que bem fundamentada, tratada como tal e não será revelada sem autorização expressa da parte que a forneceu. } \\
\text { I - As informações classificadas como sigilosas constituirão processo em separado. } \\
\text { II - Será considerada informação sigilosa por sua própria natureza: } \\
\text { a) informação cuja revelação confira substancial vantagem competitiva a um competidor; } \\
\text { b) informação que tenha efeito substancialmente negativo sobre quem a está prestando; e/ou }\end{array}$ \\
\hline
\end{tabular}




\begin{tabular}{|c|c|}
\hline & $\begin{array}{l}\text { c) informação que tenha efeito substancialmente negativo sobre quem forneceu a informação àquele que a está prestando. } \\
\text { III - Deverá ser aposto o termo CONFIDENCIAL de forma centralizada no alto e no pé de cada página, preferencialmente em cor } \\
\text { contrastante com a do documento, devendo ainda ser indicado em cada página numeração sequencial, constando o número da página e o } \\
\text { total de páginas que compõem o documento, consoante o previsto no art. } 13 \text { do Decreto no } 2.910 \text {, de } 29 \text { de dezembro de } 1998 \text {. }\end{array}$ \\
\hline Proposta 04 & $\begin{array}{l}\text { Art. } 28 \text { Informação que seja sigilosa por sua própria natureza ou seja fornecida em base sigilosa pelas partes de uma investigação será, } \\
\text { desde que bem fundamentada, tratada como tal e não será revelada sem autorização expressa da parte que a forneceu. As informações } \\
\text { classificadas como sigilosas constituirão processo em separado. } \\
\S 1^{\circ} \text { Será considerada informação sigilosa por sua própria natureza: } \\
\text { I - informação cuja revelação confira substancial vantagem competitiva a um competidor; } \\
\text { II - informação que tenha efeito substancialmente negativo sobre quem a está prestando; } \\
\text { III - informação que tenha efeito substancialmente negativo sobre quem forneceu a informação àquele que a está prestando; ou } \\
\text { IV - outras informações sigilosas, segundo apreciação da SECEX. } \\
\text { §2 } \\
\text { compreensão razoável da informação fornecida. Nos casos em que não seja possível a apresentação do resumo, as partes justificarão por } \\
\text { escrito tal circunstância. } \\
\text { §3º Caso se considere que uma informação sigilosa não traz plenamente justificado esse caráter, e se o fornecedor da informação } \\
\text { recusar-se a torná-la pública na totalidade ou sob forma resumida, poderá ser desconsiderada tal informação, salvo se demonstrado, de } \\
\text { forma convincente, e por fonte apropriada, que tal informação é correta. }\end{array}$ \\
\hline \multicolumn{2}{|r|}{ Artigo 29} \\
\hline $\begin{array}{l}\text { Redação } \\
\text { original }\end{array}$ & $\begin{array}{l}\text { Art. 29. Será dada oportunidade aos setores produtivos usuários do produto sob investigação e representantes de organizações de } \\
\text { consumidores, caso o produto seja habitualmente comercializado no varejo, para que forneçam informações importantes para a } \\
\text { investigação. }\end{array}$ \\
\hline Proposta 01 & $\begin{array}{l}\text { Art. } 29 \text { - As partes interessadas terão até } 90 \text { dias da abertura da investigação para apresentarem questões preliminares, tais como: } \\
\text { viabilidade do valor normal; insignificância do volume importado de determinada origem; falhas na petição e no exame de abertura; } \\
\text { composição da indústria doméstica e grau de apoio à petição; definição do escopo do produto sob investigação e similaridade. }\end{array}$ \\
\hline & Artigo (a ser definido) \\
\hline
\end{tabular}




\begin{tabular}{|c|c|}
\hline Proposta & $\begin{array}{l}\text { Art. (a definir). A SECEX deverá elaborar parecer sobre a determinação preliminar de existência de dumping e consequente dano à } \\
\text { indústria doméstica. } \\
\S 1^{\circ} \text { A ausência de determinação preliminar positiva de dumping e consequente dano à indústria doméstica não enseja necessariamente o } \\
\text { término da investigação. } \\
\$ 2^{\circ} \mathrm{O} \text { ato que contenha a decisão de aplicação de medidas antidumping provisórias deverá ser publicado pela CAMEX no prazo de até } \\
\text { cento e vinte dias, contados da abertura da investigação. }\end{array}$ \\
\hline \multicolumn{2}{|r|}{ Artigo (a ser definido) } \\
\hline Proposta & $\begin{array}{l}\text { Das Determinações Preliminares e Das Medidas Antidumping Provisórias } \\
\text { Art. ( ) - A Secex formulará, em todas as investigações, determinação preliminar em prazo de até cento e vinte dias a contar da data de } \\
\text { abertura da investigação, onde as partes serão informadas sobre entendimento preliminar da Secex acerca da existência de dumping, dano } \\
\text { e nexo causal entre eles. O texto completo da versão pública do Parecer Preliminar será disponibilizado no endereço eletrônico do } \\
\text { Ministério do Desenvolvimento, Indústria e Comércio Exterior (MDIC). }\end{array}$ \\
\hline \multicolumn{2}{|r|}{ Artigo 31} \\
\hline $\begin{array}{l}\text { Redação } \\
\text { original }\end{array}$ & $\begin{array}{l}\text { Art. 31. Ao longo da investigação, as partes interessadas disporão de ampla oportunidade de defesa de seus interesses. Para essa } \\
\text { finalidade, caso haja solicitaçãa, dentro do prazo indicado no ato que contenha a determinação de abertura, serão realizadas audiências } \\
\text { onde será dada oportunidade para que as partes interessadas possam encontrar-se com aquelas que tenham interesses antagônicos, de } \\
\text { forma a que interpretações opostas e argumentação contrária possam ser expressas. } \\
\S 1^{\circ} \text { A parte que tenha solicitado a realização da audiência deverá fornecer, junto com a solicitação, a relação de aspectos específicos a } \\
\text { serem tratados. } \\
\S 2^{\circ} \text { As partes interessadas serão informadas da realização da audiência e dos aspectos a serem nela tratados, com antecedência mínima } \\
\text { de trinta dias. } \\
\S 3^{\circ} \text { Não existirá qualquer obrigatoriedade de comparecimento a tais audiências e a ausência de qualquer parte não poderá ser usada em } \\
\text { prejuízo de seus interesses. } \\
\S 4^{\circ} \text { As partes interessadas deverão indicar os representantes legais, que estarão presentes à audiência, até cinco dias antes de sua } \\
\text { realização, e enviar, por escrito, até dez dias antes da sua realização, os argumentos a serem apresentados na mesma. As partes } \\
\text { interessadas poderão, se devidamente justificado, apresentar informaçôes adicionais oralmente. } \\
\S 5^{\circ} \text { Somente serão levadas em consideração as informações fornecidas oralmente, caso sejam reproduzidas por escrito e colocadas à }\end{array}$ \\
\hline
\end{tabular}




\begin{tabular}{|c|c|}
\hline & $\begin{array}{l}\text { disposição das outras partes interessadas, no prazo de dez dias após a realização da audiência. } \\
\S 6^{\circ} \text { Será levada em consideração, porém, quando couber, a necessidade de ser preservado o sigilo e a conveniência das partes. } \\
\S 7^{\circ} \text { A realização de audiências não impedirá que a SECEX chegue a uma determinação preliminar ou final. }\end{array}$ \\
\hline Proposta 01 & $\begin{array}{l}\S 1^{\circ} \text { - Caso haja solicitação, dentro do prazo indicado no ato que contenha a determinação de abertura, serão realizadas audiências onde } \\
\text { será dada oportunidade para que as partes interessadas possam encontrar-se com aquelas que tenham interesses antagônicos, de forma a } \\
\text { que interpretações opostas e argumentação contrária possam ser expressas. } \\
\S 2^{\circ} \text { - A parte que tenha solicitado a realização da audiência deverá fornecer, junto com a solicitação, a relação de aspectos específicos a } \\
\text { serem tratados, observado o prazo máximo para apresentar questões preliminares conforme disposto no artigo } 29 \text {. } \\
\text { (...) } \\
\S 8^{\circ} \text { - A realização de audiência durante a fase de instrução do processo ocorrerá até } 240 \text { dias da data abertura da investigação. }\end{array}$ \\
\hline Proposta 02 & $\begin{array}{l}\S 4^{\circ} \text { As partes interessadas deverão indicar os representantes legais, que estarão presentes à audiência, até cinco dias antes de sua } \\
\text { realização, e enviar, por escrito, até quinze dias antes da sua realização, os argumentos a serem apresentados na mesma. As partes } \\
\text { interessadas poderão, se devidamente justificado, apresentar informaçôes adicionais oralmente. } \\
\S 5^{\circ} \text { Somente serão levadas em consideração as informações fornecidas oralmente Somente serão levadas em consideração as } \\
\text { informações fornecidas oralmente caso sejam reproduzidas por escrito e colocadas à disposição das outras partes interessadas no prazo } \\
\text { de dez dias após a realização da audiência. }\end{array}$ \\
\hline \multicolumn{2}{|r|}{ Artigo 32} \\
\hline $\begin{array}{l}\text { Redação } \\
\text { original }\end{array}$ & $\begin{array}{l}\text { Art. 32. As partes interessadas poderão solicitar, por escrito, vistas das informações constantes do processo, as quais serão prontamente } \\
\text { colocadas à disposição das partes que tenham feito tal solicitação, excetuadas as informações sigilosas e os documentos internos de } \\
\text { governo. Será dada oportunidade para que estas defendam seus interesses, por escrito, com base em tais informações. }\end{array}$ \\
\hline Proposta 01 & $\begin{array}{l}\text { As partes interessadas poderão solicitar, por escrito, vistas das informações constantes do processo, as quais serão prontamente } \\
\text { colocadas à disposição das partes que tenham feito tal solicitação, excetuadas as informações sigilosas e os documentos internos de } \\
\text { governo. Será dada oportunidade para que estas defendam seus interesses, por escrito, com base em tais informaçães. As vistas das } \\
\text { informações constantes do processo dar-se-ão por meio de cópia física ou acesso eletrônico administrado pela Secex. O acesso } \\
\text { eletrônico será feito mediante senha de acesso individual concedida apenas a partes interessadas, responsabilizando-se as mesmas pela } \\
\text { não divulgação de referida senha, sob pena de perder o direito de acompanhamento do processo por meio eletrônico no processo em } \\
\text { questão. }\end{array}$ \\
\hline
\end{tabular}




\section{Artigo 33}

\begin{tabular}{|c|c|}
\hline & $\begin{array}{l}\text { Art. 33. Antes de ser formulado o parecer com vistas à determinação final, será realizada audiência, convocada pela SECEX, onde as } \\
\text { partes interessadas serão informadas sobre os fatos essenciais sob julgamento que forma a base para seu parecer, deferindo-se ás partes } \\
\text { interessadas o prazo de quinze dias contados a partir da realização da audiência, para se manifestarem a respeito. } \\
\S 1^{\circ} \text { A Confederação Nacional da Agricultura (CNA), a Confederação Nacional da Indústria (CNI), a Confederação Nacional do } \\
\text { Comércio (CNC) e a Associação do Comércio Exterior Brasileiro (AEB) serão igualmente informadas sobre os fatos essenciais sob } \\
\text { julgamento que formam a base para o parecer da SECEX. } \\
\S 2^{\circ} \text { Findo o prazo previsto no caput, será considerada encerrada a instrução do processo e informações recebidas posteriormente não } \\
\text { serão consideradas para fins de determinação final. } \\
\S 3^{\circ} \text { Também se aplicam a este artigo as disposições previstas nos } \S \S 3^{\circ}, 4^{\circ}, 5^{\circ} \text { e } 6^{\circ} \text { do art. } 31 \text {. }\end{array}$ \\
\hline Proposta 01 & $\begin{array}{l}\text { Antes de ser formulado o parecer com vistas à determinação final, será realizada audiência final, convocada pela Secex, onde as partes } \\
\text { interessadas serão informadas através de uma Nota Técnica sobre os fatos essenciais sob julgamento que formarão a base para seu } \\
\text { parecer. } \\
\S 1^{\circ} \text { - As partes interessadas serão informadas da realização da audiência final com antecedência mínima de trinta dias. } \\
\S 2^{\circ} \text { - Não existirá qualquer obrigatoriedade de comparecimento a audiência final e a ausência de qualquer parte não poderá ser usada } \\
\text { em prejuízo de seus interesses. } \\
\S 3^{\circ} \text { Partes interessadas deverão indicar os representantes legais, que estarão presentes à audiência final, até cinco dias antes de sua } \\
\text { realização, e enviar, até dez dias antes de sua realização, documentos, dados, provas e/ou evidencias a serem consideradas no processo } \\
\text { de investigação. } \\
\S 4^{\circ} \text { - Somente serão levadas em consideração os argumentos fornecidos oralmente na audiência final, caso sejam reproduzidas por } \\
\text { escrito e colocadas à disposição das outras partes interessadas, no prazo de quinze dias após a realização da audiência. } \\
\S 5^{\circ} \text { - Será levada em consideração, porém, quando couber, a necessidade de ser preservado o sigilo e a conveniência das partes. } \\
\S 6^{\circ} \text { - A Confederação Nacional da Agricultura (CNA), a Confederação Nacional da Indústria (CNI), a Confederação Nacional do } \\
\text { Comércio (CNC) e a Associação do Comércio Exterior Brasileiro (AEB) serão igualmente informadas sobre os fatos essenciais sob } \\
\text { julgamento que formarão a base para o parecer da Secex. } \\
\S 7^{\circ} \text { Findo o prazo previsto no } \S 4^{\circ} \text {, será considerada encerrada a fase de instrução do processo e argumentos e manifestaçães recebidas } \\
\text { posteriormente não serão consideradas para fins de determinação final. }\end{array}$ \\
\hline
\end{tabular}




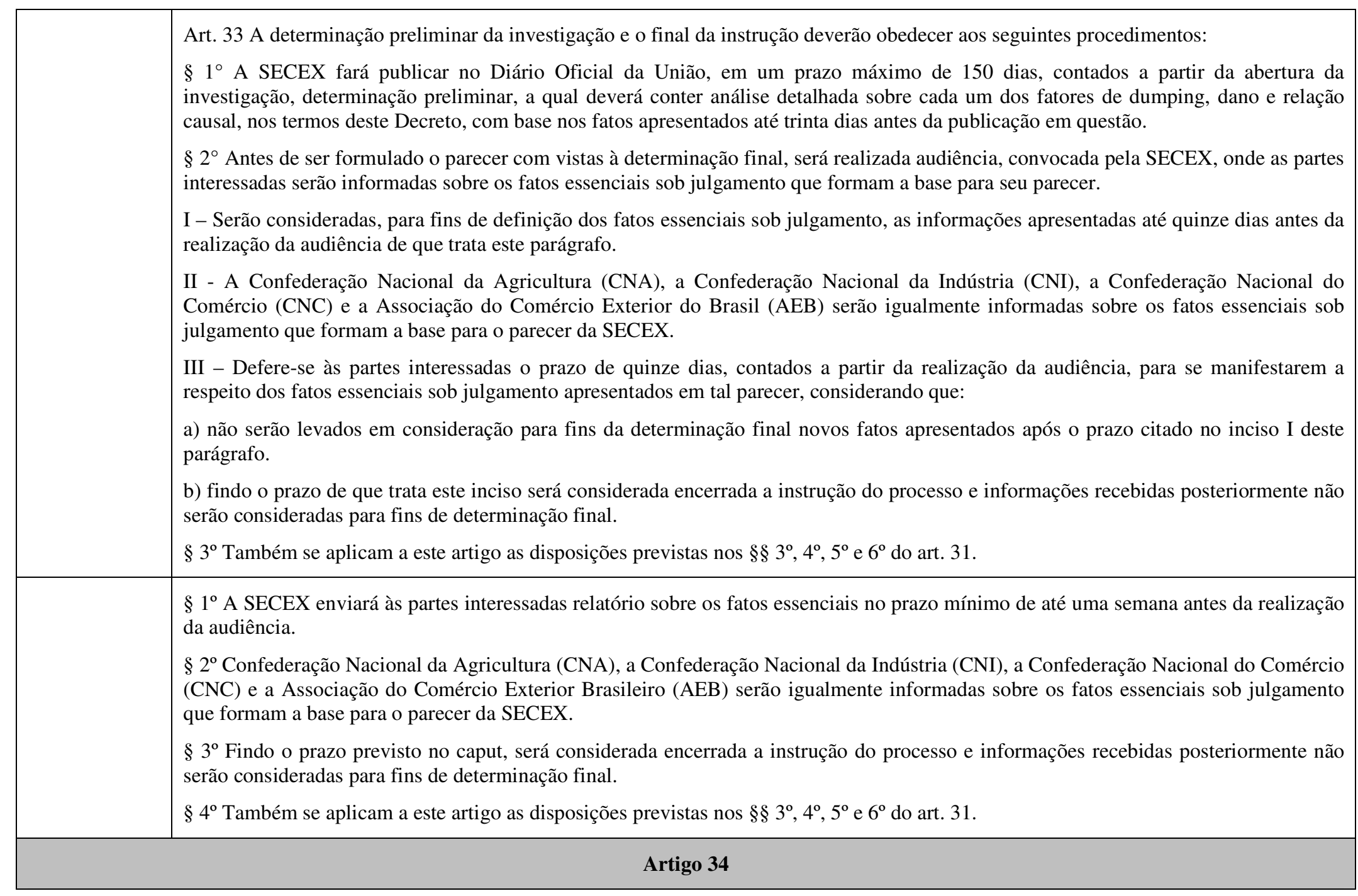




\begin{tabular}{|c|c|}
\hline $\begin{array}{l}\text { Redação } \\
\text { original }\end{array}$ & 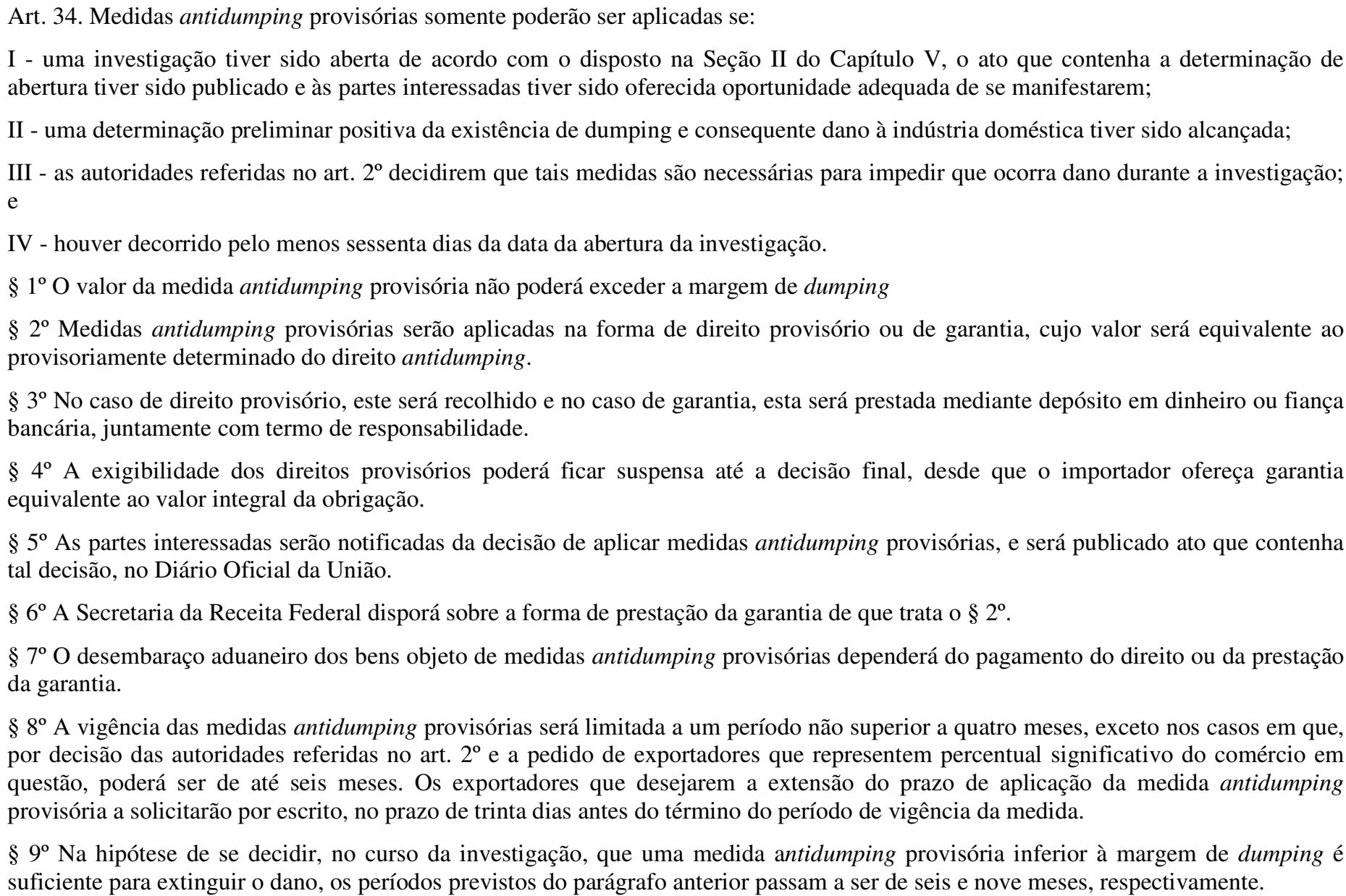 \\
\hline Proposta 01 & $\begin{array}{l}8^{\circ} \text { - A vigência das medidas antidumping provisórias será limitada a um período não superior a quatro meses, exceto nos casos em } \\
\text { le, por decisão das autoridades referidas no art. } 2^{\circ} \text { e a pedido de exportadores que representem percentual significativo do comércio }\end{array}$ \\
\hline
\end{tabular}




\begin{tabular}{|c|c|}
\hline & $\begin{array}{l}\text { em questão, poderá ser de até seis meses. Os exportadores que desejarem a extensão do prazo de aplicação da medida antidumping } \\
\text { provisória a solicitarão por escrito. }\end{array}$ \\
\hline Proposta 02 & $\begin{array}{l}\text { III - as autoridades referidas no parágrafo único do art. } 2^{\circ} \text { decidirem que tais medidas são necessárias para impedir que ocorra dano } \\
\text { durante a investigação; }\end{array}$ \\
\hline \multicolumn{2}{|r|}{ Artigo 35} \\
\hline $\begin{array}{l}\text { Redação } \\
\text { original }\end{array}$ & $\begin{array}{l}\text { Art. 35. Poderão ser suspensos os procedimentos sem prosseguimento de investigação e sem aplicação de medidas antidumping } \\
\text { provisórias ou direitos antidumping, se o exportador assumir voluntariamente compromissos satisfatórios de revisão dos preços ou de } \\
\text { cessação das exportações a preços de dumping, destinadas ao Brasil, desde que as autoridades referidas no art. } 2^{\circ} \text { fiquem convencidas } \\
\text { de que o mencionado compromisso elimina o efeito prejudicial decorrente do dumping. } \\
\S 1^{\circ} \text { O aumento de preço, ao amparo desses compromissos, não será superior ao necessário para eliminar a margem de dumping } \\
\text { podendo ser limitado ao necessário para cessar o dano causado à produção doméstica. } \\
\S 2^{\circ} \text { Os exportadores somente proporão compromissos de preços ou aceitarão aqueles propostos pela SECEX, após se haver chegado a } \\
\text { uma determinação preliminar positiva de dumping e dano por ele causado. } \\
\S 3^{\circ} \text { Os exportadores não estão obrigados a propor compromisso de preços, nem serão forçados a aceitar os oferecidos. Estes fatos não } \\
\text { prejudicarão a consideração do caso, nem alterarão a determinação preliminar a que se tiver chegado. } \\
\S 4^{\circ} \text { É facultado à SECEX o direito de recusar ofertas de compromissos de preços, se sua aceitação for considerada ineficaz. } \\
\S 5^{\circ} \text { No caso de recusa, e se possível serão fornecidas ao exportador as razões pelas quais foi julgada inadequada a aceitação do } \\
\text { compromisso, sendo-lhe oferecida oportunidade de manifestar-se. }\end{array}$ \\
\hline Proposta 01 & $\begin{array}{l}\S 2^{\circ} \text { - Os exportadores somente proporão compromissos de preços ou aceitarão aqueles propostos pela SECEX, desde que feitos durante } \\
\text { o período compreendido entre a publicação no Diário Oficial da União do ato que contenha a determinação preliminar positiva de } \\
\text { dumping e dano por ele causado e quinze dias após a realização da audiência final. }\end{array}$ \\
\hline
\end{tabular}




\begin{tabular}{|c|c|}
\hline Proposta 02 & $\begin{array}{l}\text { Art. 35. Poderão ser suspensos os procedimentos sem prosseguimento de investigação e sem aplicação de medidas antidumping } \\
\text { provisórias ou direitos antidumping definitivos, se o exportador assumir voluntariamente compromissos satisfatórios de revisão dos } \\
\text { preços ou de cessação das exportaçôes a preços de dumping, destinadas ao Brasil, desde que as autoridades referidas no art. } 2^{\circ} \text { fiquem } \\
\text { convencidas de que o mencionado compromisso elimina o efeito prejudicial decorrente do dumping. } \\
\S 6^{\circ} \text { A SECEX emitirá Circular com roteiro a respeito das informações que deverão ser necessariamente incluídas nos compromissos de } \\
\text { preços. (acrescentar) }\end{array}$ \\
\hline Proposta 03 & $\begin{array}{l}\S 6^{\circ} \text { Antes da decisão pelas autoridades referidas no art. } 2^{\circ} \text { quanto à aceitação ou recusa dos compromissos de preços propostos pelos } \\
\text { exportadores, a indústria doméstica deverá ser consultada para que se manifeste quanto a tais compromissos. }\end{array}$ \\
\hline \multicolumn{2}{|r|}{ Artigo 40} \\
\hline $\begin{array}{l}\text { Redação } \\
\text { original }\end{array}$ & $\begin{array}{l}\text { Art. 40. O peticionário poderá, a qualquer momento, solicitar o arquivamento do processo. Na hipótese de deferimento, a investigação } \\
\text { será encerrada. Caso a SECEX determine o prosseguimento da investigação, esta será comunicada por escrito, ao ato peticionário. }\end{array}$ \\
\hline Proposta 01 & Art. 40. 0 peticionário poderá, a qualquer momento, solicitar o arquivamento do processo \\
\hline \multicolumn{2}{|r|}{ Artigo 44} \\
\hline $\begin{array}{l}\text { Redação } \\
\text { original }\end{array}$ & $\begin{array}{l}\text { Art. 44. O ato que contenha a determinação ou a decisão de encerrar a investigação, nos casos previstos nesta Seção, será publicado no } \\
\text { Diário Oficial da União. As partes interessadas serão notificadas sobre o encerramento da investigação. } \\
\text { Parágrafo único. No caso de decisão de encerramento com aplicação de direitos antidumping, o ato que contenha tal decisão deverá } \\
\text { indicar o fornecedor ou fornecedores do produto em questão, com os direitos que lhes correspondam. No caso de o número de } \\
\text { fornecedores ser especialmente alto, o ato conterá o nome dos países fornecedores envolvidos, com os respectivos direitos. }\end{array}$ \\
\hline Proposta 01 & $\begin{array}{l}\text { Art. } 44 \text { - O ato que contenha a determinação ou a decisão de encerrar a investigação, nos casos previstos nesta Seção, será publicado no } \\
\text { Diário Oficial da União. As partes interessadas serão notificadas sobre o encerramento da investigação, e o texto completo da versão } \\
\text { pública do Parecer Final será disponibilizado imediatamente no endereço eletrônico do Ministério do Desenvolvimento, Indústria e } \\
\text { Comércio Exterior (MDIC). }\end{array}$ \\
\hline \multicolumn{2}{|r|}{ Artigo 45} \\
\hline Redação & Art. 45. Para os efeitos deste Decreto, a expressão "direito antidumping" significa um montante em dinheiro igual ou inferior à margem \\
\hline
\end{tabular}




\begin{tabular}{|c|c|}
\hline original & $\begin{array}{l}\text { de dumping apurada, calculado e aplicado, em conformidade com este artigo, com o fim exclusivo de neutralizar os efeitos danosos das } \\
\text { importações objeto de dumping. } \\
\S 1^{\circ} \text { O direito antidumping será calculado mediante§ a aplicação de alíquotas ad valorem ou e specíficas, fixas ou variáveis, ou pela } \\
\text { conjugação de ambas. } \\
\S 2^{\circ} \text { A alíquota ad valorem será aplicada sobre o valor da mercadoria, em base CIF, apurado nos termos da legislação pertinente. } \\
\S 3^{\circ} \text { A alíquota específica será fixada em dólares dos Estados Unidos da América e convertida em moeda em moeda nacional, nos } \\
\text { termos da legislação pertinente. }\end{array}$ \\
\hline Proposta 01 & $\begin{array}{l}\text { Art. } 45 \text { - Para os efeitos deste Decreto, a expressão "direito antidumping" significa um montante em dinheiro igual ou inferior à margem } \\
\text { de dumping apurada, calculado e aplicado, em conformidade com este artigo, com o fim de neutralizar os efeitos danosos das } \\
\text { importações objeto de dumping. } \\
\S 1^{\circ} \text { - O direito antidumping será calculado mediante a aplicação de alíquotas ad valorem ou específicas, fixas ou variáveis, ou pela } \\
\text { conjugação de ambas. } \\
\S 2^{\circ} \text { - A alíquota ad valorem será aplicada sobre o valor da mercadoria, apurado nos termos da legislação pertinente. } \\
\S 3^{\circ} \text { - A alíquota específica será fixada em dólares dos Estados Unidos da América e convertida em moeda nacional, nos termos da } \\
\text { legislação pertinente. }\end{array}$ \\
\hline Proposta 02 & $\begin{array}{l}1^{\circ} \text { O direito antidumping será calculado mediante a aplicação de alíquotas ad valorem ou específicas, fixas ou variáveis, ou pela } \\
\text { conjugação de ambas, sendo permitido ao peticionário sugerir, no curso do procedimento, a forma de aplicação do direito antidumping } \\
\text { que considere mais apropriada para fins de neutralização do efeito danoso das importações objeto de dumping. } \\
4^{\circ} \text { A aplicação do direito antidumping de que trata este artigo poderá ser estendida a importações de produtos de terceiros países, bem } \\
\text { como a partes, peças e componentes do produto objeto de medidas vigentes, caso seja constatada a existência de práticas elisivas que } \\
\text { frustrem a aplicação do direito antidumping em vigor. } \\
\text { I - A extensão de que trata este parágrafo terá por finalidade assegurar efetividade aos direitos antidumping em vigor e poderá incidir } \\
\text { sobre: } \\
\text { a) produto igual sob todos os aspectos ao produto objeto do direito antidumping ou a outro produto que, embora não exatamente igual, } \\
\text { apresente características muito próximas às do produto sujeito à aplicação do direito antidumping; e/ou } \\
\text { b) partes, peças e componentes do produto de que trata o item "a", assim considerados as matérias primas, os produtos intermediários e } \\
\text { quaisquer outros bens empregados na industrialização do produto. }\end{array}$ \\
\hline
\end{tabular}




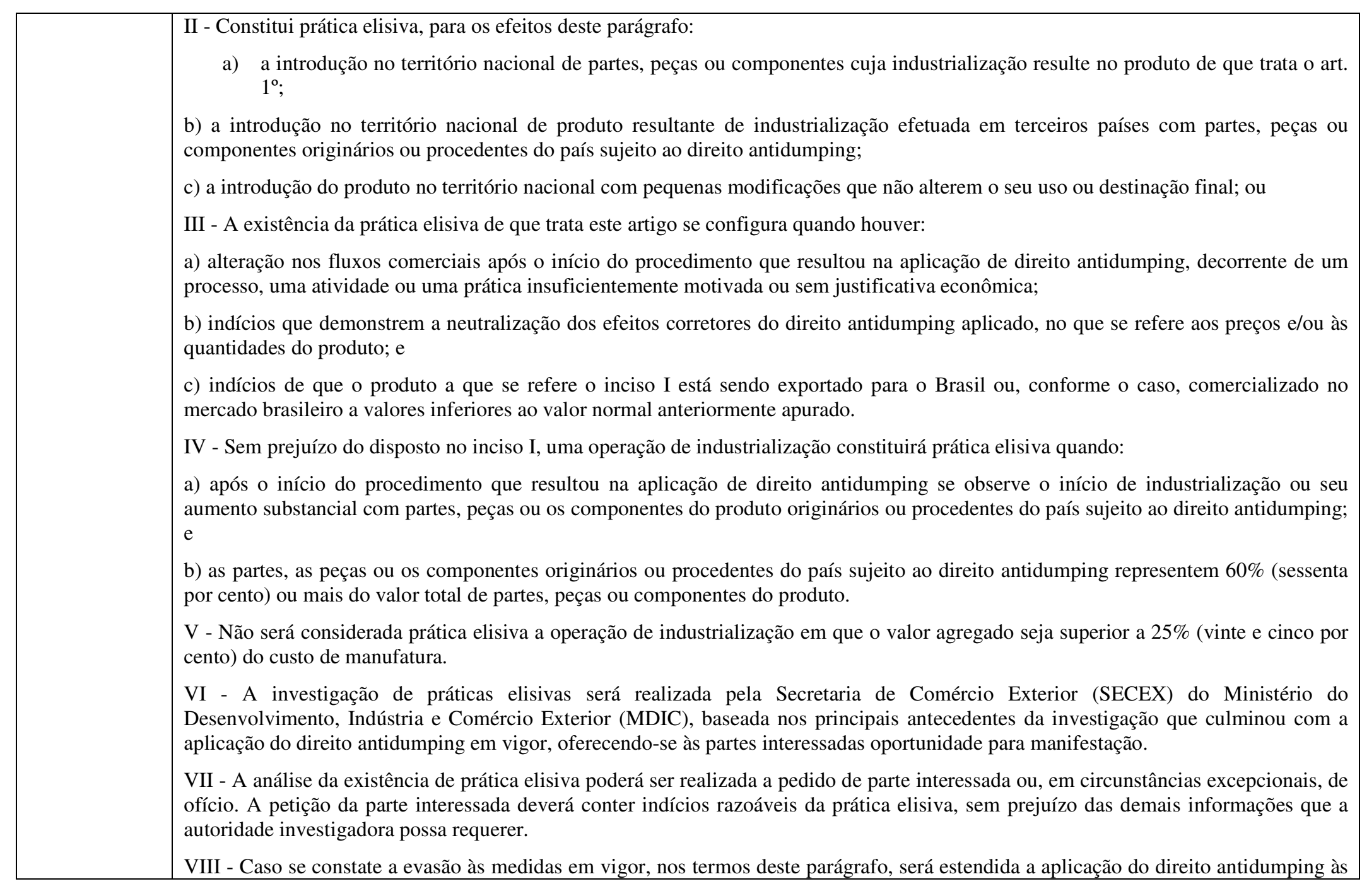




\begin{tabular}{|c|c|}
\hline & $\begin{array}{l}\text { importações de partes, componentes e/ou produtos idênticos ou similares substitutos objeto da revisão, mesmo que classificados em } \\
\text { posição tarifária distinta e/ou procedentes de terceiro país, bem como será cobrado o valor relativo ao direito antidumping sobre tais } \\
\text { importações realizadas entre a data em que entrou em vigor o direito antidumping objeto da evasão e o final do processo de revisão. } \\
\text { IX - Em caso de conflito entre as regras determinadas neste parágrafo e aquelas constantes em Regime de Origem em acordos } \\
\text { preferenciais, prevalecerão as primeiras. }\end{array}$ \\
\hline Proposta 03 & $\begin{array}{l}\text { Art. 45. Para os efeitos deste Decreto, a expressão "direito antidumping" significa um montante em dinheiro igual ou inferior à margem } \\
\text { de dumping apurada, calculado e aplicado, em conformidade com este artigo, com o fim exclusivo de neutralizar os efeitos danosos das } \\
\text { importações objeto de dumping. } \\
\text { (...) } \\
\S \text { (a definir) O direito antidumping será aplicado, preferencialmente, em montante equivalente à totalidade da margem de dumping. } \\
\S \text { (a definir) Excepcionalmente, e mediante decisão devidamente justificada, o direito antidumping poderá ser aplicado em montante } \\
\text { inferior à totalidade da margem de dumping, desde que suficiente para neutralizar os efeitos danosos à indústria doméstica das } \\
\text { importações objeto de dumping. } \\
\S \text { (a definir) A decisão a que se refere o parágrafo anterior poderá levar em consideração as políticas comerciais, bem como as práticas } \\
\text { de defesa comercial, adotadas por outros membros da Organização Mundial do Comércio e que afetam ou possam afetar as exportações } \\
\text { brasileiras. } \\
\S 1^{\circ} \text { O direito antidumping será calculado mediante a aplicação de alíquotas ad valorem ou específicas, fixas ou variáveis, ou pela } \\
\text { conjugação de ambas. } \\
\S 2^{\circ} \text { O peticionário poderá indicar, no curso do procedimento, a forma de aplicação do direito antidumping que considera mais } \\
\text { apropriada para a eliminação dos efeitos danosos das importações objeto de dumping, conforme o } \S 1^{\circ} \text { acima. } \\
\S 3^{\circ} \text { A decisão referida no art. } 2^{\circ} \text { sobre a forma de aplicação do direito deverá ser justificada, levando em consideração a manifestação } \\
\text { do peticionário e os fatos sob análise na investigação. } \\
\S 4^{\circ} \text { A alíquota ad valorem será aplicada sobre o valor da mercadoria, em base CIF, apurado nos termos da legislação pertinente. } \\
\S 5^{\circ} \text { A alíquota específica será fixada em dólares dos Estados Unidos da América e convertida em moeda em moeda nacional, nos } \\
\text { termos da legislação pertinente. }\end{array}$ \\
\hline \multicolumn{2}{|r|}{ Artigo (a ser definido) } \\
\hline Proposta & direitos antidumping provisórios o \\
\hline
\end{tabular}




\begin{tabular}{|c|c|}
\hline & $\begin{array}{l}\text { definitivos, ou a compromissos de preços, serão submetidas ao Licenciamento Não Automático. } \\
\text { Parágrafo único. A análise e emissão das licenças não automáticas a que se referem o caput acima deverão ser realizadas, de maneira } \\
\text { indelegável, pela SECEX, sem prejuízo da intervenção de outros órgãos anuentes. }\end{array}$ \\
\hline \multicolumn{2}{|r|}{ Artigo 48} \\
\hline $\begin{array}{l}\text { Redação } \\
\text { original }\end{array}$ & $\begin{array}{l}\text { Art. 48. Quando um direito antidumping for aplicado sobre um produto, este será cobrado, independentemente de quaisquer obrigações } \\
\text { de natureza tributária relativas à sua importação, nos valores a cada ano, sem discriminação, sobre todas as importações do produto que } \\
\text { tenham sido consideradas como efetuadas a preços de dumping e danosas à indústria doméstica, qualquer que seja sua procedência. } \\
\text { Parágrafo único. Não serão cobrados direitos sobre aquelas importações procedentes exportadores com os quais tenham sido acordados } \\
\text { compromissos de preços. }\end{array}$ \\
\hline Proposta 01 & $\begin{array}{l}\text { Art. } 48 \text { - Respeitada a competência da receita Federal para esclarecimento de dúvidas acerca da correta classificação de mercadorias, } \\
\text { qualquer interessado, entendido como pessoa física ou jurídica, nacional ou estrangeira, desde que tenha sido parte interessada no } \\
\text { processo ou que guarde relação com o produto em questão ou seus produtores, poderá formular à Secex consulta se determinado } \\
\text { produto encontra-se ou não incluído dentro do escopo de direito antidumping em vigor, provisório ou definitivo. Em caso de resposta } \\
\text { positiva, a indústria doméstica deverá ser ouvida. Referida consulta deverá ser respondida pela Secex dentro de trinta dias a contar de } \\
\text { seu protocolo junto à Secex e, caso haja a participação da indústria doméstica, dentro de quarenta e cinco dias a contar de seu protocolo. }\end{array}$ \\
\hline Proposta 02 & $\begin{array}{l}\S 1^{\circ} \text { Não serão cobrados direitos sobre aquelas importações procedentes de exportadores com os quais tenham sido acordados } \\
\text { compromissos de preços. } \\
\S 2^{\circ} \text { O cumprimento das obrigações resultantes da aplicação dos direitos antidumping, sejam definitivos ou provisórios, será condição } \\
\text { para a introdução no comércio do País de produtos objeto de dumping. } \\
\S 3^{\circ} \text { Será competente para a cobrança dos direitos antidumping, provisórios ou definitivos, quando se tratar de valor em dinheiro, bem } \\
\text { como, se for o caso, para sua restituição, a Secretaria da Receita Federal do Brasil-RFB do Ministério da Fazenda. } \\
\S 4^{\circ} \text { Verificado inadimplemento da obrigação, a Secretaria da Receita Federal do Brasil-RFB encaminhará a documentação pertinente à } \\
\text { Procuradoria-Geral da Fazenda Nacional para inscrição do débito em Dívida Ativa da União e respectiva cobrança }\end{array}$ \\
\hline \multicolumn{2}{|r|}{ Artigo 54} \\
\hline $\begin{array}{l}\text { Redação } \\
\text { original }\end{array}$ & $\begin{array}{l}\text { Art. 54. Direitos antidumping definitivos poderão ser cobrados sobre produtos importados, objeto de dumping, que tenham sido } \\
\text { despachados para consumo, até noventa dias antes da data de aplicação das medidas antidumping provisórias, sempre que se determine, }\end{array}$ \\
\hline
\end{tabular}




\begin{tabular}{|c|c|}
\hline & $\begin{array}{l}\text { com relação ao produto em questão, que: } \\
\text { I - há antecedentes de dumping causador de dano, ou que o importador estava ou deveria estar ciente, de que o produtor ou exportador } \\
\text { pratica dumping e de que este causaria dano; e } \\
\text { II - o dano é causado por volumosas importações de um produto a preços de dumping em período relativamente curto, o que, levando } \\
\text { em conta o período em que foram efetuadas e o volume das importaçóes objeto de dumping e também o rápido crescimento dos } \\
\text { estoques do produto importado, levará provavelmente a prejudicar seriamente o efeito corretivo dos direitos antidumping definitivos } \\
\text { aplicáveis, desde que tenha sido dada aos importadores envolvidos a oportunidade de se manifestar sobre a medida; } \\
\text { Parágrafo único. Não serão cobrados sobre produtos que tenham sido despachados para consumo antes da data de abertura da } \\
\text { investigação. }\end{array}$ \\
\hline Proposta 01 & $\begin{array}{l}\text { Artigo 54: Direitos antidumping definitivos poderão ser cobrados sobre produtos importados, objeto de dumping, que tenham sido } \\
\text { despachados para consumo, até noventa dias antes da data de aplicação das medidas antidumping provisórias, sempre que se determine, } \\
\text { com relação ao produto em questão, que: } \\
\text { I - há antecedentes de dumping causador de dano, ou que o importador estava ou deveria estar ciente, de que o produtor ou exportador } \\
\text { pratica dumping e de que este causaria dano; e } \\
\text { II - o dano é causado por volumosas importações de um produto a preços de dumping em período relativamente curto, o que, levando } \\
\text { em conta o período em que foram efetuadas e o volume das importaçôes objeto de dumping e também o rápido crescimento dos } \\
\text { estoques do produto importado, levará provavelmente a prejudicar seriamente o efeito corretivo dos direitos antidumping definitivos } \\
\text { aplicáveis, desde que tenha sido dada aos importadores envolvidos a oportunidade de se manifestar sobre a medida. } \\
\S 1^{\circ} \text { Para fins de aplicação do disposto neste artigo, será considerado que: } \\
\text { a) há antecedentes de dumping causador de dano, quando os produtos importados objeto de dumping foram objeto de medida } \\
\text { antidumping, provisória ou definitiva, aplicada no Brasil ou quando os produtos importados objeto de dumping são ou foram objeto de } \\
\text { medida antidumping, provisória ou definitiva, aplicada em terceiro país; e } \\
\text { b) o importador estava ou deveria estar ciente de que o produtor ou exportador pratica dumping e de que este causaria dano, quando a } \\
\text { data do conhecimento de embarque dos produtos importados a preços de dumping for posterior à data da publicação da Circular SECEX } \\
\text { que deu início à investigação. } \\
\S 3^{\circ} \text { Os fatores que levaram à conclusão quanto à existência de volumosas importações de um produto a preços de dumping em período } \\
\text { relativamente curto constarão da Resolução CAMEX que determinar a cobrança retroativa de direitos antidumping. } \\
\S 4^{\circ} \text { Não serão cobrados direitos sobre produtos que tenham sido despachados para consumo antes da data de abertura da investigação. } \\
\S 5^{\circ} \text { Para fins de não pagamento do direito em decorrência do disposto do inciso II, cabe ao importador comprovar, junto à Secretaria da }\end{array}$ \\
\hline
\end{tabular}




\begin{tabular}{|c|c|}
\hline & $\begin{array}{l}\text { Receita Federal do Brasil (RFB), que a data do conhecimento de embarque é anterior à data da publicação da Circular SECEX que deu } \\
\text { início à investigação. } \\
\S 6^{\circ} \text { A decisão sobre a cobrança retroativa do direito antidumping pela Câmara de Comércio Exterior-CAMEX será instruída por } \\
\text { parecer da Secretaria de Comércio Exterior-SECEX, conforme disposto no art. } 20 \text { deste Decreto. }\end{array}$ \\
\hline & 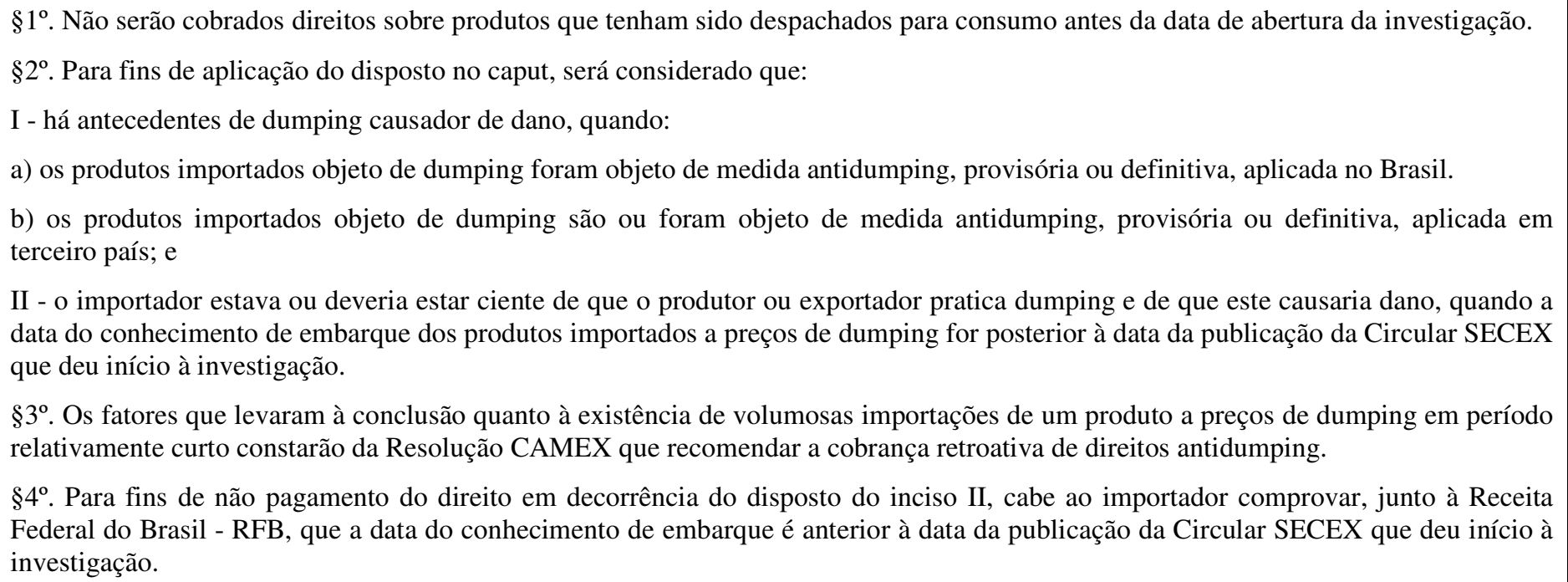 \\
\hline Proposta 02 & Considerar a inclusão das demais disposições da Resolução CAMEX $n^{\circ}$ 64/2011, referente a direitos antidumping retroativos. \\
\hline \multicolumn{2}{|r|}{ Artigo (a ser definido) } \\
\hline Proposta & $\begin{array}{l}\text { Art. (a definir). As importações realizadas por meio de classificação fiscal do produto sujeito a direitos antidumping provisórios ou } \\
\text { definitivos, ou a compromissos de preços, que apresentarem indícios de fraude serão incluídas no canal cinza de conferência aduaneira. } \\
\text { Parágrafo único: O canal cinza de conferência aduaneira também será aplicado para as importações com indícios de falsa classificação } \\
\text { fiscal envolvendo produtos sujeitos a direitos antidumping. }\end{array}$ \\
\hline & Artigo 57 \\
\hline
\end{tabular}




\begin{tabular}{|c|c|}
\hline $\begin{array}{l}\text { Redação } \\
\text { original }\end{array}$ & $\begin{array}{l}\text { Art. } 57 \text {. Todo direito antidumping definitivo será extinto no máximo em cinco anos após a sua aplicação, ou cinco anos a contar da data } \\
\text { da conclusão da mais recente revisão, que tenha abrangido dumping e dano dele decorrente. } \\
\S 1^{\circ} \text { O prazo de aplicação de que trata o caput deste artigo poderá ser prorrogado mediante requerimento, devidamente fundamentado, } \\
\text { formulado pela indústria doméstica ou em seu nome, por iniciativa de órgãos ou entidades da Administração Pública Federal, ou da } \\
\text { SECEX, desde que demonstrado que a extinção dos direitos levaria muito provavelmente à continuação ou retomada do dumping e do } \\
\text { dano dele decorrente. } \\
\S 2^{\circ} \text { As partes interessadas terão prazo de cinco meses antes da data do término da vigência de que trata o caput, para se manifestarem, } \\
\text { por escrito, sobre a conveniência de uma revisão para solicitarem audiência se necessário. } \\
\S 3^{\circ} \text { A revisão seguirá o disposto na Seção III do Capítulo V deverá ser concluída no prazo de doze meses contados a partir da data de } \\
\text { sua abertura. Os atos que contenham a determinação de abertura e de encerramento da revisão serão publicados no Diário Oficial da } \\
\text { União e as partes interessadas conhecidas notificadas. } \\
\S 4^{\circ} \text { Os direitos serão mantidos em vigor, enquanto perdurar a revisão. } \\
\S 5^{\circ} \text { O disposto neste artigo aplica-se aos compromissos de preços aceitos na forma do art. } 35 \text {. }\end{array}$ \\
\hline Proposta 01 & $\begin{array}{l}\S 2^{\circ} \text { As partes interessadas na revisão deverão: } \\
\text { a) se manifestar por escrito, no prazo de cinco meses antes da data do término da vigência de que trata o caput, sobre a conveniência de } \\
\text { uma revisão; e } \\
\text { b) apresentar o requerimento de que trata o } \S 1^{\circ} \text { com antecedência de no mínimo noventa dias da data do término da vigência de que } \\
\text { trata o caput. }\end{array}$ \\
\hline \multicolumn{2}{|r|}{ Artigo 58} \\
\hline $\begin{array}{l}\text { Redação } \\
\text { original }\end{array}$ & $\begin{array}{l}\text { Art. 58. Proceder-se-á a revisão, no todo ou em parte, das decisões relativas à aplicação de direito antidumping, a pedido de parte } \\
\text { interessada ou por iniciativa de órgão ou entidade da Administração Pública Federal, ou da SECEX, desde que haja decorrido, no } \\
\text { mínimo, um ano da imposição de direitos antidumping definitivos e que sejam apresentados elementos de prova suficientes de que: } \\
\text { I - aplicação do direito deixou de ser necessária para neutralizar o dumping; } \\
\text { II - seria improvável que o dano subsistisse ou se reproduzisse caso o direito fosse revogado ou alterado; ou } \\
\text { III - o direito existente não é ou deixou de ser suficiente para neutralizar o dumping causador de dano. } \\
\S 1^{\circ} \text { Em caso excepcionais de mudanças substanciais das circunstâncias, ou quando for de interesse nacional, poderão ser efetuadas }\end{array}$ \\
\hline
\end{tabular}




\begin{tabular}{|c|c|}
\hline & $\begin{array}{l}\text { revisões em intervalo menor, por requerimento de parte interessada ou de órgãos ou entidades da Administração Pública Federal, ou } \\
\text { iniciativa do órgão investigador. } \\
\S 2^{\circ} \text { Constatada a existência de elementos de prova que justifiquem a revisão, esta será aberta e o ato que contenha tal determinação será } \\
\text { publicado no Diário Oficial da União e as partes interessadas conhecidas notificadas. } \\
\S 3^{\circ} \text { A revisão deverá ser concluída no prazo de doze meses contados a partir de sua abertura e seguirá o disposto na Seção III do } \\
\text { Capítulo V. } \\
\S 4^{\circ} \text { Enquanto não for concluída a revisão, os direitos não serão alterados e permanecerão em vigor até o final da revisão. } \\
\S 5^{\circ} \text { As autoridades referidas no art. } 2^{\circ} \text {, com base no resultado e de conformidade com as provas colhidas no curso da revisão, poderão } \\
\text { extinguir, manter ou alterar o direito antidumping Caso se constate que o direito em vigor é superior ao necessário para neutralizar o } \\
\text { dano à indústria doméstica ou não mais se justifica, será determinada a devida restituição. } \\
\S 6^{\circ} \text { O ato que contenha a decisão de encerramento da revisão será publicado no Diário Oficial da União e as partes interessadas } \\
\text { conhecidas notificadas. } \\
\S 7^{\circ} \text { O disposto neste artigo aplica-se aos compromissos de preço aceitos na forma do art. } 35 \text {. }\end{array}$ \\
\hline Proposta 01 & $\begin{array}{l}\S 5^{\circ} \text { As autoridades referidas no art. } 2^{\circ} \text {, com base no resultado e de conformidade com as provas colhidas no curso da revisão, poderão } \\
\text { extinguir, manter ou alterar o direito antidumping. }\end{array}$ \\
\hline Proposta 02 & $\begin{array}{l}\S 6^{\circ} \text { A Receita Federal do Brasil - RFB regulamentará o processo de restituição de que trata o } \S 5^{\circ} \text {. } \\
\S 7^{\circ} \mathrm{O} \text { ato que contenha a decisão de encerramento da revisão será publicado no Diário Oficial da União e as partes interessadas } \\
\text { conhecidas notificadas. } \\
\S 8^{\circ} \mathrm{O} \text { disposto neste artigo aplica-se aos compromissos de preço aceitos na forma do art. } 35 \text {. }\end{array}$ \\
\hline \multicolumn{2}{|r|}{ Artigo (a definir) } \\
\hline Proposta & $\begin{array}{l}\text { Art. (a definir) Quaisquer atos e termos processuais previstos neste Decreto poderão ser praticados sob a forma eletrônica, podendo os } \\
\text { documentos eletrônicos ser transmitidos até às } 24 \text { horas das respectivas datas limites de envio. } \\
\text { Parágrafo Único. Cabe à SECEX disciplinar a forma de aplicação do disposto no caput. }\end{array}$ \\
\hline \multicolumn{2}{|r|}{ Artigo 59} \\
\hline Redação & rt. 59. Quando um produto estiver sujeito a direitos antidumping, proceder-se-á, caso solicitado, de imediato, revisão sumária com \\
\hline
\end{tabular}




\begin{tabular}{|c|c|}
\hline original & $\begin{array}{l}\text { vistas a determinar, de forma acelerada, margens individuais de dumping para quaisquer exportadoras ou produtores do país exportador } \\
\text { em questão, que não tenham exportado o produto para o Brasil durante o período da investigação, desde que esses exportadores ou } \\
\text { produtores possam demonstrar não ter relação com os exportadores ou produtores no país exportador sujeitos aos direitos antidumping } \\
\text { aplicados sobre seu produto. } \\
\S 1^{\circ} \text { Não serão cobrados direitos antidumping sobre as importações originárias de exportadores ou produtores referidos no caput deste } \\
\text { artigo, durante a realização da revisão sumária. } \\
\S 2^{\circ} \text { Iniciada a revisão SECEX comunicará à Secretaria da Receita Federal para que adote as providências cabíveis que possibilitem, no } \\
\text { caso, de determinação positiva de dumping, a cobrança de direitos antidumping sobre as importações originárias dos produtores ou } \\
\text { exportadores em questão, a partir da data em que se iniciou a revisão sumária. }\end{array}$ \\
\hline Proposta 01 & $\begin{array}{l}\text { [Nota: Revisão sumária precisa ser amplamente regulamentada, com indicação dos requisitos da petição e do detalhamento do } \\
\text { procedimento.] }\end{array}$ \\
\hline Proposta 02 & $\begin{array}{l}\S 2^{\circ} \text { Iniciada a revisão, a SECEX comunicará à Secretaria da Receita Federal do Brasil (RFB) para que adote as providências cabíveis } \\
\text { que possibilitem, no caso de determinação positiva de dumping, a cobrança de direitos antidumping sobre as importações originárias } \\
\text { dos produtores ou exportadores em questão, a partir da data em que se iniciou a revisão sumária. }\end{array}$ \\
\hline \multicolumn{2}{|r|}{ Artigo 61} \\
\hline $\begin{array}{l}\text { Redação } \\
\text { original }\end{array}$ & $\begin{array}{l}\text { Art. 61. Os atos decorrentes das decisões das autoridades referidas no art. } 2^{\circ} \text { e das determinações da SECEX serão publicadas no Diário } \\
\text { Oficial da União e conterão informação detalhada das conclusões estabelecidas sobre cada matéria de fato e de direito considerado } \\
\text { pertinente. } \\
\text { Parágrafo único. Para fins que de notificação, cópia dos atos mencionados no caput deste artigo será encaminhada ao governo do país } \\
\text { ou países exportadores dos produtos que tenham sido objeto de investigação e, também as outras partes interessadas conhecidas. }\end{array}$ \\
\hline Proposta 01 & $\begin{array}{l}\S 1^{\circ} \text { - Parágrafo único - Para fins que de notificação, cópia dos atos mencionados no caput deste artigo será encaminhada ao governo do } \\
\text { país ou países exportadores dos produtos que tenham sido objeto de investigação e, também as outras partes interessadas conhecidas. } \\
\S 2^{\circ} \text { - O texto completo da versão pública dos Pareceres que servirem de base para os atos publicados no Diário Oficial da União } \\
\text { referidos no caput deste artigo será disponibilizado no endereço eletrônico do Ministério do Desenvolvimento, Indústria e Comércio } \\
\text { Exterior (MDIC) tão logo o ato seja publicado. }\end{array}$ \\
\hline & Artigo 64 \\
\hline
\end{tabular}




\begin{tabular}{|c|c|}
\hline $\begin{array}{l}\text { Redação } \\
\text { original }\end{array}$ & $\begin{array}{l}\text { Art. 64. As determinações ou decisões, preliminares ou finais, relativas à investigação, serão adotadas com base em parecer da SECEX. } \\
\S 1^{\circ} \text { No prazo de vinte dias contados da data do recebimento do parecer pelo Secretário de Comércio Exterior, a SECEX publicará ato } \\
\text { que contenha a determinação de abertura de investigação, prorrogação de prazo de investigação, arquivamento do processo a pedido do } \\
\text { peticionário, início do processo de revisão do direito definitivo ou de compromissos de preços ou encerramento da investigação sem } \\
\text { aplicação de medidas. } \\
\S 2^{\circ} \text { No prazo de dez dias contados da data do recebimento do parecer, pelos Ministros de Estado da Indústria, do Comércio e do } \\
\text { Turismo e da Fazenda será publicado ato que contenha a decisão de aplicação de medidas antidumping provisórias, prorrogação das } \\
\text { medidas, aceitação ou término de compromissos de preços, encerramento da investigação com aplicação de direitos, suspensão dos } \\
\text { direitos definitivos, ou o resultado da revisão dos direitos definitivos ou compromissos de preços. } \\
\S 3^{\circ} \text { Em circunstâncias excepcionais, mesmo havendo comprovação de dumping e de dano dele decorrente, as autoridades referidas no } \\
\text { art. } 2^{\circ} \text { poderão decidir, por razões de interesse nacional, pela suspensão da aplicação do direito ou pela não homologação de } \\
\text { compromissos de preços, ou, ainda, respeitado o disposto no parágrafo único do art. } 42 \text {, pela aplicação de direito em valor diferente do } \\
\text { que o recomendado, e, neste caso, o ato deverá conter as razões que fundamentaram tal decisão. }\end{array}$ \\
\hline Proposta 01 & $\begin{array}{l}\text { Art. } 64 \text { - As determinaçães ou decisões, preliminares ou finais, relativas à investigação, serão adotadas com base em parecer da Secex. } \\
\text { O texto completo da versão pública do Parecer da Secex será disponibilizado no endereço eletrônico do Ministério do } \\
\text { Desenvolvimento, Indústria e Comércio Exterior (MDIC). } \\
\S 1^{\circ} \text { - No prazo de vinte dias contados da data do recebimento do parecer pelo Secretário de Comércio Exterior, a Secex publicará ato } \\
\text { que contenha a determinação de abertura de investigação, prorrogação de prazo de investigação, arquivamento do processo a pedido do } \\
\text { peticionário, início do processo de revisão do direito definitivo ou de compromissos de preços ou encerramento da investigação sem } \\
\text { aplicação de medidas. } \\
\S 2^{\circ} \text { - No prazo de vinte dias contados da data do recebimento do parecer da Secex, pelos Ministros que compõem a Câmara de } \\
\text { Comércio Exterior (CAMEX)de Estado da Indústria, do Comércio e do Turismo e da Fazenda será publicado ato que contenha a } \\
\text { decisão de aplicação de medidas antidumping provisórias, prorrogação das medidas, aceitação ou término de compromissos de preços, } \\
\text { encerramento da investigação com aplicação de direitos, suspensão de direitos definitivos, ou o resultado da revisão dos direitos } \\
\text { definitivos ou compromissos de preços. } \\
\S 3^{\circ} \text { - As partes interessadas poderão ter ciência das datas em que se realizarão as reuniões na Câmara de Comércio Exterior (CAMEX) } \\
\text { nas quais o parecer Secex será discutido, para que possam defender seus interesses e, se aplicável, apresentar os esclarecimentos } \\
\text { necessários. } \\
\S 4^{\circ} \text { - Em circunstâncias excepcionais, mesmo havendo comprovação de dumping e de dano dele decorrente, as autoridades referidas no } \\
\text { art. } 2^{\circ} \text { poderão decidir, por razões de interesse nacional, pela suspensão da aplicação do direito ou pela não homologação de }\end{array}$ \\
\hline
\end{tabular}




\begin{tabular}{|c|c|}
\hline & $\begin{array}{l}\text { compromissos de preços, ou, ainda, respeitado o disposto no parágrafo único do art. } 42 \text {, pela aplicação de direito em valor diferente do } \\
\text { que o recomendado, e, neste caso, o ato deverá conter as razões que fundamentaram tal decisão. } \\
\S 5^{\circ} \text { - Os pedidos de suspensão da aplicação de direito, não homologação de compromissos de preços ou da aplicação de direito em } \\
\text { valor diferente do que o recomendado por razões de interesse nacional serão protocolizados na Câmara de Comércio Exterior } \\
\text { (CAMEX). } \\
\S 6^{\circ} \text { - No caso de pedidos de suspensão da aplicação de direito, não homologação de compromissos de preços ou da aplicação de direito } \\
\text { em valor diferente do que o recomendado por razões de interesse nacional, o texto completo da versão pública dos referidos pedidos } \\
\text { serão disponibilizados no endereço eletrônico do Ministério do Desenvolvimento, Indústria e Comércio Exterior (MDIC) } \\
\text { imediatamente após protocolizados. Será dada oportunidade, no prazo de trinta dias após a divulgação dos referidos pedidos no } \\
\text { endereço eletrônico do MDIC, de apresentação de manifestações e argumentos de partes interessadas no pedido. } \\
\S 7^{\circ} \text { - O texto completo da versa pública das manifestações e argumentos relativos aos pedidos decorrentes de interesse nacional serão } \\
\text { imediatamente disponibilizados no endereço eletrônico do MDIC. }\end{array}$ \\
\hline Proposta 02 & $\begin{array}{l}2^{\circ} \text { No prazo de dez dias contados da data do recebimento do parecer pela Câmara de Comércio Exterior-CAMEX será publicado ato que } \\
\text { contenha a decisão de aplicação ou prorrogação de medidas antidumping provisórias, aceitação ou término de compromissos de preços, } \\
\text { encerramento da investigação com aplicação de direitos, suspensão do direito definitivo, extensão da aplicação do direito definitivo em } \\
\text { casos de elisão, estabelecimento de regras de origem específicas para o produto investigado, ou o resultado da revisão dos direitos } \\
\text { definitivos ou compromissos de preços. }\end{array}$ \\
\hline & Artigo 65 \\
\hline $\begin{array}{l}\text { Redação } \\
\text { original }\end{array}$ & $\begin{array}{l}\text { Art. } 65 \text {. Aberta a investigação, as autoridades do país exportador e as empresas interessadas serão informadas da intenção de realizar } \\
\text { investigações in loco. } \\
\S 1^{\circ} \text { Em circunstâncias excepcionais, havendo intenção de incluir peritos não-governamentais na equipe de investigação, as empresas e } \\
\text { autoridades do país exportador serão informadas a respeito, e esses peritos, em caso de quebra de sigilo, serão passíveis das sanções } \\
\text { previstas no art. } 325 \text { do Código Penal Brasileiro. } \\
\S 2^{\circ} \text { Deverá ser previamente obtida a anuência expressa das empresas envolvidas no país exportador, antes da realização da vista. } \\
\S 3^{\circ} \text { Obtida a anuência de que trata o parágrafo anterior, as autoridades do país exportador serão informadas de imediato, por nota, dos } \\
\text { nomes e endereços das empresas que serão visitadas, bem como as datas previstas para as visitas. } \\
\S 4^{\circ} \text { As empresas envolvidas serão informadas com suficiente antecedência sobre a visita. } \\
\S 5^{\circ} \text { Visitas destinadas a explicar o questionário, de que trata o caput do art. } 27 \text {, poderão ser realizadas apenas a pedido da empresa }\end{array}$ \\
\hline
\end{tabular}




\begin{tabular}{|c|c|}
\hline & $\begin{array}{l}\text { produtora ou exportadora e só poderão ocorrer a SECEX notificar representante do país em questão e este não fizer objeção à visita. } \\
\S 6^{\circ} \text { A vista será realizada após a restituição do questionário, a mesmo que a empresa concorde com o contrário e que o governo do país } \\
\text { exportador esteja informado da visita antecipada e não faça objeção. } \\
\S 7^{\circ} \text { Antes da visita, será levada ao conhecimento das empresas envolvidas a natureza geral da informação pretendida, e poderão ser } \\
\text { formulados, durante a visita, pedidos de esclarecimentos suplementares em consequência da informação obtida. } \\
\S 8^{\circ} \text { As respostas aos pedidos de informação ou às perguntas formuladas pelas autoridades ou empresas do país exportador essenciais ao } \\
\text { bom resultado da investigação in loco deverão, sempre que possível, ser fornecidas antes que se realize a visita. }\end{array}$ \\
\hline Proposta 01 & $\begin{array}{l}\text { Art. } 65 \text { - Aberta a investigação, as autoridades do país exportador e as empresas interessadas serão informadas da intenção de realizar } \\
\text { investigações in loco. } \\
\S 1^{\circ} \text { - Em circunstâncias excepcionais, havendo intenção de incluir peritos não-governamentais na equipe de investigação, as empresas e } \\
\text { autoridades do país exportador serão informadas a respeito, e esses peritos, em caso de quebra de sigilo, serão passíveis das sanções } \\
\text { previstas no art. } 325 \text { do Código Penal Brasileiro. }\end{array}$ \\
\hline Proposta 02 & $\begin{array}{l}\S 6^{\circ} \text { A visita será realizada após a restituição do questionário, a menos que a empresa concorde com o contrário e que o governo do país } \\
\text { exportador esteja informado da visita antecipada e não faça objeção. }\end{array}$ \\
\hline & Artigo 66 \\
\hline $\begin{array}{l}\text { Redação } \\
\text { original }\end{array}$ & $\begin{array}{l}\text { Art. 66. Tão logo aberta a investigação, serão especificadas, pormenorizadamente, as informações requeridas ás pares envolvidas e a } \\
\text { forma pela qual tais informações deverão estar estruturadas na resposta da parte interessada, bem como prazos de entrega. } \\
\S 1^{\circ} \text { A parte será notificada de que o não fornecimento da informação, dentro do prazo fixado, permitirá estabelecer determinação com } \\
\text { base nos fatos disponíveis, entre eles os contidos na petição de abertura da investigação. } \\
\S 2^{\circ} \text { Ao se formular as determinações, levar-se-ão em conta as informações verificáveis que tenham sido adequadamente apresentadas e } \\
\text { que, portanto, possam ser utilizadas na investigação sem dificuldades e tenham sido apresentadas tempestivamente. } \\
\S 3^{\circ} \text { Caso a SECEX não aceite uma informação, esta comunicará, imediatamente, à parte o motivo da recusa, a fim de que a mesma } \\
\text { possa fornecer novas explicações, dentro de prazos estabelecidos, respeitados os limites de duração da investigação. Caso as } \\
\text { explicações não sejam satisfatórias, as razões da recusa deverão constar dos atos que contenham qualquer decisão ou determinação. } \\
\S 4^{\circ} \text { Caso uma parte não forneça informação solicitada ou fornecê-la parcialmente e esta informação relevante não seja trazida ao } \\
\text { conhecimento das autoridades investigadoras, o resultado poderá ser menos favorável àquela parte do que seria caso a mesma tivesse } \\
\text { cooperado. }\end{array}$ \\
\hline
\end{tabular}




\begin{tabular}{|c|c|}
\hline & $\begin{array}{l}\S 5^{\circ} \text { Caso na formulação das determinações sejam utilizadas informações de fontes secundárias, inclusive aquelas fornecidas na petição, } \\
\text { buscar-se-á compará-las com informaços de fontes independentes ou com aquelas provenientes de outras partes interessadas. } \\
\S 6^{\circ} \text { A SECEX poderá solicitar que uma parte interessada forneça suas respostas em linguagem de computador. } \\
\S 7^{\circ} \text { A parte interessada, que não mantiver contabilidade informatizada ou a entrega de resposta neste sistema lhe representar sobrecarga } \\
\text { adicional, com o acréscimo injustificado de custos e dificuldades, ficará desobrigada de apresentá-la na forma do parágrafo anterior. } \\
\S 8^{\circ} \text { Sempre que a SECEX não dispuser de meios específicos para processar a informação, por tê-la recebido em linguagem de } \\
\text { computador, não compatível com o seu sistema operacional, a informação deverá ser fornecida sob a forma de documento escrito. }\end{array}$ \\
\hline Proposta 01 & $\begin{array}{l}\S 7^{\circ} \text { A parte interessada que não mantiver contabilidade informatizada ou a entrega de resposta neste sistema the representar sobrecarga } \\
\text { adicional, com o acréscimo injustificado de custos e dificuldades, ficará desobrigada de apresentá-la na forma do parágrafo anterior. }\end{array}$ \\
\hline & Artigo 67 \\
\hline $\begin{array}{l}\text { Redação } \\
\text { original }\end{array}$ & Art. 67. Os prazos previstos no presente Decreto serão contabilizados de forma corrida. \\
\hline Proposta 01 & $\begin{array}{l}\text { Artigo. } 67 \text {. Os prazos previstos no presente Decreto expressos em dias contam-se de modo contínuo. Os prazos fixados em meses ou } \\
\text { anos contam-se de data a data. Se no mês do vencimento não houver o dia equivalente àquele do início do prazo, tem-se como termo o } \\
\text { último dia do mês. } \\
\S 1^{\circ} \text { Os prazos começam a correr a partir da data de expedição da correspondência, excluindo-se da contagem o dia do começo e } \\
\text { incluindo-se o do vencimento. } \\
\S 2^{\circ} \text { O dia do começo da contagem do prazo é o primeiro dia útil subsequente à expedição da correspondência. } \\
\S 3^{\circ} \text { O dia do vencimento é o da data de protocolo da resposta junto ao Departamento de Defesa Comercial - DECOM. Considera-se } \\
\text { prorrogado o prazo até o primeiro dia útil seguinte se o vencimento cair em dia em que não houver expediente ou este for encerrado } \\
\text { antes da hora normal. } \\
\S 4^{\circ} \text { Os pedidos de prorrogação, quando admitidos na legislação, só poderão ser conhecidos se apresentados antes do vencimento do } \\
\text { prazo original. } \\
\S 5^{\circ} \text { É permitido às partes a utilização de sistema de transmissão de dados e imagens tipo fac-símile ou outro similar, para o } \\
\text { fornecimento de informações, com o objetivo de assegurar o cumprimento de prazos. Somente serão consideradas postadas no prazo as } \\
\text { informaçôes e documentos recebidos pela autoridade investigadora até às } 19 \text { horas (horário de Brasília) da data de vencimento do prazo } \\
\text { concedido, cabendo à citada autoridade confirmar, por escrito, à parte que os enviou, a lista de documentos recebidos tempestivamente. }\end{array}$ \\
\hline
\end{tabular}




\begin{tabular}{|c|c|}
\hline & $\begin{array}{l}\text { Os originais de tais informações e documentos deverão ser entregues, sob a forma impressa, no Setor de Protocolo, necessariamente, até } \\
\text { cinco dias após o vencimento. }\end{array}$ \\
\hline & Artigo 71 \\
\hline $\begin{array}{c}\text { Redação } \\
\text { original }\end{array}$ & Art. 71. Para os efeitos deste Decreto, o termo "indústria" inclui também atividades ligadas à agricultura. \\
\hline Proposta 01 & Art. 71. Para os efeitos deste Decreto, o termo "indústria" inclui também as atividades ligadas à agricultura e à mineracão. \\
\hline
\end{tabular}


